UNIVERSIDADE DE SÃO PAULO

ESCOLA DE COMUNICAÇÕES E ARTES

\title{
A FLECHA E A FARDA: Legibilidade, violência e sobrevivência em 'Arara'
}


MIGUEL ANTUNES RAMOS

A FLECHA E A FARDA: Legibilidade, violência e sobrevivência em

'Arara'

Versão Original

Dissertação apresentada à Escola de Comunicações e Artes da Universidade de São Paulo, para a obtenção do título de Mestre em Meios e Processos Audiovisuais.

Área de concentração: Meios e Processos Audiovisuais.

Orientador: Prof. Dr. Ismail Xavier

São Paulo 
Autorizo a reprodução e divulgação total ou parcial deste trabalho, por qualquer meio convencional ou eletrônico, para fins de estudo e pesquisa, desde que citada a fonte.

Catalogação na Publicação

Serviço de Biblioteca e Documentação

Escola de Comunicações e Artes da Universidade de São Paulo

Dados inseridos pelo(a) autor(a)

Ramos, Miguel Antunes

A Flecha e a Farda: Legibilidade, violência e

sobrevivência em 'Arara' / Miquel Antunes Ramos

orientador, Ismail Xavier. -- São Paulo, 2021.

144 p.: il.

Dissertação (Mestrado) - Programa de Pós-Graduação em Meios

e Processos Audiovisuais - Escola de Comunicações e Artes /

Universidade de São Paulo.

Bibliografia

Versão original

1. Guarda Rural Indígena (GRIN) 2. Ditadura Militar 3.

Povos Indígenas 4. Arquivo I. Xavier, Ismail II. Título.

CDD 21.ed. - 791.43

Elaborado por Alessandra Vieira Canholi Maldonado - CRB-8/6194 


\section{FOLHA DE APROVAÇÃO}

Miguel Antunes Ramos

A FLECHA E A FARDA: Legibilidade, violência e sobrevivência em 'Arara'

Dissertação apresentada à Escola de Comunicações e Artes da Universidade de São Paulo, para a obtenção do título de Mestre em Meios e Processos Audiovisuais.

Área de concentração: Meios e Processos Audiovisuais.

Orientador: Prof. Dr. Ismail Xavier

Aprovado em:

\section{Banca examinadora}

Prof. Dr.:

Instituição: Julgamento:

Prof. Dr.:

Instituição: Julgamento:

Prof. Dr.:

Instituição: Julgamento: 


\section{AGRADECIMENTOS}

Ao Prof. Dr. Ismail Xavier, pela orientação constante e pelas leituras atentas.

À Profa. Dra. Claudia Mesquita e ao Prof. Dr. Mateus Araújo, pela leitura do texto apresentado ao Exame de Qualificação e por seus comentários extensos e precisos, que muito ajudaram na (re)estruturação desta dissertação.

À Profa. Dra. Esther Hamburger e à Profa. Dra. Cecília Antakly de Mello pela interlocução rica e constante.

Ao Leco, que abriu os caminhos, pelos diálogos, pela paciência e apoio.

Ao Ernesto, Angelo e Luisa pelas extensas e profundas conversas no processo de feitura do filme, que ressoaram imensamente nesta dissertação.

Ao Ian Packer, pela generosidade no compartilhamento de ideias.

Ao Marcelo Zelic, por ter me introduzido ao material que deu origem à esta pesquisa.

À Ju, pelos insights, pela paciência e carinho.

À minha família, pelo apoio.

À Coordenação de Aperfeiçoamento de Pessoal de Nível Superior (CAPES), pela bolsa concedida. 


\title{
RESUMO
}

\section{A FLECHA E A FARDA: Legibilidade, violência e sobrevivência em 'Arara'}

Em 2012, durante as investigações da Comissão Nacional da Verdade foi encontrado no Museu do Índio um DVD com a recente digitalização de um conjunto de rolos de película filmados em 1970 e intitulados 'Arara'. Se tratava da cerimônia de formatura da primeira e única turma da Guarda Rural Indígena (Grin), em fevereiro de 1970, em um batalhão policial em Belo Horizonte. Nossa pesquisa se debruça sobre essas imagens, buscando, primeiro, refletir sobre esse reaparecimento (reemergência, sobrevivência), depois, sobre o que foi a Grin, suas contradições e campos de força. Posteriormente, nos dedicamos a compreender o autor das imagens, o fotógrafo Jesco Von Puttkamer, para então nos dedicarmos em um longo mergulho de análise propriamente dita das imagens. Fazemos uma análise plano a plano dos 26 minutos de película, buscando ler sob o acetato envelhecido a violência e o recalque dos militares, a forma como Jesco registrou e estetizou o acontecido, e a forma como os indígenas encenaram, lidaram e resistiram a performar em si a imagem do outro que os militares queriam ver desfilada.

Palavras-chave: Guarda Rural Indígena ; Grin ; ditadura militar ; questão indígena ; Comissão da Verdade.

\begin{abstract}
The Arrow and the Uniform: image, legibility and survival in 'Arara'

In 2012, during the investigations of the National Truth Commission, a DVD with a recent digitization of a set of film rolls shot in 1970 and entitled 'Arara' was found at the Indigenous Museum in Rio de Janeiro. The film had survived along 40 years untouched and, when we examined its content, it was shown that it brought the images of the graduation ceremony of the first and only group of the so called Indigenous Rural Guard (GRIN), which took place in February 1970, in a police battalion in Belo Horizonte. Our research focuses on these images, seeking, first, to evaluate the effects of the reappearance of this material that could reveal precious data related to the creation of that Guard by a federal law. Subsequently, we focus on the trajectory of the photographer Jesco Von Puttkamer, the man who documented that ceremony producing the material that became the central object of our analysis. A shot by shot close reading of the 26 minutes film, trying to read under the aged acetate the violence and repression of the military as expressed by the way Jesco recorded and aestheticized the ceremony. In our reading of the images we devoted special attention to the way the natives staged, dealt with and resisted performing in their own bodies and faces that image of disciplined soldiers that the military wanted to see in that parade.
\end{abstract}

Keywords: Rural Indigenous Guard; Grin; military dictatorship; indigenous group; National Truth Comission. 


\section{SUMÁRIO}

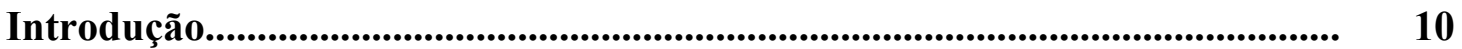

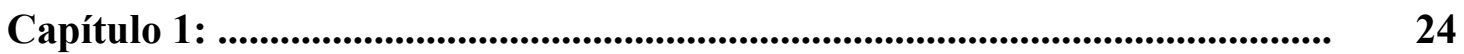

Capítulo 2: ..................................................................................................................... 47

Capítulo 3: ........................................................................................................................... 70

Considerações Finais: ......................................................................................... 139

Referências Bibliográficas: ..................................................................... 143

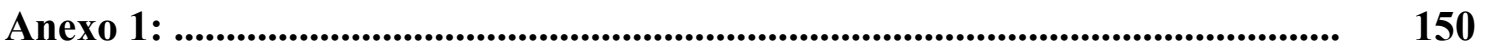

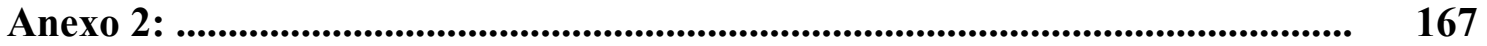


"O presente trabalho foi realizado com apoio da Coordenação de Aperfeiçoamento de Pessoal de Nível Superior - Brasil (CAPES) - Código de Financiamento 001

"This study was financed in part by the Coordenação de Aperfeiçoamento de Pessoal de Nível Superior - Brasil (CAPES) - Finance Code 001 


\title{
INTRODUÇÃO
}

\author{
"nós, que fingimos acreditar \\ que tudo isso pertence a um só tempo" \\ Alain Resnais/Jean Cayrol, Noite e Neblina
}

"quem controla o passado, controla o futuro"

George Orwell, 1984

Em 2012, foi encontrado no Museu do Índio um DVD com a recente digitalização de um conjunto de rolos de película filmados em 1970 e intitulados 'Arara'. O termo 'encontrado' talvez não seja o mais preciso, uma vez que estas imagens não foram declaradas perdidas, nem por ninguém reclamadas. Elas permaneceram guardadas, silenciosas, por mais de 40 anos no Museu do Índio, até que em 2012, no contexto de investigações em torno da criação da Comissão Nacional da Verdade, elas pudessem ser reconhecidas, isto é, lidas.

As imagens mostram um grupo de indígenas fardados que, diante da cúpula do Regime Militar, marcham, juram a bandeira, performam gestos militares. Se tratava da cerimônia de formatura da Guarda Rural Indígena, em fevereiro de 1970. Dentre os elementos performados, um deles chama especialmente a atenção: dois indígenas carregam um terceiro, com os braços amarrados, em um pau-de-arara. Esta é a única imagem oficial da técnica de tortura conhecida como 'pau-de-arara' de todo o período militar. Técnica denunciada inúmeras vezes por militantes torturados nos porões da ditadura mas nunca admitida pelos militares, ela foi, nessa cerimônia, desfilada à céu aberto à vista de todos os presentes - dos militares à população do entorno, que a tudo aplaudia.

Estas imagens foram tornadas públicas em uma reportagem da Folha de São Paulo intitulada "Como a ditadura ensinou técnicas de tortura à Guarda Rural Indígena1", assinada pela jornalista Laura Capriglione. A matéria traz um bom resumo do que foi a Grin, descreve o material encontrado e dá especial destaque às imagens do pau-de-arara. Depois, expande o

\footnotetext{
1 Folha de São Paulo, São Paulo, 11 de novembro de 2021. https://www1.folha.uol.com.br/ilustrissima/ 2012/11/1182605-como-a-ditadura-ensinou-tecnicas-de-tortura-a-guarda-rural-indigena.shtml?origin=folha acessado em 17 de dezembro de 2020.
} 
olhar para a forma como a ditadura lidou com os povos indígenas, com uma longa descrição do funcionamento do presídio Krenak, em Minas Gerais, também comandado pelo Capitão Pinheiro, o policial militar que foi o idealizador da Grin, como veremos.

Este material encontrado é composto por 26 minutos e 55 segundos de película, sem som, que compõe o registro bruto da formatura. Há no material claquetes aparentes, e tomadas feitas repetidamente. $\mathrm{O}$ conjunto dessas imagens são o centro desta dissertação.

O encontro quase fortuito deste material fala sobre a fragilidade de nossa memória enquanto país, simétrica à de nossas instituições. Estas imagens, guardadas sob um nome cifrado, que não condizia com o que foi registrado uma vez que a etnia Arara não estava presente nas imagens encontradas; estas imagens, silenciosas, sem explicações evidentes do que afinal continham; essas imagens só puderam começar a alcançar uma legibilidade quando o Estado Brasileiro começou a organizar uma tardia, tímida e frágil política de memória - a instauração, em 2010, da Comissão Nacional da Verdade².

Compreendemos, com Paul Ricoeur, a história (e por que não dizer, o cinema), como uma investigação. O autor francês, citando Carlo Guinzburg, afirma que: "se a realidade é opaca, existem zonas privilegiadas - rastros, indícios - que permitem decifrá-la ${ }^{3} . ”$ Nos parece que estamos diante de um desses indícios, e assim, a busca por decifrá-lo será nosso percurso ao longo deste texto.

Paul Ricoeur continua, afirmando que como toda escrita, "um documento de arquivo está aberto a quem quer que saiba ler; ele não tem, portanto, um destinatário designado, diferentemente do testemunho oral, dirigido a um interlocutor preciso; além disso, o documento que dorme nos arquivos não é somente mudo, mas órfão; os testemunhos que encerra desligaram-se dos autores que os 'puseram no mundo', estão submetidos aos cuidados de quem tem competência para interrogá-los e assim defendê-los, prestar-lhes socorro e assistência ${ }^{4}$." No entanto, podemos pensar que, mesmo mudo, esse material antigo, pouco legível, em processo avançado de deterioração, também fala. Cabe à nós, portanto, conseguir

\footnotetext{
${ }^{2}$ Cabe destacar aqui que, ao contrário das políticas de memória da Argentina e do Chile, a Comissão da Verdade brasileira não tinha o poder de punir algozes ou torturadores, nem era capaz de revogar a Lei da Anistia, de 1979, promulgada pelos próprios militares.

${ }^{3}$ RICOEUR, Paul. A memória, a história, o esquecimento. Campinas, Editora da Unicamp, 2007. Página 185.

${ }^{4}$ Idemibidem, página 179.
} 
escutá-lo. E para tal, tentaremos olhar, ler, escutar, entre as frestas de uma história cheia de lacunas, de não ditos, de impossibilidades.

Esta dissertação se divide em três capítulos. No primeiro, narraremos o que foi a GRIN, atentando para os campos de força que se explicitam na cerimônia cujo registro é nosso material de arquivo. Partiremos da hipótese de que a GRIN pode ser explicada a partir de dois eixos distintos, que se confundem e atravessam: de um lado, como um passo em um processo antigo que atinge seu ápice no pós AI-05, a saber: a militarização da relação entre indígenas e Estado brasileiro. De outro, como uma resposta imagética a um contexto de acusações variadas, em especial fora do Brasil, de violências contra povos indígenas cometidas pela ditadura - acusações motivadas em grande parte, às repercussões da divulgação, em 1967, do Relatório Figueiredo ${ }^{5}$.

No segundo capítulo, nos deteremos sobre a figura de Jesco Von Puttkamer, o fotógrafo que, segundo consta na claquete visível nas imagens, efetuou o registro a que ora nos detemos. Refletiremos sobre algumas ambiguidades de sua figura, e tentaremos compor o quebra-cabeça de sua relação com o Estado brasileiro nos anos 70 .

Por fim, nosso terceiro e principal capítulo consiste em um mergulho nas imagens. Procederemos a uma descrição minuciosa, buscando ler em cada plano a sobreposição das ações de três grupos: primeiro, a agência dos militares, que criaram a GRIN, que treinaram os indígenas e organizaram a cerimônia de formatura; depois, a agência de Jesco, que através de escolhas formais, de posições de câmera, de enquadramentos específicos, registrou o que se passava; e, por fim, a agência dos guardas, dos indígenas que, no contexto da apressada, equivocada e violenta política de criação de uma Guarda Rural Indígena, performaram em seus corpos, diante dos militares, a imagem de algo que não escolheram para si.

\footnotetext{
5 Relatório Figueiredo. Processo nº4.483/68. Disponível em: http://www.mpf.mp.br/atuacao-tematica/ccr6/ dados-da-atuacao/grupos-de-trabalho/violacao-dos-direitos-dos-povos-indigenas-e-registro-militar/relatoriofigueiredo - último acesso: 29.01.2021.
} 


\section{A sobrevivência das imagens}

Para melhor compreender nosso material de arquivo talvez seja preciso pensar, primeiro, o reaparecimento, a sobrevivência, a reemergência enfim dessas imagens. Conforme relata Marcelo Zelic, o pesquisador responsável pelo encontro dessas imagens, ele estava compondo um grupo da sociedade civil de apoio às investigações da Comissão Nacional da Verdade $^{6}$. Neste papel, ele se dirigiu a diversos acervos públicos, entre eles o Museu do Índio, e conversou longamente com outros pesquisadores e com funcionários da instituição sobre a Comissão da Verdade e o tipo de material em que ela estava interessada. Poderíamos pensar, portanto, que o esforço de Zelic foi o de dirigir perguntas aos arquivos. Não apenas individualmente, mas estendendo essas perguntas através de uma ampla rede de funcionários e técnicos, utilizando portanto uma infraestrutura já existente, técnica e humana, mas que não estava necessariamente atenta ao tipo de interesse, ao tipo de olhar com o qual agora, quase 30 anos depois do final da ditadura militar, se olhava os mesmos arquivos.

Segundo seu relato, nessa conversa ele ouviu dizer que um dos funcionários do Museu do Índio, Rodrigo Piquet, teria ficado estarrecido alguns anos antes, durante a digitalização de alguns arquivos, diante de alguns rolos de película. Zelic retornou ao museu no dia seguinte, encontrou Piquet, e este, enfim, lhe mostrou as imagens já digitalizadas, que foram assim 'encontradas'.

Esse processo merece ser melhor pensado. Conforme se percebe no relato, essas imagens, depositadas há décadas em uma caixa no Museu do Índio, foram primeiro vistas por Rodrigo Piquet poucos anos antes em um procedimento rotineiro de digitalização, ou seja, de mudança de suporte do acervo, de físico a digital, que exige que os materiais sejam vistos uma visada a princípio técnica, apenas para conferir que a mudança de suporte se deu de forma satisfatória. As imagens chamaram a atenção do funcionário do Museu, a ponto de ele ter comentado com outros funcionários e ainda se lembrar delas anos depois; mas não o suficiente para que ele tivesse caminhado sozinho em direção a tentativas de torná-las legíveis. Não fosse o contexto de investigação da CNV e as perguntas dirigidas aos arquivos por Marcelo Zelic, o fato de as imagens terem chamado a atenção do arquivista talvez não

\footnotetext{
6 Conversamos ao longo da pesquisa com Marcelo Zelic algumas vezes; as informações e relatos que aqui trazemos foram dadas à nossa pesquisa ao longo dessas conversas.
} 
tivesse tido maiores consequências. Talvez as imagens, mudas, continuassem 'perdidas', isto é, guardadas, arquivadas sem serem lidas. A legibilidade, portanto, se oferece a partir de um questionamento. A instauração de uma política de memória é a produção de uma interrogação ampla a nosso passado recente, uma forma de apuração do olhar, já que os acervos a serem olhados muitas vezes, como neste caso, são os mesmos que eram vistos antes - o que muda, aqui, é a pergunta, ou seja, a forma de ver. O processo de legibilidade tem a ver com o gesto de nomear - simétrico ao que aqui chamamos de escutar as imagens sem som. Foi o gesto de Marcelo Zelic de capilarizar os questionamentos da $\mathrm{CNV}$ em direção aos funcionários dos arquivos públicos do país todo que deu ao estranhamento mudo sentido por Rodrigo Piquet um nome possível. Ou melhor, um espaço no qual o estranhamento pudesse começar a se desenhar como uma investigação. Essa passagem, de um estranhamento sem nome para a possibilidade de uma investigação que comece a nomear, a registrar, a tornar legível esse estranhamento, ou melhor, a buscar caminhos de acolher um estranhamento que poderia ser melhor descrito como a percepção de uma violência não nomeada; essa passagem reafirma a importância da criação de uma política de memória. Uma política que poderia, na formulação de Vladimir Safatle e Edson Telles, fazer os "corpos de nossos mortos serem acolhidos pela memória"7.

Rodrigo Piquet, em contato telefônico com nossa pesquisa ${ }^{8}$, contesta a formulação de que essas imagens estivessem perdidas. Ele afirma que, nos anos 60 e 70, todo filme produzido em áreas indígenas tinha uma espécie de depósito legal na Funai. O Museu do Índio seria, portanto, o depositário desse tipo de material. Segundo ele, ainda hoje existem na instituição dezenas de rolos de filmes produzidos em áreas indígenas. Ele afirma, portanto, que o material não estava perdido, ele estava depositado num arquivo público, preservado. Não estava identificado, mas estava guardado.

Sobre o 'encontro' do material, ele afirma que começou a trabalhar no acervo do Museu do Índio primeiro como funcionário terceirizado. Na época, fazia parte do 'serviço de registro de audiovisual'. Nessa época, por volta de 2008, foi feita uma telecinagem, ou seja, a

\footnotetext{
7 SAFATLE, Vladimir e TELES, Edson (org). Introdução, in: O que resta da ditadura. São Paulo, Boitempo Editorial, 2010. Página 12.

${ }^{8}$ diálogo telefônico feito com Rodrigo Piquet no dia 10 de novembro de 2020.
} 
transformação dos rolos de acetato para DVD. Piquet afirma que nos anos 2000 o Museu do Índio não tinha moviola para ver os rolos, então esse momento de passagem técnica de suporte foi quando, pela primeira vez em décadas, parte desses rolos puderam ser de fato vistos (ele afirma não saber se esses materiais haviam sido convertidos para VHS anteriormente).

Rodrigo afirma que, trabalhando como terceirizado, seu trabalho era fazer a indexação e a decupagem desses filmes para a base de dados do museu. Ele afirma que, ao ver as imagens, achou "uma coisa curiosa, mas na época nem tive muita noção da importância histórica desse material". Nessa época, segundo ele, "a Comissão da Verdade, esse processo todo ainda não estava bem consolidado. Então esses materiais mais sensíveis não estavam tão em voga". Ele continua: "aí anos depois, me disseram que o Zelic tava me procurando, e daí foi o encontro". Sua descrição, portanto, nos parece convergente com o narrado acima. Apesar de sua objeção quanto a descrever o estatuto dessas imagens como 'perdidas', sua descrição confirma o que dissemos, que foi o gesto de Marcelo Zelic de direcionar perguntas aos arquivos, a partir do ensejo criado pela Comissão da Verdade, que deu legibilidade às imagens que Piquet havia colocado na base de dados do Museu sem nomear ao certo o que continham. A brutal imagem do pau-de-arara, por exemplo, não havia sido percebida até o 'encontro' dessas imagens, em $2012^{10}$.

Anita Leandro escreve que "durante a ditadura, os militares se aplicaram em documentar suas ações repressivas: há registros fotográficos de investigações, estouros de aparelhos, atos de prisão, laudos cadavéricos, inquéritos, exames de corpo de delito, processos de banimento e até mesmo imagens de crimes de guerra e lesa-humanidade, como as marcas da tortura nos rostos e corpos dos prisioneiros fotografados ${ }^{11}$ ". No entanto, estes documentos

\footnotetext{
${ }^{9}$ transcrição literal do contato telefônico feito com nossa pesquisa em 10 de novembro de 2020.

${ }^{10} \mathrm{Na}$ base de dados do Museu do Índio consta uma decupagem de nosso material de arquivo. No trecho que descreve a imagem do pau-de-arara, consta: 'índios segurando suspeitos'.

http://base2.museudoindio.gov.br/cgi-bin/wxis.exe?IsisScript=ph182.xis\&cipar=phl82.cip\&lang=por - acesso em 20 de janeiro de 2021.

11 LEANDRO, Anita. Montagem e História: uma arqueologia das imagens da repressão, in: BRANDÃO, Alessandra Soares; SOUSA, Ramayana Lira de (orgs). A Sobrevivência das imagens. São Paulo, Editora Papirus, 2015.
} 
estão fragmentados, guardados em locais diferentes, alguns tendo sido desaparecidos ${ }^{12}$. Leandro procede, em seu filme Retrato de Identificação (Brasil, 2014, 72 minutos), a um trabalho minucioso de montagem de material encontrado sobre três vítimas do regime, como forma de desvelar uma parte desse aparato repressivo que quase 50 anos depois dos eventos retratados permanece pouco conhecida.

É possível, neste sentido, refletir sobre a fragilidade da memória histórica no Brasil quando se trata da violência de Estado. Simétrico ao desaparecimento dos corpos de vítimas da ditadura durante o período militar, dos quais até hoje não se sabe o paradeiro, a memória também é muitas vezes dificultada.

Lucas Figueiredo, em seu preciso estudo sobre os arquivos militares do período ditatorial, demonstra a contradição entre o interesse minucioso por parte das Forças Armadas em registrar suas ações e a falta de acesso público a esses mesmos registros, tantos anos após o final da ditadura ${ }^{13}$. Ele mostra, por exemplo, que o Cenimar, serviço de inteligência da Marinha, possui desde os anos 60 um arquivo chamado 'prontuário de pessoas mortas', ao qual o autor teve acesso ${ }^{14}$, e que traz o nome de alguns militantes que são até hoje desaparecidos políticos - esses acervos, portanto, provam que os militares sabiam e sabem do destino dos assim chamados desaparecidos políticos, possuindo fichas catalográficas com dados e informações sobre cada um dos casos. Figueiredo narra com precisão as recorrentes negativas das Forças Armadas, durante o período democrático, em abrir seus arquivos, sempre sob a afirmação de que teriam sido destruídos anos antes - o autor demonstra como essas afirmações são falsas. Seu texto narra a falta de ingerência civil no poder militar mesmo tantos anos depois do final da ditadura, assim como a falta de atitudes mais assertivas no que diz respeito à busca por esses arquivos por parte de todos os presidentes da redemocratização. Como formula o autor: "é preciso dizer: as graves violações de direitos humanos cometidas na

\footnotetext{
12 Escreve Anita: "grande parte desse material - os documentos textuais, principalmente - já vem sendo estudada pelos historiadores desde 1990, com a abertura dos primeiros acervos do Departamento de Ordem Política e Social (Dops), e a partir de 2012 uma nova lei facilitou o acesso aos arquivos - para uma evolução da política de acesso aos arquivos da ditadura, remetemos ao artigo de Rodrigo Patto Sá Motta (2013) e à conferência proferida pelo historiador em 9/9/2014 no seminário internacional 'a Pesquisa em Arquivos', intitulada 'O historiador e as agencias de repressão. Desafios e perspectivas". LEANDRO, Anita. Montagem e História: uma arqueologia das imagens da repressão, in: BRANDÃO, Alessandra Soares; SOUSA, Ramayana Lira de (orgs). A Sobrevivência das imagens. São Paulo, Editora Papirus, 2015.Página 103.

13 FIGUEIREDO, Lucas. Lugar Nenhum - Militares e civis na ocultação dos documentos da ditadura. São Paulo, Companhia da Letras, 2015.

${ }^{14}$ Idemibidem, p. 32.
} 
ditadura foram (e seguem sendo) ocultadas graças a um pacto entre militares e civis. Um pacto desenhado no final do regime militar e amadurecido em tempos de democracia. $\mathrm{O}$ acordo silencioso subverte a própria lógica da democracia, ao permitir que o poder militar negue subordinação ao poder civil. E também aceitar que o poder civil, por sua vez, seja incapaz de enquadrar o poder militar ${ }^{15}$ ".

É interessante pensar que a existência desses arquivos joga para o presente uma disputa que em tese seria pretérita. Afinal, discutir os crimes cometidos pelos militares seria algo em tese pertencente ao passado - algozes e vítimas estariam ambos envelhecidos, a maioria já tendo falecido. No entanto, a existência de um arquivo que prova violações de direitos humanos pela ditadura presentifica essa disputa. A falta de acesso público a esses arquivos demonstra a existência de um recalque no presente, que se expressa na dificuldade de acolher a memória das violências cometidas no período ditatorial. Recalque que atinge algozes e vítimas. Como escreve Maria Rita Kehl, "hoje ninguém desconhece a existência da tortura no Brasil - nem do passado, nem do presente. Não podemos assimilar nossa indulgência para com os torturadores de ontem e de hoje como se fosse efeito de desconhecimento do fato. Mas se nós aceitamos com certa tranquilidade a existência da tortura e a impunidade dos torturadores, o que é que teria ficado recalcado, silenciado, depois da nossa pseudoanistia, e que ainda hoje produz sintomas sociais de violência policial com frequência ainda maior no presente do que durante a ditadura? Não é o fato de ter havido e haver tortura que ficou recalcado, e sim a convicção de que ela é intolerável. O argumento da tortura como mal necessário parece convincente ainda a grandes parcelas da população brasileira. Nós nos esquecemos que o outro torturado nos diz respeito; que se a tortura separa corpo e sujeito, cabe a nós assumir o lugar de sujeito em nome daqueles que já não tem direito a uma palavra que os represente ${ }^{16}$ ". É interessante, também, atentar para os elos entre a violência policial e miliciana no Brasil contemporâneo e o discurso da 'guerra justa', que antes seria feita contra os 'comunistas', e hoje, contra os 'bandidos'. Bruno Paes Manso, em 'A República das Milícias ${ }^{17}$ ' formula essa linha de continuidade profunda entre passado e

\footnotetext{
15 idemibidem, p. 131

${ }^{16}$ KEHL, Maria Rita. Tortura e sintoma social, in: SAFATLE, Vladimir e TELES, Edson (org). O que resta da ditadura. São Paulo, Boitempo Editorial, 2010. Página 131.
}

${ }^{17}$ MANSO, Bruno Paes. A República das Milícias. São Paulo, Companhia das Letras, 2018. 
presente do país. É possível, novamente, ver o termo recalque aí: a violência dos porões da ditadura, nunca contestada ou punida, se autonomiza e se espraia para outros grupos do corpo social.

Safatle e Telles argumentam que "quando estudos demonstram que, ao contrário do que aconteceu em outros países da América Latina, as práticas de tortura em prisões brasileiras aumentaram em relação aos casos de tortura na ditadura militar; quando vemos o Brasil como o único país latino americano onde torturadores nunca foram julgados, onde não houve justiça de transição, onde o Exército não fez um mea culpa de seus pendores golpistas; quando ouvimos sistematicamente oficiais na ativa e na reserva fazerem elogios inacreditáveis à ditadura militar; quando lembramos que 25 anos depois do fim da ditadura convivemos com o ocultamento de cadáveres daqueles que morreram nas mãos das Forças Armadas; então começamos a ver, de maneira um pouco mais clara, o que significa exatamente 'violência'. Pois nenhuma palavra melhor do que 'violência' descreve essa maneira que tem o passado ditatorial de permanecer como um fantasma a assombrar e contaminar o presente ${ }^{18}$ ". Este fantasma que assombra o presente parece se reatualizar no caráter frágil da conservação da memória histórica dos abusos cometidos durante a ditadura militar, caráter do qual fala a difícil sobrevivência de nosso material. Assim, gostaríamos de apontar para a questão dos arquivos como um campo no qual se pode observar as disputas em relação à memória da ditadura, bem como as tensões entre passado e presente.

Se tanto demorou para que a ditadura pudesse ser sutilmente questionada, é surpreendente a proximidade temporal entre a promulgação do relatório final da Comissão Nacional da Verdade, em 2014, e o retorno dos militares à arena política, com a volta de procedimentos que esperávamos estar há muito superados ${ }^{19}$. Não nos parece, tampouco, equivocado supor relações causais entre esses dois movimentos, como atesta entrevista recente dada pelo ex-presidente Michel Temer, no qual destaca a proximidade com os militares quando do processo de impeachment de Dilma Rousseff, em 2016, e o fato de ter

\footnotetext{
${ }^{18}$ SAFATLE, Vladimir e TELES, Edson (org). O que resta da ditadura. São Paulo, Boitempo Editorial, 2010. Página 11.

19 Os caso abundam, mas a título de exemplo, destacamos o controle e vigilância exercido pela Abin contra participantes da cúpula do Clima, em dezembro de 2019, evento fértil para manifestações críticas ao governo de Jair Bolsonaro (https://noticias.uol.com.br/ultimas-noticias/agencia-estado/2020/10/16/heleno-admite-que-abinmonitorou-maus-brasileiros-na-conferencia-do-clima.htm - acessado em 07 de novembro de 2020).
} 
sido procurado por militares ainda em 2015 por conta de 'incômodos com a Comissão da Verdade' ${ }^{20}$. Novamente, a noção de recalque se faz presente para poder explicar porquê quase 30 anos após o final da ditadura, a simples instauração de uma política de memória pode influir no presente a ponto de contribuir para um processo de impeachment que marcou decisivamente os rumos do país.

Esta pesquisa se desenvolveu em sua maior parte durante o governo de Jair Bolsonaro, que buscou revogar medidas de acesso à informação, dificultando assim que os arquivos pudessem ser perguntados. Assistimos todos, consternados, a um embrutecimento e fechamento do país, que se verifica também nos arquivos e nas instituições de memória, tenha-se em vista, por exemplo, o descalabro pelo qual passa a Cinemateca Brasileira. Como formulou Walter Benjamin, cabe lembrar que 'nem os mortos estarão seguros diante do inimigo, se ele for vitorioso. E esse inimigo não tem cessado de vencer ${ }^{21}$.' Ou, como Figueiredo termina seu texto, que data de 2014, antes, portanto, da regressão política que enfrentamos hoje: "a cumplicidade de militares e civis na ocultação dos arquivos secretos da ditadura é um entrave para a conclusão do processo de redemocratização. Em 1985, o Brasil deixou para trás a ditadura. Três décadas depois, ainda não alcançou a plena democracia. Entre um e outro regime, o país está em algum lugar. Ou em lugar nenhum. Como os papéis e microfilmes da repressão. Como os desaparecidos políticos 22 ”.

Se tanto frisamos a importância das perguntas que a Comissão da Verdade direciona a um tempo histórico, que geram a possibilidade de acolher, de tornar legível, de fazer ver violências e arbítrios cometidos pelo Estado até aqui desconhecidas, é necessário ressaltar que essa importância aumenta exponencialmente quando se trata das continuadas porém pouco vistas violações de direitos humanos de populações indígenas que ocorrem no Brasil desde a assim chamada invasão portuguesa. Como afirma o capítulo que apura violações indígenas do

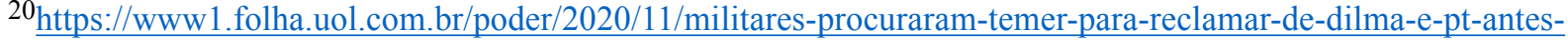
do-impeachment-diz-entrevistador.shtml - acessado em 07 de novembro de 2020.

21 LOWY, Michael. Walter Benjamin: aviso de incêndio - uma leitura das teses "sobre o conceito de história". São Paulo, Boitempo editorial, 2005.

22 FIGUEIREDO, Lucas. Lugar Nenhum - Militares e civis na ocultação dos documentos da ditadura. São Paulo, Companhia da Letras, 2015. Página 132.
} 
relatório final da Comissão Nacional da Verdade: “os povos indígenas no Brasil sofreram graves violações de seus direitos humanos no período entre 1946 e 1988. O que se apresenta neste capítulo é o resultado de casos documentados, uma pequena parcela do que se perpetrou contra os índios. Por eles, é possível apenas entrever a extensão real desses crimes, avaliar o quanto ainda não se sabe e a necessidade de se continuar as investigações. Não são esporádicas nem acidentais essas violações: elas são sistêmicas, na medida em que resultam diretamente de políticas estruturais de Estado, que respondem por elas, tanto por suas ações diretas quanto pelas suas omissões ${ }^{23}$."

Se a frágil situação dos arquivos impede que tenhamos a real dimensão da violência de Estado no Brasil, é preciso ter em conta que, quando se trata de violações contra povos indígenas, estamos diante de um verdadeiro abismo no qual faltam documentos e sobram violências de todo tipo. Podemos ter uma pequena noção desse abismo ao comparar dois números: enquanto a conclusão do Relatório da CNV fala que "a CNV teve condições de confirmar 434 mortes e desaparecimentos de vítimas do regime militar, que se encontram identificados de forma individualizada no Volume III deste Relatório24", o capitulo sobre violações contra povos indígenas afirma que "como resultados dessas políticas de Estado, foi possível estimar ao menos 8.350 indígenas mortos no período de investigação da CNV, em decorrência da ação direta de agentes governamentais ou da sua omissão. Essa cifra inclui apenas aqueles casos aqui estudados em relação aos quais foi possível desenhar uma estimativa. O número real de indígenas mortos no período deve ser exponencialmente maior, uma vez que apenas uma parcela muito restrita dos povos indígenas afetados foi analisada e que há casos em que a quantidade de mortos é alta o bastante para desencorajar estimativas 25 ."

A diferença de quase 20 vezes nas duas estimativas em relação ao total de vítimas da ditadura militar dá a ver o tamanho do que aqui chamamos provisoriamente de abismo. Nas discussões sobre a memória do período autoritário, convivemos com a equivocada formulação

\footnotetext{
23 Comissão Nacional da Verdade. 2014b. Volume II - Textos temáticos. Texto 5: "Violações de direitos humanos dos povos indígenas". Disponível em: http://www.cnv.gov.br/. Último acesso: 29.01.2021.

24 Comissão Nacional da Verdade. 2014a. Volume I. Capítulo 18: “Capítulo 18 - Conclusões e recomendações”. Disponível em: http://www.cnv.gov.br/. Último acesso: 29.01.2021.

25 Comissão Nacional da Verdade. 2014b. Volume II - Textos temáticos. Texto 5: "Violações de direitos humanos dos povos indígenas". Disponível em: http://www.cnv.gov.br/. Último acesso: 29.01.2021.
} 
de 'ditabranda ${ }^{26}$, segundo a qual, ao contrário de nossos vizinhos Argentina e Chile, em que os números oficiais de vítimas da ditadura se dão na casa das dezenas de milhares, no Brasil a barbárie teria sido consideravelmente menor, não chegando a 500 as vítimas fatais. Gostaríamos de sugerir, tendo em vista o acima exposto, que tal formulação equivocada só se faz possível porque continuamos, como país, a ignorar as violações cometidas contra grupos subalternizados - indígenas, negros, pobres, camponeses e quilombolas ${ }^{27}$. Assim, olhar, tentar ver, a violência cometida pela ditadura contra os povos indígenas se faz essencial também para poder desenhar uma feição mais verdadeira do tamanho da violência daquele período que ecoa ainda no presente.

Esse abismo, importante dizer, continua até hoje pouco visível entre nós. Se Rithy Pahn formulou (e produziu) imagens que faltam do genocídio cambojano ${ }^{28}$, podemos, de forma análoga, nos questionar sobre o quanto, no que tange às violações contra povos indígenas no Brasil, sobram violências e faltam imagens ${ }^{29}$. Seria de se perguntar sobre o efeito dessa falta de imagens na forma como essas violências insistem em se reatualizar no contemporâneo.

Como dizíamos, esta pesquisa é tributária do esforço de memória que a instauração de uma Comissão Nacional da Verdade ensejou. Didi-Huberman fala que as imagens possuem uma 'tenaz vocação para tornar visível ${ }^{30}$ '. Cabe refletir sobre o quê, então, se faz visível aqui. A esta pergunta tentaremos responder ao longo deste texto.

Paula Berbert descreve sua reação ao ver essas imagens pela primeira vez: "Lembrome de ler essa reportagem com assombro no dia em que foi publicada. As imagens da formatura da Guarda Rural Indígena eram mesmo desconcertantes e a surpresa que elas

\footnotetext{
${ }^{26}$ https://www1.folha.uol.com.br/fsp/opiniao/fz1702200901.htm - acessado em 15 de janeiro de 2020.

${ }^{27}$ no mesmo sentido, se olharmos, por exemplo, para as ações do Esquadrão da Morte, chefiado pelo delegado Sérgio Paranhos Fleury, um dos principais torturadores da ditadura, teremos nota de inúmeros assassinatos feitos por este grupo para-legal que nunca foram contabilizados como mortes da ditadura - https:// www1.folha.uol.com.br/ilustrissima/2020/10/esquadroes-mataram-em-3-anos-o-dobro-da-ditadura-em-21.shtml? utm_source=twitter\&utm_medium $=$ social\&utm_campaign $=$ comptw

${ }^{28}$ A imagem que falta (Rithy Panh, 2013)

29 importante destacar o essencial trabalho de produção de imagens feita em tempos recentes por cineastas indígenas e não-indígenas, tal como aqueles que participam do projeto Vídeo nas Aldeias. Um filme recente como Martírio (Vincent Carelli, 2016) é uma importante contribuição em relação a essa lacuna apontada.
}

${ }^{30}$ DIDI-HUBERMAN, Georges. Imagens apesar de tudo. Lisboa, Editora KKYM. 2004. 
causaram reveladoras. Tínhamos uma medida do quão arguto foi o projeto repressivo dos militares e do quanto ele foi especialmente minucioso em relação aos índios. Ao mesmo tempo nos dávamos conta da eficiência das estratégias que o poder usa para nos fazer esquecer de sua violência. Não é que desconhecíamos a existência da Guarda, das prisões indígenas, da repressão e do genocídio dos povos originários - as imagens de Jesco mostram quantos testemunharam, aplaudindo, os índios soldados marcharem, a reportagem de Laura recupera manchetes dos jornais da época que noticiavam o fato - nós sabíamos e nos esquecemos. Assim funciona a memória dessa gente a quem Davi Kopenawa chama de o “povo do esquecimento" (Kopenawa \& Albert, 2015 [2010]), confusa e repleta de uma névoa vazia. ${ }^{31 "}$

Podemos refletir sobre isso a que ela chama 'esquecimento'. Porque de fato, a história da Grin é uma história pública, fruto de uma política de Estado que não era segredo. A cerimônia foi acompanhada por órgãos de imprensa do Brasil e do exterior. No entanto, algumas décadas depois, essa história era ignorada do debate público. Ela retorna, agora, não pela discussão de sua política mas pela potência da imagem - sua 'tenaz vocação para tornar visível'. Há algo que as imagens carregam, corporificam, produzem. Não apenas pela história nelas inscritas - a política da Grin - mas por traduzir, por dar a ver de forma única uma certa constelação. Há de se perguntar, portanto, pela agência das imagens - o que as imagens produzem. O que essa ressurgência, a sobrevivência desse material produz, tantos anos depois de sua feitura.

Algo se passa em nós ao olhar essas imagens até então desconhecidas. Há algo nelas inscrito que nos faz tremer. Há uma espécie vertigem despertada pelos 26 minutos de película envelhecida, guardadas por mais de 4 décadas. Kracauer atenta para o caráter 'redentor' das imagens, através da parábola da Medusa, na qual Perseu é instado por Atenas a não encarar diretamente a Medusa, sob o risco de virar pedra, mas apenas sua imagem refletida em seu escudo; segundo ele, o maior feito de Perseu teria sido não o gesto da decapitação, mas o de

\footnotetext{
${ }^{31}$ BERBERT, Paula. "Para nós nunca acabou a ditadura": instantâneos etnográficos sobre a guerra do Estado brasileiro contra os Tikmu'un_Maxacali. Dissertação de Mestrado FAFICH - Faculdade de FIlosofia e Ciências Humanas. Belo Horizonte, $201 \overline{7}$.
} 
vencer o medo e olhar o escudo ${ }^{32}$. Didi-Huberman retoma essa formulação para pensar como o horror paralisa, "mas o horror refletido, reconduzido, reconstruído como imagem pode ser fonte de conhecimento, na condição todavia de se comprometer a sua responsabilidade com o dispositivo formal da imagem produzida ${ }^{33}$ ". No caso de nosso material de arquivo, pensar seu dispositivo significa levar em conta sua forma de produção - como veremos, temos a hipótese de ser em verdade o material bruto de uma propaganda de Estado nunca realizada. No entanto, ele carrega inscrito em si, ele fala e é também documento, de uma longa história de violações contra os povos indígenas, história da qual o Estado Brasileiro no auge da ditadura queria, contraditoriamente, se defender. Como veremos, a produção dessas imagens se dá em um contexto contraditório, atravessada por campos de força distintos. Portanto, cabe a nós conseguir ver, conseguir ler o que as imagens carregam, o que falam. Ou, na bela formulação com que o filósofo francês encerra seu livro, "seria preciso saber ver nas imagens aquilo de que elas são as sobreviventes. Para que a história, liberta do puro passado (desse absoluto, dessa abstração), nos ajude a abrir o presente do tempo ${ }^{34}$."

\footnotetext{
32 KRACAUER, Siegried. Theory of fim, in: DIDI-HUBERMAN, Georges. Imagens apesar de tudo. Lisboa, Editora KKYM. 2004.

33 DIDI-HUBERMAN, Georges. Imagens apesar de tudo. Lisboa, Editora KKYM. 2004. Página 224.

${ }^{34}$ Idemibidem. Página 229.
} 


\section{CAPITULO 01}

Para melhor situar e compreender nosso material de arquivo, é necessário entender os motivos que levaram à criação de uma Guarda Rural Indígena pela ditadura, buscando entrever os campos de força que resultaram na cerimônia registrada por Jesco, e que estavam certamente inscritos na cerimônia. Não faremos uma explicação extensa, mas um cotejamento de algumas teses e documentos primários para lançar luz a esse contexto. Defenderemos, ao longo do capítulo, que a criação da Grin deve ser pensada a partir de dois prismas diferentes e algo contraditórios. O primeiro diz respeito ao tema da militarização indígena, entendendo a Grin no contexto do projeto de integração e segurança nacional do pós-AI-5. O segundo diz respeito a uma preocupação acima de tudo imagética, tendo em vista as acusações que se fazia ao Brasil no contexto internacional, e o papel preponderante da questão indígena nessas acusações. Assim, a criação da Grin seria parte de um esforço da ditadura por melhorar sua imagem, em especial no exterior, em relação à questão indígena.

O decreto de criação da Grin data de 25 de setembro de 1969. Assim, é necessário pensá-lo simultaneamente em relação a dois eventos anteriores: a promulgação do AI-05, em dezembro de 1968, e as disputas a partir da CPI que deu origem ao Relatório Figueiredo, que levaram à extinção do SPI (Serviço de Proteção aos Índios) e à criação da Funai, em 1967.

O AI-05 pode ser descrito como um fechamento do regime militar, com a tomada de poder pela assim chamada 'linha-dura', e uma maior militarização de diversos espaços da administração pública. Adriano Codato formula que "o golpe político-militar de 31 de março/ 1 de abril de 1964 somente se concretiza como regime ditatorial-militar em 13 de dezembro de 1968, após a edição do Ato Institucional n. $5^{35 " .}$ Assim, a formulação do golpe como regime se daria no processo pós AI-5, com uma maior militarização do aparelho de Estado ${ }^{36}$. Egon Heck confirma essa proposição ao analisar a militarização dos quadros da Funai a partir

\footnotetext{
35 CODATO, Adriano Nervo. O Golpe de 1964 e o regime de 1968: aspectos conjunturais e variáveis históricas, em: História: Questões e Debates. Curitiba, Editora UFPR, 2004.

36 Essa instigante formulação, sobre quando uma forma de poder se torna de fato um regime, pode ajudar a pensar nosso turbulento presente, no qual um político eleito democraticamente busca moldar a estrutura de poder federal à sua imagem e semelhança, de forma antidemocrática.
} 
de 1970 - ele salienta a importância da criação do Ministério do Interior, em 1967: "compreender essa militarização do Ministério do Interior é essencial para uma análise das políticas indigenistas, posto que é desta instância que emanam as orientações e indicação (em princípio) do presidente da Funai" ${ }^{37}$. Ele associa, também, a iniciativa de criação da GRIN com a doutrina de segurança nacional. O binômio fundamental dessa doutrina, desenvolvimento e segurança tem, sem dúvida, desdobramentos sobre a problemática dos povos indígenas. Diz o autor: "E quando vemos que a GRIN se desenvolve no período do 'milagre brasileiro' - expansão acelerada das frentes econômicas sobre os territórios, especialmente na Amazônia - e do AI 5 - repressão e remoção dos óbices e ameaças aos objetivos nacionais - não fíca difícil enxergar aí a preocupação com a questão indígena. ${ }^{38 "}$

No entanto, é preciso ressaltar que a militarização indígena não começou com a instalação, em 1964, de uma ditadura militar no Brasil. Edinaldo Bezerra de Freitas assinala que, em realidade, tal questão se coloca desde o período colonial, quando indígenas eram arregimentados pelos europeus para tomar parte nas disputas entre distintas forças colonizadoras $^{39}$. É sabido, também, que na Guerra do Paraguai haviam regimentos indígenas que combatiam do lado brasileiro ${ }^{40}$. Mas foi a criação do SPI, em 1911, por um militar, o Marechal Rondon, que deu um passo maior nessa direção: “sabemos que na tática de aliança com as lideranças indígenas, constava da parte de Rondon presentear aos caciques de cada grupo com um fardamento militar. Desta ação, alimentava a posição das chefias indígenas como 'capitães' e em sentido figurado, anexava os agrupamentos como verdadeiras milícias de trabalho" 41 . No entanto, tal precedente não significa que a ruptura do golpe de 64 e da

\footnotetext{
${ }^{37}$ HECK, Egon Dionísio. Os índios e a caserna - políticas indigenistas dos governos militares - 1964 a 1985. Dissertação de Mestrado. IFICH, Unicamp, 1997.

${ }^{38}$ Idemibidem.

39 "na saga Tupinambá, o uso de sua gente enquanto mecanismo militar da colonização estará presente por todo o século XVI e XVII e, além de fazer parte dos conflitos mais internos do implante colonial, como aqueles descritos no regimento de 1548 , se fará visível sobremaneira no momento de disputas contra o projeto mercantil português nas tentativas de implantes coloniais por parte de franceses e holandeses. As crônicas de tais episódios são descrições de verdadeiros exércitos indígenas usados pelas partes conflitantes". FREITAS, Edinaldo Bezerra de. Índios-Soldados - A GRIN e a tradição Militar da Política Indigenista Brasileira. Tese de Doutorado, Programa de pós-graduação em História Social da Universidade de São Paulo. São Paulo, 1999. Página 63.
}

40 "a memória coletiva de vários grupos indígenas atuais remetem para a participação na Guerra do Paraguai, inclusive porque teriam pela ocasião recebido garantias de posse de terra. Passando a vigorar em formas de mitologia própria, vamos encontrar relatos da guerra enter os Terena, Kadiwéu, Fulni-ô, entre outros". Idemibidem, página 80.

${ }^{41}$ Idemibidem. Página 63. 
promulgação do AI-05 não tenham mudado drasticamente a relação do Estado com os povos indígenas; nem que a criação de uma polícia indígena para, como diz em seu decreto de criação, 'executar o policiamento ostensivo das aldeias' não fosse algo até então inédito. $\mathrm{O}$ Relatório da Comissão Nacional da Verdade, em seu capítulo que analisa violações contra povos indígenas, assinala: "omissão e violência direta do Estado sempre conviveram na política indigenista, mas seus pesos respectivos sofreram variações. Poder-se-ia assim distinguir dois períodos entre 1946 e 1988, o primeiro em que a União estabeleceu condições propícias ao esbulho de terras indígenas e se caracterizou majoritariamente (mas não exclusivamente) pela omissão, acobertando o poder local, interesses privados e deixando de fiscalizar a corrupção em seus quadros; no segundo período, o protagonismo da União nas graves violações de direitos dos índios fica patente, sem que omissões letais, particularmente na área de saúde e no controle da corrupção, deixem de existir. Na esteira do Plano de Integração Nacional, grandes interesses privados são favorecidos diretamente pela União, atropelando direitos dos índios. A transição entre os dois períodos pode ser datada: é aquela que se inicia em dezembro de 1968, com o AI-5"42. Portanto, nos parece correto ler a criação da Grin dentro do contexto da militarização do aparato de Estado no pós AI-05, e também do início iminente do período de grandes obras, como a Transamazônica, e maior intervenção estatal no Norte do país. Cumpre lembrar que, depois do primeiro presidente da Funai, José de Queiroz Campos, os seguintes foram militares.

É importante, também, `situar o processo de criação da GRIN em um contexto local: três anos antes, em 1966, ocorrera uma rebelião entre os índios Maxacali, na divisa entre Minas e Bahia. Em meio a uma crise de alimentos, os índios começaram a atacar e matar o gado de fazendas vizinhas. Também questionaram os baixos preços pagos pelos arrendatários de suas terras. Por fim, insurgiram-se contra uma tentativa de fazendeiros de, por meios judiciais, reduzir a área indígena de uma aldeia da região. Como narra Rubens Valente: "Cerca de 350 guerreiros fabricaram arcos, tacapes e 'flechas envenenadas', segundo relatou um engenheiro agrônomo"43 . É nesse contexto que surge a figura do Capitão Pinheiro, capitão da

\footnotetext{
42 Comissão Nacional da Verdade. 2014b. Volume II - Textos temáticos. Texto 5: "Violações de direitos humanos dos povos indígenas". Disponível em: http://www.cnv.gov.br/. Último acesso: 29.01.2021.

${ }^{43}$ VALENTE, Rubens. Os fuzis e as flechas - histórias de sangue e resistência indígena na ditadura. São Paulo, Companhia das Letras, 2017.
} 
Polícia Militar de Minas Gerais e sobrinho do governador, Israel Pinheiro, que assume o controle da administração do posto indígena e idealiza a GRIN. Como ele próprio afirma: "fui eu quem criou a Grin [...] Tratei logo de prender os índios que lideravam o movimento [maxacali] e fui pouco a pouco restabelecendo a paz no local. Meu trabalho foi considerado excelente e assim fui convidado pela presidência da Funai para trabalhar com os índios de Minas Gerais"44. Assim, um componente fortemente repressivo marca a história da Grin desde sua origem. Codato chama a atenção para a ideologia anticomunista como aglutinador da passagem do golpe a regime no pós AI-5 ${ }^{45}$. É necessário enxergar a criação da GRIN num contexto mais amplo de combate, pelo regime, à dita 'subversão'. Não apenas no que tange à rebelião Maxacali, especificamente, mas, tendo em vista a formulação do projeto de formar até 3 mil indígenas militares ${ }^{46}$, também como um desejo de infiltrar olhos do Estado nos interiores onde se localizam as aldeias. Freitas assinala, por exemplo, que a Ajudância Minas Bahia, a mesma chefiada por Capitão Pinheiro, "mobilizava-se por dar conta da possível travessia por aquelas bandas do guerrilheiro Carlos Lamarca ${ }^{47 "}$. Criada por decreto em 1969 e tendo sua primeira (e única) turma formada em meados de 1970, a GRIN é contemporânea ao acirramento da repressão política no país, e uma decorrência da mesma.

Um ano antes da promulgação do AI-05 foi divulgado o assim chamado 'Relatório Figueiredo', que trouxe diversas consequências para a relação da ditadura com os povos indígenas $^{48}$. Relatório Figueiredo foi o nome dado ao relatório conclusivo de uma CPI

\footnotetext{
${ }^{44}$ Jornal do Brasil, Rio de Janeiro, Primeiro Caderno, 27 agosto 1972.

45 "essa ideologia funcionava como o elemento de coesão entre as facções radicais e moderadas"; CODATO, Adriano Nervo. O Golpe de 1964 e o regime de 1968: aspectos conjunturais e variáveis históricas, em: História: Questões e Debates. Curitiba, Editora UFPR, 2004.

46 “ao todo, a guarda deverá ter mais de 3 mil índios, que serão selecionados e treinados, gradativamente, pela Polícia Militar de Minas Gerais”. O Globo, Rio de Janeiro, Geral, p. 14, 18 de novembro de 1969.

${ }^{47}$ FREITAS, Edinaldo Bezerra de. A guarda rural indígena (GRIN). Aspectos da militarização indígena no Brasil. Anais do XXVI Simpósio Nacional de História - ANPUH. São Paulo, julho de 2011. Página 11.

48 O Relatório Figueiredo tem trajetória semelhante a nosso material de arquivo: sendo originalmente do final dos anos 60, ele foi considerado perdido até sua reemergência, em 2012, também pelas mãos de Marcelo Zelic. Segundo Zelic, em conversa com nossa pesquisa: 'o Relatório Figueiredo e o 'arara' são frutos da mesma visita. Os dois são frutos da incidência lá [no Museu do Índio], passar um dia conversando com os funcionários e explicando todo o contexto que muda, da importância dos arquivos, com a Comissão da Verdade. Os dois materiais encontrados saem dessa relação.' - Relatório Figueiredo. Processo n4.483/68. Disponível em: http:// www.mpf.mp.br/atuacao-tematica/ccr6/dados-da-atuacao/grupos-de-trabalho/violacao-dos-direitos-dos-povosindigenas-e-registro-militar/relatorio-figueiredo - último acesso: 29.01.2021.
} 
instaurada por determinação do então Ministro do Interior, General Afonso de Albuquerque Lima. O contexto dessa investigação é complexo ${ }^{49}$. Rubens Valente atenta para o fato de que uma das justificativas dadas pelos militares para o golpe de 64 era a alegada necessidade de moralizar a administração pública ${ }^{50}$. A título de exemplo, cabe notar que a edição do AI-01 comparava o crime contra o Estado ou seu patrimônio à deflagração de 'atos de guerra revolucionária'. Assim, as extensas denúncias de corrupção e violações por parte de servidores do SPI, em períodos anteriores à 1964, se encaixavam nos procedimentos de Estado que, em tese, os militares teriam vindo moralizar. Outro elemento importante foi o conflito entre índios Bororo e fazendeiros do Mato Grosso, que, apoiados pelo Governador do Estado, Pedro Pedrossian, tinham invadido e tentavam se apropriar de parte de uma terra indígena já demarcada, conflito este que havia levado à instalação de uma CPI prófazendeiros no ano de 1963, que resultou inconclusa. Nesse contexto, Albuquerque Lima decidiu ampliar o escopo das investigações dessa CPI, e trazer alguém de fora do SPI para chefiá-la. Jáder Figueiredo era procurador do Departamento Nacional de Obras contra a Seca, e não tinha nenhuma relação anterior com o tema da investigação ${ }^{51}$. O procurador atuou em consonância não apenas com Albuquerque Lima, mas também com o SNI ${ }^{52}$ - como afirma Rubens Valente: "suas ligações com o SNI devem ser ressaltadas para prevenir a eventual interpretação de que o procurador se 'rebelou' contra a ditadura. $\mathrm{Na}$ realidade, seu trabalho todo foi amparado e acompanhado pelos militares. Talvez seus apoiadores não contassem com a repercussão do resultado final do trabalho, mas Jáder estava longe de ser um opositor do governo $^{53}$ ". Jader não investigou pontos sensíveis à ditadura, como a transferência de índios Xavante em $1966^{54}$. Ele também não visitou todos os postos do SPI, apenas alguns - ele

49 Para um aprofundamento no que foi o Relatório Figueiredo e suas denúncias, ver GUIMARÃES, Elena. RELATÓRIO FIGUEIREDO: entre tempos, narrativas e memórias. Dissertação de Mestrado, Programa de Pós- Graduação em Memória Social, Universidade Federal do Estado do Rio. Rio de Janeiro, 2015

${ }^{50}$ VALENTE, Rubens. Os fuzis e as flechas. São Paulo, Companhia das Letras, 2017.

51 Jader Figueiredo: "eu não conhecia o problema indígena, a não ser por leituras esparsas como, acredito, qualquer brasileiro". Relatório com a íntegra dos depoimentos prestados à CPI do índio constituída em abril de 1968 (Diário do Congresso Nacional, Brasília, 28 abril 1971, suplemento ao n. 15).

52 Jader Figueiredo: "durante todo o nosso trabalho, desde que iniciamos em Brasília, fomos muito auxiliados pelo SNI. Verdadeiramente, fomos acompanhados em todos os momentos por elementos do SNI que se prestaram a colaborar conosco e nos ajudaram demais". Idemibidem.

${ }^{53}$ VALENTE, Rubens. Os fuzis e as flechas. São Paulo, Companhia das Letras, 2017. Página 37.

${ }^{54}$ Idemibidem. 
próprio chegou a calcular que visitou apenas um terço do necessário. Apesar disso, a Comissão produziu um documento devastador - nas palavras do próprio relatório: "mas se não é possível uma exata apuração nem por isso deixou-se de averiguar serem tantos e tão horríveis os crimes, que o SPI pode ser considerado o maior escândalo administrativo do Brasil $55 \%$.

O Relatório agrupou as denúncias mais diversas e bárbaras. Esbulho de terras indígenas, escravidão, tortura, sequestro de crianças, extermínio de aldeias inteiras; eram desta ordem as acusações feitas. Nas palavras do próprio Relatório, em sua conclusão: “O índio, razão de ser do SPI, tornou-se vítima de verdadeiros celerados, que lhe impuseram um regime de escravidão e lhe negaram um mínimo de condições de vida compatível com a dignidade da pessoa humana. É espantoso que exista na estrutura administrativa do País repartição que haja descido a tão baixos padrões de decência. E que haja funcionários públicos, cuja bestialidade tenha atingido tais requintes de perversidade. Venderam-se crianças indefesas para servir aos instintos de indivíduos desumanos. Torturas contra crianças e adultos, em monstruosos e lentos suplícios, a título de ministrar justiça ${ }^{56}$. (...) O Serviço de Proteção aos índios degenerou a ponto de persegui-los até ao extermínio. Relembram-se aqui os vários massacres, muitos dos quais denunciados como escândalo sem, todavia, merecer maior interesse das autoridades. Citaremos, entre outros as chacinas do Maranhão, onde fazendeiros liquidaram toda uma nação, sem que o SPI opusesse qualquer reação. (...) Jamais foram apuradas as denúncias de que foi inoculado o vírus da varíola nos infelizes indígenas para que se pudessem distribuir suas terras entre figurões do Governo. Mais recentemente os Cintas-Largas, em Mato Grosso, teriam sido exterminados a dinamite atirada de avião, e a extricnina adicionada ao açúcar enquanto os mateiros os caçam a tiros de "pi-ri-pipi” (metralhadora) e racham vivos, a facão, do púbis para a cabeça, o sobrevivente!!! Os criminosos continuam impunes, tanto que o Presidente desta Comissão viu um dos asseclas deste hediondo crime sossegadamente vendendo picolé às crianças em uma esquina de Cuiabá, sem que justiça Matogrossense o incomode 57 ".

\footnotetext{
${ }^{55}$ Relatório Figueiredo. Processo n4.483/68. Vol. XX. Fl. 4915.

56 Ibid. Fl. 4912.

${ }^{57}$ Ibid. Fls. 4916-17.
} 
Não iremos aqui nos deter nas inúmeras e contundentes denúncias - o trabalho de Guimarães é profícuo nesse sentido. Nos interessa aqui mensurar o tamanho do escândalo e da intensa repercussão que se seguiu às primeiras publicações das conclusões da CPI, em especial fora do país. Conforme registra Guimarães: “Em 20 de março de 1968 o Ministro do Interior, o Gen. Albuquerque Lima, deu uma entrevista coletiva no Rio de Janeiro, onde tornou público o resultado do Relatório Figueiredo. A imprensa nacional e internacional dá repercussão às denúncias, e a imprensa da época divulga o relatório como sendo 'o escândalo do século'. O Jornal do Brasil de 28 de março de 1968 publica em seu editorial e em matéria de página inteira texto em que narra a indignação da opinião pública e da imprensa internacional diante do conhecimento dos diversos crimes cometidos contra os índios. Estes textos mostram, ainda, a defensiva do Ministério diante da repercussão internacional. Houve manifestações pela imprensa de diversos países, aparecendo na primeira página do New York Times (EUA) e como tema em edições do Los Angeles Times (EUA), Sunday Times (Inglaterra), Neue Revue (Alemanha), L’Express e Le monde (França) e Limen (Romênia). No L'Express, a abertura da matéria Genocídio na Amazônia é falando sobre os 'três meses de inquérito que acabam em um enorme escândalo'. E a Lumen, revista romena, órgão oficial dos Jornalistas da Romênia, pediu à Agência JB, 'o noticiário completo sobre o inquéritoescândalo ${ }^{58}$. Há de se acrescentar ainda a publicação, pelo jornalista britânico Norman Lewis, em fevereiro de 1969 no Sunday Times de Londres intitulado 'Genocídio - de Fogo e Espada a Arsênico e Balas, a Civilização mandou seis milhões de índios para a extinção'59"’.

Não deve ser subestimada a importância, para o regime ditatorial, da imagem internacional do mesmo. As denúncias de massacre e genocídio prejudicavam as relações internacionais em um período em que os grandes empreendimentos planejados pelo governo, como a construção de rodovias e usinas hidrelétricas, demandavam parceria e investimento de capital estrangeiro.

Ainda conforme Guimarães: "Em 1968, às vésperas da realização da I Conferência Internacional sobre Direitos Humanos, em Teerã, o governo brasileiro é pressionado a

\footnotetext{
58 Jornal do Brasil, Rio de Janeiro, 28 de março de 1968.
}

59 GUIMARÃES, Elena. RELATÓRIO FIGUEIREDO: entre tempos, narrativas e memórias. Dissertação de Mestrado, Programa de Pós- Graduação em Memória Social, Universidade Federal do Estado do Rio. Rio de Janeiro, 2015. 
apresentar explicações acerca das violações de direitos humanos aos povos indígenas, sob o risco de o caso brasileiro vir a ser tema de discussão na Conferência. Em nota publicada, prestando contas ao Itamaraty, em resposta às acusações da imprensa e, em especial, ao Le Monde, o Ministério do Interior tenta minimizar a dimensão dos crimes, dizendo que 'os pretensos crimes de genocídio não passam de conflitos muito mais violentos na história de outros povos'. E que a mortandade é resultado da 'cobiça da civilização', aliada ao fato de que o índio é 'desequipado mental e materialmente para defender sua propriedade' 60 ". Rubens Valente ressalta que "diante da possibilidade de as denúncias virem a ser tratadas numa reunião da Organização Internacional do Trabalho (OIT), no México, o ministro do Trabalho, coronel Jarbas Passarinho, recebeu um dossiê sobre o assunto para municiar a delegação brasileira. O governo procurava dizer que os problemas eram de governos anteriores (...) Numa parada em Lisboa a caminho do México, Passarinho foi interpelado por jornalistas sobre as denúncias de 'genocídio' indígena. Ele respondeu: 'É verdade que existe esse problema, criado pela nossa própria imprensa, mas são coisas já ultrapassadas no tempo'61”.

As respostas do governo federal incluíram o afastamento de mais de 300 servidores do SPI, a extinção deste órgão e a criação, em dezembro de 1967, da Funai. Segundo declaração do Ministro Albuquerque Lima ao Jornal do Brasil, em 1968, "Por iniciativa do Ministério do Interior, está em via de implantação a Fundação Nacional do Índio, entidade moderna e despida dos erros antigos, e que tem por finalidade precípua impor o respeito à pessoa do índio e às instituições e comunidades tribais, bem como garantir a posse permanente das terras que habitam e o usufruto exclusivo dos recursos naturais e de todas as utilidades nela existentes $^{62}$ ". Guimarães assinala que "as decisões de fechar o SPI e criar a FUNAI em seu lugar, a promessa de punição dos envolvidos no escândalo e a promessa de devolução das terras aos indígenas foram medidas propostas para remediar a imagem negativa que foi projetada no exterior. Estas promessas levaram a um enfraquecimento do protesto internacional contra a política indigenista brasileira e, com isso, o governo brasileiro evitou a

\footnotetext{
60 Idemibidem.

61 O Estado de São Paulo, p. 78. 13 de junho de 1968, in: VALENTE, Rubens. Os fuzis e as flechas. São Paulo, Companhia das Letras, 2017.
}

${ }^{62}$ Ministério diz que não acusou no caso SPI. Jornal do Brasil, Rio de Janeiro, 28 de março de 1968. 
investigação pelas Nações Unidas ${ }^{63} "$.

É neste contexto, portanto, que é criada a Funai, em dezembro de 1967, e que é proposta, dois anos depois, a instalação de uma Guarda Rural Indígena. Gostaríamos, portanto, de sublinhar a luta do regime por defender a imagem da ditadura no exterior. Assim, a produção de uma cerimônia pública de formatura, com diversos jornalistas nacionais e estrangeiros convidados, parece corroborar tal preocupação.

Como já dito, não era pequena dentro do regime militar a preocupação com sua imagem internacional. Após intensos movimentos oposicionistas ao longo de 68 e o endurecimento do regime com o AI-5, pressões por mudanças eram controladas com lupa um movimento internacional de críticas ao regime por conta da questão indígena era tudo o que o governo queria evitar. A título de exemplo desta preocupação com a imagem do regime, cabe destacar a criação da Embrafilme, em 12 de setembro de 1969 (contemporâneo, portanto, à GRIN), sendo que seu começo não se deu na área de fomento à produção, mas sim na distribuição internacional de filmes brasileiros. Em um contexto não só de politização de parte da produção nacional, como também de difusão das chamadas 'pornochanchadas', o governo decidiu agir investindo numa empresa que centralizasse e controlasse a forma de difusão no exterior desses filmes, temendo prejuízo à imagem internacional do país e do regime. Também, é do mesmo ano a formação de uma infra-estrutura de transmissão televisiva, possibilitando a transmissão em rede nacional - o primeiro Jornal Nacional é de 10 de setembro de 1969; e a copa do mundo de 1970, um ano depois, foi a primeira transmitida nacionalmente ao vivo.

O prisma aqui proposto se evidencia quando analisamos os discursos oficiais à época da formatura da primeira turma da GRIN. Matéria do Jornal do Brasil de 6 de fevereiro de 1970 anuncia que na cerimônia, diante dos indígenas fardados, o ministro do Interior, coronel Costa Cavalcanti, afirmou que "esta é a resposta mais eloquente aos que, desconhecendo o nosso índio ou por motivos não confessados, referem-se ao problema do silvícola brasileiro

63 GUIMARÃES, Elena. RELATÓRIO FIGUEIREDO: entre tempos, narrativas e memórias. Dissertação de Mestrado, Programa de Pós- Graduação em Memória Social, Universidade Federal do Estado do Rio. Rio de Janeiro, 2015. 
em termos caluniosos"64. A própria matéria se refere a um convite feito pela Funai para que jornalistas estrangeiros assistissem à cerimônia. Mais do que apenas se esquivar das acusações, a criação da GRIN se insere em um esforço de ativamente combatê-las, como se evidentemente a criação de uma guarda militar indígena em tudo se contrapusesse às críticas de violações de direitos por parte do Estado. É este o motivo dos diversos desfiles militares de que participaram os guardas indígenas ao longo do ano de 1970: matéria do Jornal do Brasil anuncia 04 desfiles distintos na semana do índio de 1970, chamada de 'páscoa da fraternidade' 65 .

Freitas assinala que "de imediato, a Grin passou a ser fator de propaganda oficial. Uma matéria editada no Correio da Manhã de 14 de janeiro de 1970 afirmava que o Presidente da República, Emílio Gastarrazu Médici aprovara o relatório sobre os índios, elaborado por uma comissão mista do governo, onde desmentia-se a acusação 'leviana' de massacre do indígena brasileiro. Na reportagem, o Ministro do Interior, Costa Cavalcante, tentava esclarecer os 'equívocos', afirmando que as 'boas coisas' feitas em favor do índio não eram reconhecidas pela imprensa. Nesse caso, citava a Guarda Indígena que 'estava sendo treinada para proteger seus próprios irmãos. Cada tribo teria sua polícia e o objetivo é evitar que elementos estranhos se infiltrem entre os índios '66".

Ampla matéria do Diário de Notícias de 3 de maio de 1970 traz um verdadeiro painel publicitário do governo, sob o sugestivo título "São bem tratados os índios do Brasil"67. Além de defender o golpe de 64 e a extinção do SPI e a criação da Funai, a matéria fala que a Guarda foi criada "a fim de que o índio participe ativamente em sua própria aculturação", e a localiza como uma "resposta que o Governo dá à campanha infamante partida do exterior e que tanto repercutiu no espírito de um povo orgulhoso das suas origens indígenas e cioso dos compromissos assumidos perante os organismos internacionais". A forma direta com que são conjugados na frase a 'campanha difamante' e os 'organismos internacionais' dá a ver não só o

\footnotetext{
${ }^{64}$ Jornal do Brasil, Rio de Janeiro, 6 de fevereiro de 1970.

65 Jornal do Brasil, Rio de Janeiro, 6 de abril de 1970.

66 FREITAS, Edinaldo Bezerra de. A guarda rural indígena (GRIN). Aspectos da militarização indígena no Brasil. Anais do XXVI Simpósio Nacional de História - ANPUH. São Paulo, julho de 2011. Página 10.
}

${ }^{67}$ Diário de Notícias, Rio de Janeiro, 3 de maio de 1970. 
tamanho da importância atribuída a esses fatos, mas também a relação direta entre a criação da GRIN e a tentativa de responder a tais acusações.

A GRIN foi instituída por uma portaria, a portaria 231/69, datada de 25 de setembro de 1969, que foi assinada pelo presidente da Funai, José de Queiroz Campos, conforme imagem abaixo:

\begin{tabular}{|c|c|}
\hline 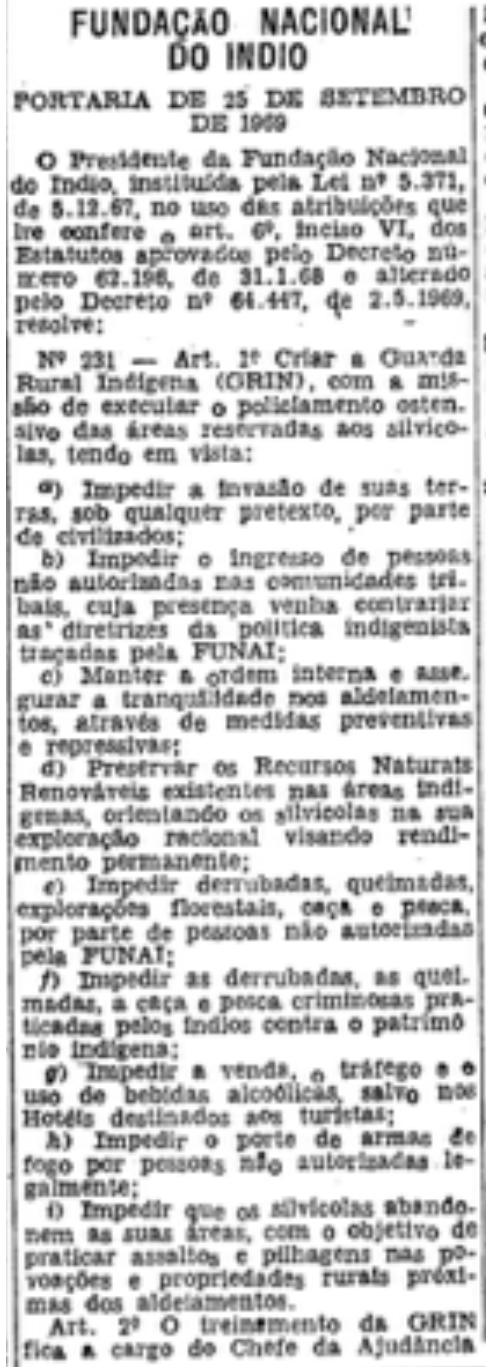 & 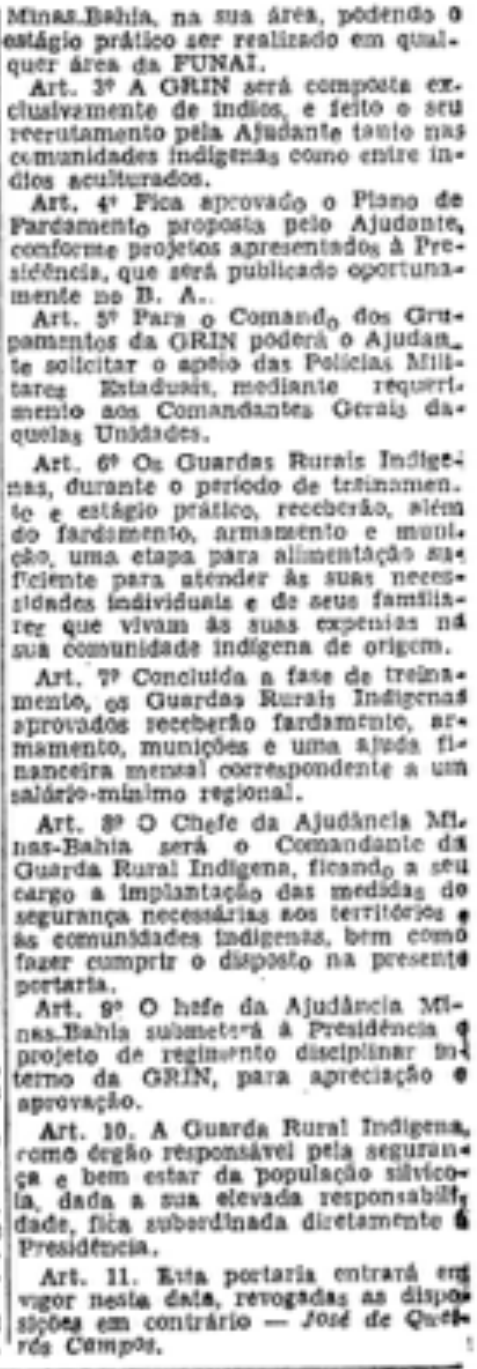 \\
\hline
\end{tabular}

Não é nossa intenção aqui narrar detidamente o evento histórico da GRIN, com as violências, opressões e contradições que lhe são próprias - para tal narrativa, o trabalho de Freitas $^{68}$ é bastante detalhado. O que nos interessa, para poder melhor compreender nosso

68 FREITAS, Edinaldo Bezerra de. Índios-Soldados - A GRIN e a tradição Militar da Política Indigenista Brasileira. Tese de Doutorado, Programa de pós-graduação em História Social da Universidade de São Paulo. São Paulo, 1999. 
material de arquivo, é entender o percurso que se deu até o dia da formatura - a escolha das etnias que fariam parte da guarda, o recrutamento e o posterior treinamento, que culminariam na formatura registrada por Jesco. Até aqui, buscamos apontar os motivos de criação da GRIN do ponto de vista dos militares - os idealizadores e responsáveis pelo estabelecimento da Guarda. Começaremos, agora, a entrever a experiência dos próprios indígenas, que foram submetidos a esse estranho experimento histórico.

"Para saber é preciso imaginar-se ${ }^{69 "}$. É preciso que imaginemos nós o tamanho do equívoco, do desencontro cultural, histórico e político que significou o encontro provisório entre militares e indígenas gerado a partir da criação de uma Guarda Rural Indígena. É preciso imaginar a situação concreta: os 84 indígenas, a maior parte dos quais quase sem relações anteriores com os brancos, quase sem falar português, de 5 etnias distintas, arrancados a suas aldeias por uma visita do Capitão Pinheiro, uma seleção apressada e uma ida longa de caminhão até Belo Horizonte, onde receberam, por curtos três meses, um treinamento militar. É preciso imaginar a situação dos policiais que eram professores, o contexto, no auge da repressão da ditadura civil-militar, com o combate à luta armada, as práticas de tortura cada vez mais frequentes dentro dos quartéis, e a tentativa de disciplinar, de forma acelerada, violenta e atrapalhada, estes 84 indígenas.

É preciso que imaginemos a série de desentendimentos, de incompreensões, de violências, de equívocos enfim, que essa situação algo surreal provocou, é preciso que tenhamos isso em mente para que possamos, mais à frente, conseguir ler nosso material de arquivo.

Viveiros de Castro aponta a noção de equívoco como fundante da relação entre indígenas e não-indígenas: o equívoco é a "condição de possibilidade do discurso antropológico - ele é aquilo que justifica a existência da antropologia. Traduzir é instalar-se no espaço do equívoco e habitá-lo. Não para desfazê-lo, pois isso suporia que ele nunca existiu, mas, ao contrário, para enfatizá-lo ou potencializá-lo, isto é, para abrir e alargar o espaço que se imaginava não existir entre as linguagens conceituais em contato - espaço que, justamente, o equívoco ocultava. O equívoco não é aquilo que impede a relação, mas aquilo

${ }^{69}$ DIDI-HUBERMAN, Georges. Imagens apesar de tudo. Lisboa, Editora KKYM. 2004. 
que a funda e a propele, uma diferença de perspectiva. Traduzir é presumir que há desde sempre e para sempre um equívoco; é comunicar pela diferença, em vez de silenciar o Outro, ao presumir uma univocalidade originária e uma redundância última - uma semelhança essencial - entre o que ele e nós 'estávamos dizendo"70". Ele afirma, ainda, citando Roy Wagner, que o conceito antropológico de cultura seria o equívoco que surge como tentativa de solução para a equivocidade intercultural; e ele seria equívoco porque se assentaria "no paradoxo criado ao se imaginar uma cultura para um povo que não a imagina para si mesmo $^{71}$ ". Viveiros usa tal dimensão para pensar a relação entre antropólogos e indígenas. $\mathrm{O}$ que pensar então quando do contato provisório, incerto e violento entre indígenas e militares feito a partir da ideia, concebida por um policial de Minas Gerais, de estabelecer, no ápice da ditadura militar, uma guarda indígena para policiar as aldeias? Queremos aqui sublinhar não a delicada noção de Viveiros, mas a distância violenta e intransponível entre aqueles que formularam a política da Grin e os indígenas que efetivamente a vivenciaram. Mais do que a noção inevitável de equívoco, podemos aqui imaginar o imenso fosso entre militares e indígenas, um equívoco ao quadrado, um verdadeiro abismo.

Em nossa pesquisa, tivemos o privilégio de conversar com alguns indígenas que fizeram parte, quase meio século atrás, da GRIN ${ }^{72}$. Equívocos de tradução à parte, tendo em vista a imensa distância existente também entre nossa equipe e eles, é possível entrever nas conversas o imenso fosso entre aquilo que era dito pelos militares no processo de recrutamento e treinamento, e o que era compreendido pelos indígenas. Em relação ao período de recrutamento e, em especial, de treinamento, as teses a que tivemos acesso em geral pouco tratam - apenas algumas matérias de jornal, a que também faremos referência. Por isso, trazemos aqui os relatos que colhemos em campo para retratar melhor a experiência histórica da GRIN.

\footnotetext{
${ }^{70}$ VIVEIROS DE CASTRO, Eduardo. Equívocos da Identidade, in: GONDER, Jô e DOBEDEL, Vera (orgs.) O que é memória social. Rio de Janeiro, Contracapa, 2005.

${ }^{71}$ Wagner, Roy. The invention of Culture. Chicago: chicago university press. 1981. P. 27.

72 Esta pesquisa é paralela ao documentário A Flecha e a Farda (Miguel Antunes Ramos, 2020), de nossa direção, que conversou com guardas Xerente e Krahô no final de 2018. Pesquisa e filme são objetos autônomos. Nesta dissertação, citaremos alguns trechos de conversas gravadas - alguns estão também presentes no filme, outros não. Os depoimentos podem ser melhor acompanhados no documentário.
} 
Segundo o Capitão Pinheiro, em depoimento registrado nos anos 90, a escolha das etnias que comporiam a GRIN teria se dado em grupos cujo contato com os brancos teriam acontecido há algum tempo - ele afirma que participaram da GRIN 'só tribos aculturadas, que tavam trazendo um problema sério para a Funai, de bebida, de alcoolismo e prostituição ${ }^{73}$. Apesar dessa formulação equivocada, a grande maioria dos indígenas selecionados não sabia uma palavra de português. Segundo Alcides Pirka Krahô, em depoimento à nossa pesquisa:

"Talvez os brancos ficaram com vergonha da gente [no caminho entre a aldeia e Belo Horizonte], onde a gente parava a gente fazia fogueira pra assar nossa comida. Vinha os brancos olhar a gente porque a gente tava pelado. Alguns que nunca tinham viajado nem queriam comer pão, nem café, porque não conheciam ${ }^{74 "}$.

Alguns dos indígenas que conversamos nos narraram como foi feita a seleção, pelo próprio Capitão Pinheiro, daqueles que viriam a se formar em Belo Horizonte. O nível de mal-entendidos, bem como a imensa distância entre os militares e os indígenas deixa explícita a brutalidade da ação do Estado. Alcides narra a chegada do avião - os próprios indígenas construíram a pista de pouso onde Capitão Pinheiro pousou para efetuar seu recrutamento; o caminhão que os levaria para se tornarem guardas saiu apenas três dias depois da chegada de Pinheiro. Segundo Alcides:

“Algumas pessoas da aldeia se juntaram. Não teve aviso prévio, de repente... já haviam encomendado os materiais para serem usados, depois ficou tudo certo...

E avisaram o Pedro Penon [o cacique Krahô à época] lá na Aldeia Pedra Branca... e avisaram também na Cachoeira e no Galheiro.

Naquele dia o pessoal se juntou no campo de pouso, ali pro rumo da serrinha.

Eles se juntaram e começaram a capinar o campo de pouso. Campo de avião.

Ai fomos trabalhando. E depois terminamos.

Ai disseram: agora vai vir um avião e pousar aqui.

\footnotetext{
73 FREITAS, Edinaldo Bezerra de. Índios-Soldados - A GRIN e a tradição Militar da Política Indigenista Brasileira. Tese de Doutorado, Programa de pós-graduação em História Social da Universidade de São Paulo. São Paulo, 1999.

${ }^{74}$ Reproduzimos aqui um trecho do depoimento falado na língua Krahô e depois traduzido ao português, com intervenções de um mediador, Renato Krahô, que nos auxiliou na conversa com Alcides.
} 
Naquela época era tempo de chuva. A chuva era como essa de agora. O pessoal se ajuntou no tempo da seca ainda. E aí, depois que terminaram, veio um aviãozinho que pousou, um tal de dois motores.

'Pronto, tô chegando agora com a proposta de pegar alguns jovens pra Grin, guarda rural indigena'.

O avião estava lá, e alguns foram correndo pro rumo do posto.

Depois ao entardecer, chamaram o pessoal, e foi escolhendo quem ia levar.

- quem escolhia?

- Um branco

- vocês se juntaram no pátio?

- foi lá no posto mesmo, um lugar muito limpo. Na época do SPI tinha um pessoal que ficava limpando ali

- era os brancos que escolhiam as pessoas e não o cacique?

- sim, eram os brancos mesmo. Eles falaram pra gente que dentro de três dias ia vir um carro buscar a gente.

'vamos levar vocês pra se transformarem em Grin, soldados', foi isso o que eles pensaram.

Depois todo mundo se espalhou, e dentro de dois dias o pessoal que tinha sido escolhido já estava no lugar marcado.

(...)

O que eu ia levar? Naquela época eu não tinha nada. Não tinha sacola, nada. Eu não tinha nem calção. Tava nu. Só amarrado com coberta.

- mas vocês subiram assim mesmo?

- aí nós subimos no caminhão. ${ }^{75}$ ”

Valdir Xerente narra que no começo ${ }^{76}$, “A gente foi, nós não sabia o que é ser soldado, não sabia o que era a Grin. Lá que botaram o nome de a Grin. Chegou lá um capitão, o Capitão Pinheiro, pra levar nós, foi aqui de carro.

\footnotetext{
${ }^{75}$ Idemibidem.

${ }^{76}$ Valdir Xerente deu sua entrevista em português. A transcrição aqui está feita idêntica à fala. Há uma pergunta, feita por nós durante a conversa, assinalada com um travessão.
} 
Chegou lá. Lá pediu nós se nós queria ser soldado. Nós com 18 anos. Escreveu nas nossas costas, cada um que queria escreveu nas nossas costas. Foi lá, não tinha nem estrada.

(...)

- como que foi, ele desceu do avião, como que aconteceu?

- Ele veio, depois que nós fizemos o campo, ele veio... Mil metros. Daí desceu o avião lá. Trazia cesta básica pra nós. 'Cês vão?' Se levar eu vou, tem que ir.

- ele explicou pra que que era na hora?

- não, explicou pra ser soldado só. Lá que depois explicou, falou que era pra fazer demarcação, pra vigiar as áreas”.

Esse ponto, de uma promessa por demarcação das áreas indígenas, aparece em diversas falas dos ex-guardas, em especial entre os Xerente. Basílio Xerente, por exemplo, afirmou, quando perguntado por nossa equipe sobre como o que Capitão Pinheiro falou no ato do recrutamento ${ }^{77}$ :

"Ele veio aqui... E disse que se nós interessássemos era para ir daqui fazer curso lá, em Belo Horizonte. Pra ser Guarda Rural Indígena. Defender. Defender as áreas. Então a gente se interessou e foi lá.

- Quando vocês perguntaram o que era Guarda Rural Indígena, ele falou que era para defender as áreas?

- Uhum. Para nós defendermos as áreas, porque... invasão aqui era muita... Bem aqui, era a tapera de um branco que morava aqui. Aqui era cheio [de branco]."

Manoel Suken confirma um relato parecido, se referindo ao que teria sido dito pelo Capitão Pinheiro quando da formatura, em Belo Horizonte ${ }^{78}$ :

"Ele falou... A Funai mesmo falou, esse capitão: 'Vocês estão vendo isso aqui? Isso aqui, determinado para ser a GRIN, é para vocês adquirirem a terra de vocês. Lá, vocês vão trabalhar com posseiro. E a terra de vocês vai ser demarcada, através de vocês'."

\footnotetext{
77 Basílio Xerente também deu sua entrevista em português, aqui transcrita de forma literal.

78 Manuel Suken, idem.
} 
Esse ponto nos parece ser um dos equívocos que rondam essa história. É recorrente, em especial nos relatos dos ex-guardas Xerente, essa narrativa, da demarcação da terra como objetivo da criação da Guarda. E de fato, a demarcação da Terra Indígena Xerente se deu em 1972, durante o período de vigência da GRIN. Porém, seria um equívoco imaginar ou formular que essa fosse uma intenção do projeto, de demarcar as terras dos grupos que participavam da guarda. Em primeiro lugar, cabe destacar que a demarcação de qualquer terra indígena é um processo longo, que se faz através de lutas e movimentações extendidas no tempo. Seria, portanto, equivocado pensar que a ação do Capitão Pinheiro, em Minas Gerais, ao imaginar a criação de uma Guarda Rural Indígena teria relação com essa demarcação. $\mathrm{O}$ que parece haver, aqui, é a concomitância de dois processos - e é importante estar atento à essa concomitância, ou melhor, às formas como temporalidades distintas convivem e se atropelam. De um lado, processos e temporalidades que remetem ao Estado, bem como às lutas políticas que envolvem o Estado, como procuramos descrever neste capítulo - entre os quais constam elementos como o AI-05, o Relatório Figueiredo, entre outros. De outro lado, a temporalidade dos embates entre indígenas e os brancos do entorno, nas lutas por terra que caracterizam o cenário da maioria das etnias que estão em contato com o universo envolvente. Assim, os próprios indígenas são explícitos quando destacam a agência indígena na luta pela terra, como Nedina Xerente ${ }^{79}$ :

"Foi meu pai que foi atrás da reserva, da reserva indígena. Foi meu pai que foi. Se não fosse meu pai, não tinha mais nenhum índio, não. Já tinha morrido, tinham matado tudo. Porque eles queriam matar a gente”.

Além disso, se olharmos em conjunto para a questão da terra nas outras etnias, podemos notar que a Terra Indígena Krahô, por exemplo, já estava demarcada ${ }^{80}$, e que, entre os Maxacali, por outro lado, não apenas a terra não estava demarcada, como o próprio Capitão Pinheiro é acusado de possuir fazendas até hoje na Terra Indígena Maxacali ${ }^{81}$. Ou seja, a

\footnotetext{
${ }^{79} \mathrm{O}$ depoimento de Nedina também foi dado em português e transcrito aqui de forma literal.

${ }^{80}$ A Terra Indígena Krahô foi demarcada nos anos 40, e homologada em 1990 - https://pib.socioambiental.org/ pt/Povo:Krah\%C3\%B4 - acessado em 20 de janeiro de 2021.

81 Ministério Público Federal. 2015. Ação civil pública com pedido de antecipação de tutela, no 64483-95.2015.4.01.3800 de 10.12.15. Disponível em: https:/goo.gl/8qxWm4. Último acesso: 29.01.2021. Página 76.
} 
ocorrência histórica da gestão policial pelo Capitão Pinheiro da Terra Indígena Maxacali, que se deu em parte através da GRIN, teve como resultado, lá, o esbulho da terra indígena. Em suma, o que queremos frisar é que essa recorrência do discurso da terra parece fazer parte mais da percepção dos ex-guardas do que ali se passava, ou das estratégias de convencimento adotadas pelos militares, do que de um projeto do governo ditatorial que envolvesse de fato uma demarcação desses territórios. Isso se encaixa naquilo que queremos aqui sublinhar, a saber: a imensa e violenta distância entre os militares, que propuseram essa política, e os indígenas, que a viveram. Distância que pode ser entrevista no depoimento de Benjamin Xerente, que narra a ida até Belo Horizonte de caminhão. Ele descreve como passaram fome no caminho, comendo só rapadura e farinha ${ }^{82}$ :

“Aí nós saímos dia 01 de novembro. Dia do santo.

Pousemo lá em Miracema. Dia 02 de novembro nós toquemos.

Não tinha asfalto, só estrada de chão. Nessa época chovia muito. A gente viajou comendo rapadura com farinha branca, só o pó. Se você botasse a mão cheia na boca, tudo entalava. Engasgava. Era um saco grande de rapadura assim. E a gente enjoou daquilo, jogava nos pastos, irritado. 'Isso aqui não é comida não!'. Jogava nos carros que passava.

Aí chegaram no Ribeirão... a gente acampava, dormia. Todo mundo em cima da carroceria. No outro dia tocava.

Um dia a gente chegou lá pra lá de Porangatú, tem um rio lá, rio do ouro. Aí encostou lá. Aí os caras foram pescar. Pescaram arraia. Os Krahô pegavam, acendiam o fogo... a gente comia, porque não tinha outra coisa.

Ai o chefe de posto, tinha uma fazenda lá em Porangatu. Aí ele colocou nóis lá cedo. Mandou os vaqueiro juntar o gado, mandou escolher o boi maior que tivesse pra matar. Ai escolheu um boi, os krahô mataram lá.

'ai é o seguinte, eu vou dar uma banda pra vocês fazerem o que quiserem. E a outra banda vou salgar pra ter comida na estrada'. E não tinha outra coisa não, era só essa carne e a farinha branca. Aí os krahô 'vamo muquiá'. Acenderam o fogo. Aí a chuva veio desse jeito. Molhou tudo, apagou o fogo. Comemo assim mesmo, cru.

${ }^{82}$ Entrevista dada em português. A transcrição aqui está feita idêntica à fala. 
Chegamo em Goiânia, cheguemo lá na Funai, mandaram cozinhar. Panelinha pequena. Que hora que ferve? De manhã até hora dessas ainda tava esperando arroz cozinhar, e carne. Ainda comemos arroz duro e carne dura. Lá em Goiânia. Pousemo lá em goiânia, na Funai mesmo, no outro dia seguimo pra Brasília, e de Brasília seguimos pra Belo Horizonte”.

Ele continua seu relato, falando sobre a chegada em Belo Horizonte. Diz Benjamin: “Chegamos em Belo Horizonte era mais ou menos 8 horas da manhã.

Lá na Funai, que o Capitão Pinheiro trabalhava. Levou nóis pro quartel.

Nós dormia lá no colchão, na sala.

Fiquemos lá, só comendo. Dormindo, comendo. Ai eles deram remédio pra verme. Remédio forte... ei, nós ficamos até tonto. Todo mundo morto lá.

'Ninguém vai comer. Ninguém vai tomar café nem almoçar'

Nesse dia só tomei sopa. E café não.

Rapaz... Ficamo lá deitado, tonto. Por causa do remédio.

Aquilo é forte.

Aí meio dia a corneta tocou, todo mundo correu, pensando que era almoçar. Chegou lá, 'quem tomou remédio pra verme não vai comer não, só vai tomar sopa'. Sopa sem sal... quem que quer? Aí um krahô falou: 'eu quero é comer, quero comer arroz, não quero sopa não. Eu vou comer, nem que eu morra mas eu quero comer arroz, bota arroz ai.' Aí o Xerente, 'eu também quero, desse jeito. Nem que eu morra. Vou morrer de barriga cheia'.

Aí fiquemo lá, aí terminou. Aí ninguém podia sair de jeito nenhum, sair pra rua”.

Alcides Krahô faz narrativa semelhante, explicitando a estranheza do que se passava, bem como o aspecto propriamente biopolítico ${ }^{83}$ da gestão dos corpos indígenas que os militares faziam ao medicar, tirar sangue e controlar os corpos dos guardas. Diz Alcides:

“Quando chegamos lá,

Eles nos pesaram na balança, pra ver quantos kilos a gente pesava. Ai depois, quando era 13hs, eles colheram nosso sangue pra exame. Aí examinaram nosso sangue.

Eu fiquei só olhando o jeito que eles tavam fazendo e mesmo assim fiquei com medo, a gente não era acostumado com isso não. A gente não tinha costume com os brancos, por isso

${ }^{83}$ FOUCALT, Michel. O Nascimento da Biopolítica. São Paulo, Edições 70, 2010. 
estávamos com medo dessas coisas. Talvez um deles poderia nos enganar e fazer qualquer tipo de coisa ruim.

Depois disso eles passaram remédio contra verme na gente e nós tomamos, e depois ficamos com diarréia.

No dia seguinte eles nos deram uma comida bem leve pra comer.

A gente ficou com diarreia.

Depois que a gente melhorou ele falou: tá, agora tá tudo ok. Eles mediram a nossa cintura pra gente ganhar roupas, calça, camisa, boina... Pegaram o nosso número de sapato. Falaram que na próxima semana a gente ia iniciar o treino.

Eles falaram isso e ele foi embora e depois veio de novo

Tinha um negócio grande tipo caixa d'água que eles colocavam produto de noite e ateavam fogo. Quando eles colocavam fogo, era baixinho mas muito quente. Tinha um cheiro muito forte. A gente tinha que cheirar durante 10 minutos.

Dava vontade de vomitar. Os que tinham coração fraco, os que ficavam com medo não conseguiam ficar parado”.

Essa estranha cena, de uma fumaça que eles precisavam respirar, é descrita também por Manoel Sunken Xerente 84 :

“Aí passemo por aquele banho. A pessoa... a gente não morreu não sei porquê né. Botaram nós num lugar quente, né?! Quente mesmo... saía um suor que eu vou te dizer né?! Diz que isso era para a guerra né?!

O soldado diz que dá muito suor, né?! Quando ataca os outros, e quando corria, né, diz que tinha que suar pra não morrer de estupor. Aí botava nóis lá. Aí cada um de nós mergulhemo lá."

Valdir Xerente faz narrativa semelhante, descrevendo mais tal cena bizarra ${ }^{85}$ :

"Nós sofremos muito lá também. Sofremos mesmo.

Pra poder aprender, sol quente.

\footnotetext{
${ }^{84}$ Manoel Sunken deu seu depoimento em português, aqui transcrito de forma literal.

${ }^{85}$ Valdir Xerente, idem.
} 
A gente deitava assim no cimento. A gente não era acostumado. Mas quando a gente passou lá dez dias... Aí pegaram nós, botaram numa casa de gás lá, tudinho, fechou... Quase que nós morria lá dentro, aquele cheiro de gás... Quando abriu, cada um correu....

Sofremos, sofremos."

O grotesco dessa cena é quase inenarrável. Os indígenas, sacados de suas aldeias e levados de caminhão, sem nenhuma explicação, sem conseguirem compreender sequer o português direito, são levados a experienciar o que parecem ser táticas de contra-insurgência, algo como uma sauna, talvez um procedimento como acontece hoje em treinamentos da tropa de elite da polícia militar, respirando gás lacrimogênio para se habituar com eventuais confrontos urbanos? Estavam sendo treinados 'para a guerra'. O termo equívoco evidentemente não dá conta de narrar o tamanho da violência do gesto dos militares, a falta de percepção mínima em relação aos indígenas, bem como do imenso abismo entre o que eles tinham na cabeça em seus 'ensinamentos', no auge da ditadura, com a tortura e a repressão sendo cada vez mais institucionalizada, e o que de fato os indígenas ouviram ou apreenderam desse estranho encontro.

Destacaremos mais alguns trechos. Diz Alcides Krahô:

"Nós voltamos de lá e dentro de uma semana já trouxeram todos os equipamentos. Nós ganhamos calças e cada um foi vestindo a sua.

Só tinha um quarto para nós todos, éramos muitos, nós nos vestimos de madrugada e quando amanheceu o dia todos estavam preparados.

O treinamento começou rápido.

Nós não compreendíamos o português, só algumas poucas coisas. Aí iniciaram o treino com a gente. Durante uma semana, foi pra três semanas... Nós íamos marchando.

Dentro de um mês a gente foi conhecer um lugar de minério.

O lugar onde o pessoal lutava com as armas mesmo...

Passamos a tarde inteirinha lá, e depois voltamos para o alojamento.

(...)

Eles nos aconselhavam. Nos aconselhavam...

Eles nos aconselhavam pra todo tipo de coisa. 
'Polícia não tem parente, não tem irmão. Policia não tem parente. Não tem pai nem filho. Porque você é um só. Se alguma coisa acontecer com você e você morrer, nenhum dos seus parentes vai embora junto com você. Você vai morrer sozinho.'

A gente escutava eles. Quem entendia melhor o português contava para os outros".

\section{Diz Benjamin Xerente:}

"Aí depois a gente recebeu a farda. A gente recebeu a farda, ai todo mundo fardado. Agora, instrução. Do sargento comandante, tenente.... Agora, aí pesou.

As 05 horas levantava. Corneteiro tocava. Ai vinha o guarda: 'levanta, levanta. Tomar banho, tomar banho! Vestir a farda! Cinco minutos, cinco minutos!'

Todo mundo corria...

'Vai lá vestir a farda! Cinco minutos marcado! Banhar e vestir'

Aquele coturno, pra amarrar dá um trabalho danado...

Aí cada um, cada grupo um instrutor tomou conta...

Cada um tem um instrutor que comandava. Ai ficou...

'ó, pra desmontar a arma, revolver, ó, pra desmontar peça por peça. Tempo marcado. Desmontar revolver aí'.

E depois montava de novo... 'tempo marcado!'

Rapaz, o tempo foi... 'agora pra cavalaria, aprender a montar no cavalo!'

Ficava um tempo assim..".

E, por fim, a formulação lapidar de Manoel Sunken:

"Diz que a pessoa, depois que já jura a bandeira do brasil, diz que não pode ser irmão, tem que prender né?! Pode ser amigo...

Diz que depois de jurado a bandeira do Brasil, tem que prender qualquer um, né?! Pode ser irmão... se tá errado, não pode.... Pode ser amigo, né, tem que... [prender]” 
"Para saber é preciso imaginar-se", repetimos. Mais à frente, quando analisarmos nosso material de arquivo, nos deteremos sobre a imagem recalcada do pau-de-arara, que tem sua única aparição em documentos oficiais em toda nossa história na cerimônia de que tratamos aqui. Por ora, gostaríamos de sublinhar esse abismo, esse equívoco ao quadrado, entre esses militares-torturadores, ensinando técnicas avançadas de contra-insurgência, incluso aí a tortura de prender indivíduos no pau-de-arara, e esses indígenas, tentando apreender um mundo em tudo estranho, afeitos às promessas de que a GRIN seria usada para proteger suas terras, e retendo as partes que compreendiam do discurso militarista daqueles que lhes ensinavam. É interessante nas narrativas como eles lembram de frases que eram ditas em sua externalidade, apreendendo mais a ordem como som (cinco minutos!) do que o sentido daquilo que os militares tentavam violentamente impor. Guardadas as devidas proporções e nítidas diferenças, é interessante remeter a Primo Levy e sua narrativa sobre como os concentracionários, muitos dos quais não falavam alemão ou polonês, guardavam os sons das ordens que os SS davam ${ }^{86}$.

Isso a que chamamos provisoriamente abismo se fará visível em nosso material de arquivo em algumas brechas, nos momentos em que apesar da ordenação militar, apesar da forma militarista do registro, apesar de tudo, podemos apreender a externalidade daqueles gestos em relação aos corpos que a performam.

Três meses depois de iniciado o treinamento, seria realizada a cerimônia de formatura. É ela, afinal, que nosso material de arquivo registra.

\footnotetext{
${ }^{86}$ Em Os afogados e os sobreviventes, Primo Levi descreve uma memória sonora que tinha, de uma fala de interno francês se referindo a um SS, que transcreveu em É isto um homem, e que pensava ser do alemão. Levi descreve como o tradutor do livro (ele escreve em italiano) para alemão não entendeu a sonoridade nem as palavras, e redigiu diferente sua formulação. Apenas décadas depois ele compreendeu que era uma frase em íidiche, e que sua memória sonora estava correta. LEVI, Primo. Os Afogados e os Sobreviventes. São Paulo, Paz e Terra, 2004. Página 88.
} 


\section{CAPITULO 2}

Este capítulo busca se debruçar sobre a figura de Jesco Von Puttkamer, o fotógrafo que, ao que tudo indica, registrou nosso material de arquivo. Nos interessa tentar entender quem foi Jesco e em que posição efetuou o registro que ora nos debruçamos.

É difícil traçar, tanto tempo depois, o perfil de um homem. A pesquisa em torno de sua figura encontrou diversos obstáculos, portas fechadas, dificuldades de acesso. Não ajudou o fato de os últimos e decisivos 12 meses de pesquisa terem se dado em meio a uma pandemia que fechou diversos órgãos públicos, dificultando ainda mais o processo de pesquisa.

Este capítulo lida com uma impossibilidade: embora Jesco tenha doado, no final de sua vida, todo seu acervo ao Instituto Goiano de Pré-História e Arqueologia, este mesmo Instituto não nos concedeu acesso a seu acervo, não nos concedeu entrevistas ou acesso a seus diários, por motivos que não se fazem claros, mas que tentaremos refletir ao logo do texto. Escrevemos este capítulo, portanto, com os rastros que se fizeram acessíveis: publicações na imprensa, um livro de caráter propagandístico editado pelo IGPA, conversas com pessoas que conheceram Jesco (em especial a antropóloga Betty Mindlin) e documentos internos, alguns originalmente arquivados como 'confidenciais', que nossa pesquisa encontrou nos arquivos da Funai. Estes documentos, tal qual nosso material de arquivo, são também opacos: trechos antigos, por vezes pouco legíveis, pedaços de burocracias antigas. Nem sempre conseguimos compreendê-los inteiramente. Há, por exemplo, uma carta privada que Jesco recebeu de um colega americano - não sabemos se o próprio forneceu à Funai a carta, ou se, em uma época de censura, havia um monitoramento do que ele recebia. Alguns documentos estão grifados, marcados, o que indica uma leitura, um olhar, semelhante ao de um censor, a esses arquivos. Como sabemos não ter esgotado estes interessantes arquivos aqui, optamos por incluir alguns deles em nossa pesquisa, como anexos, na esperança de que outros pesquisadores no futuro possam ler neles elementos que, agora, não se apresentam a nós como legíveis.

Primeiro, é preciso destacar que não conhecemos, até aqui, nenhum material que prove que tenha sido Jesco Von Puttkamer o autor de nosso material de arquivo, ou elucide em que posição ele portava a câmera. Desde as primeiras matérias sobre o encontro do material, seu nome foi aventado como o autor do registro por causa da claquete. No entanto, é 
importante notar que esta traz apenas o nome 'Jesco', sem sobrenome. E que nos 26 minutos de material, apenas os 3 primeiros rolos possuem claquete. Voltaremos a isso.

Na base de dados do Museu do Índio, consta, na primeira frase da descrição de nosso material: "registro produzido pelo engenheiro e naturalista chamado W. Jesco von Puttkamer de lutas indígenas e parada militar ${ }^{87 \%}$. Conforme conferimos com Rodrigo Piquet, que fez a descrição, a colocação do nome completo de Jesco na base de dados se deu a partir da claquete, em uma 'decorrência lógica ${ }^{88}$ '.

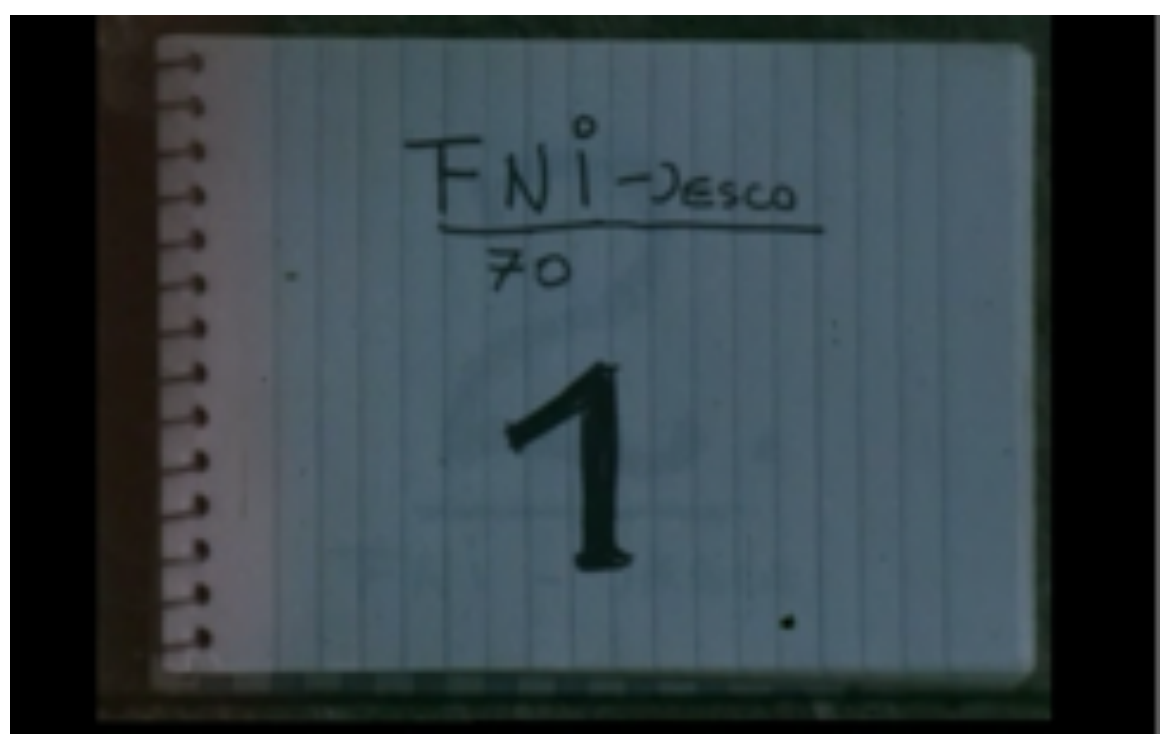

\section{A negativa do IGPA}

Uma vez que não obtivemos acesso ao acervo de Jesco, nos pareceu justo explicitar as comunicações, para depois buscar pensar porque o resultado foi este.

Nossa primeira diligência ao museu foi um e-mail de 20 de março de 2019, no qual especificávamos nosso interesse por informações concernentes à filmagem, tentando entender o que fazia Jesco naquela situação. A resposta do Instituto foi clara: "Infelizmente não temos conhecimento das informações solicitadas. O material depositado no Museu do Índio constitui-se num registro realizado num período anterior aos que se encontram acervados no IGPA, sem qualquer referência ou vinculação. Informamos ainda que não possuímos qualquer

\footnotetext{
87 base de dados do museu do índio: http://base2.museudoindio.gov.br/cgi-bin/wxis.exe?IsisScript=ph182.xis\&cipar=phl82.cip\&lang=por - acessado em 15 de novembro de 2020.

88 conversa telefônica com nossa pesquisa, novembro de 2020 .
} 
documento complementar (escrito ou informação oral), que possa responder suas necessidades."

Um mês depois, escrevemos de novo, diretamente à diretora do Instituto, buscando conversar com pessoas que conheceram Jesco, que pudessem ter mais informações. A resposta foi: "Como já te adiantei em uma resposta por meio da Secretaria do IGPA infelizmente não podemos te auxiliar muito. Conversei com a profa. Maria Eugenia que me adiantou que o Jesco não deixou nada escrito ou referências aqui no IGPA, sobre o trabalho realizado com a guarda indígena. Me ocorre que talvez no Museu do Índio você possa ter alguma informação complementar, uma vez que o filme foi depositado naquela Instituição”.

Nossa próxima investida, alguns meses depois, foi com um ofício de nossa pesquisa, buscando acesso ao acervo do museu. Primeiro obtivemos uma resposta formal, que dizia que “O IGPA dispõe somente de uma cópia em baixa resolução deste documentário, uma vez que o Museu do Índio detém a versão original. Por essa razão sugerimos que sua solicitação seja feita ao Museu do Índio.” Posteriormente, explicitamos nosso interesse de ter acesso aos diários de Jesco, já que no ano de feitura de nosso material de arquivo ele poderia ter assinalado algo elucidativo. A resposta do IGPA: "O Núcleo de Documentação Audiovisual do IGPA/PUC Goiás, está em reestruturação este semestre, não sendo possível viabilizar o acesso aos seus materiais". Por fim, como uma última tentativa, escrevi repetindo sobre a importância, para nossa pesquisa, em ter acesso aos diários, e perguntando sobre a disponibilidade da diretora do IGPA para uma conversa virtual, para poder explicar melhor nosso intuito, e pensar em formas de cooperação, dado o interesse imediato e relativamente simples em entradas no diário de Jesco perto da data da cerimônia de formatura (fevereiro de 1970). A resposta foi curta e enfática:

\section{Sr. Miguel Antunes bom dia.}

Infelizmente os Diários de Jesco Puttkamer não estão disponiveis para consulta pública.

\section{Atenciosamente,}

Profa. Dra. Eliane Lopes

Diretora do IGPA, 04/06/2020

Pontificia Universidade Católica de Goiás

IGPA - Instituto Goiano de Pré-História e Antropologia

(62) 3946-1654 / (62) 3946-1655 
Em assim sendo, podemos apenas explicitar essa porta fechada, que nos impediu de cotejar as anotações de Jesco com os eventos que conhecemos de criação da Grin, e buscar em outras fontes tentativas de elucidação.

\section{Quem foi Jesco von Puttkamer}

A matéria da Folha de São Paulo, a primeira feita sobre o encontro de nosso material de arquivo, diz que: "o filme é parte do acervo sobre 60 povos indígenas, coletado durante quatro décadas pelo documentarista Jesco von Puttkamer (1919-94) e doado em 1977 ao IGPA (Instituto Goiano de Pré-História e Antropologia), da Pontifícia Universidade Católica de Goiás. Descendente da nobreza alemã, mas nascido no Brasil, Von Puttkamer sabia o que era a repressão. Foi preso pela Gestapo quando concluía os estudos em química na Universidade de Breslau (Alemanha), por se recusar a se alistar no Exército durante a Segunda Guerra (1939-45). Safou-se ao provar que era cidadão brasileiro nato. Trabalhou como fotógrafo no Tribunal de Nuremberg (1945-46), que julgou hierarcas nazistas por crimes de guerra. Já de volta, foi um dos fotógrafos oficiais da construção de Brasília (1956-60). Nos anos 1960, integrou pela primeira vez uma expedição em busca de tribos isoladas no Brasil central. Nunca mais largou os índios. Deixou 43 mil slides, 2.800 páginas de diários de campo e filmes na bitola $16 \mathrm{~mm}$ que, desenrolados, chegariam a $330 \mathrm{~km}$. São registros delicados e muitas vezes emocionantes da aproximação dos índios e de seu encontro com as frentes de exploração --e também das epidemias e mortandades por gripe, varíola e sarampo 89,

Nos parece que nesta matéria, feita no calor do momento da descoberta de nosso material de arquivo, a excelente jornalista Laura Capriglione comete um equívoco, ao associar o fato de as imagens terem supostamente sido produzidas por Jesco a seu acervo, gerido pelo IGPA. Não é correto afirmar que essas imagens são ‘parte do acervo’ de Jesco, já que não estavam depositadas lá, nem há registro legal que documente em que posição empunhava Jesco a câmera - como aliás foi reiterado pela própria direção do IGPA nas mensagens citadas acima. De fato, Jesco fez diversas reportagens fotográficas, em especial para a BBC, sobre os

\footnotetext{
${ }^{89}$ Folha de São Paulo, São Paulo, 11 de novembro de 2012.

https://www1.folha.uol.com.br/ilustrissima/2012/11/1182605-como-a-ditadura-ensinou-tecnicas-de-tortura-aguarda-rural-indigena.shtml - acessado em 25 de novembro de 2020.
} 
povos indígenas, e doou todo seu acervo para o IGPA. No entanto, nosso material de arquivo não estava no IGPA, nem havia lá uma cópia, mas sim no Museu do Índio - pertencente à Funai. Há aqui inclusive uma disputa legal, no sentido de a quem, a que instituição, pertence essas imagens, se ao IGPA ou ao Museu do Índio - e neste sentido, qual instituição poderia cobrar pelo direito de uso de tais imagens. Até o momento em que escrevemos, há uma divergência entre as duas instituições que não parece ter chegado a termo.

Assim, este material não constitui um elemento que participe da memória oficial de Jesco Von Puttkamer - memória gerida e zelada pelo IGPA. Ao contrário, nos parece, tendo em vista as repetidas recusas do IGPA em nos fornecer informações ou mesmo acesso aos diários de Jesco, que o registro da Grin tensiona a gestão de sua memória.

O livro 'Os últimos dias do Eden', produzido por jornalistas da $\mathrm{BBC}$ em homenagem a Jesco, pinta o retrato de um homem "bom", traumatizado pelo nazismo e que buscou nos indígenas brasileiros uma imagem de pureza. Segundo o livro, em seu diário Jesco teria escrito que o que mais desejava era "observar e documentar os índios ainda puros e não atingidos pela civilização ${ }^{90 "}$. O texto, assinado por Loren McIntyre, o repórter americano que escrevia as matérias que acompanhavam as fotos de Jesco nas edições da National Geographic, fala que Jesco ficou preso por quase 3 anos em Breslau, campo de concentração nazista. Segundo o texto, de linguagem grandiloquente, "interrogatórios violentos, ameaças de execução. Jesco decidiu então que, se algum dia escapasse da prisão, acharia um jeito de viver entre os índios brasileiros, completamente livre, em sua floresta paradisíaca, onde os gritos fossem apenas de alegria ${ }^{91}$ ". O livro abunda de passagens estereotipadas dos povos indígenas, dando a entender que a visão de Jesco seria da mesma ordem - "Jesco lamentava o fim da nudez natural dos índios, dizendo: 'eles não são mais perfeitos'92"'.

Em conversa telefônica com nossa pesquisa, a antropóloga Betty Mindlin afirmou que conheceu Jesco em suas viagens de pesquisa junto aos Suruí, em Rondônia, etnia também fotografada por ele. A antropóloga repetiu algumas vezes o mesmo adjetivo para descrevê-lo:

\footnotetext{
90 PUTTKAMER, Jesco Von. Os últimos dias do Éden - as imagens de W. Jesco Von Puttkamer. Textos Adrian Cowell [et all]. São Paulo, Terra Virgem, 2005. Página 13.

91 idemibidem.

92 idemibidem.
} 
ingênuo. Disse que só tem uma imagem positiva dele, 'ingênua e positiva'. Para ela, era destoante a imagem que tinha de Jesco da hipótese de ter sido ele o autor das imagens da Grin, em uma cerimônia oficial, possivelmente no papel de contratado pela ditadura. Segundo Betty, o Jesco que ela conheceu teria 'uma recusa àquilo tudo, ele ficava horrorizado com coisas que aconteciam aos índios ${ }^{93}$, Quando relatamos a hipótese, aventada por nós, de que Jesco tivesse renomeado o material de arquivo para preservar a imagem do pau-de-arara de uma eventual censura (ver capítulo 3), Betty disse que achava que Jesco não faria isso por ser 'muito ingênuo'. Betty relata Jesco como 'principalmente uma vítima, alguém que enveredou pelo mundo indígena, e que tirou boas fotos'. Ela reafirmou como a experiência da prisão nazista foi decisiva em sua vida, tendo perdido o irmão.

No livro, o texto de seu editor na National Geographic, John Scheneeberger, traz o seguinte relato: "o presentear incessante, que causava desconforto para algumas pessoas. A disposição em ser o palhaço, se necessário, para ganhar atenção e aprovação. Seu interesse em jovens garotos indígenas e a preocupação em fotografá-los, um afeto possível de ser mal interpretado. Os artifícios que empregava - acordeão, corneta, armas e, em última instância, suas câmeras - tudo indicava a ânsia de Jesco em ser aceito. Quer dizer, de encorajar aceitação, e nunca de maneira exploratória. Havia algo de diferente sobre Jesco, mas não necessariamente algo de errado sobre ele ${ }^{94 "}$ ". Tal relato, em livro tão oficioso, parece falar sobre acusações que estão no fora de campo desta memória. O mesmo texto completa: "Jesco era o indivíduo mais benigno, modesto e recatado que eu já havia encontrado $95 \%$ ".

Adrian Cowell, no mesmo livro, afirma: "posso estar errado em considerar que esse fato [a prisão e tortura nazistas] tenha dominado Jesco pelo resto de sua vida. Ele mesmo jamais falava sobre isso. Mas, assim como outros sobreviventes de campos de concentração, Jesco sempre pareceu, durante toda sua vida, uma alma machucada, carregando uma ferida aberta. Eu creio que foi esse sofrimento que o levou para perto dos índios ${ }^{96 "}$.

\footnotetext{
${ }^{93}$ Betty Mindlin, em contato telefônico com nossa pesquisa, feito em abril de 2020.

94 PUTTKAMER, Jesco Von. Os últimos dias do Éden - as imagens de W. Jesco Von Puttkamer. Textos Adrian Cowell [et all]. São Paulo, Terra Virgem, 2005. Página 101.

95 Idemibidem. Página 99.

${ }^{96}$ Idemibidem. Página 105.
} 
Gostaríamos de reter aqui o estranhamento narrado por Betty Mindlin, quando soube que Jesco seria o autor dessas imagens. Para ela, a possibilidade de ele estar contratado pelo Estado brasileiro em uma cerimônia oficial que produzia uma imagem tão violenta era destoante da figura que conheceu.

De fato, como dissemos, não conhecemos provas da contratação de Jesco pelo Estado, ou mesmo de sua presença na cerimônia - apenas a claquete. No entanto, endossamos a posição dos outros pesquisadores em relação à autoria das imagens, mas retemos o estranhamento descrito por Betty, a falta de encaixe entre a persona descrita nos variados relatos que obtivemos até aqui e a produção das imagens em si, que será melhor pensada no próximo capítulo. Esse estranhamento, mais do que colocar em dúvida a hipótese de ter sido ele o produtor das imagens, fala sobre o caráter ambíguo de nosso material, registrado sobre a áurea de um elogio à ditadura, uma vez que o desfile era um elemento de propaganda para o regime militar, e ao mesmo tempo, um registro e um testemunho de uma violência inédita contra os povos indígenas.

No site Xapuri, há uma matéria assinada por Altair Sales Barbosa, um dos fundadores do IGPA, que traz uma mini-biografia de Jesco. O texto, de tom oficialesco e propagandístico, narra o percurso do fotógrafo até a doação de seu acervo à PUC:

"Nascido no Brasil em 1919, na cidade de Niterói, filho de descendência nobre alemã, ligado genealogicamente a Frederico II, Jesco deixou para a humanidade um patrimônio de valor inestimável ${ }^{97}$.

Seu pai, um nobre barão alemão, serviu na Namíbia, África, à época colônia alemã. Num desses deslocamentos do navio que transportava a tropa, recebeu um comunicado para atracar num porto seguro, durante a primeira guerra Mundial, para fugirem dos navios ingleses. Esse porto era o Rio de Janeiro.

Por ali mesmo ele ficou, casou-se com uma dinamarquesa e tiveram três filhos, Jesco, o mais velho, Olavo e Helga, todos até então residentes no Rio. Tempos depois, Jesco e Olavo foram estudar na Alemanha, Olavo fazia agronomia e Jesco fazia o doutorado em química, na Universidade de Munique, quando estourou a segunda Guerra Mundial.

Tendo em vista que tinham também a cidadania alemã, ambos foram procurados pelas forças alemãs, para se alistaram no exército alemão. Mas se negaram, por serem também cidadãos brasileiros. Este fato os levou à prisão num campo de concentração. O irmão foi fuzilado e Jesco conseguiu sair e voltar ao Brasil, graças à intervenção do Consulado Sueco.

\footnotetext{
${ }^{97}$ https://www.xapuri.info/homenagem/o-centenario-jesco-puttkamer/ - acessado em 20 de dezembro de 2020.
} 
Nesse período, o pai já havia se mudado para Goiás, adquirindo uma grande área de terras, que ia das cabeceiras do córrego Vaca Brava até o onde hoje se situam os setores Coimbra e Bueno, em Goiânia.

Com o fim da Segunda Guerra, Jesco foi nomeado embaixador do Brasil no Leste Europeu, ficando por lá até a instalação do Tribunal de Nuremberg.

De volta ao Brasil, veio direto para Goiânia, sendo convidado pelo então governador Jeronimo Coimbra Bueno, para junto com Bernardo Sayão implantarem um Projeto de Colônias Agrícolas em Goiás, aproveitando a migração de técnicos e trabalhadores oriundos do leste europeu. Nessa perspectiva foram implantadas as Colônias de Ceres, Rialma, Montividiu e Uvá, dentre outras.

Também, tanto Jesco como Sayão foram designados pelo governo de Goiás para integrarem a equipe de Juscelino Kubistchek na construção de Brasília.

Passada a inauguração da nova capital, Jesco integrou-se à Fundação Brasil Central, iniciando dessa forma um trabalho singular de documentação dos Povos Indígenas do Brasil.

No início foi a Operação Bananal, com Acary de Passos Oliveira; depois, integra a equipe dos irmãos Leonardo, Cláudio e Orlando Villas Boas, realizando magnífico trabalho na região do Xingu. Mais tarde, passa a acompanhar Francisco Meirelles e seu filho Apoena Meirelles, em trabalhos de atração de povos isolados, noutras áreas mais a oeste do território brasileiro.

Jesco von Puttkamer inaugurou de forma sistemática a Antropologia Visual no Brasil. Seu trabalho, desenvolvido durante décadas de convivência direta nas aldeias e frentes de atração com índios e sertanistas, registra o cotidiano de vários grupos indígenas, alguns dos quais extintos atualmente, como cultura e como população.

Os indígenas americanos, de modo geral, como também os brasileiros, contribuíram muito para a humanidade moderna. Essa contribuição vai desde alimentos, utensílios e remédios. Entretanto, essa contribuição poderia ser muito maior se essas comunidades fossem melhor conhecidas.

Dentro dessa perspectiva, a obra do Dr. Jesco constitui um verdadeiro Patrimônio da Humanidade, um verdadeiro Patrimônio Universal, pois além de registrar parte desse saber, hoje já perdido, constitui uma chave importante para a auto compreensão da humanidade.

Conheci o Dr. Jesco em 1971, nas aldeias dos índios Nambikwara. Desde aquele ano, percebi que seu lugar era dentro de uma Universidade, instituição que reunia condições para abrigar seu grande acervo sonoro, visual e diários de campo, sobre índios do Brasil, sem sombra de dúvida, o maior acervo do mundo sobre o tema.

Foram quase oito anos tentando convencer os reitores da então Universidade Católica de Goiás dessa necessidade. Ganhei, por causa disso, um pouco de cabelos brancos, mas compensou.

Hoje a Pontifícia Universidade Católica de Goiás se orgulha de possuir este patrimônio, e eu me orgulho de ter sido escolhido pelo professor Jesco para ser o curador desse acervo, que está muito bem cuidado e aproveitado pelos professores do Instituto Goiano de Pré-História e Antropologia-IGPA, Instituto este que fundei em 1972." 
Diversas coisas poderiam ser destacadas, do quanto um texto tão oficial parece ter fora de campos evidentes. Para destacar um deles, cabe mencionar que dizer que Jesco 'inaugurou de forma sistemática a Antropologia Visual no Brasil' é ignorar uma série de fotógrafos e cinegrafistas anteriores, como por exemplo o Major Reis, que desde o começo do século registrou imagens icônicas que faziam parte do acervo da Comissão Rondón. Aqui, gostaríamos de reter o quanto essa trajetória narrada de forma oficialesca pelo site culmina com a entrada dele na PUC e a doação de seu acervo - culmina, em suma, na própria fundação do IGPA, Instituto que parece umbilicalmente ligado à trajetória de nosso cinegrafista.

\section{Documentação sobre Jesco}

Chama a atenção de nossa pesquisa a dificuldade de provar, ou de compreender ao certo em que posição portava nosso fotógrafo a câmera na formatura da Grin. Ele foi contratado pela Funai para realizar uma filmagem oficial? Ele registrava como contratado por um órgão de imprensa? Para fins pessoais, com interesse antropológico?

A claquete, com o título 'FNI', e o fato de as imagens estarem arquivadas em um museu sob a guarda da Funai são fortes indicativos de que Jesco teria sido contratado para a filmagem. Em conversa com nossa pesquisa, Rodrigo Piquet lembrou que naquela época não haviam concursos públicos para registros assim, então uma eventual contratação de Jesco não teria saído no Diário Oficial.

Solicitamos à Funai, que atualmente possui boa parte de seu acervo digitalizado, todos os arquivos com o nome 'Jesco Von Puttkamer'. Recebemos ao todo seis arquivos, todos em PDF. Eles são um aglomerado de documentos, cujo motivo de estarem juntos não é claro. Em todos eles, o nome de Jesco consta pelo menos uma vez - motivo pelo qual nos foi enviado. Um deles, por exemplo, consiste em 263 páginas de telegramas internos da Funai sobre publicações no exterior que digam respeito à política indigenista brasileira. Outro, consiste em 775 páginas sobre a 'Operação Bananal', de 1961 - nele, o nome de Jesco aparece apenas uma vez, e sem explicações. Narraremos abaixo o que foi possível perceber a partir desse estranho material. Pouco a pouco, se revela uma persona distinta daquela que à princípio tínhamos formado. 
O arquivo BR_RJANRIO_TT_0_IRR_PRO_0002_d0001de0001 traz uma série de memorandos internos ao Estado brasileiro que giram em redor de uma 'Operação Bananal', ocorrida em 196198. A operação, financiada pela Fundação Brasil Central, aparentemente uma espécie de antecessora da Sudam, visava à construção, na Ilha do Bananal, de uma série de elementos abaixo transcritos. A Ilha do Bananal é uma grande ilha fluvial na qual vivem diversas etnias indígenas, entre eles os Karajá, que anos depois fariam parte da Grin. Os documentos não especificam a relação dessas construções com os grupos indígenas, mas é de se supor que a iniciativa do Governo Federal fazia parte de um projeto de ocupação do Oeste brasileiro, tenha-se em vista as menções a turismo (hotel) e estação de transporte. As construções previstas:

1) Construção de $2.500 \mathrm{~ms}$. de pista para pouso de aviões, com $40 \mathrm{~ms}$. de largura, sendo $1.500 \mathrm{~ms}$. pavimenta dos a asfalto e $500 \mathrm{~ms}$., em cada cabeceira, encascalhados, com pintura asfáltica;

2) Construção de uma estação de passageiros;

3) Construção de uma escola e de um hospital;

4) Construção de 10 casas destinadas à Fundação Brasil Central, Ministério da Aeronáutica e Ministério da Saúde;

5) Construção de um hotel com 40 apartamentos.

A "Operação Bananal" previa ainda a construção, em diversos pontos, de "Ranchos Pioneiros tipo JK, para apoio e incremento ao turismo" 99

Nas diversas diligências, especula-se sobre um possível mau uso do dinheiro público, uma vez que aparentemente as construções não foram entregues. Não há quase nenhuma menção a questões indígenas em todas as 775 páginas do documento. Em dado momento, o presidente da Fundação Brasil Central, Cel. Nelio Gonçalves Cerqueira, escreve a Juscelino Kubistchek, então Presidente do Brasil:

\footnotetext{
98 Não nos é claro a melhor forma de citar e trazer aqui estes documentos primários, uma vez que não estão disponíveis publicamente. Optamos pela seguinte organização: nos Anexos, colocaremos como Anexo 1 as páginas que aqui trabalhamos dos primeiros 3 documentos - de forma que o Anexo 1 terá páginas de documentos distintos, estando assinalado nas notas de rodapé as páginas a que nos referimos aqui. O último destes documentos, e o mais profícuo, constará na íntegra como Anexo 2.
}

99 anexo 1, Páginas 2 e 3. 
"Cumpre finalmente informar que na distante região do Xingu, continua o trabalho desta entidade [a Fundação Brasil Central], abrindo novos caminhos e pistas aéreas, que tem permitido a penetração da FAB pelo "hinterland" de nosso pais e oferecido maior segurança a aviação comercial e particular.

Tal trabalho de penetração feito exclusivamente através da Fundação, tem sua base, no momento, no Diauarum, setor aberto pelos irmãos Orlando e Cláudio Vilas Boas. Estes dois sertanistas da Fundação, cujo trabalho é já mundialmente conhecido, lá fixaram residência para melhor executar a patriótica tarefa que tem a seu cargo ${ }^{100 . "}$

Neste mesmo documento, algumas páginas à frente, há uma espécie de auditoria de gastos feitos pela Fundação na Operação Bananal. A grande maioria dos gastos se dá com materiais de construção, mobiliário, etc. No fim desta auditoria, há uma folha intitulada 'relação de contas a pagar resultantes de fornecimentos de materiais ou serviços (ou de encomendas de materiais e/ou serviços - 'OPERAÇÃO bananal' (tal como se encontram na contabilidade da fundação)." Nesta lista, junto a empresas como 'S A Indústrias Votorantim' ou 'Texaco (Brazil) Inc', consta o gasto de 14.500 Cruzeiros com a rubrica 'Wolf Jesco Von Puttkamer'. Algumas linhas acima, o gasto de 255.320 Cruzeiros com o 'Serviço de Proteção aos Índios (Posto Indíg. Get. Vargas)' ${ }^{101}$ :

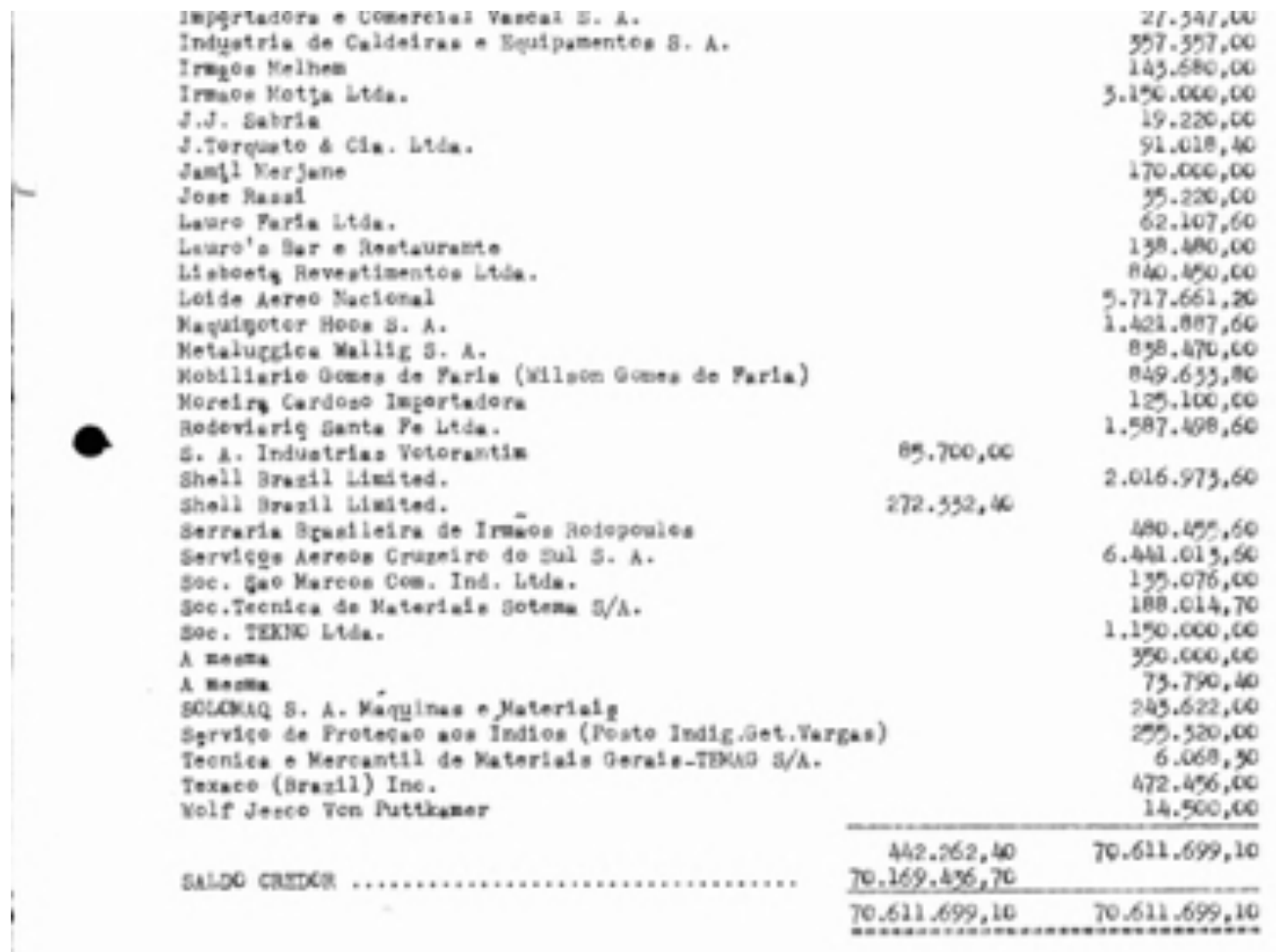

100 Anexo 1, Páginas 4 a 10.

${ }^{101}$ Anexo 1, Página 11. 
Em nenhum lugar desses documentos se menciona qualquer coisa relacionada a filmagem, fotografia ou registro. Aparentemente, a Operação Bananal tratava-se da tentativa de construção de pistas de pouso, casas, um hotel. Por isso, não nos parece claro o porquê de Jesco ter sido contratado. Em relação à quantia, é pouco mais de uma vez e meia o salário mínimo do ano de $1960^{102}$, o que parece indicar um serviço prestado não muito extenso.

Acima de tudo, gostaríamos de reter que, em 1961, nove anos portanto antes da cerimônia de formatura da Grin, Jesco havia sido contratado pelo Estado brasileiro. O fato em si não prova nada, mas sugere uma relação entre Jesco e o Estado, de prestação de serviço, que pode bem ter se repetido em fevereiro de 1970, num batalhão policial em Minas Gerais.

O documento BR_DFANBSB_N8_0_PSN_EST_0326_d0001de0001103 traz uma troca de mensagens de 1968 entre órgãos do Estado ditatorial para aprovar ou não uma viagem da Geographical Magazine of Britain, que iria de Manaus a São Felix, na Venezuela. Entre os tripulantes dessa viagem, consta o nome de Jesco. Essa parece ser a forma de relação principal de Jesco para com o Estado Brasileiro, alguém que por diversas vezes solicita autorização do Estado para adentrar áreas indígenas que lhe interessavam fotografar. Como bem narra o livro 'os últimos dias do Éden', Jesco foi por vários anos patrocinado pela National Geographic, tendo feito parte relevante de sua produção a pedido desta. Nestes documentos que mencionamos, vê-se o controle estrito do Governo sobre visitas internacionais, uma vez que diversos ofícios questionam se as viagens seriam ou não um 'risco à segurança nacional'. O fato de o nome de Jesco não ser tratado em nenhum desses ofícios com destaque, estando apenas listado entre os ocupantes da embarcação (quase todos ingleses), parece sugerir que, à altura, em 1968, ele era razoavelmente desconhecido, tendo seu acesso a áreas indígenas pleiteado através da mediação de uma revista estrangeira.

\footnotetext{
102 segundo o site AUDETEC, o salário mínimo em 1960 era de 9.600 Cruzeiros. Jesco recebeu 14.500 Cruzeiros. https://audtecgestao.com.br/capa.asp?infoid=1336 - acesso em 3 de dezembro de 2020.

${ }^{103}$ As páginas aqui citadas estarão presentes no Anexo 1, páginas 12 a 15.
} 


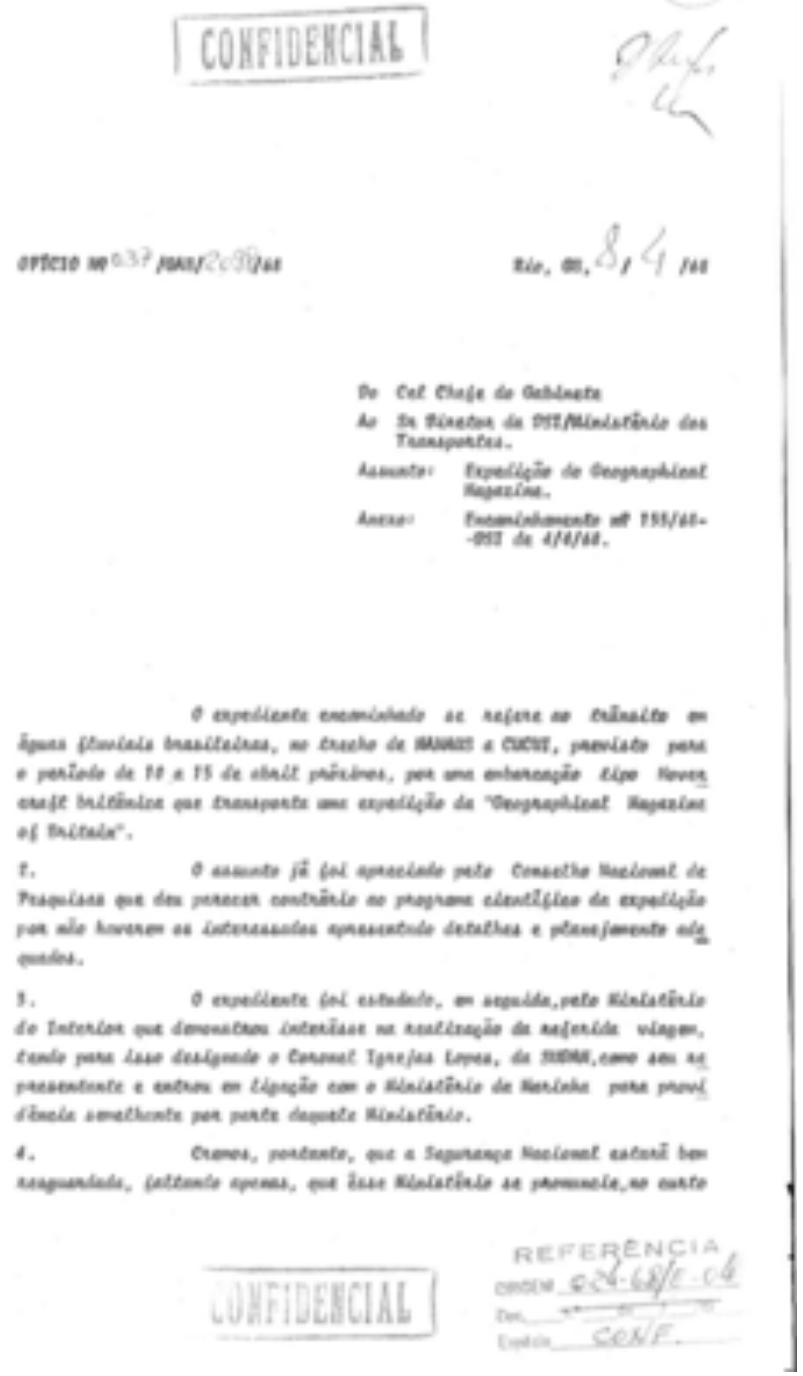

O arquivo BR_DFANBSB_Z4_DHU_0_0080_d0001de0001 se refere a uma longa lista de telegramas trocados por órgãos de inteligência, que monitoravam com preocupação as matérias publicadas no exterior que faziam críticas à política indigenista da Funai - o que, como discutimos no Capítulo 1, atesta a centralidade dessa questão nas preocupações da ditadura. Em todas as 263 páginas dessa troca de telegramas e mensagens, há menção a apenas uma matéria positiva: uma matéria da National Geographic, de autoria de Jesco von Puttkamer. Diz o telegrama, datado de 25 de janeiro de 1975 e assinado por João Augusto de Araujo Castro, embaixador do Brasil em Washington: “A 'National Geographic' acaba de publicar em sua edição de fevereiro do corrente ano, extenso artigo de 30 páginas contendo fotografias e comentários do senhor W. Jesco Von Puttkamer sobre as tribos de índios brasileiros 'kreen-akarores' e dos 'txukahameis', seu contato com o mundo do civilizado e a ação da Funai no decorrer deste processo. Puttkamer documenta as atividades desenvolvidas 
pela Funai em um artigo extremamente favorável à política indigenista brasileira, descrevendo as dificuldades do trabalho dos sertanistas e transmitindo uma ideia clara da sensibilidade requerida para essa tarefa. A reportagem eh [sic] documentada com material fotográfico de excelente nível, como eh costume do 'National Geographic', cuja penetração nos mais diversos setores deste país é das mais significativas. O texto contem inúmeras referências elogiosas à Funai e parte da introdução do editor, que transcrevo à seguir, revela o seu teor essencialmente positivo à política de integração do índio no Brasil104".

Não queremos com isso sugerir que Jesco ou a revista inglesa estivessem trabalhando para a ditadura. No entanto, é significativo que, em todas as 263 páginas do documento, apenas uma matéria monitorada seja positiva. Era de fato incomum, na cobertura estrangeira sobre a questão indígena no Brasil, matérias positivas, pelo fato de abundarem denúncias de violações de direitos humanos por parte do Estado brasileiro. Assim, a existência desta matéria gera um outro despacho da embaixada, que propõe que se compre vários exemplares da revista como parte de um esforço da ditadura em defender sua imagem de críticas no exterior, conforme imagem abaixo ${ }^{105}$ :

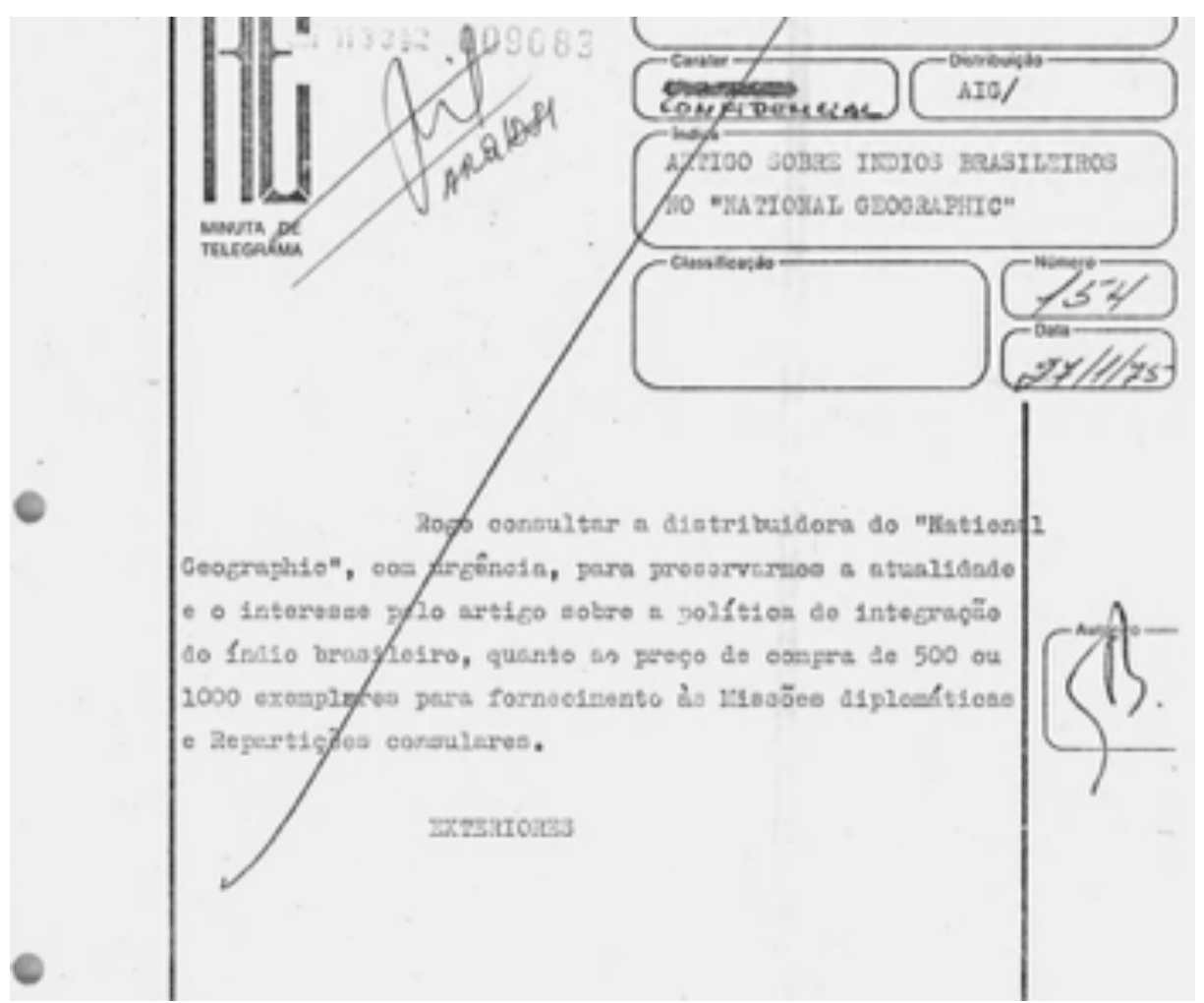

\footnotetext{
104 Ver Anexo 1, página 16.

105 Ver Anexo 1, página 17.
} 
Por fim, gostaríamos de comentar o arquivo_dc00014a0144558sos_t, incluído na íntegra como anexo em nossa pesquisa (Anexo 2), de longe o arquivo mais interessante e revelador, que traz, em suas 169 páginas, menções a Jesco em 64 delas. O longo percurso dos documentos começa com um pedido de Jesco para a Funai para ingressar em área indígena para fazer uma reportagem com a National Geographic. O pedido, de $1^{\circ}$ de setembro de 1976 , foi feito pelo próprio Jesco. Ao contrário do que vimos acima, em 1968, quando a revista fazia o pedido, aqui já é o próprio fotógrafo quem se comunica com a Funai - escrevendo diretamente a seu presidente (à época, o General Ismarth). Jesco parece à vontade na missiva, fala afirmando que 'em cartas anteriores, que enviei ao Mr. Mc Intyre e à National Geographic Society, tenho lhes dito da grande simpatia que V. Excia sempre têve para toda gente de bem e que deseja colaborar com as nossas boas causas ${ }^{106}$ ”. Ele narra, então, que foi convidado a participar de uma viagem (para a revista National Geographic) em direção "ao interior e às zonas remotas de nosso Paiz [sic] e onde estamos em plena fase de INTEGRAÇÃO [sic]. Uma integração que está se operando com grande capacidade de planejamento e respeitando, como nunca antes tinha sido feito, os direitos de terceiros, principalmente de nosso índio ainda arredio ${ }^{107}$ ". Se por um lado há de se ter em conta que Jesco escrevia com o interesse de obter autorização para adentrar as áreas indígenas, o que talvez explique o tom bajulatório da missiva, por outro lado, é necessário sublinhar que a formulação do autor é grave. Ele registra um apoio explícito à política da ditadura de integrar os povos indígenas, escrevendo a palavra em maiúsculas, política esta sabidamente violenta, que resultou em inúmeras mortes e desastres variados para as mais distintas comunidades ${ }^{108}$. Assim, em 1976, quando eram notórias as inúmeras violações de direitos indígenas por conta da política de integração - com a abertura da Transamazônica, com a construção da Usina de Tucuruí, entre outras ações, dizer que a política de integração está 'respeitando, como nunca antes tinha sido feito, os direitos de terceiros, principalmente de nosso índio ainda arredio' é grave e sintomático de um certo alinhamento à ditadura militar em seu período mais bárbaro.

\footnotetext{
106 Anexo 2, Página 6.

107 idemibidem.

108 para um apanhado dessas violências, ver o capítulo sobre violações de direitos indígenas da Comissão Nacional da Verdade - Comissão Nacional da Verdade. 2014b. Volume II - Textos temáticos. Texto 5: "Violações de direitos humanos dos povos indígenas". Disponível em: http://www.cnv.gov.br/. Último acesso: 29.01.2021.
} 
Mais à frente, Jesco envia o roteiro da reportagem que está sendo preparada, para que a Funai autorize. Consta do roteiro que a primeira parte se debruçaria sobre Rondônia, Mato Grosso e Acre, e teria por objetivo: "mostrar o rápido desenvolvimento dessa parte (colonização, estradas e o empenho do Governo de assistir essa evolução e fomentá-la (INCRA, FUNAI, CODEMAT etc) Projeto Rondon, Sudam etc ${ }^{109}$." Quer dizer, ele propõe, sem tirar nem pôr, fazer uma propaganda institucional dos esforços da ditadura de colonização na região Norte, esforços que, repetimos, foram os responsáveis por inúmeras violações de direitos humanos de grupos indígenas Brasil afora. Importante ressaltar que não é que Jesco tenha sido contratado pelo Estado para fazer essa reportagem propagandística; quem paga a viagem é a revista americana.

A carta cumpriu seus objetivos, e pouco tempo depois Jesco e o repórter da National Geographic obtiveram autorização de entrada em áreas indígenas.

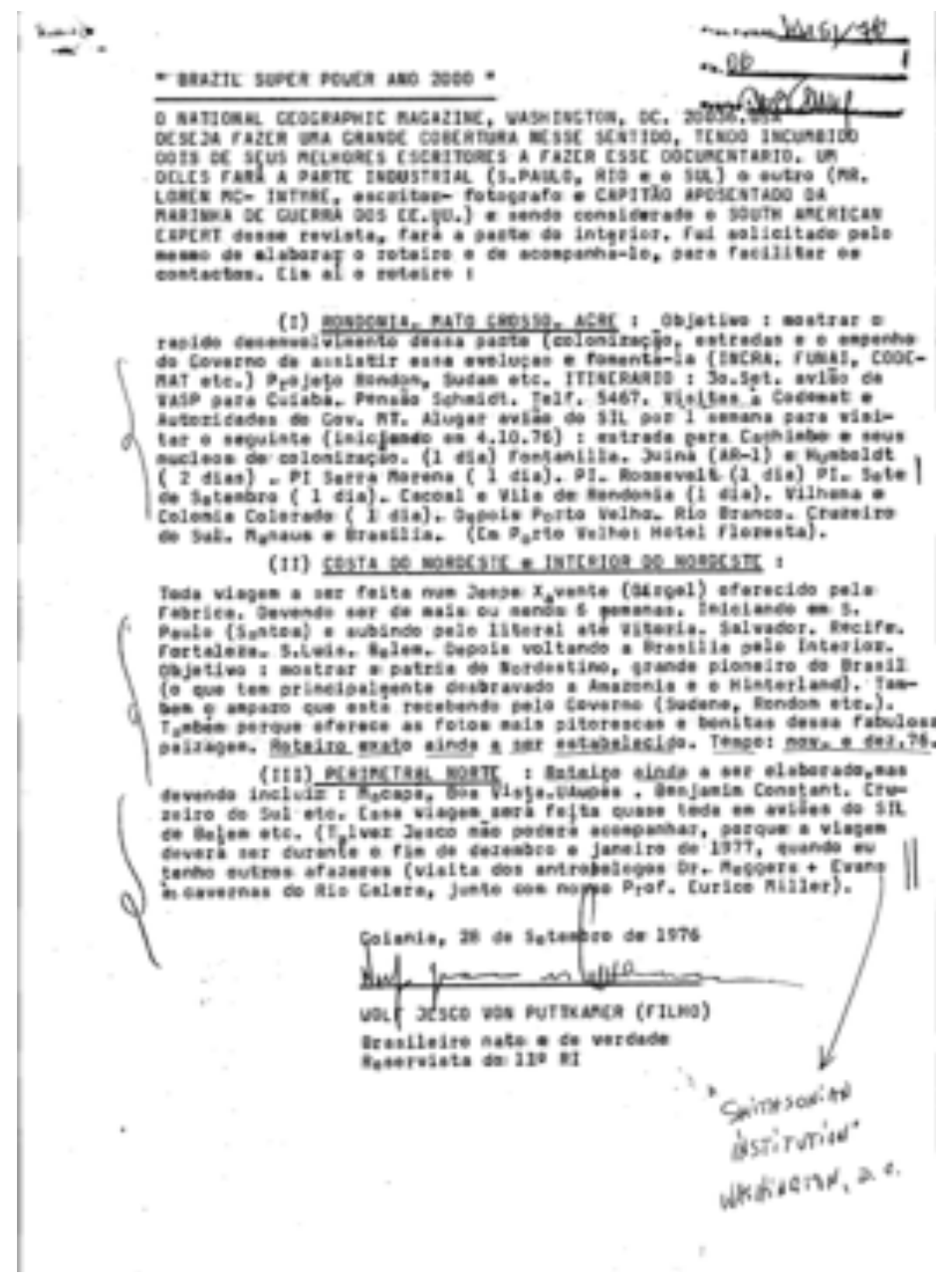

109 Anexo 2, página 11. 
Mas o documento mais revelador, e que toma as 100 páginas finais de nosso anexo, nos parece ser uma longa troca de mensagens dentro da Funai a partir de um relatório enviado por Jesco em 1984 sobre os resultados de uma viagem feita aos EUA e à Alemanha ${ }^{110}$.
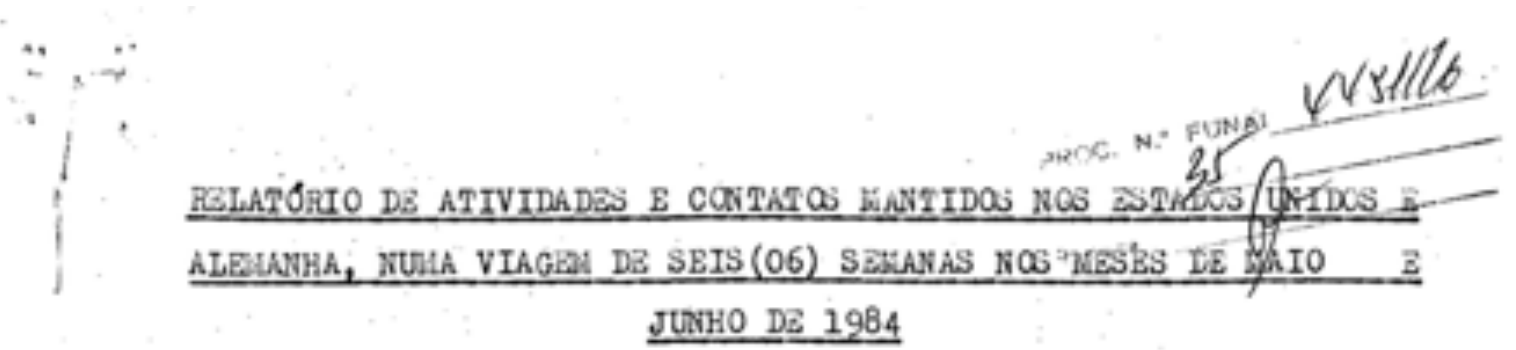

Instituiçōes contactadas:

$\underline{\text { E.U.A. }}$

18) National Geocraphic Socisty

20) Univeresty Harward

FUNAI SEC/GAB

38) Forld Fildilfe Fund

\section{ALZiANH OCIDarThL}

10) Luseu Etaolócico de Berlin

25) Depto, de Ztno-mísica do huseu de Berlin

3e) Univeroidade de Berlia

4a) Indústría Farnacêutica hoechst.

Não é claro porquê Jesco envia um relatório sobre suas atividades. Ele não viajou a pedido da Funai, e não exercia nenhum cargo ou papel dentro do Estado. A leitura de sua carta faz parecer que ele se via como uma espécie de embaixador das questões indígenas, fazendo contatos a seu bel-prazer, inclusive com indústrias farmacêuticas que poderiam estar interessadas em explorar elementos da flora cujo uso teria sido descoberto por grupos indígenas. Sem qualquer procuração legal ou legitimidade pra tais contatos, Jesco se mostra aqui, além de portador de uma conduta fortemente questionável, também francamente ingênuo em achar que as coisas que descreve em sua carta não iriam ser lidas pela Funai como problemáticas, e até passíveis de processos legais.

O texto gerou um extenso relatório interno na Funai, que analisava o trabalho de Jesco nos últimos 30 anos buscando saber "quem mais se beneficiou com esse trabalho, se ele ou os

110 Anexo 2, páginas 51 a 57. 
índios ${ }^{111 " . ~ D i z ~ o ~ r e l a t o ́ r i o: ~ “ d e s d e ~ a ~ e ́ p o c a ~ d o ~ S e r v i c ̧ o ~ d e ~ P r o t e c ̧ a ̃ o ~ a o ~ I ́ n d i o ~-~ S P I, ~ o ~ f o t o ́ g r a f o ~}$ e cinegrafista WOLF JESCO VON PUTTKAMER (FILHO) vem realizando trabalhos de documentação audiovisual em áreas indígenas, tendo como resultado a produção de vários filmes para a BBC de Londres, matérias para o National Geographic Magazine, gravações e cartões postais vendidos em todo o território nacional. Com a extinção do SPI e consequente criação da Fundação Nacional do Índio, em dezembro de 1967, prosseguiu o Sr. WOLF JESCO VON PUTTKAMER (FILHO) a visitar as áreas indígenas. Com a instalação da Fundação Nacional do Índio, conseguiu o Sr. VON PUTTKAMER (FILHO), dada a proximidade entre Goiânia, onde reside, e a Capital da República, conquistar a amizade e confiança dos dirigentes do órgão tutelar, notadamente dos Presidentes JOSÉ DE QUEIROZ CAMPOS, OSCAR JERONYMO BANDEIRA DE MELLO e ISMARTH DE ARAÚJO OLIVEIRA, os quais, por diversas vezes, o fotógrafo acompanhou quando de viagens de inspeção a áreas indígenas. Foi graças a esta confiança que o fotógrafo WOLF JESCO VON PUTTKAMER (FILHO) obteve dos sucessivos Presidentes desta Fundação, uma credencial permitindo seu ingresso em qualquer área indígena do país, motivo pelo qual ficamos impedidos de realizar um levantamento detalhado de todos os trabalhos realizados pelo referido fotógrafo ${ }^{112}$."

Algumas coisas se abrem a partir dessa leitura. A descrição, em linhas gerais, é a de alguém que, através de laços pessoais, obtinha o que queria: a autorização para adentrar as áreas indígenas. Há um trânsito constante com a burocracia oficial, e uma verdadeira obtenção de privilégios da parte dele devido a contatos pessoais com os presidentes da Funai. Mais que isso: podemos delinear alguém que esteve próximo de um registro propagandístico/ oficial da política indigenista da ditadura, ao 'acompanhar' diversos presidentes da Funai, em sua maioria militares, a viagens de inspeção a áreas indígenas. Temos aqui também a primeira e única menção que encontramos sobre o contexto da relação de Jesco com a Funai quando da feitura de nosso material de arquivo, dado que a presidência de José de Queiroz Campos terminou poucos meses depois da cerimônia de formatura da Grin. Esta descrição parece concordar com nossa hipótese, de Jesco ser um fotógrafo oficial naquela cerimônia, a serviço do Estado ditatorial, tentando traduzir em imagens a política de 'integração' do qual a Grin

\footnotetext{
111 Anexo 2, página 64.

112 Anexo 2, página 65.
} 
era epítome.

É interessante destacar a menção a Jesco como alguém sedutor - o que não se encaixa exatamente na descrição reiterada de sua suposta ingenuidade. $\mathrm{O}$ contundente relatório foi respondido pelo fotógrafo com uma nota escrita à mão, em tom pessoal, para o presidente da Funai, e acrescido de uma matéria elogiosa a ele mesmo, intitulada 'Jesco, o brasileiro' 113 . Nos interessa frisar a opinião de um relatório técnico da Funai sobre a resposta de Jesco: "Em vista do exposto somos, salvo melhor juízo, da seguinte opinião: 1. Que o presente processo seja encaminhado ao sr. Presidente desta Fundação para que o mesmo tome conhecimento das atividades envolvendo o fotógrafo WOLF JESCO VON PUTTKAMER (Filho), visando que o mesmo não seja envolvido pelo respectivo profissional, pessoa por demais simpática e persuasiva, como aconteceu com todos os Presidentes, desde a criação da FUNAI ${ }^{114 " .}$
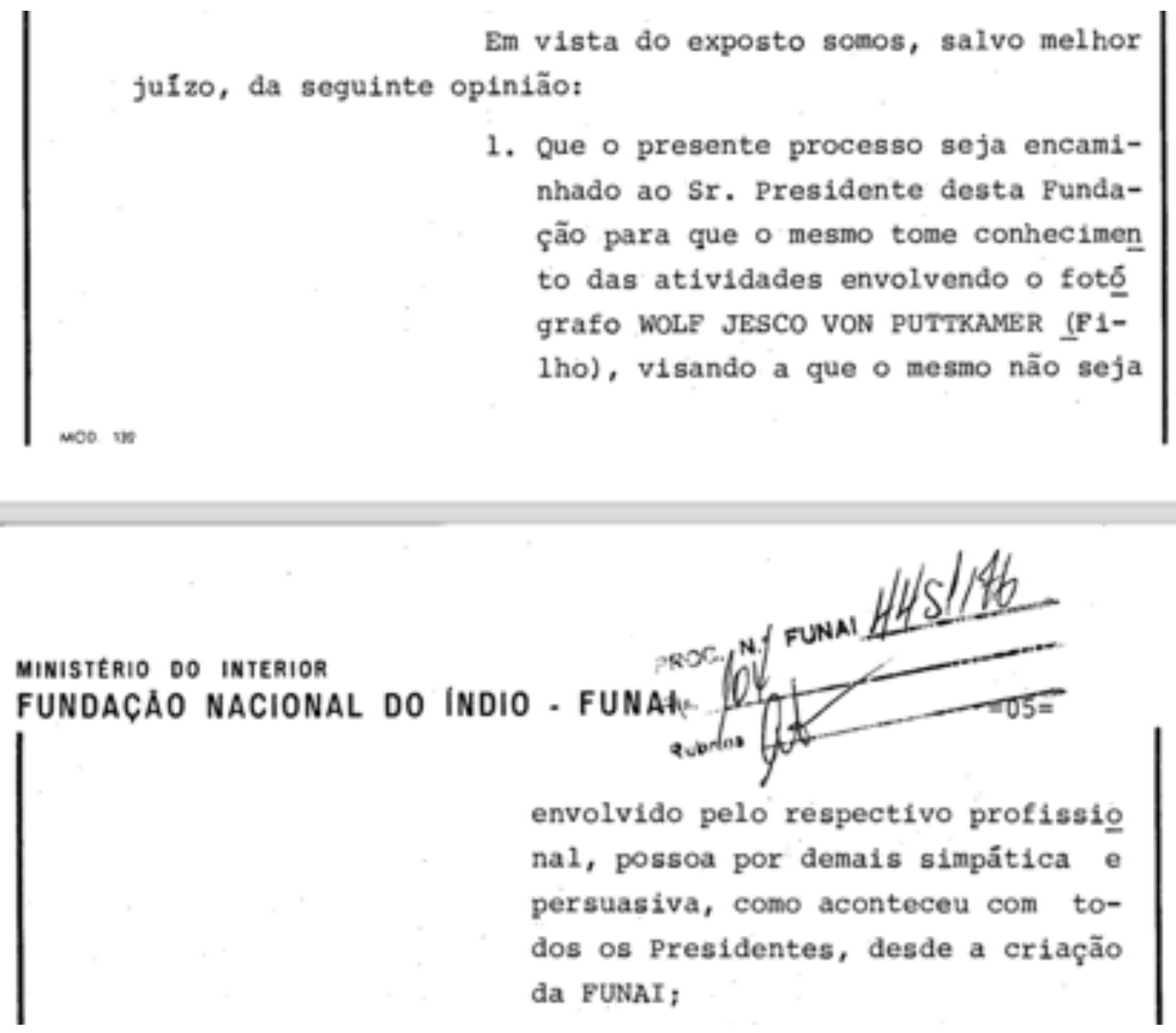

113 Anexo 2, página 95.

114 Anexo 2, página 129. 
Voltando ao relatório, ele menciona um parecer bastante crítico de 1979 da antropóloga Delvair Montagner Melatti, que indefere a entrada de Jesco em uma comunidade indígena, dizendo que : "o Sr. JESCO comercializa fotos (cartões postais) e slides sem que a FUNAI cobre as taxas regulamentares. Urge que a PJ providencie com urgência as normas de pagamento para por fim a esta exploração. O Sr. JESCO nunca cumpriu as Portarias e não teve um assessoramento antropológico, por conseguinte seu material é de péssima qualidade etnográfica (posada, atitudes artificiais, fotos tomadas por solicitação...) ${ }^{115}$ ”. O tema da comercialização é bastante grave, e reiterado nas denúncias. No relatório que enviou à Funai, sobre sua viagem à Europa e EUA, o fotógrafo escreveu que o Museu de Berlim já teria adquirido duas mil fotografias, e que iria adquirir mais ou menos mil duplicatas de slides. Comenta o memorando interno da Funai: "encaramos esta afirmativa como uma confissão. O fotógrafo auferindo altos lucros com a venda de fotografias e slides obtidos em área indígena - lucros estes que chegam a permitir que realize viagens periódicas aos Estados Unidos e à Alemanha - sem que os índios ou grupos tribais retratados recebam um só tostão a título de direito de imagem como determina a legislação em vigor no nosso país ${ }^{116}$." Acrescenta, ainda, uma acusação referente a um 'projeto' expresso por Jesco de fazer um disco com músicas indígenas que teria colhido, sem, novamente, propor qualquer retorno às comunidades indígenas:

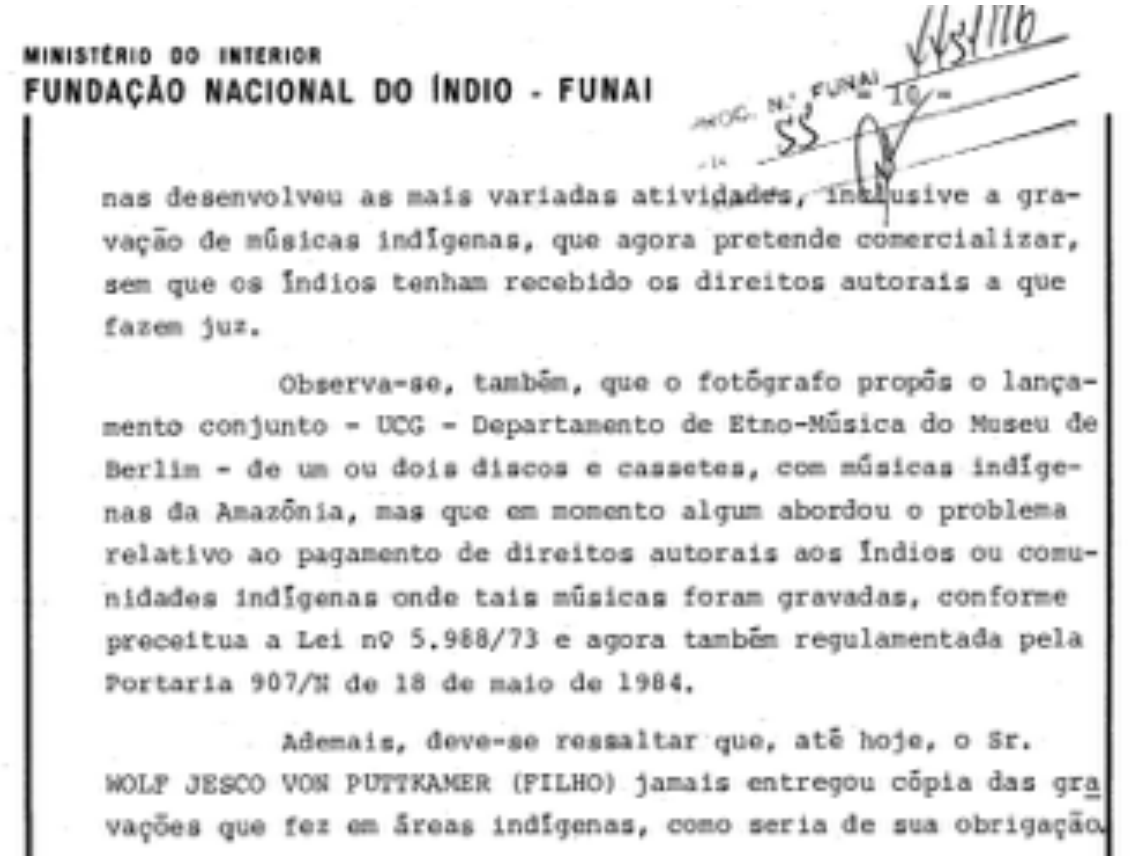

115 Anexo 2, página 66.

116 Anexo 2, página 71. 
Há ainda um último elemento, que nos parece o mais grave, escrito a partir da narrativa do próprio Jesco: "somente em abril de 84 conseguimos sob o comando do experiente sertanista brasileiro APOENA DE MEIRELLES pacificar e fazer o pacto de amizade com um grupo ainda desconhecido e hostil de indigenas, e que tem o nome de "UruEu-Wau-Wau" (...) Conseguimos firmar tão boa amizade, que o jovem Cacique fez questão de nos mostrar um de seus segredos máximos: uma árvore, para nós ainda desconhecida, que eles chamam de 'PADÍA', que ao que parece está nativa no altiplano tropical (600 a 800 metros de altura) e cuja casca fresca fornece um líquido avermelhado com o qual untam suas pontas de flechas, depois fixam no fogo baixo, e que produz sangramento tão volumosos que a pessoa ou a caça (antas e porcos selvagens) quando feridos com essas flechas estão irremediavelmente sujeitos a morte em poucos minutos. Eles dizem também que o "Padía" é tão potente que dissolve o sangue coagulado. Achamos que esses índios de alta inteligência têm conhecimento de outras plantas importantes, que poderiam interessar a medicina ${ }^{117}$." Após narrar a 'descoberta' de uma planta medicinal, o fotógrafo narra um encontro que teve, sozinho, com representantes da indústria farmacêutica alemã Hoechst, encontro no qual promoveu "uma projeção de duas horas de slides, de minha parte, com comentários sobre os Uru-Eu-Wau-Wau e o progresso em Rondônia e, especificamente, sobre a planta descoberta pela Universidade Católica de Goiás, o célebre PADÍA. Diante disso, o pessoal ficou muito interessado e querem também, em conjunto com a UCG, estudar essa planta para uso farmacêutico". Jesco aqui age como um lobista, sem autorização legal para tanto, em uma matéria séria, que implicaria um grupo estrangeiro explorando uma área indígena, assunto extremamente delicado e potencialmente prejudicial aos índios.

A conclusão do relatório é contundente: "Pelo que foi exposto, conclui-se que o fotógrafo WOLF JESCO VON PUTTKAMER (FILHO) vem, há mais de 30 (trinta) anos explorando as comunidades indígenas, seja através da fotografia, filmes ou gravações sonoras, constituindo-se tal fato numa violação da Lei n. 5.988, de 14 de dezembro de 1973, que regula os direitos autorais ${ }^{118 "}$ ". A crítica se estende ao IGPA: "Outro ponto gritante de atuação do fotógrafo WOLF JESCO VON PUTTKAMER (FILHO) diz respeito as doações de filmes,

\footnotetext{
117 Anexo 2, página 76.

118 Anexo 2, página 81.
} 
slides e gravações recolhidas por ele em áreas indígenas, ao INSTITUTO GOIANO DE PRÉHISTÓRIA e ANTROPOLOGIA DA UNIVERSIDADE CATÓLICA DE GOIÁS, quando a FUNAI não recebeu nem $10 \%$ de cópias das fotos por ele colhidas e nenhum filme ou gravação tenha sido fornecido ao órgão tutelar". Por fim, o relatório conclui com um contundente paralelo com a exploração colonial dos indígenas pelos portugueses: "Vale lembrar, ao encerrar a presente informação, que, já em 1511, onze anos, portanto, após o descobrimento do Brasil, a Nau Bretoa levava para Portugal uma carga de Pau Brasil e alguns animais e pássaros engaiolados. Hoje, decorridos mais de quatro séculos, continua o nosso índio explorado em seus direitos, agora, sob a forma de fotografias, filmes e gravações, comercializadas no Brasil e no exterior. Urge, pois a adoção de medidas enérgicas visando a por fim, de uma vez por todas, com este tipo de exploração de que vêm sendo vítima nossos índios, etnia que não só a FUNAI mas todos os brasileiros tem obrigação de admirar e proteger $^{119}$ '.

A troca de mensagens, depois deste relatório, se estende por cobranças cada vez mais insistentes, financeiras inclusive, relativas aos direitos autorais dos indígenas que a comercialização de fotos por Jesco, e também pelo IGPA, viria a ferir. Jesco responde sempre de forma cordial, afirmando não estar bem de saúde. Seis anos após a primeira notificação, ele viria a falecer.

Se nos registros que já lemos sobre Jesco, tanto nos oficiais (como o livro 'os últimos dias do Éden'), quanto na matéria de Laura Capriglione, muito se destacou a influência do trauma da prisão nazista sobre seu interesse pelos indígenas e, supostamente, sobre sua estética, gostaríamos de contribuir com uma percepção oposta. Gostaríamos de sublinhar o caráter institucional de sua produção. A leitura atenta dos documentos faz ver o quanto Jesco esteve sempre perto do poder, buscando registros, por um lado, idealizantes dos índios, o mesmo registro que Delvair classificou como 'de péssima qualidade etnográfica' (que poderia talvez ser traduzido pelo próprio Jesco na máxima idealizante 'fotografar os índios enquanto eles ainda são puros'), e ao mesmo tempo, se esmerando em produzir uma visão positiva da ação do Estado ditatorial e suas 'políticas de integração'. Escusado dizer que esta imagem

119 Idemibidem. 
positiva da ação do Estado brasileiro servia à ditadura, em primeiro lugar, e ao próprio Jesco, em segundo, mas certamente não aos índios, alvos de violência sistêmica, aumentada exponencialmente, como vimos, depois do AI-05.

Também, este último documento, ao narrar a tensão institucional entre o IGPA e a Funai, pode ajudar a explicar a reiterada recusa, ou desinteresse, do IGPA em colaborar com pesquisas que estejam tentando ler justamente essa relação, de Jesco com o Estado brasileiro.

Isso tudo reforça nossa intuição original, sobre nosso material de arquivo como uma peça de propaganda, ou um registro oficial. Se no Capítulo 1 foi possível ver uma intenção propagandística dos militares na produção e condução do evento da formatura, nos parece que já temos elementos suficientes para poder ler no arquivo intenções semelhantes também no que se refere à forma de filmar, às escolhas particulares que nosso cinegrafista fez numa tarde de fevereiro de 1970.

Vamos então, finalmente, às imagens. 


\section{CAPÍTULO 3}

Eis-nos agora diante de nosso material de arquivo. Este material sobrevivente, perdido, encontrado. Este material que retorna, quase cinquenta anos depois de sua produção, no contexto de uma tardia investigação sobre os crimes perpetrados pelo Estado brasileiro durante a ditadura civil-militar.

Nosso material se fez, assim, subitamente visível. A partir do contexto da Comissão da Verdade e dos esforços do pesquisador Marcelo Zelic, que estendeu perguntas ao acervo do Museu do Índio. Eis-nos diante deste material, de origem incerta e ambígua. Vemos as imagens, vemos e revemos. Mas como podemos lê-las? Como atingir não a visibilidade, mas a legibilidade de nosso material?

Georges Didi-Huberman analisa imagens da abertura dos campos de concentração nazistas, em $1945^{120}$. Ele nomeia um duplo movimento: as imagens nos campos paralisam diante de sua visibilidade, ao mesmo tempo em que anestesiam por sua falta de legibilidade intrínseca. O filósofo recorre à formulação de Walter Benjamin sobre a leitura: "a marca histórica das imagens não indica somente que elas pertencem a uma determinada época, ela indica sobretudo que elas alcançam a legibilidade somente a uma época determinada. E o fato de alcançar 'a legibilidade' certamente representa um determinado ponto crítico do movimento que as anima ${ }^{121 " .}$ Mas essa legibilidade se oferece de forma momentânea e perigosa: "somente as imagens dialéticas são imagens autenticamente históricas, isto é, não arcaicas. A imagem que é lida - quero dizer, a imagem no Agora da conhecibilidade - leva ao mais alto grau a marca do momento crítico, perigoso, que é o fundamento de toda leitura ${ }^{122 " .}$

\footnotetext{
${ }^{120}$ DIDI-HUBERMAN, Georges. Remontagens do tempo sofrido - o olho da história II. Belo Horizonte, Editora UFMG, 2018.

121 BENJAMIN, Walter. Passagens. São Paulo, Imprensa Oficial, 2009.

122 idemibidem.
} 
Assim, para o filósofo francês, tornar legíveis as imagens de arquivo com que ele se deparava - efetuar a leitura perigosa de que falava Benjamin, estava vinculado à noção de experiência, a tornar visível a construção de tais imagens. Ele afirma: "continuaremos a fechar os olhos sobre essas imagens enquanto não encontrarmos o 'ponto crítico', como disse Walter Benjamin, de onde surgiria uma possibilidade de que fossem 'lidas', isto é, temporalizadas, reatadas - ainda que por um limite imanente - à palavra da experiência. (...) Abrir os olhos sobre um acontecimento histórico não significa captar um aspecto visível que o resumiria como um fotograma - still, frozen, picture, como se diria em inglês -, tampouco escolher uma significação que o esquematizaria de uma vez por todas. Abrir os olhos sobre a história significa temporalizar as imagens que nos restam dela ${ }^{123} . "$

Eis-nos novamente, portanto, diante de nosso material de arquivo. Antes de proceder a um olhar atento a cada plano, é necessário destacar alguns pontos.

Em primeiro lugar, trata-se de um material bruto. Ou seja, de algo que não foi montado; de um material no qual as intenções finais que motivaram a filmagem estão inscritas mas não necessariamente evidentes a todo momento. Como tratamos no Capítulo 2, não é totalmente claro em que termos empunhava Jesco a câmera dentro do batalhão da Polícia Militar de Minas Gerais. Em uma cerimônia aberta, pública, que se queria visível, não é claro se Jesco trabalhava para si, para algum canal de mídia ou, como é nossa hipótese, se havia sido contratado pelo própria Funai para um registro oficial. Assim, é de se aventar se nosso material de arquivo se constitui, em verdade, do material bruto de uma propaganda de Estado nunca realizada. Material bruto, portanto, no qual as intenções que motivaram sua produção estão inscritas, mas não lapidadas.

Este material bruto e silencioso parece carregar inscrita em si três agências diferentes, que buscamos aqui nomear. O material fala, testemunha e é documento, da forma como três grupos distintos agiram naquele fevereiro de 1970. Em

123 DIDI-HUBERMAN, Georges. Remontagens do tempo sofrido - o olho da história II. Belo Horizonte, Editora UFMG, 2018. Página 30. 
primeiro lugar, existe a agência militar, a forma como estes, em especial Capitão Pinheiro mas não só, desenharam a performance, a controlaram, montaram. Afinal de contas, o material é o registro de uma formatura, de uma performance ensaiada, na qual indígenas e não-indígenas performam uma série de rituais militares para uma plateia branca. Há uma série específica de ações, de gestos, de performatividades que foi desenhada, organizada e ensaiada pelos militares.

De outro lado, existe a agência do fotógrafo, que, como aventamos acima, filmava por razões não totalmente conhecidas, mas cujas escolhas formais apontam em determinadas direções. Seus enquadramentos, suas escolhas formais, registram o evento de forma particular, e o acesso que temos ao que naquele dia se passou se dá através de seus quadros e das lentes que escolheu.

E por fim, existe a agência indígena, ou melhor, a forma como os corpos indígenas perfazem, percorrem a performance organizada pelos militares e filmada por Jesco, e a forma como dela se apropriam, a ela resistem, com ela dialogam. O termo 'agência' talvez não seja o mais preciso, posto que se trata de uma situação de opressão, e ressaltamos que descrever essas três 'agências' não significa conferir a elas uma igualdade inexistente. Queremos apenas destacar que é necessário conseguir ler nas imagens também a forma específica como os indígenas lidaram com a violenta encenação a que estavam sujeitos.

Este material se encontra fisicamente em uma situação frágil, próximo à decomposição. Por conta disso, nossa pesquisa não pôde ter acesso físico à película - ainda localizada no Museu do Índio. Conseguimos apenas uma fotografia do estado do material, que mostra os diferentes rolos juntos, colados algo que se deu durante a digitalização, conforme consta na ficha catalográfica do Museu do Índio: “Os rolos de vídeo (notação FDVI002) foram agrupados, quando de sua telecinagem, em um grande rolo único ${ }^{124}$."

\footnotetext{
$124 \mathrm{O}$ conjunto de rolos de película intitulados 'Arara', analisado nesta dissertação, encontra-se arquivado no Museu do Índio - no Fundo/Série/Subsérie: Fundação Nacional do Índio / Filmes depositados / Filme - sob o título Arara.
} 


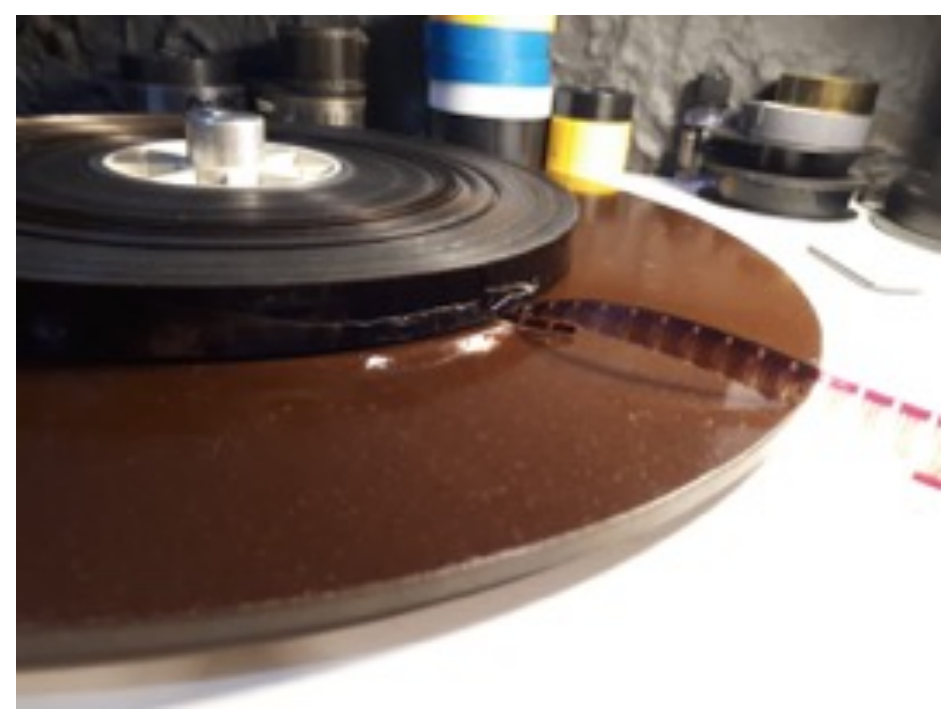

Nossa relação com o arquivo, portanto, se deu com o material já digitalizado, na mesma telecinagem que Rodrigo Piquet nos descreveu (ver Introdução). $\mathrm{O}$ arquivo digital veio com os diferentes rolos juntados em ordem aleatória. Por isso, não é fácil entender ao a ordenação original dos rolos. Fizemos pequenas mudanças de ordem em relação ao arquivo recebido, todas indicadas no material através de um black (um espaço sem imagens, tela preta de 3 segundos). Cortamos sempre que o material indicava final de rolo.

Por fim, é necessário destacar que há uma mancha em quase todo o material na parte central da película, que deixa elementos fora de foco. É difícil precisar se tal mancha é causada pela má-conservação da película ou se por algum defeito na lente quando da filmagem - o fato de o material entrar em foco em determinados tamanhos de lente poderia indicar que uma das lentes usadas estivesse com defeito.

Como dissemos no Capítulo 1, "para saber é preciso imaginar-se ${ }^{125 "}$. Ao olhar as imagens, é preciso que imaginemos o tamanho do equívoco, do desencontro cultural, histórico e político que significou o encontro provisório e violento entre militares e indígenas gerado a partir da formulação, pelos militares, da criação de uma Guarda Rural Indígena. Tal equívoco está presente, também, no reencontro, na sobrevivência, no reaparecimento deste material. Pois se é um fato fundante da história da Grin que ela consiste em um atravessamento da

125 DIDI-HUBERMAN, Georges. Imagens apesar de tudo. Lisboa, Editora KKYM. 2004. 
temporalidade branca na temporalidade indígena - uma política militarista constituída no ápice do embrutecimento da ditadura civil-militar que atropela os processos internos das aldeias que são alvo dessa política; é um fato que o reaparecimento dessas imagens se deve também à temporalidade da política branca e seus próprios processos. Foi a emergência (frágil, tardia, insuficiente) de uma política de memória pelo Estado brasileiro, a Comissão da Verdade, que fez com que o evento histórico da Grin voltasse à tona, afetando não apenas a memória branca, mas também, novamente, a memória indígena. Como afirmou Joel Krahô, neto de um Grin e tradutor das entrevistas Krahô, foi o surgimento deste material que fez ele próprio se interessar por esse aspecto da trajetória do avô, até então desconhecida do próprio neto. É preciso, portanto, se questionar sobre a agência dessas imagens hoje em dia, sobre como seu reaparecimento gera ações e reações; gera, também, novos equívocos.

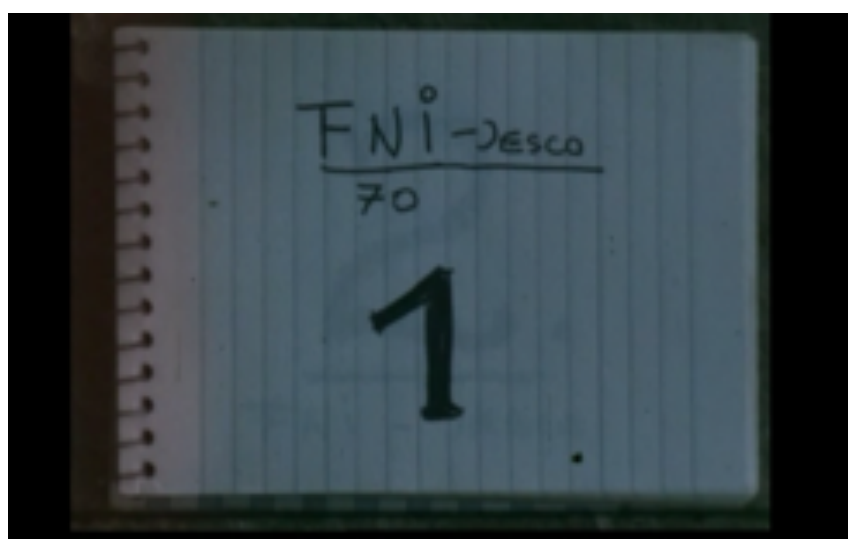

Imagem 01

O material começa com uma claquete, feita em folha de caderno, onde se lê "FNI - Jesco", e em seguida o número 70 - ano em que a filmagem foi realizada (imagem 01). Não há mais informações no papel. FNI era uma das nomenclaturas para a recém-criada Funai - Fundação Nacional do Índio. Assim, a claquete é um forte indicativo de nossa hipótese, de uma relação oficial entre Jesco e Funai, já que traz o nome dos dois, fotógrafo e contratante, assinalados na folha de papel. Curiosamente, podemos pensar que qualquer outra folha que tenha registrado esse possível vínculo empregatício se perdeu; sobreviveu apenas aquela que foi impressa em nitrato de prata, emulsionada pela luz solar através da objetiva. A 
sobrevivência das imagens depende também do suporte material em que estão impressas $^{126}$.

A primeira imagem após a claquete é um plano geral que enquadra o prédio do Batalhão da PM, vendo ao longe uma movimentação. É um plano bem enquadrado, que parece traduzir o começo de um trabalho de registro, que aos poucos mostra o cinegrafista se aproximando daquilo que filma.

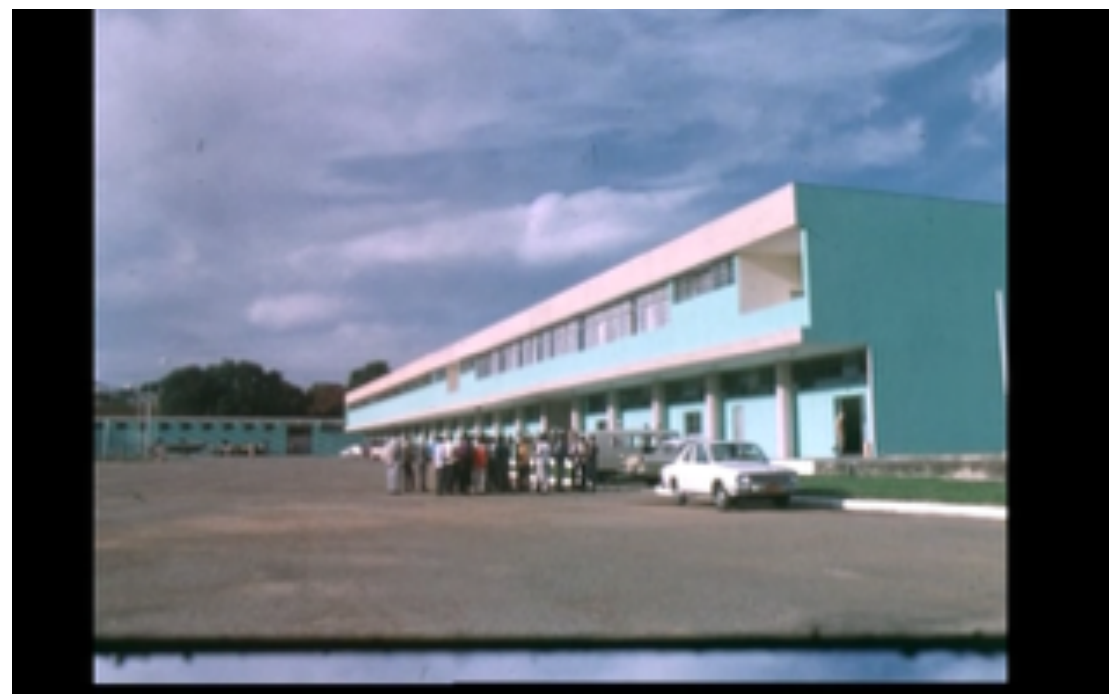

Em seguida, acompanhamos a situação dos guardas se preparando para a formatura. Eles estão conversando, em pequenos grupos, arrumando os uniformes (imagens 03 e 04), em uma sequência que dura três minutos.

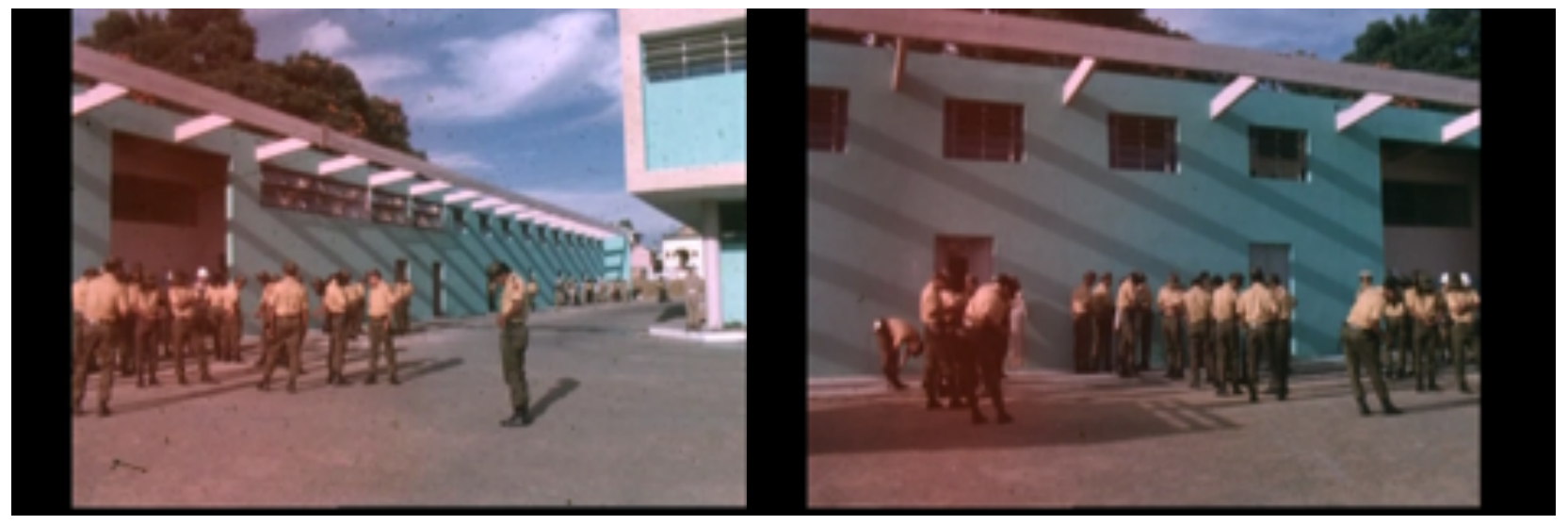

Imagem 03

Imagem 04

\footnotetext{
126 Lucas Figueiredo comenta algo semelhante ao descrever o passo importante, para os arquivos dos órgão de repressão, que foi a microfilmagem dos documentos, impulsionada nos anos 70. FIGUEIREDO, Lucas. Lugar Nenhum - Militares e civis na ocultação dos documentos da ditadura. São Paulo, Companhia da Letras, 2015.
} 
O primeiro desses planos, um plano geral que mostra diversos guardas, é feito duas vezes. Uma lenta PAN faz a passagem da imagem 3 para a 4 - passagem que se dá duas vezes. Se por um lado a repetição indica um início de trabalho, com o cinegrafista ainda se habituando ao ato de registrar, pode também indicar o apuro que ele precisava ter, buscando refazer uma imagem com a qual não ficou satisfeito. Em todo o material, este é o único plano refeito. Jesco então filma mais de perto, em planos menos gerais, alguns dos guardas que se preparam. Um deles fuma descontraído um cigarro. Ouro arruma o cinto de um guarda de outra etnia, como podemos super pela diferença entre seus cabelos (imagens 5 e 6 ).

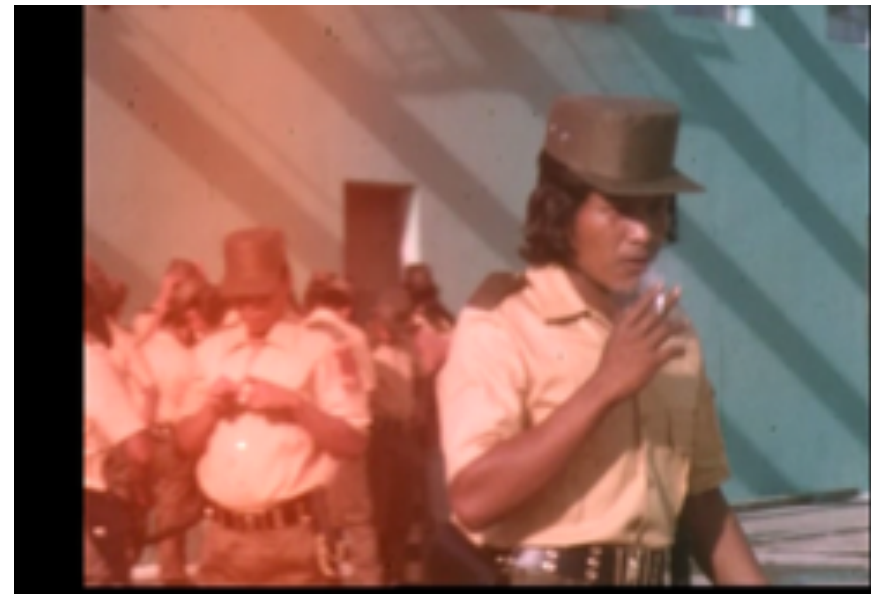

Imagem 05

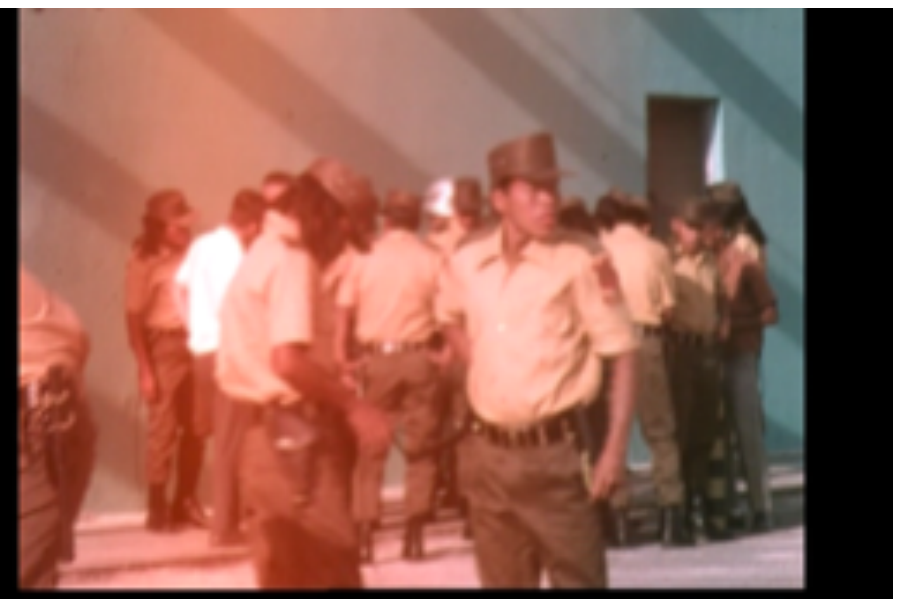

Imagem 06

Depois, o fotógrafo escolhe registrar as braçadeiras dos guardas, nas quais está bordada a etnia a que pertencem, junto com o brasão da Funai. Em seguida, em um movimento de câmera, revela o rosto, em primeiríssimo plano (imagens 07 e 08). O híper close, tanto na braçadeira quanto no rosto, parece carregar uma certa grandiosidade - os olhares distantes desses indígenas fardados, como se a aludir à existência de um novo sujeito. Parece haver no enquadramento uma positivação

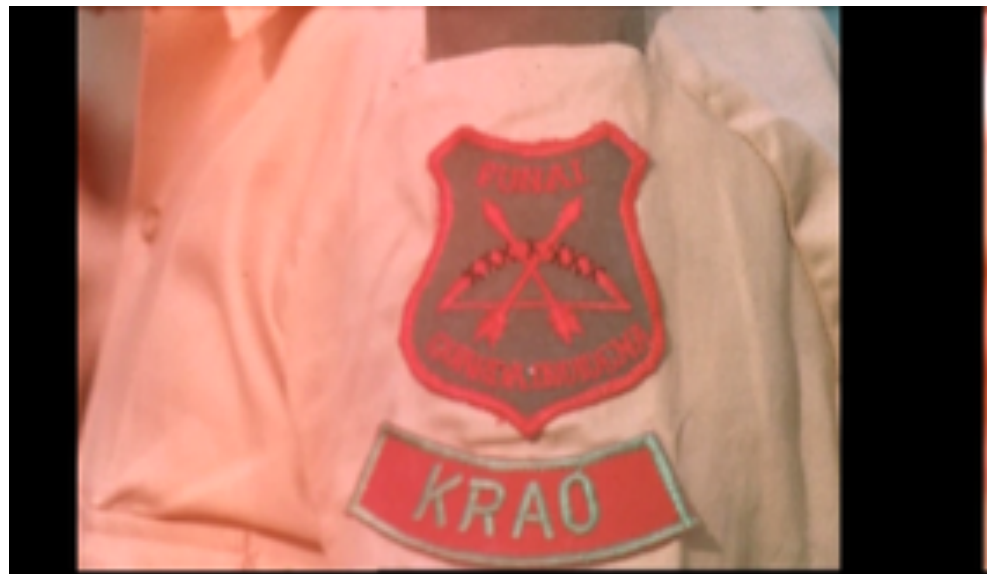


dos personagens filmados, tentando construir uma ideia de grandiloquência no evento que vemos. Em todo o material, abundam tentativas de criar uma iconografia militarista, este é um dos exemplos.

Em seguida acompanhamos a preparação para o desfile: os guardas, já enfileirados, são vistoriados pelo Capitão Pinheiro.

É interessante que este momento é o único, de todo o material, que é filmado mas não performado. Há algo aqui de um making-off, de um backstage, ao se registrar a preparação para a performance que viria a seguir. Assim, a atenção com que Capitão Pinheiro arruma a farda de cada guarda atenta para a dimensão imagética do que ocorria - independente da filmagem de Jesco, o que vemos aqui era a preparação de uma imagem. Imagem tornada pública na formatura, para a qual foram chamados repórteres de diversos jornais do Brasil e do exterior.

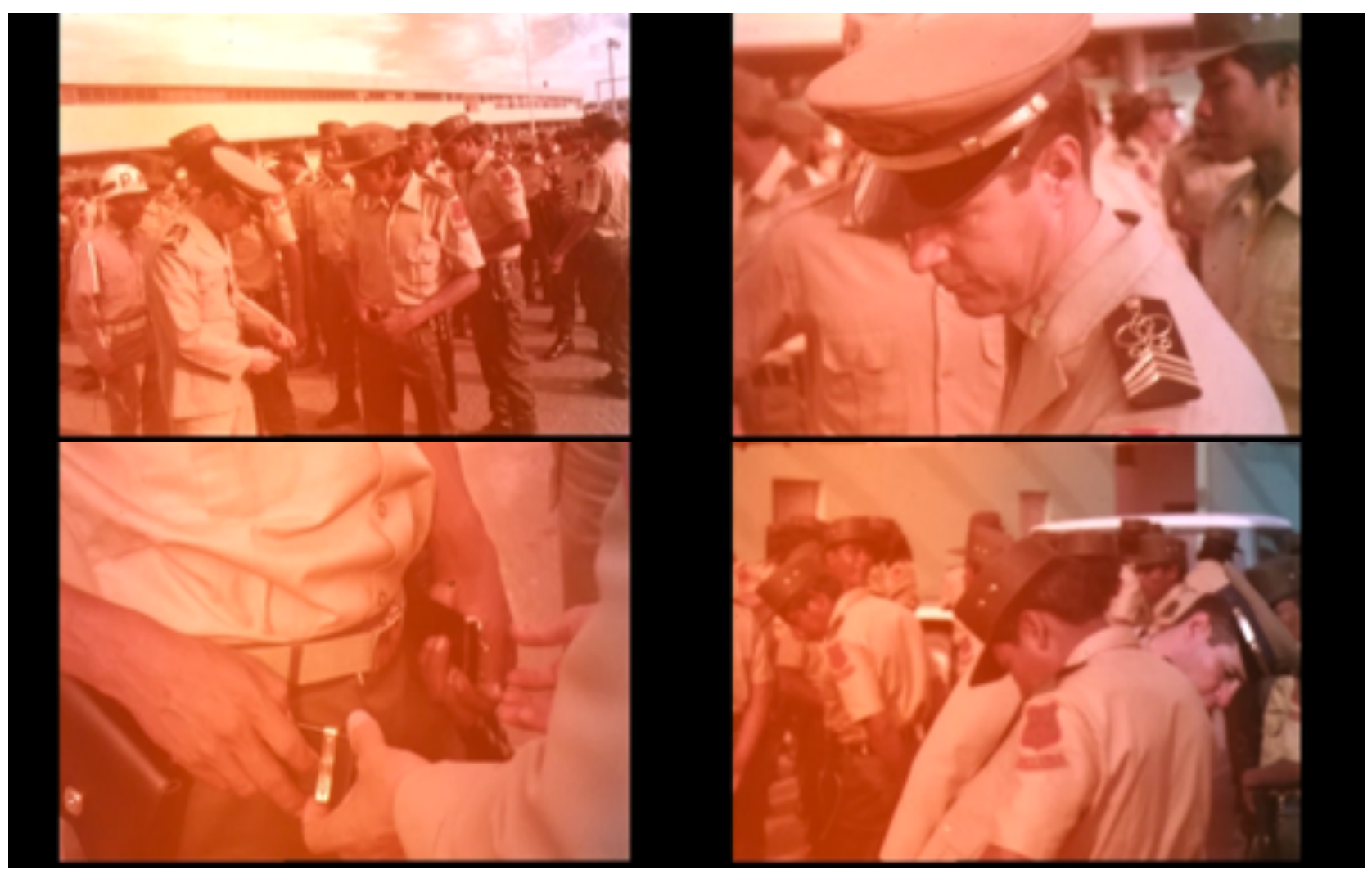

Imagens $09,10,11$ e 12

O depoimento de Valdir Xerente, dado a nossa pesquisa, confirma o aspecto propriamente imagético da performance. Ele descreve o esforço do Capitão Pinheiro por fazê-los performar de forma aparentemente militar: 
"Aí o Capitão falou: 'tem que dar certo! Todo mundo vai ver! Vocês não têm que fazer errado não. Vocês fazem ó, faz a boca assim, que nem nosso comandante, faz mesmo. Vocês não vão errar não, que todo mundo vai ver!' Ele falou pra nós desse jeito. (...) 'Não pode nem rir, não pode nem errar. Deixa esse povo olhar. Vocês vão olhar só pro que o comandante tá mandando. Se apresentar as armas, quando tá hasteando a bandeira, não vai olhar pras pessoas. Tem muita gente que vai gritar, mas vocês não olham. Se vocês olharem, vocês erram '127'”.

A preocupação de Capitão Pinheiro em evitar que os guardas rissem na cerimônia demonstra com precisão como, por um lado, era evidente ao policial a distância entre os guardas indígenas e a corporeidade militar tradicional - a risada é em tudo oposto à sobriedade da instituição militar; e, por outro lado, ressalta sua tentativa de fazê-los parecer soldados.

Desde o capítulo 1 refletimos sobre o aspecto propriamente imagético, para os militares, da Grin. Já discutimos os usos mais diretos pelo Estado dessa imagem, para defender a ditadura de acusações de violências contra povos indígenas feitas no exterior. No entanto, podemos nos perguntar sobre essa imagem, sobre o que ela representa, sobre o que ela revela, ou talvez sobre o que ela concretiza. Por que, aos olhos dos militares, a imagem dos indígenas fardados poderia lhes defender das críticas que sofriam? Há aqui um elemento importante, que retomaremos adiante, sobre uma certa fantasia, para os óculos dos militares, que essa imagem realiza: a de indígenas puros e fardados, ao mesmo tempo indígenas e policiais, iguais e diferentes aos militares que lhes assistiam das tribunas. Voltaremos a esse raciocínio.

Olhando as imagens acima com atenção, é possível ver também aquilo que não encaixa. É possível ver como, apesar da agência militar, apesar do gesto de Capitão Pinheiro arrumando os cintos e tentando disciplinar os corpos, um guarda Krahô fuma um cigarro, displicentemente, em uma gestualidade nada marcial

\footnotetext{
${ }^{127}$ Como dito no Capítulo 1, esse e outros depoimentos foram coletados por nós durante o processo de feitura do documentário A Flecha e a Farda, que é paralelo à esta pesquisa. Valdir Xerente deu sua entrevista em português. A transcrição aqui está feita idêntica à fala.
} 
(imagem 09). Embora os indígenas estejam enfileirados, simetricamente dispostos no espaço, a maioria olha para o lado, para a própria roupa, para a do vizinho, como a se perguntar se estão certos, se é necessário fazer algum ajuste. A distância entre o desejo disciplinador dos militares e a forma que os indígenas performam essa disciplina se explicita no corpo de cada um deles, neste momento prévio à formatura em si. É interessante notar como esse momento, frisamos, filmado mas não performado, explicita o quanto a disciplinaridade que será performada em todo o evento era, também para os indígenas, uma imagem, algo exterior a seus corpos. Há aí, talvez, uma forma de resistência que merece ser melhor pensada.

Eduardo Viveiros de Castro retoma a imagem trazida pelo Padre Vieira do mármore e da murta para falar sobre as dificuldades da catequização indígena no Brasil do século XVI: "A estátua de mármore custa muito a fazer, pela dureza e resistência da matéria; mas, depois de feita uma vez, não é necessário que lhe ponham mais a mão: sempre conserva e sustenta a mesma figura; a estátua de murta é mais fácil de formar, pela facilidade com que se dobram os ramos, mas é necessário andar sempre reformando e trabalhando nela, para que se conserve ${ }^{128 "}$. Viveiros de Castro reflete sobre as narrações dos padres jesuítas do século XVI, que se exasperavam com a nomeada inconstância da alma selvagem: "O que exasperava os padres não era nenhuma resistência ativa que os 'brasis' oferecessem ao Evangelho em nome de uma outra crença, mas sim o fato de que sua relação com a crença era intrigante: dispostos a tudo engolir, quando se os tinha por ganhos, eis que recalcitravam, voltando ao vômito dos antigos costumes ${ }^{129 "}$.

Essa dicotomia retomada por Viveiros é interessante de ser pensada aqui. Não é forçoso dizer que a noção de resistência indígena gera dificuldades no embate de memórias do pós-ditadura - afinal, resistência seria aquela impressa no mármore rígido das ações políticas, das organizações culturais, das lutas estruturadas. A imagem da murta seria, desse ponto de vista, por demais dispersiva para ser lida como resistente. Um exemplo concreto desta dificuldade foram os

\footnotetext{
128 VIVEIROS DE CASTRO, Eduardo. O mármore e a murta: sobre a inconstância da alma selvagem, in: A inconstância da alma selvagem. São Paulo, Cosacnaify, 2002. Página 183.

129 idemibidem, página 190.
} 
embates dentro da Comissão da Verdade em torno da inclusão, ou não, de um capítulo sobre as violações de direitos indígenas no relatório final - embate expresso ainda, como já dissemos, na contagem oficial de mortos que o Relatório traz (ver Introdução). Padre Vieira formula, ainda, na mesma temática: "Há outras nações, pelo contrário - e estas são as do Brasil - que recebem tudo o que lhes ensinam com grande docilidade e facilidade, sem argumentar, sem replicar, sem duvidar, sem resistir, mas são estátuas de murta que, em levantando a mão e a tesoura o jardineiro, logo perdem a nova figura, e tornam à bruteza antiga e natural, e a ser mato como dantes eram ${ }^{130 " . ~ M a i s ~ a ̀ ~ f r e n t e, ~ e x a s p e r a d o, ~ s e ~ q u e i x a: ~}$ "a gente dessas terras é a mais bruta, a mais ingrata, a mais inconstante, a mais avessa, a mais trabalhosa de ensinar a quantas há no mundo ${ }^{131}$ ". É necessário estar atento, portanto, às estratégias 'murtosas' de resistência, resistência secular, que se apropria da alteridade, do contato violento com os brancos, do equívoco e da violência que permeia este contexto - e que tem sua eficiência atestada nas queixas do catequizador.

Voltando a nosso material, é importante destacar que Jesco também parece ter sentido que a imagem 09 feria sua representação oficiosa do evento. Ele corta o plano, e continua a filmar em close, registrando primeiro o gesto de Capitão Pinheiro de fechar o cinto dos guardas, e depois seu rosto, ignorando assim a forma particular e pouco militarista como o guarda Krahô recebia a indicação. Novamente, temos enquadramentos que sugerem uma montagem glorificante, a partir de planos próximos. Aqui acaba o primeiro rolo de nosso material.

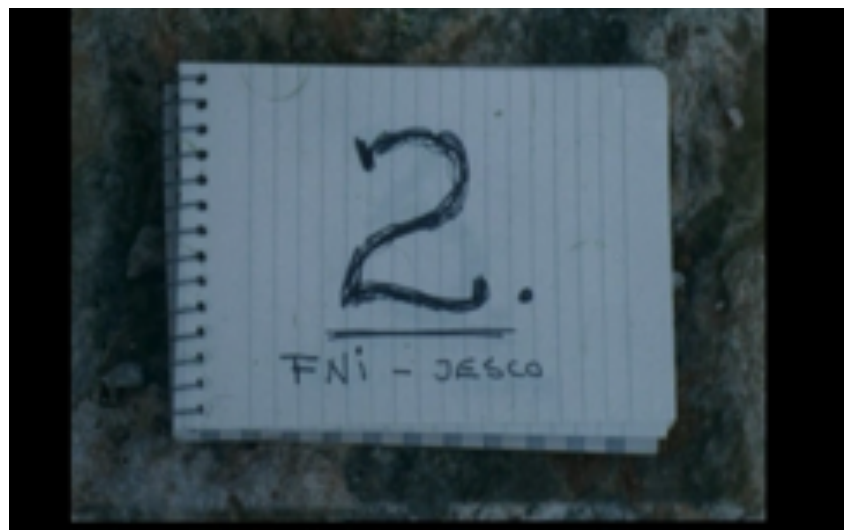

Imagem 13

130 idemibidem, página 184 - grifo nosso.

131 idemibidem. 
Em seguida, começa o rolo 02 (imagem 13). Vemos os Grins se aproximarem da câmera marchando, em três filas dispostas simetricamente (imagem 14). Eles levantam exageradamente o braço, em uma gestualização quase pantomímica. O fotógrafo se posiciona de forma precisa, pois eles fazem a curva muito perto da câmera, de forma que o mesmo enquadramento começa como um plano geral e se transforma em um close dos rostos dos guardas passando (imagens 14 e 15). Vemos aqui que o grupo Krahô, o único que manteve os cabelos compridos, está à frente do batalhão, em papel de destaque.

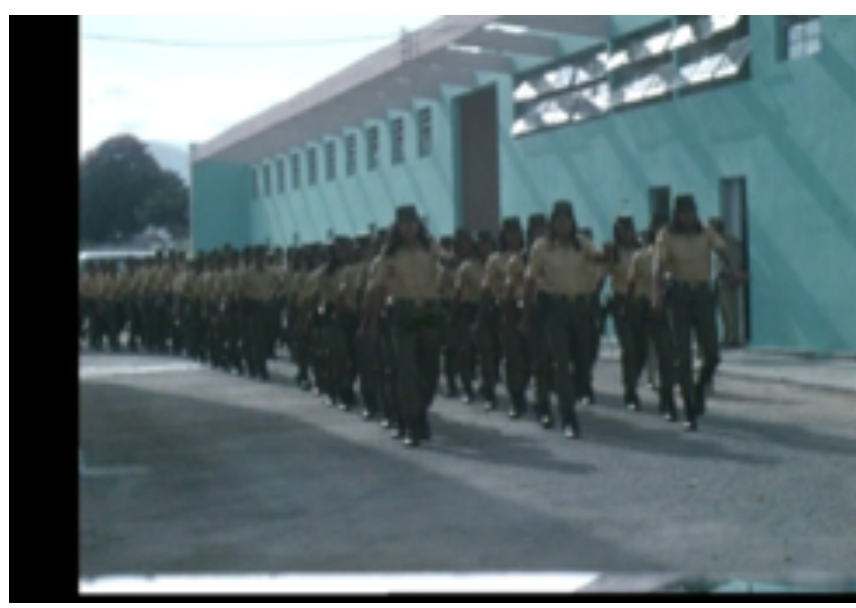

Imagem 14

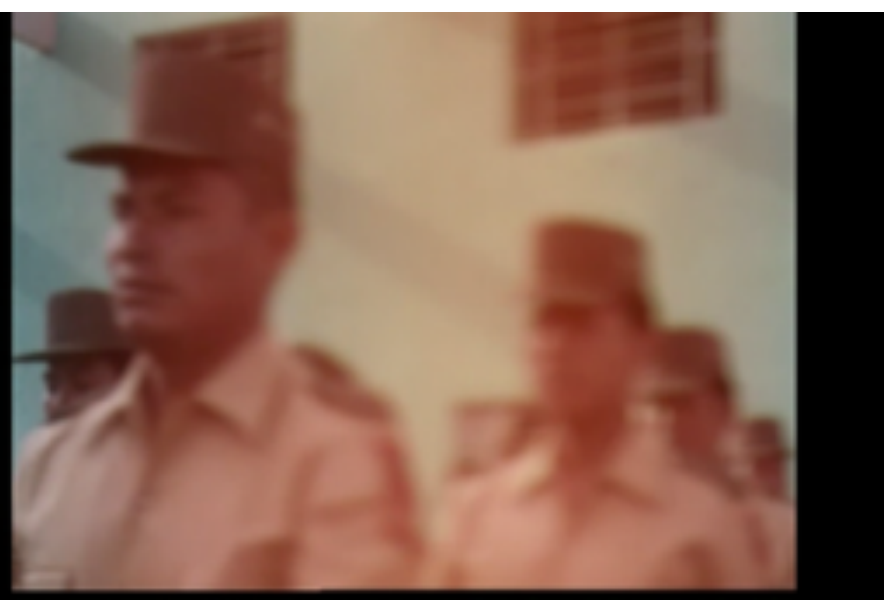

Imagem 15

No plano seguinte, vemos os guardas marchando até onde está um batalhão de policiais não-indígenas. Em todo este trecho teremos uma certa performatividade tradicional policial-militar que será efetuada pelos não-indígenas. Tanto a filmagem de Jesco quanto a organização do evento buscam sugerir a todo momento uma identidade entre os dois grupos. A ida dos guardas indígenas para onde estão os policiais militares parece sugerir que este novo grupo agora passa a fazer parte daquele.

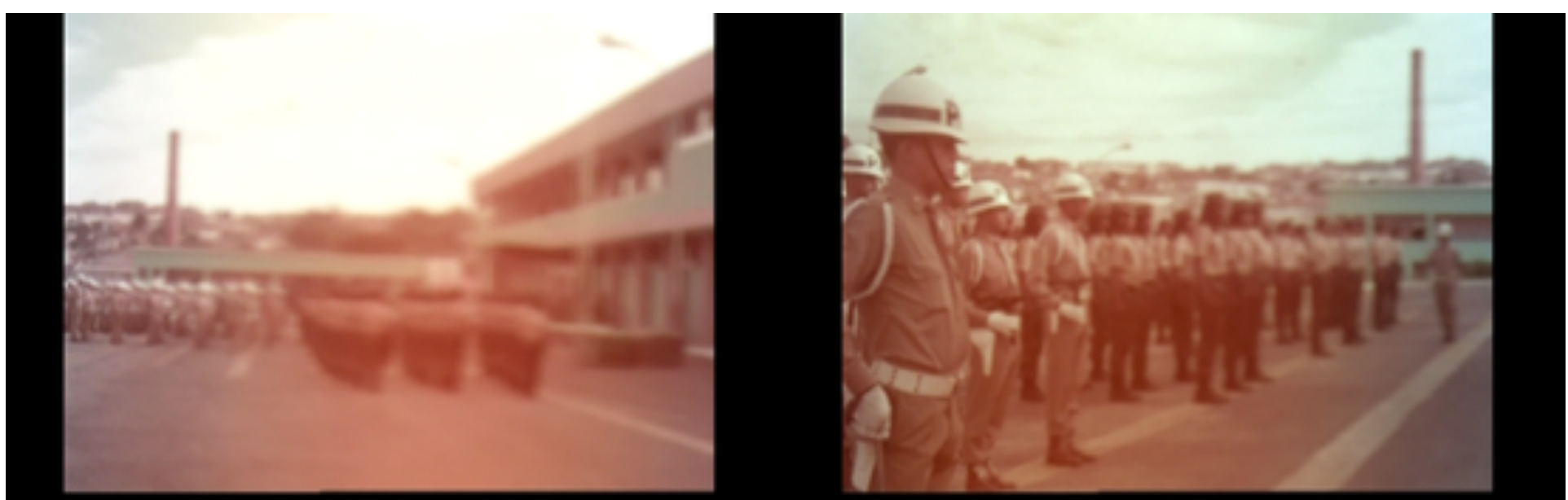




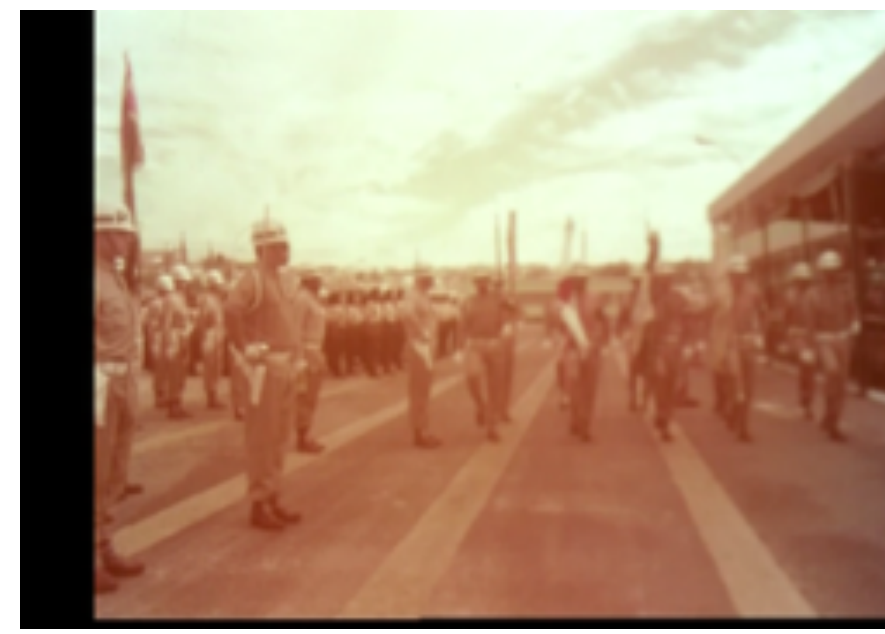

Imagem 18

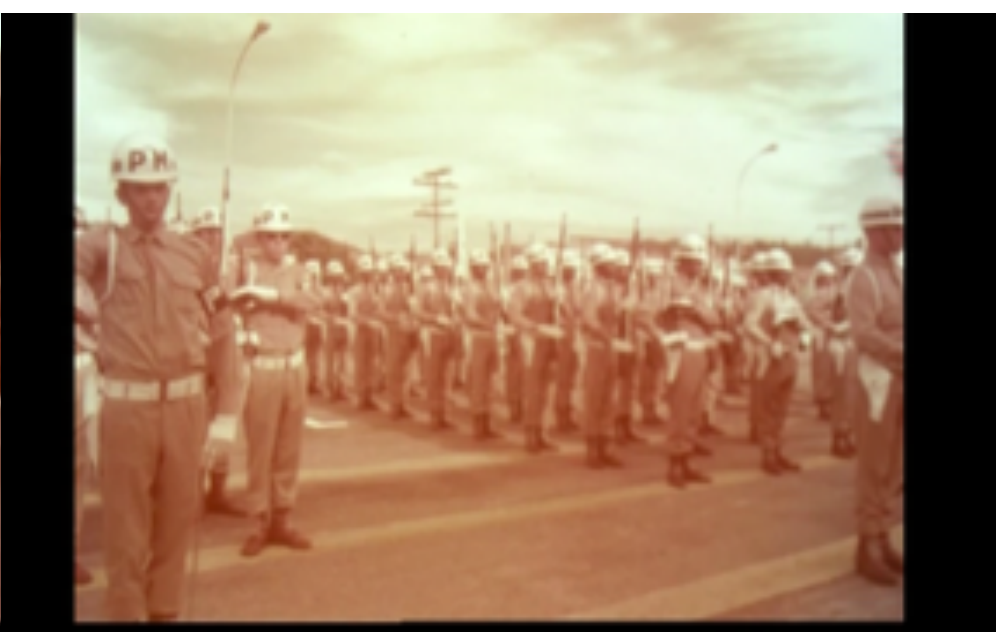

Imagem 19

A imagem 17, bem composta, coloca os militares brancos em primeiro plano, e ao fundo o pelotão Grin - a justaposição indica semelhança, ambos estão agora no mesmo espaço; apesar das diferenças, haveria um solo em comum, militar, que o enquadramento se esforça em fazer ver.

$\mathrm{Na}$ sequência (imagens 18 e 19), temos a continuação da mesma performatividade, efetuada pelos policiais não-indígenas: primeiro a banda marcial que marcha à frente da tropa, depois o gesto duro, efetuado por todos ao mesmo tempo, de bater continência.A filmagem se concentra então no ritual de jurar bandeira: a bandeira brasileira é hasteada, o hino é tocado, os militares fazem gestos idênticos (imagens 20, 21, 22 e 23). A cerimônia se estende até o final do segundo rolo.

Imagens 20,21, 22 e 23

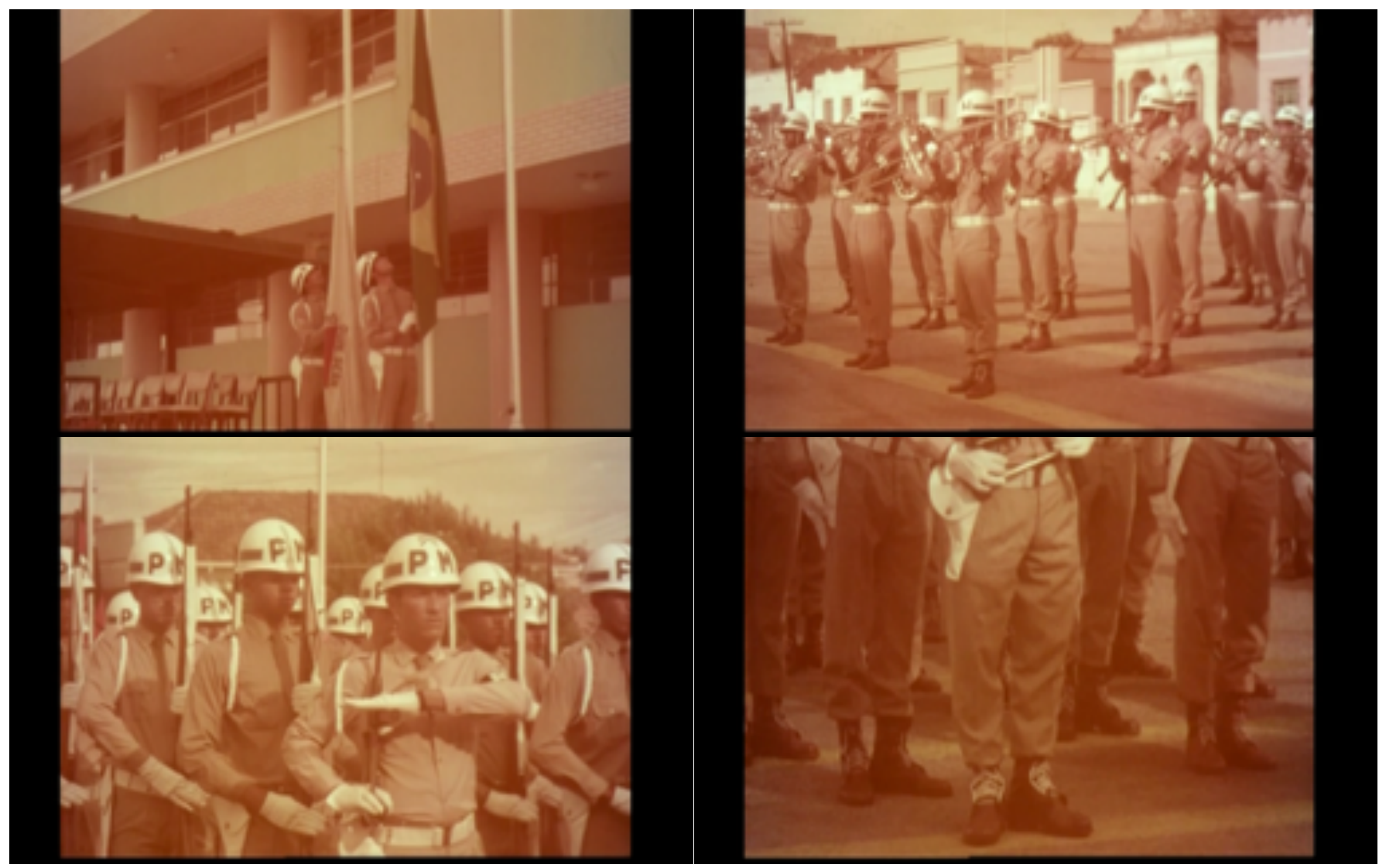


Olhando esse momento com atenção, é possível fazer alguns apontamentos. O primeiro é a alta qualidade estética do registro. Os quadros são bem compostos, Jesco escolhe com rapidez os enquadramentos que produz, por vezes fazendo mais de um quadro da mesma ação, em escolhas inteligentes. A título de exemplo, destaque-se o corte entre as imagens 24 e 25 :

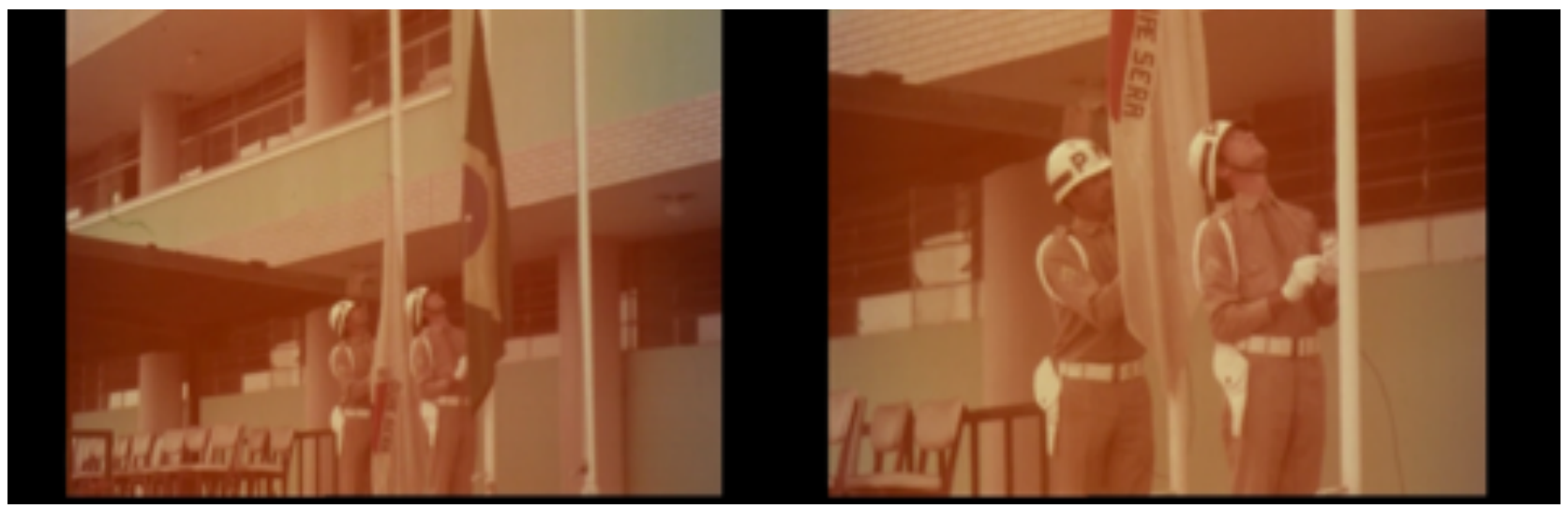

Imagens 24 e 25

Jesco reenquadra a ação de levantar a bandeira, enquadrando mais de perto o policial que a puxa, e espera que ele levante a cabeça, como ocorreu no plano geral, para fazer o corte. Assim, o fotógrafo se mostra sagaz em suas escolhas e preocupado, ao fazer o registro, com as possibilidades de montagem de seu material.

Imagens 26, e 27

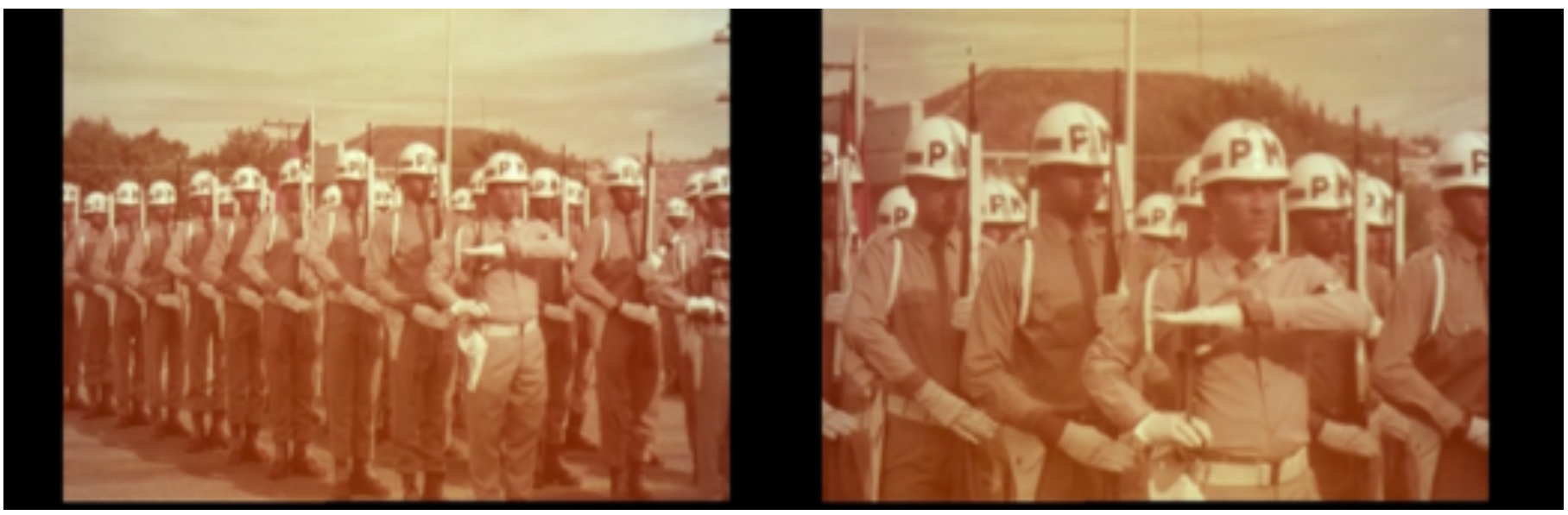

Nos momentos finais do rolo vemos algo que se repetirá ao longo do material: a tentativa de registrar o gestual militar em planos médios. A filmagem aqui parece se dar com uma expectativa de Jesco em relação aos gestos a serem realizados - ele enquadra planos médios, e move a câmera logo após os gestos 


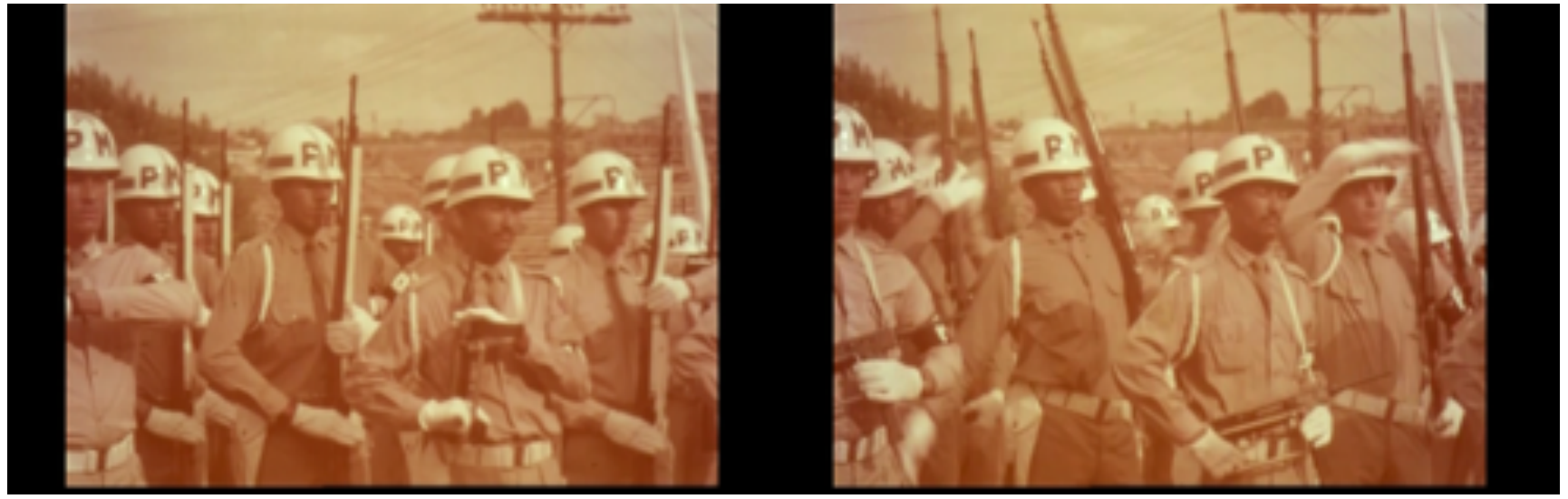

ritualizados ali encenados. Podemos notar, por exemplo, o corte entre as Imagens 28 e 29 imagens 26 e 27, se aproximando dos guardas no momento em que irá acontecer o gesto ritual, que se dá na imagem 29.

Também, podemos notar o movimento de câmera que Jesco realiza entre as imagens 29 e 30, fazendo logo após o gesto militar uma TILT que enquadra as botas dos policiais. Jesco repetirá esse gesto em outros momentos diante dos

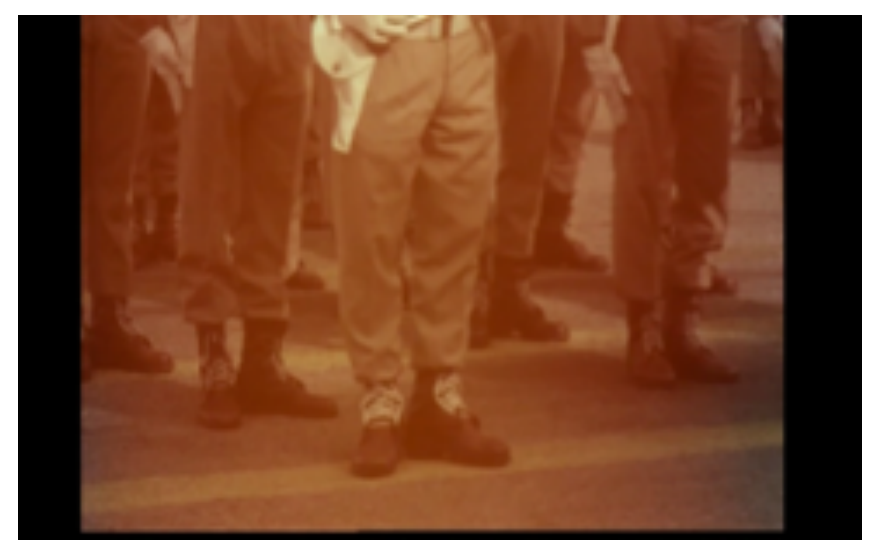
guardas indígenas; novamente, há a criação deliberada de uma iconografia militarista, que uniria indígenas e não indígenas. A filmagem de Jesco não apenas registra o evento como uma existência bruta e imprevisível, mas se preocupa com uma construção iconográfica, na qual o militarismo assume papel central. Começa o rolo 03 .

O rolo começa com a cerimonização do 'passar em revista', que é feita duas vezes, por duas autoridades presentes: o Governador de Minas Gerais, Israel Pinheiro, e, depois, o Coronel Costa Cavalcanti, Ministro do Interior. Nas imagens, vemos os policiais não-indígenas enfileirados, e as autoridades caminharem lentamente diante dos guardas. É interessante destacar alguns elementos. Podemos notar a diferença das imagens 32 e 33 . Na

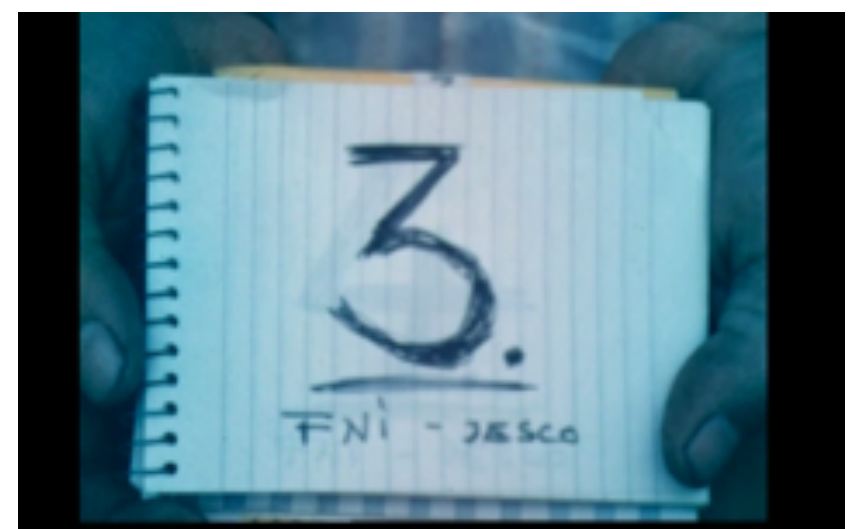
primeira, vemos a zona à esquerda, que é uma zona na qual circulavam outros fotógrafos, uma zona, por assim dizer, fora $\mathrm{da}$ representação oficial. Jesco então ajusta a câmera para compor a imagem institucional, buscada pela performação coletiva. 


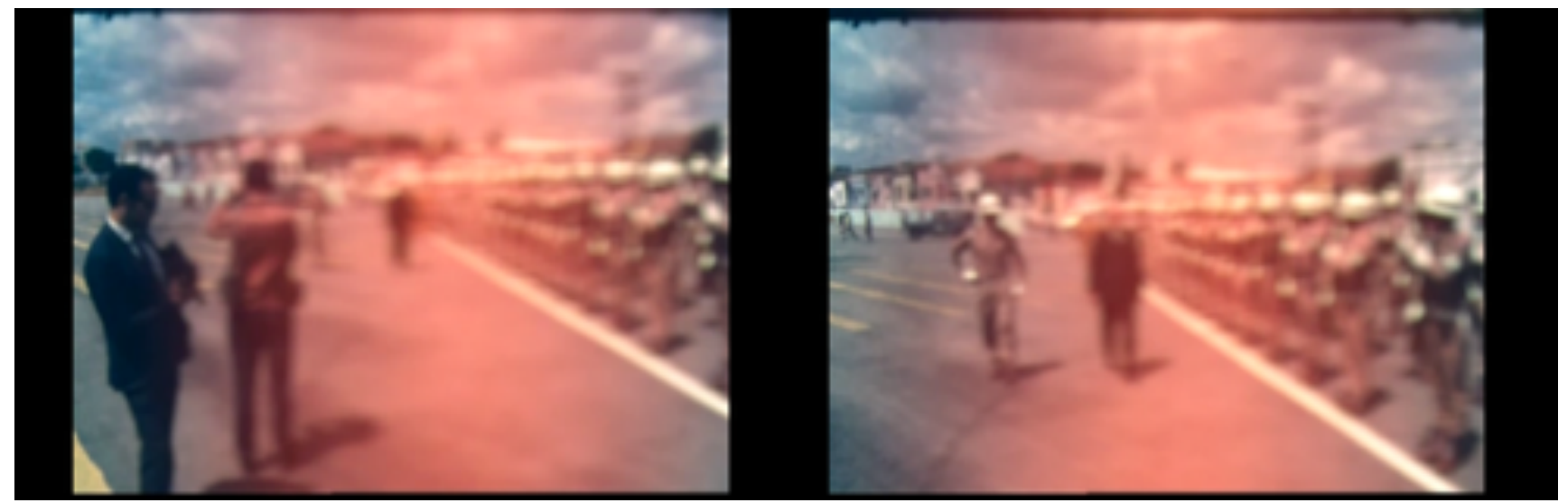

Há, ao longo dos 26 minutos, momentos como este, momentos que escapam, que por vezes parecem gravados 'por engano'. A imagem 32 é apenas o começo do plano, que é logo reenquadrado com um passo à frente do cinegrafista, indo 'ao que interessa'. Mas esses momentos 'fora da representação oficial' são também reveladores; eles apontam para o esforço coletivo, partilhado por Jesco e por aqueles que desenharam o evento, de criação de uma performance imagética.

Também, podemos notar na imagem 32 outro cinegrafista, que segura o que parece ser uma câmera $16 \mathrm{~mm}$ e filma Israel Pinheiro caminhando. Nossa pesquisa não teve notícia de outras filmagens desse evento. Apenas os 3 primeiros rolos possuem claquetes, todas com o nome de Jesco; todo o resto do material está sem claquetes. É possível que Jesco, na correria do registro do evento, não tenha conseguido fazer outras claquetes; é também possível que nosso material una o registro de mais de um cinegrafista. No entanto, tendo em vista a coerência formal dos diferentes rolos, esta hipótese não ganha maiores evidências. De toda forma, a existência de outros fotógrafos e cinegrafistas, que aparecem de forma recorrente ao longo dos 26 minutos, sempre nas bordas dos planos, atesta o quanto a cerimônia de formatura se quis visível - em 1970, no auge da vigência do AI-5, a cobertura de imprensa de um evento como este teria de ser autorizada pelo regime.

Após a passagem de Israel Pinheiro, enquanto esperava a próxima autoridade se aproximar, Jesco se preocupa repetidamente em registrar gestos militares. Ele filma de forma curta, começando pouco antes dos movimentos

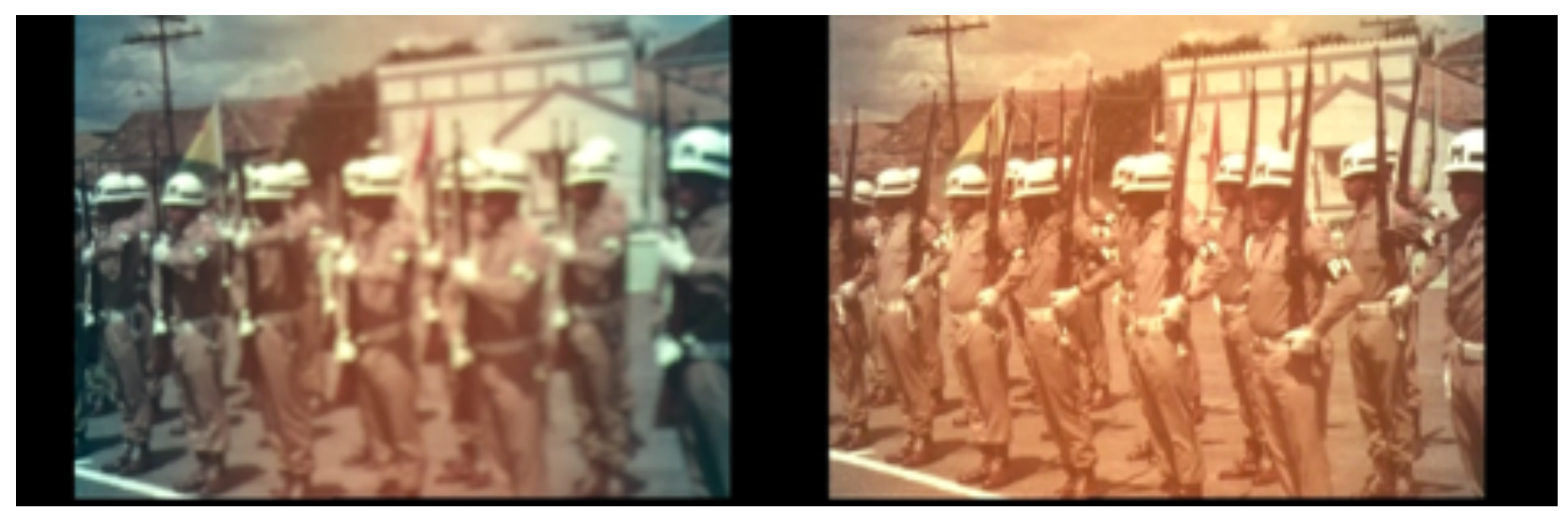

Imagens 34 e 35 


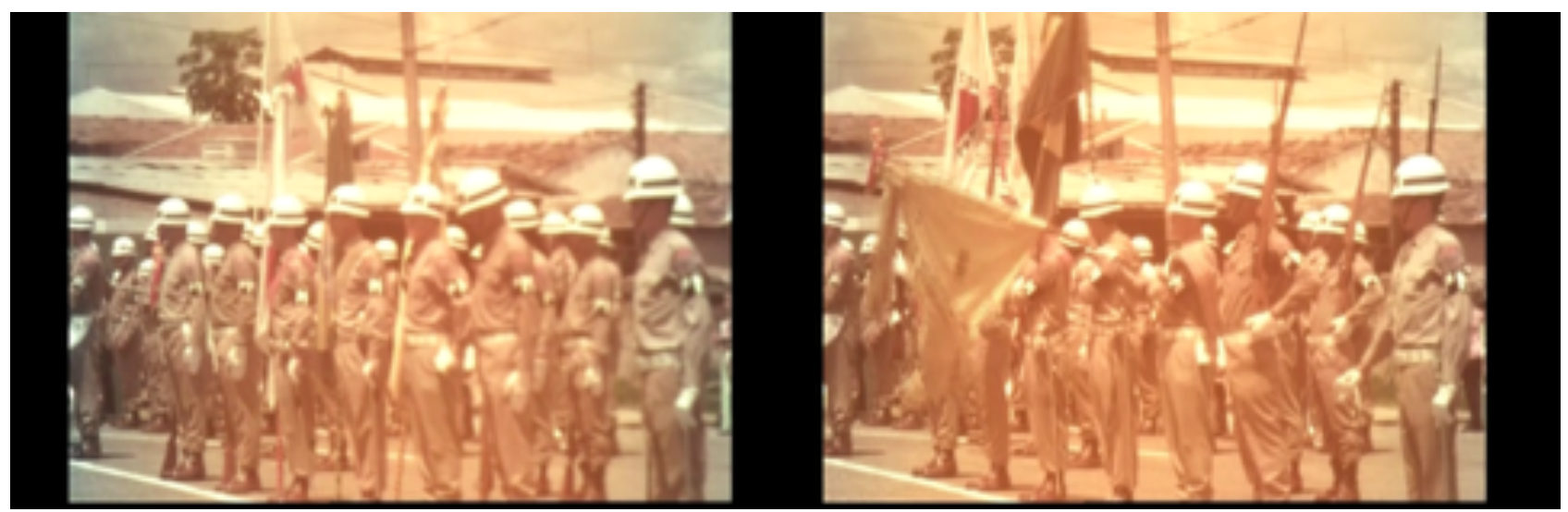

Imagens 36 e 37

rituais, e cortando logo após (imagens 34, 35, 36 e 37). O fato de tais registros serem filmados de forma curta, com o corte logo após o movimento dos guardas, reitera uma noção de montagem que está impressa na filmagem, bem como uma precisão do cinegrafista no uso de película.

A entrada do Coronel Costa Cavalcanti é precedida por planos curtos que buscam chegar até o quadro dele andando, lidando assim com uma já referida 'fronteira da representação oficial'. Novamente, é possível perceber o esforço coletivo por trás da produção de uma imagem oficial, que aqui só se faz visível pelo fato de estarmos diante de um material bruto. No caso, a imagem 41 é precedida de outras três tentativas até ser alcançada:

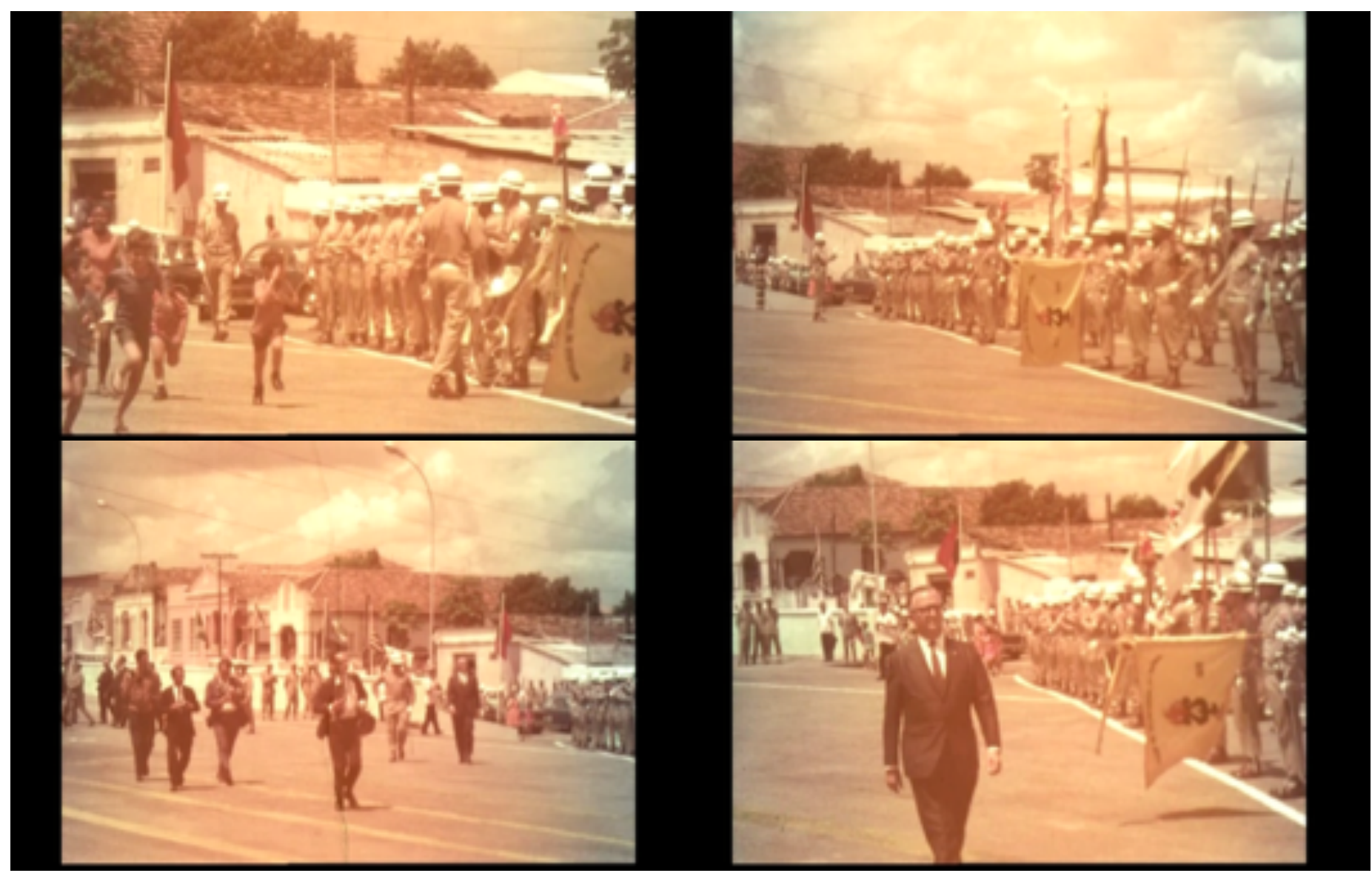

Imagens 38, 39, 40 e 41 
E então, a imagem oficial enfim acontece: Costa Cavalcanti, Ministro do Interior do Governo Médici, passa em revista os guardas perfilados, enquanto, ao fundo, a banda marcial toca. Sorridente, ele vistoria os policiais, todos enfileirados.

Depois que o Ministro cruza o pátio, Jesco se detém mais uma vez sobre a ritualística militar, em novo plano feito para uma montagem iconográfica. Ele ensaia algumas posições de câmera até que consegue captar um movimento completo dos policiais movendo as armas de forma idêntica:

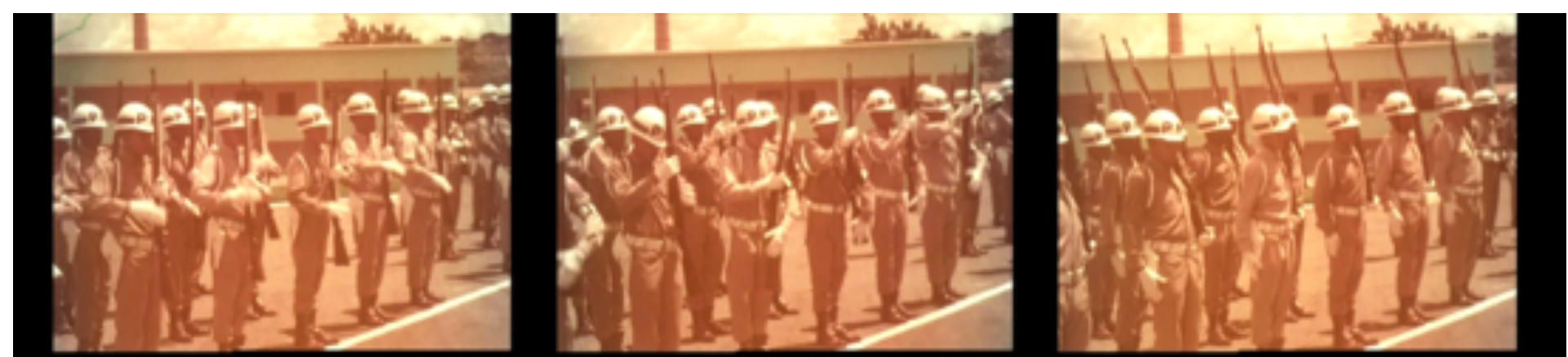

Imagens 42,43 e 44

A cerimônia continua. Em um canto, vemos o pelotão da Grin. Os indígenas estão rígidos, esperando um sinal para começarem (imagem 45). Mas o take deles parados dura apenas alguns segundos, indicando que o fotógrafo estava mais interessado na performance do que no registro da cerimônia em seus tempos mortos. Quando eles começam a marchar, a câmera se reposiciona e pega, em um plano único bem realizado, a marcha, um enquadramento dos pés que se movimentam ritmadamente, os rostos, e por fim o pelotão adentrando o pátio do batalhão policial (imagens 46, 47 e 48).

Imagens 45 e 46

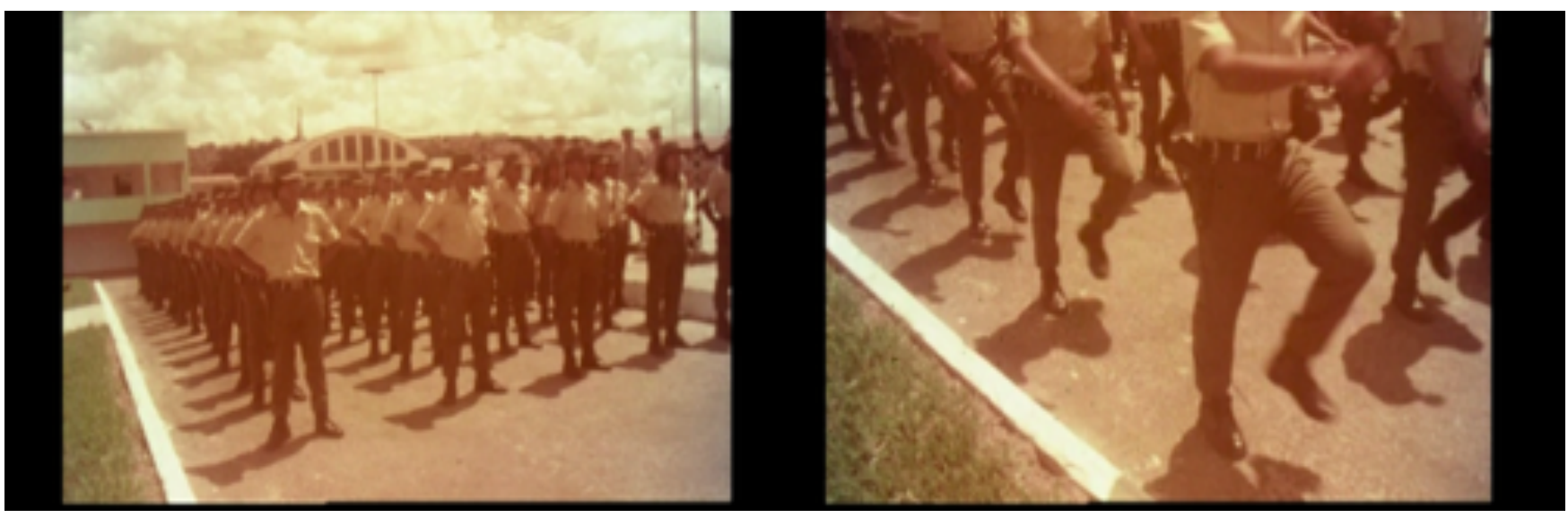




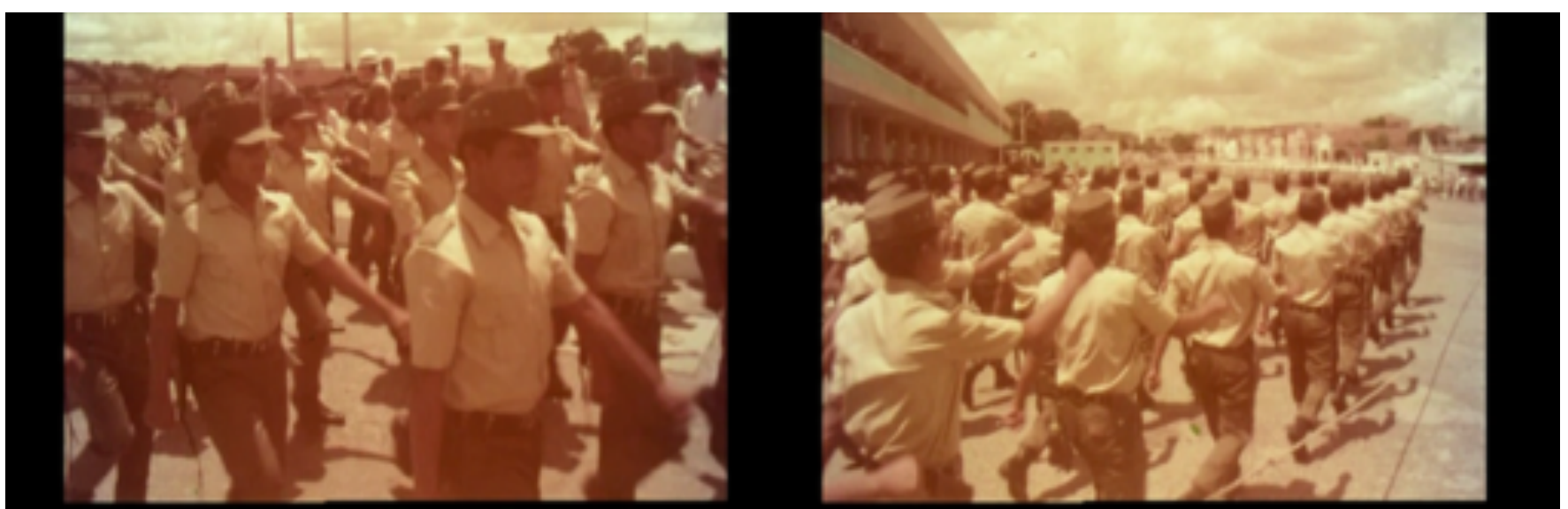

Imagens 47 e 48

A imagem 46 pode ser destacada. Como vimos assinalando, Jesco faz uma série de enquadramentos que remetem a uma iconografia de cunho militar; este é mais um deles. A imagem, bem enquadrada, das pernas dos guardas indígenas marchando busca retirar a individualidade ou as reações deles ao que se passava, focando no ícone: a marcha, a calça, a bota.

Conforme os guardas indígenas se aproximam do centro do batalhão, a câmera enquadra um dos elementos centrais da disposição da performance: a plateia (imagens 49 e 50). Há aqui uma primeira imagem do que chamaremos de olhar branco: uma plateia não-indígena, majoritariamente masculina e branca, com membros do alto escalão do governo ditatorial. É a essa plateia que a performance se dirige, é para estes olhos que o evento foi desenhado. Há aqui um jogo reflexivo: se a performance como um todo se constitui na construção de uma imagem, aqui temos formulada e registrada a posição daqueles que olham, daqueles a quem a imagem se dirige. Se os militares tanto organizaram a cerimônia da Grin como uma imagem do outro, dos guardas fardados, a cerimônia supõe também uma imagem de si próprios, dos militares que sorriem das tribunas.

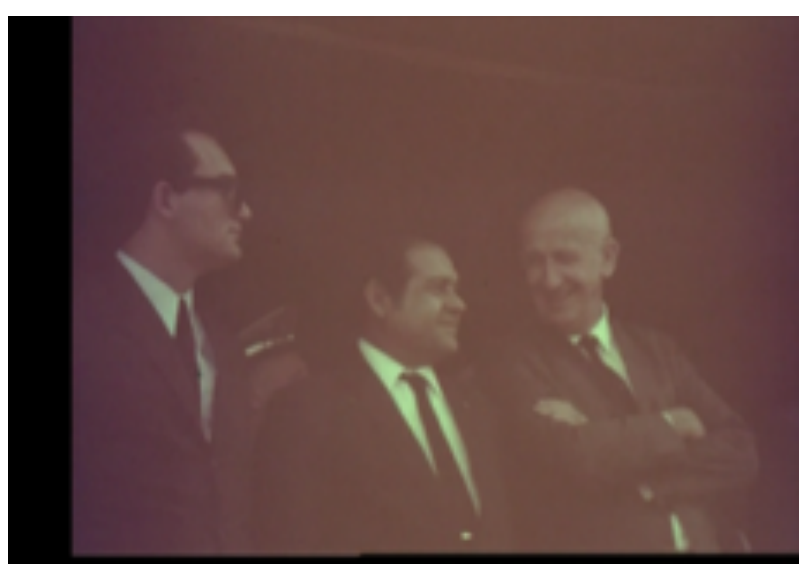

Imagem 49

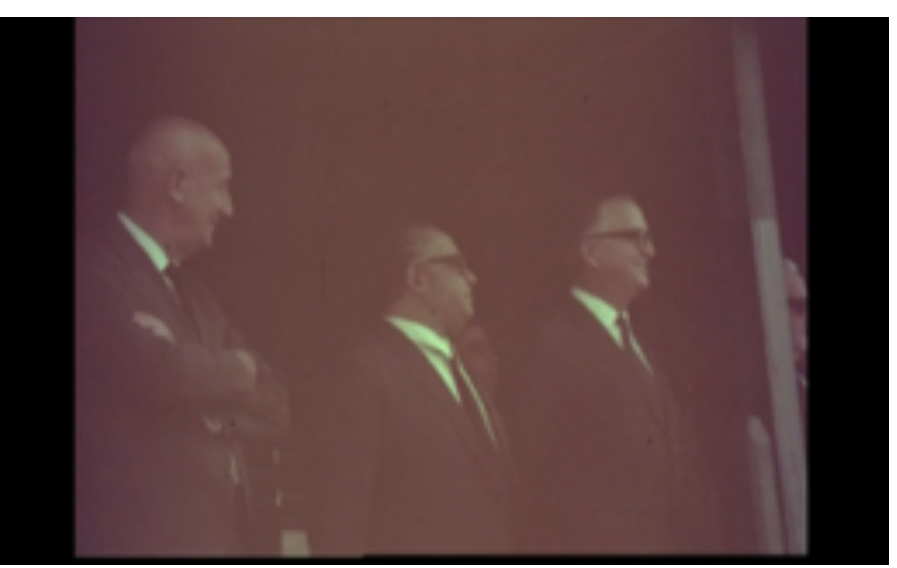

Imagem 50 
Há uma contradição aí posta: como apontamos, a criação desta imagem buscava defender a ditadura de acusações vindas do exterior - poderíamos pensar, portanto, que é a eles, aos críticos estrangeiros da ditadura militar brasileira, que essas imagens seriam endereçadas. Porém, a cúpula da ditadura, aqueles que criaram a política da Grin, que desenharam o evento, que aprovaram o que se passava, ocupam aqui a posição da platéia, a posição daquele que olha. Nesse sentido, podemos situar a posição de Jesco como intermediária - ele não está nem no palco nem na plateia. Ele filma os que são olhados, os guardas indígenas, e também aqueles que olham.

Além disso, se até aqui tanto destacamos a Grin como a criação de uma imagem, é necessário pensar que há um ritualização acontecendo também para os militares. Do alto da plateia, sorrindo, eles afinal também estão em cena. Os militares sussurram entre si, o Ministro do Interior olha a cena e sorri: o que vê lhe agrada. A encenação do outro envolve também uma encenação de si mesmo.

Um contra-plano (imagens 51 e 52) nos mostra o que faz o ministro sorrir: os guardas indígenas marcham ritmadamente em frente à plateia e realizam movimento sincrônico de baixar os braços, à moda militar. Para os óculos da cúpula da ditadura, a imagem era nitidamente positiva.

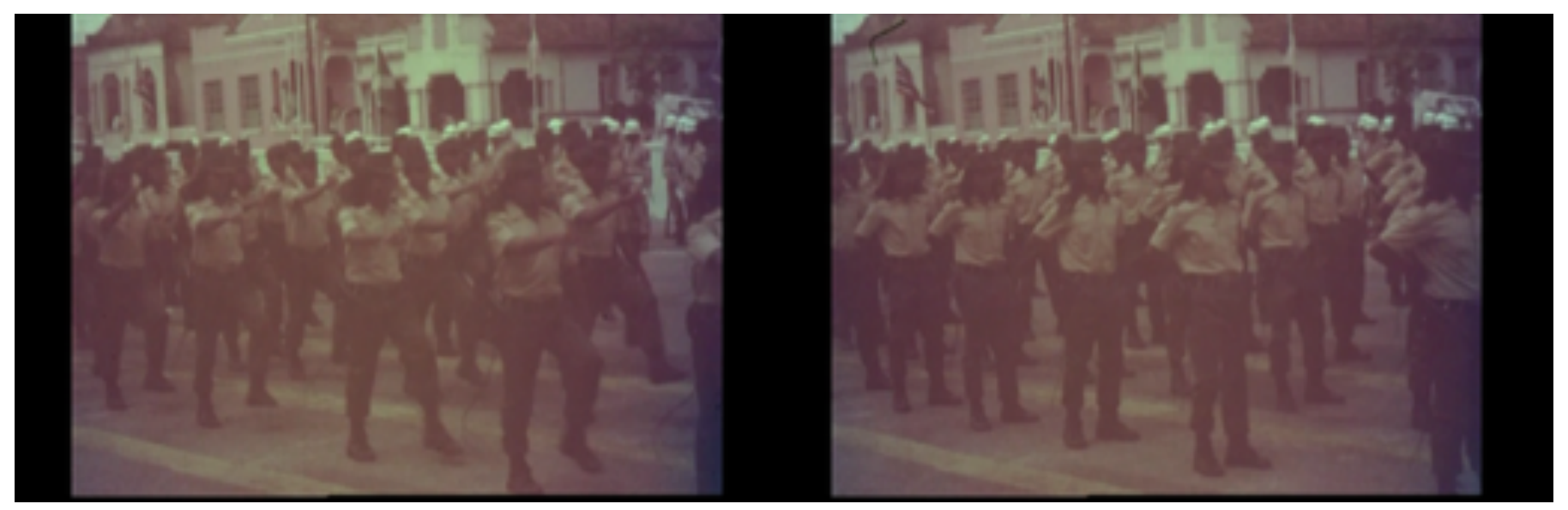

Imagens 51 e 52

Gostaríamos de aprofundar a reflexão sobre o aspecto propriamente ritual que ali se passava. Estamos diante de uma cerimônia. O que afinal está sendo ritualizado? Nos parece produtivo traçar um paralelo com um filme em tudo diverso, realizado 15 anos antes de nossa cerimônia: Os Mestres Loucos, de Jean 
Rouch (1955), no qual o cineasta francês registra um ritual Hauka, um ritual complexo, estranho e violento, no qual, aos poucos percebemos, está sendo encenada ou ritualizada uma relação com os colonizadores europeus. Como comenta Renato Stuztman: "uma seqüência bastante emblemática nesse filme é aquela que passa do altar do sacrifício, durante o ritual em que todos já estão possuídos pelos espíritos hauka, para a cena que mostra o desfile de oficiais britânicos. Passamos da imagem de um ovo sendo quebrado sobre o altar para o amarelo e branco das penas do capacete de um oficial britânico. O comentário de Rouch, presente do início ao fim do filme, como que explica (e domestica) essa conexão de imagens ao alegar que é naquela ocasião solene que os seus personagens vão buscar o modelo do ritual secreto realizado nos finais de semana, longe do centro da cidade. Michael Taussig (1993) vê no fenômeno apresentado por Rouch um ato de mimese: ao imitar os colonizadores, os africanos se apropriam de sua força. Paul Stoller (1995), não muito distante dessa interpretação, vê esses atos como produção de uma memória inscrita no corpo, incorporada. À luz de Wagner podemos colher aí um movimento de reversibilidade, de reflexão sobre o outro e de extensão de um simbolismo próprio, que resulta em resistência a um só tempo política e cognitiva, uma espécie de descolonização do imaginário ${ }^{132}$."

O filme de Rouch tem inúmeras diferenças com nosso material, que não serão aqui tratadas. Filme complexo, despertou leituras díspares e contundentes desde sua primeira exibição ${ }^{133}$. No entanto, ele nos interessa por atentar para as formas de apropriação do ritual dos opressores pelos oprimidos, ao narrar a forma como os Hauka dialogam com os rituais dos colonizadores em sua cerimônia, bem como o papel central das cerimônias oficiais em seu processo de ritualização.

\footnotetext{
132 SZTUTMAN, Renato. A utopia reversa de Jean Rouch: de Os Mestres Loucos a Petit à petit. Belo Horizonte, Revista Devires, Volume 6, 2009.

${ }^{133}$ Segundo relato do próprio Rouch, sobre a primeira exibição do filme: "Marcel Griaule, meu orientador de doutorado, estava vermelho de ódio: „É preciso destruir esse filme imediatamente... e o primeiro cineasta africano, Paulin Vieyra, então aluno do IDHEC (Institut des Hautes Études Cinématographiques) e crítico de filmes da revista Présence Africaine, estava cinza de raiva: „Jean, pelo menos uma vez eu concordo com o professor Griaule, este filme é um escândalo, é preciso destruí-lo". Sozinho, o etnólogo-cineasta Luc de Heusch (futuro professor da Université Libre de Bruxelles) reagiu favorávelmente: „Jean, não os escute! Em dez anos esse filme será um clássico..." ROUCH, Jean. L'autre e le sacré: jeu sacré, jeu politique. In: Thompson, C. W. (Ed): L'autre e le sacre: surrealisme, cinema, ethnologie. Paris, Galimard, 1995.
} 
Aqui, gostaríamos de sublinhar o aspecto cerimonial do que se passava, e o quanto essa cerimônia foi desenhada por e para os militares, que, como dissemos, a tudo assistiam, sorrindo, das tribunas. Assim, aqui, a ritualização que estamos buscando ver era inteiramente construída pelos militares - como se estes se dirigissem a si próprios. O sorriso alegre do Ministro do Interior em ver os indígenas fardados aponta para um pano de fundo da cerimônia. Há uma exultação, talvez algo fetichista, com o que era disposto enquanto imagem, uma imagem concretizada e no entanto impossível - a imagem de que os indígenas membros da Grin seriam, ao mesmo tempo, habitantes plenos dos próprios universos simbólicos e das próprias comunidades às quais deveriam retornar após o treinamento, e membros plenos do Exército Brasileiro, olhos e ouvidos do Estado ditatorial infiltrados nos rincões do país. Uma imagem que buscaria guardar em estado bruto uma relação estranha entre identidade e diferença - os guardas seriam totalmente indígenas e totalmente militares ao mesmo tempo; idênticos e opostos aos brancos que brilhavam os olhos. Talvez assim possamos compreender o porquê de os Krahô, com seus cabelos compridos, estarem sempre na primeira fileira da cerimônia; o grupo que imageticamente mais resistiu à transformação na monotonia militar, ao manter os cabelos compridos, foi aquele que recebeu maior destaque daqueles que organizaram o evento.

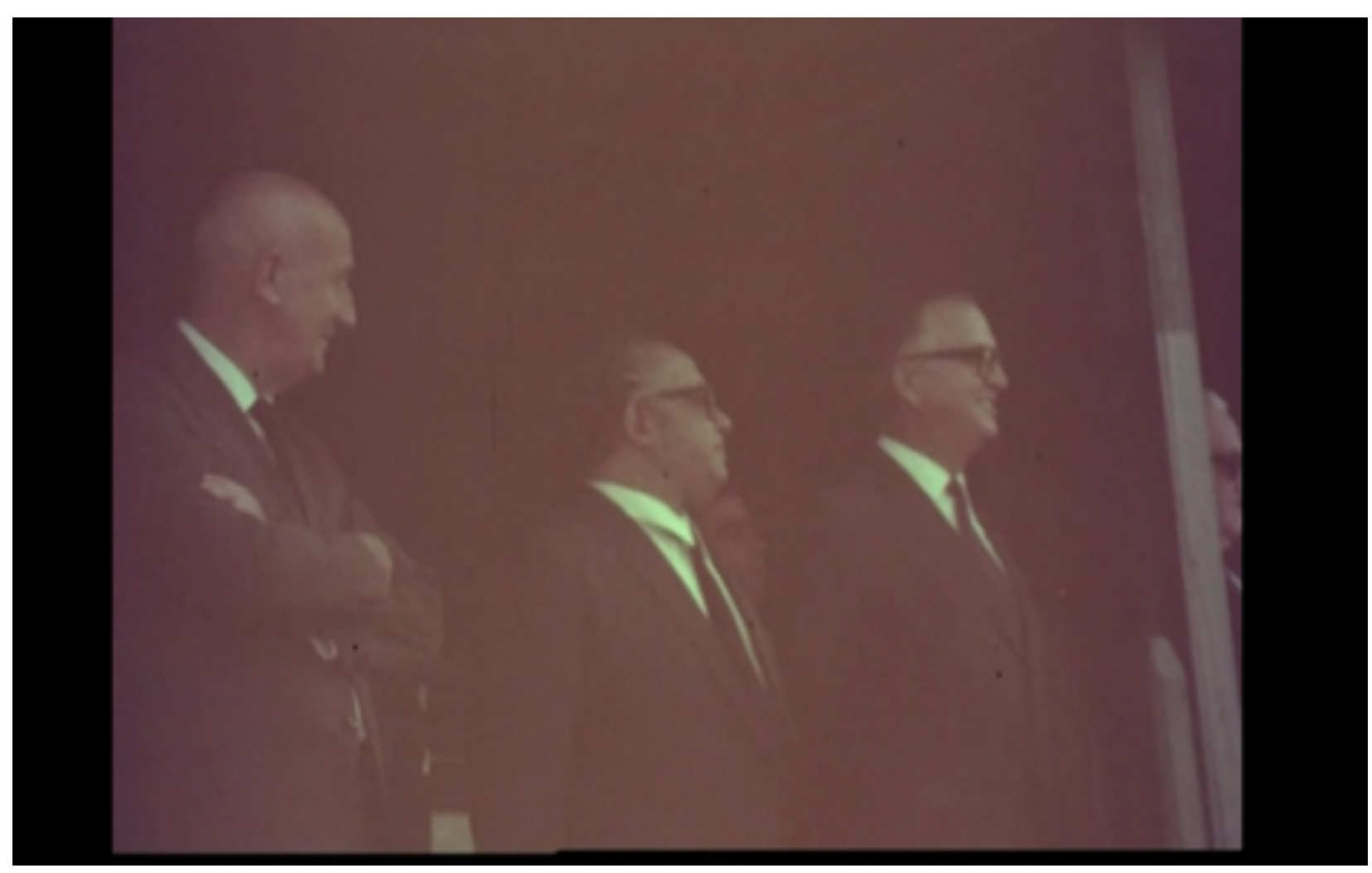


Eis então que os militares, no ápice da violência do período ditatorial, quando chamados a reagir às críticas que recebiam em relação ao trato com os povos indígenas, responderam não apenas com uma imagem, mas com a redução do outro a uma imagem de si próprios. A militarização dos indígenas não deixa de ser a imagem mais acabada do projeto ditatorial de tornar todo o país, até mesmo o grupo mais improvável e distante da militarização estatal, à imagem e semelhança daqueles que detinham o poder. Das tribunas, se vendo performados nos corpos assinalados como diferentes, os militares sorriam.

Tal fetiche, no fim das contas, não passou, justamente, de uma imagem. A realidade, bem mais complexa, foi outra, como veremos.

O quarto rolo não possui claquete.

Ele inteiro é realizado a uma maior distância do evento, e não é clara a relação temporal que estabelece com o rolo anterior. Vemos, inicialmente, uma marcha tanto dos guardas brancos quanto dos Grins. A imagem é feita do alto, à distância (imagem 53).

Vemos a linha de frente da marcha: a banda militar, que atravessa o pátio tocando. Era uma banda poderosa: podemos ver, na imagem 54, três tubas, instrumento de sopro grande. Podemos apenas imaginar o tamanho da zoada militarista que tomava o ambiente, bem como seus efeitos sobre os guardas indígenas.

Conforme o grupo se aproxima da plateia, é possível entender a dimensão do evento pela primeira vez - podemos perceber que tanto o andar de baixo quanto o de cima estão tomados de gente (imagem 55). O plano seguinte são planos das

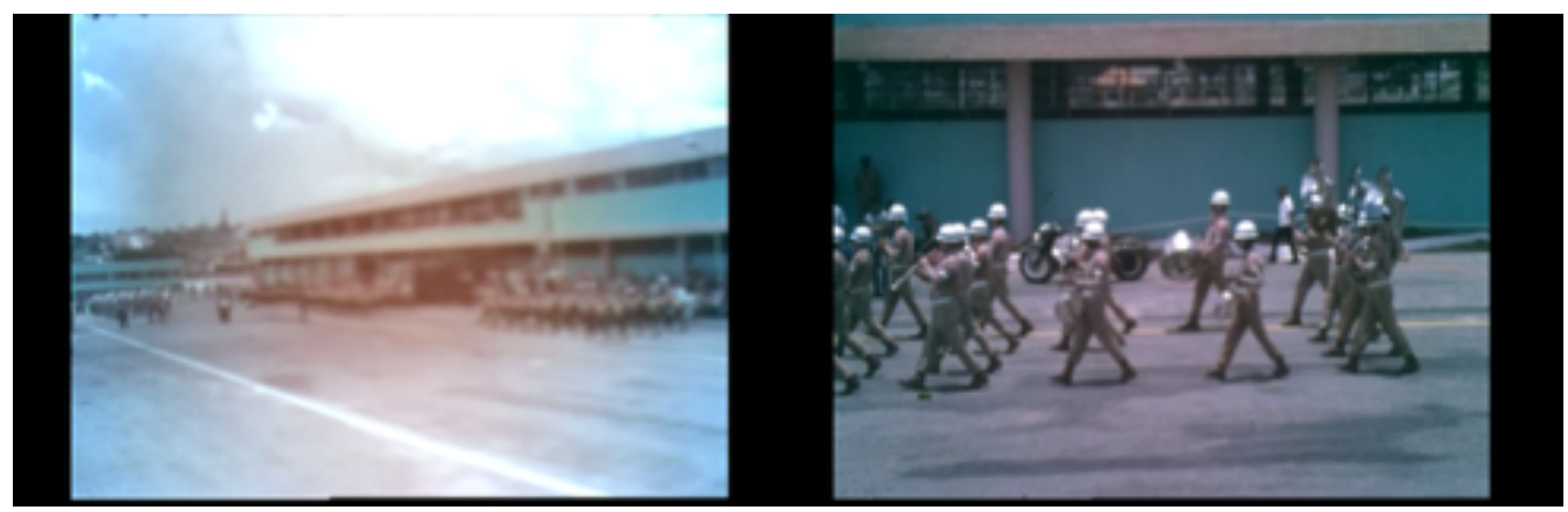




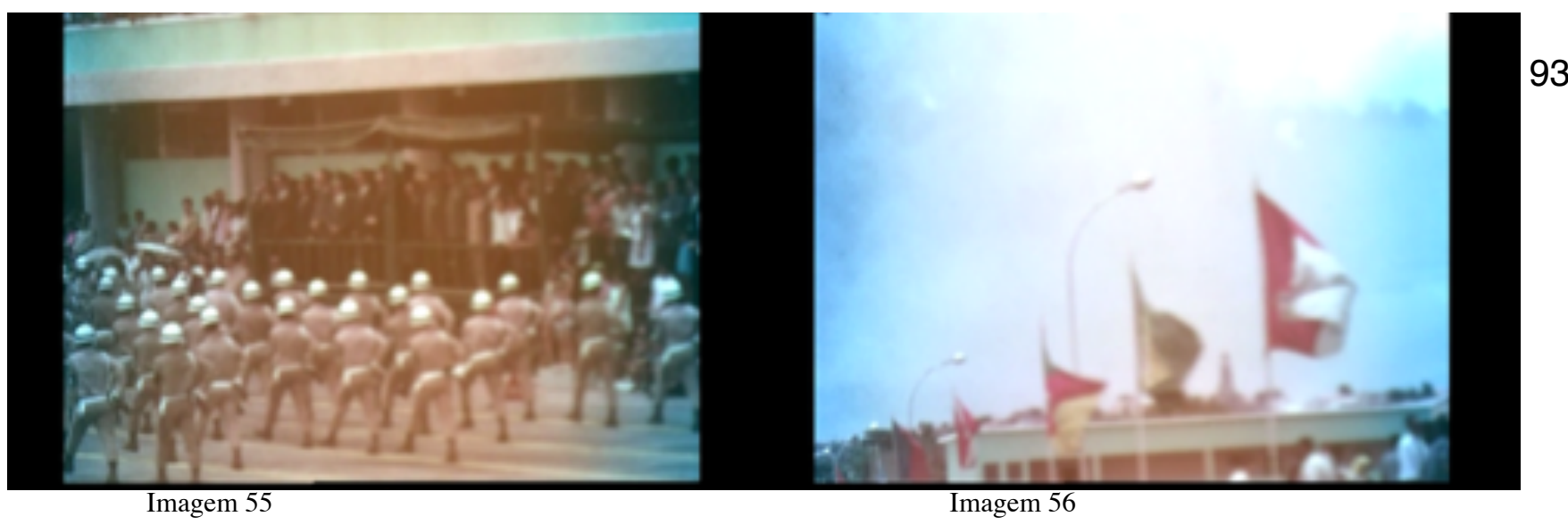

bandeiras. Jesco primeiro enquadra, de forma fortuita, bandeiras dos Estados brasileiros, em uma tomada curta e pouco convicta (imagem 56), até que se detém sobre a imagem, de forte significado simbólico, da bandeira brasileira. Jesco faz 4 planos diferentes da bandeira (imagens 57, 58, 59 e 60), repetição que aponta para a centralidade da iconografia nacionalista - mais uma vez, o caráter oficial de sua filmagem fica evidente.

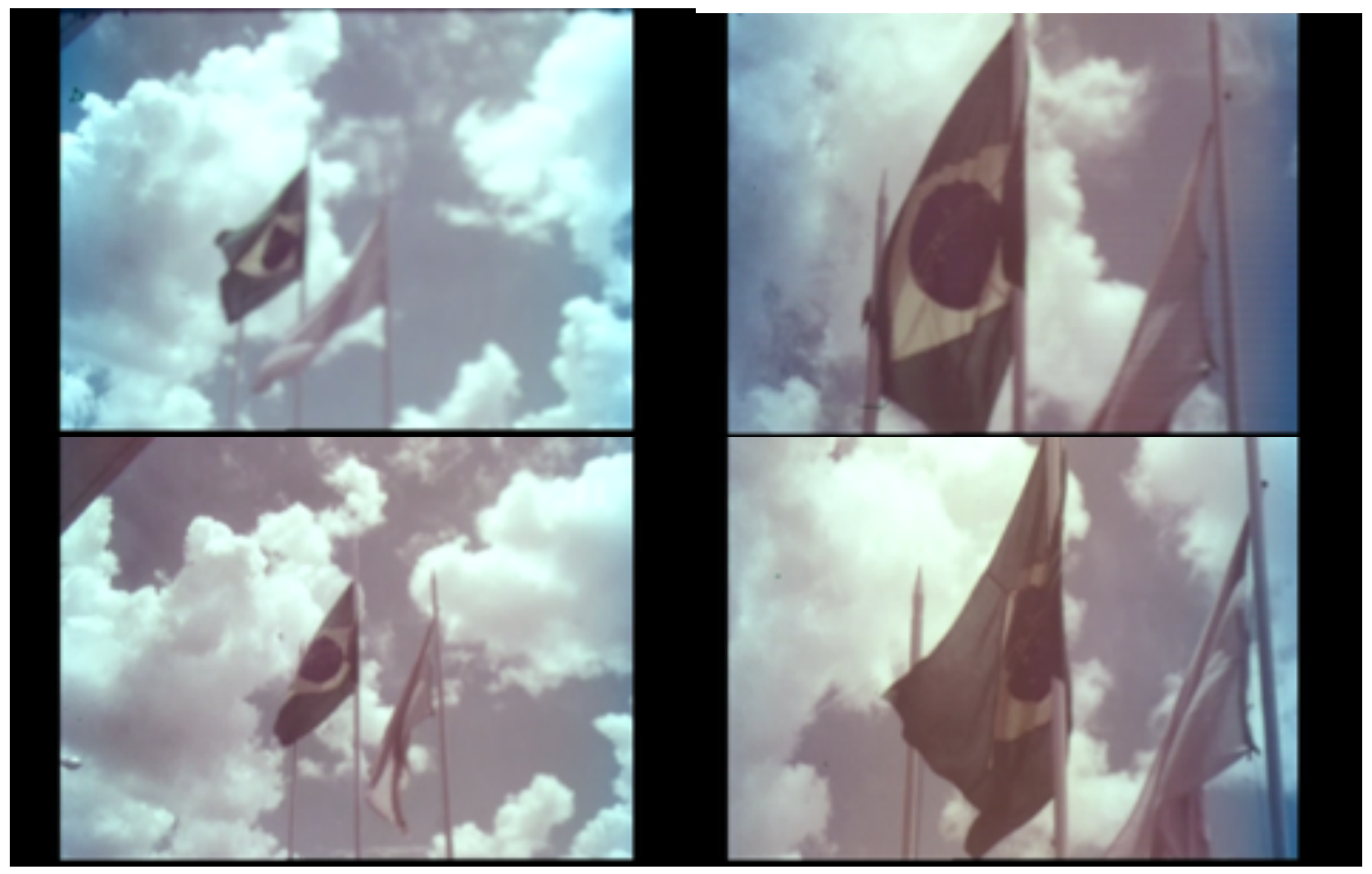

Imagens 57, 58, 59 e 60

Vemos em seguida um novo rolo que se inicia, sem claquete.

Tem início a cerimônia de juramento à bandeira. A filmagem se inicia no meio da cerimônia, como se Jesco tivesse sido surpreendido pelos acontecimentos, ou tivesse demorado mais do que esperava para trocar de rolo. Primeiro o fotógrafo enquadra o púlpito, depois, numa rápida PAN, os guardas, que estão 


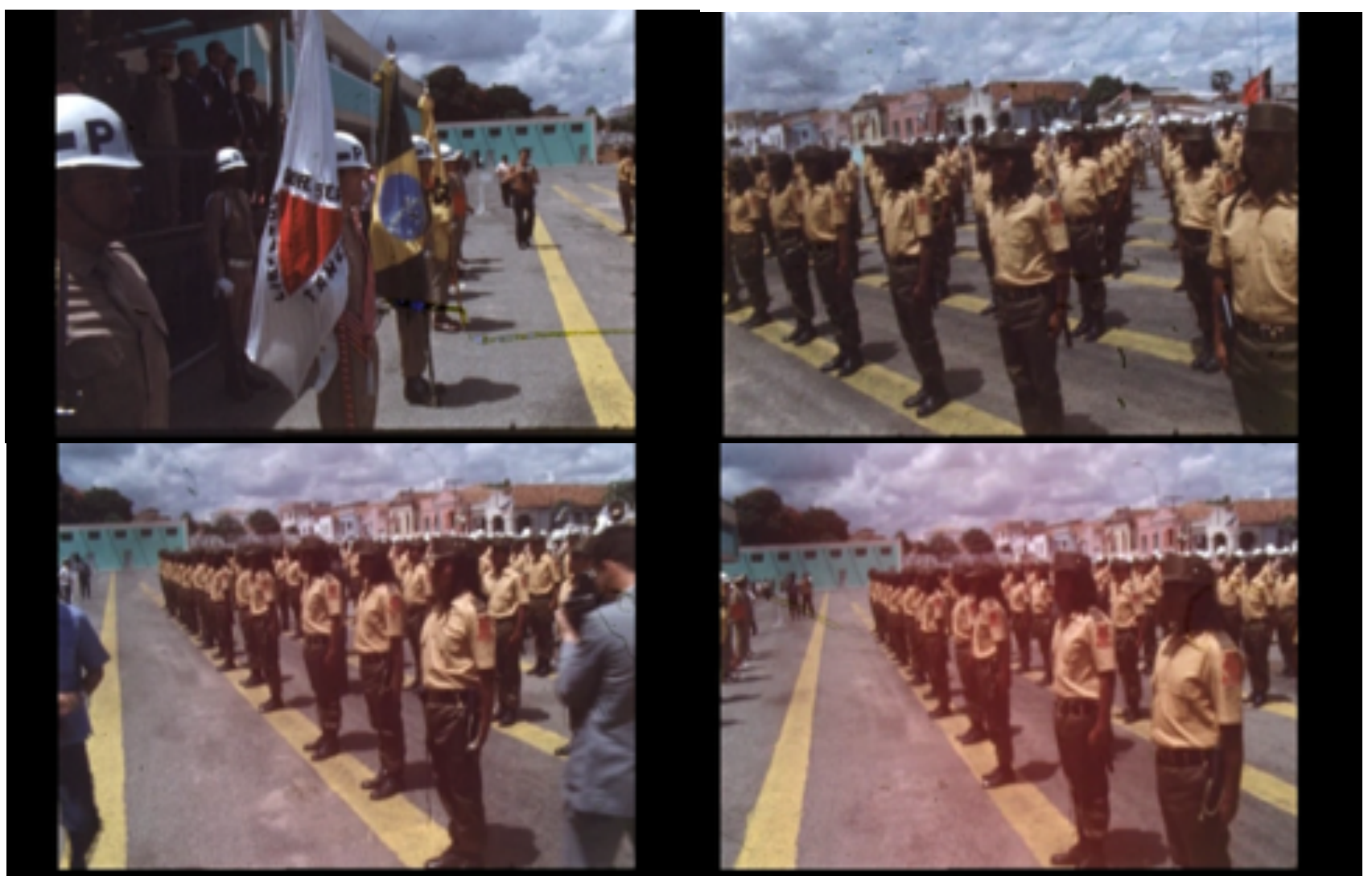

Imagens 61, 62, 63 e 64

dispostos de forma simétrica, como um verdadeiro batalhão militar (imagens $61 \mathrm{e}$ 62). Em seguida, Jesco se aproxima dos guardas e tem, uma vez mais, um esforço para definir o campo do visível: aparecem nas bordas dos quadros outros fotógrafos, como vemos no canto direito da imagem 63. Jesco dá um passo a frente, para reenquadrar o batalhão sem interferências (imagem 64). Depois, curiosamente, ele faz um quadro muito semelhante ao que o fotógrafo que ele desenquadrou provavelmente fazia, filmando em close a braçadeira do guarda Krahô (imagem 65). Jesco levanta a câmera em TILT, e reenquadra, também em close, o guarda (imagem 66). Uma vez mais, temos aqui uma busca por imagens icônicas.

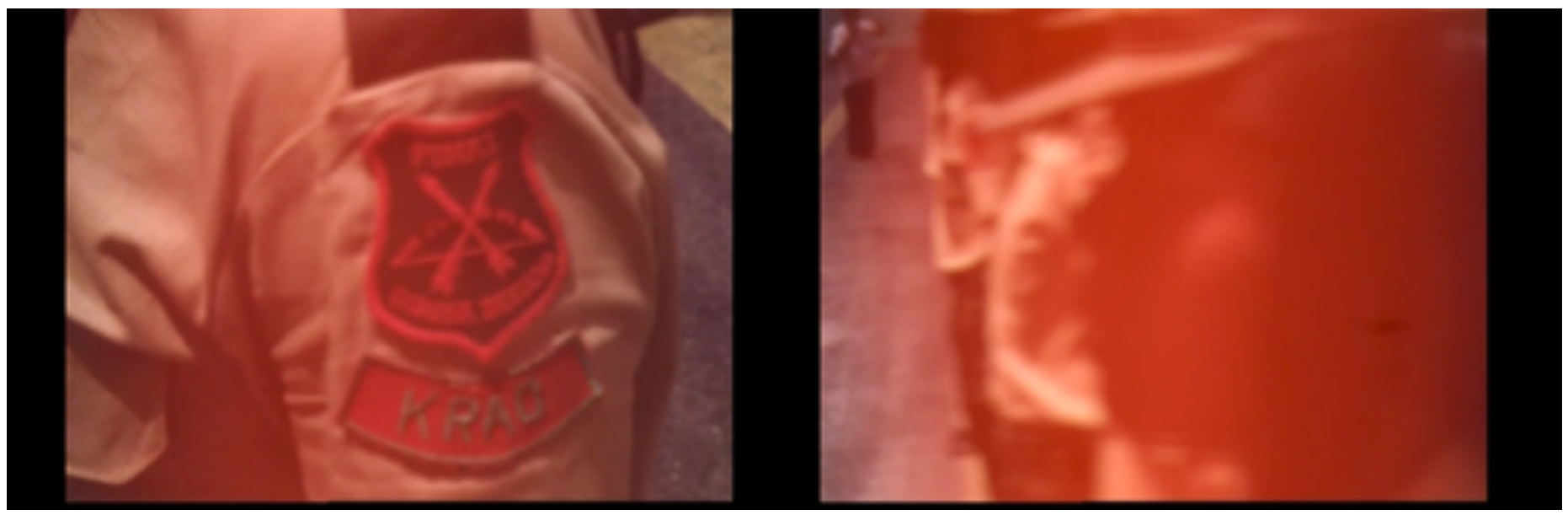


É notável que a proeminência dos Krahô no evento se repete também em relação a nosso material de arquivo - eles atraíram a atenção igualmente de militares e do cinegrafista. Se foram mantidos na linha de frente do evento, foram também eles os escolhidos por Jesco para o registro em close. Acima, destacamos a posição de nosso fotógrafo como intermediária, uma vez que ele registra os guardas e também os militares. No entanto, Jesco também está imbuído daquilo que chamamos provisoriamente olhar branco, como atesta a escolha dos Krahô, com seus cabelos compridos, para o close e o registro da braçadeira. Ele é também partícipe do esforço da ditadura por transformar os indígenas fardados em uma imagem - e extrair futuramente um uso dessa imagem.

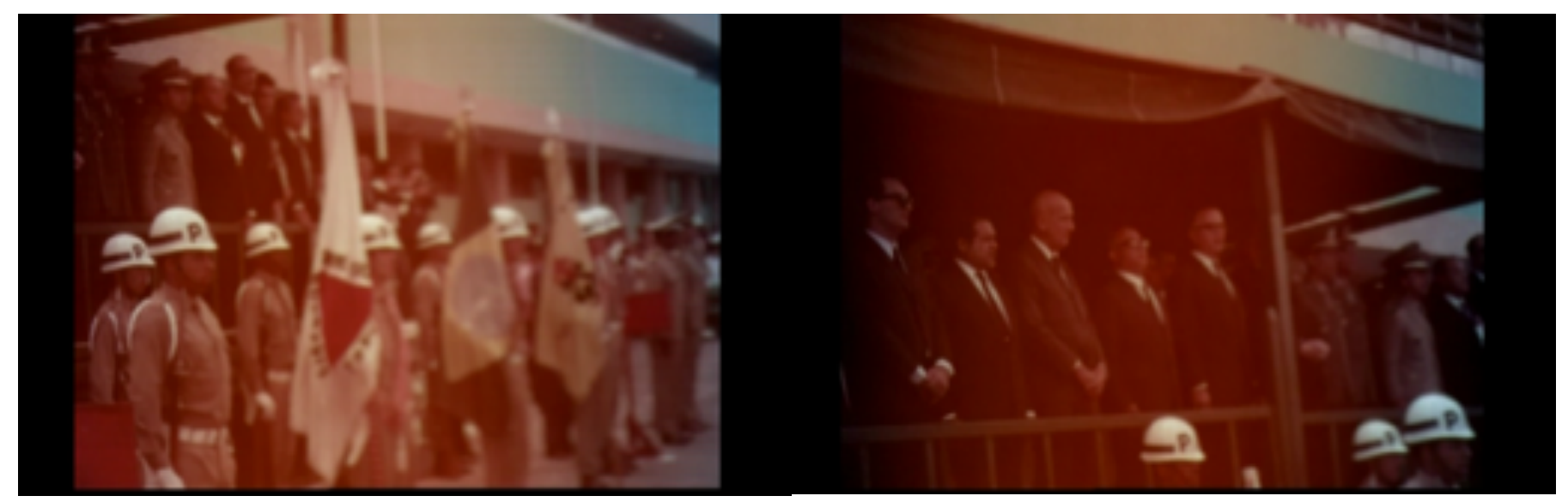

Imagens 67 e 68

Tem início, então, a cerimônia de juramento à bandeira brasileira.

De início, Jesco enquadra a forma como a platéia canta o hino (imagens 67 e 68). Podemos ver alguém que rege a banda; depois, em uma PAN, Jesco encontra a cúpula do regime, que canta em coro.

A imagem seguinte é um plano conjunto dos guardas enfileirados, que é reenquadrado por uma pequena PAN, encontrando um guarda em primeiro plano, que também canta (imagens 69 e 70). Ao fundo, podemos observar duas tubas, que

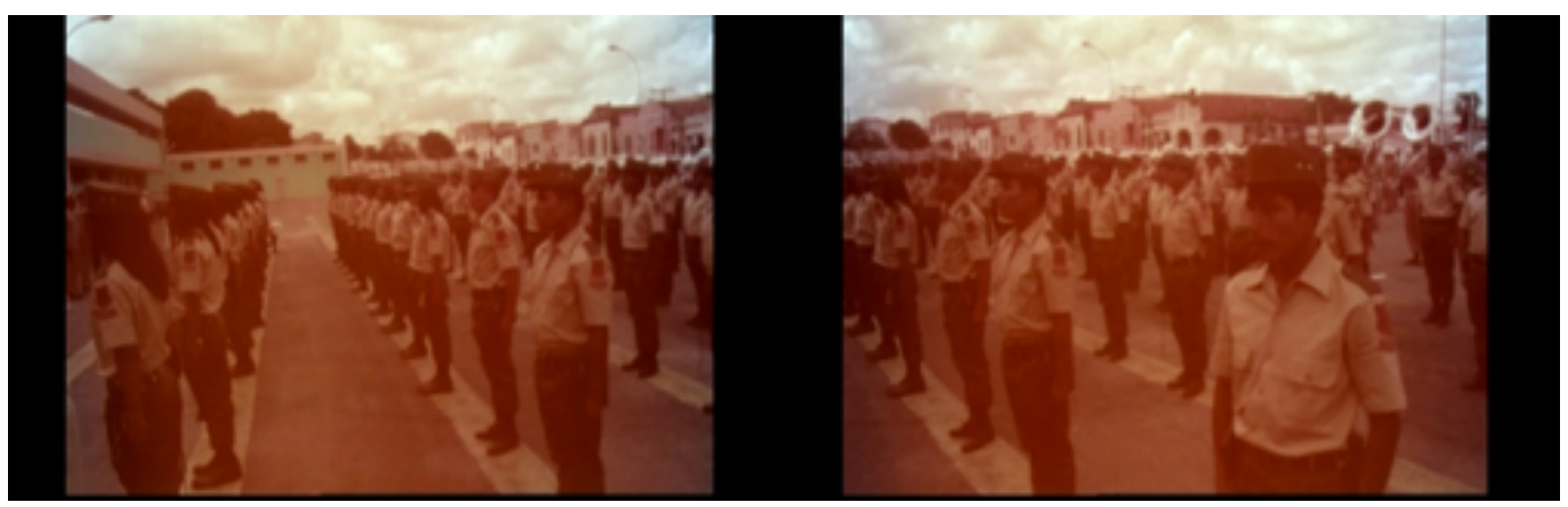




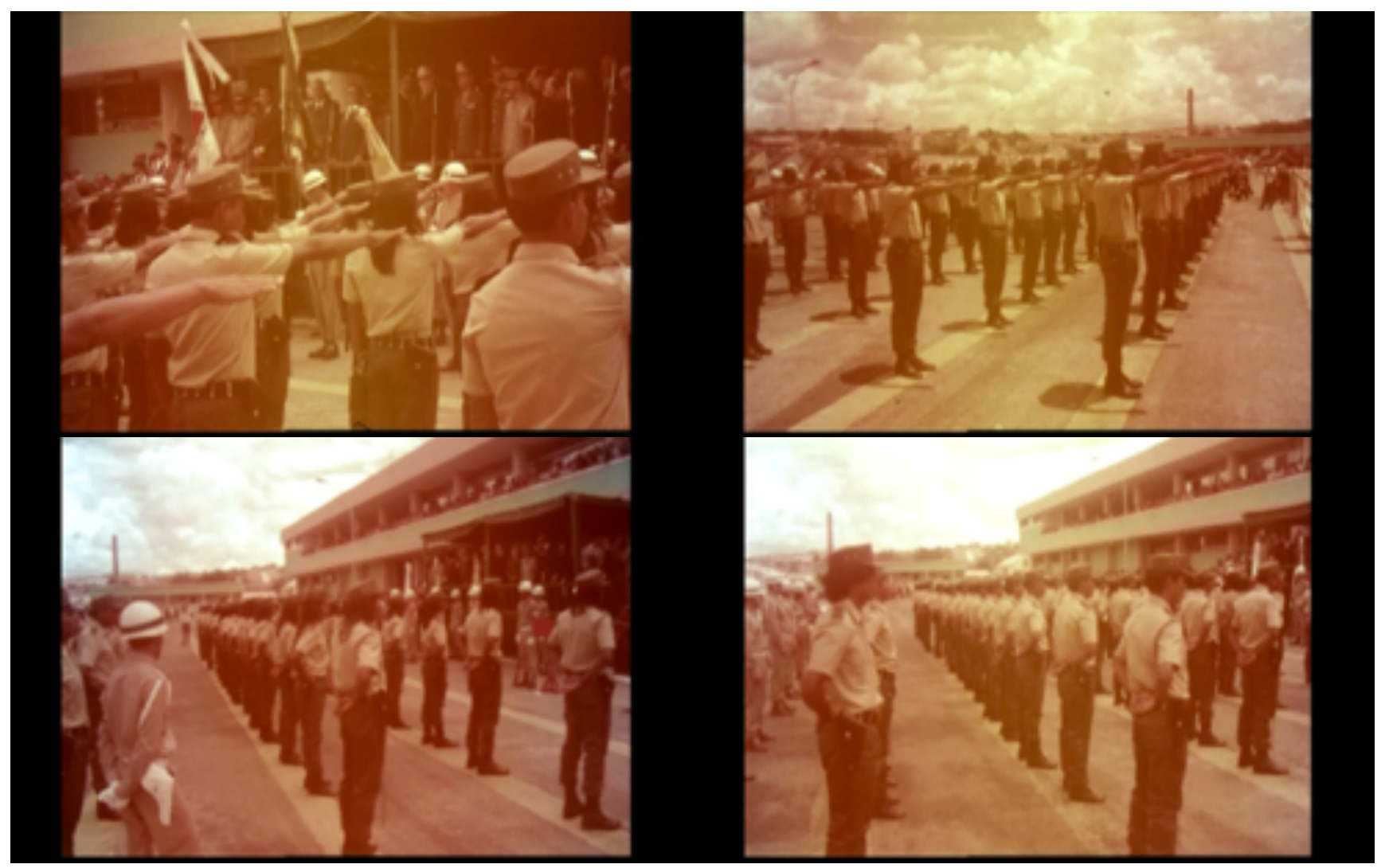

Imagens $74,75,76$ e 77

No entanto, alguns elementos podem ser destacados. Se observarmos atentamente a PAN que percorre o espaço em que os guardas indígenas estão dispostos (imagens 76 e 77), podemos perceber uma dimensão do confinamento a que estavam sujeitos - confinamento que é constitutivo das relações militares. $\mathrm{O}$ batalhão está literalmente cercado por policiais - na imagem 76 podemos ver um que os espreita na margem direita do batalhão; na 77, podemos ver que atrás deles está composta uma linha de policiais. E nas duas podemos ver que à frente dos guardas indígenas, a plateia era composta por membros do governo ditatorial, e mesmo que à frente da plateia há uma linha de policiais parada. Essa percepção física, de eles estarem cercados por todos os lados, dá a ver o aspecto compulsório do que se passava. Como disse Benjamin Xerente em depoimento à nossa pesquisa, narrando a chegada deles ao batalhão e o início do treinamento: " $A i$ fiquemo lá, aí terminou. Aí ninguém podia sair de jeito nenhum, sair pra rua ${ }^{135}$." Basílio Xerente afirma algo parecido, ao narrar o treinamento dizendo que "nós ficamos três meses presos. Depois que nós ganhamos essa identidade é que nós

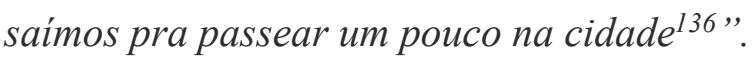

\footnotetext{
135 depoimento dado à nossa pesquisa em português, e aqui transcrito de forma literal.

136 depoimento dado à nossa pesquisa em português, e aqui transcrito de forma literal.
} 
Analisando o desmonte da Grin, Egon Dionísio Heck traz um ofício de abril de 1971, do DGPE (Departamento Geral de Pesquisa e Estudo), que responde negativamente a uma solicitação da PM de comprar metralhadoras para a Guarda, e afirma: "Este DGEP considera como a mais potente arma de efeito moral do arsenal da GRIN a conduta de seus integrantes, entre os quais, infelizmente, há exemplos de alcoolismo e outras infrações a corrigir, observando-se que, armados, eles poderiam tornar-se ainda mais perigosos ${ }^{137 " . ~ A ~ f o r m u l a c ̧ a ̃ o, ~ e m ~ t u d o ~ c l a r a, ~}$ atenta para essa tensão instalada, do ponto de vista dos militares, no trato com os indígenas. Se em algum momento passou pela cabeça de membros do Estado brasileiro que os indígenas poderiam atuar como braços deste Estado nas próprias comunidades, essa atuação não deixa de ser, em algum sentido, perigosa. Não apenas em relação à sociabilidade das aldeias, mas em relação ao próprio poder disciplinar pretendido pelo Estado.

O juramento à bandeira termina com alguns planos dos guardas, em close, cantando o hino. Primeiro um plano médio, que reenquadra com uma PAN, de forma bem executada, um guarda Krahô que canta (imagens 78 e 79), e em seguida, depois de um plano geral que permite enxergar todos eles com os braços levantados (imagem 80), a câmera se dedica a um dos guardas, e o capta de forma frontalizada. O gesto de baixar os braços é divido em três planos unidos por uma rápida TILT (imagens 81,82 e 83). A imagem da bota do guarda indígena ecoa as botas dos policiais brancos registradas no começo da cerimônia - novamente, uma iconografia militar; as botinas, as calças, os gestos mecânicos. Há a sugestão de uma continuidade entre a militarização dos policiais e a dos indígenas - as botas afinal são as mesmas.

Imagens 78,79 e 80

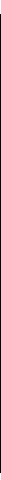

${ }^{137}$ HECK, Egon Dionísio. Os índios e a caserna - políticas indigenistas dos governos militares - 1964 a 1985. Dissertação de Mestrado. IFICH, Unicamp, 1997. Página 45. 


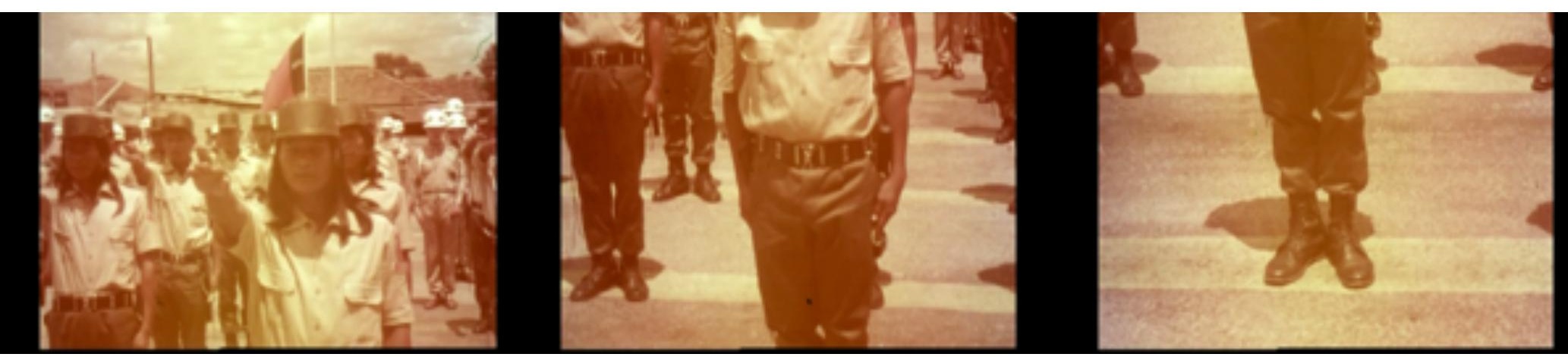

Imagens 81,82 e 83

Cabe refletir sobre o que escapa à representação oficial. Porque se, de um lado, dissemos que esse trecho é o auge de uma certa transparência, no sentido de que a imagem pretendida pelos militares e a registrada por Jesco parecem se somar numa sequência forte e bem realizada; podemos notar, por outro lado, no final da imagem 81, que o guarda Krahô, antes de abaixar o braço, dá uma olhada para a sua esquerda, tentando entender, de forma discreta, se executa o gesto corretamente. "Os documentos de arquivo nunca nos dão a ver um 'absoluto'138", escreve Didi-Huberman. A discreta olhada do guarda, ignorada por Jesco, que segue impassível sua produção iconográfica focando nas botas militares, aponta para esse esforço coletivo de tornar algo imagem - e consequentemente, ignorar tantas outras imagens possíveis naquilo que era filmado.

A última cena do rolo mostra um Krahô se descolar do grupo, dar um passo à frente, se dirigir ao Ministro do Interior, Costa Cavalcanti, e entregar um colar indígena, colocando-o em seu pescoço (imagem 84). A filmagem pára antes da ação terminar, passando por um instante de branco, que aparenta ser o fim do rolo.

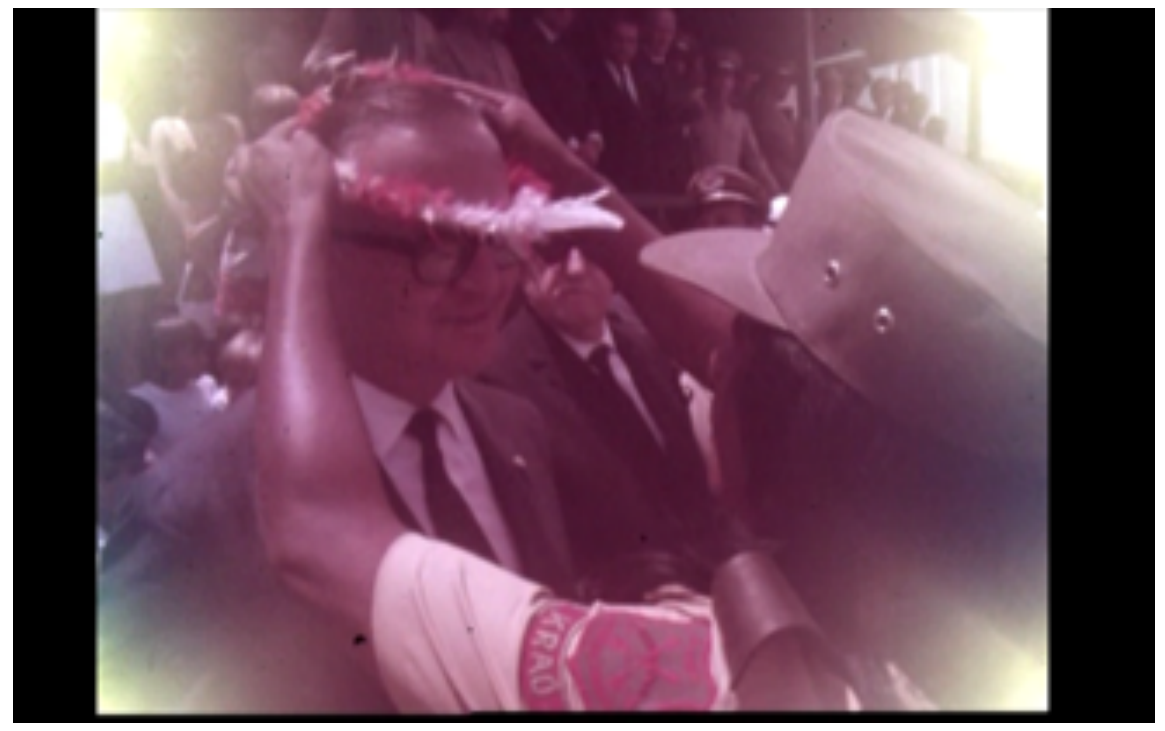

Imagem 84

${ }^{138}$ DIDI-HUBERMAN, Georges. Imagens apesar de tudo. Lisboa, Editora KKYM. 2004. Página 110. 
O que é encenado aqui é uma suposta aliança entre Estado ditatorial e os povos indígenas. Segundo matéria do Jornal do Brasil, o Ministro, "presenteado pelo líder dos índios karaós [sic] com um cocar, transmitiu aos formandos, todos em fila e vestidos com uniformes próprios, a palavra de fé do Presidente Médici e pediu que levassem às suas tribos, pequenas comunidades, o apoio do Governo federal aos índios do Brasil139". Há aqui uma metonímia operando em ato, uma vez que talvez se possa definir a Grin exatamente como a tentativa de criação desta imagem, que pode ser resumida em uma frase da matéria do Diário de Notícias de 1970, quando afirma que a Grin teria sido criada "a fim de que o índio participe ativamente em sua própria aculturação ${ }^{140 "}$. Neste sentido, o fetiche abordado acima, do olhar militarista branco que ensejou a Grin, pode ser talvez formulado como a produção de uma imagem na qual estaria implícito o caráter violento da relação do Estado com os povos indígenas, mas seriam os próprios indígenas os responsáveis por essa violência. Uma imagem na qual o Estado brasileiro, produtor de uma longa História de violações contra os povos indígenas (tanto enquanto agente direto quanto como omissão em relação aos poderes locais), estaria desimplicado desta mesma violência. É essa a imagem que faz sorrir ao Ministro do Interior presenteado com o colar - vendo tudo do alto, a tudo sorri e a tudo aprova, exultante (imagem 85).

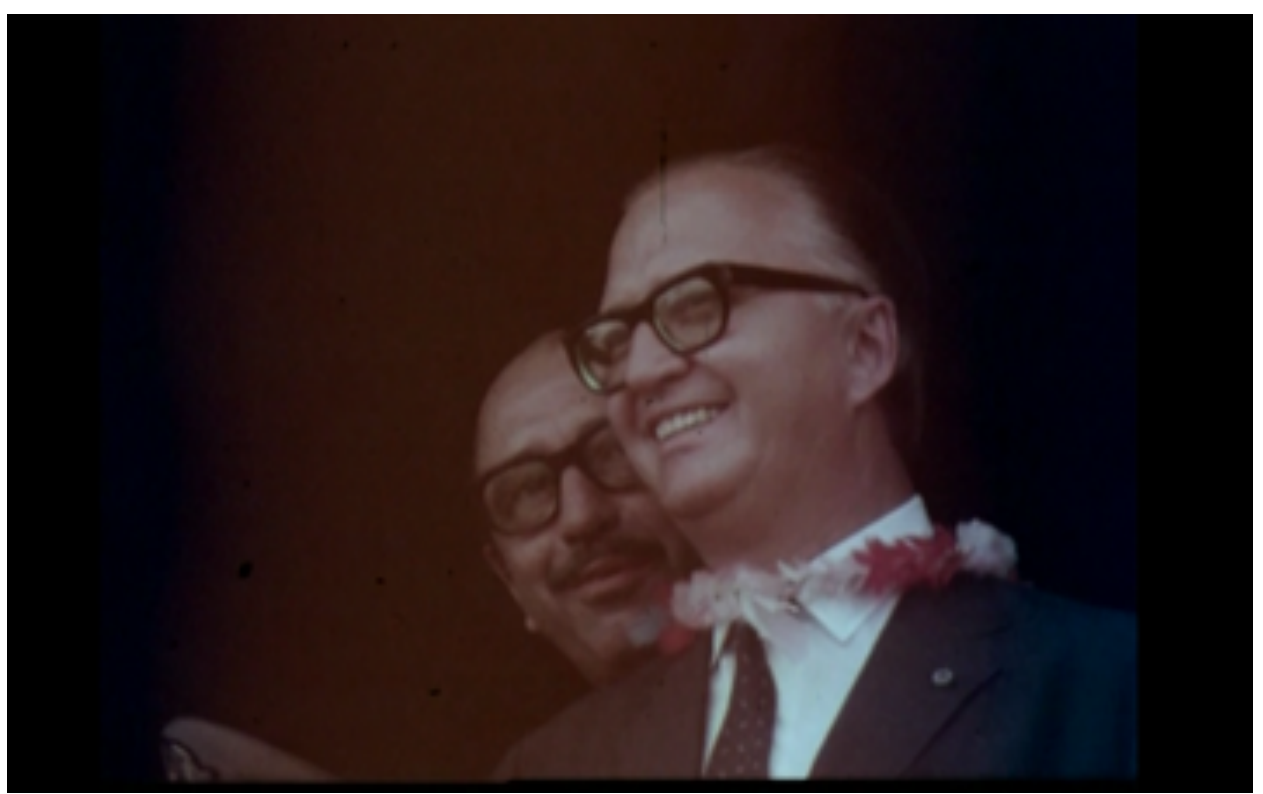

139 Jornal do Brasil, Rio de Janeiro, 06 de fevereiro de 1970.

140 Diário de Notícias, Rio de Janeiro, 3 de maio de 1970. 
$\mathrm{O}$ rolo seguinte registra as falas oficiais que compuseram o evento. $\mathrm{O}$ primeiro a falar seria um dos guardas, João Xerente. Jesco começa a tomada na miríade de repórteres, cinegrafistas e profissionais de imprensa presentes no evento, fazendo depois uma PAN até João, que falava. Mais uma vez, podemos nos perguntar sobre o porquê de esses outros materiais não terem chegado até conhecimento público tantos anos depois - apenas algumas fotografias, que compuseram reportagens nos principais jornais da época. Também denota o apuro de nosso cinegrafista, que com uma simples e bem executada PAN revela não apenas a fala, mas o aspecto público desta, e um pouco do aparato, midiático inclusive, que esteve em funcionamento naquele dia.

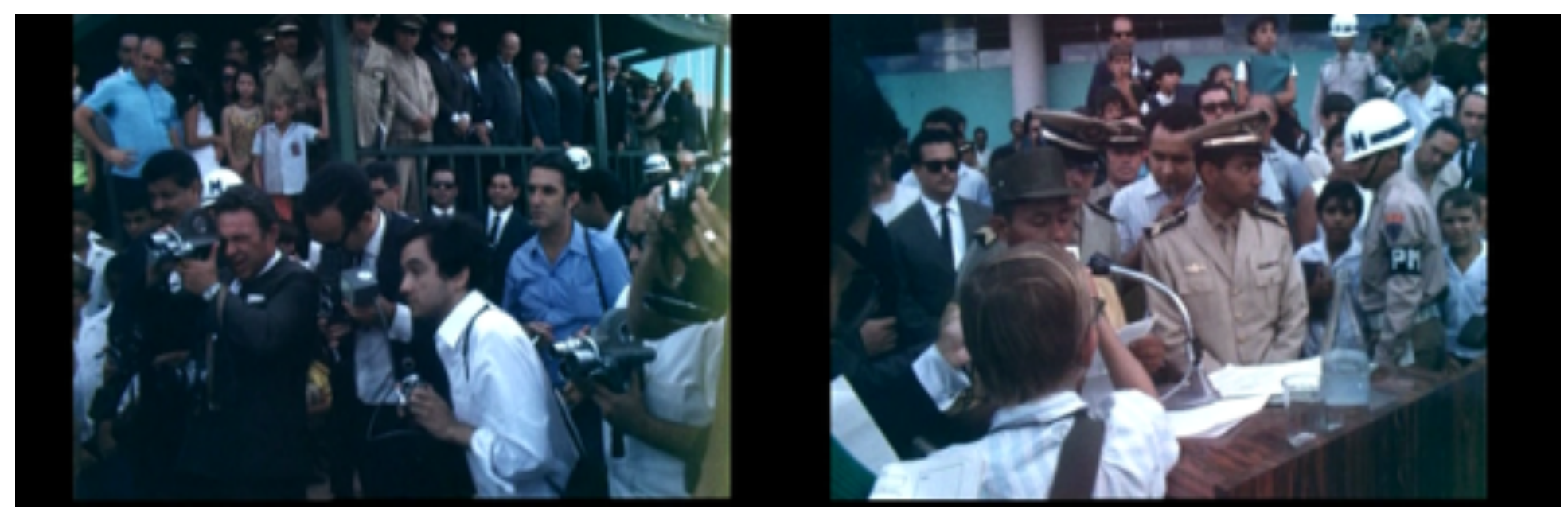

Imagens 86 e 87

A fala de João é registrada em 5 planos diferentes, todos curtos (imagens $88,89,90,91,92$ e 93). Primeiro um close, depois um plano aberto no qual vemos Capitão Pinheiro atrás de João, então um plano lateral e por fim duas tentativas distintas de registrar em close o indígena falando, descendo a câmera para a braçadeira da Funai.

Podemos refletir um pouco sobre as escolhas de Jesco aqui. Em primeiro lugar, o fato de os planos serem todos bastante curtos - não há a tentativa de registro de uma inteireza de sua fala, mas sim a formulação de planos curtos e variados, que supõe uma montagem. Também, mais uma vez a busca por uma imagem icônica, ao registrar em close o rosto de João e depois, em uma TILT, 
enquadrar a braçadeira. É de se destacar também a fisicalidade que pode ser notada na imagem 89 - Capitão Pinheiro está muito perto de João, como se o estivesse vigiando, garantindo que a fala iria sair da forma como esperava. Aqui se faz presente novamente a dimensão de confinamento, de tutela militar a que aludimos acima. Podemos refletir sobre o esforço para a produção de uma imagem de aliança entre a ditadura e os povos indígenas, em relação à qual a fala de um guarda indígena na cerimônia parece ser mais um passo em sua construção. O desconforto de Pinheiro, quase segurando fisicamente João enquanto este discursa, é eloquente do quanto, novamente, a aliança que a ditadura se esforçava por transformar em imagem era, justamente, apenas uma imagem, que poderia ser fraturada se o guarda Xerente fosse deixado à vontade, distante da opressão militar que Capitão Pinheiro ali performava. O desconforto de Pinheiro na cena fala sobre a distância entre a imagem que os militares pretendiam criar e a forma concreta com que os guardas indígenas lidavam, recebiam e performavam os ensinamentos militares. Talvez seja também índice daquilo que chamamos de estratégias 'murtosas' de resistência frente à tentativa militarista de disciplinar seus corpos. 
É digno de nota, também, o quanto esta filmagem de uma fala entrecortada parece supor uma gravação de som contínua. Chama nossa atenção o garoto jovem e loiro, que pode ser visto nas imagens 89 e 90 , e parece segurar um gravador de som. Infelizmente, o registro sonoro da gravação se perdeu, ou permanece desconhecido de nossa pesquisa até aqui - a título de nota, cabe destacar as duas menções que tivemos a essa gravação sonora: quando entramos em contato com o Museu do Índio, nos foi reportado que haveriam fitas de áudio também registradas sob o mesmo nome 'arara'. Muito nos animou a perspectiva de encontrar a sonorização de nosso material de arquivo, porém a fita sonora era em verdade uma série de entrevistas sobre o povo Arara - não tendo portanto nenhuma relação com nosso material de arquivo, e padecendo do mesmo equívoco fundamental que está inscrito na sobrevivência dessas imagens, a saber: a nomenclatura dada, 'arara', a um material que não tem nenhuma relação com o povo Arara, como discutiremos adiante. A segunda informação que tivemos se deu lendo uma entrevista que Capitão Pinheiro deu nos anos 90 para a tese de Freitas, no qual afirma que "eu tenho inclusive uma fita do dia da formatura da guarda indígena com a presença do governador do Estado com o ministro do interior na época, o general Costa Cavalcante, o Presidente da FUNAI Dr José de Queiroz Campos e o comandante geral da Policia Militar Coronel José Ortiga, eu tenho a fita gravada na solenidade, gravada numa fita de... não é fita cassete, é uma fita de um gravador, aquela fita rotativa, então depois vê se tem jeito de tirar uma cópia, eu te arranjo uma cópia do discurso proferido pelas autoridades que compareceram na formatura ${ }^{141}$." Entramos em contato com o pesquisador para saber se ele teria essa fita, ou se teve acesso a ela ou à transcrição, e a resposta foi negativa. Tentamos entrar em contato com o próprio Capitão Pinheiro, mas não obtivemos sucesso nem na solicitação de uma conversa, nem na solicitação desta fita. Portanto, uma vez que nem no Museu do Índio, nem no IGPA ninguém tinha notícia desse registro sonoro, nos parece que ele realmente se perdeu.

${ }^{141}$ FREITAS, Edinaldo Bezerra de. Índios-Soldados - A GRIN e a tradição Militar da Política Indigenista Brasileira. Tese de Doutorado, Programa de pós-graduação em História Social da Universidade de São Paulo. São Paulo, 1999. 
De todos os ex-guardas Xerente de que tivemos notícias, João é o único que abandonou sua aldeia poucos anos depois do advento da Grin. Os relatos, dispersos e variados, davam conta de que teria ido para o garimpo, de que teria se envolvido em confusões variadas. Entre as pessoas que conversamos, ninguém sabia seu paradeiro, nem se estava vivo; não tinham notícias dele há anos. Assim, não foi possível registrar sua memória deste dia. Na tentativa de desvendar aquilo que foi dito no evento, nossa pesquisa solicitou o serviço de transcrição orofacial a uma instituição responsável. A resposta que obtivemos foi a seguinte: "O recurso utilizado para a realização da tradução do vídeo foi a leitura labial, também conhecida por leitura orofacial, uma técnica que consiste na observação do posicionamento dos lábios e da língua da pessoa que está falando, sendo desenvolvida por surdos experientes (e oralizados, ou seja, treinados desde crianças para aprenderem a falar) e acompanhados por profissionais ligados à educação de surdos. Assim, o vídeo apresenta baixa resolução de imagem por questões ligadas à tecnologia da época em que foi produzido, além de cortes realizados pelo profissional que operava a câmera - fato que dificultou o trabalho da equipe, impossibilitando o encerramento de diversas frases. Diante disso, acreditamos que seja interessante apresentar um contexto geral de cada fala com o intuito de ajudar ou dar mais pistas para o entendimento dos relatos apresentados no vídeo. Assim, podemos concluir que o guarda indígena é o orador da primeira turma da Guarda Nacional Rural Indígena e a sua fala é composta por duas partes: a primeira parte fica evidente que o guarda está lendo um informe possivelmente da polícia, como se fosse um boletim informativo, mas sem possibilidade de tradução da fala por conta dos cortes, microfone posicionado na frente da boca e qualidade da imagem. Aqui o recurso utilizado pela equipe foi a leitura corporal e especialmente as expressões faciais do orador (guarda). A segunda parte da fala é composta por um discurso, evidenciando gratidão e orgulho, com fortes indícios de enaltecimento do sentimento nacionalista de todas as comunidades indígenas. ${ }^{142}$ "

Em seguida, a mesma transcrição relatou as seguintes falas que teriam sido ditas por João: “....informo os itens(?) dos... da polícia na sua missão de garantir a

142 tradução feita por Priscilla Perugini e equipe, professora no Iesp-Derdic. 
segurança...e preservar a ordem... [Os surdos não identificaram as falas, mas toda a equipe é unânime em afirmar que o indígena faz um agradecimento e lê uma lista de nomes de pessoas.] ... com respeito e orgulho... por fazer parte da primeira...fevereiro de um mil novecentos e setenta... curso de formação da Guarda Nacional Rural Indígena... ajudar ao meu povo...e irmãos de raça... tornaram mais úteis e mais orgulhosos de si mesmos...agradecemos os profissionais... em especial a Fundação Nacional do Índio pelo esforço com ...estamos equipados para... agora... onde nos capacitamos e aprendemos métodos de defesa... assim possibilitar...defender, proteger... nossas terras, nossos costumes, nossos famílias... queremos viver em paz...manter tradições... vizinhos... tarefa cumprida... que ajudará ... ${ }^{143 "}$

Imagens 94 e 95

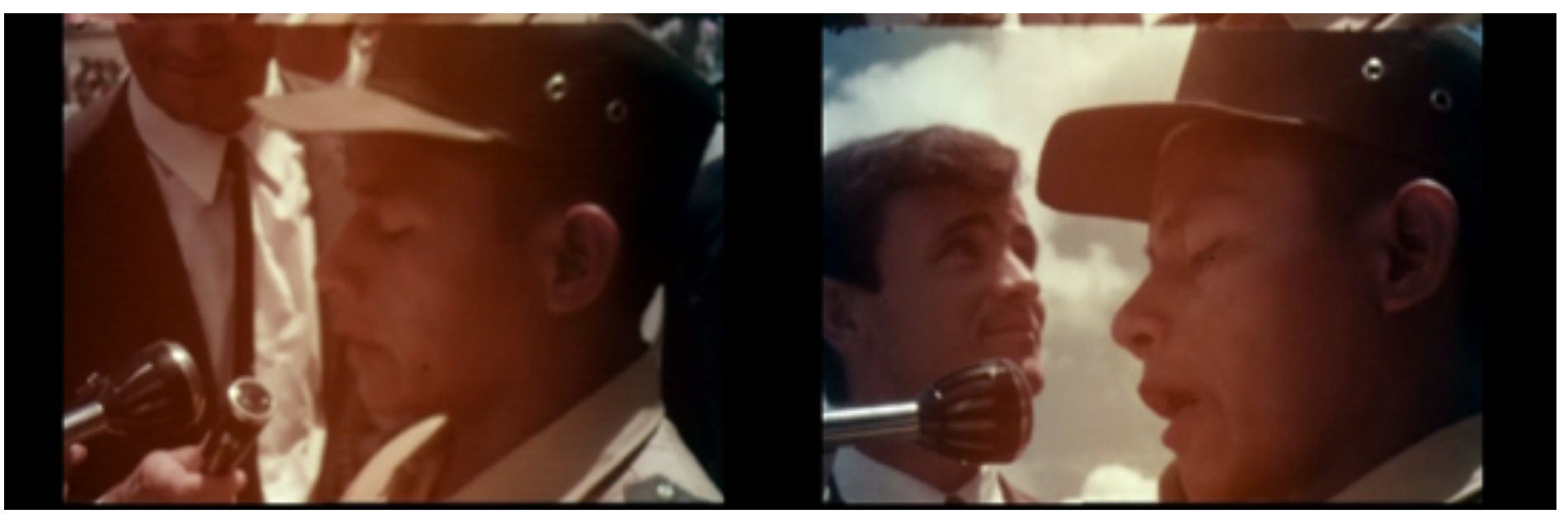

Em reportagem à época da formatura, matéria do Jornal do Brasil narra que “em nome dos índios falou João Xerente, líder da tribo goiana, saudando as autoridades e esclarecendo em linguagem bastante fluente que voltavam para as tribos de origem para demonstrar o domínio de si mesmos como índios protetores das aldeias ${ }^{144 "}$.

Por fim, importante notar a diferença desses dois planos (imagens 94 e 95). Jesco começou registrando em close a fala de João Xerente na altura dos olhos, para depois optar por um quadro em contra-plongée, sendo uma estratégia de

\footnotetext{
143 idemibidem. Em nosso filme, tentamos sincrozinar essa transcrição com a imagem de João falando, mas não obtivemos sucesso nessa empreitada.
}

144 Jornal do Brasil, Rio de Janeiro, 6 de fevereiro de 1970. Grifo nosso. 
grandiloquência, de criação de uma imagem, em algum sentido, publicitária do que estava acontecendo.

Imagens 96,97 e 98

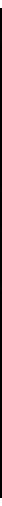

O próximo a discursar foi o presidente da Funai, José de Queiroz Campos. Ele é registrado em 3 planos diferentes, com variações de tamanho de quadro (imagens 96, 97 e 98). Na imagem 97 podemos notar a performatividade do Capitão Pinheiro, que, na beira do quadro, segura o microfone com uma gestualidade segura, ficando boa parte do discurso com o braço estendido. Interessante refletir sobre a posição dele, o idealizador e comandante da Grin, que naquele dia permaneceu à parte dos discursos públicos, apenas organizando e conduzindo o evento para que saísse como o planejado.

Uma matéria do Jornal do Brasil, misturando discurso direto e indireto, afirma que Queiroz Campos teria feito menção à Guerra do Paraguai, "lembrando o valor dos guaicurus que defenderam a retirada de Laguna ${ }^{145}$ ", e teria dito que "novamente, a História do Brasil marca encontro em Minas Gerais, disse o orador, acrescentando que naquele momento se penitenciava da tragédia do tempo de D. João VI, quando foi declarada a guerra aos botocudos, varridos pelos crenaques e pelos maxacalis ${ }^{146} "$

Jesco então registra a fala mais de longe, de trás da fila dos guardas fardados. Primeiro compõe um plano dos Krahô em posição militar, enfileirados em silêncio, para então encontrar um único plano (imagem 100) no qual vemos, ao fundo, Queiroz Campos falando, e em primeiro plano, de costas, os guardas Krahô.

145 a retirada de Laguna foi um episódio da Guerra do Paraguai: https://pt.wikipedia.org/wiki/ Retirada_da_Laguna

146 Jornal do Brasil, Rio de Janeiro, 6 de fevereiro de 1970. 
importância da imagem do sorriso complacente da mais alta autoridade pública presente na cerimônia. Podemos aqui novamente refletir sobre o esforço de construção das imagens oficiais - esse sorriso tão casual não teria sido, assim, captado ao léu, mas construído por uma estratégia sagaz de filmagem de nosso fotógrafo.

Por fim, é o próprio Costa Cavalcanti quem discursa. Ele é filmado em três quadros distintos (imagens 103, 104 e 105). Depois, Jesco registra os aplausos da população do entorno (imagens 106). Interessante observar como, na imagem 103, podemos notar a posição corporal de Capitão Pinheiro, em tudo diversa à exposta quando da fala de João Xerente ou Queiroz Campos. Aqui, diante do todopoderoso coronel e Ministro do Interior, Capitão Pinheiro, em posição de sentido, não demonstra mais proximidade nem controle do evento. Ele pode ser visto também no fundo da imagem 105, com o olhar distante, sem expressão, à moda militar.

Imagens 103, 104, 105 e 106

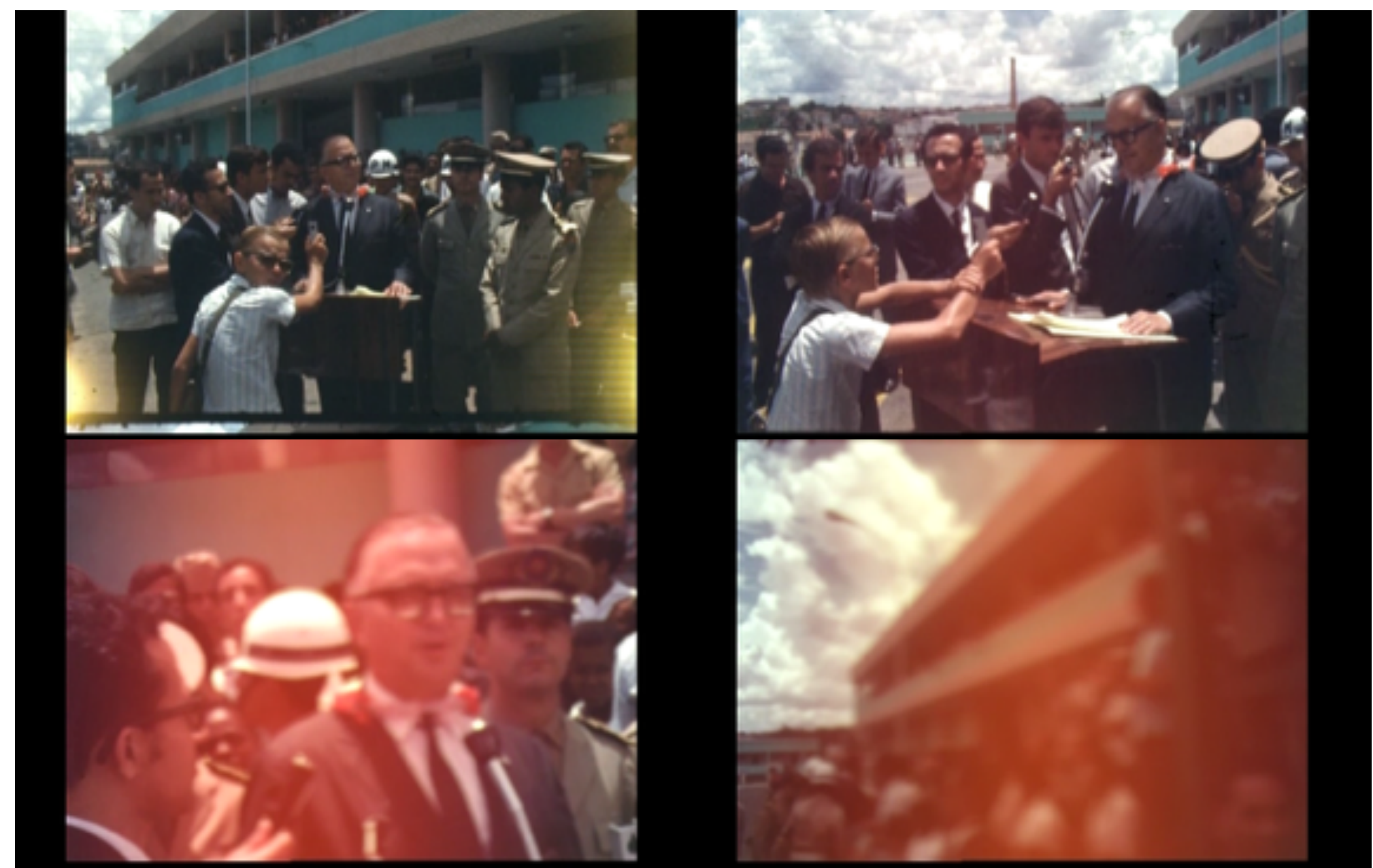


Segundo a mesma matéria do Jornal do Brasil, Costa Cavalcanti teria dito: “tenho certeza de que o espírito do Marechal Rondón visualizou que a guarda indígena viria preencher uma lacuna nas comunidades tribais, através de índios líderes, hígidos, sadios, fortes e inteligentes ${ }^{147}$ ”. E acrescentado: “é esta uma turma pequena para a vastidão do país, mas não deixa de ser um começo com a certeza de que novas turmas se repetirão anualmente com a mesma responsabilidade, plantando a disciplina e a compreensão nas aldeias, protegendo os parques indígenas. Assim, está afixada a responsabilidade da integração gradativa do índio brasileiro, com a melhoria de sua condição de vida, assimilando a civilização, embora sem a quebra de tradição salutar ${ }^{148}$ ".

Como discutimos no Capítulo 1, a Grin não foi a primeira relação militarista do Estado brasileiro com os povos indígenas. Os próprios militares fazem menções a momentos dessa relação - Queiroz Campos se refere à Guerra do Paraguai149, e Costa Cavalcanti, ao Marechal Rondon. Acima de tudo, gostaríamos de reter o quanto, do ponto de vista dos militares, há a reivindicação de uma linha de continuidade histórica, a partir da qual, inclusive, justificavam as políticas do presente.

Não iremos discutir em profundidade a experiência da Comissão Rondon, que guarda inúmeras diferenças com o experimento histórico da Grin. Sylvia Caiuby define o marechal Rondon como "um positivista convicto, homem que tem uma mãe indígena, sua mãe era Bororo, ele falava Bororo, e do lado paterno tem uma ascendência Terena. Ele tem em sua história de vida uma rixa com os missionários salesianos, pois achava que não seria preciso converter os índios, mas seria necessário prepará-los para uma integração na sociedade brasileira através do

\footnotetext{
147 Jornal do Brasil, Rio de Janeiro, 6 de fevereiro de 1970.

148 idemibidem.
}

${ }^{149}$ Repetimos aqui a citação à tese de Freitas, sobre o papel de grupos indígenas na Guerra do Paraguai: “a memória coletiva de vários grupos indígenas atuais remetem para a participação na Guerra do Paraguai, inclusive porque teriam pela ocasião recebido garantias de posse de terra. Passando a vigorar em formas de mitologia própria, vamos encontrar relatos da guerra enter os Terena, Kadiwéu, Fulni-ô, entre outros". FREITAS, Edinaldo Bezerra de. Índios-Soldados - A GRIN e a tradição Militar da Política Indigenista Brasileira. Tese de Doutorado, Programa de pós-graduação em História Social da Universidade de São Paulo. São Paulo, 1999. Página 80. 
trabalho ${ }^{150}$ ". Ela destaca também o contexto de criação da Comissão Rondon e posteriormente do SPI, no começo do século XX, no qual, diante de conflitos entre indígenas e proprietários de terras, em especial no interior de São Paulo, haviam pessoas, como H. Ihering, então diretor do Museu de São Paulo, que defendiam abertamente o extermínio de indígenas como os Kaingang. Como discutimos no Capítulo 1, Freitas vê na criação do SPI um passo a mais na relação militarista do Estado com os povos indígenas: "sabemos que na tática de aliança com as lideranças indígenas, constava da parte de Rondon presentear aos caciques de cada grupo com um fardamento militar. Desta ação, alimentava a posição das chefias indígenas como 'capitães' e em sentido figurado, anexava os agrupamentos como verdadeiras milícias de trabalho"151.

Diferenças à parte, se a Grin não foi a primeira relação militarista do Estado brasileiro com os povos indígenas, tampouco foi a primeira vez que o Estado se utilizaria da imagem dos índios. Como analisa Fernando Tacca: "a importância que Rondon atribuía aos registros imagéticos como forma de convencimento pode ser avaliada pelo relatório que a Comissão encaminhou ao Presidente da República, Artur Bernardes, em 1922. (...) Nesses relatórios, Rondon enfatizava os trabalhos das linhas telegráficas, mas não deixava de mencionar os contatos com os grupos indígenas. Se as autoridades eram persuadidas pelas fotografias, as apresentações dos filmes e os artigos publicados nos principais jornais do país visavam principalmente outro grupo formador de opinião, a elite urbana sedenta de imagens e informações sobre o sertão brasileiro, e Rondon alimentava o espírito nacionalista construindo etnografias de um ponto de vista estratégico ${ }^{152}$ ". Fernando Tacca analisa extensamente essa produção em

\footnotetext{
150 https://www.youtube.com/watch?v=OYf7aYLPfUo - acessado em 15 de janeiro de 2020.

151 FREITAS, Edinaldo Bezerra de. Índios-Soldados - A GRIN e a tradição Militar da Política Indigenista Brasileira. Tese de Doutorado, Programa de pós-graduação em História Social da Universidade de São Paulo. São Paulo, 1999. Página 63.
}

152 TACCA, Fernando de. A imagética da Comissão Rondon: etnografias fílmicas estratégicas. Campinas, SP, Papirus Editora, 2001. Página 17. Importante destacar ainda que Rondon, ao solicitar que o Major Thomas Reis registrasse o ritual funerário Bororo, em 1916, foi responsável por aquele que talvez possa ser entendido como o primeiro documentário etnográfico da História, já que data de 6 anos antes do famoso filme de Flaherty, Nanook do Norte - https://pib.socioambiental.org/en/Not\%C3\%ADcias?id=178626 - acessado em 16 de janeiro de 2021 
seu belo ensaio, analisando três tipos de representações imagéticas que os militares faziam dos indígenas, cada qual servindo a propósitos diferentes ao longo do tempo: 'selvagens', 'pacificados' e 'integrados/civilizados'.

Aqui, gostaríamos apenas de aproximar arbitrariamente duas experiências históricas distintas através daquilo que Tacca define como um "contexto de criação de uma imagem 'oficial' do índio brasileiro". Assim, se é possível questionar os vínculos históricos entre as duas experiências, nos interessa pensar o quanto uma imagem ecoa a outra. Um dos filmes realizados pela Comissão Rondon, presente na compilação posteriormente exibida com o título 'Ao redor do Brasil ${ }^{153}$ ', traz a icônica imagem dos militares vestindo os indígenas, no que era lido à época como um passo no processo de 'civilização' destes (imagem 107).

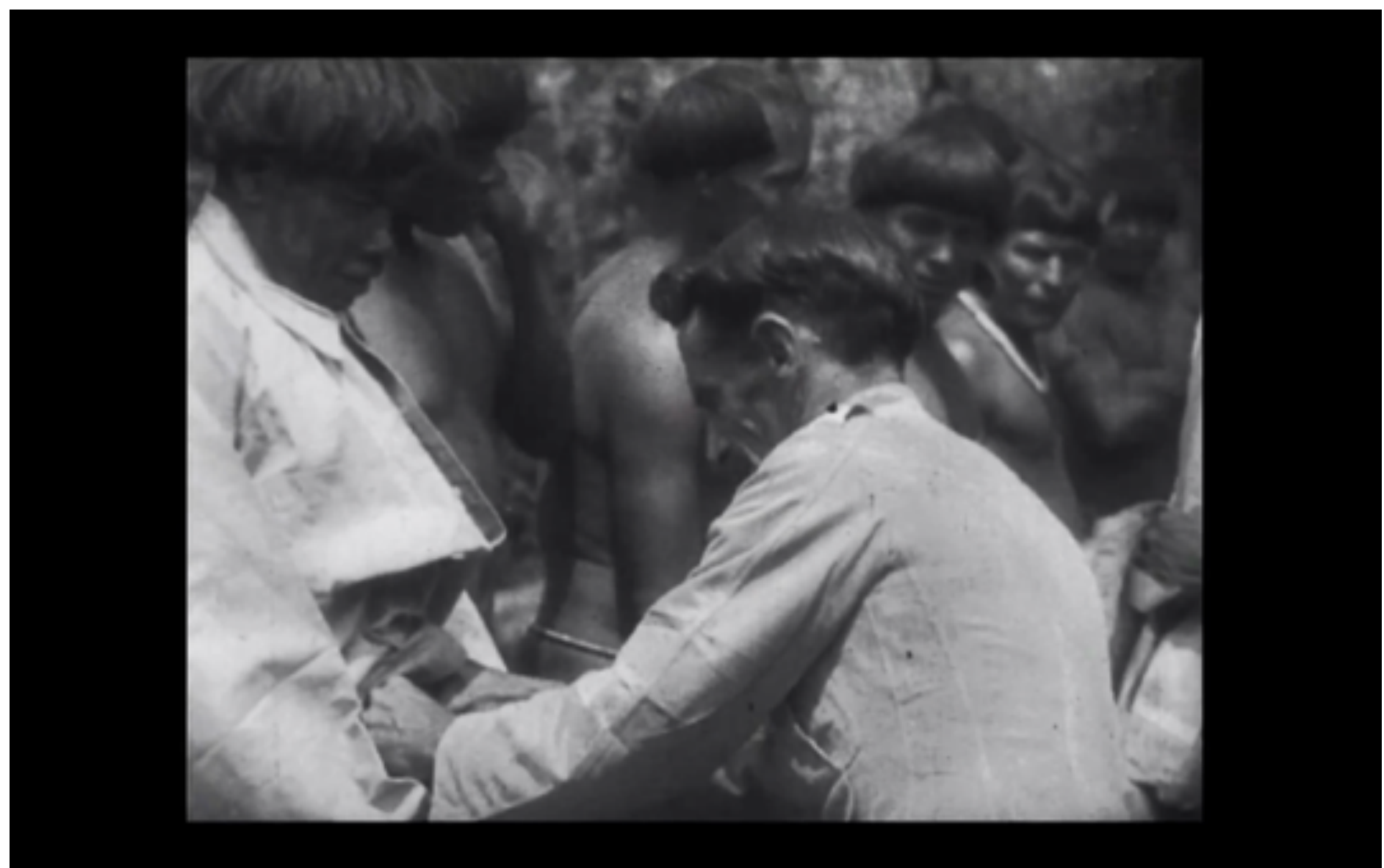

Imagem 107

Impossível não lembrar da imagem presente no rolo 1, na qual Capitão Pinheiro orienta o fardamento dos guardas (imagem 108):

153 Ao Redor do Brasil, Major Thomaz Reis, 1932. 


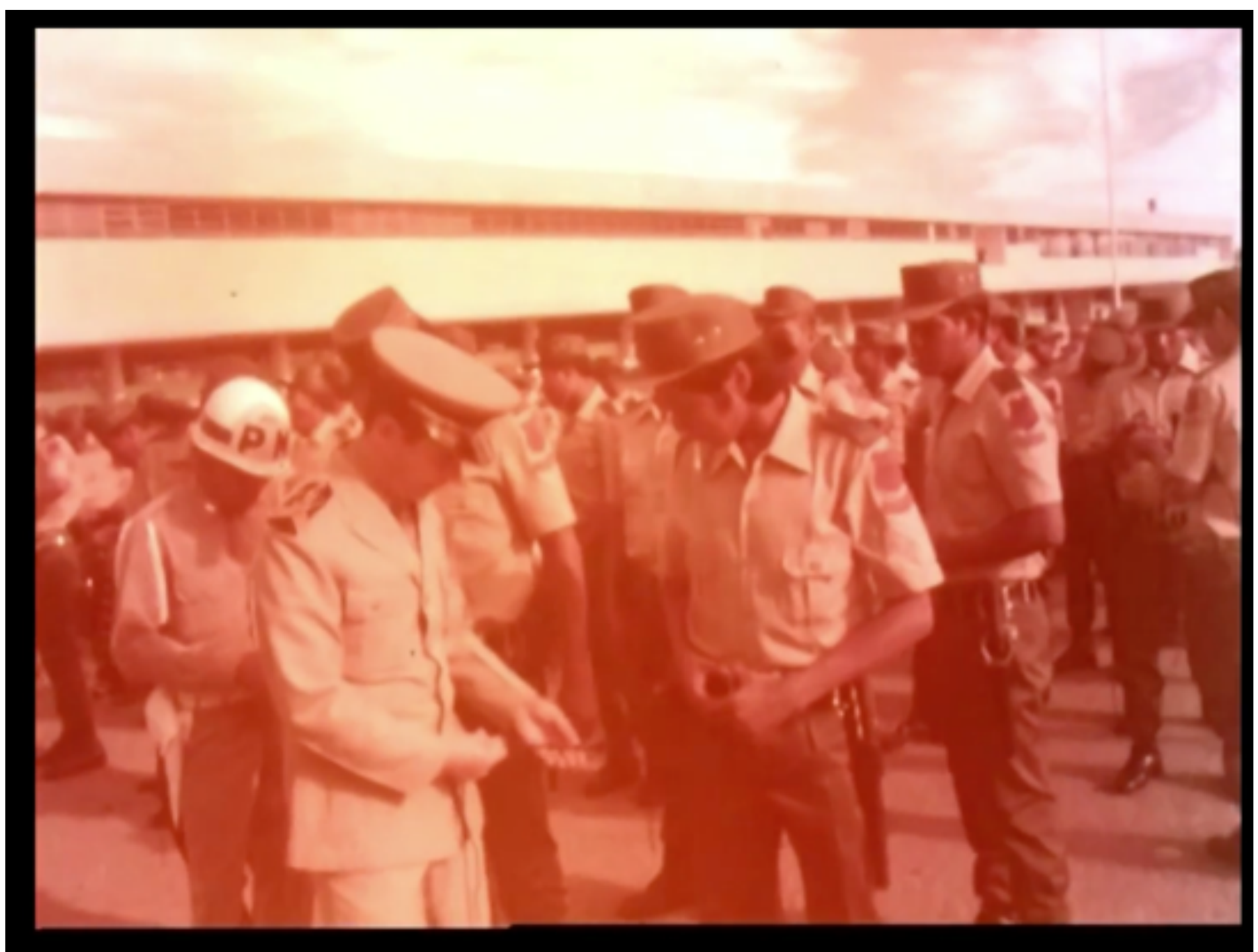

Imagens 108

As duas imagens, separadas por quase meio século, se ecoam de forma estranha. Da roupa à farda, é difícil não ver que algo sobrevive, e se acirra, na desde sempre violenta relação entre o Estado e os povos indígenas.

O rolo termina com os guardas marchando (imagens 109, 110, 111 e 112). Em frente à cúpula militar, eles marcham, em linha reta, sempre em frente. O enquadramento pega primeiro de longe, a grande fila de guardas, depois em contra-plongée - novamente uma certa grandiloquência buscada. Um plano das pernas dos guardas, simétricas. E por fim, na imagem 112, a conjugação, no mesmo plano, da plateia e dos rostos dos guardas em contra-plongée, bem de perto. Duas vezes, no mesmo quadro, um olhar branco: os brancos que olham ao fundo, atentos e sorridentes, e a formulação dos rostos dos indígenas fardados como esse 'novo sujeito'. Olhar branco: transformar a experiência da Grin em uma 


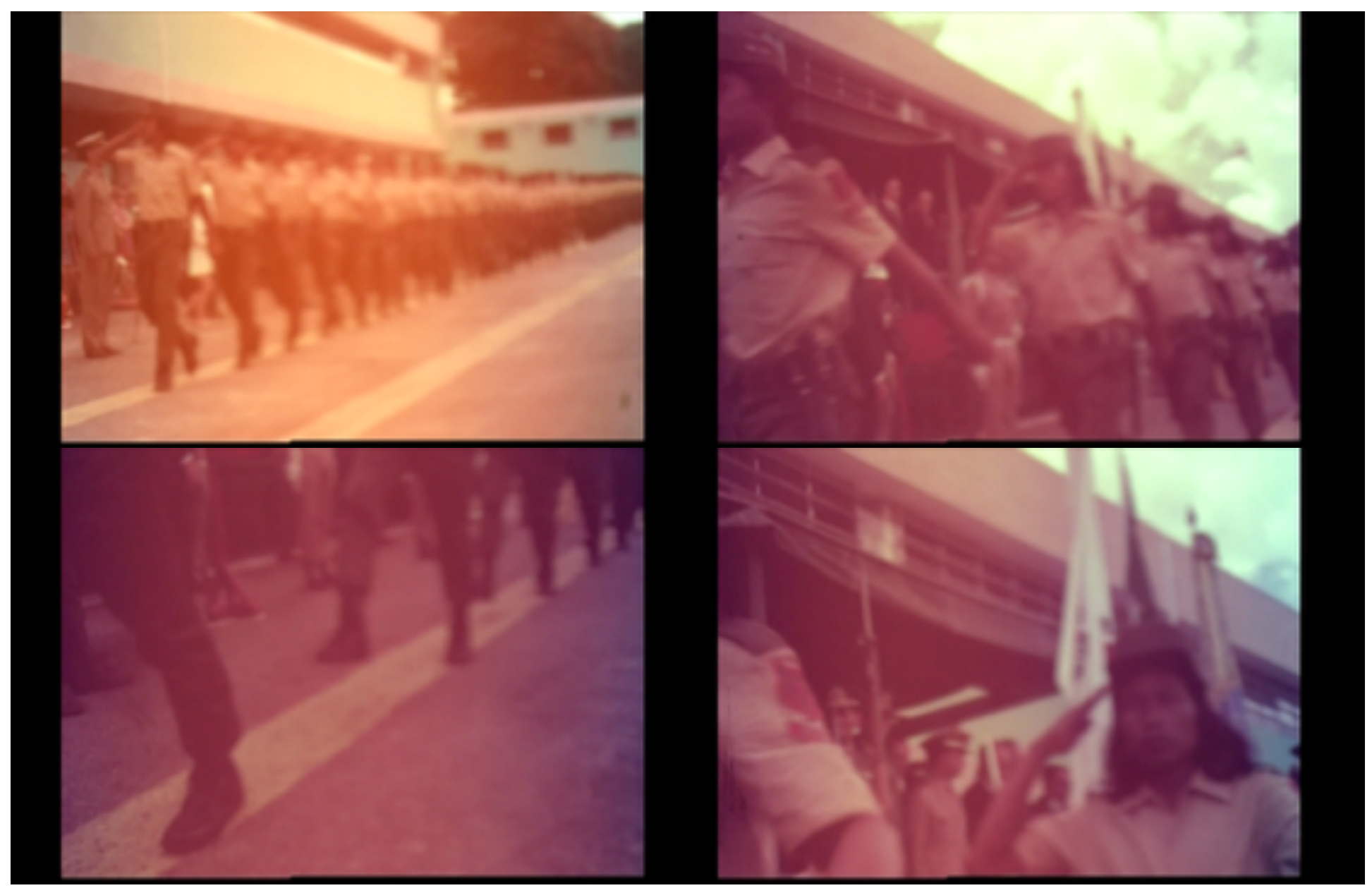

Imagens 109, 110, 111 e 112

imagem. Transformação que passa por tornar os guardas um objeto genérico. Nessas imagens, é como se percebêssemos apenas a exterioridade confusa de seus corpos, que marcham ritmadamente - há novamente uma bem-sucedida transparência, pouca coisa parece escapar à construção pretendida pelo Estado: os guardas, uniformizados, marcham; os militares, sorridentes, assistem.

Se até aqui a performance orbitou em torno a rituais militares, como o juramento da bandeira, agora chega o momento em que os formandos vão encenar aquilo que aprenderam. Os Grins vão encenar uma série de "procedimentospadrão" policiais que aprenderam nos três meses de treinamento.

Em primeiro lugar, os cavalos.

Os guardas aparecem montados, cavalgando de um lado a outro, e em dado momento cercam um homem que encena querer fugir. Em seguida, um grupo Krahô encena um enquadro - desce do cavalo, cerca um homem não-indígena, e, enquanto um guarda aponta fixamente um revólver, o outro revista o não-indígena, procurando uma arma. A cena é bem filmada, em um plano único com movimento (imagens 113, 114 e 115). Ao fundo, o público local aplaude (imagem 116). 


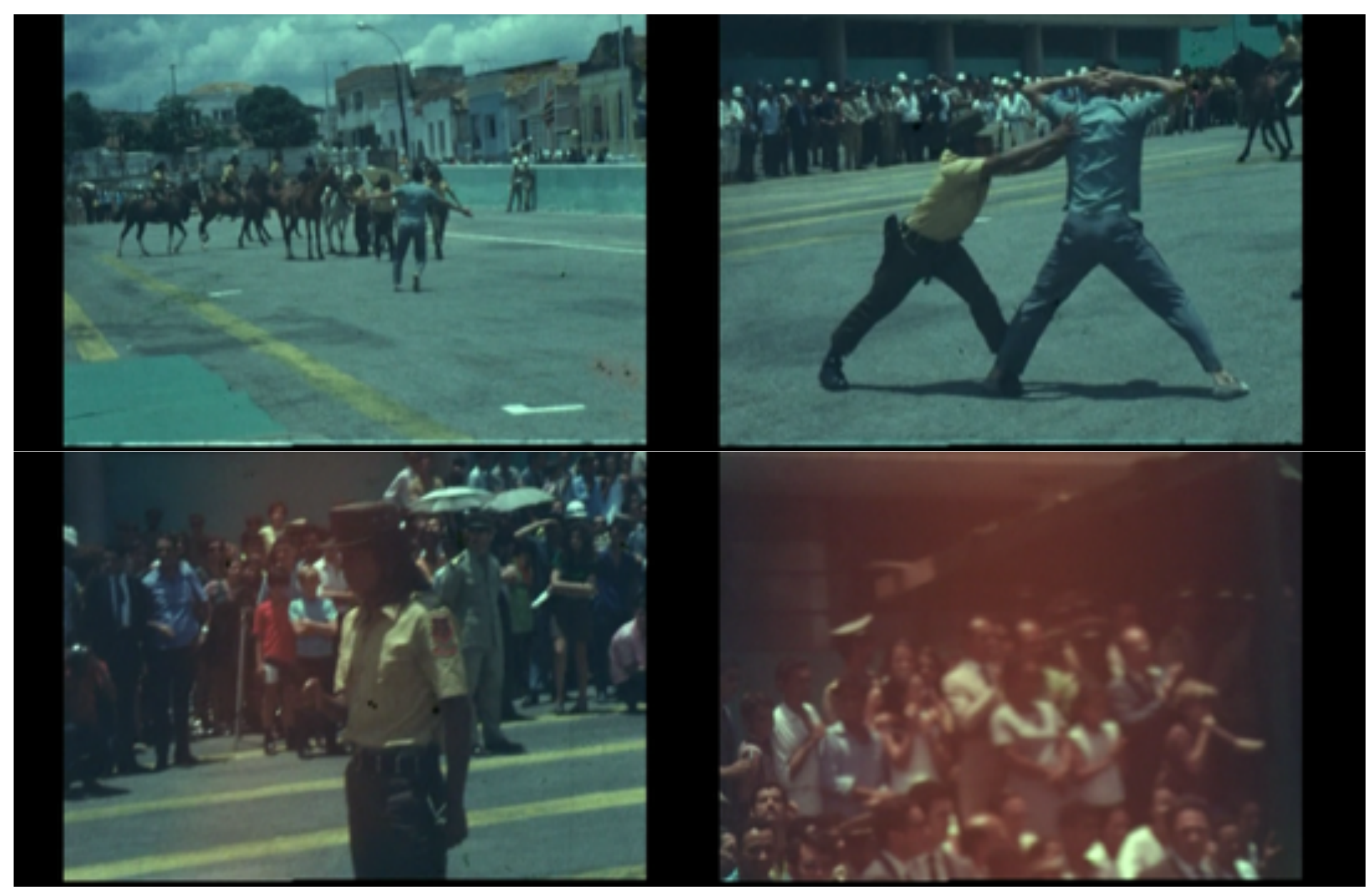

Imagens $113,114,115$ e 116

Se até aqui tínhamos a performance dos guardas sempre em sentido mais coletivo, aqui temos individualizada uma certa corporeidade. Os guardas atuam de fato como policiais. Podemos contar seis guardas, uma espécie de destacamento, todos Krahô, que atuam fazendo gestos policiais característicos.

Alguns elementos podem ser destacados. Como vimos apontando, há sempre algo que escapa às imagens. Nessa sequência, podemos notar que o guarda Krahô que realiza a revista, ao terminar olha para o outro de canto de olho e leva os braços à cintura, em uma gestualidade nada militar, que aponta, mais uma vez, para a exterioridade daquilo que era performado (imagem 117). Jesco corta o plano

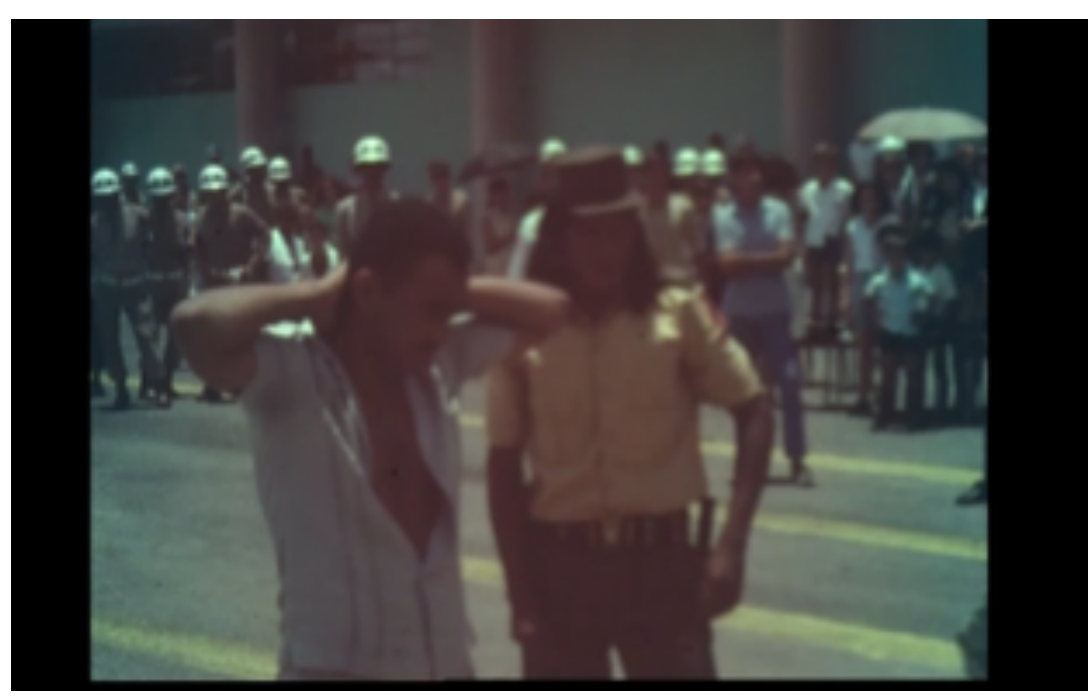

nesse exato instante, desinteressado que estava em registrar as fissuras na imagem militarista que ali se produzia. 
Essa relação entre interioridade e exterioridade merece ser melhor pensada. Viveiros de Castro afirma que "o corpo aparece como o grande diferenciador nas cosmologias amazônicas 154 ", completando: "a Bildung ameríndia incide sobre o corpo antes que sobre o espírito: não há mudança espiritual que não passe por uma transformação do corpo, por uma redefinição de suas afecções e capacidades ${ }^{155}$ ". Ele chama a atenção para o papel, na cosmologia ameríndia, da metamorfose ${ }^{156}$, que se dá notadamente através do corpo, marcadamente formulado como uma roupa: "a noção de metamorfose está diretamente ligada à doutrina das roupas animais (...) trata-se menos do corpo ser uma roupa do que da roupa ser um corpo (...) vestir uma roupa-máscara é menos ocultar uma essência humana sob uma aparência animal que ativar os poderes de um corpo outro ${ }^{157 "}$. Assim, cabe refletir sobre os efeitos dessa roupa-corpo nos indígenas que fizeram parte desse estranho experimento histórico, ou melhor, dos 'poderes do corpo outro', esse outro militar, que são ativados a partir das fardas - literalmente, a roupa militar com a qual foram vestidos.

Dona Nedina, ex-esposa de um dos guardas, narra assim o retorno deles à aldeia (as perguntas são de nossa equipe) ${ }^{158}$ :

"quando eles voltaram, ninguém reconhecia eles. Quando eles chegaram com a farda.

- o pessoal tava muito diferente quando desceu do avião?

Chegou muito diferente

- como eles tinham mudado?

154 CASTRO, Eduardo Viveiros de. Perspectivismo e multinaturalismo na América indígena, in: A inconstância da alma selvagem e outros ensaios de antropologia. São Paulo. Cosacnaify. 2002. Página 387.

155 idemibidem

156 “se o solipsismo é o fantasma que ameaça perenemente nossa cosmologia - traduzindo o medo de não nos reconhecermos em nossos semelhantes, por eles na verdade não o serem, dada a singularidade potencialmente absoluta dos espíritos -, a possibilidade de metamorfose exprime o temor oposto, o de não se poder mais diferenciar o humano do animal, e, sobretudo, o temor de se ver a alma humana que insiste sobre o corpo animal que se come", idemibidem, página 391.

157 idemibidem. Página 393.

158 depoimento dado em português e aqui transcrito literalmente. 
Mudou, porque eles chegaram com outra roupa. Porque a gente não conhecia a roupa. Eles chegaram, parece que tudo gordo assim, tudo grandão. Aí a gente ficou com medo."

As pesquisas que refletem sobre a atuação da Grin nas próprias comunidades registram denúncias de violações e violências perpetradas por alguns guardas, noticiadas em jornais. Conforme Freitas: "Tais atos de violência, arbitrariedade e insubordinação eram localizados na GRIN do Bananal. São citados casos de tortura de índios e não-índios, havendo até acusações de prática de abusos sexuais por parte dos guardas. Estes teriam se transformado em uma 'plutocracia', pagando a outros índios para pescar e trabalhar para si. Elementos desagregadores desrespeitavam a autoridade dos chefes e a hierarquia da própria tradição ${ }^{159}$."

Foge ao escopo de nossa pesquisa fazer uma análise detalhada das contradições da atuação dos guardas em suas próprias comunidades. Mas gostaríamos de reter a ideia de uma tensão latente, uma contaminação possível entre os indígenas e as roupas-fardas que trajavam.

Repetimos aqui a formulação lapidar de Manoel Sunken, já referida no Capítulo 1: "Diz que depois de jurado a bandeira do Brasil, tem que prender qualquer um, né?! Pode ser irmão... se tá errado, não pode... Pode ser amigo, né, tem que... [prender]”.

Antonio Cavalcanti Txo-kan Krahô nos narrou o trágico evento de quando ele, fazendo parte da Grin, foi fazer uma brincadeira com um sobrinho utilizando sua arma e, sem saber que estava carregada, acabou por matá-lo. A tragédia marcou não apenas Txo-kan e sua família, mas toda a comunidade Krahô, uma vez que pouco tempo depois do acontecido, a Grin começou a ser descontinuada. Até hoje, quando, no presente, voltamos às aldeias buscando informações sobre este tempo, vários dos ex-guardas culpam Txo-kan por terem 'perdido seu emprego',

159 FREITAS, Edinaldo Bezerra de. A Guarda Rural Indígena - GRIN. Aspectos da Militarização da Política Indigenista no Brasil. Anais do XXVI Simpósio Nacional de História - ANPUH. São Paulo, julho de 2011. 
pensando que este evento singular teria sido o causador do fim da Grin $^{160}$. Gostaríamos de sublinhar como, em seu relato, Txo-kan destaca a farda como um elemento com agência na tragédia ocorrida.

Ele descreve, primeiro, que tinha levado a arma para casa, para engraxar, pensando que não tinha bala no tambor. Seu sobrinho estava nos fundos de sua casa, estudando. Diz Txo-kan:

"eu pensava que a arma não tinha bala.

Com a brincadeira, eu matei meu sobrinho.

Matei meu próprio... com a farda.

Entenderam?

Agora tá sabendo né?

Todo mundo tá sabendo né?

Então...

Botaram eu como castigo, ia ser preso...

De lá mesmo tirei a minha farda e entreguei.

Me trouxeram aqui no posto. Depois, até Goiânia. De lá eu contei toda a verdade. Aí eu voltei. Passei mais um mês aqui. Ai eu voltei pra aldeia. ${ }^{161}$ ",

$\mathrm{Na}$ narrativa de Txo-kan, parece ser a farda, mais do que a arma, a causadora da violência. Seu primeiro gesto, ao ser preso, foi justamente se despir da roupa-outro e sua violência inerente, para assim, despido, poder voltar para a aldeia. A contaminação possível, que queremos aqui destacar, parece, ao próprio Txo-kan, bastante evidente.

Em nossa última conversa, Txo-kan terminou seu relato com uma reflexão em torno, novamente, das roupas: "Hoje, eu conto pra vocês porque eu sou índio. Eu sou dono da terra, nasci. nasci pelado da mãe... hoje eu tô respeitando vocês, mas quando eu tô sozinho, eu tiro [a roupa]... meu pensamento é assim ${ }^{162}$."

Por fim, há um fora de quadro aqui que cabe refletir, e que toca em um elemento nevrálgico dos equívocos que geram e são gerados pela Grin. Há aqui

\footnotetext{
${ }^{160}$ Este depoimento pode ser visto na íntegra em A Flecha e a Farda, bem como a forma como ainda hoje ressoa na aldeia.

161 depoimento dado em português, aqui transcrito de forma literal.

162 idemibidem.
} 


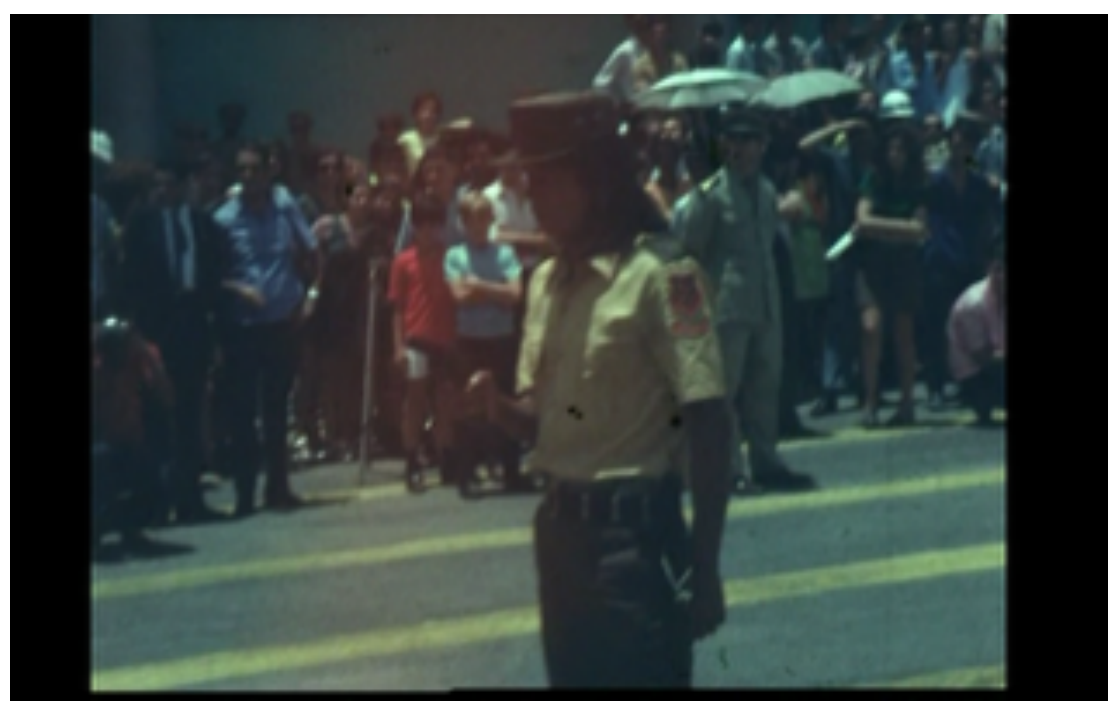

uma relação contraditória entre identidade e diferença. Assim, a imagem acima, onde vemos um guarda indígena apontando uma arma para um branco sendo revistado, é pacífica a um olhar militar pela sensação de identidade - um indígena que neste momento atua e gestualiza exatamente como um policial. Porém, a mesma imagem carrega seu próprio negativo, que não parece ter sido visível aos militares na ocasião: há um perigo, um risco também no que é performado ali. Temos, afinal, um grupo indígena organizado, militarizado, que empunha uma arma diante de um branco. Para um governo tão paranóico, um ano depois da promulgação do AI-5, com qualquer formulação que toque na palavra 'subversão', não deixa de chamar a atenção o fora de campo dessa imagem, uma certa latência de uma autonomia militarizada que a própria imagem, em chave reversa, parece sugerir.

Como narrou Alcides Krahô à nossa pesquisa, falando de um conflito de terra com fazendeiros do entorno:

"Depois nós fomos fiscalizar o território. Eu e outros guardas fomos pro rumo da casa de um fazendeiro que tava dentro da nossa área, o Olvídio. Nós levamos o ofício para ele desocupar nossa terra e entregamos pra ele, ele ficou só olhando. Ele não gostou, não. "Eu não vou sair daqui não. Isso aqui já foi registrado, eu não saio daqui não." Nós falamos pra ele que, se ele não cumprisse e passasse do prazo de sair, não ia ficar bom pra ele não. Hikjêhtiyc falou pra nós: "vamos pra cima dele. Ele sabe, se ele atacar a gente, nós vamos revidar”. Enquanto conversávamos, o gado passou, e a gente atirou numa vaca na frente dele. Depois que atiramos, outros que estavam com a gente já foram tirando o couro e separando a carne, e o dono ficou só olhando. "Vocês mataram o gado, né?! Tá 
bom. Eu vou desocupar a terra. Não quero brigar por causa de terra, a terra é de vocês. A terra é de vocês, eu que tô errado ${ }^{163}$ ".

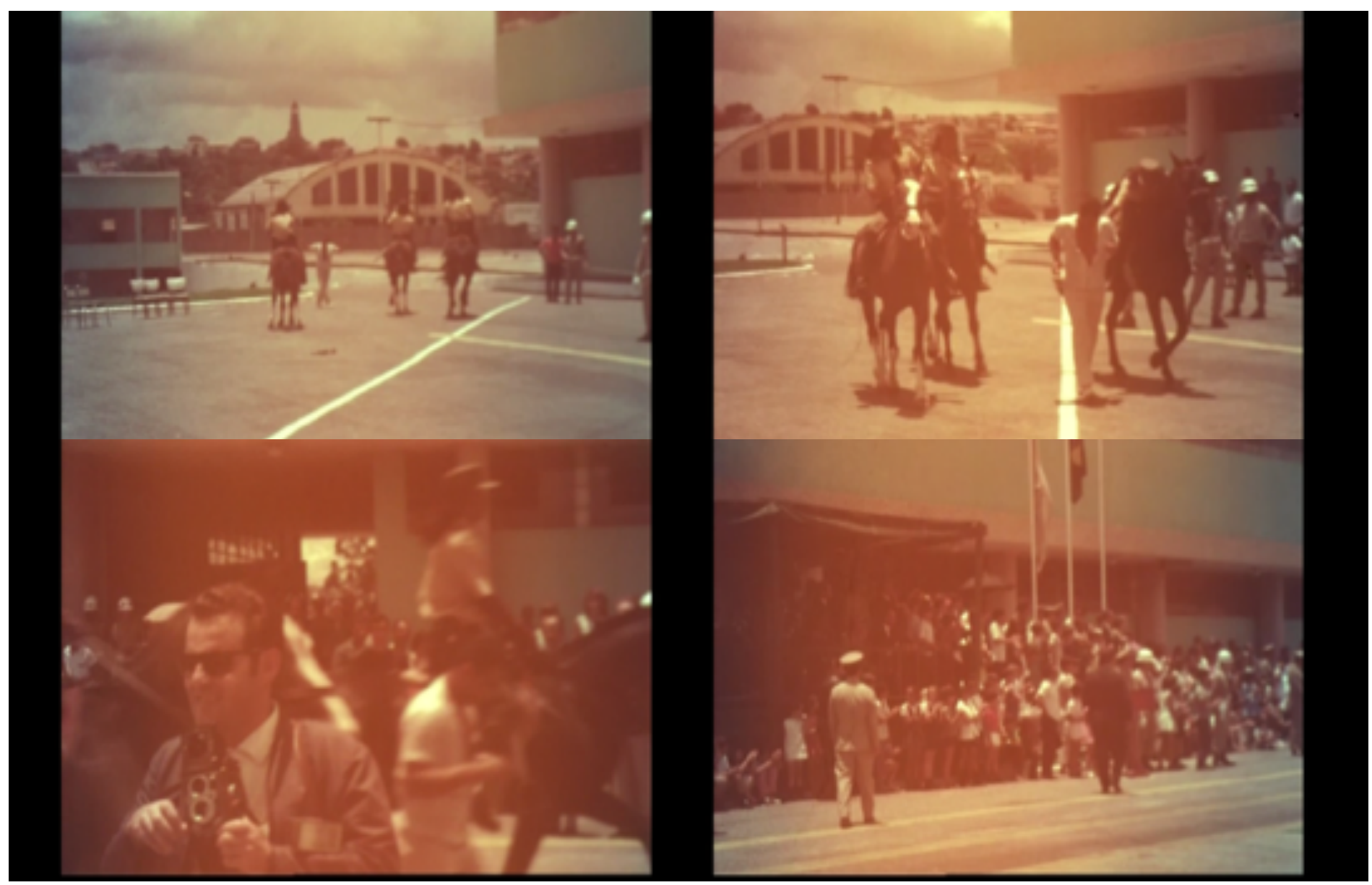

Imagens $118,119,120$ e 121

Em seguida temos um curto momento no qual os guardas novamente galopam para 'capturar' um homem que encena uma fuga. A sequência tem um quê teatral. Como podemos no sorriso do cinegrafista (imagem 120), há uma pantomima coletiva, visível no cooper preguiçoso que o 'fugitivo' perfaz depois de ter sido capturado (imagem 119) e nas palmas da população que assistia (imagem 121), que descreve bem o clima geral no qual a cerimônia se passava. Independente da violência do gesto de fardar os indígenas, o clima geral da cerimônia parece ter sido, ao menos para os não-indígenas, de leveza e descontração. E é sob este clima que temos um dos trechos mais fortes de nosso material de arquivo, e aquele que talvez revele melhor as contradições que

163 depoimento dado na língua e traduzido depois por Joel Krahô. 
rondavam aquela cerimônia. É, também, este trecho que deu a nosso material uma imediata relevância pública a partir de sua reemergência.

Uma fila de guardas encena trazer, em duplas, cada qual um não-indígena que está detido. De dois em dois, ou até sozinhos, eles puxam pelo braço os cativos. Atravessam o pátio inteiro nessa formação. No meio da fila, diante dos olhares sorridentes da plateia local, dois Grins atravessam o batalhão policial carregando um homem preso a um pau-de-arara (imagens 122 e 123). Ao fundo, as pessoas aplaudem. Olhando bem, podemos ver que atrás do cortejo há algumas crianças, que aplaudem a estranha procissão.

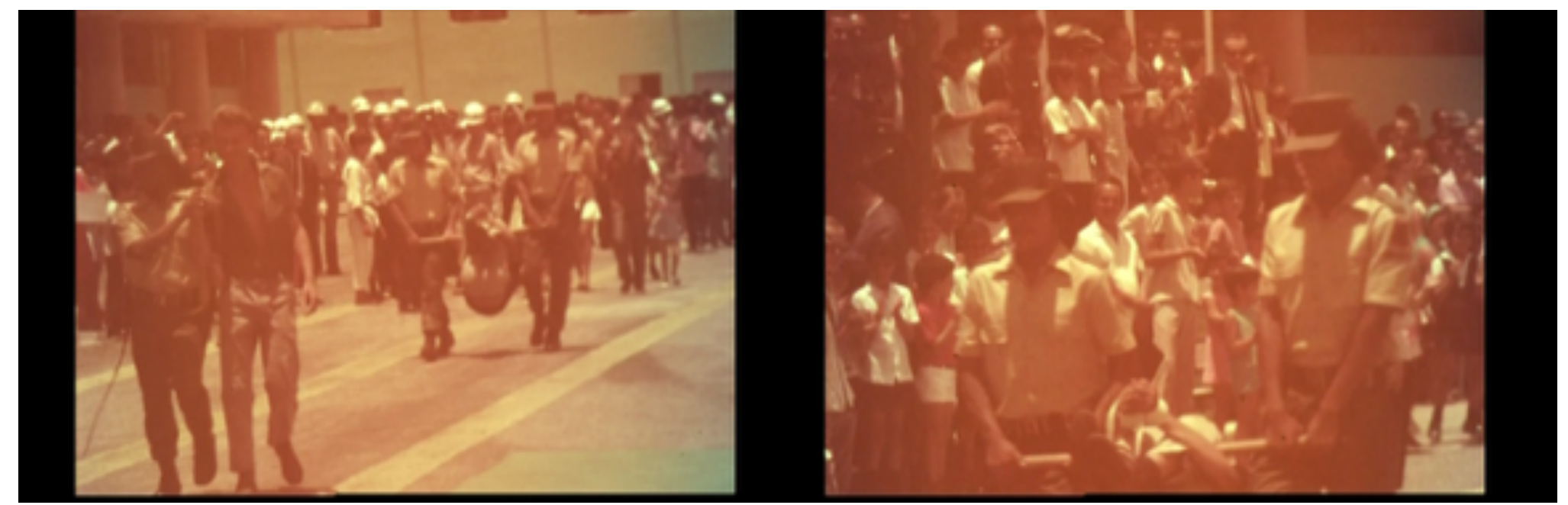

O pau-de-arara, um dos principais elementos de tortura utilizados pelos militares durante a ditadura, sempre teve sua existência negada pelo regime. A formatura da Grin se deu em fevereiro de 1970, período no qual a tortura começava a se institucionalizar dentro dos quartéis. A OBAN teve início em julho de $69^{164}$. Elio Gaspari descreve como, no dia 8 de outubro de 1969, os militares “escreveram uma triste página da história da corporação", ao terem organizado uma aula pública de tortura: “Os presos eram dez. Entre eles, seis rapazes do Colina. Foram tirados das celas, postos em fila e escoltados até um salão. No caminho, ouviram uma piada de um cabo: 'são esses os astros do show?'. A

164 GASPARI, Elio. As ilusões armadas - volume 2: a ditadura escancarada. São Paulo, Companhia das Letras, 2002. Página 63. 
plateia, sentada em torno de mesas, chegava perto de cem pessoas. Eram oficiais e sargentos, tanto do Exército quanto da Marinha e Aeronáutica. Numa das extremidades do salão havia uma espécie de palco, e nele o 'tenente Ailton' presidia a sessão com um microfone e um retroprojetor: 'agora vamos dar a vocês uma demonstração do que se faz clandestinamente no país'165". O jornalista continua seu relato: "no pau-de-arara penduraram Zezinho, que estava na PE por conta de crimes militares. Ailton explicou, enquanto os soldados demonstravam, que essa modalidade de tortura ganhava eficácia quando associada a golpes de palmatória ou aplicações de choques elétricos, cuja intensidade aumenta se a pessoa está molhada"166.

Este era, portanto, o clima dentro das Forças Armadas quando da formatura que ora analisamos. Como vemos, o pau-de-arara ocupava papel central nas torturas praticadas nos quartéis. Esta imagem possui importância histórica inegável por constituir verdadeira prova de que técnicas de tortura eram ensinadas de forma naturalizada em batalhões de polícia pelo país afora. Em a formação da Grin se tratando de um curso rápido (o treinamento durou três meses), cujos alunos tinham tido pouquíssimo contato com o mundo branco antes do treinamento, a execução, pelos próprios indígenas, do método de tortura diante de todos é uma verdadeira prova daquilo que diversas acusações de presos políticos já evidenciavam: para o Estado ditatorial, a tortura era em verdade a regra, uma tecnologia ensinada de forma banal a policiais e membros das Forças Armadas no país afora. Esta imagem, portanto, tem importância pública por ser a única representação oficial da tortura de todo o período militar, um atestado da existência daquilo que era negado pelo regime.

Mas como é possível que em uma cerimônia tão ensaiada, tão controlada, seja reproduzida, aos olhos de toda a população, em desfile aberto, aquilo que os militares a todo custo escondiam? Aguiar e Lissovsky, em belo ensaio, se fazem a

\footnotetext{
165 GASPARI, Elio. As ilusões armadas - volume 1: a ditadura envergonhada. São Paulo, Companhia das Letras, 2002. Página 363.

${ }^{166}$ Idemibidem, página 364.
} 
mesma pergunta: "durante a vigência da ditadura, a tortura não teve nenhum amparo jurídico - ao contrário da censura ou da incomunicabilidade do preso. A prática da tortura nunca foi assumida - e menos ainda publicamente exaltada. Como é possível que, em 1970, no auge da repressão, um desfile desta natureza tenha sido possível? ${ }^{167 \% "}$. Novamente, se faz presente a dimensão que já trabalhamos do recalque, aludida em nossa Introdução. Bernardo Kuscinski fala em uma "extensa e insuspeita muralha de silêncio ${ }^{168 "}$ " que cercava os violentos atos para-legais que aconteciam nos porões da ditadura, em especial em relação aos desaparecidos políticos - muralha que aliás permanece erguida, como atesta o fato de os desaparecidos políticos ainda não terem sido encontrados, e os arquivos secretos da ditadura não terem sido abertos. Como afirma Lucas Figueiredo: "quando o assunto eram os arquivos secretos da ditadura, os militares em nada tinham mudado em 27 anos de redemocratização. Sob o governo Dilma, as Forças Armadas agiam como nos tempos de Sarney. E o Poder Civil, por sua vez, permanecia indiferente ${ }^{169}$ ".

Elio Gaspari reflete sobre a dualidade de a tortura ser ao mesmo tempo permitida e organizada pelo Governo Central, e publicamente negada: "a ambiguidade obriga o governo a manter ao mesmo tempo uma situação mentirosa e um mundo clandestino (...) a negação da tortura pela retórica do regime catapulta a 'tigrada' da condição de infratora à de intocável. Quando ela mostra que pode fazer algo que o governo nega e condena, não se pode mais saber por onde passa a linha que separa o que lhe é permitido daquilo que lhe é proibido. $\mathrm{O}$ porão ganha o privilégio de uma legitimidade excepcional. A mentira oficial é o reverso da covardia da tortura. Através dela os hierarcas sinalizam um medo de assumir a responsabilidade por atos que apoiam e recompensam ${ }^{170}$ ". Não é

\footnotetext{
${ }^{167}$ AGUIAR, Ana; LISSOVSKY, Mauricio. Monumentos à deriva, in: ARAUJO, Denize Correa, MORETTIN, Eduardo Victorio e REIA-BATISTA, Vitor. Ditaduras Revisitadas - cartografias, memórias e representações audiovisuais. Faro, Portugal, CIAC, Universidade do Algarve, 2016.
}

${ }^{168}$ KUCINSKI, Bernardo. K - Relato de uma Busca. São Paulo, Companhia das Letras, 2016.

${ }^{169}$ FIGUEIREDO, Lucas. Lugar Nenhum - Militares e civis na ocultação dos documentos da ditadura. São Paulo, Companhia da Letras, 2015. Página 111

170 GASPARI, Elio. As ilusões armadas - Volume 2: a ditadura escancarada. São Paulo, Companhia das Letras, 2002. Página 25. 
escusado dizer que essa posição, de criminosos como intocáveis, está no coração daquilo da ditadura que sobrevive na democracia, em sua sempre reatualizada incapacidade de punir agentes de segurança envolvidos em ilegalidades e ações brutais, e que reaparece, como todo recalque acaba por reaparecer, nas declarações de nosso atual presidente em favor de um dos principais torturadores da ditadura, dedicando seu voto quando do impeachment de Dilma Rousseff ao torturador Carlos Alberto Brilhante Ustra. Esse mesmo recalque se observa nas falas dos próprios torturadores no período democrático, incomodados de terem sido 'abandonados' pela cúpula militar depois do fim do AI-5: “a zanga da 'tigrada' pode ser ouvida no depoimento do ex-tenente do Exército Marcelo Paixão de Araújo, que torturou presos de 1968 a 1971 nos porões do 12o RI, em Belo Horizonte: 'as altas autoridades do país foram as primeiras a tirar o seu da reta (...) todos os agentes do governo que escreveram sobre a época do regime militar foram muito comedidos. Farisaicos, até. Não sabiam de nada, eram santos, achavam a tortura um absurdo. Quem assinou o AI-5? Não fui eu. Ao suspender-se garantias constitucionais, permitiu-se tudo o que aconteceu nos porões'. Ou mesmo no depoimento de Ustra à Comissão da Verdade, em maio de 2013: 'quem deveria estar sentado aqui é o Exército Brasileiro, não eu' ${ }^{\prime 171 "}$.

Gaspari faz em seu livro extensa análise de como essa dupla linguagem, de negação pública e autorização privada à tortura, corrói por dentro o aparelho de Estado. Aqui, gostaríamos de reter essa noção de recalque, que nos parece aplicável ao dia da formatura, uma vez que operava em ato essa dupla lógica, uma visível outra recalcada: ao mesmo tempo a produção de uma imagem propagandística, e o ensino de práticas de tortura por parte dos militares. Assim, nos parece que a aparição pública da imagem recalcada do pau-de-arara se trata de verdadeiro ato-falho. Numa performance destinada a produzir uma imagem positiva da relação do regime com os povos indígenas, os militares acabam por revelar a brutalidade verdadeira do momento histórico que o país atravessava.

171 GASPARI, Elio. As ilusões armadas - Volume 2: a ditadura escancarada. São Paulo, Companhia das Letras, 2002. Página 26. 
Aguiar e Lissovsky respondem sua própria pergunta: "Os índios são, nos marcos dos estatutos legais que os protegem, inimputáveis. Isto é, só podem ser julgados por um tribunal comum se for provada sua condição de completo aculturamento. Por mais confiança que tivessem os militares em seu poder e na proteção de seus superiores hierárquicos, sua condição de cidadãos civilizados não lhes concedia imunidade legal. A segunda dimensão alegórica deste cortejo se torna então inteligível. Tratava-se de uma quinta-feira, antevéspera do Carnaval. Ostentada pelos braços inimputáveis dos índios brasileiros, os militares desfilavam sua própria impunidade ${ }^{172 "}$. Seu argumento é concordante com uma dimensão que surgiu durante nossa pesquisa: com todos os guardas indígenas que conversamos, mostramos essas imagens e perguntamos o que havia sido ensinado. Todos deram respostas parecidas, de que era para levar o preso de um lado a outro. Durante as exibições coletivas que realizamos em duas aldeias, este momento, para nós o mais pesado do material, era objeto de risadas dos espectadores indígenas, em especial dos jovens. Tais reações parecem apontar para o fato de que, nas comunidades visitadas, o pau-de-arara como método de tortura permanece desconhecido - o que eles viam, portanto, era apenas dois indígenas carregando um terceiro, e eles riam, sem peso, do fato de o terceiro elemento da cena ter se dado mal e estar amarrado. Assim, talvez possamos dizer que a técnica de tortura foi ensinada mas não aprendida pelos guardas indígenas. Eles efetuam em cena o gesto - carregam o preso no pau-de-arara. Mas, ao que tudo indica, não o incorporaram, não aprenderam a tecnologia da tortura, nem a perversão específica de torturar um corpo alheio para obter dele informações ocultas. No conjunto de denúncias de violências em torno da Grin a que tivemos acesso ao longo de nossa pesquisa, não há menção à utilização de tecnologias de tortura por parte dos guardas indígenas. Ao contrário, como consta na Ação Penal Reformatório Krenak, produzida pelo Ministério Público Federal em 2015 com denúncias de violência por parte do Estado e de Capitão Pinheiro em relação à Grin e ao Reformatório Krenak, os indígenas foram, no Reformatório, vitimados por este instrumento: "Manelão

172 AGUIAR, Ana; LISSOVSKY, Mauricio. Monumentos à deriva, in: ARAUJO, Denize Correa, MORETTIN, Eduardo Victorio e REIA-BATISTA, Vitor. Ditaduras Revisitadas - cartografias, memórias e representações audiovisuais. Faro, Portugal, CIAC, Universidade do Algarve, 2016 
Pankararu assim descreve o presídio: 'era uma cadeia grande. Tinha muitas celas, e cada cela tinha 4 camas. Era igual hospital'. Havia uma cela que ele chamou de 'cubículo', que era onde eles pegavam os índios e 'metiam o cacete'; era possível ouvir os índios gritando. 'Era ali que o índio tomava couro'. Havia um pau-dearara, 'igual cadeia'; no cubículo havia um pau-de-arara e também o 'cachorro quente', que era um aparelho que ficava jogando água do teto o tempo inteiro e o índio ficava dois dias numa cela molhada. Lembra de índios que iam para o paude-arara e 'cachorro quente' por qualquer motivo, sempre que 'fazia alguma coisa errada' ${ }^{\prime 173}$ ".

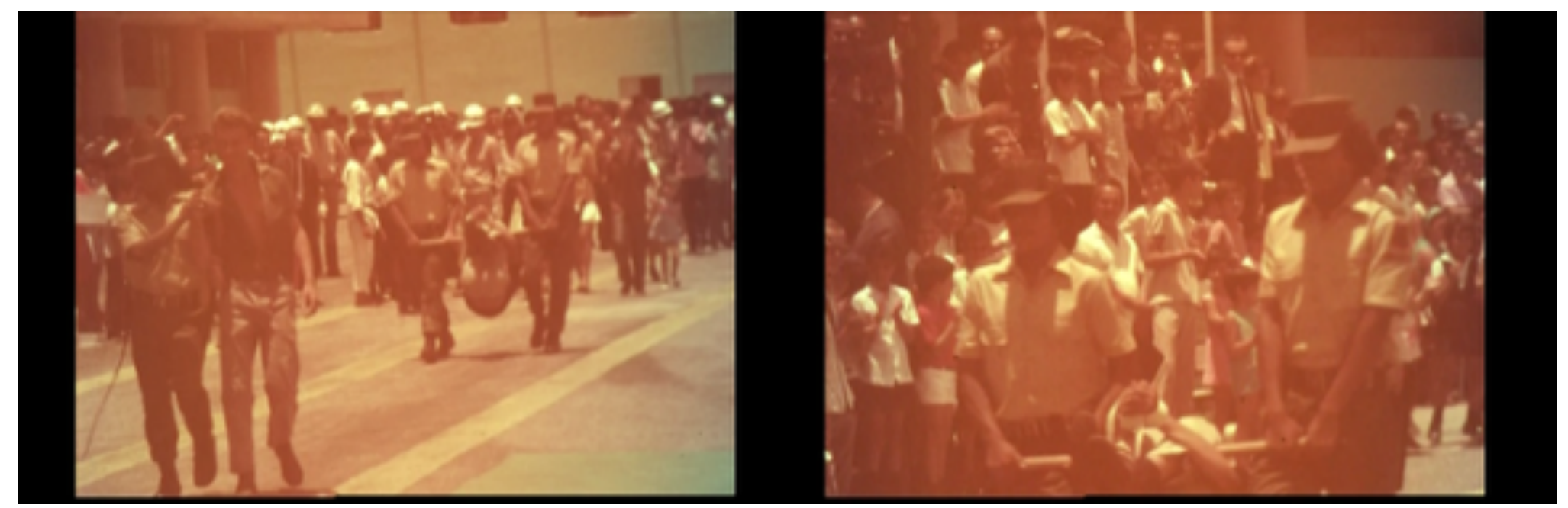

Restaria então perguntar: se o pau-de-arara não era de fato um instrumento a ser utilizado, por que então foi desfilado daquela maneira? Esta imagem parece carregar o núcleo do que chamamos até aqui de fetiche - uma imagem que não tinha uso para os indígenas que a performaram, mas que parece satisfazer a algo do olhar daquela plateia. Talvez não apenas a própria impunidade, como destacado por Aguiar e Lissovsky, mas o ápice da relação ambígua entre identidade e diferença - uma tentativa de incluir os indígenas, ápices da diferença, na identidade do crime histórico cometido - eles agora são iguais a nós, fazem o que fazemos, torturam como torturamos. Talvez aqui possamos ver por inteiro, num átimo, o coração perverso da imagem da Grin, tal qual pretendida por aqueles que a desenharam: tornar os indígenas iguais aos militares, incluí-los no horror 
histórico da tortura. Ainda indígenas e já torturadores, condenados portanto ao mesmo inferno que os poderosos que os assistem sorridentes escondem que se sabem condenados. Se já destacamos o uso para os militares da criação de uma imagem na qual estaria implícito o caráter violento da relação do Estado com os povos indígenas mas seriam os próprios indígenas os responsáveis por essa violência, a imagem dos Grins carregando o pau-de-arara é a epítome dessa tentativa: agora seriam os próprios indígenas os responsáveis pela tortura de que em verdade são vítimas. Em um ato-falho narcisista, os militares, na tentativa de reduzir o outro a uma imagem de si mesmos, parecem ter revelado sobre si aquilo que era recalcado no discurso público.

Como já observamos, do ponto de vista dos indígenas tal pretensão não passou, justamente, de uma imagem.

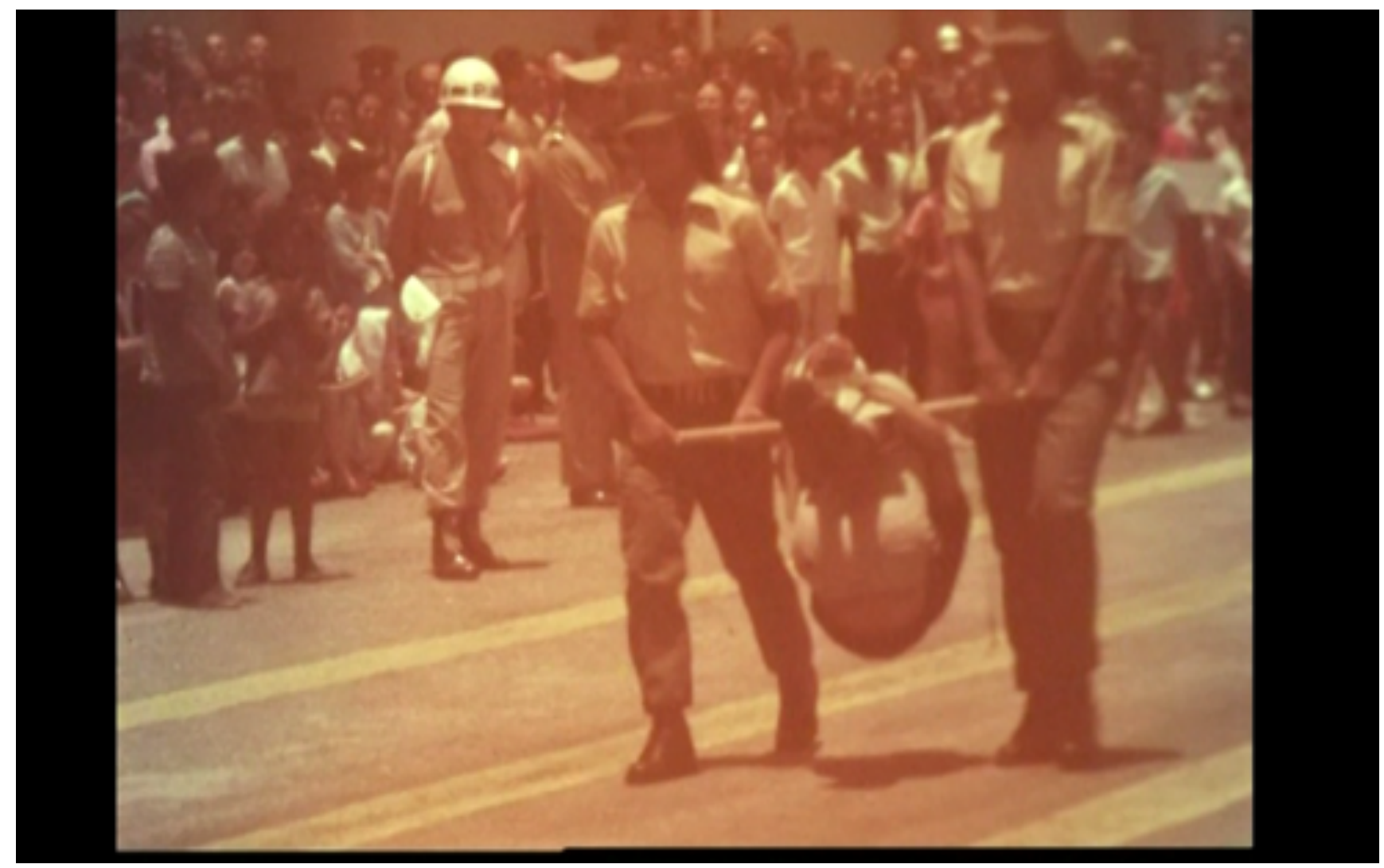

Imagem 124 
que efetuam - daí, inclusive, o humor. A relação a que vimos aludindo, a tensão entre exterioridade e interioridade, entre corpo e roupa, aqui parece estar diluída na forma como os guardas se divertem apesar da roupa militar - como repetem um gesto ensinado, aprendido como exterioridade, uma luta sem sentido prático que é performada como aparência. Uma gestualidade pura, a graça de copiar algo que não lhes diz respeito. Ao fundo, os brancos aplaudem, acreditando na exterioridade da imagem construída para estes mesmos olhos.

O riso é um dos elementos que os militares buscavam combater na forma como os indígenas lidavam com a 'roupa militar'. Retomamos a formulação de Valdir Xerente sobre o que Capitão Pinheiro disse logo antes de eles 'entrarem em cena':

“Ele falou pra nós desse jeito. (...) 'Não pode nem rir, não pode nem errar. Deixa esse povo olhar. Vocês vão olhar só pro que o comandante tá mandando. Se apresentar as armas, quando tá hasteando a bandeira, não vai olhar pras pessoas. Tem muita gente que vai gritar, mas vocês não olham. Se vocês olharem, vocês erram,".

Dona Nedina faz relato semelhante do que seu pai, cacique da aldeia, disse aos guardas, buscando sustentar a autoridade militar de que estavam imbuídos:

“Ele falou pro grupo assim: 'vocês não vão rir pra ninguém. Se vocês andarem brincando aí, vão ficar sem valor'. E acompanhou o conselho do meu pai. Eles conversavam tudo sério, não riam não. Não brincavam com ninguém."

Els Lagrou reflete sobre o significado do riso entre os Kaxinawa: "É de Lévi-Strauss (1991, p. 110-32), nas Mitológicas, a primeira reflexão sistemática sobre o tema entre os ameríndios. O autor mostra como a gargalhada é associada ao excesso de abertura, que pode ser perigoso para a pessoa que ri. A abertura de um dos orifícios do corpo pode corresponder estruturalmente a de outros. ${ }^{174}$ ". Já

${ }^{174}$ LAGROU, Els. Rir do poder e o poder do riso nas narrativas e performances Kaxinawa. São Paulo, Revista de Antropologia, Volume 49. 2006. 
Pierre Clastres, analisando o papel do ridículo em alguns mitos ameríndios, vê no riso "uma paixão dos índios, a obsessão secreta de rir daquilo que se teme. ${ }^{175}$ "

Localizado em algum ponto entre uma abertura perigosa e uma estratégia contra o temido, o riso era combatido pelos militares, por entenderem ser avesso àquilo que queriam ensinar. Talvez neste caso tivessem os militares razão: é possível que o riso fosse uma das 'estratégias murtosas de resistência' que buscamos aqui enxergar, em tudo avesso à cerimonização que se espraiava naquela tarde de fevereiro.

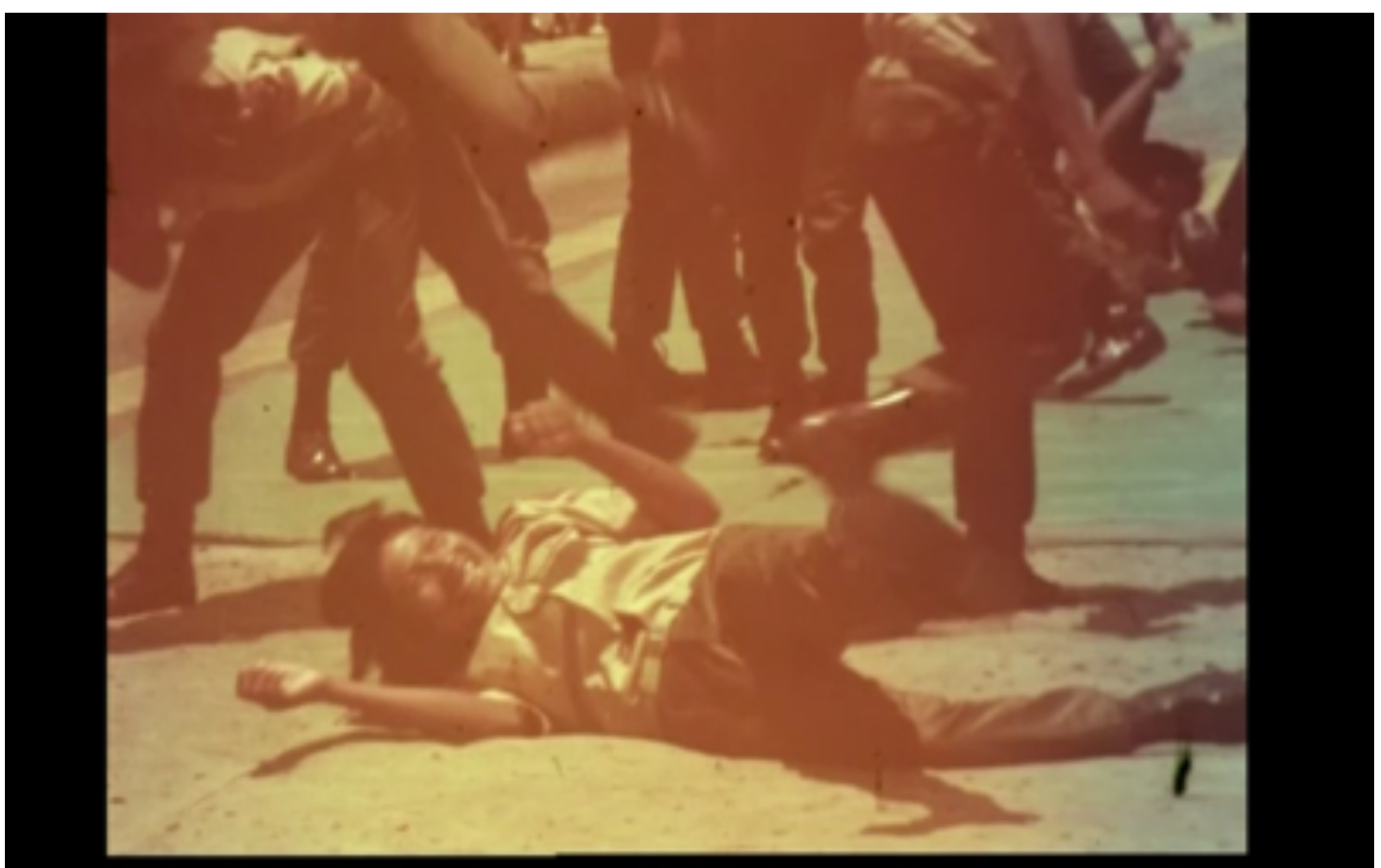

Imagem 127

Começa então um novo rolo.

Vemos uma nova etapa da brincadeira: primeiro crianças brancas, todas trajando kimonos e vestimentas de judô, praticam gestos clássicos da luta japonesa (imagens 128 e 129). Em sequência, vemos os guardas indígenas, no mesmo local, praticando gestos parecidos mas de forma desordenada (imagens 130 e 131). Importante notar que entre as duas imagens há um corte feito 'no gatilho' de forma muito precisa, quase não há sobras de material bruto do plano das crianças fazendo a cambalhota para a mesma imagem performada pelos indígenas - novamente, um índice da precisão de nosso cinegrafista.

${ }^{175}$ CLASTRES, Pierre. De que riem os índios? in: A sociedade contra o Estado. São Paulo, Cosacnaify, 2003. Página 163. 


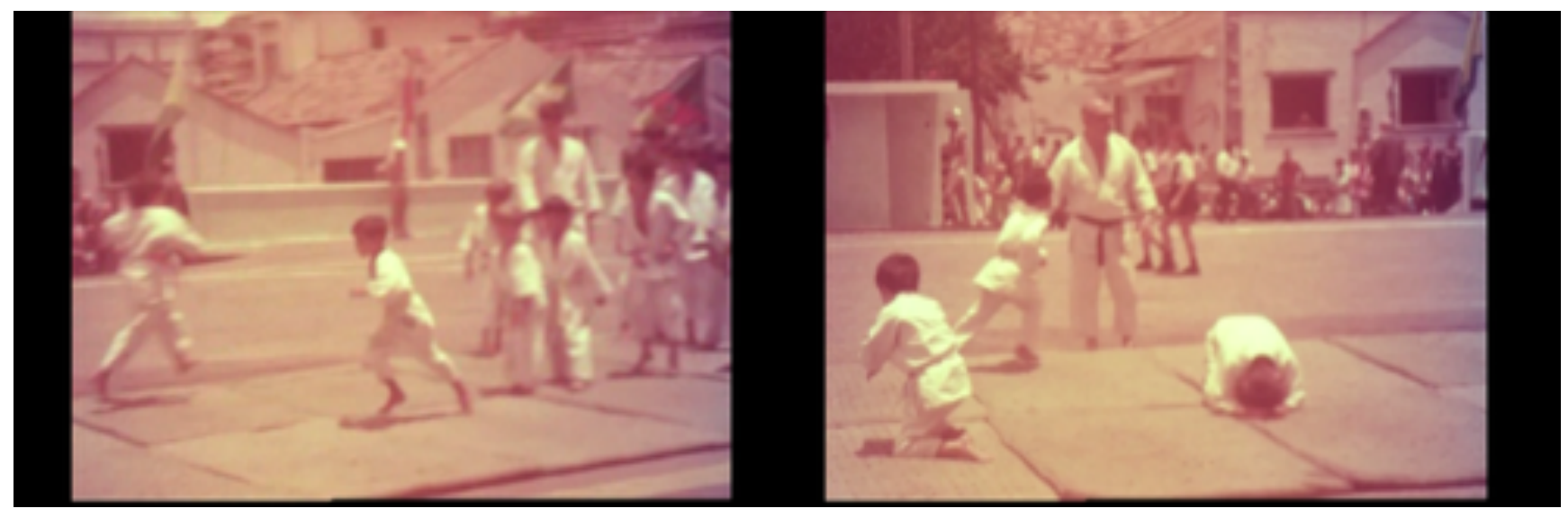

Imagens 128 e 129

A associação entre crianças e indígenas possui forte carga semântica. A imagem de crianças pequenas performando gestos 'de adultos' possui uma atração a partir de um estranhamento - as crianças estão fazendo algo que lhes é antinatural, que atesta um deslocamento de seu lugar de origem; elas são protótipos dos adultos que um dia serão. $\mathrm{O}$ corte dessa imagem para os indígenas no mesmo gesto busca construir efeito semelhante - os indígenas seriam também crianças, repetindo gestos que lhes seriam estranhos. Há na imagem 'ingênua' da cambalhota uma promessa de que ambos, crianças e indígenas, um dia serão efetivamente a imagem desestranhada - adulta - do que hoje performam com estranhamento. Mas enquanto as crianças se 'adultizarão' com o tempo, ao crescerem, os indígenas se 'adultizariam' com o processo de integração e de militarização que a Grin promove. Assim, a violência daquilo que destrói comunidades inteiras (a integração e a aculturação) é o ponto de fuga da imagem supostamente bonita e alegre dos indígenas fazendo cambalhotas 'como crianças'.

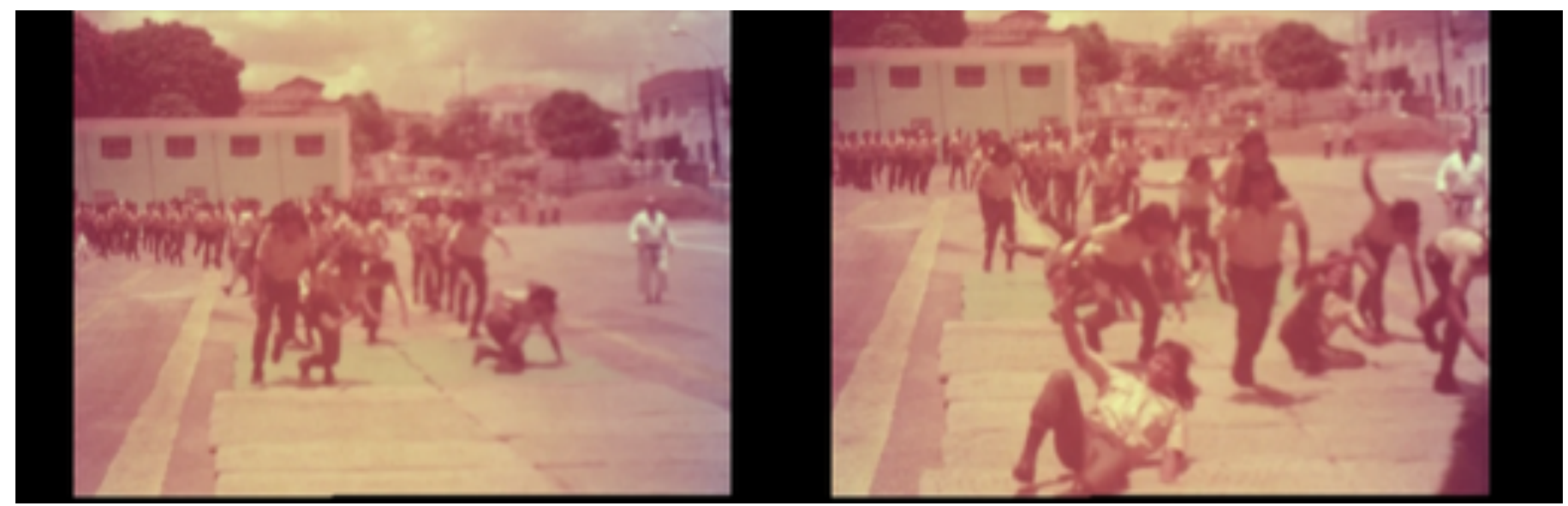

Imagens 130 e 131

Didi-Huberman analisa o filme de Harun Farocki, Respite, no qual vemos imagens do campo de Westerbork produzidas com fins publicitários. Nas imagens, 
despidos da parte de cima, eles praticam esse misto de brincadeira e luta (imagens 135, 136, 137 e 138). Embora assistidos pelo instrutor branco, a luta se difere do judô em muitos sentidos, e parece guardar semelhanças com práticas indígenas de lutas corporais, como o Huka Huka no Alto Xingu ou o Idjassú entre os Karajá178 (etnia presente na Guarda). Há portanto um aspecto híbrido, nessa luta que é branca e é também indígena. Como se a montagem proposta, do judô à luta indígena, desse a ver a tentativa de criação discursiva de um fundo militar à tradição indígena.

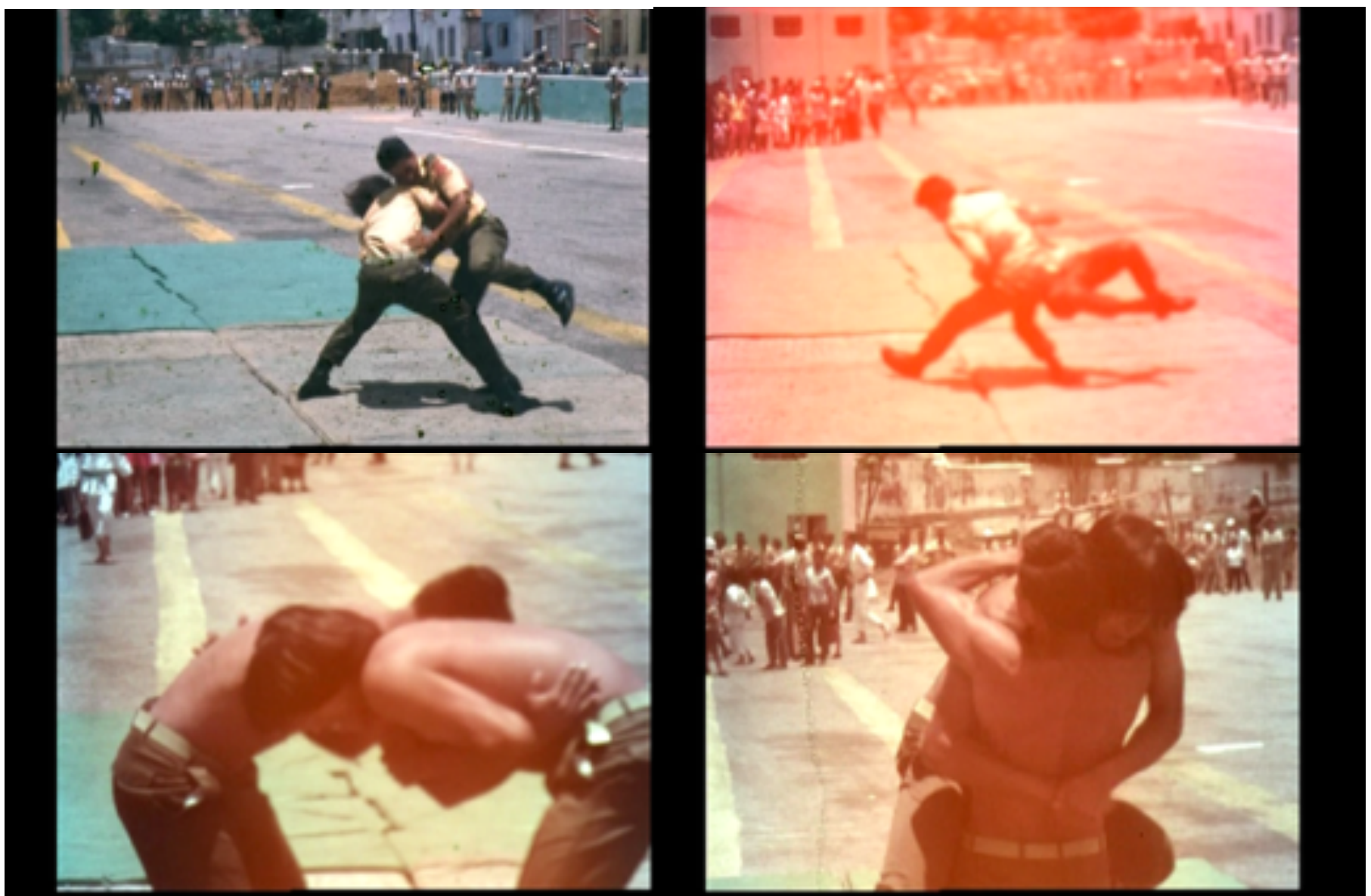

Imagens $135,136,137$ e 138

A filmagem, no entanto, se deixa levar pelos gestos rituais, como que atraída. A imagem é bonita, e os guardas parecem verdadeiramente se divertir. Há algo aqui que escapa à militarização sugerida pela ordenação do evento, e se deixa

178 https://web.archive.org/web/20130804191017/http://www.funai.gov.br/indios/jogos/foto principal/ luta corporal.htm\# - acessado em 15 de janeiro de 2021. 
ver nos gestos corporais da luta, na forma como os indígenas riem, na inteireza como se divertem.

Jesco abaixa a câmera, em TILT, para os pés dos guardas, na busca de mais um enquadramento icônico e militarista. Mas neste momento os guardas vão ao chão, de forma que a câmera registra em close o sorriso divertido com que se abraçam, na brincadeira ritual. Apesar da tentativa de Jesco, o que sobressai é mesmo a beleza dos movimentos, e a graça do sorriso (imagens 139 e 140).

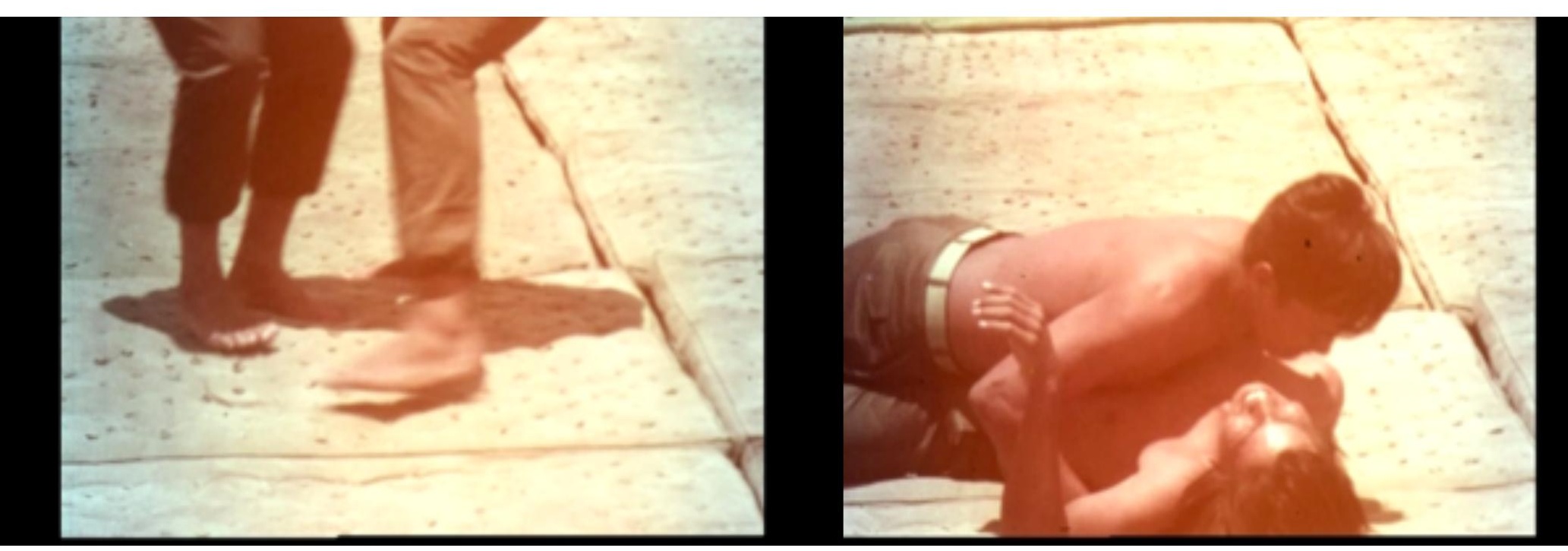

Imagens 139 e 140

Em seguida, e por fim, assistimos a um material também híbrido.

Os guardas Krahô fazem o que parece ser uma dança (imagens 141, 142, 143 e 144). Trazendo nas pernas um instrumento musical que parece ser um Txï, instrumento tradicional krahô, os guardas marcham e cantam ao mesmo tempo.

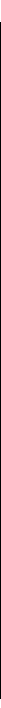




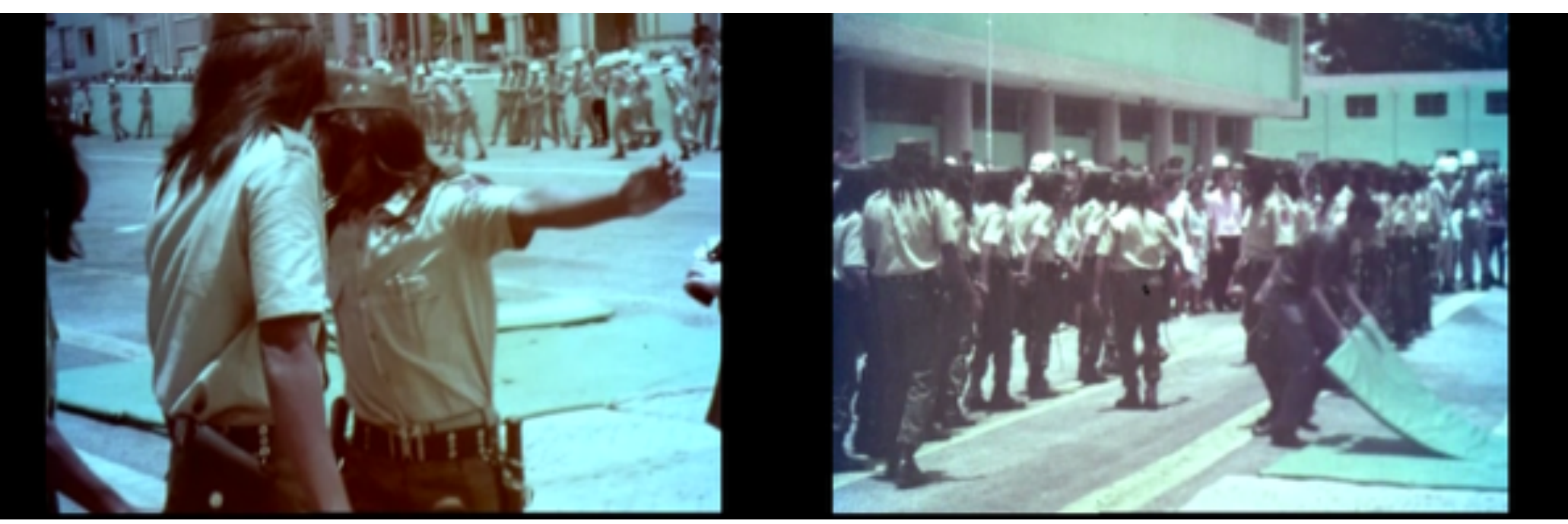

Imagens 143 e 144

Enquanto um deles, munido do tradicional maracá, coordena a cena, os outros batem o pé ritmadamente, concentrados na própria música.

Novamente, temos uma subordinação semântica dada por uma montagem, no caso, a montagem do evento: a dança ritual Krahô, com sua musicalidade, sua historicidade e suas características próprias, parece ser aqui enxergada pelos brancos como uma variação da marcha militar que os guardas brancos encenam. Da plateia, os militares aplaudem e riem com entusiasmo (imagem 145). Os guardas, no entanto, estão afeitos à própria dança (imagem 146). Equívocos à parte, é possível ler a descrição acima invertida, como uma apropriação: não a dança se encaixando na temporalidade militar, mas o militarismo recém-aprendido se encaixando na temporalidade ritual.

A oposição entre as imagens 145 e 146 parece guardar o coração das contradições da Grin. Da plateia, os militares sorriem, satisfeitos. Para eles, a imagem que viam era de sucesso; menos, nos parece, em relação ao que concretamente poderia significar a criação de uma guarda indígena para policiar as aldeias, e mais à organização, tornada imagem, dos elementos que faziam dos indígenas uma imagem dos militares.

Os guardas, por sua vez, estão dispostos em círculo, voltados à si. No exato momento em que estão performando aquilo da cerimônia que lhes é mais 
próprio - a música, eles se voltam a si, em um círculo fechado, dispostos concentricamente tal como as casas em suas aldeias ${ }^{179}$, dando por um momento as costas ao que lhes é externo.

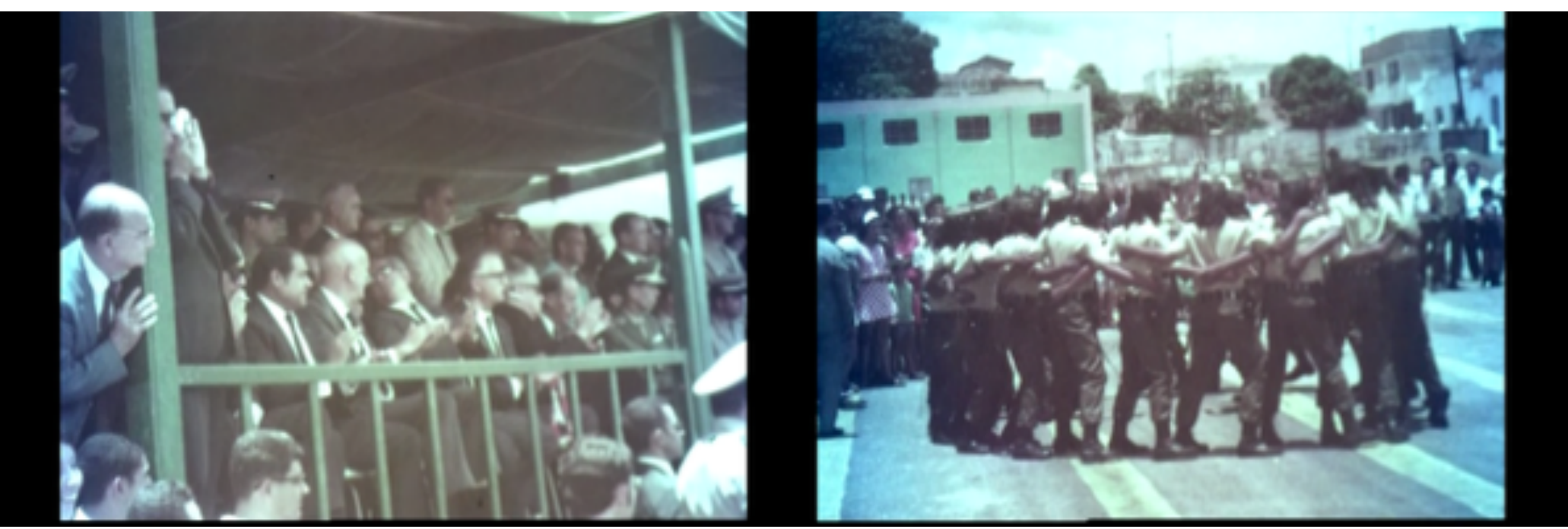

Imagem 145

Imagem 146

Talvez essa imagem (146) seja a que melhor concretize a tensão a que vimos nos referindo. Já aludimos à formulação de Viveiros de Castro sobre a roupa como um corpo, que fala não apenas sobre os poderes da farda que eles vestiam, mas sobre o papel devotado à relação com a alteridade pelos povos ameríndios. Como escreve James Clifford, refletindo sobre narrativas de contato entre povos ameríndios e colonizadores, "as narrativas de contato e mudança cultural têm sido estruturadas por uma dicotomia onipresente: absorção pelo outro ou resistência ao outro [...] Mas, e se a identidade for concebida não como uma fronteira a ser defendida, e sim como um nexo de relações e transações no qual o sujeito está ativamente comprometido? A narrativa ou narrativas da interação devem, nesse caso, tornar-se mais complexas, menos lineares e teleológicas. O que muda quando

\footnotetext{
179 “Os Krahô, como os demais povos Jê, também concebem seu universo demarcado de forma dualística. Essa cosmovisão tem sua representação empírica na planta da aldeia, que possui uma disposição circular com as casas (esfera privada) dispostas em torno do pátio (esfera pública e cerimonial). Isso confere uma visão de mundo concêntrica de forma que as referências à identidade Krahô estão diretamente ligadas às atividades da aldeia (e que é característico da maioria dos povos Jê, especialmente dos Timbira), com prevalência cerimonial do pátio, enquanto que a alteridade remete-se para as esferas que se afastam desse ponto central dado pelo pátio e pela aldeia.", in: GIRALDIN, Odair, "Os jovens não querem escutar, eles só querem ler" - a escola para os Krahô. Revista Eletrônica Ñanduty, PPGAnt, UFGD.
} 
o sujeito da 'história' não é mais ocidental? Como se apresentam as narrativas de contato, resistência ou assimilação do ponto de vista de grupos para os quais é a troca, não a identidade, o valor fundamental a ser afirmado? ${ }^{180 "}$

De forma semelhante, talvez possamos retomar a comparação com o filme de Jean Rouch, Os Mestres Loucos, refletindo se no filme francês não estaríamos diante, mais do que de formas de apropriação do ritual do opressor pelo oprimido, da performação do encontro com uma alteridade, ou melhor, da própria abertura a esse encontro. Se assim for, o ritual filmado não se proporia somente a performar o, por assim, dizer, 'inimigo', mas a performar uma relação com os colonizadores (violenta, à altura inevitável), à qual os Haouka souberam conferir um valor de si mesmos.

Viveiros de Castro formula que "se europeus desejaram os índios porque viram neles, ou animais úteis, ou homens europeus e cristãos em potência, os Tupi desejaram os europeus em sua alteridade plena, que lhes apareceu como uma possibilidade de autotransfiguração, um signo da reunião do que havia sido separado na origem da cultura, capazes portanto de vir alargar a condição humana, ou mesmo de ultrapassá-la. Foram então talvez os ameríndios, e não os europeus, que tiveram a 'visão do paraíso' no desencontro americano. Para os primeiros, não se tratava de impor maniacamente sua identidade sobre o outro, ou recusá-lo em nome da própria excelência étnica; mas sim de, atualizando uma relação com ele (relação desde sempre existente sob o modo virtual), transformar a própria identidade ${ }^{181}$."

"Para saber, é preciso imaginar-se", repetimos uma última vez. Podemos apenas imaginar o que significou para os indígenas essa cerimônia, trajando as roupas-corpo dos donos do poder, aturdidos pela zoada militarista da banda militar, cercados pelos olhares brancos da cúpula de um regime tão bárbaro quanto

180 CLIFFORD, James. The predicament of culture: twentieh century ethnography, literature, and art. Cambridge, Mass: Harvard University Press. 1988, in: VIVEIROS DE CASTRO, Eduardo. O mármore e a murta: sobre a inconstância da alma selvagem, in: A inconstância da alma selvagem. São Paulo, Cosacnaify, 2002. Página 196.

181 VIVEIROS DE CASTRO, Eduardo. O mármore e a murta: sobre a inconstância da alma selvagem, in: A inconstância da alma selvagem. São Paulo, Cosacnaify, 2002. Página 206. 
ignorante. No momento final de sua performance, cercados pelos militares enquanto fazem no batalhão o ritual que lhes é próprio e tão caro, os Krahô se olhavam, voltados à si, como se tentassem reter algo de si mesmos no perigoso encontro com o outro que lhes foi imposto pela estranha aventura da instalação de uma Guarda Rural Indígena.

Viveiros de Castro termina seu belo ensaio refletindo sobre as narrativas ameríndias de encontros sobrenaturais, que narram encontros "entre um humano sempre sozinho - e um ser que, visto primeiramente como um animal ou uma pessoa, revela-se como um espírito ou um morto, e fala com o homem. (...) a forma canônica desses encontros sobrenaturais consiste, então, na intuição súbita de que o outro é humano, entenda-se, que ele é o humano, o que desumaniza e aliena automaticamente o interlocutor, transformando-o em presa - em animal. E este, enfim, seria o verdadeiro significado da inquietação ameríndia sobre o que se esconde sob as aparências. As aparências enganam porque nunca se pode estar certo sobre qual é o ponto de vista dominante, isto é, que mundo está em vigor quando se interage com outrem. Tudo é perigoso, sobretudo quando tudo é gente, e talvez nós não sejamos ${ }^{182}$ \%.

Se retomarmos o ofício trazido por Egon Dionísio Heck, que falava que armados com metralhadoras os Grins poderiam se tornar ainda mais perigosos ${ }^{183}$, podemos apenas imaginar o quanto o verdadeiro perigo do que se passava se dava para os indígenas. No ápice da ditadura militar, levados a um treinamento apressado, violento e equivocado, fardados e armados por um grupo de militares, desfilando para a cúpula do Regime, podemos apenas imaginar a disputa de mundos em vigor que operava em ato, no ensolarado batalhão da polícia militar. Concentrados, em círculo, no final de sua performance, os guardas Krahô se voltavam a si, buscando talvez algo reter - havia algo em suspenso, algo sendo mantido, coletivamente, por aqueles que foram obrigados a performar em si a imagem do outro que os brancos queriam ver desfilada.

182 CASTRO, Eduardo Viveiros de. Perspectivismo e multinaturalismo na América indígena, in: A inconstância da alma selvagem e outros ensaios de antropologia. São Paulo. Cosacnaify. 2002. Página 397.

183 HECK, Egon Dionísio. Os índios e a caserna - políticas indigenistas dos governos militares - 1964 a 1985. Dissertação de Mestrado. IFICH, Unicamp, 1997. 


\section{CONSIDERAÇÕES FINAIS}

Não é fácil, nem é nosso propósito, narrar detidamente os eventos marcantes e contraditórios da atuação da Grin, nem seu ocaso ${ }^{184}$. Desde o princípio, pulularam denúncias, na imprensa, de abusos e violações por parte de alguns guardas. Matéria do Estado de São Paulo de 07 de junho de 1970 trazia como título: 'Acusada a Guarda Indígena ${ }^{185}$ '. A matéria fala em 'atos de espancamento, arbitrariedades e insubordinação', e também que 'para antropólogos e sertanistas, a grave falha da Guarda foi a implantação do sistema policialesco no meio indígena, com o emprêgo [sic] de delações e métodos de espionagem ${ }^{186}$. Em meio a tantas denúncias, apenas 4 meses depois da formatura da primeira e única turma da Grin, o presidente da Funai, Queiroz Campos, foi exonerado. Em 08 de junho de 1970 assumiria a Funai seu segundo presidente, o General Bandeira de Melo.

Capitão Pinheiro foi demitido da Funai no final de 1972, em meio a denúncias não apenas na Grin mas também no Reformatório Krenak, em especial com o violento e desastroso processo de transferência de índios Krenak para a Fazenda Guarany, em $1972^{187}$. Hoje, ele é acusado pelo Ministério Público pelos seguintes crimes contra a humanidade: 'escravidão, transferência forçada, prisão, tortura, agressão sexual, perseguição de um grupo por motivos étnicos e outros atos desumanos que provocaram grande sofrimento físico e mental ${ }^{188}$.

Ao longo dos anos, houve denúncias variadas e recorrentes de abusos e violências por parte de alguns guardas. Também foram recorrentes projetos de 'reorganização' da Grin.

\footnotetext{
184 Para tal intuito, ver FREITAS, Edinaldo Bezerra de. Índios-Soldados - A GRIN e a tradição Militar da Política Indigenista Brasileira. Tese de Doutorado, Programa de pós-graduação em História Social da Universidade de São Paulo. São Paulo, 1999.

185 O Estado de São Paulo, São Paulo, 7 de junho de 1970. https://acervo.estadao.com.br/pagina/\#!/19700607-29191-nac-0011-999-11-not - acessado em 15 de janeiro de 2021.

186 idemibidem.

${ }^{187}$ Sobre esse processo, ver denúncia de 2015 do Ministério Público: Ministério Público Federal. 2015. Ação civil pública com pedido de antecipação de tutela, no 64483-95.2015.4.01.3800 de 10.12.15. Disponível em: https://goo.gl/8qxWm4. Último acesso: 29.01.2021.

188 idemibidem.
} 
Matéria do Jornal do Brasil de 21 de outubro de 1973 noticiava que: 'a Funai anunciou ontem que vai reorganizar a Guarda Rural Indígena ${ }^{189}$. A matéria afirma que a Grin teria tido 'desvirtuamentos' e que 'acabou imobilizada, sem meios para se locomover e, geralmente, abrigando-se sob o teto do posto indígena da Funai ${ }^{190}$. Freitas assinala que no final de sua gestão, Bandeira de Melo propunha a desativação da GRIN, que, todavia, não aconteceu. Segundo o próprio autor: "os anos finais da década de setenta corresponderiam ao ocaso da GRIN. De um lado, temos as críticas e reclamações de sempre: de parasitismo, inoperância, conflitos hierárquicos. Por outro, a visível incapacidade da FUNAI de por fim de vez na experiência. ${ }^{191 "}$ A Grin nunca foi formalmente desativada. Freitas assinala que apenas “cortaram-se os pagamentos dos guardas e parte deles de fato foram contratados para o quadro do Órgão indigenista ${ }^{192}$." Nas conversas que tivemos com aqueles que participaram da Guarda, a pergunta mais recorrente que nos fizeram era, exatamente, o porquê de ela ter terminado - nem nós nem eles tínhamos uma resposta precisa.

Parece evidente que muito cedo a Grin se transformou em um problema para a Funai. Passado o impulso inicial, a concretude do projeto de transformar indígenas em policiais começou a mostrar suas profundas fissuras. Em sintonia com o que vimos aqui colocando, este fim 'lento e gradual' parece falar sobre o caráter propriamente imagético por trás da criação da Grin. Nos parece que uma vez sanado aquilo que acreditamos ter sido seu impulso original, a produção de uma imagem que servisse ao Estado ditatorial, a Grin como política tenha perdido sua razão de existir, e tenha se tornado um resto ${ }^{193}$ - um pedaço, uma ruína de um projeto antigo, violento, errático.

\footnotetext{
189 Jornal do Brasil, Rio de Janeiro, 21 de outubro de 1973. http://memoria.bn.br/docreader/DocReader.aspx? bib=030015 09\&pagfis $=93843$ - acessado em 15 de janeiro de 2021.

190 idemibidem.

${ }^{191}$ FREITAS, Edinaldo Bezerra de. A guarda rural indígena (GRIN). Aspectos da militarização indígena no Brasil. Anais do XXVI Simpósio Nacional de História - ANPUH. São Paulo, julho de 2011.

192 Idemibidem.

${ }^{193}$ AGAMBEN, Giorgio. O que resta de Auschwitz. São Paulo, Boitempo Editorial, 2008.
} 
A Grin durou um certo tempo, teve um certo uso para o Estado, depois teve seu final em câmera lenta. Nesse percurso, atropelou as vidas e trajetórias dos grupos indígenas que dela fizeram parte.

Em depoimento à nossa pesquisa, Domingos Kraté, um ex-guarda Krahô, quando questionado sobre o porquê de a guarda ter sido desmontada, disse que "o pensamento dos brancos é como a rama da melancia, tem vários caminhos”, refletindo sobre a opacidade, para ele, do que se passava na cabeça dos militares. Depois, ele aventa explicações possíveis: "Por isso que acabou mesmo, foram os brancos ruins que entraram na Funai, se os brancos bons entrassem talvez nos ajudassem. Talvez na época os Krahô não entendessem o pensamento dos brancos. Talvez eles quisessem tomar nossa terra, por isso terminou a Grin. Trocou o presidente também. É por isso que acabou." Em outra conversa, ele continuou o raciocínio: "os Presidentes da República, tem deles que é bom, tem deles que é ruim. O que não dá certo pra ele, o outro novo entra e corta. Começa a plantar, ele... o outro planta, e o outro não dá certo pra ele, ele corta. Eu penso desse jeito ${ }^{194}$."

Como já dissemos, esta pesquisa é paralela a um documentário de nossa autoria, intitulado A Flecha e a Farda ${ }^{195}$. No filme, buscamos registrar algumas das fraturas que ficaram nas trajetórias destes indígenas - foram várias as violências, os horrores, foram várias as coisas ditas e caladas. Fraturas profundas, para as quais faltam imagens.

Dona Nedina levou nossa equipe ao local que funcionava a cadeia na Terra Indígena Xerente, e mostrou uma área onde hoje se pode ver apenas construções novas:

“Era bem aqui assim. Nesse trecho aqui. A cadeia era aqui, assim. Nesse lugar aqui (...) Era esse aqui ó, aqui que era o lugar... do sofrimento.

- e aí não sobrou nada aqui?

Nada, nada. Só mesmo o chão. Tá com muitos anos ${ }^{196}$."

\footnotetext{
${ }^{194} \mathrm{O}$ depoimento foi dado em português, aqui transcrito de forma literal.

195 A Flecha e a Farda (Miguel Antunes Ramos, 2020)

${ }^{196}$ Entrevista dada a nossa equipe em português, transcrita literalmente. A pergunta no meio é nossa.
} 
Didi-Huberman, analisando as quatro fotografias tiradas em Auschwitz, formula que “é claro que as quatro fotografias de Agosto de 1944 não dizem 'toda a verdade' (...) mas elas são para nós, para o nosso olhar de hoje - a própria verdade, isto é, um vestígio, um fragmento dessa verdade: o que resta, visualmente, de Auschwitz ${ }^{197 ”}$.

Simétrico à trajetória de Grin, também nosso material de arquivo é algo que restou. De origem incerta e ambígua, jamais editado e com o som perdido, com partes deterioradas e quase se rompendo, ele é também um resto, aquilo que sobreviveu desse estranho experimento histórico. Assim como a política concreta da Grin, também ele é uma ruína. Ruína de uma longa história de projetos estatais que violentam povos indígenas. Ruína de uma longa história de como esse mesmo Estado se registra, e como registra os outros. Ruína desse todo confuso, ambíguo e barbaramente violento a que chamamos Brasil.

Robert Smithson fala sobre 'escombros ao contrário': “ou seja, todas as construções que teriam sido construídas. É o contrario da ruína romântica: essas obras não se arruínam após a sua construção. Tendem à ruína ainda antes de serem construídas ${ }^{198}$."

Talvez assim possamos compreender a forma como estes retângulos antigos de película relampejam sobre nosso turvo presente. Pois se ele, o resto, aquilo que sobreviveu, é uma ruína, não é difícil enxergar como esta já estava inscrita antes de ser construída: os equívocos e violências do projeto da Grin fissuravam de saída a estrutura de sua construção. Assim, poderíamos estender nosso olhar ao difícil presente que nos coube viver e nos perguntar, simetricamente, quantas e quais ruínas futuras não estão sendo inscritas nesse país que se constrói tão regressivamente.

${ }^{197}$ DIDI-HUBERMAN, Georges. Imagens apesar de tudo. Lisboa, Editora KKYM. 2004. Página 58.

198 SMITHSON, Robert. A Tour of the Monument of Passaic, New Jersey, 1967, in: CARERI, Francesco. Walkscapes - o caminhar como prática estética. São Paulo, Editora G. Gilli, 2015. Página 147. 


\section{REFERÊNCIAS BIBLIOGRÁFICAS}

\section{BIBLIOGRAFIA}

AGAMBEN, Giorgio. O que resta de Auschwitz. São Paulo, Boitempo Editorial, 2008.

AGUIAR, Ana; LISSOVSKY, Mauricio. Monumentos à deriva, in: ARAUJO, Denize Correa, MORETTIN, Eduardo Victorio e REIA-BATISTA, Vitor. Ditaduras Revisitadas cartografias, memórias e representações audiovisuais. Faro, Portugal, CIAC, Universidade do Algarve, 2016.

AUMONT, Jacques. Ensaio sobre a análise fílmica. São Paulo, Editora Papirus, 2004.

BARTHES, Roland. A câmara clara - notas sobre a fotografia. Rio de janeiro, Editora Nova Fronteira, 2015.

BAZIN, André. Ontologia da imagem fotográfica, em: O Cinema, ensaios. São Paulo, Editora Brasiliense, 1991.

BENJAMIN, Walter. Obras escolhidas, volume 3. São Paulo, Editora Brasiliense, 1985. Obras escolhidas, volume 1. São Paulo, Editora Brasiliense, 1985. Passagens. São Paulo, Imprensa Oficial, 2009.

BERBERT, Paula. "Para nós nunca acabou a ditadura": instantâneos etnográficos sobre a guerra do Estado brasileiro contra os Tikmu'un_Maxacali. Dissertação de Mestrado FAFICH - Faculdade de FIlosofia e Ciências Humanas. Belo Horizonte, 2017.

BRANDÃO, Alessandra Soares; SOUSA, Ramayana Lira de (orgs). A Sobrevivência das imagens. São Paulo, Editora Papirus, 2015.

CAIUBY, Sylvia. Corpo, imagem e memória - reflexões a partir de duas fotos do funeral Bororo, in: MAMMI, Lorenzo, SCHWARCZ, Lilia (orgs): 8x Fotografia. São Paulo, Companhia das Letras, 2008.

CARNEIRO DA CUNHA, Manoela. Cultura com aspas. São Paulo, Cosacnaify, 2009. 
CLASTRES, Pierre. A sociedade contra o Estado. São Paulo, Cosacnaify, 2003.

CODATO, Adriano Nervo. O Golpe de 1964 e o regime de 1968: aspectos conjunturais e variáveis históricas, em: História: Questões e Debates. Curitiba, Editora UFPR, 2004.

CORREA, José Gabriel. A ordem a se preservar: a gestão dos índios e o reformatório agrícola indígena Krenak. Dissertação de mestrado, Programa de Pós Graduação em Antropologia Social, Museu Nacional, UFRJ. Rio de Janeiro, 2000.

Tutela \& Desenvolvimento/Tutelando o desenvolvimento:

questões quanto à administração do trabalho indígena pela Fundação Nacional do Índio. Tese de doutorado, Programa de Pós Graduação em Antropologia Social, Museu Nacional, UFRJ. Rio de Janeiro, 2008.

DIAS FILHO, Antonio Jonas. Sobre os viventes do Rio Doce e da Fazenda Guarany: Dois presídios federais para índios durante a Ditadura Militar. Tese de Doutorado, Pontifícia Universidade Católica de São Paulo. São Paulo, 2015.

DIDI-HUBERMAN, Georges. O que vemos, o que nos olha. São Paulo, Editora 34, 1998. Imagens apesar de tudo. Lisboa, Editora KKYM. 2004.

A sobrevivência dos vaga-lumes. Belo Horizonte, Editora

UFMG, 2011.

A imagem sobrevivente. História da arte e tempo dos fantasmas segundo Aby Warburg. Rio de Janeiro, Editora Contraponto, 2013.

Diante da Imagem. São Paulo, Editora 34, 2013.

Cascas. São Paulo, Editora 34, 2017.

Remontagens do tempo sofrido - o olho da história II. Belo Horizonte, Editora UFMG, 2018.

FIGUEIREDO, Lucas. Lugar Nenhum - Militares e civis na ocultação dos documentos da ditadura. São Paulo, Companhia da Letras, 2015.

FLUSSER, Vilém. Filosofia da caixa preta - Ensaios para uma filosofia da fotografia. Rio de Janeiro, É Realizações Editora, 2018.

FORTES, Luiz Roberto Salinas. Retrato Calado. São Paulo, Cosacnaify, 2012.

FOUCALT, Michel. O Nascimento da Biopolítica. São Paulo, Edições 70, 2010. 
FREITAS, Edinaldo Bezerra de. A guarda rural indígena (GRIN). Aspectos da militarização indígena no Brasil. Anais do XXVI Simpósio Nacional de História - ANPUH. São Paulo, julho de 2011.

Índios-Soldados - A GRIN e a tradição Militar da

Política Indigenista Brasileira. Tese de Doutorado, Programa de pós-graduação em História Social da Universidade de São Paulo. São Paulo, 1999.

GASPARI, Elio. As ilusões armadas - volume 1: a ditadura envergonhada. São Paulo, Companhia das Letras, 2002.

As ilusões armadas - volume 2: a ditadura escancarada. São Paulo, Companhia das Letras, 2002.

GIRALDIN, Odair, “Os jovens não querem escutar, eles só querem ler” - a escola para os Krahô. Revista Eletrônica Ñanduty, PPGAnt, UFGD.

GUIMARÃES, Elena. RELATÓRIO FIGUEIREDO: entre tempos, narrativas e memórias. Dissertação de Mestrado, Programa de Pós- Graduação em Memória Social, Universidade Federal do Estado do Rio. Rio de Janeiro, 2015.

GUNNING, Tom. O retrato do corpo humano: a fotografia, os detetives e os primórdios do cinema, in: CHARNEY, Leo e SCHWARTZ, Vanessa (orgs.) O cinema e a invenção da vida moderna. São Paulo, Cosacnaify, 2001.

HECK, Egon Dionísio. Os índios e a caserna - políticas indigenistas dos governos militares - 1964 a 1985. Dissertação de Mestrado. IFICH, Unicamp, 1997.

KOPENAWA, Davi; ALBERT, Bruce. A queda do céu - Palavras de um xamã Ianomami. São Paulo, Companhia das Letras, 2015.

KRENAK, Ailton. Encontros. Rio de Janeiro, Azougue, 2015.

KUCINSKI, Bernardo. K - Relato de uma Busca. São Paulo, Companhia das Letras, 2016.

LAGROU, Els. Rir do poder e o poder do riso nas narrativas e performances Kaxinawa. São Paulo, Revista de Antropologia, Volume 49, 2006.

LIMA, Antonio Carlos de Souza. O exercício da tutela sobre os povos indígenas: considerações para o entendimento das políticas indigenistas no Brasil contemporâneo. LACED/DA-Museu Nacional-UFRJ. Rio de Janeiro, 2012. 
LEVI, Primo. Os Afogados e os Sobreviventes. São Paulo, Editora Paz e Terra, 2004. . É isto um homem? Rio de Janeiro, Editora Rocco, 1988.

. A Trégua. São Paulo, Companhia das Letras, 2010.

LOWY, Michael. Walter Benjamin: aviso de incêndio - uma leitura das teses "sobre o conceito de história". São Paulo, Boitempo editorial, 2005.

MANSO, Bruno Paes. A República das Milícias. São Paulo, Companhia das Letras, 2018. MESQUITA, Claudia. Resistir à morte: a presentificação de João Pedro Teixeira no filme de Eduardo Coutinho. Revista Devires volume 12, Belo Horizonte, 2015.

PUTTKAMER, Jesco Von. Os últimos dias do Éden - as imagens de W. Jesco Von Puttkamer. Textos Adrian Cowell [et all]. São Paulo, Terra Virgem, 2005.

RICOEUR, Paul. A memória, a história, o esquecimento. Campinas, Editora da Unicamp, 2007.

SAFATLE, Vladimir e TELES, Edson (org). O que resta da ditadura. São Paulo, Boitempo Editorial, 2010.

SHOHAT, Ella e STAM, Robert. Crítica da imagem eurocêntrica. São Paulo, Cosacnaify, 2006 .

SMITHSON, Robert. A Tour of the Monument of Passaic, New Jersey, 1967, in: CARERI, Francesco. Walkscapes - o caminhar como prática estética. São Paulo, Editora G. Gilli, 2015. Página 147.

SONTAG, Susan. Sobre fotografia. São Paulo, Companhia das Letras, 2004.

Diante da dor dos outros. São Paulo, Companhia das Letras, 2008.

SZTUTMAN, Renato. A utopia reversa de Jean Rouch: de Os Mestres Loucos a Petit à petit. Belo Horizonte, Revista Devires, Volume 6, 2009.

TACCA, Fernando de. A imagética da Comissão Rondon: etnografias fílmicas estratégicas. Campinas, SP, Papirus Editora, 2001.

VALENTE, Rubens. Os fuzis e as flechas. São Paulo, Companhia das Letras, 2017.

VIVEIROS DE CASTRO, Eduardo. A inconstância da alma selvagem. São Paulo, Cosacnaify, 2002. 
Encontros. São Paulo, Azougue Editorial, 2007.

Equívocos da Identidade, in: GONDER, Jô e DOBEDEL, Vera (orgs.) O que é memória social. Rio de Janeiro, Contracapa, 2005.

XAVIER, Ismail. O discurso cinematográfico - a opacidade e a transparência. São Paulo, Editora Paz e Terra, 2005.

\section{DOCUMENTOS}

Comissão Nacional da Verdade. 2014a. Volume I. Disponível em: http://www.cnv.gov.br/. Último acesso: 29.01.2021.

Comissão Nacional da Verdade. 2014a. Volume I. Capítulo 18: “Capítulo 18 - Conclusões e recomendações”. Disponível em: http://www.cnv.gov.br/. Último acesso: 29.01.2021.

Comissão Nacional da Verdade. 2014b. Volume II - Textos temáticos. Texto 5: "Violações de direitos humanos dos povos indígenas". Disponível em: http:/www.cnv.gov.br/. Último acesso: 29.01.2021.

Ministério Público Federal. 2015. Ação civil pública com pedido de antecipação de tutela, no 64483-95.2015.4.01.3800 de 10.12.15. Disponível em: https:/goo.gl/8qxWm4. Último acesso: 29.01.2021.

Relatório Figueiredo. Processo n4.483/68. Disponível em: http://www.mpf.mp.br/atuacaotematica/ccr6/dados-da-atuacao/grupos-de-trabalho/violacao-dos-direitos-dos-povos- 
indigenas-e-registro-militar/relatorio-figueiredo - último acesso: 29.01.2021

\section{MATERIAS DE JORNAL}

Jornal do Brasil, Rio de Janeiro, 28 de março de 1968.

Jornal do Brasil, Rio de Janeiro, 6 de fevereiro de 1970.

Jornal do Brasil, Rio de Janeiro, 6 de abril de 1970.

Diário de Notícias, Rio de Janeiro, 3 de maio de 1970.

O Estado de São Paulo, São Paulo, 7 de junho de 1970.

https://acervo.estadao.com.br/pagina/\#!/19700607-29191-nac-0011-999-11-not - acessado em 15 de janeiro de 2021.

Jornal do Brasil, Rio de Janeiro, 21 de outubro de 1973.

Folha de São Paulo, São Paulo, 11 de novembro de 2012.

https://www1.folha.uol.com.br/ilustrissima/2012/11/1182605-como-a-ditadura-ensinoutecnicas-de-tortura-a-guarda-rural-indigena.shtml - acessado em 25 de novembro de 2020. Uol, São Paulo, 16 de outubro de 2020.

https://noticias.uol.com.br/ultimas-noticias/agencia-estado/2020/10/16/heleno-admite-que-

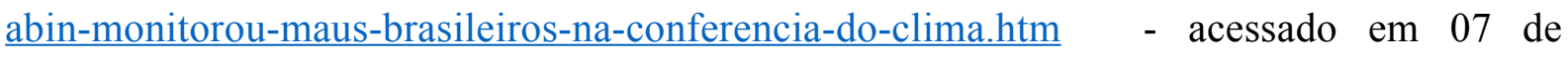
novembro de 2020).

Folha de São Paulo, São Paulo, 06 de novembro de 2020.

https://www1.folha.uol.com.br/poder/2020/11/militares-procuraram-temer-para-reclamar-dedilma-e-pt-antes-do-impeachment-diz-entrevistador.shtml - acessado em 07 de novembro de 2020. 


\section{FILMES CITADOS}

Rituais e Festas Bororo (Comissão Rondon, 1917)

Nanook, o Esquimó (Robert Flaherty, 1922)

Ao Redor do Brasil (Thomaz Reis, 1932)

Os Mestres Loucos (Jean Rouch, 1955)

Respite (Harun Farocki, 2007)

A imagem que falta (Rithy Panh, 2013)

Retrato de Identificação (Anita Leandro, 2014)

Martírio (Vincent Carelli, 2016)

A Flecha e a Farda (Miguel Antunes Ramos, 2020)

[O conjunto de rolos de película intitulados 'Arara', analisado nesta dissertação, encontra-se arquivado no Museu do Índio - no Fundo/Série/Subsérie: Fundação Nacional do Índio / Filmes depositados / Filme - sob o título 'Arara'.] 


\section{ANEXO 1}

Este anexo se constitui da junção de páginas dos seguintes memorandos internos da Funai, a que nossa pesquisa teve acesso:

BR_RJANRIO_TT_0_IRR_PRO_0002_d0001de0001 (páginas 1 a 11)

BR_DFANBSB_N8_0_PSN_EST_0326_d0001de0001 (páginas 12 a 15)

BR_DFANBSB_Z4_DHU_0_0080_d0001de0001 (páginas 16 e 17) 
PRESIDÉNCIA DA REPUUBUCA

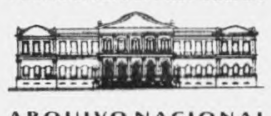

ARQUIVONACIONAL

Coordenação de Documentos Escritos

Documentos do Executivo e do Legislativo

\section{BR RJANRIO.TT.0.IRR.PRO.2}

647 folhas/ 766 páginas 
$\underline{C} O P I A$

FUNDAÇIO BRASIL CEINTRAI

Brasilia, 22 de junho de 1960

Senhor Superintendente:

Comunico a Vossa Excelência que, de acôrdo com as ordens do Excelentíssimo Senhor Presidente da República, - Plano de Trabalho para a Ilha de Bananal, a cargo da Fun dação Brasil Central, referente a $\Subset \$ 350.000 .000,00$ (trezentos e cinquenta milhões de cruzeiros), é o seguinte:

1) Construção de $2.500 \mathrm{~ms}$. de pista para pouso de aviões, com $40 \mathrm{~ms}$. de largura, sendo $1.500 \mathrm{~ms}$. pavimentados a asfalto e 500 ms., em cada cabeceira, encascalhados, con pintura asfáltica;

2) Construção de uma estação de passageiros;

3) Construção de uma escola e de um hospital;

4) Construção de 10 casas destinadas à Fundação Brasil Central, Ministério da Aeronáutica e Ministério da Să de;

5) Construção de um hotel com 40 apartamentos.

Estas obras serão realizadas em Santa Isabel.

Nos demais pontox da ilha, devidamente selecionados, serão construidos Ranchos Pioneiros tipo JK, para a pôio e incremento do turismo.

Para a execução dêste plano impõe-se a aquisiçã de material pesado, compreendendo aviões, frota de caminhões basculantes e de tipo comum, balsas, lanchas, moto niveladoras, tratores de vários tipos, rôlos de vibro, caldeiras,etc. bem como outros equipamentos de pequeno porte, para apoiamento das obras.

Esta Fundação se encarregará da construção da pis ta para pouso de aviões.

Quanto ao hotel, será construido pela Fundação, sob administração de firma particular.

A fim de que tais serviços sejam executados den tro do prazo fixado, solicito as providências de Vossa Excelen 
P. R.-SUPERINTENDENCIA DO PLANO DE VALORIZAÇÃO ECONOMICA DA AMAZONIA IIS.

Excelência, para que sejam entregues à Fundação Brasil Central, por adiantamento, os $₫ \$ 350.000 .000,00$ referidos, sem os quais não se poderá dar início imediato às obras. Apresentando a Vossa Excelência meus protestos de estima e consideração.

a) Nélio Cerqueira Gonçalves

Presidente da Fundação Brasil Central

A Sua Excelência Dr. Waldir Bouhid

Superintendente da SPVEA 
FUNNDAÇÃO BRASIL CENTRAL

Brasília, 17 de janeiro de 1961

$0 f .9$

Senhor Presidente:

Tenho a honra de submeter à elevada apreciação de Vossa Excelência, o relatório das atividades desenvolvidas pela Fundação Brasil Central, no exercício de 1960.

Criada com objetivo principal de desbravamento e colonização de extensa área de nosso país (decreto-lei no

$5878 / 43$ e 17 274/4/4), não tem esmorecido ante a realização dessa gigantesca e patriótica tarefa.

Prova do entusiasmo e do espírito pioneiro de que se revestem seus trabalhos se encontra no integral cumprimento que deu às determinações de Vossa Excelência, relativas às obras na Ilha do Bananal.

Com efeito, fui designado por Vossa Excelência em $9 / 5 / 60$, e já na segunda quinzena de maio a Fundação Brasil Central dava início a planejamento meticuloso, para que ditas determinações fossem realizadas.

Considerando a reduzida verba de cr\$. $60.000 .000,00$ (sessenta milhões de cruzeiros) com que contava esta entidade para 0 ano de 1960, foi a Operação Bananal garantida através de convënio efetuądo com a S.P,V.E.A. que liberou, para a Fundação em $27 / 7 / 60$, a verba de $\operatorname{cr} \$ 350.000 .000,00$ (trezentos e cinquenta milhões de cruzeiros).

Já nos primeiros dias de agosto principiava a aquisição das máquinas necessrias às obras em aprêço.

Vale relembrar, Senhor Presidente, o que re presentou, em heroismo e alta demonstração cívica, o transpor - 


\section{(57) $\frac{57}{y_{2}^{2}}$}

FUŃNAÇÃO BRASIL CENTRAL

te dessas máquinas, feito através da colaboração da Rodobrás fh por terra, para aquela distante IIha. Somente a 22/8/60, chegaram as m áquinas em Bananal, tendo os trabalhos da operação própriamente dita, começado em $2 / 1 / 8 / 60$ com início do desmatamento da área da pista.

Em 28/7/60, encontrava-se concluído o Alvoradinha, rancho pioneiro JK, que foi naquela data inaugurado por Vossa Excelência.

Em 23 de novembro, com a presença do Exmo. Sr. Ministro da Aeronáutica, foi inaugurada a pista de pouso Brigadeiro Lysias Rodrigues.

CARACTERÍSTICAS DA PISTA:

a) - pista de $1.550 \mathrm{~m} \times 42 \mathrm{~m}$ - asfaltada - cabeceiras livres em $500 \mathrm{~m}$;

b) - altitude de $173 \mathrm{~m}$.

Encontra-se concluído e completamente equipado

- hospital Sarah Kubitschek, projeto do Dr. Oscar Niemeyer com as seguintes características:

Construção de alvenaria - área $52 / 4 \mathrm{~m} 2$ - duas enfermarias com 6 leitos cąda - sala de operaçoess - raios $\mathrm{X}$ - consultórios - gabinete dentário e dependencias completas para copa e cosinha.

Em final de construção, temos uma pequena estação de passageiros, projetada dentro das reais necessidades da Ilha, construída em alvenaria, numa área de $120 \mathrm{~m} 2$.

Temos ainda, já concluída uma aldeia Karajá, materializando o auxílio que, durante toda a operação Bananal vem a Fundação dando aos índios Karajás. Foi construída uma aldeia totalmente nova, com perfeitas condições higiênicas, numa área aproximada, por casa, de $62 \mathrm{~m} 2$, isto, sem alterar, entretanto - "habitat" do índio.

Finalmente, para coroar a Operação Bananal, será inaugurado no dia 25 do corrente, o que espero seja feito por Vos- 


\title{
(58) $-3=$
}

sa Excelência, o hotel de turismo da II ha do Bananal.

\section{CARACTERÍSTICAS DO HOTEL:}

\author{
Projeto- Oscar Niemeyer \\ Construção a cargo da Empresa de Construções \\ Gerais S.A. pelo regime de administração de \\ contratata. \\ Toda a obra consta de 3 blocos, a saber: \\ Bloco A - Apartamentos - \\ Estrutura metálica sôbre pilares de al- \\ venaria - cobertura metálica Tekno \\ forro de enxatex friggrifico - aarea \\ construida $1270 \mathrm{~m} 2$ - numero de aparta- \\ mentos, 29 com divisoes internas em \\ formiplac e instalaçoes de ar condi- \\ cionado.
}

Bloco B - Em alvenaria, constando de: recepção, salas de estar, restayrante, jardim, copa cosinha, etc. - área conștruida, $1045 \mathrm{~m} 2-$ tambem cobertura metálica.

Bloco C - Anexo do hotel

Em alvenaria, cobertura metálica - área construida, $432 \mathrm{~m} 2$ constando de lavanderia, quartos e apartamentos para servidores do hotel.

A grande batalha que enfrentamos foi a dos transportes. Por via área, terrestre e fluvial (Rio Araguaia), levou-se para a Ilha do Bananal de tudo, desde os gêneros alimentícios até as estruturas metálicas para a construção do hotel.

Para podermos, realmente apresentar, dentro dos prazos previstos, todas as obras programadas, tivemos que nos aparelhar devidamente, e, isto significou a execução de obras e serviços de base, imprescindíveis ao alcance de nossos objetivos. Estas obras e serviços, que exigiram maior esforço e dedicação do nosso pessoal, foram:

Reaparelhamento e aproveitamento das oficinas do SPI - construção de 20 barracoes com cobertura de palha para alojamento e cosinha do pessoal - conștrução de casas de madeirra destinadas a eştação de rádio, a casą de máquínas, ao posto medico de emergencia e as residencias - construçao do almoxarifado da Ilha numa area de $200 \mathrm{~m} 2$ - em madeira, instalação de uma olaria cuja produção alcançou mais de 600 mil tijolos instalação de um conjunto completo de britagem - 
FUNDAÇÃO BRASIL CENTRAL

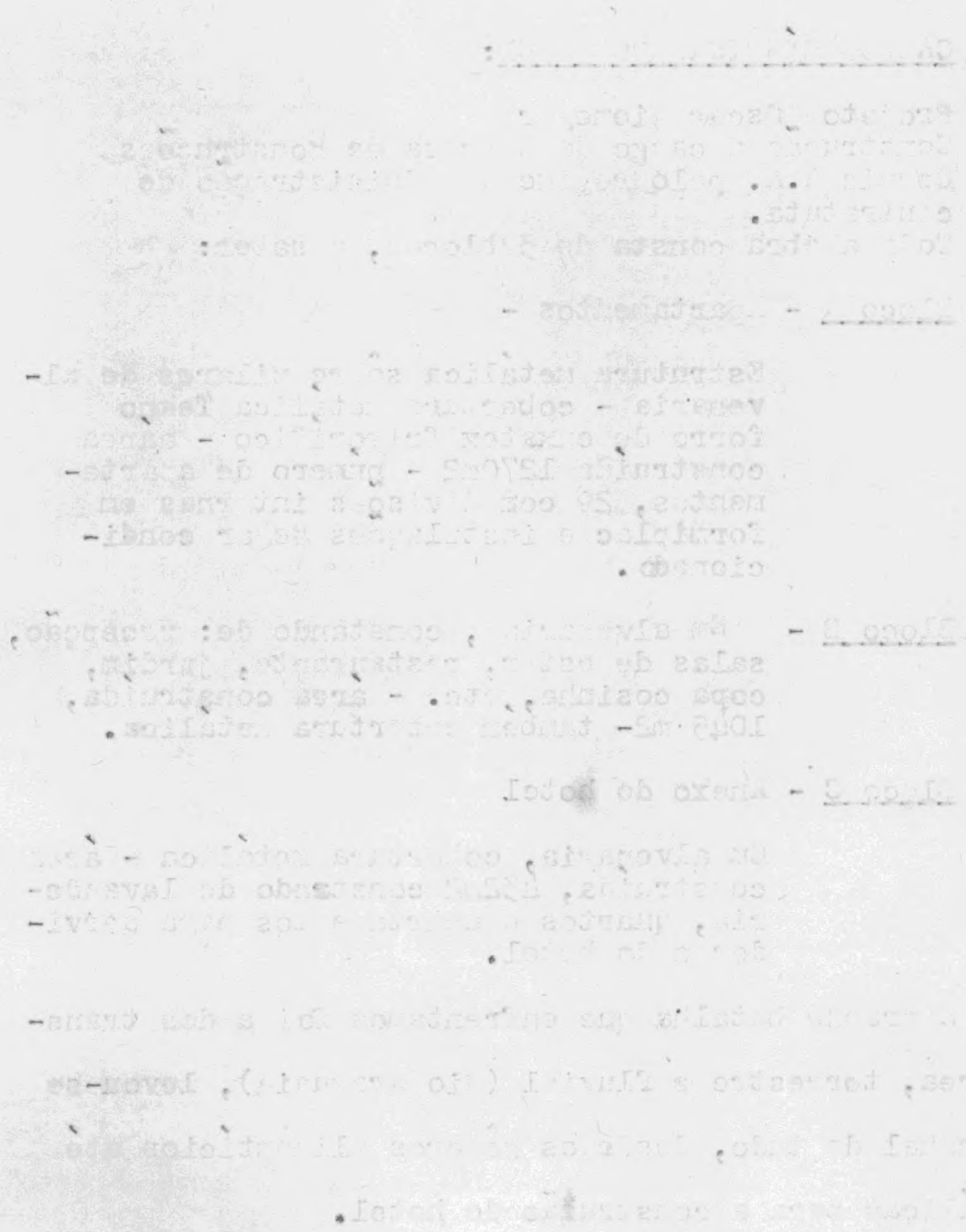

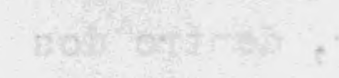

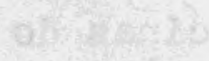

$a^{2}+2+2000$

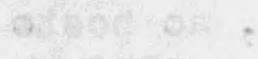

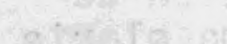




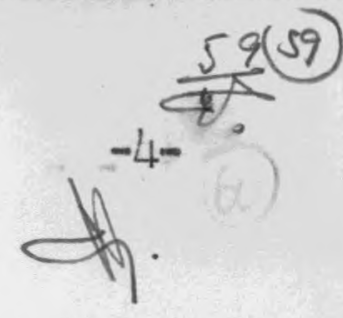

(um britador e dois rebritadores), com produção de mais de $3.000 \mathrm{~m} 3$ de pedra-serraria e carpintaria para as obras - construção de estradas de acesso para os diversos serviços num total aproximado de $20 \mathrm{~km}$ - instalação do, depósito para tratamento de asfalto - rede elétrica para os acampamentos e construçoes - rede de agua para distribuição dentro da base da Fundaçãoconstrução de um pequeno porto flutuante com cobertura - instalaçao de poştos de rádio em Porangatu, Luis Alves, Brasillia, e ainda,dentro da Il hha, no local denominado Benvinda construçao do alojanento, com 18 apartamentos, destinado ao pessoąl da Fundaçå̃o, que passarịa, a operar na nova sede, em Brasília- construção de uma estação para a F.B.C. no aeroporto Militar em Brasilia.

$E^{\prime}$ de se notar o extraordinário movimento de "caboclos", existente na Ił̧ha, em virtude dêsses melhoramentos. Pelo Rio Araguaia, chegam embarcações típicas do nosso interior e seus tripulantes já sabem que ali encontrarão o apôio da Fundação Brasil Central.

Operação das mais relevantes foi a da mudança quasi total, dos escritórios da Fundação Brasil Central, do Rio de Janeiro para esta Capital, fixando sua séde no 50 andar do edifício do Ministério da Saúde, Praça dos Três podêres, bloco 11.

Em seu trabalho absolutamente pioneiro, vê-se a Fundação de certa forma, obrigada a compensar a falta dos outros serviços executivos, nas regisões que alcança, como vanguardeira. Assim, principia pela abertura de pistas de pouso e de estradas. Surge depois a colonizaçã e, com ela, a necessidade urgente de assistência médica àqueles heróis desconhecidos que tentan fixar-se à região. Vem a necessidade imperiosa das escolas, e a Fundação providencia a abertura das mesmas, tudo dentro de seus modestos recursos. Por isso, desdobra-se em tão extraordinárias e variadas atividades.

Em Aragarças, a escola que ali mantemos, funcionou normalmente, e o hospital da rundação prosseguiu atendendo à população não só da cidade como dos municípios visinhos, num raio 
de $300 \mathrm{~km}$. Ainda em Aragarças, continuou o trabalho de consertação e reconstrução das estradas que ligam Piranhas a Aragarças a esta a Xavantina, num total de $286 \mathrm{~km}$.

No setor agrícola aumentou o beneficiamento do arroz : foram produzidos $1.300 \mathrm{~kg}$ de.mel e, de seus pomarés e hortas colhidas milhares de frutas cítricas, legumes e verduras.

- Escritório de Uberlândia, realizou eficientemente sua tarefa de suprir outros centros desta entidade com lubrificantes e combustíveis.

No Centro Ministro João Albérto (Kavantina) funcionaram os serviços internos, tais como a serraria e a carpintaria, e oficina para reparo de viaturas e motores. roram realizados, por via aérea e terrestre, os transportes de todas as utilidades necessárias entre Garapú, Ministro João Alberto, Aragarças, Uberlänia e Brasília. O hospital local atendeu aos funcionários e colônos que dele necessitaram, e mesmo acontecendo com o gabinete dentário. o grupo escolar funcionou normalmente.

No setor norte, o Escritório de Belém, se encarregou da lavratura de Acôrdos, têrmos aditivos e prestações de contas de verbas anteriormente recebidas da S.P.V.E.A. Tais verbas foram empregadas sobretudo na ligação terrestre entre os aeroportos de Jacaréacanga e Cachimbo, bem assim para melhoramentos da. Estrada de Ferro Tocantins, a qual funcionou com toda a normalidade no decorrer do ano de 1960.

Prova da assistência que a F.B.C. presta às populações rurais de nosso país se encontra no movimento desenvolvido pelo hospital da E.F.Tocantins, em Tucuruí, o qual atendeu a 4248 servidores e 4776 particulares, de 10 de janeiro a 30 de outubro deste ano.

A secção escolar dessa estrada apresentou, paraigual período o seguinte: 
Escola supletiva - 46 alunos

Escolas ao longo da linha - 74 alunos

Escola de Jatobal - 148 alunos

Continuaram também, os serviços de serralheira, verraria, fundição, corte e soldagem, caldeiragem, de manutenção e revisão de material e muitos outros imprescindíveis ao funcionamento de uma ferrovia.

Impõe-se, entretanto, maiores recursos para o reaparelhamento e reequipamento adequado da estrada bem como um planejamento racional que vise prolongá-la de forma a melhor servir a rica zona Tocantina.

Cumpre finalmente informar que na distante região do Xingu, continua o trabalho desta entidade, abrindo novos caminhós e pistas aéreas, que têm permitido a penetração da FAB pelo "hinterland" de nosso país e oferecido maior segurança à aviação comercial e particular.

Tal trabalho de penetração feito exclusivamente através dá Fundação, tem sua base, no momento, no Diauarum, setor aberto pelos irmãos Orlando e Cláudio Vilas Boas. Estes dois sertanistas da Fundação, cujo trabalho é já mundialmente conhecido, lá fixaram residência para melhor executar a patriótica tarefa que têm a seu cargo.

São êstes, em resumo, Senhor Presidente, os encargos de que se desincumbiu a Fundação Brasil Central no decorrer do ano de 1960:

Apresentando agradecimentos pela confiança em mim depositada, sirvo-me da oportunidade para renovar a Vossa Excelência os protestos da mais elevada estima e profundo respeito, com que me subscrevo,

CEL. Nélio Gonçalves Cerqueira

Presidente

A Sua Excelência o Senhor Doutor

Juscelino Kubitschek de Oliveira- M.D. Presidente da República.

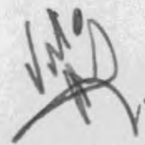


RELAÇÃO DE CONT'AS A PAGAR RESULTANTES DE FCRNECIMENTOS DE MATERIAIS OU SERVIÇOS (OU DE ENCOMENDAS DE MATERIAIS E/OU SERVI ÇOS - "CPERAGAO BANANAL". (v.fls. 3 a 8 laudo de 3.7.61)::::

(TAL COMO SE ENCONTRAN NA CONTABILIDADE DA FUNDAÇÃO)

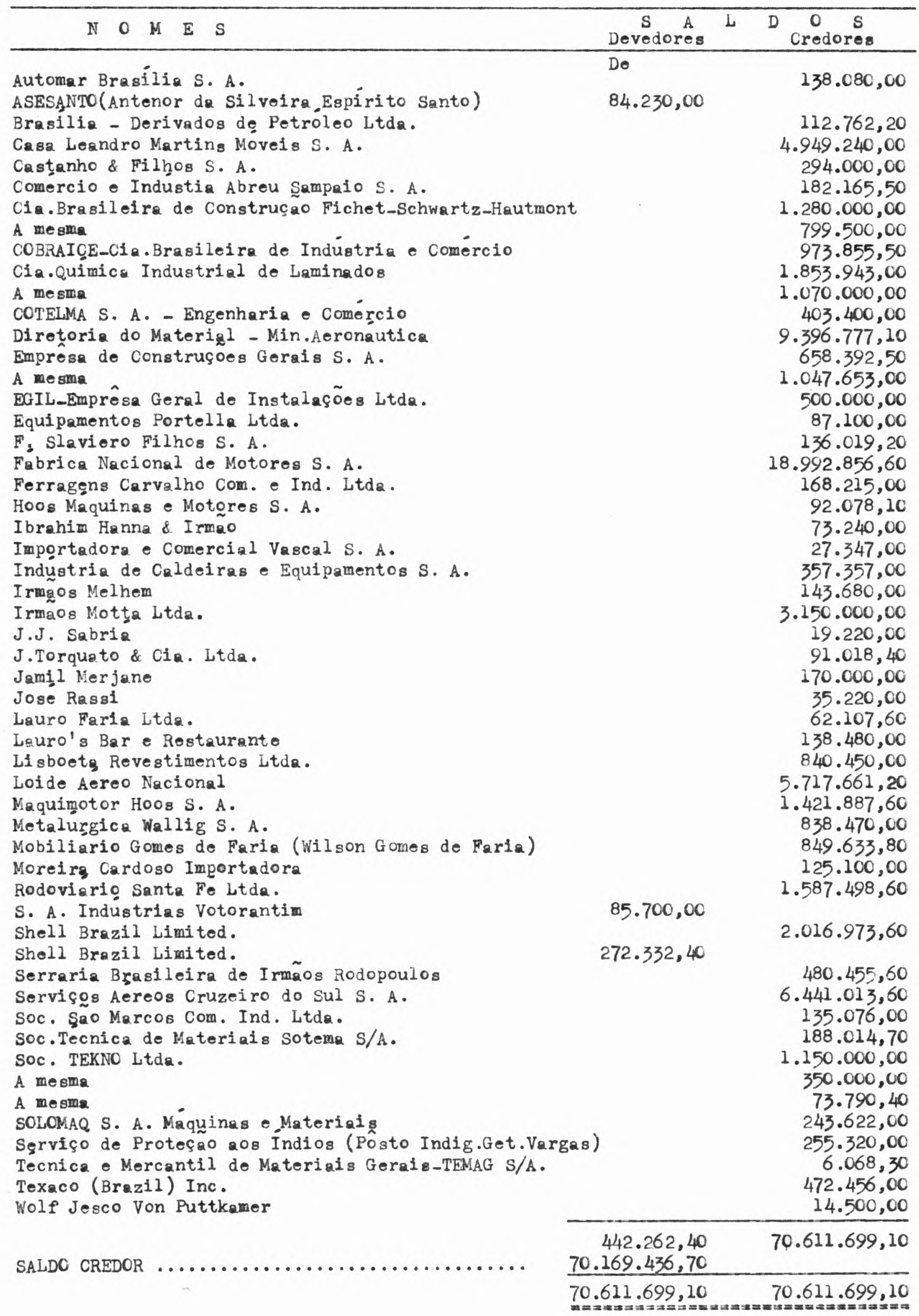


Do cel Che fe do Gabinete

Ao Sr Diretor da DST/Ministërio dos Transportes.

Assunto: Expediçäo do Geographical Magazine.

Anexo: Enconinhamento ne 155/68-DSI de $4 / 4 / 68$.

- expediente encominhado se refere ao trânsito m äguas fluviais brasileiras, no trecho de MAuus a cucur, previsto para - periodo de 10 a 15 de abril pröximos, por una enbarcaçäo tipo Hover craft britânica que transporta wna expedição da "Geographical Magazine. of Britain".

2.

0 assunto jä foi apreciado pelo Conselho Nacional de Pesquisas que deu parecer conträrio ao progrona cientísico da expediçäo pon näo haveron os interessados apresentado detalhes $e$ planejomento ade quados.

3.

0 expediente foi estudado, seguida, pelo Ministērio do Interior que demonstrou interêsse na realizaçăo da referida viagen, tendo para isso designado o Coronel Igrejas Lopes, da SUDAM, como seu re presentante e entrou en Rigaçäo com o Ministërio da Marinha para provi dência semelhante por parte daquele Ministërio.

4. Cremos, pontanto, que a Seguranca Nacional estarä ben resguardada, faltando apenas, que êsse Ministërio se pronuncie, no curto

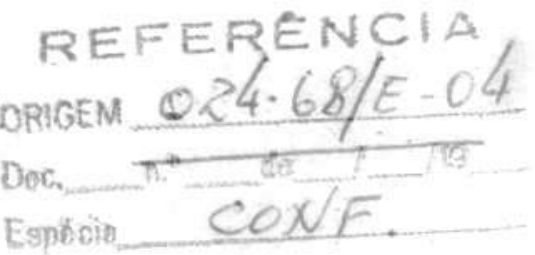




\section{COMPIDEMCLAL}

espaço de tempo que resta, do seu interêsse participar direta ou in diretanente da referida expediçäo.

Aproveito a oportunidade para renovar a Vossa Senho hia os protestos de estima $e$ distinta consideraçäo.

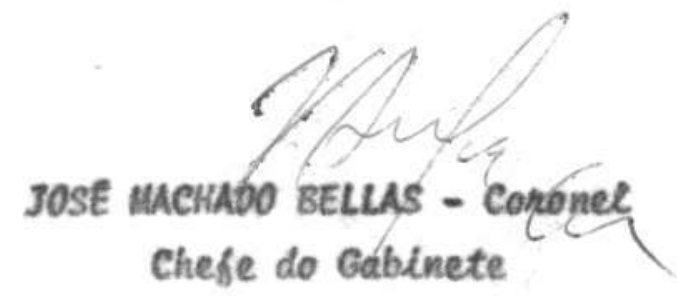




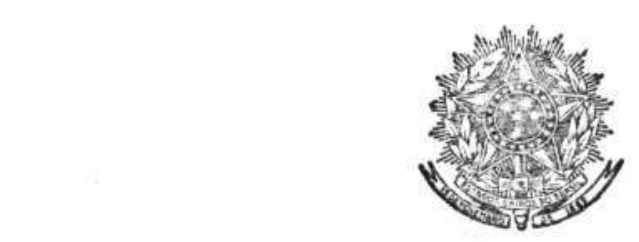

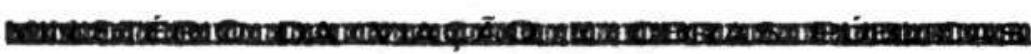

MIN ISTERIO DOS TRANSPORTES

DIVISÃO DE SEGURANÇA E INFORMAÇŐES

oficio ne $6 / \mathrm{k} / \mathrm{DSI}$

Em 9 de abril de 1968

Do Diretor da Divisão de Segurança e Informações

Ao Sr. Cel José Machado Bellas

M.D. Chefe do Gabinete da Secretaria Geral do Conselho de Segurança Nacional.

Assunto: Expedição do Geographical Magazine.

Este Ministério, estudando os objetivos e interêsses que a Expedição do Geographical Magazine poderia despertar na área de nossas atividades, não encontrou de imediato, razões diretas ou indiretas, que motivasse a designação de um representante para participar do projeto.

Aproveito a oportunidade para renovar a V.Sa. os pro testos de estima e consideração.

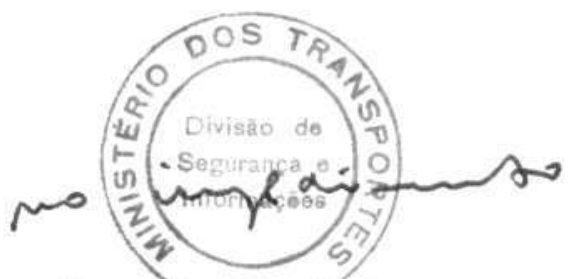

Augusto Cesar dé Sa Rocha Maia

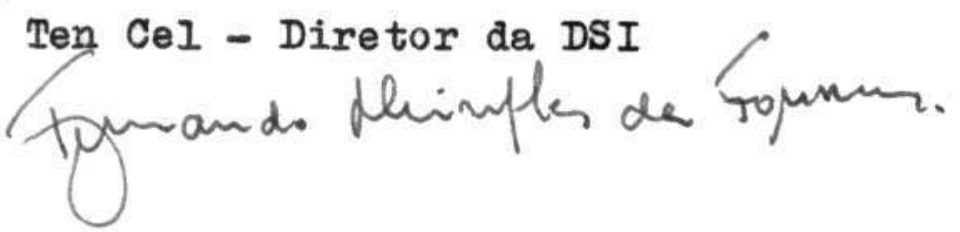

Ref. Proc. 155/68-DSI/MT.

RMRM/mlsd.

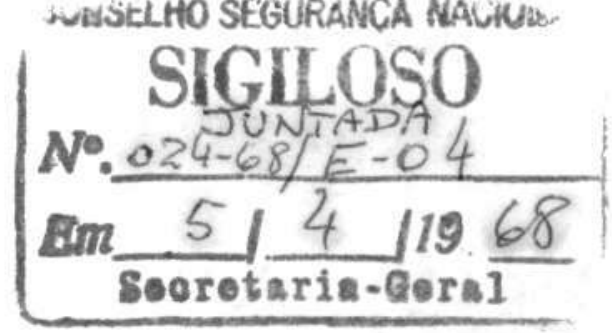


MINISTÉRIO DOS TRANSPORTES

Divisão de Segurança e Informações

\section{CONFIDENCIAL}

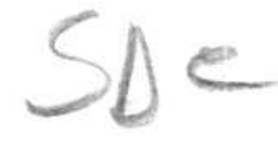

\begin{tabular}{|c|c|c|c|}
\hline Tipo:INFORME NN 65 & Classificação: B-2 & N. ${ }^{\circ} 155 / 68-D S I$ & Data. $23 / 4 / 68$ \\
\hline \multicolumn{4}{|c|}{ Assunto: Expedição do GEOGRAPHICAL MAGAZINE } \\
\hline \multicolumn{2}{|c|}{ Referência: Fnceminhamento ne 39/68-DSI/MT. } & Prazo para atendiment & \\
\hline \multicolumn{3}{|c|}{ Difusão desde a origem: DSI/MIT. } & \begin{tabular}{l|l} 
Divisaso de \\
Soguranga
\end{tabular} \\
\hline \multicolumn{3}{|c|}{ Destinatários: SG/CSN - SNI/ARJ } & \\
\hline
\end{tabular}

- A expedição teria partido de Manáus (AM) no dia 10/11 do corrente e era composta além do Cel IGREJAS IOPES, Cap Corveta MANOEL DE OII VEIRA PEREZ e do prático SOARES dos seguintes membros:

- ARTHUR HELLIWELLLOBIN HANBURY TENISON

- BRIAN BRANSTON

- CONRAD GORINSKY

- DAVID HARRIS

- DAVID SMITHERS

- DOUGLAS BOTTING

- GRAHAN CLARK

- HANBURY TENISON

- HENRY FARRAR

- JAMES SWEENEY

- JESCO VON PUTIKAMER

- JOHN TORNES

- JOHN HOYLAND

- JULIO CASTILIO (venezuelano?)

- MICHAEL EDENN

- PETER SMITH (Roayal Navy?)

- ROBERT SAUNDERS

- SIUART SYRAD

- Tinha previstas paradas nas localidades de MOURA - TAPUCURUARA UAPES.

$x-x-x-x-x-x$

UNSELHO SEGURANCA MAVIGS AS

SIGIOSO

$\left.N^{\circ} .024-68\right)=04$

Em 25/4, 1968

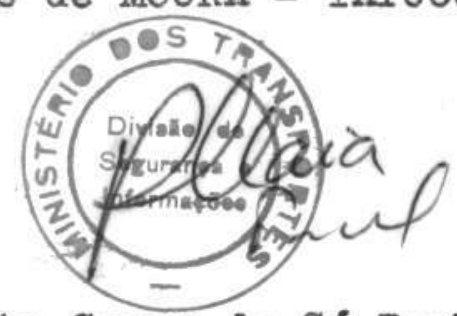

Augusto Cezar de Sá Rocha Maia

Ten CeI - Diretor da DSI 


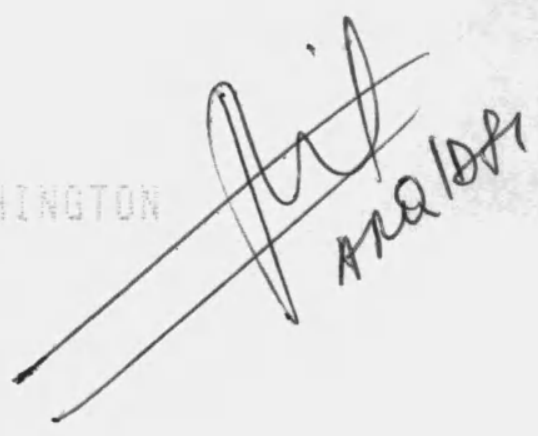

Indigenas

Lul

$-1$

in

DRGENTE

BRAGEHB AASH

E) $25: 04: 75$

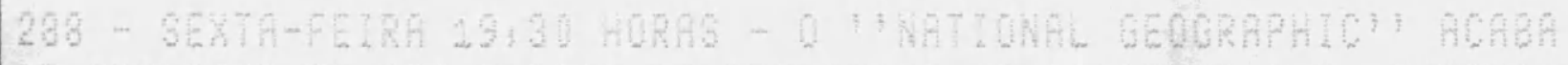

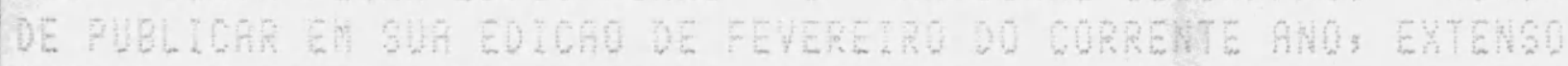

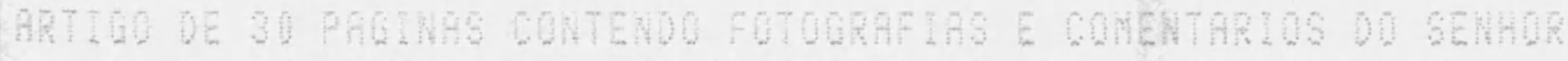

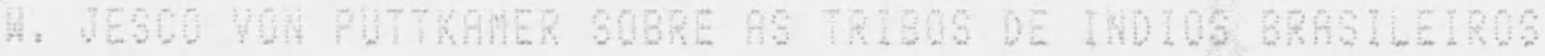

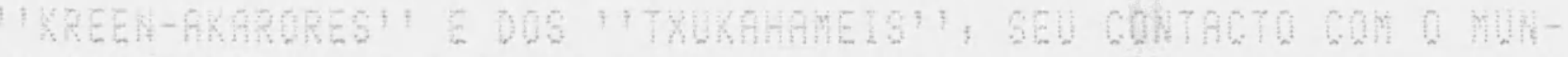
00 GHLLRAODE A ACAD DA FUAAL NO DECORRER DESTE PROCESSO. PU-

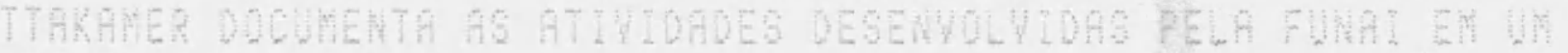

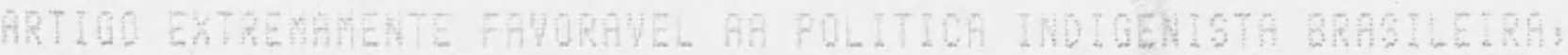

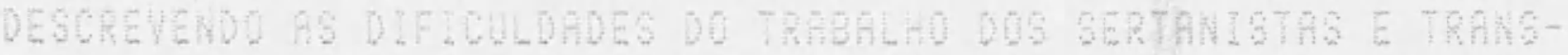

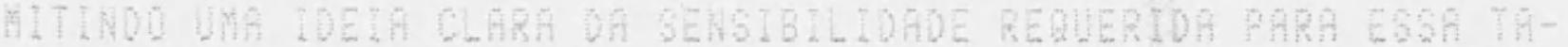
REFA: A REPORTAQEN EH QOCUHEXTHDA COH MATERIAL FUTOGRAFIOA DE $+$ $\circlearrowleft$ W

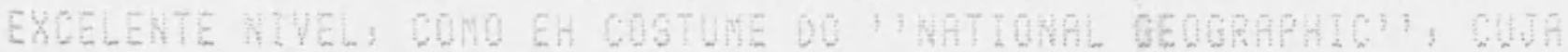

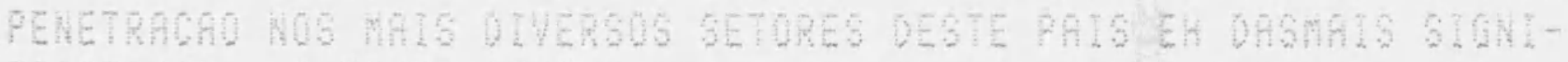
FICATIHAS, O TEXTO CONTGH WHUHERG REFEREMGAS ELOGMSAS GA

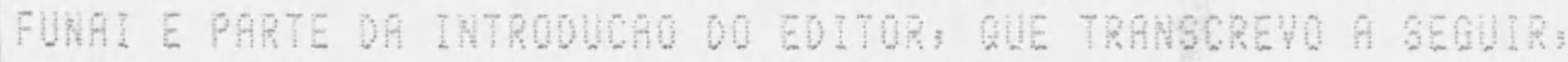
REUELA O SEU TEOR ESSENCHALMENE POSHHO AA POLTTMAA DE IMTEGRA-

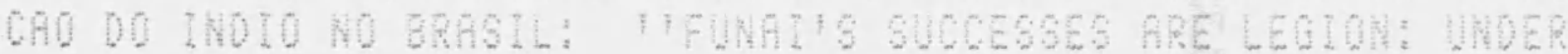
ITS SHPATHETIC GUWANCE: TRIBE AFTER GTONE GGE TRIBE HAS GEEN INTRODUCEO TO THE MOOERH WORLO; hWO AT THE SAHE THE HAS bEEN SHIELOEO FROH ITS IHEMTTABLE DANGERS, " EGTOU EHMANOO h REMGTA EH QUESTAO PELA PROXIHA MALA:

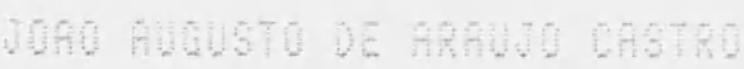




\section{- Imdigenas \\ DHU, \&IN,, $105 / 263$}

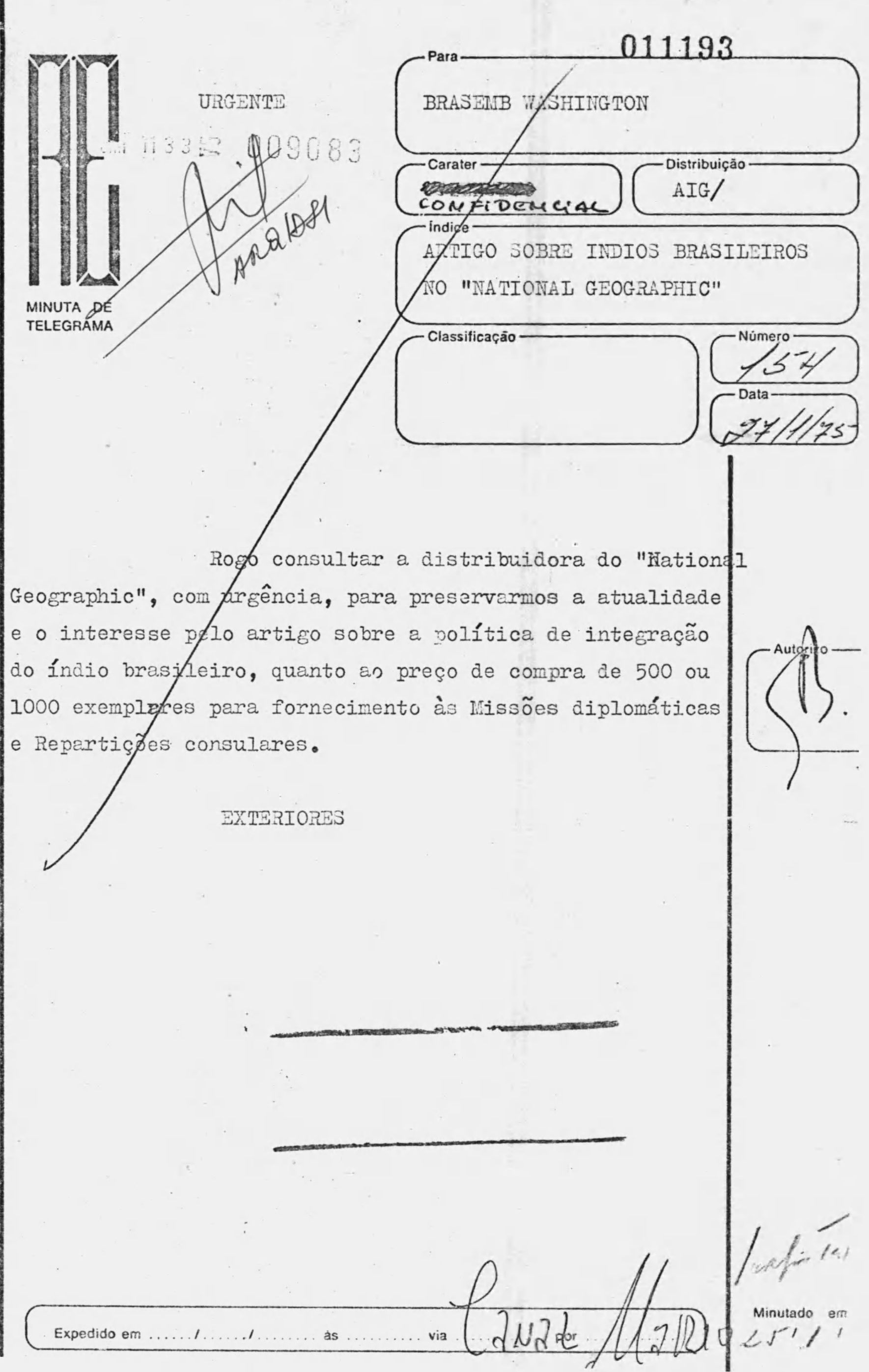




\section{ANEXO 2}

Este anexo se constitui na íntegra do seguinte memorando interno da Funai, a que nossa pesquisa teve acesso:

_dc00014a0144558sos_ _ $\quad$ (páginas 1 a 169) 


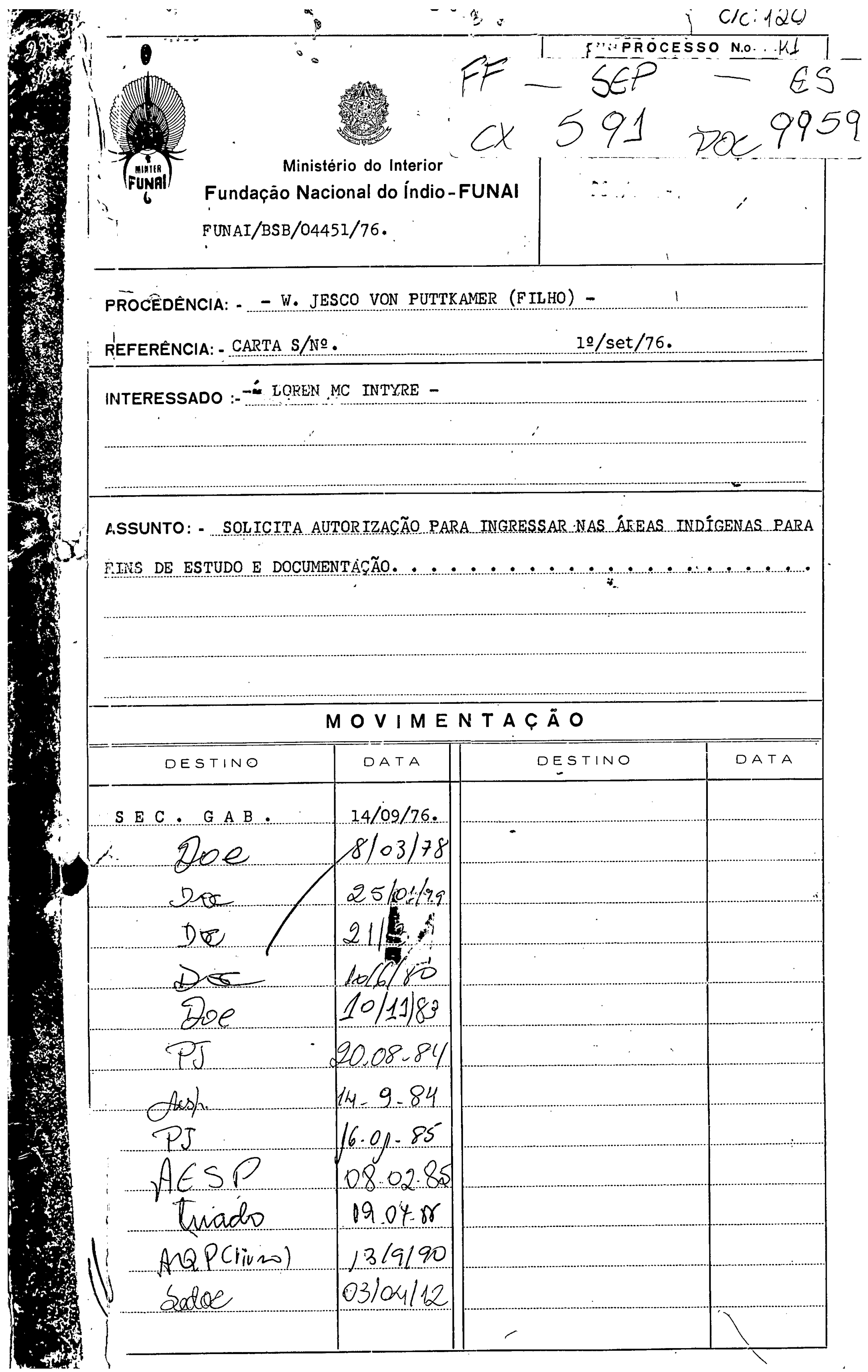




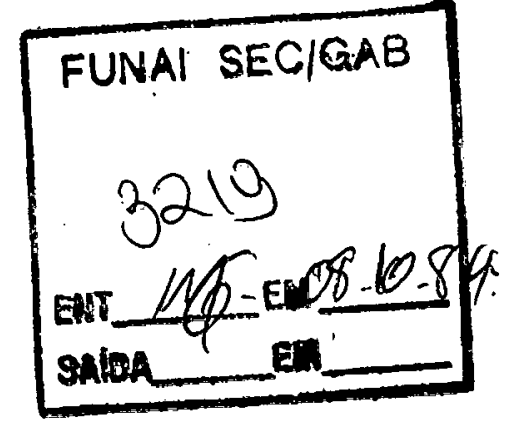




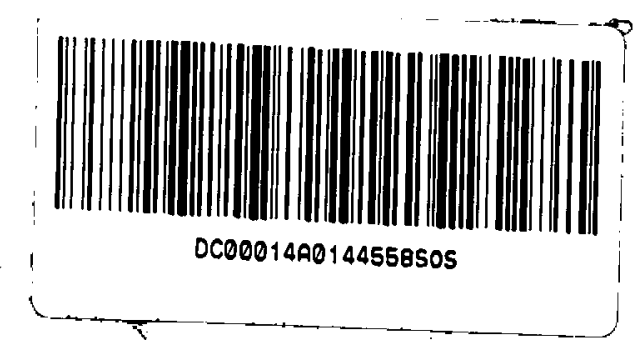




\section{FUNDAÇĀO NACIONAL DO ÍNDIO DEPARTAMENTO DE DOCUMENTAÇÃO - DEDOC ARQUIVO HISTÓRICO "CLARA GALVÃO"}

\section{Formulário de Inventário Analítico}

Dados Básicos para o Inventário Analítico

1. Fundo: $F V / A I$

2. Série: StP

3. Subsérie:

ES

4. Espécie Documental:

$P r o \cos \theta$

5. N. 4452

6. Data: $21,09,1976$

7. Instituição de Origem:

9. Destinatário: Presialente

UNH

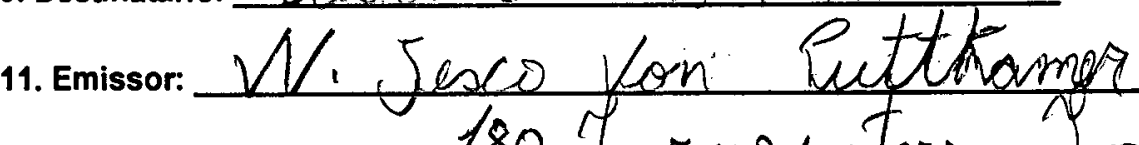

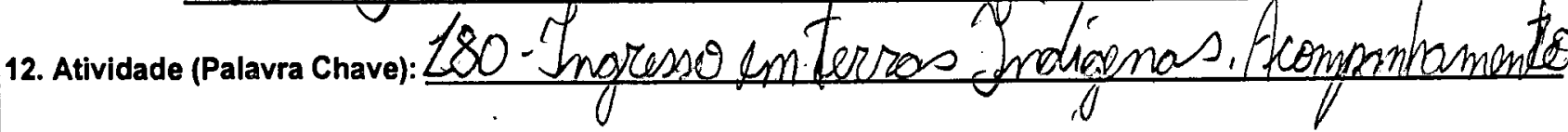

8. Unidade:

10. Unidade: Tresidincia 
13. Etnia:

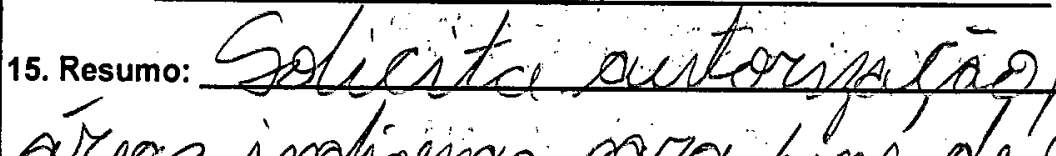
Queves imakgenias

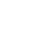

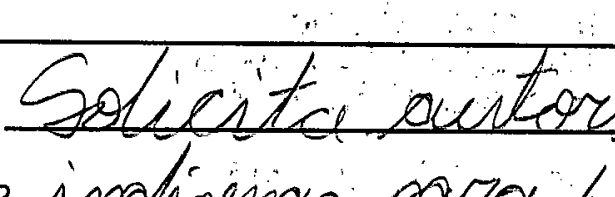
0 .

14. UF:

16. No de páginas: 130 17. Estado/Conservação: Bom (t) Regular ( ) Péssimo ( ) 18. Qualidade: Original $\left(X\right.$ Datilografado $(X)^{\prime}$ - Cópia Única ( ) Manuscrito $(X)$ Digitado ( ) Duplicata (1) 19. Código de Referência (LocalizaçãolAcervo): 20. Observação: 


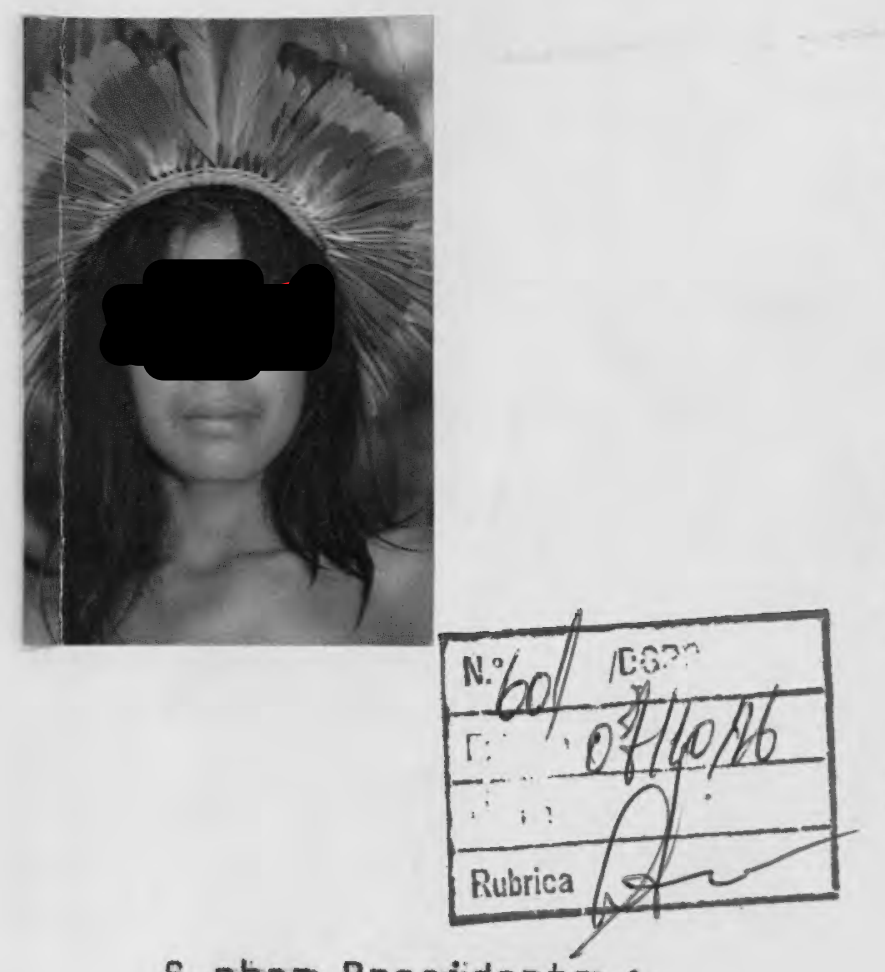

W:JESCO VON PUTTKAMER (FILHO)

GOIANIA, Lo de Set. 1976.

$$
04451+\therefore-1900
$$

Exmo.: Snr.

GENERAL ISMARTH ARAUJO DE OLIVEIRA M.D. PRESIDENTE DA FUNAI

EDIFICIO ALVORADA

BRASILIA, D.F.

REF. : "BRAZIL PACKAGE" DO NATIONAL GEOGRAPHIC MAGAZINE.

Senhor Presidente:

Conforme tive oportunidade de comunicar a V. Excia. durante anossa última viagem, o NATIONAL GEOGRAPHIC MAGAZINE. Washington, DC. 20036, deseja fazer um grande trabalho de divulgação sobre o nosso País, o que eles chamam de "Brazill Package". Além de ser um precioso documentário (isento de: qualquer sensacionalismo) orgulhome, como Brasileiro, de vêr o potencial do nosso Paíz e de nossa bốa gente ser apresentado ao mundo por gente tão copetente amigos do nasso $\mathrm{Paiz}$.

Conforme a carta anexa do nosso amigo LOREN MC INTYRE, que é um dos mais brilhantes fótógrafos e escritares dessa conceituada revista, o mesmo chegará aqui a Brasilia, no dia 21 de Setembro próximo.

Deverei, nessa data estar na nossa Caṕital afim de auxiliar a essa bốa pessôa em que tudo for necessário e ten-

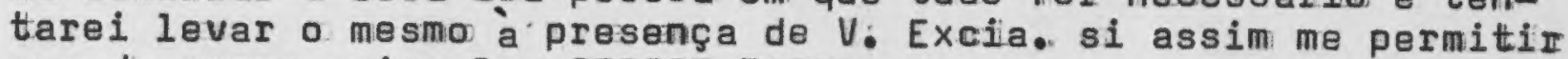
a a do nosso amigo Dr. GEORGE ZARUR.

Em cartas anteriores, que enviei ao Mr. MC INTYRE a a NATIONAL GEOGRAPHIC SOCIETY, tenho ihes dito da grande simpatia

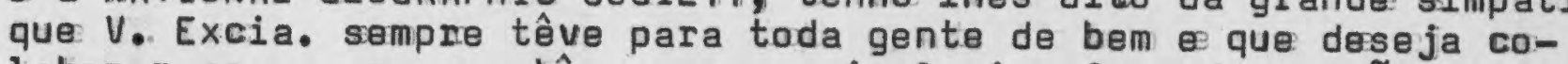
laborar com as nossas bôas causas, inclusive fazendo mensão do apoin que sempre tive de V. Excia e da FUNAI; apoiando nosso trabalbjo de documentação da vida dos nóssos índios.

Novamente fui convidade a acompanhar o sr. MCINTYRE em toda sua viagem (que será de aproximadamente 3 meses) e que nos levará principalmente ao interior e as zonas remotas de nosso $\mathrm{Pa} i z$ e onde estamos em plena fase de INTEGRAÇẨ. Uma integração que está se operando com grande caparidade de planejamento e respeitando, como nunca antes tinha sido feito, os direitos de terceiros, principalmente do nosso índio ainda arredio.

Deșde já peço que a licênça que V. Excia. tem me dado a enttar nas áreas índigenas (onde se fizer necessario) para fins de estudos a dicumentação, seja extebdida também a esse meu digno e admirável companheiro ("e que vem altameñte credenciado tanto pela NATIONAL GEỌGRAPHIC SOCIETY, como também pelo Governo daquele $\mathrm{Pa} i \mathrm{z}$, através de sua Embaixada).

Ao ensejo, apresento a V. Excia. os protestos de minha elevada estima e distinta consideração.

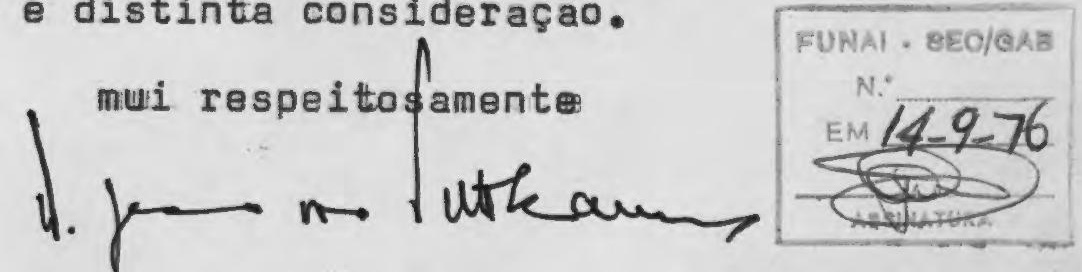



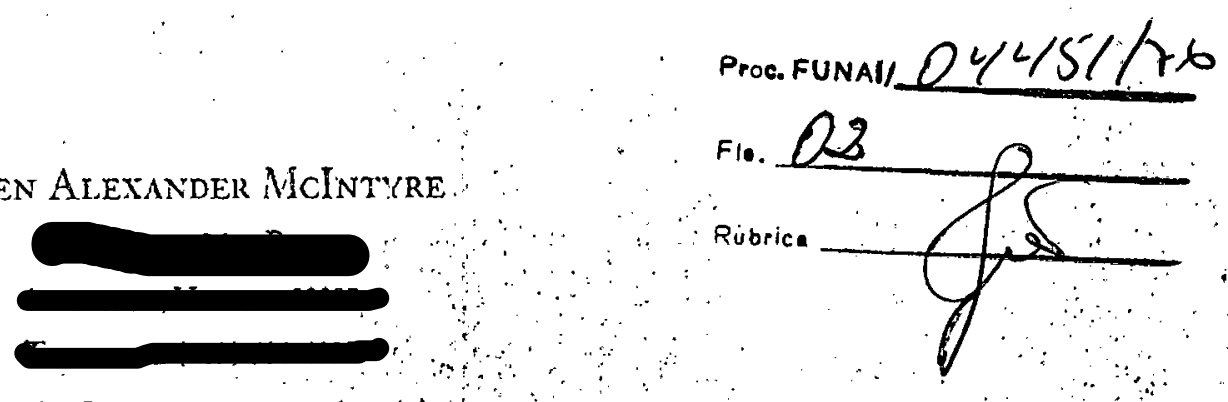

2 September 1976

Tear jesco,

I $20 \%$ plan to arrive in Brasilia via PunAn at 5 a.m. September $21 \mathrm{st.}$ It wil be a Tuesday--'terca feira. I hope you can meet me. I have socumentation from the Brazilian Embassy tor my" equipment-put possibly it: will not cover such a large amount of tilin as I am bringlipor myself ana fon you.

It it is convenient for you, I hope to procesd with you tine same day to sitaria, to leave some of my film, cquipment, and chothine in suto stor i. ir your homo.

i. $x$ you I am bringing 100 Kodachrome $64,1.00:$ Ektachrome E;.

In apite of Jon's efforts, the Geographic wa reluctant to supply the In at this time. They are wajting for next year when they should nove o. the cive project. However, J am buying 5 rolls for you and Jon is 0.150 30 rolls. And another 100 roj.ls for you was authorjod today

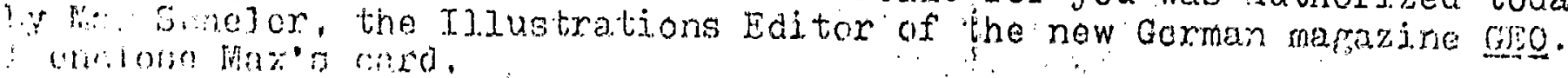

I: visited ny home yesterday and today to complete some deiails on my iCA tory which will appear in their first issue, November. 1976 . (Max as aso here last winter.) We talked about Jesco and the film problem.
$\therefore$ offered 100 rol. Is to keep you going.

¿ur wat project? Well, Wax sugrests you send him 3 or 4 ideas for Geograpicic-type stories on Brasil. Meanwhile, fon is serding some of jour naterial to Germany. Not the caves, of courise. If you wish, you can send rev ideas to Max now--or you can wai.t untj. you talk it over with me.

Do not confuse this film supply with othei hip you may have gotten from Dieter Steiner who works for DER STERN. Ihi 100 rolls and this request. for ideas is from Nax Scheler of GEO, a sjst r-magazine to be published. $\because$ a different staff: Both Nax's 100 rolls ind the 100 rolis from Jon aid he can be processed. by the Geographic. I. believe.

A mar whom I have not met has been phoring mi frequently, asking for irformatjon. His name is Alex Shoumatoff. He says he is 29, a writer, traveling with another man throughout the Amizon of Brazil, 'Peru, Ecuador, Cciombia, etc. 'to write a book about Amazon life for the Sierra club, $a$; ISi. organization devoted to conservation. Unfortunately, Mr. Shoumatoff.

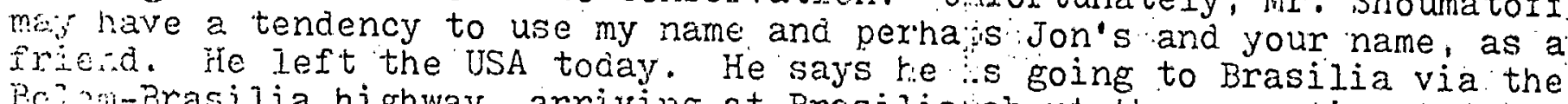
Bcini-Brasilia highway, arriving at Brasiliasabout the sane time I'do.'He plan to phone you in Goiania trying to lcrawe both me and you. I to id

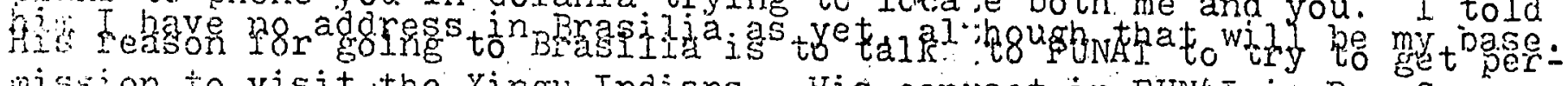
inission to visit the Xingl Indians. His con iact in FUNAI is Dr. George Zarur. Diretor, Seccäo Pesquisas. Mr. Shoumatoff is going to tel]. FuNAI 
Jesco - - Page Two

that he is writing an Amazon book for the Sierra Club--but what he is NOT going to tell FUNAI is that he=is=also=writing a series of irticless

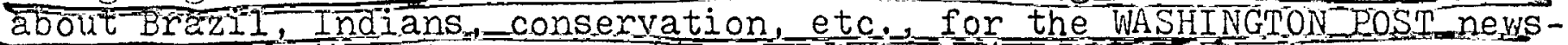
paper, one of the biggest and most political (a bit leftist) newspapers in the USA.

Well, they will probably not let him go to Xingu anyway...but I am writing to warn you to beware of his claims that he is my close friend, or Jon's, for we have never met him. He has no connection with the Geographic. He has told me all these things on the long-distance telephone. I fear that re may use your name to get special.treatment from FUNAI--which may later cause trouble if he publishes criticall newspaper articles. Or perhaps the Geographic may be annoyed. Mr. Shoumatoff's book will probably be a serious one, and he seems to be preparing himself very carefully. He is a biologist and. will work from November 15 to December 15 with Dr. Ghillean Prance of INPA, in Manaus. But be careful if tries to use you. "Jon warns you also that this man may be tricky.

Jesco, it will be good to go driving with you again soon--even if I leave to go for my run at sundown while you sip cachaça and nibble cheese bits.

Enclosed: Max Scheler's card -- GEO 
Pn, FunAI/HWS1/76

For. (0)

Rubrica Dop lavp

MINISTÉRIO DO INTERIOR
FUNDACAAO NACIONAL DO ÍNDIO

FUNAI

1)- Marcar andiéncia forsa o dia 22, à tanda

2)- Ineformar ao Jereo.

Qen, 15.09 .75

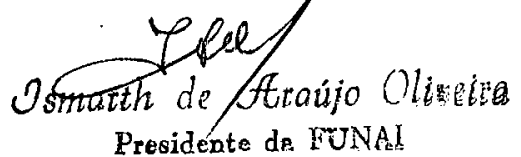

Ao su Cheqe de fabinuts

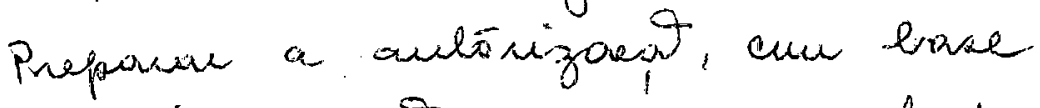

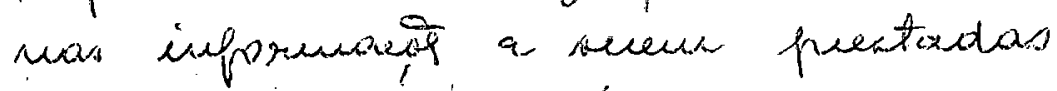
pelo Jescos sole as ánear a receur viai tadan. San, 23.09.76

Ssmarth de 


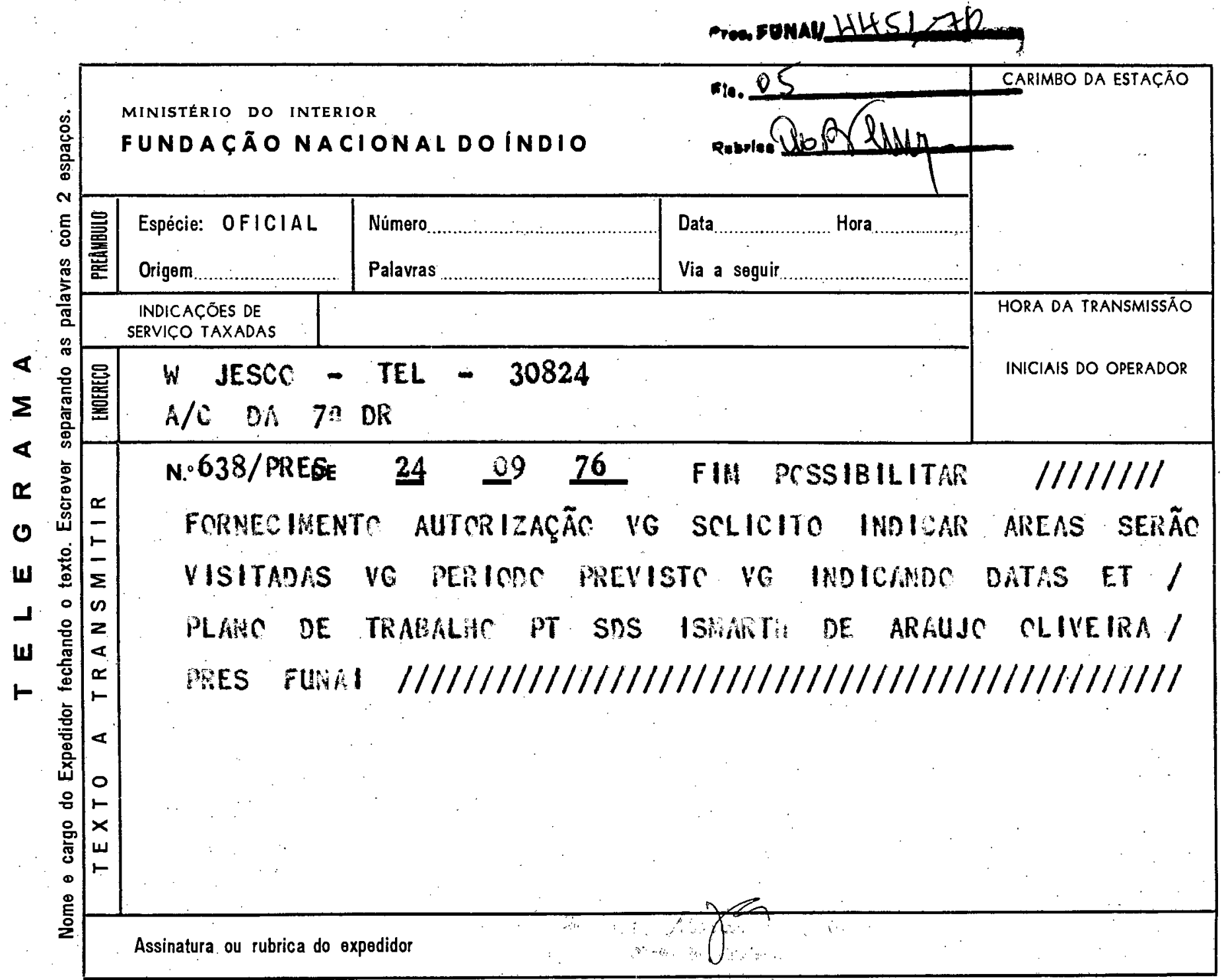




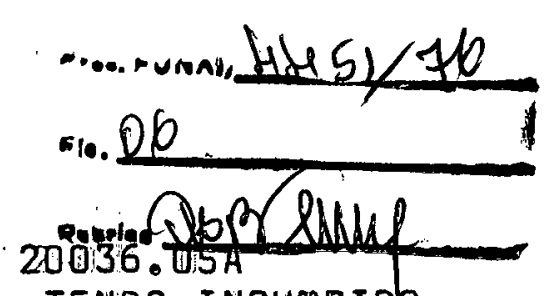

DESEJA FAZER UMA GRANDE COBERTIURA MESSE SENTTOO, TENDO INCUMBIDO DOIS DE SEUS MELHORES ESCRITTORES A FAZER ESSE DOCUMENTARIO. UM DELES FARÁ A PARTIE INDUSTRIAL (S.PAULO, RIO E O SUL) o outío (MR. LOREN MC- INTYRE, escrittor- fotografo CAPITÃo APOSENTADO DA MARINHA DE GUERRA OOS EE. UلU..) e sendo considerado o SOUTH AMERICAN EXPERT desse revista, fará a parte do intęrior. Fui solicitado pelo miesmo de alaborar o roteiro e de acompanha-1o, para facilitar o\$ contactos. Eis ai o roteiro:

(I) RONDONIA. MATO GROSSO. ACRE : Objetivo : mostrar a rapido desenvoluimento dessa partie (colonização, estradas e o empenho do Governo de assisttir essa evoluçao e fomentá-ia (INCRA. FUNAI, CODEMAT etc.) Projeto Rondon, sudam etc. ITINERARIO : 3o.set. avião da VASP para Cuiabá. Pensão Schmidt. Telf. 5467. Visitas a Codemat $\oplus$ Autoridades do Gov. MT. Alugar avião do SIL por l semana para visitar o seguinte (inicjiando em 4.10.76) : estrada para. Cachimbo seus mucleos de: colonização. ( 1 dia) Fontanilla.. Juina (AR-1) es Humboldt ( 2 dias). PI Serra Morena ( I dia). PI. Roasevelt (1 dia) PI. Sete de Setembro ( 1 dia). Cacoal e Vila de Rondonia ( 1 dia). Vilhena Colonia Colorado ( 1) dia). Depois Porto Velha. Rio Branco. Cruzeiro do Sull. Manaus: Brasilia. (Em Porto Velho: Hotel Floresta).

\section{(II) COSTA DO NORDESTE E INTERIOR DO NORDESTE :}

Toda viagem a ser feita num Jeepe Xavante (Otrgel) oferecido pela Fabrica. Devendo ser de mais ou menos 6 semanas. Iniciando om $S$. Paulo (Santos) e subindo pelo litoral até Vitoria. Salvador. Recife. Fortaleza.. S.Luis. Belem. Depois voltando a Brasilia pelo Interior. objetivo : mostrar a patria do Nordestino, grande pioneiro do Brasil. (o que tem principalmente desbravado a Amazonia e o Hinterland). Tambem o amparo que está recebendo pelo Governo (Sudene, Rondon etc..). $T_{a}$ mbém porque oferece as fotos mais pitorescas e bonitas dessa fabulosa paizagem. Roteiro exato ainda a ser estabelecido. Tempo: mov.. e dez.7.6.

(III) PERIMETRAL NORTE : Roteiro ainda a ser elaboradg, mas devendo incluir : Macapa, Boa Visța.UAupés. Benjamim Constant. Crulzeiro do sul etc. Essa uiagem será feita quase tada em auiõos do $\mathrm{SIL}$ de Belem etc. ( $T_{\text {l }}$ lvez Jesco não poderá acompanhar, porque a viagem deverá ser durante o fim de dezembro e janeiro de'1977, quando eu tenho outros: afazeres (uisita dos antrohologos Or.. Meggers: Evans as cavernas do Rio Galera, junto com nopso Prof. Eurico Miller).

Goiania, 28 de Setempro de 1976
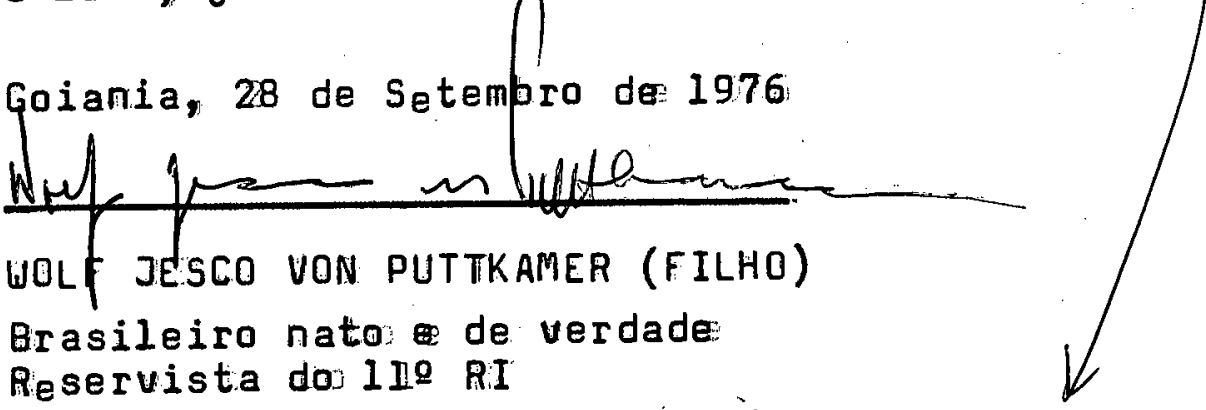

"SMiTHSONIAN INSTITUTION" WhItinatoN, D. 

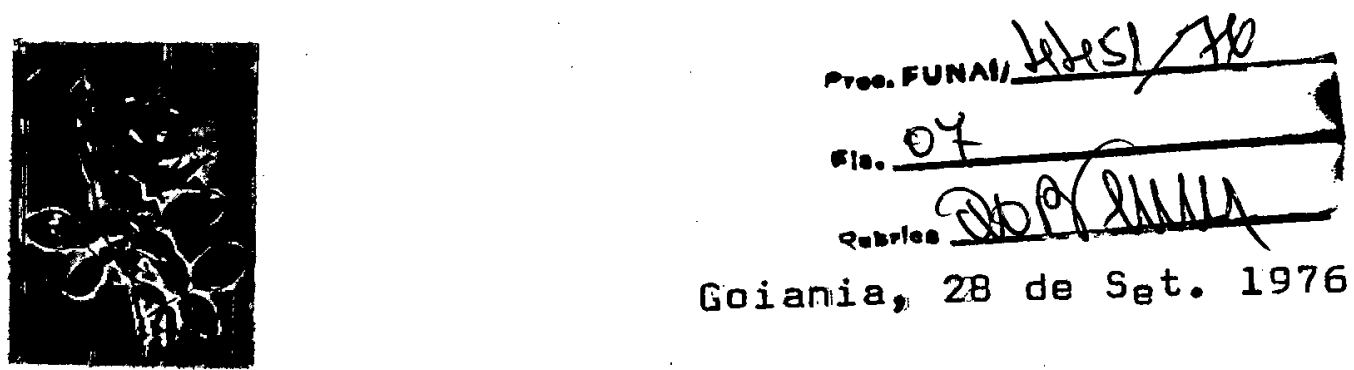

Gaiania, 28 de $S_{B} t .1976$.

Meu caro Jura :

Apenas agotra filquei sabendo do seu importantissimo trabalho (função) junto a FUNAI, e nunca deixarei faltar as necessarias informações para você (além naturalmente informar o sr. Presidente). Pode ficar descançado que aí (com as visittas) está seguindo um autentico Brasileiro e patriótta. Mas caso você: achar necessario aguardo instruções específicas. Em todosios logares contactarei as autoridades da FUNAI e por elas pode me mandar recados.

abraço do seu் sincero amigm 


\begin{tabular}{|c|c|c|c|}
\hline \multicolumn{3}{|c|}{$\begin{array}{l}\text { MINISTERIO DO INTERIOR } \\
\text { FUNDACAO NACIONAL DO INDIO }\end{array}$} & 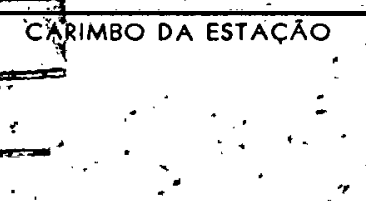 \\
\hline 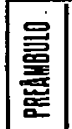 & $\begin{array}{l}\text { Espécie: OFICIAL } \\
\text { Origèn: }\end{array}$ & $\begin{array}{l}\text { Número } \\
\text { Palavras } \\
\ldots\end{array}$ & \\
\hline & $\begin{array}{l}\text { INDICAC̄OES DE } \\
\text { SERVICYO TAXADAS } \\
\end{array}$ & C I R C U L A R $\therefore$ & \multirow{2}{*}{$\begin{array}{c}\text { HORA DA TRANSMISSAO } \\
\because \\
\text { INICIAIS DO OPERADOR } \\
\vdots\end{array}$} \\
\hline 胥 & $\begin{array}{l}\text { DRs: Is, }: 2 \text { a } \\
\text { AJUDs. BAUR }\end{array}$ & 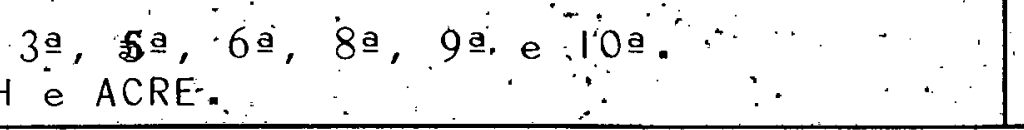 & \\
\hline & \multicolumn{2}{|c|}{ 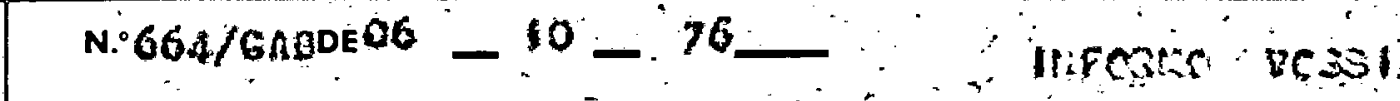 } & 37- LCSEZ \\
\hline & \multirow{5}{*}{\multicolumn{3}{|c|}{ 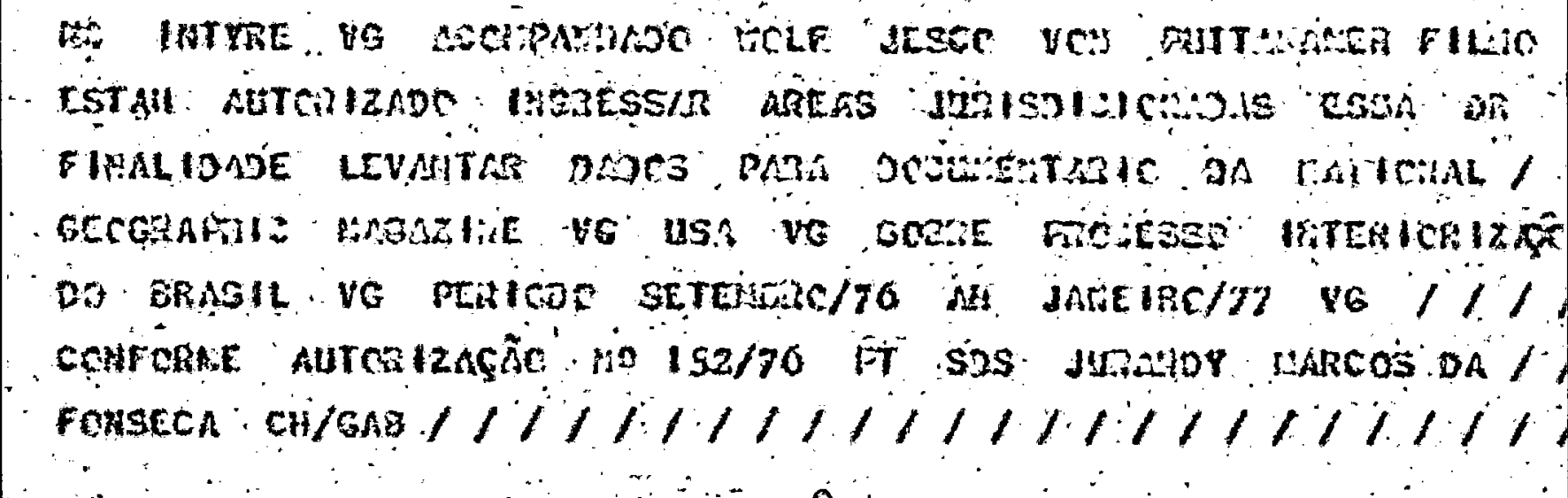 }} \\
\hline & & & \\
\hline & & & \\
\hline & & & \\
\hline & & & \\
\hline & & & \\
\hline
\end{tabular}




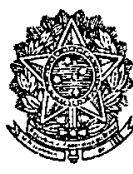

09

MINISTÉRIO DO INTERIOR

FUNDAÇÃO NACIONAL DO ÍNDIO FUNAI

A Sec/DGPC, com as cópias

da Aut. 152/76 e do Rd. 664/GAB, às unidades regionais mencionadas na autor $i z$ ação.

0 original do documento foi encaminhado ao interessado, pe lo correio.

Em, 06/outo/76.

Allarivilo

fopi za Ongélica SHEFE DA SECRETARIA DO GABINETE

Enearimtro-se a Di vinesing, pare confucie que tore portarion anquiva

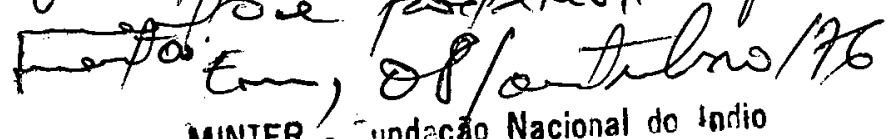
MINTER - - Indacto Nacional do Indio Dopartamento ostar amunitário

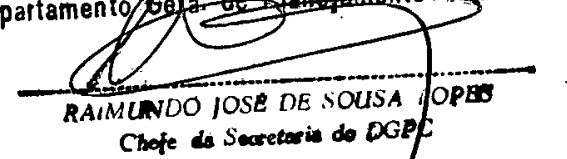

Chefe de Secreterie de DGPF

De ordem, anguive se $\eta 0$ setor de Documeutaras.

DEP. $08 \cdot 10 \cdot 16$

La Gogedo 

conformidade con o disposto no ant. Io, item VII, da Lei n. 5.37I, de 05.12.67, no ert. 20, iten VII, cos Istatutos aprovados pelo De creto n. 68.377, de 19.03.71, e na Portaria n. 120/N, de 05.07.73, ouvido o Diretor do Departamento Geral de Planejamento Comunitário da FUTAI, e tendo em vista o que consta do Nul/ary/044/76

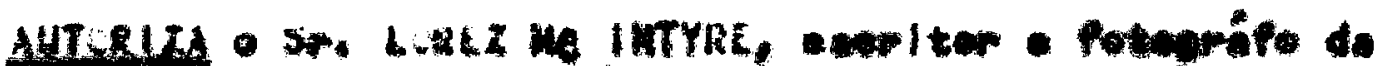

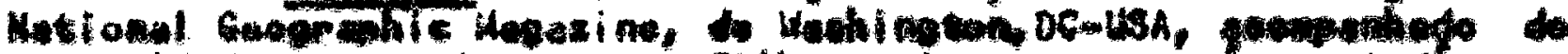

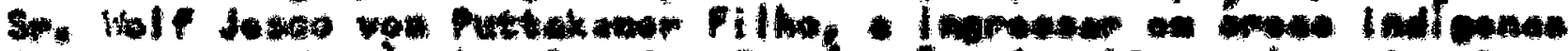

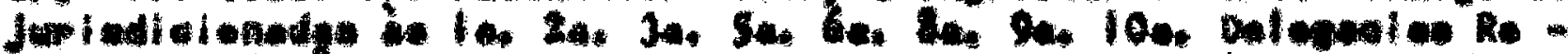

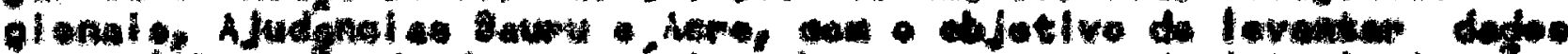

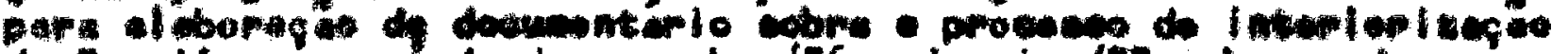

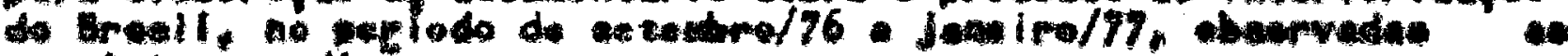 cegulinte ondi, ion!}

a) sem onus para esta Fundação (a FUNAI não se responsabiliza pelo transporte, alimentação e alojamento);

b) não interferência na vida dos silvícolas;

c) atestadoos de que não é (são) portador (es) de moléstias infecto contegiosas;

d) vacinação contra gripe, varíola, febre amarela e tifo:

e) porte de preventivo contra malária;

f) posse de remédios, instrumentos e material de uso comum destina do à proteção da saúde:

g) fornecimento a esta Fnudação de relatórios, cópias de fotografí as, filmes e gravações que forem renlizados, bem como a apresen tação dos espécimes etnográficos que, por seu caráter tenham que ficar no País:

h) retirada da área antes do prazo previsto, caso venha (m) a con trair qualquer moléstia transwissíveis;

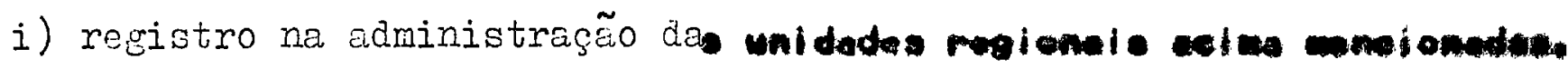
Brasília. os de uvtubro de 1976

OBS.: Comprometo-me a cumprir as conaições acima estipuladas.

Data:

Assinatura:

ORIGINAL ROI

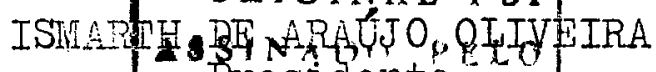

Presidente

an. PESIOXNT 


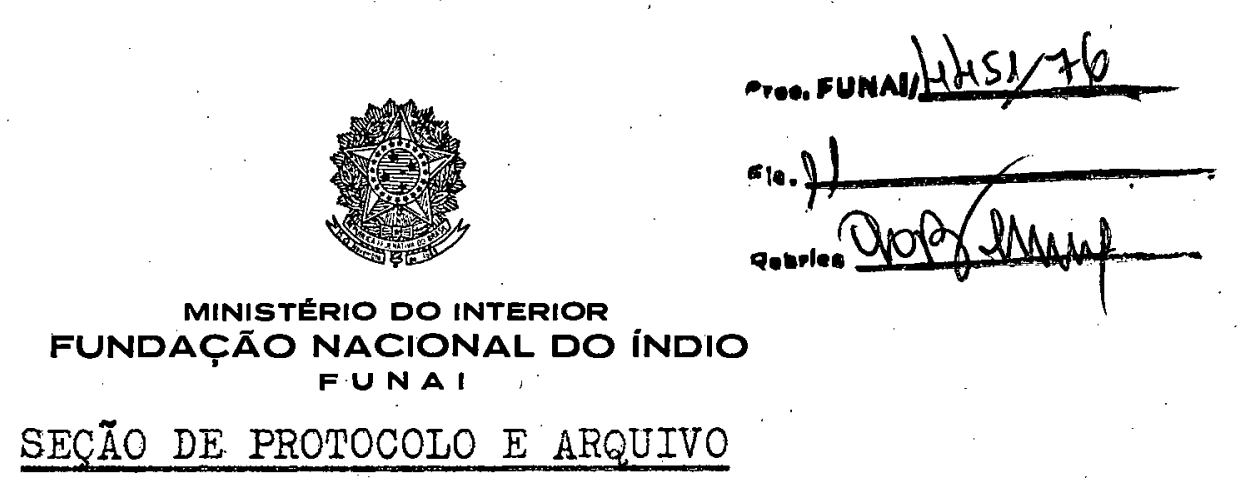

=TERMO DE JUNTADA=

$============$

Nesta data, por solicitação do DGPC, foi juntalo ao Proc.Funai/BSB/ 4451/76, mais quatro folhas e uma fotografia, compreendendo PLANO DE TRABALHO PARA 1978,DA AUTORIA DE W.JESCO VOF PUTTKAMER (FILHO).

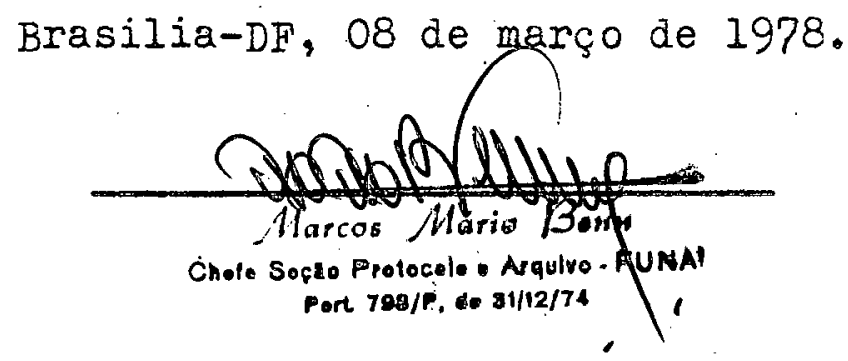



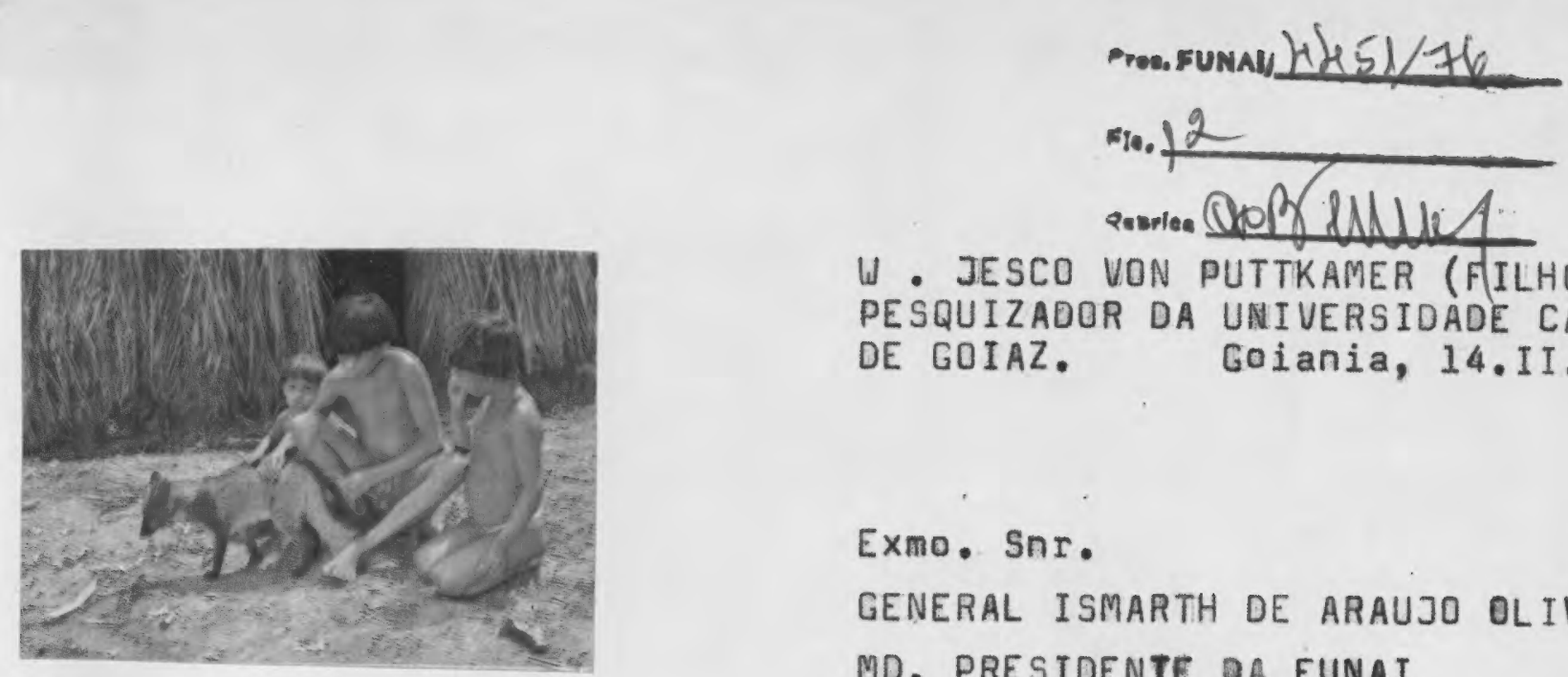

W. JESCO VON PUTTKAMER (FILHO) PESQUIZADQR DA UNIVERSIDADE CATÓLICA DE GOIAZ. Goiania, 14.1I.1978

EXmO. SnT.

GENERAL ISMARTH DE ARAUJO OLIUEIRA MD. PRESIDENTE DA FUNAI

BRASILIA, DF. EDIFICIO ALVORADA.

PLANO DE TRABALHO PARA 1978

Senhor Presidente - Como, todos os anos, tenho o prazer de enviar para apreciação de V. Excia, nosso plano de trabalho (documentario e de pesquizas etnológicas).

Desejariamas concluir esse ano os três trabalhos que atamos, ha mais de 3 anos autorizados a realizar, por V. Excia. para os quais temos recebido o apoio da UNIVERSIDADE CATÓLICA DE - GOIAZ e da NATIONAL GEOGRAPHIC SOCIETY (juntamente com o senhor Prof.. Eurico Th. Miller e C CNPq outras autoridades Federais Estaduais). o primeiro trabalho, que já é do conhecimento de $V$. Excia, se refere a importantes descobertas arqueológicas no Vale do Rijo Galera e do Rijo Guaporé e às quais fomos levadas pela ajuda que os índios WASÚSU ( da Nação Nambicuara) nos deram do Sertanista Fritz Tolksdorf (Funai).

O segundo trabalho, tem como temata a construção dófuma éstrada pioneira (AR-1, Vilhena - Aripuanã) pelo Governo de Mato Grosso os problemas ligados ao desenvolvimento de uma região de grande riquêza, encotvendo atuação da FUNAI e de CODEMAT e INPA. Um trabalha tão bem planejado executado, que qualquer Brasileiro pode se orgulhar disso.

- terceiro grabalho, é um documento importante de como os Suruás foram, finalmente (e após muito sacrifício) salvos e gnvolve a pacificação do ultimo grande grupo de CINTAS LARGAS, os ássim chamados "CAEEÇA SECA".

"A story-line " desses ultimos dois trabalhas seguem anexo a esta carta.

Dos três trabalihos esperamos conseguir publicaçâo na revista NATIONAL GEOGRAPHIC (com tiragem agora de11.000.000), mas estamos também preparando livios sobre o assunto.

Mąis uma, vêz desejamos aqui agradẹcer o apoio a

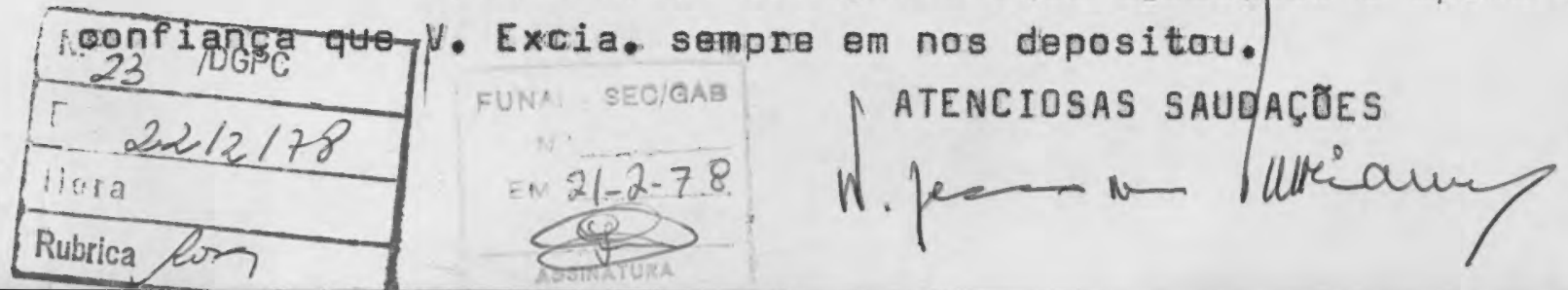




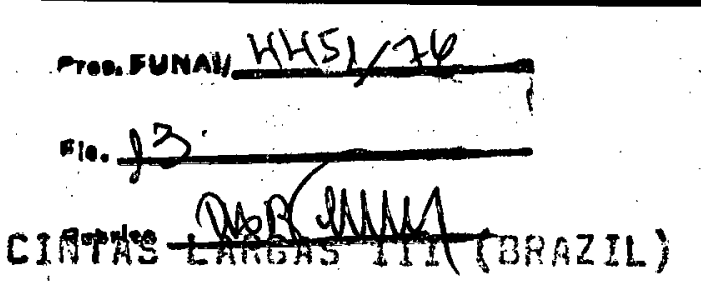

* ARIPUANÃ - THE CONQUEST GF AMAZONIAS GARDEM OF EOEA.

DURING 3 YEARS HAS JESCO FOLLQUEO UP THIS EVOLUTION . THERE ARE 1.00O PAGES DF DIAFY HOTES IJRITTEN OH THE "FRONT" AND 3.000 COLUUR PHOTOCRRPHS SELECTEO DUT ÖF 16.000 .

TO COMPLETE THIS STORY NEEDS ANOTHER VISIT OF ONE. MONTH TO "JUTNAR", "HLGECLOT" "SERFA MORERA" ANO THE AR-1 BOAO.

STony-irue: Only recently the OR- 354 High Way (Cuiaba Porto Volio) was built and leaded to the discovery of great stretches of excellent and fertile lands, a literally untous ched paradise, covering pats of the ficith into Grosso state and the Terricory of fiondonja.

This land of "rilk and horey" is mosely iom catet in the upper valoys of the Aripuena and Jurueno rivess and the River Roosevelt as well with its many affluents.There are great forests, full of crazil nuts, cacao and precious timbers and in great parts of it live still uncontacted in dian tribso of the CIUTAS LAPCAS MATION, which have become hostile because of the cruelty and violence of the civilized invadors. For thousantis of years these xegions have beer the habitat of great indian nations of Tupias and hruaken and Ge origin.

Fron VILHEN, a fast rajsing conercial center,

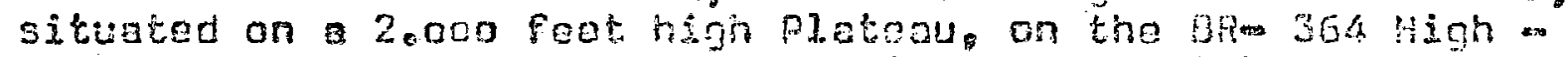
Uey, a nes important pioneer roed is boen built by tho graziIian Government, using nost sophisticated and modern road builm ding equipments and cossing throunh the niddst of an enourmeous and visgin territory, pollowing on the waterghed in botween the Valeys of tho Aripuana and Juruena Rivers and ho Roosevelt. Jesco has been with them since the very piret

beginning and partecipating on this great advencure uriting 1. ooo pages of diariog and taking 16.000 colour photographe. Still untouched and untamed uild indians appear on the road (everybody full of foar) and make first contacts on Funais frontier pose "Sinra Conena". However soon they will realize that this tine the white nen have come as reiends. brim dar the suparvision of tho Srazilian Indian Rgency (Fuiai) and sher experiented "sertanistas" the bovernment is enforcing to have the indians be rescected and theix fanilies and thols traditional huncing grounds and habitat as woll. A groat inow dian. reservation vas protected by spoctal lass and the rood was planed in such a way that it would not approach too close to the oxisting incian villages.

on the otfer hand great strotches of fortilo foxest lends were now audiate fox colonisation and two adw

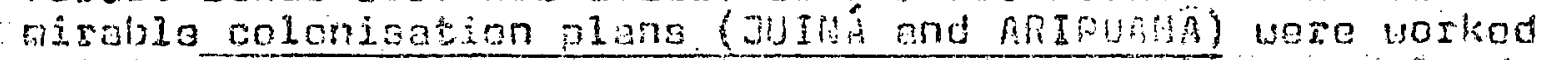
out in orde to detribuse the lamds ros sotulers and 1 and daveilnoing companies (agso- renches) in accordance uxith proviaus elaborated plans thich uould avoid a descruction of the fertale lands and of the deologiacal balance. frost of the setulers aro coning pion the south of Lrazil (bind children)

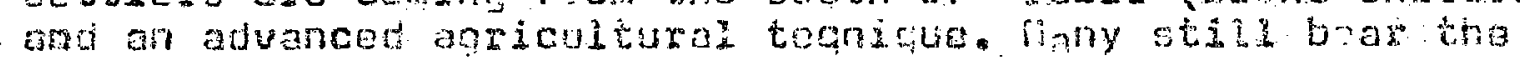
names of the in pernan and polich ancotors who many yoars

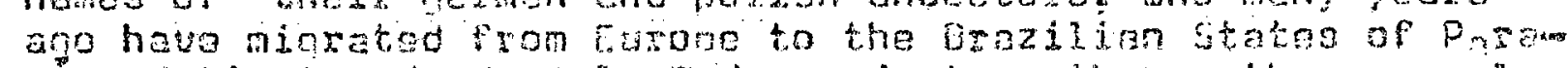

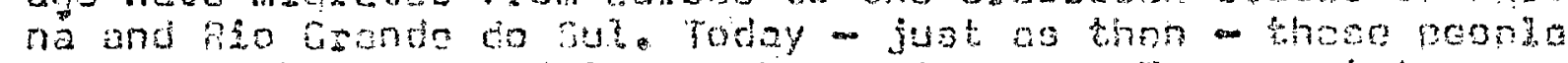

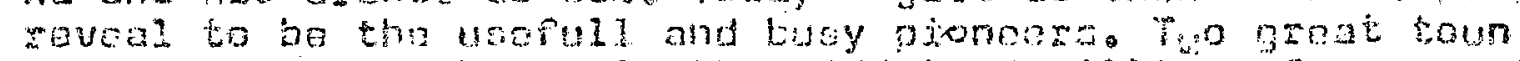

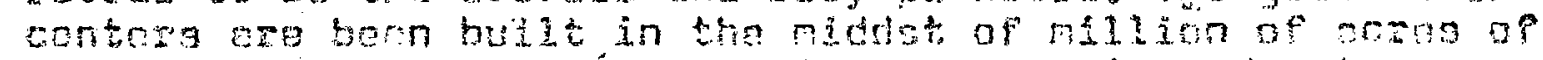

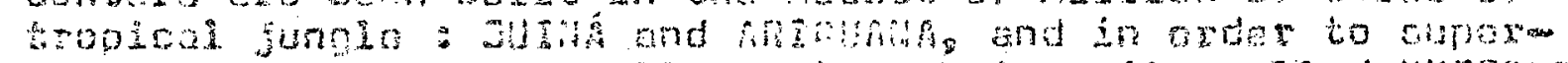

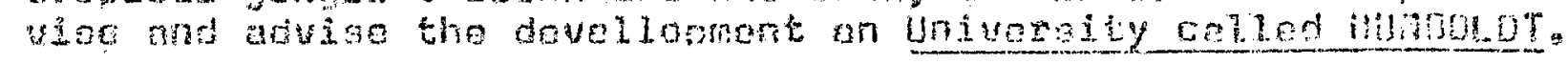


NOARA'S AND HISPEOPLES QITTER JOURHEY IUTO THE XX ERENTURY -

DURING THE LAST SEVEN YLARS HAS JESCO FOLLOLED UP THIS REMARCADLE STORY, SINCE THE MOAENT UHEA FIRST CONTACTS UERE MAOE. UITH A GROUP OF LARGE BELT INOIANS CORMNDEO GY UAR CHIEF NOARA. THIS FIRST STORY UAS PUBLISHEO BY NATIONAL GEOGRAPHIC. OUT OURIUG ALL THE VEARS AFTER UE HAVE FQLLOUED UP THE FATE OF THIS CROUP OF IHDIRISG MWD THE WG HAS JOINED TUIS MATEFIAL CALLED "CINTAS LARGAS II".

OUR LATEST PHOTOCRAPHS F ROM "POSTO SETE DE SETEMORO" ARE FROA 1977. TO COMPLETE THIS STORY UE WOULO NEED TO JOIN

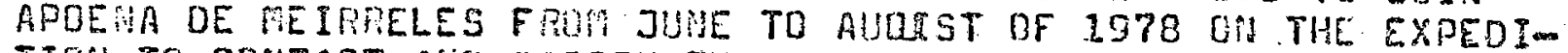
TIUN TO CONTACT NHO PACIFY THE LAST "CINTAS LARGAS " GRDUP CALLED "CABECA SECA "OR "ZORÜ".

STORY-LINE : FUll of misshappenings and bad incidenta was this fate of a group of stone age indians sho ventured to make contact with the $x X$ fesntury men. But at least some survived and theis story is full of human soljdarity and the abnegated opem forts of a certain group of men, real heroes who made their survival poseible. This was the group of loasa, later called the "SURUI". $80 \%$ of the tribe sucumbed by rieasles and $T B$. and inpluenza, which they got infected with aptes they nade incontrollad contacts with the whte setrors in fiozingo and Espinars do deste. Great extensions of thait traditional tribal Ionda were invaded by illeagal sotilers and colonists. The worst though has now passed, and better daya have coms for the survitora. The Government was after all able to sepparate an INDIAN RESERUATION for this group and the Inom dian Foundation (FUPAI) bas builta small hosnital gt the SETE DE SETEMDRO PIST and aIl the Te sick have boen hoaled now. sone op the invading colonists have now been remoom ved with the holp of another governmental agency (IVCRA) and lat was giveri to these in othor regions.

Sut there is still a last big groun of 2 goe belt indians to be contasted and protected by the Fural : The so

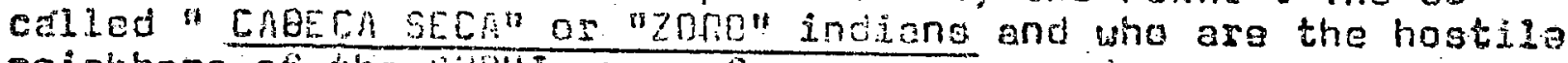
neighbors of the sunul group for ages.

Lat develloping companies from the North have all ready reached the boundarics of the zoro lands and sone of the indions havo allready began to contact these farm warkero. Thoy are doubtloss in great danger if the fultai does not cono tace thom beforo and protect theis health ujith vaccings and by tolling chen to avoid tho white woskers.

So again Apoona de Feirclies, the experienced indian expert of FUNAI, was encisarged to try the contact with these indion groups. This time the sumu will help hpoena and fosgot thos old hostility towards these Caboga Snca groups.

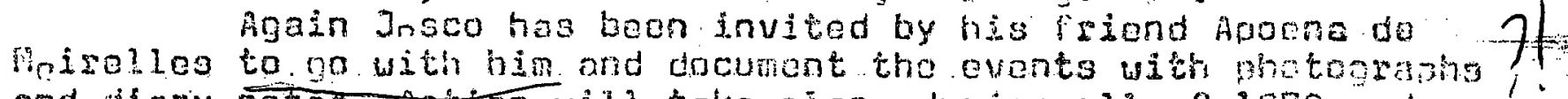
and dary notes faction uil tako plare during all of 1973 and ports of 1979. 
$-$

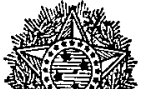

FUNANS(H) $151 / 76$

$\therefore .15$

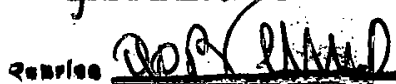

MINISTÉRIO DO INTERIOR FUNDAC̣ÃO NACIONAL DO ÍNDIO

F U N A I

So Diretoe do DGP

Solveitauds corhecer e infowar as Gxue so gresidente. len 21.02 .78

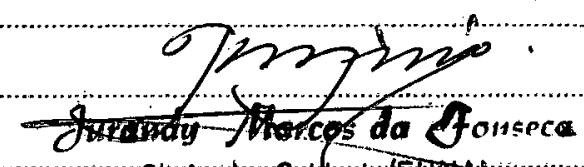

Chêfe do Gabtrute/FOTNA

Encaminhe-se à Divisão de Estudos e Pesquisas.

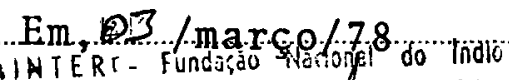

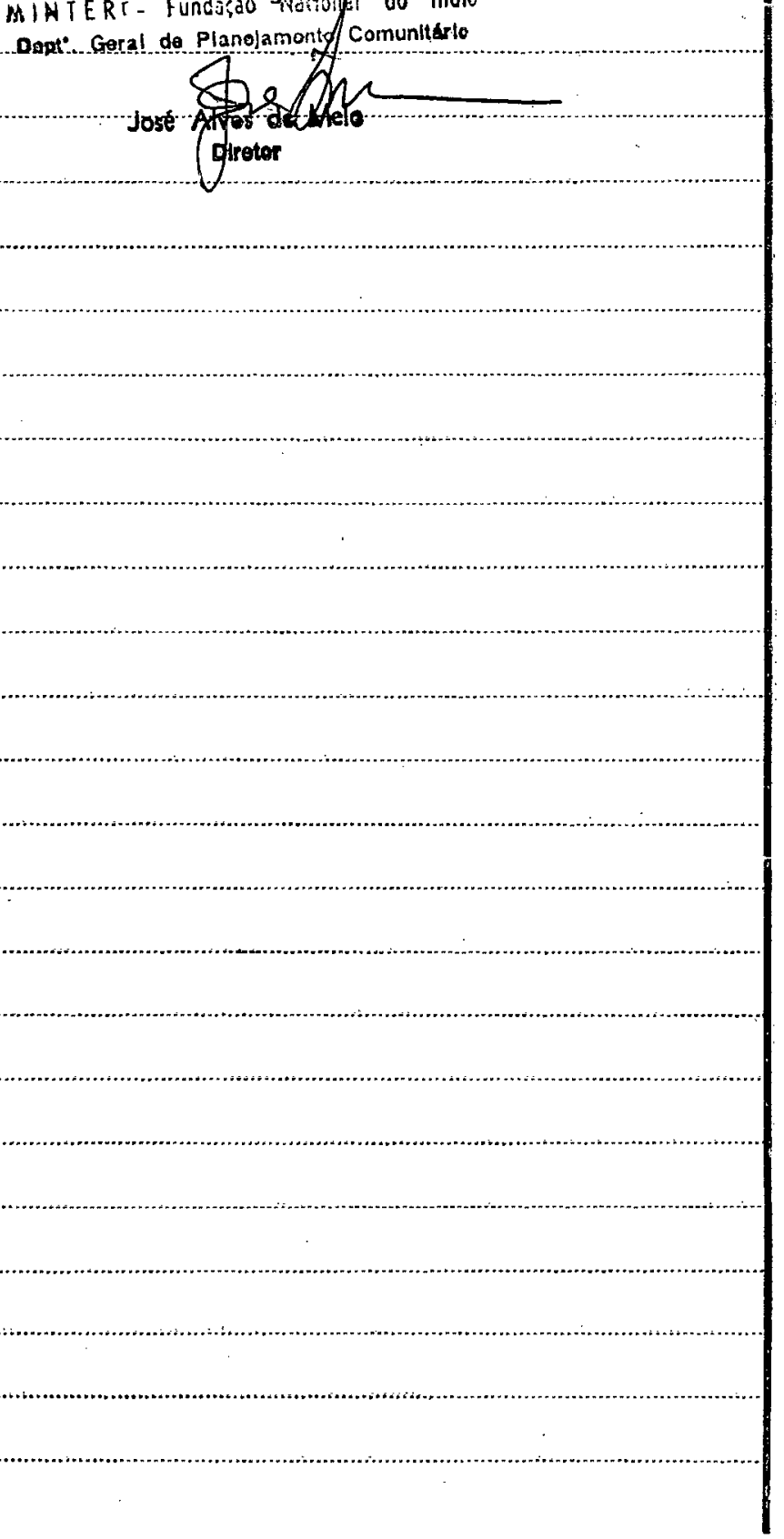




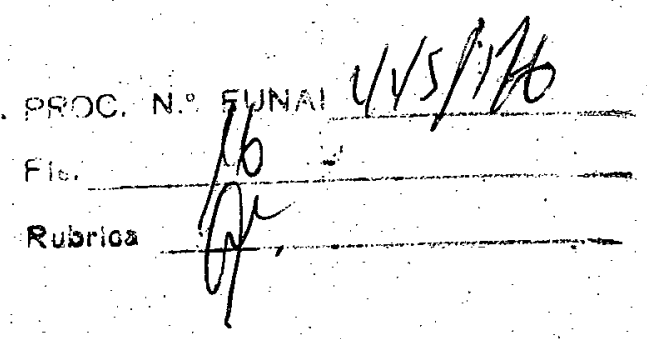

W. JESCO VON PUTTKAMER FILHO

Goiania. Go. Caixa Postal, 310

EXMO. STI. GENERAL ISMARTH ARAUJO DE OQIVEIRA

MD. PRESIDENTE DA F U MA

BRASILIA. DF.

REF.: RECOMENDAÇUES DE SCIENTISTAS AMERICANOS

PARA MEDICACSUES DE INOIOS EM FRETES DE CONTACTOS.

Sention Presidente - O escritor a pesquizador do NATIONAL GEOGRAPHIC: SOCIETY., MI. LOREN ME-INTYRE, através de sua esposa SUE, solicita que eu entregue a $U$ Exeia. os resultados de pesquizas do Dr. A.J." MC LACALAN, com recomendaçø̃es para madicaça de indios em frentes de contactos da FUNAI.
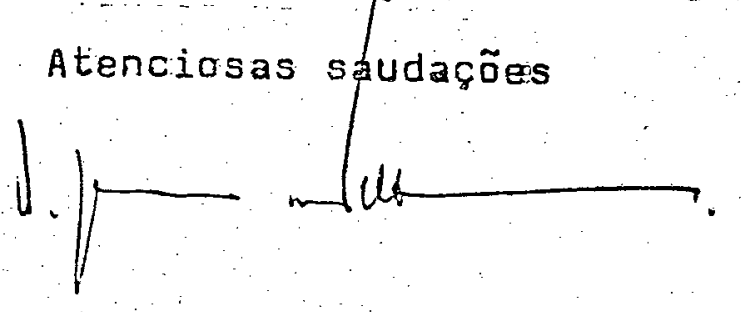


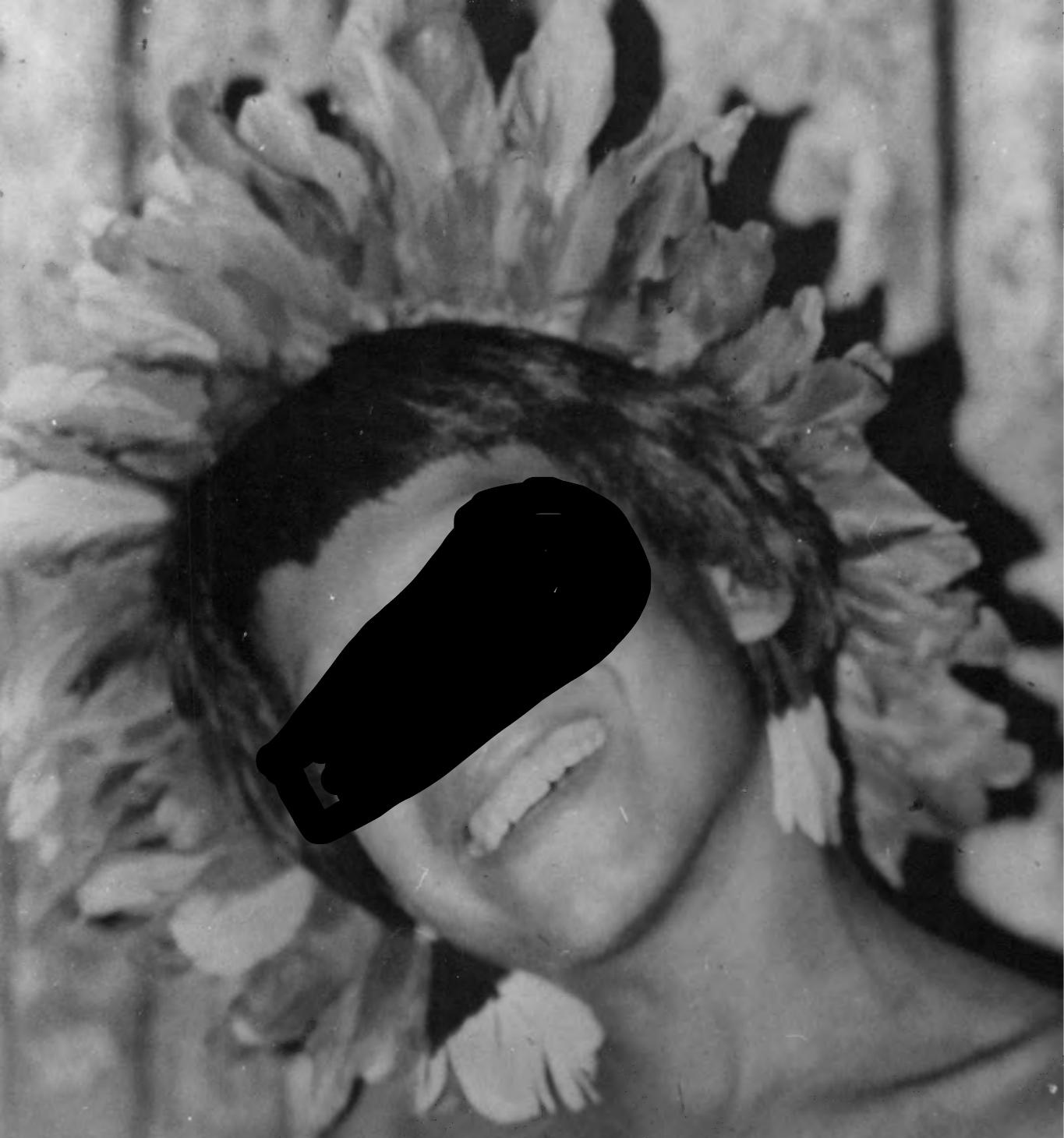


Omenimo Baimpé ficho do clupe D>AH! da trito dos URUEV-WAU, WHE.

Foto: Jesco. 


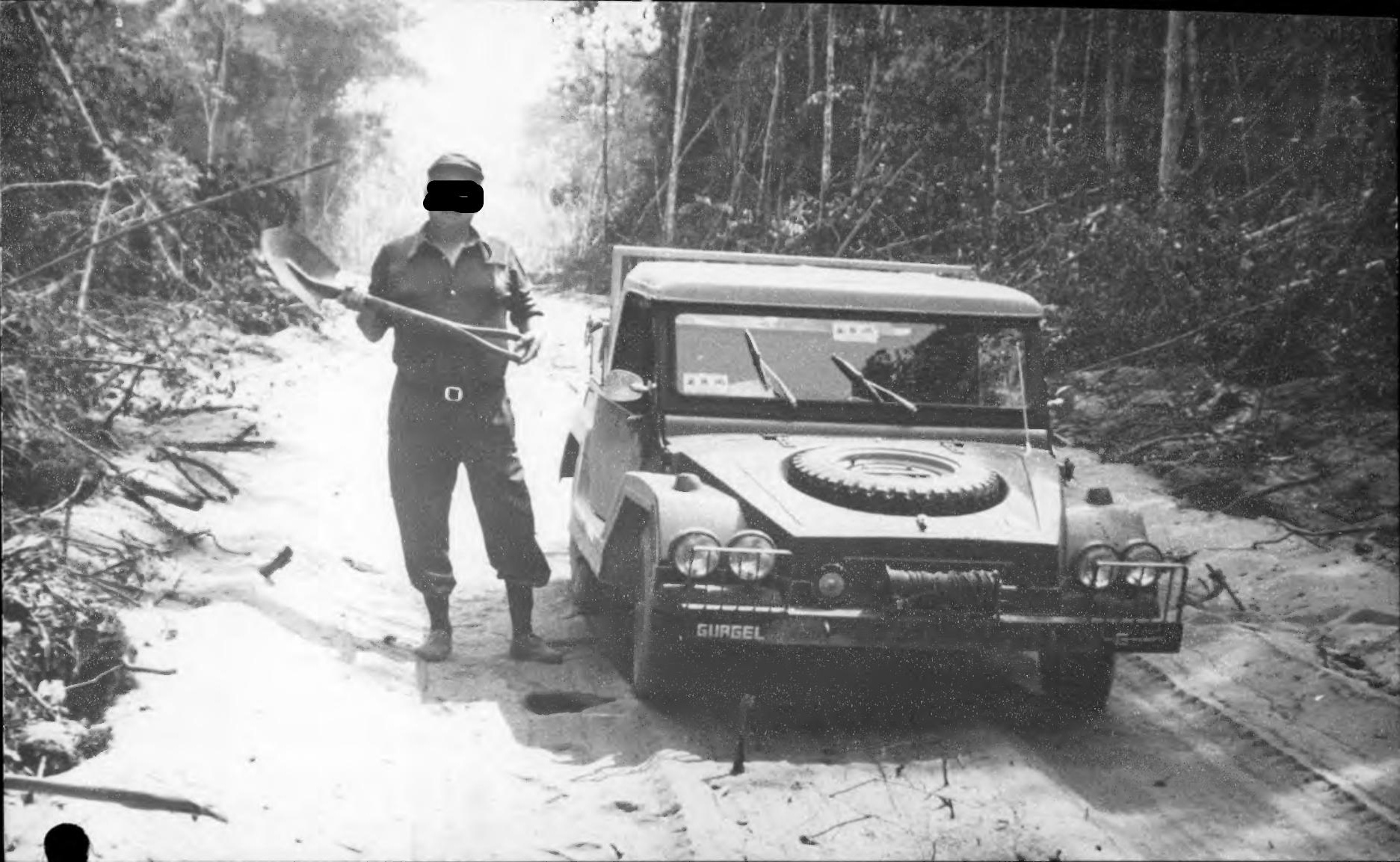


JESCO + JERPE "XA JANTRE"

NA AR-1 (Serra Maorener)

Color-Foto: Jes co

1476 


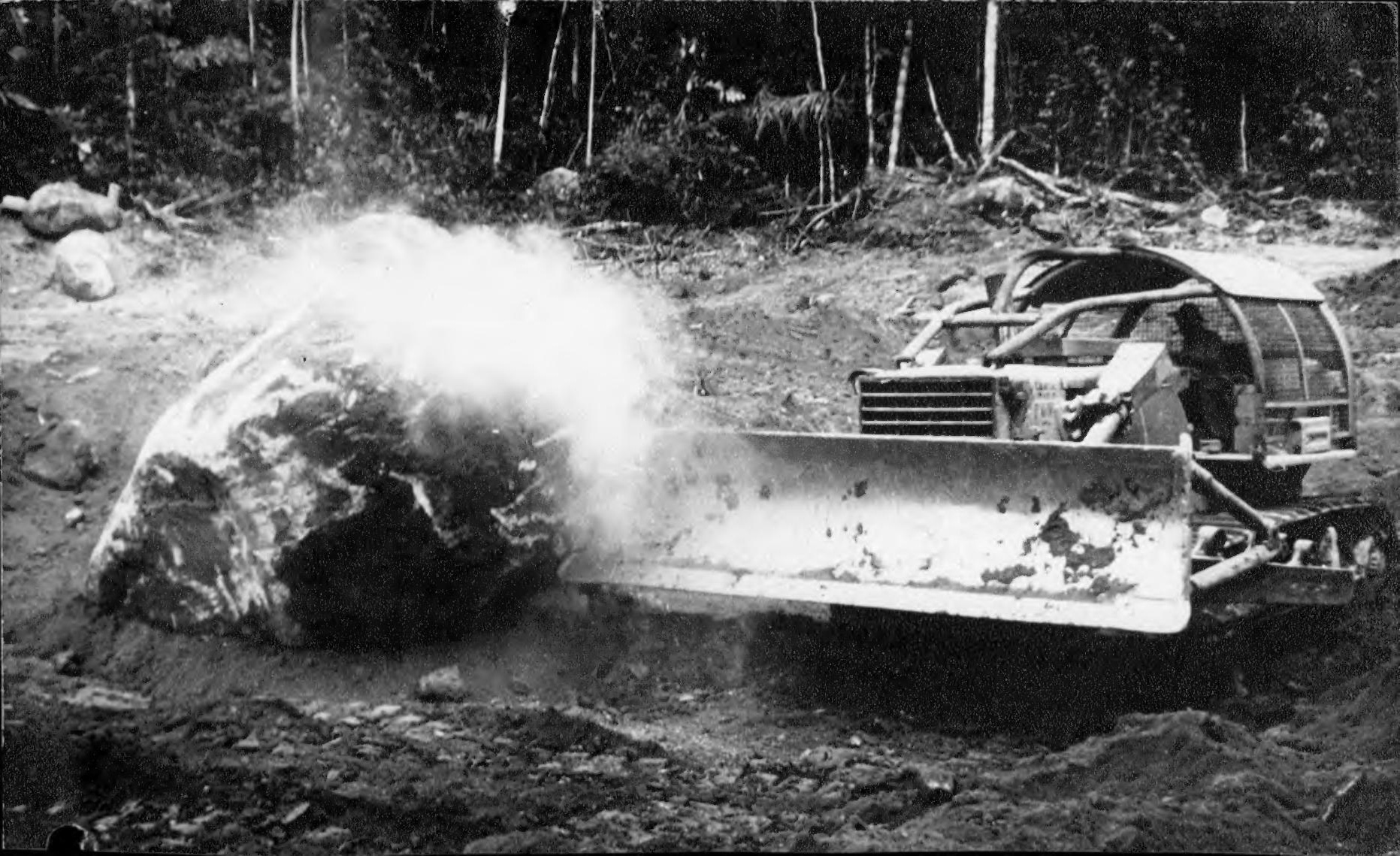


- duro trabrito de abrir. uma Estraja píoneira. (AR-1).

$$
\text { Víchana } \rightarrow \text { Arípuana. }
$$

COLOR-FOTO: JESCO 
STLVACREA (PTY) LTD.

1O1-5 MAIN CITY BUILDING 206 LONGMARKET STREET PIETERMARITZGURG, 3201

RESEARCH DIVISION

24 January 1978

Assistant Secretary (Medical)

National Geographical Society

17th and M Sts. N.W.

Washington D.C 2p036

US A
REIVITTONONCH

CONTROL DI:

FÉ́ $\& \operatorname{liqh}$

\section{].I.:}

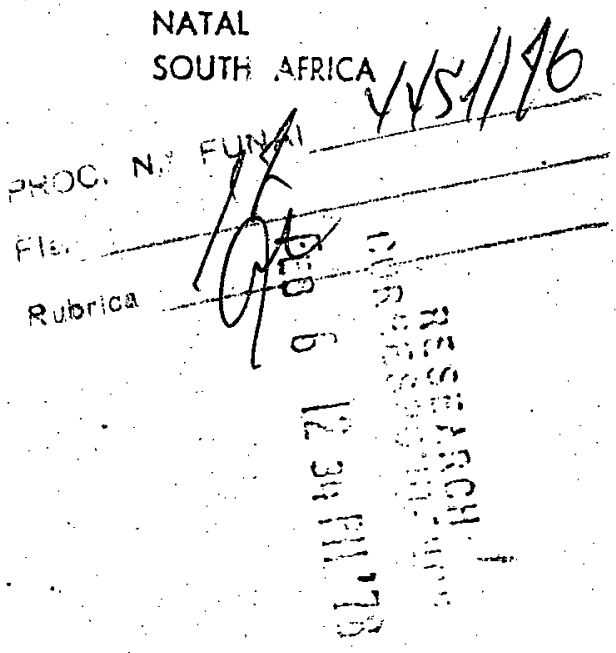

Dear Sir

BRAZIL'S UILD FRONTIER

In the abovementioned article (N.G.M. Nov 1977, 152,5 , pp 684-719) page 701 the following statements were made:-

\section{" Diseases Ravaoe Jungle Tribes}

Humboldt's most dangerous enemies include microbes borne by mice, mankeys and mosquitoes. Mice transmit leishmania parasites that eat away the nose and palate. Monkeys carry yeilow fever. Anopheles mosquitoes spread malaria. Sand flies make fieldwork an ordeal by itch. Although Indians, too; are tormented by bugs, maybe more so in their nakedness, their most deadly illnesses are caught from civilizados: measles, the common cold and tuberculosis.

I flew upriver to the isolated FUNAI post of Serra Morena to see how well one group of Wide Belts, who call themseves Kabano Pomons, was responding to pacification.

Not so well. Elders were coughing and spitting. "Many have suffered colds for two years" said Francisco de Assis, the FUNAI man in charge. Two women stayed in hammocks all the torrid day and cool night. They were dying of pneumonia, Assis said."

There is a considerable amount of medical evidence which indicates that the administration of vitamin $A$ would increase the resistance of the Indians to 
moasles, the cominon cold and tuberculosis.

Thomas Moore ${ }^{1}$ in his book Vitamin $A$ has recorded that losses of vitamin A occur in disease ( $p .381$ chapter 32 and table 62).

MEASLES: Photophobia that occurs with measlos is to depletion of the hepatic reserves of vitamin $A$ and as a result there is an insufficient supply of vitamin $A$ to maintain the visual purple, which is $90 \%$ vitamin $A$ aldehyde. The attached letter from Dr E H Cluver ${ }^{2}$ (who undertook research for this company) confirms this contention.

PNEUMONIA: Moore has quoted a paper by Lindquist ${ }^{3}$ and reproduces a diagram illustrating the excretion of vitamin $A$ in the urine at various stages in a typical case of pneumonia.

INFLUENZA: Colonel Drummond, Rhodesian Army, during one of my visits to Rhodesia confirmed an observation which I have made over a number of years, viz. that persons convalescing after a virus infection who overindulge in sunbathing usually suffer a relapse. I postulated that the virus infection would lower the patient's hepatic vitamin A reserves and would lower his resistance - then as he starts to build up his vitamin A reserves and recover - exposure to solar UV rays would deplete the reserves. 4,5 The relapse is usually more severe than the original dose of influenza. Drummond had noted this occurence among recruits who, recuperating from influenza, sunbathed then suffered a relapse.

COLDS: I have noted that persons going on holiday straight from an indoor occupation, who sunbathe (in excess) frequently develop a 'cold'. This could be due to losses of vitamin A following insolation which would result in the sunbather becoming more susceptible to cold viruses.

Brazilian Indians wear little or no clothing and although they have a degree of pigmentation which would give them some protection from solar UV, it is probably insufficient when they are removed from the protection of their forest habitat. 
STRESS: Von Euler ${ }^{6,7}$, has shown that conscious or $4 \times 1196$ subconscious stress rasults in the excretion of epinephrine. When this is considered in the ligh of the work by Thiele and Guzinski ${ }^{8}$ who have demonstrated in man and rats that adrenalin (epinephrine) injectrons deplete vitamin $A$, then the stress that must occur when the Indians come into contact with white civilisation would also reduco their vitamin A status.

I believe that injections or the administration of oral tablets of vitamin a will help to reduce the current high mortality rate of the Brazilian Indian. Please pass the information in this letter and the references to the person who is in a position to help them.

ZINC: Since zinc is an essertial catalyst in the transfer of liver reserves of vitamin $A$ to the blood serum ${ }^{9}$ it may be necessary to administer zinc supplements. Zinc deficiency is best determined by hair analysis, but one of the signs is white spots under the nails.

VITAMIN A TOXICITY: That there is minimal risk of $\Rightarrow$ vitamin A toxicity is shown in the paper by Körner and Volim ${ }^{10}$ and the attached Time/Dosage chart:

REFERENCES: If required, photostat copies of references will be sent to you. If you have any queries, please do not hesitate to write.

Yours faithfuliy,

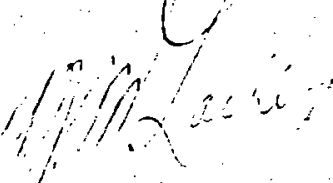

A J MCLACHLAN

Director

\section{REFERENCES:}

1. Moore, T. Vitamin A, Elsevier, Amsterdam 1957.

2. Cluver, E.H. Letter to Sylúchem re photophobia dated 10 January 1967

3. Lindquist, T. Studien Lber tas Vitamin A beim Menschen, Appleberg's Boktry riaktiebdag, Uppsala, 1938. 
4. Urbach, E. Skin Diseases, Nutrition and Metabolism Grieve and Stration, NY, 1946

5. Cluver, E.H. and Politzer, W.M. S.Afr.J. of Science 8, 61, August 1965

6. von Euler, U.S. and Lundberg, U. Physiology, 6, 9, March 1954.

7. von Euler, U.S. CIinical Pharmacology and Therapeutics, $\underline{5}, 4,1964$

8. Thiele, W. and Guzinski, P. KIiniesches Wochenschrift, 13. Apriil 1940

9. Smith, J.c. Jr., et ai. Science, 181, 7 September 1973.

10. Körner, U.F. and VöIIm, J. Internat.J.Vit.Nutr.Res. 45, 1975 .

11. Dosage/Time Relationship of Vitamin A Administration Showing Onset of. Side Effects.

\section{ENCLOSURES:}

No.11 above 
DOSAGE/TIME RELATIONSHIP OF VITAMIN A ADMINISTRATION SHOWING ONSET OF SIDE EFFECTS

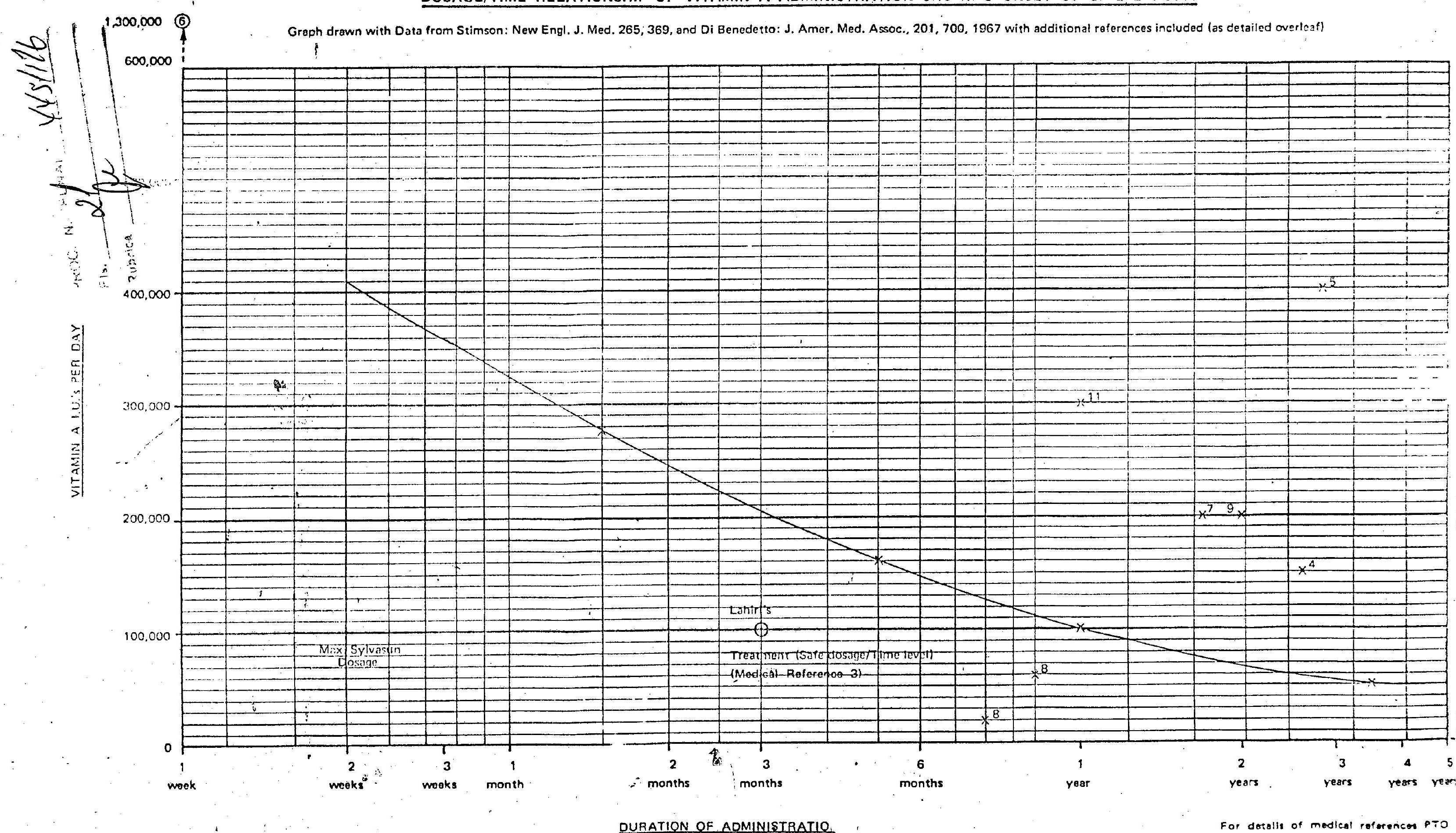


-111 "Vitamin A Intoxication in Adults" by W. H. Stimson in the New England Journat of Medicine, volumu 265, pagos 369.373, 24th August, 1961.

(2) "Chronic Hypervitaminosis A in an Adult" by R. J. Di Be'nedetto in Journal of the American Medical Association, volume 201, pages 700.702, 28th August, 1967.

(3) "Vitamin A in Acne Vulgaris" by K. D. Lahiri and F. J. Scandrett in the Journal of the Indian Med. Assoc., volume 23, pages 247.249, March, 1954.

(4) "Hypercalcemia due to Hypervitaminosis A" by Gail Fisher and Penn $G$. Skillern in Journal of the American Medical Association, Volume 227. No. 12, pages 1413.1414, 25th March, 1974.

(5) Hepatic Injury from Chronic Hypervitaminosis A resulting in Portal Hypertension and Ascites" by R. M. Russall, J. L. Boyer, S A. Bagheri and Z. Hruban in the New England Journal of Medicine, volume 291 . pages $435.440,29$ th August, 1974 .

(6) "Acute Hypervitaminosis $A$ in an Adult" by K. 1. Furman in the American Journal of Clinical Nutrition, volume 26, pages 575-577. June, 1973.

(7) "Chronic Adult Hypervitaminosis A with Hypercalcemia" by Charles M. Katz and Manuel Tzagournis in Metabolism, volume 21, No. 12 , pages 1171-176, December 1972.

(8) "Chronic Hypervitaminosis A with Intracranial Hypertension and Low Cerebrospinal Fluid Concentration of Prutein" by Normal J. Siegel and Thomas J. Spackman in Clinical Pediatrics, volume 11, No. 10, pages 580-584, October 1972

(9) "Vitamin A Intoxication" by Terence E. Hawkins and Daniel T. Burlon in the Journal of the American Osteopathic Association, volume 73 . pages 371-375, January 1974.

(i0) "Chronic Vitamin A Intoxication" by S. T. Teo, J. Newth and B. J. Pascoe in the Medical Journal of Australia, volume 2, pages 324-326, 18 th August 1973.

(11) "Chronic Intoxication with Vitamin A in Adults" by W. Raaschou Nielsen in Dermatologica, volume 123, No. 5, pages 293-300, 1961.

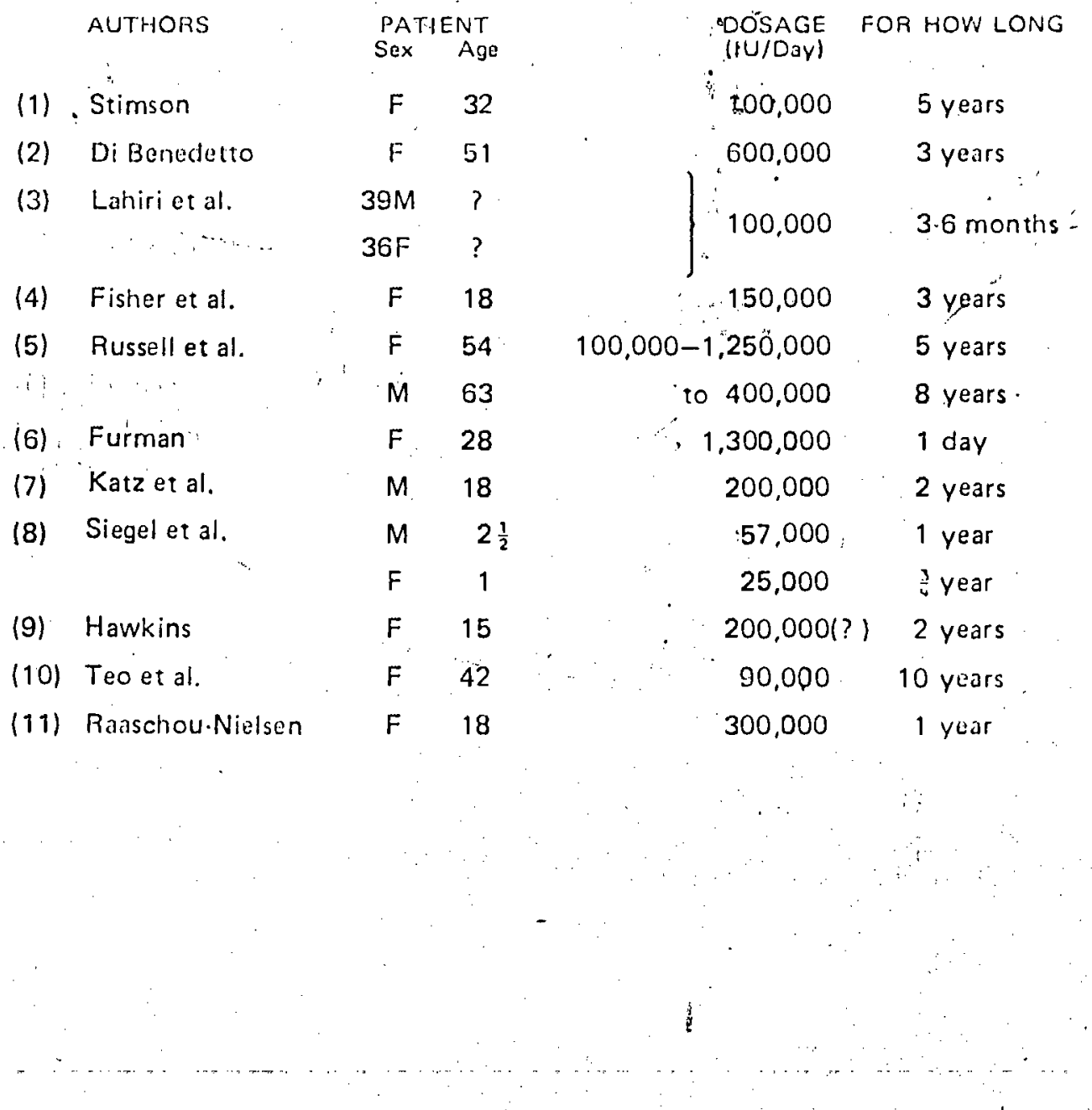




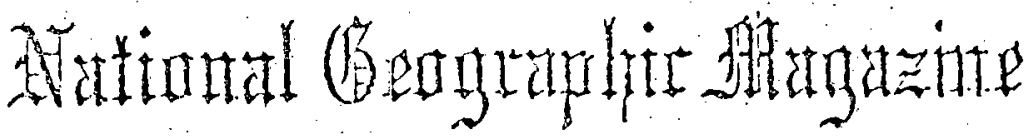

WASHINGTON, D. C. 20036

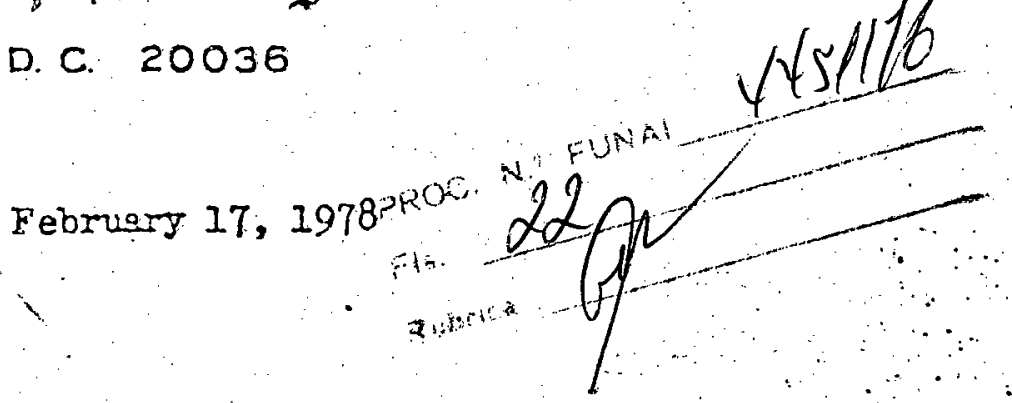

Mr. A.J. McLachlan

Director

Syivacher (Pty) Itd.

P:0. Box 734

Pieterraritzburg; 3200

Ilatal, South Africa

Dear Mr. Mctachlan:

Thank you for your recent Ietter concerning the November article on the Brazil interior. The raterial you enclosed discussing the benefits of Vitemin A supplements has been forwarded to the author, who works in this area frequently. I'm sure he will find this information very useful for future reference, and sill pass it on to those authorities Involved.

Thank you again for your concern.

Sincerely,

Jeanne E. Peters

Research Staff

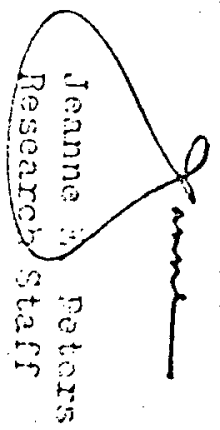


vistit6

MINISTÉRIO DO INTERIOR

FUNDACÃO NACIONAL DÖ. INDIO

F U N A I

Surico

Ao su. Drieter do DGPC

Exaniman e oprexuta parece.

Been, 29.0378

Osma de Ofraúio Olivetra

Presidente da FUNAI

Sa. chefe da DEP:

Sendo en vista que o relatónio informatino do $D_{R}$. A. J M M Lachlan, contén subsídios de Teor exchusinamente reprido ao setón de sánde su genimos emie-se-o 'a DS com ristas a obTer sua ofiniáo.

$$
\text { BSB. } 2.9103178
$$

Ráé Manimbo dos Santos Noto antrofnólogo

Si. Dinetar Solicito ensian a "ent em anexos. Posterionste encamin $=D S$ rana ofimm se reenent a ritansina A diminni o molice de dacm de

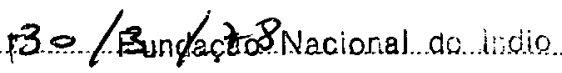
Departamento Geral de Planejam r.e . umuni.a io Que $v_{\text {Delvair Montagher Meletti }}$ eloff

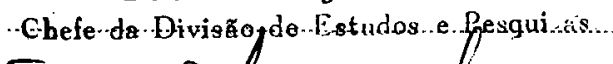
Encaunime-as, de ondeur, à

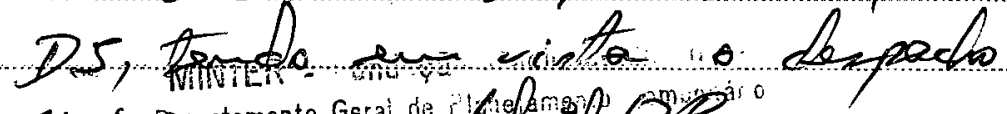

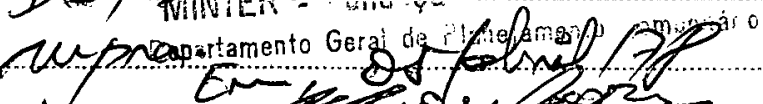

güUNDO IOSE DE SQLSA I. 


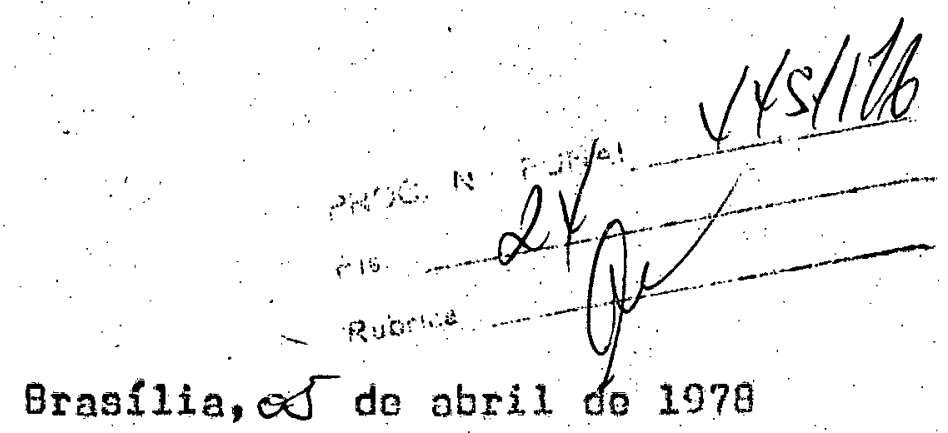

\section{Caro Senhor:}

Cumprimontando-o, informamos que faco a ne cessidados de controlo da permanência de posquisadoros o comuni cadores sociais, etc, on árees indígenas do Território Nacio nal, a Presidôncia da fundagão Nacional do Indio balxou a Porta ria de no 448: $/ N$ de 12 do setembro de 1977 , en que aprova o/ou regula as autorizaçōes para comunicação Social nas citadas ároas. Solicitarfamos portanto sua colaboraça no sentido de serem atendidos os itens do $n Q_{3} 2,3$ o 4 do jé refori do Regulemonto, tendo en vista poscibilitar so Departamento Ge rel de planejamento Comunitário, quo proceda a estudos sobre seu pedido do autorização datada do 14/11/1977.

Segue aneso cópia da Pastaria de no $44 n / N$.

Antecipando nossos agradidimontos, subscre veno-nos atenciosamento.

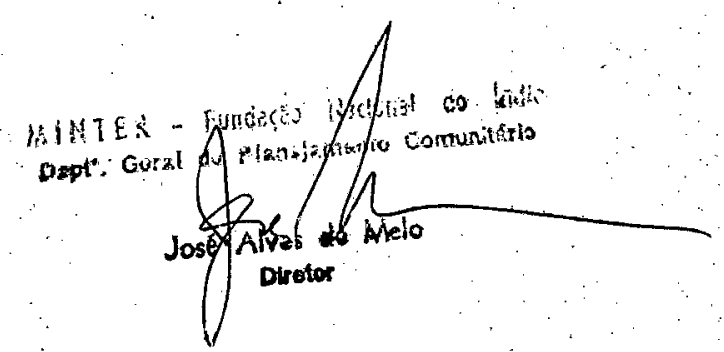

IImo. Sentiox

U.JESCO VON PUTTKAIEA (FILHO)

Goisnia - $\underline{\text { GQ }}$

CH\$N/mk

Ref. . Proc. FUNAI/BSB/4451/76 


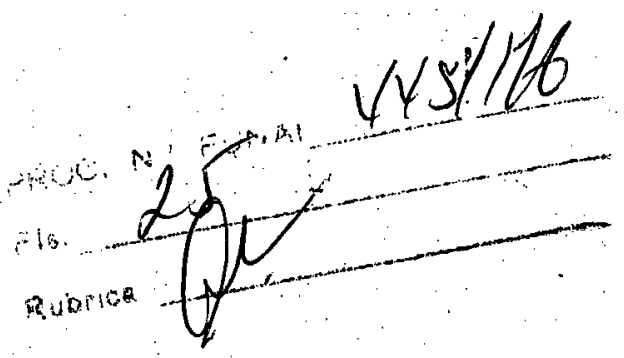

\section{W. JESCO VON PUTTKAMER FILHO} Goiania. Go.

EXmO. SNI. GENERAL ISMARTH ARAUJO DE DQIVEIRA

MD. PRESIDENTE DA F.U N A D -

BRASILIA. DF.

REF.: RECOMENDAÇOES OE SCIENTISTAS AMERICANOS

PARA MEOICAÇOES DE INDIOS EM FRETES DE CONTACTOS.

Senhor Presidente - D escritor e pesquizador do NATIONAL GEOGRA-

PHIC SOCIETY:, MI. LOREN MC-INTYRE, através de sua esposa SUE, solicita que eu entregue a Ve Exía. ós resultados de pesquizas do

Dr. A.J. MC LACALAN, com recomendaçes para medicafáa: de indios e* frenties de contactios da FUNAI.

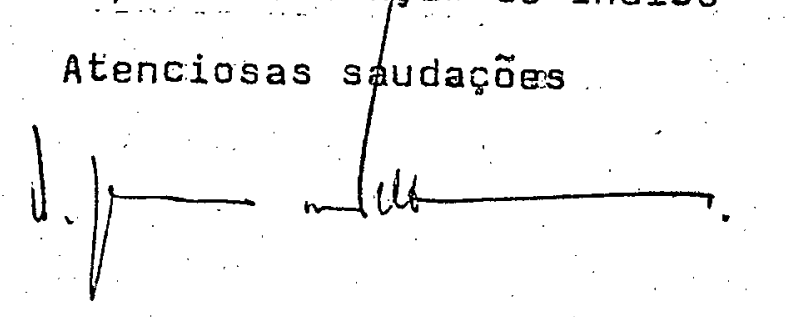


SYLYACREA (PTY) LTD.

101-5 MAIN CITY BUILDING 206 LONGMARKET STREET PIETERMARITZBURG, 3201

RESEARCH DIVISION
Tolophono 25r41.

Tolegraphic Adjrez: "SYLVACHEM"

REINTTANCLY CONTROL DI:

FEG $\fallingdotseq$ G Fi?

P.O. BOX 734

PIETERMARITZBURG, 3200

NATAL

SOUTH AFRICA

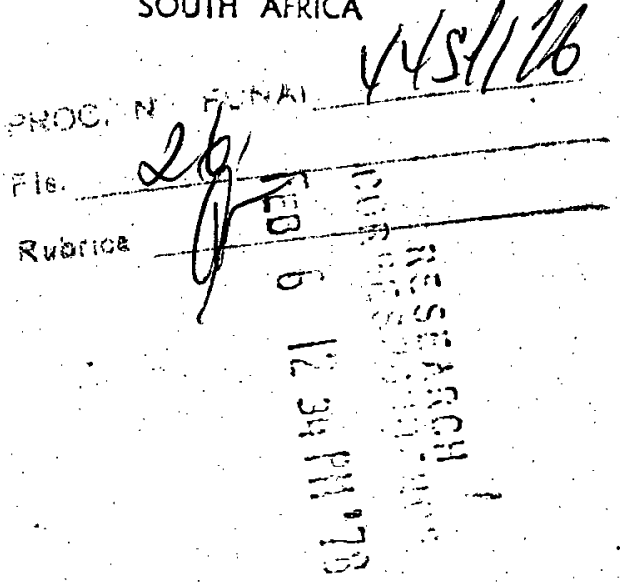

Dear Sir

BRAZIL'S UILD FRONTIER

In the abovementioned article (N.G.M. Nov 1977, 152 , 5, PP 684-719) page 701 the following statements were made:-

\section{" Diseases Ravage Jungle Tribes}

Humboldt's most dangerous enemies include microbes borne by mice, monkeys and mosquitoes. Mice transmit

$\Rightarrow$ leishmania parasites that eat away the nose and palate. Monkeys carry yellow fever. Anopheles mosquitoes spread malaria. Sand flies make fieldwork an ordeal by itch. Although Indians, too; are tormented by bugs, maybe more so in their nakedness, their most deadly illnesses are caught, from civilizados: measles, the common cold and tuberculosis.

I flew upriver to the isolated FUNAI post of Serra Morena to see how well one group of Wide Belts, who call themseves Kabano Pomons, was responding to pacification.

Not so well. Elders were coughing and spitting. "Many have suffered colds for two years" said Francisco de Assis, the FUNAI man in charge. Two women stayed in hammocks all the torrid day and cool night. They were dying of pneumonia, Assis said."

There is a considerable amount of medical evidence which indicates that the administration of vitamin $A$ : would increase the resistance of the Indiane to 
moasles, the common cold and tuberculosis.

Thomas Moore ${ }^{1}$ in his book Vitamin A has recorded that losses of vitamin $A$ occur in disease $(p .381$ chapter 32 and table 62).

MEASLES: Photophobia that occurs with measles is fue Proc. $N$ is ofue
vitamin $A$ and as a result there is an insufficient supply of vitamin $A$ to maintain the visual purple, which is $90 \%$ vitamin $A$ aldehyde. The attached letter from-Dr E H Cluver. (who undertook research for this company). confirms this contention.

PNEUMONIA: Móre has quoted a paper by Lindquist ${ }^{3}$ and reproduces a diagram illustrating the excretion of vitamin $A$ in the urine $a \dot{t}$ various stages in a typical case of pneumonia.

INFLUENZA: Colonel Drummond, Rhodesian Army, during one of my visits to Rhodesia confirmed an observation which I have made over a number of years, viz. that persons conialescing after a virus infection who overindulge in sunbathing usually suffer a relapse. I postulated that the virus infection would lower the patient's hepatic vitamin $A$ reserves and would lower his resistance - then as he starts to build up his vitamin A reserves and recover - exposure to solar UV rays would deplete the reserves. 4,5 The relapse is usually more severe than the original dose of influenza. Drummond had noted this occurence among recruits who, recuperating from influenza, sunbathed then suffered a relapse.

COLDS: I have noted that persons going on holiday straight from an indoor occupation, who sunbathe (in excess) frequently develop a 'cold'. This could be due to losses of vitamin A following insolation which would result in the sunbather becoming more susceptible to cold viruses.

Brazilian Indians wear little or no clothing and although they have a degree of pigmentation which would give them some protection from solar UU, it is probably insufficient when they are removed from the protection of their forest habitat. 
STRESS: Von Euler ${ }^{6,7}$ has shown that conscious or subconscious stress results in the excretion of Fun epinephrine. When this is considered in the light epinephrine. When this is considered in the light
of the work by Thiele and Guzinski ${ }^{8}$ who have demonst
in man and rats that adrenalin. (epinephrine) injectibns. deplete vitamin $A$, then the stress that must occur when the Indians come into contact with White civilisation would also reduce their vitamin A status.

I believe that injections or the administration of oral tablets of vitamin $A$ will help to reduce the current high mortality rate of the Brazilian Indian. Please pass the information in this letter and the references to the person who is in a position to help them.

ZINC: Since zinc is an essential catalyst in the transfer of liver reserves of vitamin $A$ to the blood serum ${ }^{9}$. it may be necessary to administer zinc supplements. Zinc deficiency is best determined by hair analysis, but one of the signs is white spots under the nails.

VITAMIN A TOXICITY: That there is minimal risk of vitamin $A$ toxicity is shown in the paper by körner and Völim ${ }^{10}$ and the attached Time/Dosage chart.

REFERENCES: If required, photostat copies of references will be sent to you. If you have any queries, please do not hesitate to write.

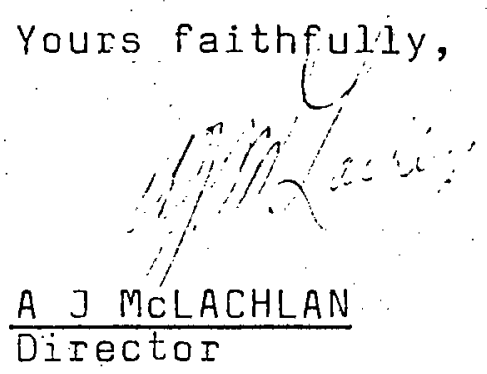

\section{REFERENCES:}

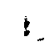

1. Moore, T. Vitamin A, Elsevicr, Amsterdam 1957.

2. Cluver, E.H. Letter to Syluachem re photophobia dated 10 January 1967

3. Lindquist, T. Studien uber las Vitamin A beim Menschen, Applebergs Boktr, iriaktiebdag, Uppsala, 1938. 
4. Urbach, E. Skin Diseases, Nutrition and Metabolism Grieve and Stratton, NY, 1946

5. Cluver, E.H. and Politzer, W.M. S.Afr.J. of Science ․, 61, August 1965

6. von Euler, U.S. and Lundberg, $U$ Physiology, 6, 9, March 1954.

7. von Euler, U.S. Clinical Pharmacology and Therapeutics, . $5,4,1964$

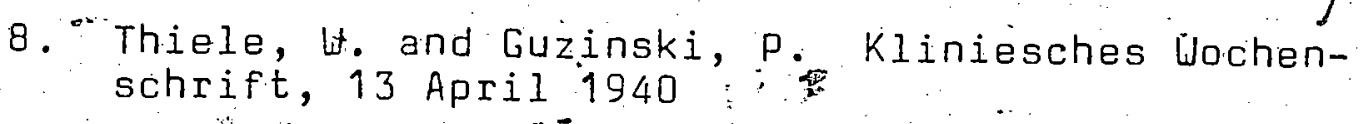
9. Smith, J.C. Jr., et al. Science, 181, 7 September

10. Körner, W.F. and Völim, J. Internat.J.Vit.Nutr.Res. 45, 1975 .

11. Dosage/Time Relationship of Vitamin A Administration Showing Onset of Side Effects.

\section{ENCLOSURES:}

No. 11 above 
DOSAGE/TIME RELATIONSHIP OF VITAMIN A ADMINISTRATION SHOWING ONSET OF SIDE EFFECTS

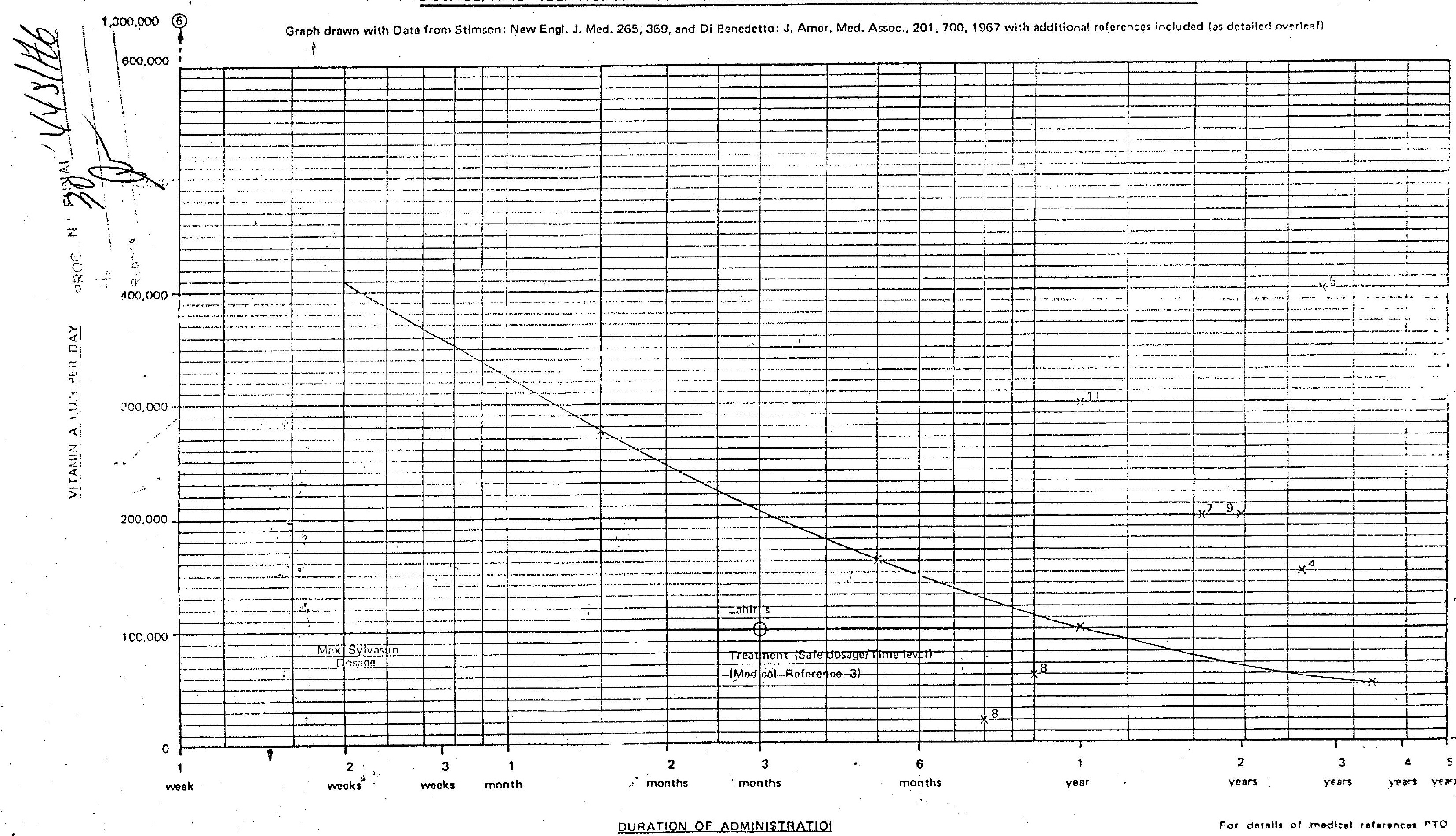


.. (1) "Vitamin A Intoxication in Adults" by W. H. Stimson in the New England Journal of Medicine, volume 265, pages 369.373, 24th August, 1961.

(2) "Chronic Hypervitaminosis A in an Adult" by R. J. Di Bènedetto in Journal of the American Medical Association, volume 201, pages 700-702, 28th August, 1967.

(3) "Vitamin A in Acne Vulgaris" by K. D. Lahiri and F. J. Scandrett in the Journal of the Indian Med. Assoc., volume 23, pages.217.249. March, 1954.

(4) "Hypercalcemia due to Hypervitaminosis A" by Gail Fisher and Penn $G$. Skillern in Journal of the American Medical Association, Volume 227, No. 12, pages 1413.1414, 25 th March, 1974.

(5) Hepatic Injury from Chronic Hypervitaminosis A resulting in Portal Hypertension and Ascites" by R. M. Russall, J. L. Boyer, S. A. Bagheri and Z. Hruban in the New England Journal of Medicine, volume 291. pages $435 \cdot 440,29$ th August, 1974.

(6) "Acute Hypervitaminosis A in an Adult" by K. I. Furman in the American Journal of Clinical Nutrition, volume 26, pages 575-577. June, 1973.

(7) "Chronic Adult Hypervitaminosis A with Hypercalcemia" by Charles M. Katz and Manuel Tzagournis in Metabolism, volume 21, No. 12. pages 1171-176, December 1972

(8) "Chronic Hypervitaminosis A with Intracranial Hypertension and Low Cerebrospinal Fluid Concentration of Prutein" by Normal J. Siegel and Thomas I. Spackman in Clinical Pediatrics, volume 11, No. 10, pages 580-584, October 1972

(9) "Vitamin A Intoxication" by Terence E. Hawkins and Daniel T. Burlon in the Journal of the American Osteopathic Association, volume 73, pages 37.9.375, January 1974.

(10) "Chronic Vitamin A Intoxication" by S. T. Teo, J. Newth and B. J. Pascoe in the Medical Journal of Australia, volume 2, pages 324.326, 18 th August 1973.

(11) "Chronic Intoxication with Vitamin A in Adults" by W. Raaschou. Nielsen in Dermatologica, volume 123, No. 5, pages 293-300, 1961.

\begin{tabular}{|c|c|c|c|}
\hline & AUTHORS & PAT & \\
\hline (1) & & & \\
\hline (2) & Di Benedetto & F & 51 \\
\hline (3) & Lahiri et al. & $39 M$ & $?$ \\
\hline & $\cdots$ & $36 \mathrm{~F}$ & $?$ \\
\hline (4) & Fisher et al. & $\mathrm{F}$ & 18 \\
\hline (5) & Russell et al. & $\mathrm{F}$ & 54 \\
\hline$\therefore$ & $\therefore \cdot \cdots \cdot$ & $\dot{M}$ & 63 \\
\hline (6) & Furman & $\mathrm{F}$ & 28 \\
\hline (7) & Katzet al. & $M$ & 18 \\
\hline (8) & Siegel et al. & $M$ & $2 \frac{1}{2}$ \\
\hline$\therefore$ & & $F$ & 1 \\
\hline (9). & Hawkins & $F$ & 15 \\
\hline (10) & Teo et al. & $F$ & 42 \\
\hline (11) & Raaschou-Nielser & $F$ & 18 \\
\hline
\end{tabular}
(IU/Oay

500,000

3 years

$100,000 \quad 3.6$ months -

$150,000: 3$ years

$100,000-1.250,000 \quad 5$ years

to $400,000 \quad 8$ years.

, $1,300,000 \quad 1$ day

$200,000 \quad 2$ years

57,$000 ; \quad 1$ year

$25,000 \quad 3$ year

200,000(?) 2 years

$90,000 \cdot 10$ years

$300,000 \quad 1$ year 
Mr. A.J. Helachlan

Director

Syirachen (Pty) Ltd.

P:0. Box 734

Pieterraritzburs; 3200

Matal, South Africa

Dear Mr. Mctachlan:

Thanis you ior your recent letter concerning the November article on the Brazil interior. The material you enclosed discussing the benefits of Vitemin A supplements has been forwarded to the authors. who works in this area frequently. I'm sure he will find this information very useful for future reference, end will pass it on to those authorities lnvolved.

Thenk you again for your concern.

के

Sincerely,

Jeanne E. Peters

Research Stafs

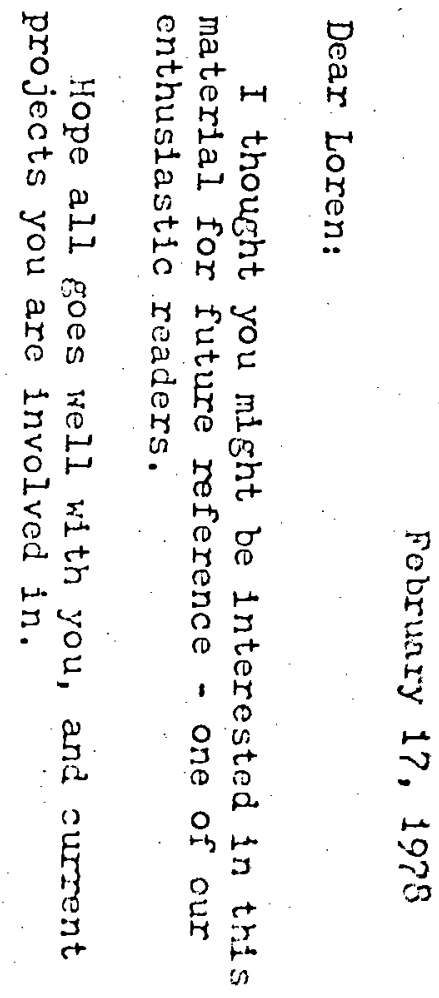




Gon wohe wiments do D CARCOS AUBERT

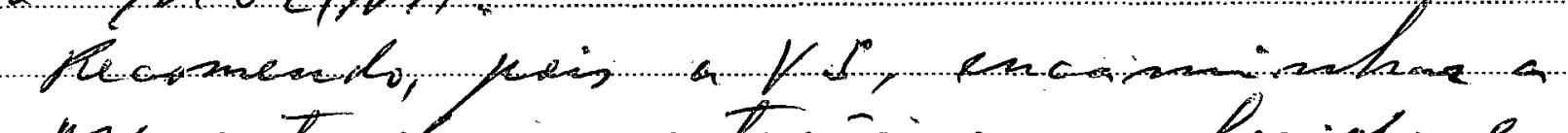

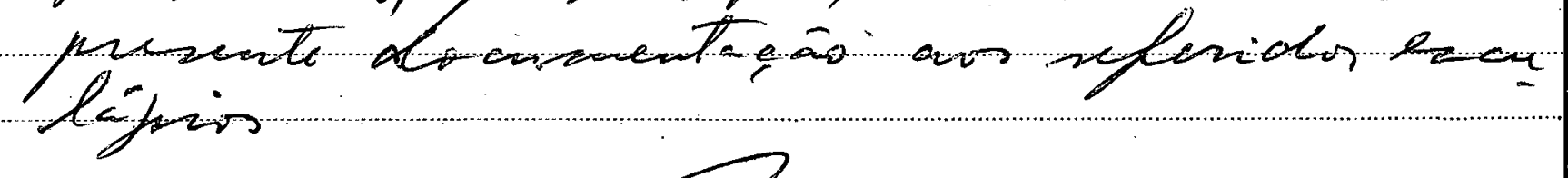

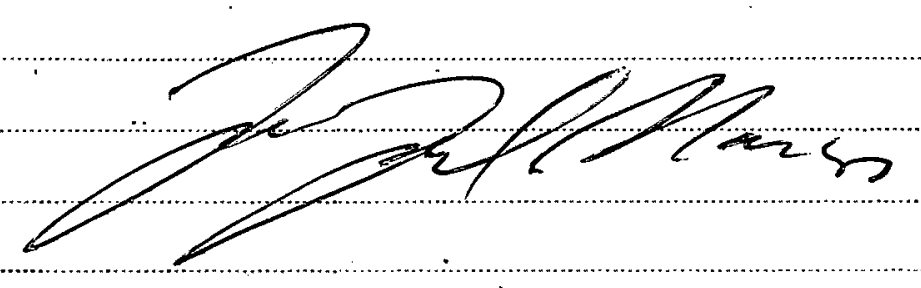
eso ler larls. asberto pera em -analise, apievintar proportos de foludás.

Cem 0.5 g. 178 .

So buetor to gGo Gulas.

Cleute. lepdo.

Selcetto enviar ao Do. Mulling, bowendo abós a liitura, endendimentur fara-uma soluced eny. IIASR 78

1 - le aucoude. 2 Cencaminle - fe eo $160 \mathrm{C}$ hora en entendiments ean o le Moline -

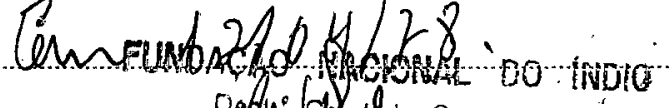

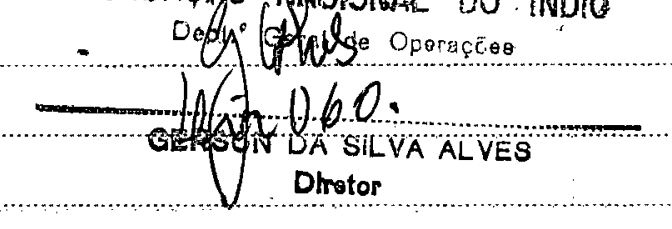


MINISTERIO DO INTERIOR

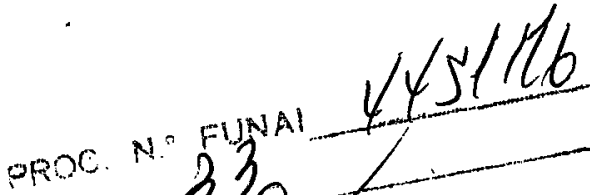
FUNDAÇÃO NACIONAL DO INDIOO F U N A I

a Secretanio pana anquizan Inpormando eue a Escola faulio tá de fedieina está exucendo Resquinan sóbre Probemas Intrieionais Reloeionados eom oloencos carenciais $B n, 03 / 10 / 70$

Otunides Abreu

os

4

Everle:

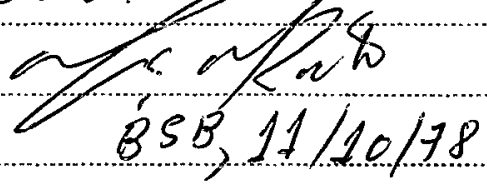




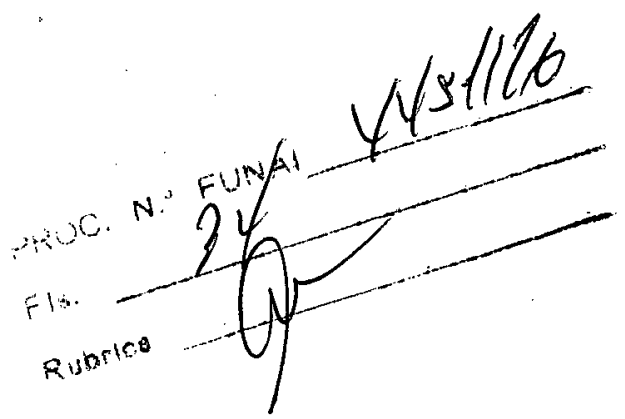

TERMO QE ANEXACÃD

Anexamos, nesta data, ao processo de ne

FUNAI/BSB/4451/76, de interesse do Sr. Wo JESCO VON

PUTTKAMER FILHO, relatório de atividades e contatos mantidos nos Estados Unidos e Alamanhä.

En, 03 de agostí de 1984

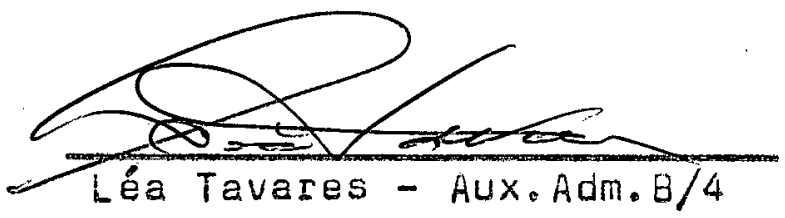


$\because$

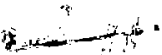

Instituto Goiano de Préhistória e Antropologia

so Universidade Católica de Goiás

Eng. ${ }^{\circ}$ W. Jesco Von Puttkamer Filho

Prof. Pesquisador Reg. Esp.

- Fone (062) 251-0103 - 74.000 - Goiânin - Goiás 


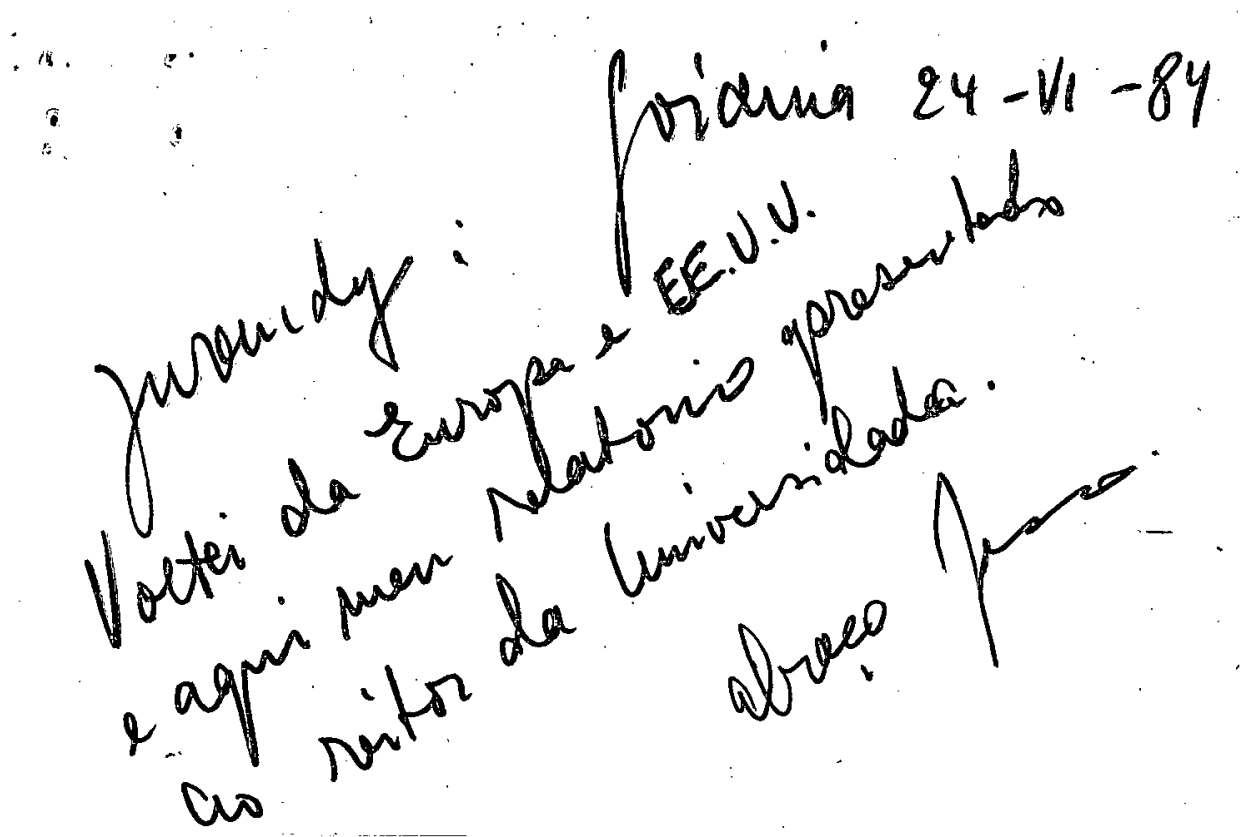


RELATORTO DE ATIVIDADES E CONTATOS BNANTIDOS NOS ESTHYOS UAYIOS E-

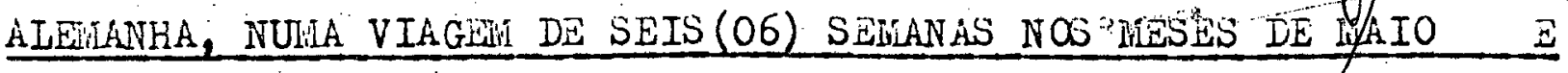

JUNHO DE 1984

Instituições contactadas:

E.U.A.

16) National Geofraphic Socizty

2) University Harward

FUNAI SEC/GAB

30) World Wildifie Fund

ALONIANH

I巨) Tuseu Etnoló cico à Berlim

2a) Depto. de ittno-música do liluseu àe Berlim

1850

3e) Universidade de Berlim

4@) Indústria Farmacêutica hoechst.

Resultados às contatos de um(OI) mês nos Estados Unidos.

\section{WATIONAL GEOGRAFHIC SOCIETY}

O pessoal da National Geograpinic gostou do material colhi do sobre os Uru iu Wau Vieu (o "FADfA") de Rondônia e resolveram fi nanciar mais uma viasem naquela regicio, afin àe complemertar cados ' para realizar una portasem àe grande estilo soble a descoberta e'

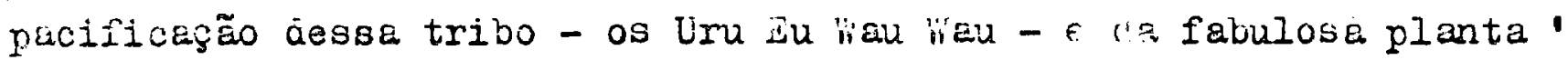
que estes ínōios àescobrirenl, talvez há milhares de enos, ajenominada

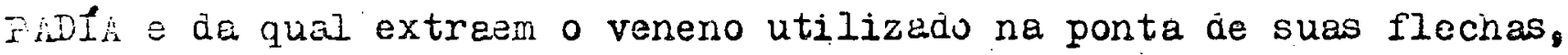
com propriedajes de anti-cokeulante.

Os recursos prevêem una estadia de três(03) meses na re -

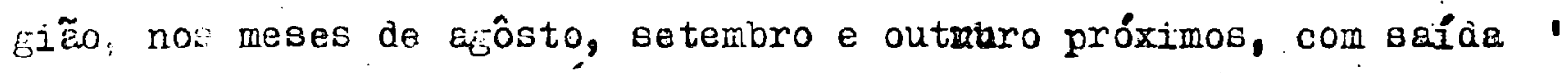
para ciezenove (19) cie ajôsto. Inclusive, o formecimento de filmes e dinieiro para custear o frete ae avião de iorto velino pura ilta if -

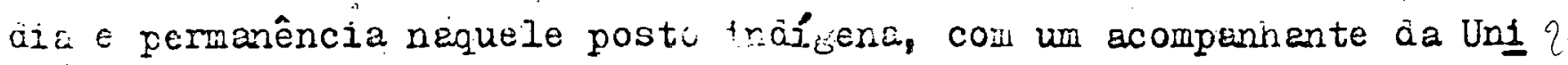
versiáade Católica de Goiés (Vanäurlei, jiério Arrudi ou outro). No c. so ào acompanhante i Universidade Católica de Goiés teria que ar - 
car apenes com a viagem de ida e volta de Goiania-por

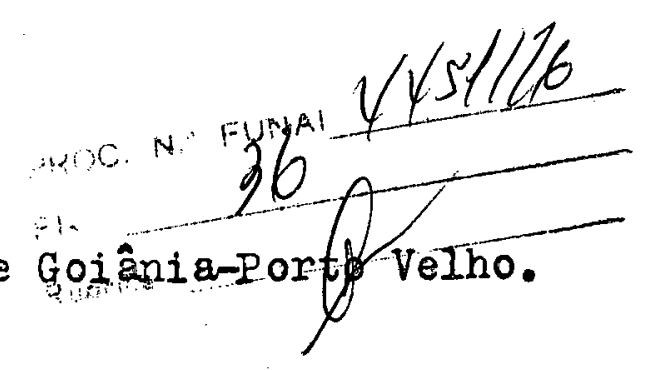

\section{UNIVERS ITY HARIYARD}

Na sede da National Geographic em Washington, recebi uma equipe de pesquisadores da Universidade de Harward, coordenaảa pelo Dr. ilark J. Plotkin, Etnobotênico, interesaados em entrosar com as equipes de pesquia da Universidade Católica de Goiás-IGPA, a serem constituídas, para realização conjunta de estudos nesta área cientí fica, principalmente na região de Rondônia, na área de Alta If́ia território indfgena Uru Eu Wau Wau, a partir da descoberta da planta FADLA usades por estes ĺndios.

O pessoal da Universidade de Harward, oportunamente irão procurar a Universióade Católica de coiás para efetivação das intenções manifestadas nesse encontro.

Entretanto, como vemos feler maje adiante, a Universidade de Berlim já vai mandar agora em agôsto, a nosso convite, um dou toranào para iniciar os contatos visando estabelecer un convênio de cooperação entre a UCG e aquela Universidade e realizar sua tese de doutorado sobre O PADIA. Assim convinha adiar para o ano que vem a participação da Universidade de fiarward nos trabalhos da UCG, para' evitar ur atrito entre as duas Universidades.

\section{WORLD VILELIFE FUND}

Também en iashington, recebi na sede da National Geographic para um alnoço, : Senhora liary O'Greày, uma das diretoras àessa. instituição filantrópica, que procurau estudar e conhecer a vida dos aninaic e sua preservaça. O interesse deles, seria em estuãar' a ecolorie e vida dos animais na área dos Uru Eu Wau Vau, pratica mente ùesconhecida e intocada neste aspécto. Também pretenderi reali zar os trebalhos em conjunto com . Iniversidade Católica de Goiás. El zes vão procurer a Universidade e nia tem perico de atrito com nin ยนé.. 
Resultados dos contatos realizados ne Alemanha durante duas (02) semanas.

\section{MUSEU ETNOLOGICO DE BERLIM}

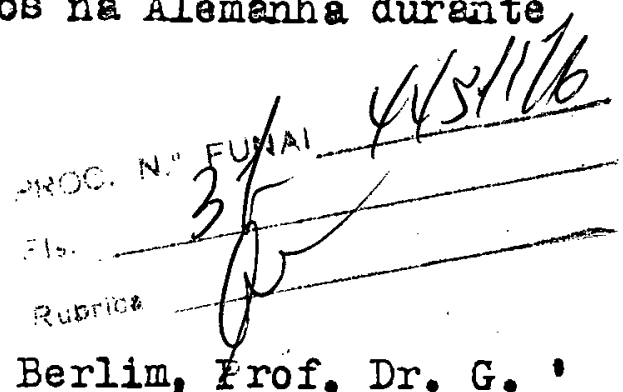

A convite do Diretor do Ilused de Berlim, trof. Dr. G.' Hartmann, hospedei em sua casa. Ali ele se intoressou em adquirir' duas mil (2.000) fotografias, de valor etnolófico incalculável, ' mas como eu queria doar estas fotografias a Universiade Católica" de Goiás, apenas permiti que tjrasse cópias (duplicata) e depois ' devolvesse os originais. O Prof. Hartmann, ainda vaj adquirir mais ou menos mil(1.000) duplicatas dos slides de Lonares, cujos orifinais voltarão e oportunamente serão doados $\dot{a}$ UCG.

\section{UNIVERSIINDE DE BERIIII}

Hospedado na cas do Prof. Hartmann, fiz conhecimento ' con aeu filho, Sr. Mathias Hartmann, que está se doutorando em HeCiicina na Universiàde de Berlim e assim, conseoui através de sua' pessoa, contato com esta Universidade.

Daí ficou resolvido o seguinte: O Sr. lhathies Hartiann, virá para o Brasil e viajarei para o Rio de Janetro para recebê-1o no lik 10 de agfisto próxiwo. Após a permanência de cinco(05) dias' no Fio, hospedado ne casa de um cuninado meu, que é nédico taniém, ' ele viré para Goiénia, devendo chegar aqui no dici wis(06) ou sete (07) de agósto. Ficará en minina casa por uns quinze(15) dias, quan ỏo vai expressar à Universidade Católica de Goiás, seu interesse ' de realizar um trabalro conjunto, seje para a realização de seu ' doutorado sobre a árvore $\mathrm{FDL}$-(se tem propriedades medicinais importartıs ou não) - seja para iniciar as conversaçôes concretas para o estäbelecimento àe um convênio da UCG com a Universiãade de ' Berliii. O que ele publicar depois sobre os Uru su Wau Wa e o Is $D i_{q}$ já toria a participaçãa da Uu...

Adiantei a y ssoal da Universidace de Berlim (e também 


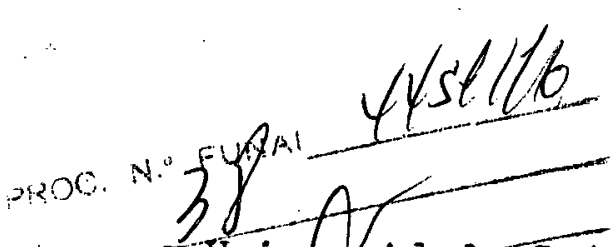

para o pessoal contactado em Washington), que a Univegesidade Católica de Goiás é pioneira em pewquisas nesta área do Qlentro-0este o Noroest由 Brasileiro, possuindo inclusive, una autorizaça e delimi tação de área de pesquisas na regtão, por parte do Conselno Nacional de Desenvolvimento Científico e Tecnológico - CNPq, grangendo tembém a área dos Uru Eu Wau Wau. Este pioneirismo advém de trabaIros de vinte(20) anos atráa, através de minha pessoa e do Prof.' Altair e hoje, atualizado pelas últimao viagems e trabalhos na regi ão, realizados por mim, Adrian Cowell, Mário Arruda, Vanderlei ' de Castro, Vicente Rios e Altair Sales. De modo geral, expliquei ' que os goianos sempre tem dado apolo para o desbravamento do cen tro-Oeste Brasileiro, primeiro através da Fundação Brasil Central' e âepois pela Universidade de Goiás, favorecendo as penetrações ' nesse área territorial.

Argumentei da necessidade de realizar pesquisas conjuga * * des de einologia, arqueologia, ecologia, botânica, zoologia, medicina, etc, neste neio ambiente do altiplano tropical, a exemplo, a regiẽo de Alta líaia, praticanerite inexplorada. E com os resulta dos destes trebalros executedos e divulgados, procurar preserver o meio ambiente original e o homem dali - o Uru Eu Wau Wau. Com es tas explicações, efetivou-se um vivo interesse de atuarem nestas ' áreas, conveniados coll a Universidade Católica de Goiás.

O Sr. Hathias Hartmann pretende permanecer uns quinze '? (15) dias em Goiônia se possfrel ssteugiando ne ?, e depois viajará conigo até Rondônia, acompanhado de majs un pesquisador da.' UCG e lé permanecerá en torno de dois(02) meses. Ele já tem recursos próprios, nocessistanòo da UCG apenas as devidas autorizações ou melhor - apresenteções às autoridades compotentes, para facilitação ha erecusão de seus trabalhos previstos em cooperação com a UCG (a negociar com a Direção do IGPA $\in$ coll o Reitor).

Lembramos, que junto com a viabilização do trabalho pre tendido pelo ir. Hathias Hartmanr, "sté implicita a pcssibilidade" prriissora de se firmar um convênio de cooperação para pesquisas,' 
prováveis recursos materiais, financeiros e humanos. Aara reat1zam ção conjunta de projetos futuros da UCG com a Univepeidade de Berlim, em favor da preservação ecológica do meio ambiente, do Indio, etc, e concomitante enriquecimento cientifico da comunidade univer sitária de ambas instituições.

No convênio com a Universı̇aade de Berlım, inclue também a possibilidade de intercâmbio de estudates astagiários visando ' aperfeiçoamento técnico-científico.

\section{DEFTO. DE ETNO IISISA DO IUSEU DE BERLTH}

Através do Dr. Artur Simon, diretor do Depto. de Etno mísica do huseu Etnolósico de Berlim, acertamos que oportunamente' viria a UCG, um técnico daquele deprrtanento, afin de estudar as gravarões sonoras registradas por mjif, junto aos índios da Amazô IIia. Adiantei a autorização para a visita de estudos e para tirar' cópias de nossas gravações, desde que seja acertaàa a cooperação: futura UCG-Depto.de Rtno-irísica do Museu à Berlim; pare langamento conjunto de um ou dois discos e cassetes, cum músicas indfrenas da Ámazônia, o que ainda não foi feito aqui.

\section{INDUSTRIA FARLIACAUTICA HOECHST}

0 último contato na Alemanina, foi na cióade de Franis furt, eìravés do Consul Geral da República Lominicana, Sr. Horst ' ii. Lettmer, que vive naquela ciàade e é amico do meu cunhaco.o ' Consul convidou a Iireģ̃ do frande Erupo farmacêutico Hoechst e outros cientístes, pira um coquetél em sua casa afim de essistirem uma projeção de duas horas de slides, de minha parte, com comentários s obre os Uru Eu Whau hau e o progresso em Rondônia e, especifi camente, sobre a planta descoberta pela Universidade Catćlica de ' Guiés, o célebre FaDli.

Diante àissc, o pesso i? ficou muito interessado e que - reli taniém, em conjunto com a UCG, cstudar essa plante para uso 
farmacêutico. Vão entrar en contato com a Univerteboge, através do seu representante no Rio de Janeiro, Dr. Ifiader.

Entretanto, considero que o mais importante no momento

é dar prioridades aos cientf́stas, deixando esta indústria para tra balhos futuros, quando já se tiver os primeiros resultados científicos em mãos.

Outro contato não mencionado, realizado na Alemania,. fol com a Revista GEO, tipo a National Geographic jociety dos E.U. A., muito grande e rica. lías, infelizmente, competidoras, Queriam que em agôsto próximo eu fosse fazer a reportagem sobre os Uru Eu' Wau Wau e o FADLA, para eles. Has, como não quero este atrito com a Nationel Geographic, disae para o pessoal da GEO que trabalho para eles a partir do ano que vem.

\section{COICLUS ח̃O}

Espero que a Universidade Católica de Goiés, através do seu iiagnífico Reitor, Pe. José Pereira de haria e do atual Diretor ào ICPA, Prof. Ellio Garcia Iuarte, apoiem os acertos que adiantel' nos Lstados Unidos e Alemanha, considerando a minha situação ali e djutância e tenào que firmar contatos que surgiram e que podem gam rantir a realização dos nossos trabalhos futuros en benefício àas' coiviniades indigenas. Entretanto, todas as pessois que procurarão a Uüi, será para ef'etivar os primeiros contatos aáiantados e a par tir àú, dentro des conóiçoes da Universidade-IGPA e suas perspoctivas de atuação fut:ra, pois ressalvei sempre a posição âa UCG de patrocinadore, orientadora e fiscalizedora dos Projetos científi cos e:ec utacos em convênio com essas instituicōes com um mínimo' de ôns de nossa parte.

Por outro lado, o contato nlais concreto de todos foi ' con a Universiadade de Berlín e Iñseu Etrolórico, pois jé em início ae arôsto próxino, como mencionamos, chegurá por aqui representantc. para concretização das propostas de colaboração e já início dos 
trabalhos de campo.

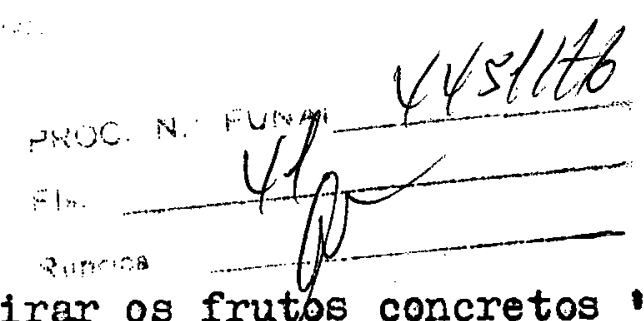

Fara receber este pessoal e tirar os frutos concretos. dos primeiros contatos, faz-se necessário que a UCG, através do ' IGPA, defina junto \& FUNAI e CIPq, seus projetos especificos de! atuação e respectivas áreas de estudo, recursos humanos e materi ais mínimos necessários. Ũtil se a reativaça do rádio para ' dar major segurança ao pesscel em campo, através da estreita comunicaร̃ão com O IGPA e Universidade.

Aproximadamente cinco mil $(5.000)$ slides serão doados no IGEA nos próximos quinze(15) dias, 10 zo após serem identificados ' por grupo tribal. O restante dos slides permanecerão na Europa e' E.U.A., até que se resolva as diverses fublicações que estão sendo cogitadas.

Com a UCG pantendo as "rélieas na mão" na amarração desses contatos ora mantidos, coloco-me a disposição da Direç̃̃̃ do ' IGPA e do ILagnífico Reitor, para ajudar com meus conhecimentos jun to à FUNAI, CNPq e instituições dos E.U.A. e Alemanha, para a definição do campo de atuação do ILPA/UCG na região do Centro-0este e Noroeste Brasileiro, através de oonvêrios de cooperaça entre as ' inúmeras instituições em pauta, para execução dos respectivos jrojetos em favor do índio brasileiro.

Anexo, xérox de memorandos enviados ao IGIA e relatórios en in lês dirieiàos à National Geographic Society, Universiáa des cie hirward, Derlin e outras instituiçôes, be cumo os nomes, ' endereços e identificação das pessoas de caña instituição contacta àa durante a viagell.

A dieposição para maiores esclarecimentos agradeço,

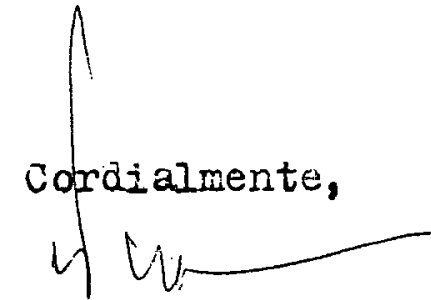

ii. Jesco von i...kamer Filho

Goiânia 20/06/84 
Relatório - Para a Universidade de Berlim, Harward (EEUU) e Parma-
Hoechst

Sobre a descoberta da nova tribo indigena na Amazonia - os asfimflteno nados "URUEU-WAU-WAU" e seu recente veneno "Padia" para fledhas letenomi

Somente em abril de 84 conseguimos sob o comando do experiente-serta nista brasileiro APOENA DE MEIRELLES pacificar e fazen o pacto de amizade com un grrupo ainda desconhecido e hostil de indigenas (cacique Djahi e caci que Dacára), e que têm o nome de "urueu-Wau-Wau", junto aos seus inimigos, donia, noroeste do Brasil.

Para nossa surpresa, foi-nos possivel observar que esses indigenas, gue falam o dialeto tupy, revelaram hábitos diferentes e não têm tido nenhura co tato ou amizade com os civilizados, a não ser de natureza hostil. Agora, que nos foi possível estabelecer relacionamento amigo, temos tido a oportunidad executar uma série de boas fotos, e a fazer algumas observacôes extraordiná
rias, principalmente na arte ornamental, ou no preparo de alimentos.

CÅRA -, que ele não fez questão de mostrar-nos um jovem cacique guerreiro UA uma árvore, para nós ainda desco mostrar-nos um de seus segredos máximos: ao que parece está nativa no altiplano tropical (600 a 800 metros de que e cuja casca fresca fornece um lúido avermelhado com 0 qual untam de altura tas de flechas, depois fixam no fogo baixo, e que produz sangram suas pon lumoso que a pessoa ou a caça (antas e porcos selvagens) sangramento tão vo essas flechaf estão irremediavelmente sujeitos com (Eles) dizem tambén que o "Padíné sujeitos á morte em poucos minutos. 1ado. Achamos que esses indios de tao potente que dissolve o sangue coagu outras plantas importantes, que poderiam interessar ámedicina

o habitat dos indigenas Urueu-Wau-Wau está no altiplano de ros, denominado Alta lídia. Possui muitas cadeias montanhosas, entre elas, as montanhas de Paacas Novas, com 800 metros em altura. No meio existe uma planicie tipo savana, e é origem de todos principais rios na região (Jarújamari-Cautário-Urupá-Paacas Novas-Jacyparaná, além de outros). Ainda está completamente virgem do invasor branco, seu tamanho é no mínimo 100 por 100 milhas em largura. Na região fronteiriça das cadeias montanhosas e do savana cerejeira, cacaueiro florestas tropicais, com muita madeira nobre, mogno, dancia, há também uma rica fauna - antas, porcos selvagens, capivaras, papa
gaios, araras vermelhas. Os rios são ricos ema inúmeras quedas d'água com rios são ricos em peixe, alta qualidade.' Há pação humana (paleoíndia); não muitonante altura, cavernas com restos da ocu Miller e eu realizamos escavações'no distante do local, o professor Eurico de homens com mais de 20 mil anos. no abrigo sob a rocha e encontramos restos

A vegetação é bastante diferente (Vide: NGM-"Abrigo do sol".)

altiplanos tropicais, os indios conhecem plica, aparentemente tipica nos esta "Padia", além de outras. Sem exagem plantas estranhas, como por exemplo é um paraíso ecológico.

Infelizmente, é tam

terita, e como agora temos obtido muitos minerais preciosos - ouro e cassi grupos de aventureiros - garimpeiros, peleiros, extratores digenas, mitos tão invadindo a terra dos indios, muito embora extratores de borracha - es Governo federal que a área pertence ao Parque seja o fato declarado pelo na. E estão abrindo pistas de pouso clandestino no meio do, reserva indíge de motoserras leves. Por causa das extensões ino no meio do mato, com auxilio rencla não pode ser evitada, e há grande perigo distancias eñormes, tal ocor cia dos indígenas, da fauna animal grande perigo atualmente para a sobreviven

Por causa disso, florestas, e dos sitios arqueológicos. encarregada pelo CNPq (Conselho Nacional de Pesquisas) sos materiais (dinheiro) estudar esta região.

assinado: Prof. Wolf Jesco von Puttkamer Junho 1984 
REPORT - TO UHIVERSITY OF BERLIN, HAOLUARD(USA) AND FARMA-HOECHST.

ABDUT THE OISCOVERY OF A NEW BRAZILIAN INDIAN TRIBE IN AMAZONIA; THE SO CALLED "URUEU WAU WAU" ANDBTHEIR NEW ARROW-POISSON "P A D I A ".

Only in Aprll of 1984 wa succeadad, under the cammand of the experianced brazilian indlan expert APOENA DE MEIRELLES, in making peace and fdiendship with a group of still not known and hostlie indlans (ckeaf Djahi and chlef Decára) andHwhich are called the "URUEU WAU WAU $n$ bei thelr eneobas and live on a troplcal High-Plateau $80 m 8180 \mathrm{~km}$ south from the town Porto Velho in the 5tate of Rondonia, in north west Brazll.

To our surprize we were eble to observe that these indians, who speak a TUPI-dialekt, revealed very diffarant customs and have also not had any contacts or friendship with olvilized peoples, except hostile. Now as we were able to stablish friendly relationshipe, we were able to make a series of good photographs and to make some extraordinary observations, mainly concerning thelr way to adorn themsolves or to prepare their meals. We succeeded to make such a good friendschip withthe youg warriorchief UACARA, that he did not mind to show to us one of thelr major $8 \mathrm{a}$ crats a tree which we still do not know and to whom they give the neme PADIA and whichbapparently grows only on such tropical high-plataaus (6oo to 800 meterg Jand from whos fresh bark they extract a redisch juice which they put on their arrow-hesds, afterwards fixing it bover a small fios and whi ch produces such a strong bleeding on Persons or big gams (as pepirs and wild plggs) wounded by them with their arrows, that the victims have to dye in a very fow minutes. They also say that the padia is so strong that it dissolves the coagulated blood. We think that these very intelligent indians know et111 other lmportant plants which might be interesting for medicine.

The habitat of these URUEU WAU WAU indians consists of a great and 600-800 meter high Plateau, and which we call ALTA LIDIA. It has many mountain chains amorigt those the mountaios of Paacas Novas which are 8oo meters high. It contains in its middle a great stripe of Savanahland and is the source of all the main rivers of the rebion (Jarl - Jomarl - Cautário - Urupk Paecas Noves - Jacyparana end others). It is yet still completelly untouched by white invadors and 1 ts $51 z e$ is at least $100 x 100$ miles. On tha border of the mountain chains and the savanah begin pertile tropical forests with many precious timbers such as mahegony. "Cerejelra" and also wild cacos and many species of frultbearing palm tress. Because of this abundancs It is also very rlch on wild life, such as tapirs, wild piggs, cablbaras, parrots and red macaws. The rivers are full of good plshes. There exist many high wetertells and caves with the remains of anclant human occupetion(paleoindlans ) fnd not 80 far from there Professor Eurico Miller and mysolf have made excavations in a rockshelter and found ramains of men which are up to 20.000 years old (88e also National Geographic Magazine : ABRIGO OO $50 L$ ).

The vegetation is very different and stragge and apparantio tipical for such troplcal High Platsaus, and the indiens know strange Plants. a for instance this PADIA and others. Without any axageration one can say that this is an ecological paradisa.

Unfortunatally it 18 also the sits of many preclous minerels such as gold and tin-ore (cassiterite) end as now we have succeeded in mekinggthe friendship with these indians, many groups of adventurese such as goldminers, skin-hunters, rubber tappers are Invading the indiens land, in spite of the fact thet the federal Government declared it es Indian Reservation. and making clandestine elrstrips in middst of the forests with small motorsaws. Because of the enourmous extansions and distances this also can be almost inavoided and a graat denger exists now for the survival of the indians, the ulddife, the forests and the archeological sites.

Eecause of this if ona could halp the Univarsity of Goles which has been encharged by the CNPq (Conselho Nacional ds Pesquizas) to study this region, with human and Pinantial resources.

74.000 Golania-Go - june 1984. Caixa Postal, 310 - Brez11

Prof.Wolf Jesco von Puttkemer

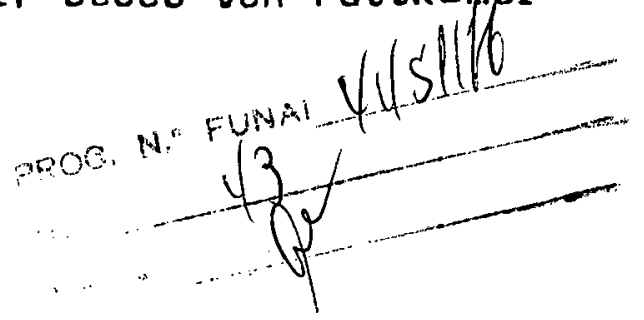


EXMO. SNR.

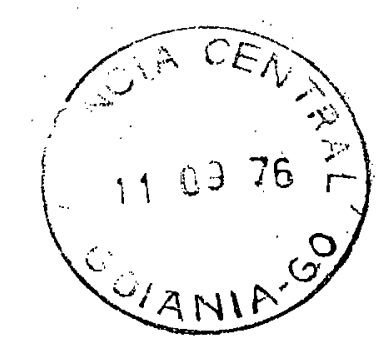

leneral ismarth araujo de oliveira n.d. Presidente da funaí

$$
\text { IJRASILIA-D,F. }
$$

Edí́cio Alvorada 



\section{MINISTERIO DO INTERIOR}

FUNDACAAO NACIONAL DO INDIO - FUNAI

INFORMAÇÃO NO $352184=\underline{A E S P}$

Referência: Processo FUNAI/BSB/04451/76

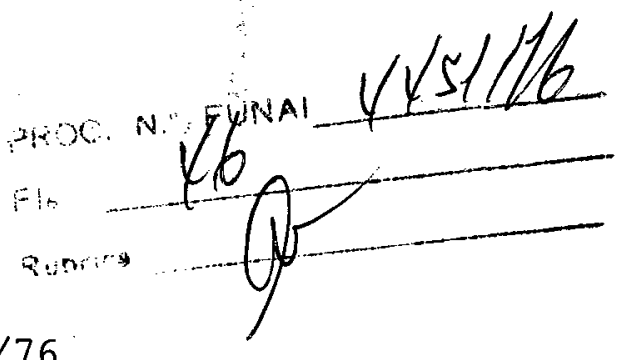

Assunto: Carta do fotógrầfo WOLF JESCO VON PUTTKAMER (FILHO)

Senhor Assessor Chefe da AESP,

Em que pese a fraternal amizade, que por mais de quinze anos nos une ao excelente fotógrafo WOLF JESCO VON PUTTKAMER (FILHO), não podemos nos furtar de analisar o presente processo à luz da Portaria 90́7/N de 18 de maio de 1984 e da Legislação concernente aos direitos autorais e conexos, visando ao cumprimento da nobre missão incumbida pelo Governo Federal à Fundação Nacional do Indio, qual seja, a defesa intransigente dos interes ses dos nossos tutelados: o indígena brasileiro.

Não podemos, também, deixar de avaliar o trabalho desenvolvido durante anos pelo Sr. WOLF JESCO VON PUTTKAMER (FILHO) em āreas indỉgenas do Território Nacional.

Por estes motivos, realizamos uma análise isenta de tu do que já foi documentado pelo fotógrafo em āreas indỉgenas, tomando como parâmetro saber quem mais se beneficiou com esse trabalho, se ele ou os indios.

\section{HISTORICO SOBRE AS ATIVIDADES DO FOTÓGRAFO}

Desde a época do Serviço de Proteção ao Indio - SPI,o fotógrafo e cinegrafista WOLF JESCO VON PUTTKAMER (FILHO) vem realizando trabalhos de documentação audiovisual em áreas indigenas, tendo como resultado a produção de vários filmes para' a $B B C$ de Londres, matērias para o National Geographie Magazine, gravações e cartões postais vendidos em todo o território nacio nal.

Com a extinção do SPI e conseqtlente criação da Fundação Nacional do Indio, em dezembro de 1967, prosseguiu o Sr. WOLF JESCO VON PUTTKAMER (FILHO) a visitar as āreas indígenas. Com a instalação da Fundação Nacional do Indio, conseguiu o Sr. VON PUTTKAMER (FILHO), dada a proximidade entre Goiânia, onde reside, e a Capital da República, conquistar a amizade e confian 


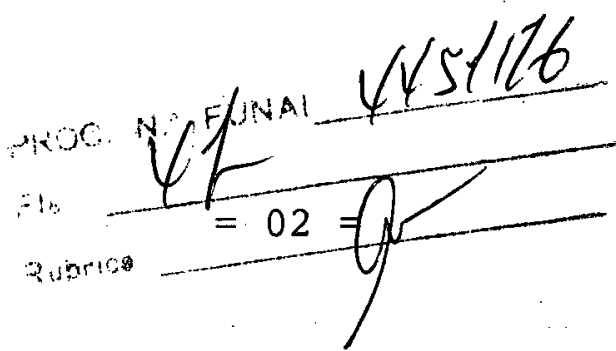

Ça dos dirigentes do órgão tutelar, notadamente dos presidentes JOSE DE QUEIROZ CAMPOS, OSCAR JERONYMO BANDEIRA DE MELLO ISMARTH DE ARAOJO OLIVEIRA, os quais, por diversas vezes, o fotógrafo acompanhou quando de viagens de inspeção à āreas indígenas.

Foi graças a esta confiança que o fotógrafo WOLF JES CO VON PUTTKAMER (FILHO) obteve dos sucessivos Presidentes desta Fundação, uma credencial permitindo seu ingresso em qualquer ārea indigena do país, motivo pelo qual ficamos impedidos de rea lizar um levantamento detalhado de todos os trabalhos realizados pelo referido fotógrafo.

Com a designação do fotógrafo WOLF JESCO VON PUTTKA MER (FILHO) ao cargo de professor pesquisador (Reg. esp.) do Instituto Goiano de Pré-história e Antropologia da Universidade Catōlica de Goiās, na gestão do Presidente ISMARTH DE ARAOUJO OLIVEIRA, tornou-se mais dificil o ingresso do Sr. JESCO VON PUTTKAMER (FILHO), mas, mesmo assim, o mesmo continuou visitando āreas indígenas, valendo-se da amizade que, com o correr dos anos, consolidou com vārios servidores desta Fundação.

Cabe destacar que no Processo FUNAI/BSB/02487/78 no verso da fl. 3, consta uma informação da então Chefe da Divisão de Estudos e Pesquisas do DGPC, Sra. DELVAIR MONTAGNER MELATTI de que "O Sr. JESCO não possui nenhum documento na Divisão e nunca pediu autorização formal apesar de 6 anos entrar em área indígena e comercializar fotos, slides e filmes, sem nunca ter dado nada em troca aos indios". (o grifo é nosso)

Já na folha 33 do mesmo processo, consta um parecer do Núcleo de Arqueologia do Museu do Indio do qual julgamos importante destacar o seguinte ponto:

"h) - por fim, manifestamos nossa estranheza quanto ao fato de o interessado, em cinco objetivos a que se propõe, citar, por três vezes, o ouro como alvo, quais sejam:

item 2) - Cemitério Inca - "... e mesmo uma peça de ouro ...." 
item 3) - Cidades Perdidas - "... gostaríamos de encontrar os sitios antigos desses antigos garimpeiros de ouro ..."

item 4) - Velha Capital do Ouro -

(o grifo é nosso)

Convém destacar que à folha no 22 do mesmo processo, encontra-se uma fotografia de recorte de jornal onde sob o titu lo "JESCO" uma reportagem conta a"vida desse fotógrafo e onde consta que "Desde cedo se interessou pelo sertão e pelo índio, quando viajava com seu pai pelas minas de ouro e manganês ou garimpo de diamantes..."

Não resta dúvida que analisando a reportagem e o parecer do Núcleo de Arqueologia do Museu do Indio, muitas dúvidas ficam no ar.

No mesmo parecer, no verso da folha no 34, encontramos o seguinte parecer da Antropóloga DELVAIR MONTAGNER MELATTI, datado de 6 de abril de 1979:

"Indeferimos o pedido de autorização solicitado pelo Sr. JESCO, por não ter formação em Antropologia e Ar queologia. Se nova autorização foi solicitada, como fotógrafo, deverá completar a documentação da Portaria $448 / \mathrm{N}$. O Sr. JESCO comercializa fotos (cartões postais) e slides sem que a FUNAI cobre as taxas regulamentares. Urge que a pJ providencie com urgência as normas de pagamento para por fim a esta exploração. O Sr. JESCO nunca cumpriu as portarias e não teve um assessoramento antropológico, por conseguinte seu material é de péssima qualidade etnográfica (posada, atitudes artificiais, fotos tomadas por solicitação ...). Atualmente os sertanistas ou delegados autorizam fotógrafos, cinegrafistas a lhes acompanharem em frente de atração. Se existe uma Portaria assi nada por presidente, parecer óbvio que todos devem cumpri-la e não apenas alguns. Isto ocasiona melindres a aqueles que cumprem religiosamente o solicita do pela DEP..." (o grifo é nosso). 


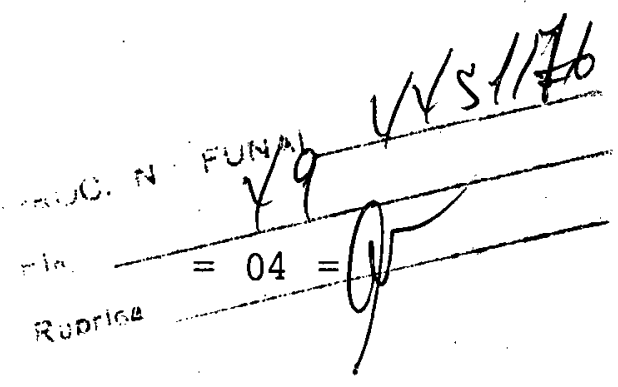

Jā a folha no 41 do Processo FUNAI/BSB/02487/78 supracitado, encontramos uma informação com o título "CARTÕES POS TAIS - PROVIDENCIAS" onde no item no 1 diz: "Verificar se o Sr. JESCO VON PATTKAMER possui autorização para ingresso em área in dígena e tomar as medidas que julgar convenientes para impedir a. comercialização de fotos. Caso não tenha autorização, determinar vigilância do DGPC no sentido de não conceder nova autorização. O item no 2 solicita "acionar a Assessoria Jurídica para impedir comercialização dos cartões postais da MERCATOR sem que o indio usufrua benefício desse comércio. Finalmente o item no 4 solicita "adotar providências para que o Sr. JESCO VON PUTTKAMER forneça à FUNAI cōpias de todas as fotos, slides e filmes realizados em ārea indígena".

Em 2 de outubro de 1979 o então diretor do DGA exarou o seguinte despacho: "A Chefe DAI - Providenciar quanto ao item 1 e, a seguir, falar comigo sobre os demais itens".

Finalmente, em 16 de outubro, após ser informado pe 1o DGPC que o Sr. JESCO não possui autorização para ingresso em ārea indígena o Sr. Diretor do DGA, inexplicavelmente, exarou co mo despacho: "Ao Chefe do DAI - Ciente. Arquive-se", sem que o processo tenha sido encaminhado à Procuradoria Juridica, como solicitado.

No que diz respeito à comercialização de cartões pos tais utilizando fotos tiradas pelo Sr. WOLF JESCO VON PUTTKAMER, cabe ressaltar que a firma MERCATOR, sediada em são Paulo, hã anos vem imprimindo uma sērie de cartões postais sob o título "Brasil Nativo" jā tendo sido coletado por nōs dezenas de cartões diferentes, sendo o número mais elevado da sērie no 62 (ses senta e dois), sem que o indio tenha recebido um só centavo a tî tulo de direito de imagem, como determina a Lei no 5.988/73 que regula os direitos autorais.

Finalmente, para não nos alongarmos mais. neste his tōrico sobre as atividades do Fotógrafo Sr. JESCO VON PUTTKAMER (FILHO), desejamos reproduzir alguns trechos da Informação no 390/83-AESP, da lavra da Antropóloga OTILIA MARIA CORREA DA ESCOSSIA NOGUEIRA: 
"- segundo informações prestadas por elenentos Assessoria de Comunicação Social, o Sr. JESCO apresentou a esta Fundação, em sua maioria, material rejeitado pela Revista "NATIONAL GEOGRAPHIC MAGAZINE", com a qual o citado $\mathrm{Sr}$. mantém permanente contato, e que tal material não corresponde em hipótese alguma, ao número de entradas, por ele realizadas em áreas indjgenas, mesmo sem a devida autorização, por parte do Departamento competente deste orgão.

- a conduta do Sr. JESCo em área indígena é um assun to delicado e discutivel, conforme declarações emitidas pelas lideranças xinguanas (a exemplo Takumã e Aritana), que não permitem de forma alguma, a presença deste $\mathrm{Sr}$. no Parque Indigena do Xingu, baseados em atitudes tomadas pelo mesmo em área indigena..." (O grifo é nosso).

\section{PRETEN SÕES ATUAIS}

Em correspondência datada de 24.06.84 e enviada ao Sr. Presidente da FUNAI, o fotógrafo encaminha cópia de relatório de atividades e contatos mantidos nos Estados Unidos e Alemanha, numa viagem de seis semanas, nos meses de maio e junho deste ano, enviado ao Magnifico Reitor da Universidade Católica de Goiás.

Desse relatório, destacamos os seguintes pontos:

2.1. - Ao referir-se aos contatos mantidos com a NATIONAL GEOGRAPHIC SOCIETY; nos Estados Unidos, o fotógrafo afirma que "O pessoal da National Geographic gostou do material colhido sobre os Uru-Eu-Wau-Wau (o "Padia") de Rondônia e resolveu financiar mais uma via gem naquela região, a fim de complementar dados para realizar uma reportagem de grande estilo sobre a descoberta e pacificação dessa tribo - os Uru-EuWau-Wau - e da fabulosa planta que estes indios des cobriram, talvez há milhares de anos, denominada Pa dia e da qual extraem o veneno utilizado na ponta de suas flechas, com propriedades de anti-coagulante. (O grififo é nosso). 


\section{MINISTERIO DO INTERIOR}

FUNDACAO NACIONAL DO INDIO - FUNAI

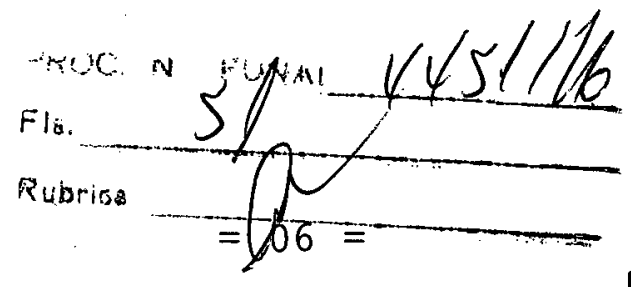

Pelo exposto, verifica-se que o fotógrafo WOLF JES CO VON PUTTKAMER (FILHO) visitou a ārea indígena Uru-Eu-Wau-Wau, ocasião em que documentou os contatos com aquele grupo tribal. Como, de acordo com a alínea IX do Art. 45, Capitulo IV do Regi mento Interno desta Fundação, aprovado em 29 de junho de 1983, incumbe ao Presidente:

"IX - conceder autorização para pesquisas, estudos e o exercício de atividades em terras indigenas por outras entidades ou pessoas estranhas ao quadro da FUNAI".

Claro está que o referido fotógrafo ingressou na área indígena sem autorização do órgão tutelar. Mesmo que esta autorização tivesse sido concedida por outra pessoa que não o Presidente, a mesma não teria a menor validade.

2.2 - Quando o Sr. JESCO VON PUTTKAMER (FILHO) relata seus contatos com a UNIVERSIDADE DE HARWARD, conta que "Na sede da National Geographic em Washington, recebi uma equipe de pesquisadores da Universidade de Harward, coordenada pelo Dr. MARK J. PLOTKIN, Etnobotânico, interessados em entrosar com as equipes de pesquisa da Universidade Catōlica de Goiás - IGPA, a serem constituidas, para realização conjunta de estu. dos nesta área científica, principalmente na Região de Rondônia, na área de Alta Lídia - território indí gena Uru-Eu-Wau-Wau, a partir da descoberta da planta PADIÁ usada: por estes índios". (o grifo é nosso) Mais adiante o fotógrafo diz que "a Universidade de Berlim já vai mandar agora em agosto, A NOSSO CONVITE, um doutourando para iniciar os contatos visando estabelecer um convênio entre a UCG e aquela Universidade e realizar sua tese de doutorado sobre o PADIÁ". (o grifo é nosso).

Como se pode observar, O Sr. JESCO VON PUTTKAMER (FI LHO), em seus contatos, seja com os representantes da Universidade de Harward, seja com a Universidade de Berlim, vem incentivando a realização de pesquisas sobre o PADIĀ na área indíge- 


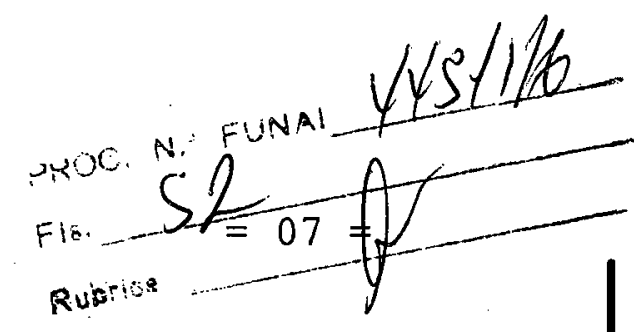

na Uru-Eu-Wau-Wau, indios de contato recente e susceptíveis, portanto, a um contágio caso a seleção de elementos que ingres sam na área indígena não seja o mais rigoroso possível.

Por outro lado, o sr. JESCO VON PUTTKAMER (FILHO)

não desconhece a legislação pertinente a pesquisas em āreas in dígenas, as quais só podem ser realizadas mediante autorização expressa do Presidente da Fundação Nacional do Indio.

2.3 - Ao referir-se aos seus contatos com a WORLD WILDLIFE FUND, durante um almoço com a sra. MARY O'GRADY, uma das'diretoras dessa instituição filantrópica, o fotógrafo afirma que "O interesse deles, seria em estudar a ecologia e vida dos animais na área dos Uru-Eu-Wau-Wau, praticamente desconhecida e intocada neste aspecto". (o grifo é nosso).

Mais uma vez, vemos o Sr. JESCO VON PUTTKAMER (FILHO) incentivar pesquisa na área indígena Uru-Ẹu-Wau-Wau. Porque este interesse em realizar pesquisas exatamente nesta área do Estado de Rondônia? Por que ñ̉a área indígena, e não em outro ponto da região, onde a fauna e ecologia são semelhantes? Certamente estas pesquisas deverão resultar em algum benefício ao fotógrafo. Quem sabe, o financiamento para a realização do seu trabalho de documentação cine-fotográfica?

2.4 - Mais ađiante, o fotógrafo WOLF JESCO VON PUTTKAMER (FILHO) relata o seu.contato com o Diretor do MUSEU DE BERLIM, Prof. G. HARTMANN e diz que "ele se interessou em adquirir duas mil (2.000) fotografias, de valor etnológico incalculável, mas como eu queria doar estas fotografias à Universidade Católica de Goiás, apenas permiti que tirasse cópias (duplicatas): e depois devolvesse os originais. O prof. Hartmann, ainda vai adquirir mais ou menos mil (1.000) duplicatas de slides de Londres, cujos originais voltarão e oportunamente serão doados à UCG". (O grifọ é nosso).

E neste ponto que se verifica o intuito de lucro nos trabalhos de documentação cinematográfica e fotográfica que o 


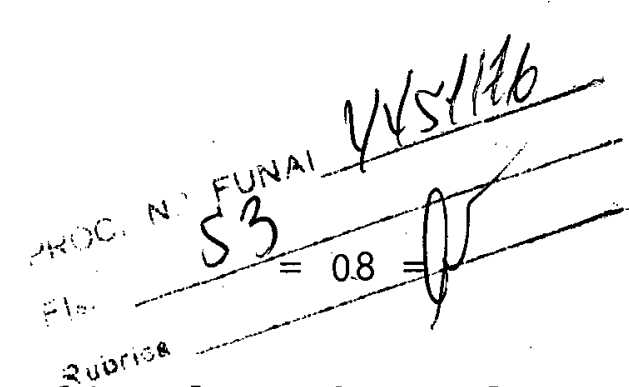

Sr. JESCO VON PUTTKAMER (FILHO) vem realizizando ao longo de todos estes anos em āreas indígenas, sem que o indio receba os direitos autorais e de imagem a que fazem juz, com base na Lei no 5.988/73 e, agora, de acordo com o que estipula a Portaria no 907/N de 18 de maio de 1984, que o Senhor presidente da FUNAI, em tão boa hora, achou por bem assinar.

Afirma o Sr. WOLF JESCO VON PUTTKAMER (FILHO) que o MUSEU DE BERLIM jā adquiriu duas mil (2.000) fotografias e vai adquirir ainda mais ou menos mil. (1.000) duplicatas de slides. Encaramos esta afirmativa como uma confissão.o fotógrafo auferindo altos lucros com a venda de fotografias e slides obtidos em área indígena - lucros estes que chegam a permitir que realize viagens periódicas aos Estados Unidos e à Alemanha - sem que os indios ou grupos tribais retratados recebam um só tostão a tîtulo de direito de imagem como determina a legislação em vigor no nosso país.

2.5 - Sobre os contatos realizados com a UNIVERSIDADE DE BERLIM, o fotógrafo JESCO VON PUTTKAMER (FILHO) afir ma que o Sr. MATHIAS HARTMANN, que está se doutoran do em Medicina naquela Universidade, virá ao Brasil em agosto, "quando vai expressar à Universidade Católica de Goiás, seu interesse de realizar um trabalho conjunto, seja para a realização de seu douto rado sobre a árvore PADIA - (se tem própriedades me dicinais importantes ou não) - seja para o estabele cimento de um convên io da UCG com a Universidade de Berlim. O que ele publicar depois sobre os Uru-EuWau-Wau e o PADIA, já teria a participação da UCG". (O grifo é nosso).

Mais adiante o Sr. JESCO VON PUTTKAMER (FILHO) afir ma haver adiantado ao pessoal da Universidade de Berlim e ao pessoal contatado nos Estados Unidos "que a Universidade Católica de Goiās è pioneira em pesquisas nesta área do Centro-Oeste e Noroeste bra sileiro, possuindo inclusive, uma autorização e delimitação de área de pesquisas na reqião, por parte do Conselho Nacional de Desenvolvimento Cientifico 


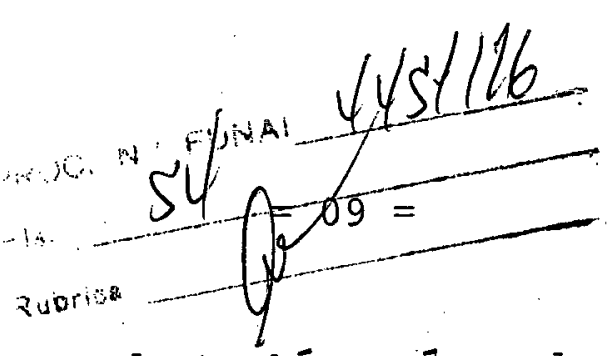

e Tecnológico - CNPq, abrangendo tambēm a ārea dos Uru-Eu-Wau-Wau". (O grifo é nosso).

Mais adiante, ○ fotógrafo afirma que "Argumentei a necessidade de realizar pesquisas conjugadas de etnologia, arqueologia, ecologia, botânica, medicina, etc, neste meio ambiente do altiplano tropical, a exemplo, a região de Alta Lídia, praticamente inexplorada". (O grifo é nosso).

Mais uma vez se constata o interesse do fotógrafo WOLF JESCO VON PUTTKAMER (FILHO) em levar pesquisadores à área indỉgena Uru-Eu-Wau-Wau visando a realizar estudos sobre a ārvore PADIA. Causa estranheza o fato do referido fotógrafo desejar que estas pesquisas se realizem na área indígena, quando po deriam ser feitos noutro ponto daquela região.

Estranhamos, também o fato de que o Conselho Nacional de Desenvolvimento Científico e Tecnológico - CNPq - tenha concedido à Universidade Católica de Goiás,autorização e delimitação de ārea de pesquisas abrangendo, também, a área dos UruEu-Wau-Wau - segundo afirma o Sr. JESCO VON PUTTKAMER (FILHO) quando é atribuição do Presidente da FUNAI conceder autorização para ingresso e pesquisas em área indígena.

2.6 - No que se refere aos contatos mantidos com o DEPARTAMENTO DE ETNO-MUSICA DO MUSEU DE BERLIM, O Sr. WOLF JESCO VON PUTTKAMER (FILHO) informa que "acertamos que oportunamente viria à UCG, um técnico daquele departamento, a fim de estudar as gravações sonoras registradas por $\mathrm{mim}$, junto aos indios da Amazônia. Adiantei a autorização para a visita de estudos e para tirar cópias de nossas gravações, desde que seja acertada a cooperação futura UCG Departamento de Etno-Música do Museu de Berlim, para lançamento conjunto de um ou do'is discos e cassetes, com música indỉgenas da Amazônia, o que ainda não foi feito agui". (O grifo é nosso).

Verifica-se, mais uma vez,que o fotógrafo WOLF JESCO VON PUTTKAMER (FILHO) durante suas visitas às áreas indíge- 
nas desenvolveu as mais variadas atividades, indulusive a gravação de músicas indígenas, que agora pretende comercializar, sem que os indios tenham recebido os direitos autorais a que fazem juz.

Observa-se, também, que o fotógrafo propôs o lançamento conjunto - UCG - Departamento de Etno-Música do Museu de Berlim - de um ou dois discos e cassetes, com músicas indígenas da Amazônia, mas que em momento algum abordou o problema relativo ao pagamento de direitos autorais aos indios ou comunidades indígenas onde tais músicas foram gravadas, conforme preceitua a Lei no 5.988/73 e agora também regulamentada pela Portaria $907 / \mathrm{N}$ de 18 de maio de 1984 .

Ademais, deve-se ressaltar que, até hoje, o sr. WOLF JESCO VON PUTTKAMER (FILHO) jamais entregou cópia das gra vações que fez em āreas indígenas, como seria de sua obrigação.

2.7 - Ainda durante a sua permanência na Alemanha, o fotógrafo WOLF JESCO VON PUTTKAMER (FILHO) manteve contatos com a INDOSTRIA FARMACEUTICA HOECHST, ocasião em que promoveu "uma projeção de duas horas de slides, de minha parte, com comentários sobre os Uru-Eu-Wau-Wau e o progresso em Rondônia e, especificamente, sobre a planta descoberta pela Universidade Católica de Goiás, o célebre PADIA.

Diante disso, o pessoal ficou muito interessado e querem também, em conjunto com a UCG, estudar essa planta para uso farmacêtico".

Novamente causa estranheza a preocupação do fotógra fo WOLF JESCO VON PUTTKAMER em promover pesquisas sobre a plan ta conhecida por PADIA, chegando ao ponto de promover uma projeção de duas horas de slides, visando a motivar o pessoal da INDOSTRIA FARMACEUTICA HOECHST, a estudar a planta para uso farmacêutico. Em momento algum se falou sobre o beneficio que a utilização dessa planta irá trazer para os indios Uru-Eu-Wau Wau. 


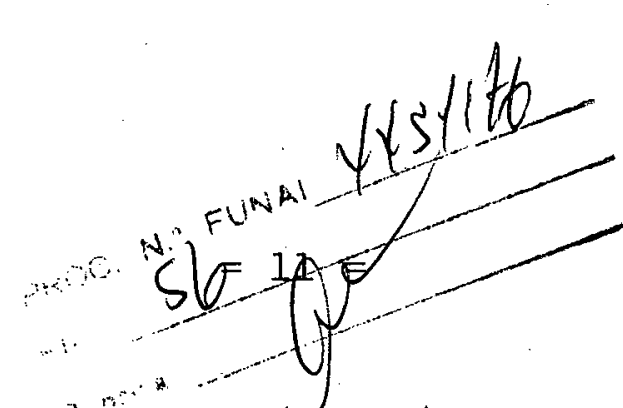

2.8 - Fala ainda o Sr. JESCO VON PUTTKAMER (FILHO) em seu relatório do contato que manteve na Alemanha com a REVISTA GEO, tipo National Geographic Society dos EUA, "muito grande e rica" - como ele mesmo afirmou. Diz ainda que "Queriam que em agosto próximo eu fosse fazer a reportagem sobre os Uru-Eu-Wau-Wau e o PADIA para eles. Mas, como não quero este atrito com a National Geographic, disse para o pessoal da GEO que trabaiho para eles a partir do ano que vem". 10 . grifo é nosso).

Como se pode observar, o fotógrafo WOLF JESCO VON PUTTKAMER (FILHO) diz que irá trabalhar, a partir do próximo ano, para a REVISTA GEO, da Alemanha, muito grande e rica. Ninguém trabalha de graça para ninguém, no mundo capitalista em que vivemos. O Sr. JESCO irá lucrar com as reportagens que fizer para a REVISTA GEO. E os indios? Vão receber alguma coisa?

Cabe perguntar, também, com autorização de quem o fotōgrafo vai ingressar na ārea indígena Uru-Eu-Wau-Wau para fazer a reportagem destinada ao NATIONAL GEOGRAPHIC MAGAZINE, se até o momento não passou por esta Assessoria qualquer solicitação, visando seu ingresso na ārea indỉgena e somente o Pre sidente da FUNAI, após ouvida a AESP, pode conceder esta autorização?

2.9 - Informa ainda o fotōgrafo WOLF JESCO VON PUTTKAMER ao encerrar seu relatório que "Aproximadamente cinco mil (5.000) slides lou serão dez mil como ele colocou à mãô) serão doados ao IGPA nos próximos quinze (15) dias, logo após serem identificados por grupo tribal. o restante dos slides permanecerão na Europa e EUA, até que se resolva as diversas publicações que estão sendo cogitadas": ( 0 grifo é nosso)

Mais uma vez, fica comprovado que o trabalho desenvolvido pelo fotógrafo WOLF JESCO VON PUTTKAMER (FILHO) ao lon go de todos estes anos continuar a auferir-lhe grandes lucros quando ele mesmo afirma que "O restante dos slides permanecerão na Europa e EUA atē que se resolva as diversas publicações que estão sendo cogitadas". (o grifo é nosso). 


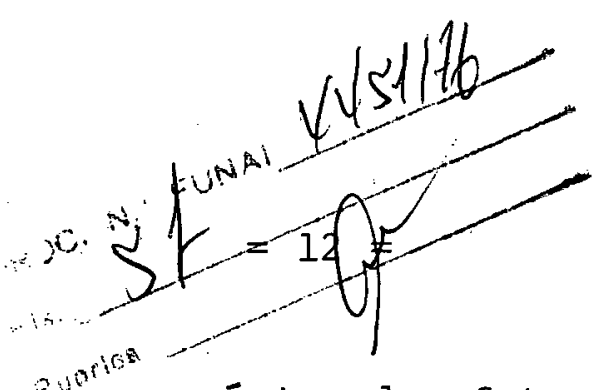

Além do mais, além de não fornecer cópias das fotos à FUNAI, como determina a Portaria que regula o ingresso em āreas indígenas, anuncia que irá doar ao Instituto Goiano de Pré-história e Antropologia "aproximadamente cinco mil (5.000) slides", "numa flagrante desconsideração para com a FUNAI, que possue em seus arquivos apenas fotos rejeitadas pelo NATIONAL GEOGRAPHIC MAGAZINE devido sua má qualidade para aproveitamento editorial.

2.10 - Ao seu relatório, o Sr. WOLF JESCO VOM PUTTKAMER (FI LHO) anexou xerox de memorandos enviiados ao IGPA, à NATIONAL GEOGRAPHIC SOCIETY, UNIVERSIDADES DE HARWARD, BERLIM e outras Instj.tuições, sobre os quais julgamos interessante tecer algumas considerações. No memorando que encaminhou para a UNIVERSIDADE DE BERLIM, HARWARD (EEUU) e FARMA-HOECHST diz o fotógra fo que "somente em abril de 84 conseguimos sob o comando do experiente sertanista brasileiro APOENA DE MEIRELLES pacificar e fazer o pacto de amizade com um grupo ainda desconhecido e hostil de indigenas (Cacique Djahi e Cacique Dacára), e que tem o nome de "Uru-Eu-Wau-Wau", junto aos seus inimigos, e habitam o altiplano tropical a $180 \mathrm{Km}$ ao sul da cidade de Porto Velho, Rondônia, Noroeste do Brasil". (0 gri fo é nosso).

Mais adiante o Sr. JESCO VON PUTTKAMER (FILHO) afirma que "temos tido a oportunidade de executar uma sé rie de boas fotos, e a fazer algumas observações extraordinárias, principalmente na arte ornamental, ou no preparo de alimentos.

Conseguimos firmar tão boa amizade, - com o jovem $\mathrm{Ca}$ cique Guerreiro UACÁRA -, que ele fez questão de mos trar-nos um dos seus segredos máximos: uma árvore, para nós ainda desconhecida, que eles chamam de "PADIA", que ao que parece está nativa no altiplano tro pical (600 a 800 rmetros de altura) e cuja casca fres ca fornece um líquido avermelhado com o qual untam suas pontas de flechas, depois fixam no fogo baixo, 
e que produz sangramento tão volumóso que q pessoa ou a caça. (antas e porcos selvagen's) quando feridos com essas flechas estão irremediavelmente sujeitos à morte em poucos minutos. Eles dizem também que o "Padía". é tão potente que dissolve o sangue coagula do. Achamos que esses indios de alta inteligência têm conhecimento de outras plantas importantes, que poderiam interessar a medicina.". (o grifo é nosso).

Jā no memorando enviado ao NATIONAL GEOGRAPHIC SOCIETY, o fotógrafo diz que "durante os últimos cinco anos, meu amigo e "afilhado", Apoena Meirelles e eu temos contatado e pacificado a tribo mais entre todas outras tribos - os Uru-Eu-Wau-Wau. Eles habitam a região de Rondônia, Brasil, $150 \mathrm{~km}$ ao sul da cidade de Porto Velho", e no outro parágrafo afir ma: "E maravilhoso que nós descobrimos uma nova tri bo, nunca contatada antes". (o grifo é nosso).

Em outro trecho desse memorando o fotógrafo informa que "por outro lado, nossa UNIVERSIDADE CATÓLICA DE GOIĀs, è pioneira nessa ārea sob pesquisa, e o CNPq doou-a para nós para estudos e documentação". (O grifo è nosso).

Neste ponto, pode se ver o artifício usado pelo fotógrafo WOLF JESCO VON. PUTTKAMER (FILHO) para impressionar as pessoas e instituições no exterior, quando afirma que "consegui mos, sob o comando do experiente sertanista Apoena Meirelles, pacificar e fazer pacto de amizade com grupo ainda desconhecido e hostil de indigenas ..." ou então quando diz que "durante os Giltimos cinco anos, meu amigo e"afilhado" Apoena Meirelles e eu temo's contactado e pacificado a tribo mais hostil entre todas outras tribos - os Uru-Eu-Wau-Wau". Isto de fato impressiona no estrangeiro, ainda mais quando a pessoa que fez esse contato é um fotógrafo profissional. Acontece que o Sr. WOLF JESCO VON PUTTKAMER (FILHO) não é sertanista da FUNAI nem, tão pouco, obteve autorização por parte da Presidência do órgão Tutelar pa ra acompanhar e documentar os trabalhos da Frente de Atração Uru-Eu-Wau-Wau. 


\section{FUNDACAO NACIONAL DO INDIO - FUNAI}

outro ponto que achamos estrantio é equando fotógrafo informa à NATIONAL GEOGRAPHIC SOCIETY qữe o CNPq "doou" à UNIVERSIDADE CATOLICA DE GOIÁs a ārea indigena Uru-Eu-Wau-Wau "para estudos e documentação", quando esta autorização deveria ser concedida - se fosse o caso - pela FUNAI.

Pelo exposto, com base no relatório enviado pelo fotógrafo WOLF JESCO VON PUTTKAMER (FILHO) ao Magnífico Reitor da Universidade Católica de Goiás, verifica-se que o referido profissional pretende continuar a realizar trabalhos de documentação audiovisual em 'áreas indígenas, no decorrer deste ano e no ano que vem, mesmo não possuindo autorização da FUNAI para ingresso nas áreas indígenas.

\section{CONCLUSŌES}

Pelo que foi exposto, conclui-se que o fotógrafo WOLF JESCO VON PUTTKAMER (FILHO) vem, há mais de 30 (trinta) anos explorando as comunidades indígenas, seja através da foto grafia, filmes ou gravações sonoras, constituindo-se tal fato numa violação da Lei no 5.988, de 14 de dezembro de 1973, que regula os direitos autorais.

Não ignoramos o disposto no Capítulo III do Título VIII da referida Lei, que trata das sanções à violação dos dí reitos do autor e direitos que lhe são conexos, e que diz no Art. 131:

"Prescreve em cinco anos a ação civil por ofensa a direitos patrimoniais do autor ou conexos, contado - prazo da data em que se deu a violação".

Acontece que, no nosso entender, salvo melhor juizo da Douta Procuradoria Jurídica, tal violação continua ocorrendo toda vez que o Sr. WOLF JESCO VON PUTTKAMER (FILHO) se utiliza de fotos, filmes e gravações para fins comerciais ou não, devendo-se considerar como "data em que se deu a violação" a data em que o material - não interessando quando foi colhido estiver sendo utilizado.

Quanto a uma possivel alegação de que ele tenha sido autorizado verbalmente pelo Presidente ou Sertanistas da 


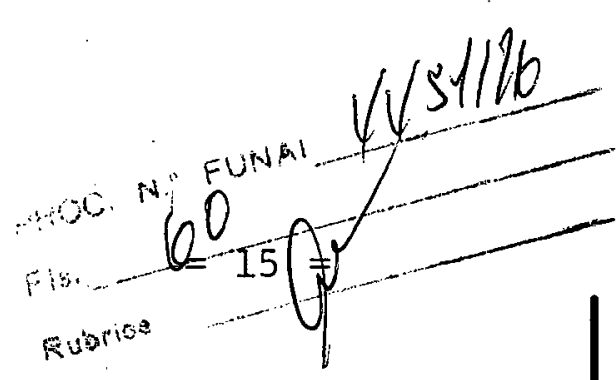

FUNAI para realizar documentação audiovisual em ārea indígena, somos de opinião que tal autorização não tem validade, limitan do-se, no máximo, ao ingresso na área indígena, uma vez que o direito de imagem é um direito personalissimo, e somente ao do no da imagem compete autorizar sua utilização, quer seja para fins comerciais ou não.

Para tanto, observe-se o que diz o artigo 29 da Lei no $5.988 / 73:$

"Cabe ao autor o direito de utilizar, fruir e dispor da obra 'literária artística ou científica, bem como o de autorizar a sua utilização ou fruição por terceiros, no todo ou em parte".

Segundo o Jurista HILDEBRANDO PONTES NETO, Membro do Conselho Nacional de Direito Autoral e do Instituto Interamericano de Direitos do Autor, no trabalho"o Indio Brasileiro e o Direito Autoral". considera que "este dispositivo, reserva ao Indio autor, e somente a ele, o direito de utilização e fruição de sua criação artística, bem como o de permitir no todo ou em parte que ela se faça através de terceiros".

Diz ainda o Jusrista HILDEBRANDO PONTES NETO que "a Lei autoral ao determinar que o autor é quem pode autorizar terceiros a explorar economicamente o seu trabalho de criação artistica, impõe que o criador seja previamente consultado e autorize ou não sobre a destinação comercial de sua obra.

u. Tal dispositivo aplica-se claramente no que diz res peito a utilização comercial de gravações em discos e cassetes com músicas indigenas, pretendidas pelo Sr. WOLF JESCO VON PUT TKAMER (FILHO).

Baseando-nos, ainda, na obra "O Indio Brasileiro e - Direito Autoral" de HILDEBRANDO PONTES NETO, verificamos que "afora reproduções dos desenhos artísticos dos índios em vasiIhames, tecidos, indumentárias, a sua arte aplicada em peças etnogrāficas, pinturas corporais, utilização de composições mùsicais e de cânticos, formas costumeiras de usurpação do seu trabalho artístico, merece destaque a violação usual de sua ima gem, um direito inserido no texto da Lei no 5.988/73". 
O Sr. JESCO VON PUTTKAMER (FILHO), repetimoś, há mais de 30 (trinta) anos vem fotografando e filmando indios em todo o território nacional. Portanto, há 30 (trinta) anos vem o referido profissional violando o direito de imagem desses indios, sem que para isso possua autorização expressa do dono da efíge representada.

Vale salientar, novamente, que não compete ao Presidente da FUNAI ou a qualquer outro representante, em nome do órgão tutelar, conceder licenças para que terceiros fotografem ou filmem o indio ou a comunidade indigena, uma vez que o direito à imagem é personalíssimo, atributo inato da personalida de do indio, por conseguinte intransferivel.

Causa espanto, também, o fato do Sr. WOLF JESCO VON PUTTKAMER (FILHO) se esforçar de todas as maneiras possiveis visando a realização de estudos sobre a planta denominada de "PADIA" pelos i̇ndios Uru-Eu-Wau-Wau, não só promovendo sua pes quisa junto a instituições internacionais, como até mesmo incentivando uma das maiores indūstrias farmacêuticas da Alema-* nha, a INDUSTRIA FARMACÊUTICA HOECHST.

Outro ponto gritante de atuação do fotógrafo WOLF JESCO VON PUTTKAMER (FILHO) diz respeito às doações de filmes, slides e gravações recolhidas por ele em āreas indígenas, ao INSTITUTO GOIANO DE PRE-HISTORIA e ANTROPOLOGIA DA UNIVERSIDADA CATOLICA.DE GOIĀS, quando a FUNAI não recebeu nem 10\% de có pias das fotos por ele colhidas e nenhum filme ou gravação tenha sido fornecido ao órgão tutelar.

Finalmente, não podemos deixar de assinalar o fato de que o fotógrafo WOLF JESCO VON PUTTKAMER (FILHO) continua comercializando fotos, slides e gravaçc̈es colhidas nas áreas indígenas por éle visitadas, como ocorreu nessa sua viagem, quan

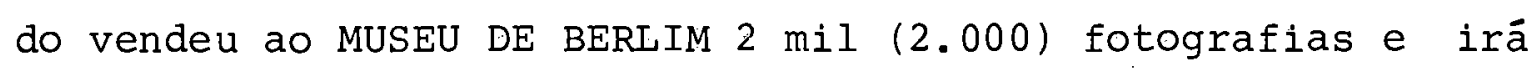
vender mais outras mil (1.000) duplicatas de slides, sem que o indio retratado tenha: qualquer participação nos lucros do fotógrafo, que certamente não são poucos. 


\section{PARECER FINAL}

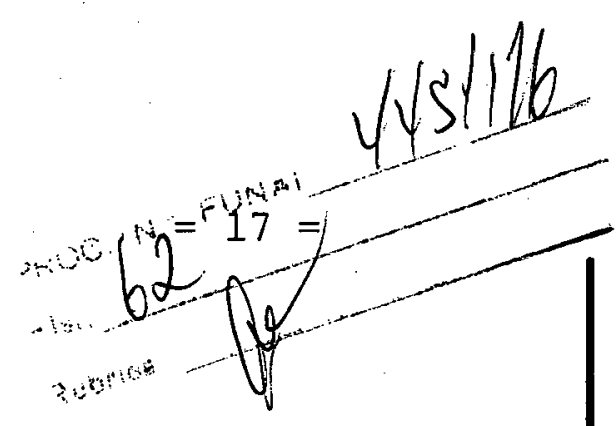

Em vista de tudo que foi exposto a respeito do fotógrafo WOLF JESCO VON PUTTKAMER (FILHO) e visando a resguardar, de maneira eficiente, os direitos autorais e de imagem das comunidades indígenas, à luz da Lei no 5.988/73 e da Portaria. $907 / \mathrm{N}$ de 18 de maio de 1984, somos, salvo melhor juizo, de opinião deva a FUNAI adotar as seguintes providências:

4.1 - Proibir o ingresso do fotógrafo WOLF JESCO VON PUTTKAMER (FILHO) em áreas indígenas até que solucione suas pendên cias para com a FUNAI e com as comunidades indigenas;

4.2 - Expedir Radiograma Circular à todas as Unidades Administrativas Regionais (Delegacias, Parques, Ajudâncias,etc) determinando que não seja permitido o ingresso do fotógrafo WOLF JESCO VON PUTTKAMER (FILHO) em ārea indígena, até ulterior deliberação;

4.3 - Alertar, por escrito, o fotógrafo WOLF JESCO VON PUTrîA MER (FILHO) de que para a comercialização de fotografias, slides, filmes, gravações, etc..., deverão ser cumprịdas as normas estabelecidas na Lei no 5.988/73 e na Portaria no 907/N de 18 de maio de 1983, sob pena de serem aplica das as sanções penais passiliveis para o caso;

4.4 - Solicitar, através da Douta Procuradoria Jurídica, ao fotōgrafo WOLF JESCO VON PUTTKAMER(FILHO), o fornecimento de cōpias de todas as fotografias, filmes e gravações recolhidas em áreas indígenas, de acordo com o disposto na Portaria no 448/N-1973 e, agora, na Portaria no 907/ $/ \mathrm{N}-1984$

4.5 - Proibir a pesquisa da planta "PADIA" na área indígena Uru-Eu-Wau-Wau (8a. DR), visto tratar-se de grupo tribal de contato recente, ainda susceptível à contaminação atravēs de contatos inadequados com elementos estranhos aos quadros da FUNAI;

4.6 - Cobrar, atravēs da Douta Procuradoria Jurídica, os direi tos de imagem sobre duas mil (2.000) fotografias e mil (1.000) slides vendidos pelo fotógrafo WOLF JESCO VON 


\section{FUNDACAAO NACIONAL DO INDIO - FUNAI}

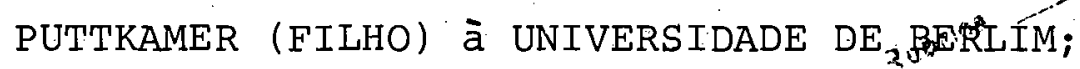

4.7 - Solicitar à Douta Procuradoria Jurídica que acione a firma MERCATOR - GRÃFICOS BRUNNER LTDA - (CP 21029 - São Pau 1o) e o Sr. WOLF JESCO VON PUTTKAMER (FILHO) visando rece ber os direitos de imagem devidos às comunidades indígenas, pela impressão e comercialização de cartões postais da série "BRASIL NATIVO";

4.8 - Encaminhar a presente informação à Douta Procuradoria Jurîdica, para análise, e execução das medidas legais cabíveis, visando resguardar os interesses da FUNAI e os direitos das comunidades indígenas, caso o fotógrafo WOLF JESCO VON PUTTKAMER (FILHO) não 'concordar em fazer um acordo amigável com esta Fundação.

Vale lembrar, ao encerrar a pressente informação, que, já em 1511, onze anos, portanto, após o descöbrimento do Brasil, a Nau Bretoa levava para Portugal uma carga de Pau Brasil e alguns animais e pāssaros engaiolados. Hoje, decorridos mais de quatro séculos, continua o nosso indio explorado em seus direitos, agora, sob a forma de fotografias, filmes e gravações, comercializadas no Brasil e no exterior. Urge, pois a adoção de medidas enérgicas visando a por fim, de uma vez por todas, com este tipo de exploração de que vềm sendo vítima nossos índios, etnia que não só a FUNAI mas todos os brasileiros tem obrigação de admirar e proteger.

E o que temos a informar, submetendo a presente, à superior consideração de V.Sa.

Brasilia, 16 de agosto de 1984 .

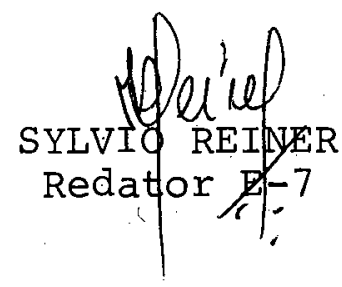

$\mathrm{AESP} / \mathrm{SR} / \mathrm{dCS}$

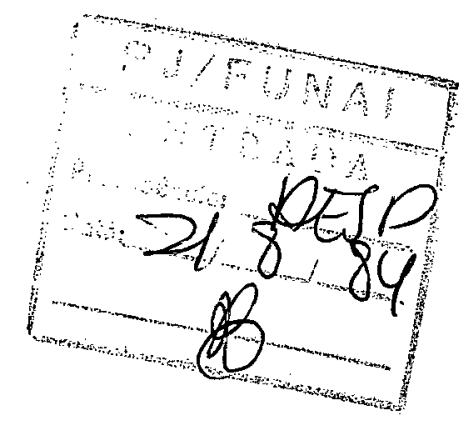


- a contidurear da Douta Prócuradona! yecidiea, solieitando as providenciass cabirreis.

Azef $20 / 08 / 84$

Assesen du witias e Resquisas

Rubens $\mathcal{E}_{u t o}$ da Cruz Olioeira Chøfo

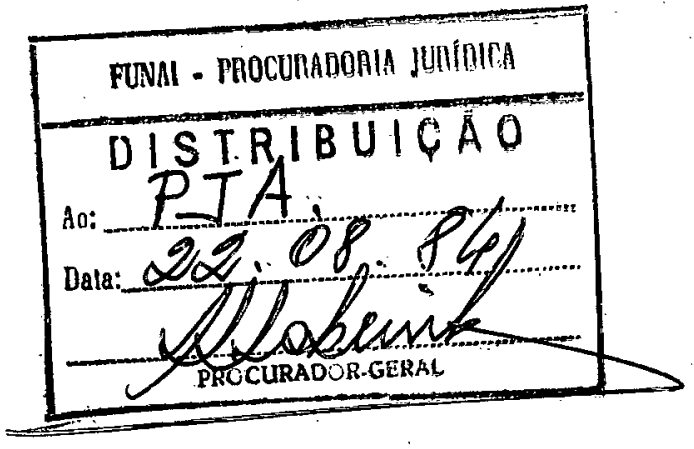


DESPACHO NQ2//PJ/84

Ref.: PROC/FUNAI/BSB/04451/76.

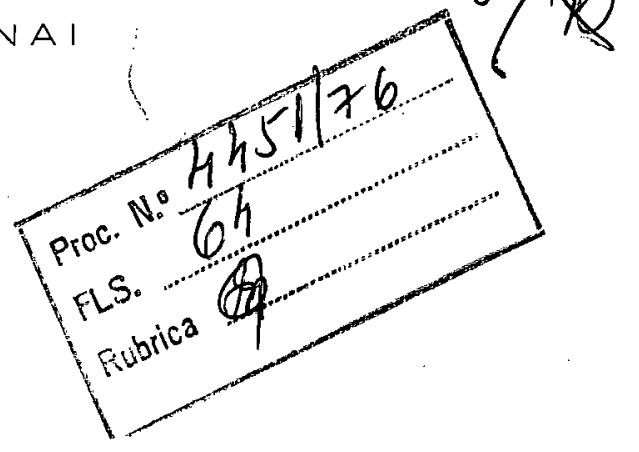

Senhor Procurador Geral,

De conformidade com as conclusões do relatório de fls. 46 à 63 , com a juntada das minutas de rädio-circular e ofícios dirigidos, respectivamente, aos Delegados' Regionais, a Firma MERCATOR-GRAFICA BRUN NER LTDA e ao Sr. WOLF JESCO VON PUTTKAMER FILHO, sugiro que o presente processo seja submetido à superior consideração da Presi dência da FUNAI.

Brasília, 24 de agosto de 1984.

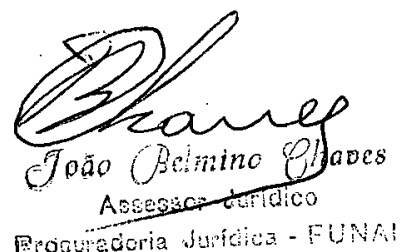

De acordo com o despacho mi $28 / 90 / 84$. Ao Suchor Pruidurte para conke ell e ascunar os ofííos e rádios ciculones anexos.

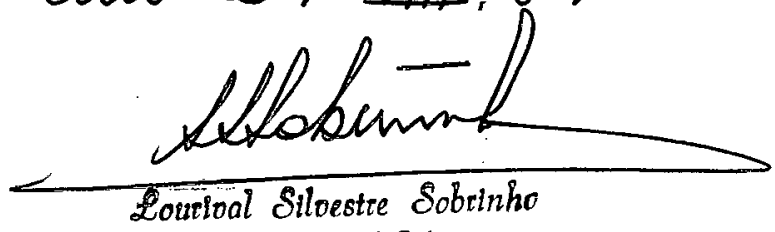




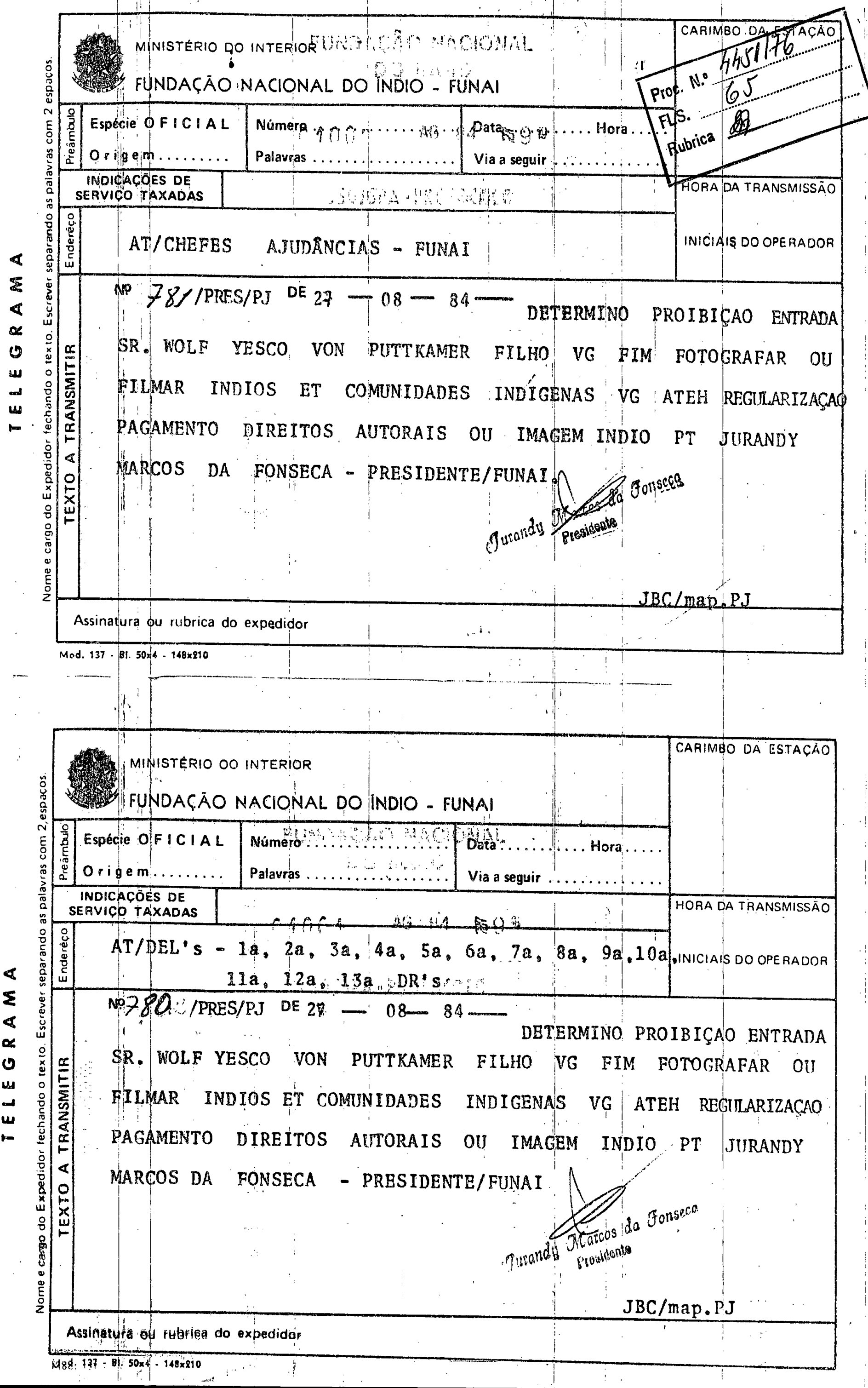


Do: Presidente da Fundação Nacional do Indio

Ao: Sr. Wolf. Yesco Von Puttkamer Filho

Assunto: Solicitaçãa (faz)

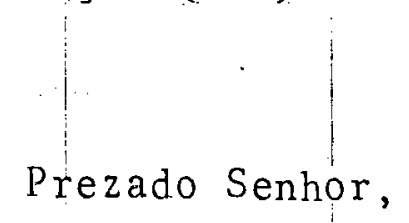

Conhecedor da ação de V.Sa em äreas indígenas, fotografando o indio, a comunidade indígena, as suas áreas e seus produtos naturais, sem autorização nem o pagamento, ao indio ou às comunidades indigenas, dos direitos autorais ou de imagem, solicit to o comparecimento de $Y . s$ a à Procuradoria Juridica, desta Ins tituição, objetivando regularizar esta situação, evitando assim constrangimento de ordem judicial.

Certo de contar com a devida compreensão, no senti do de se chegar a uma sólução amigável, aproveito a oportunidade para apresentä à V.Sạ os meus protestos de consideração e apreço.

I1m: $\mathrm{Sr}$.

WOLF YESCO VON PUTTKAMER FILHO

$74.000-601$ IึNIA -60 
FUNDAÇÁO NACIONAL DO INDIO - FUNA I-

Do

: Presidente da Fundação Nacional do Indio - FUNAI

Ao

: SrS. MERCATOR-GRAFICOS BRUNNER

Assunto : Solicitação (faz).

Tomando conhecimento da ação dessa firma, em relação a impressão e comercialização da imagem de comunidades indíge

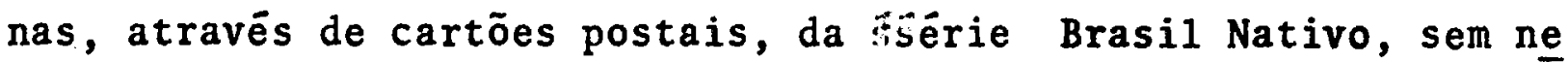
nhuma autorização nem tampouco o respectivo pagamento de diraitos autoràs ou de imagem, solictto o compatecimento de V. Sas. à Pro curadoria Jurídica, desta Instituição, objetivando regularizar es ta situacão, evitando assim constrangimento de ordem judicial.

Esperando contar com a devida compreensão, no sentido de se chegar a uma solução amigável, apresento a V. Sas. res peitosas saudações.

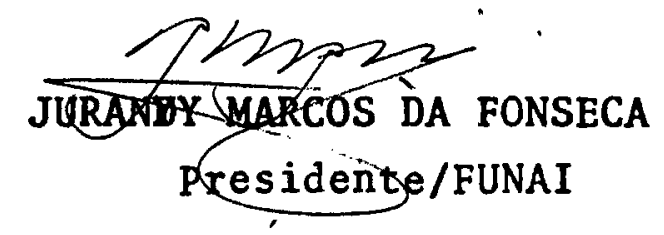

Ilms Senhores

MERCATOR - GRAFICOS BRUNNER

Caixa Postal - 21029

SAO PAULO - SP 
Anexo, nesta data, ao PROC/FUNAI/BSB/4451/76, OF. no 20/82-Instituto Goiano de Pré-histöria e Antropologia e documentação anexa, por se tratarem do mesmo assunto.

$$
\text { Brasilia, } 06 \text { de setembro de } 1984 .
$$
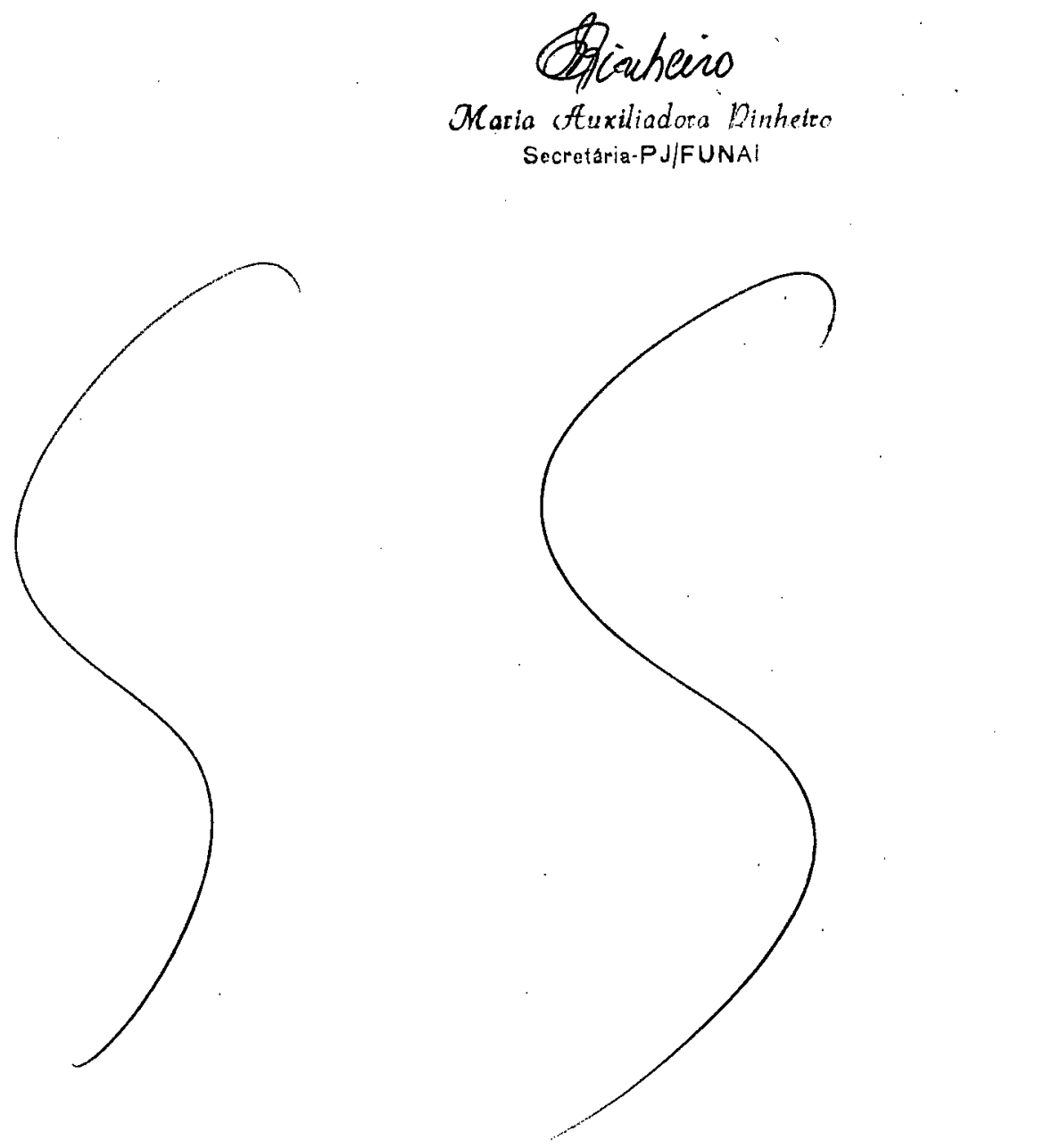


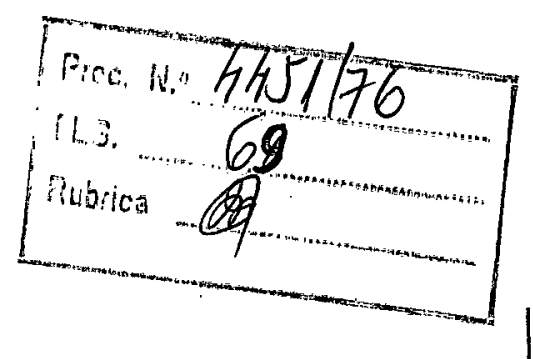

MTNNISTÉRIO DO INTERIOR

FIJNDACÃO NACIONAL DO INDIO - FUNAI

Eenhor Prourrador Griral,

Solvaitaudp, emhecer, reexauninar o arruto e, apís, eucominnhar 'e AESP.

lew 060984

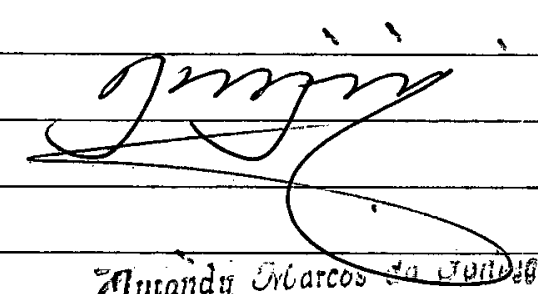

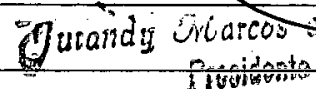
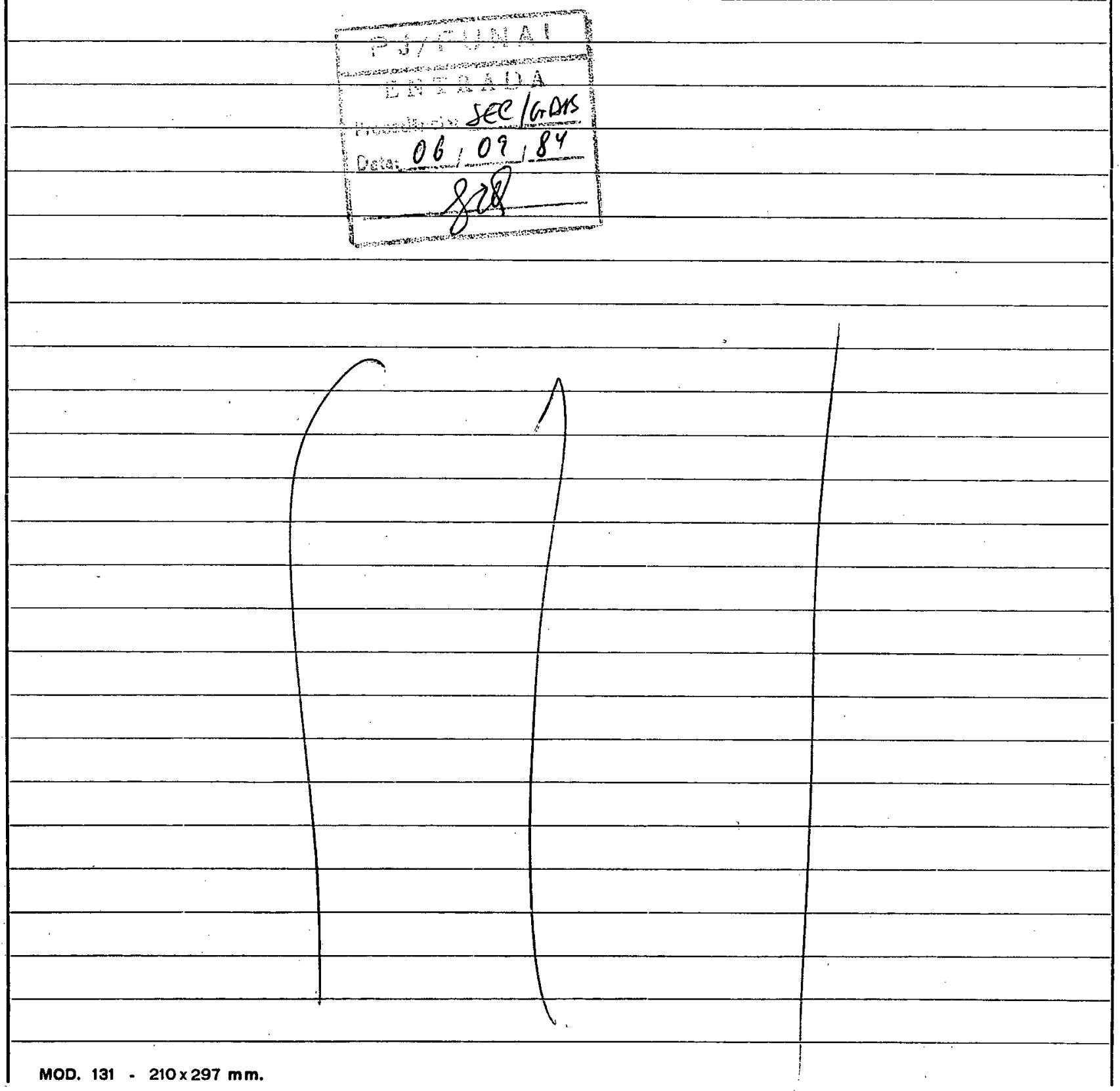
Do: Presidente da Fundação Nacional do Indio

Ao: Sr. Wolf. Yesco Von Puttkamer Filho

Assunto: Solicitação (faz)

\section{Prezado Senhor,}

Conhecedor da ação de V.Sa em áreas indígenas, fotografando o indio, a comunidade indígena, as suas áreas e seus produtos naturais, sem autorização nem o pagamento, ao indio ou às comunidades indigenas, dos direitos autorais ou de imagem, solicito o comparecimento de V.Sa à Procuradoria Jurídica, desta Ins tituição, objetivando regularizar esta situação, evitando assim constrangimento de ordem judicial.

Certo de contar com a devida compreensão, no senti do de se chegar a uma solução amigável, aproveito a oportunidade para apresentar a V.Sạ os meus protestos de consideração e apreço.

I 1 m : $\mathrm{Sr}$ 。
WOLF YESCO VON

$74.000-$ GOIANIA - GO
Jurâdy - Recebi essa carta hoje. Voltei de Rondônia me sintindo bastante doente (pressâo alta, e pernas inchadas e com uma irregularidade no coraçāo, pois sou diabético. Mas tao logo esteja melhor vou ate ai.Pedi a Universidade de responder a carta e dar os in formes desejados.

Estamos trabalhando num convenio com a. Funai.

Ats.sds.

Mod. $116 \quad J B C /$ map.PJ

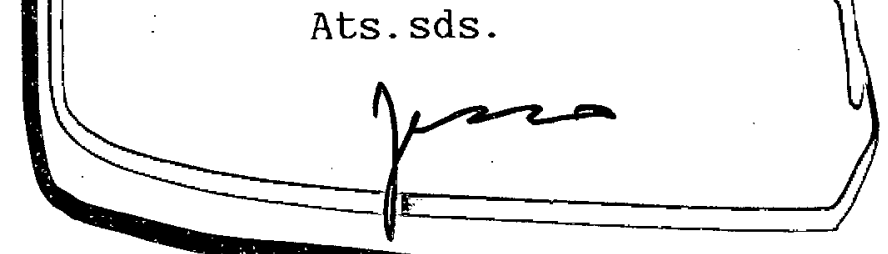


Declaro para os fins que se fizerem necessários, do interesse do CNPq, no trabalho de pesquisa fotográfica desenvolvido no território federal de Rondonia pelo Sr. JESCO VDN PUTTKAMER.

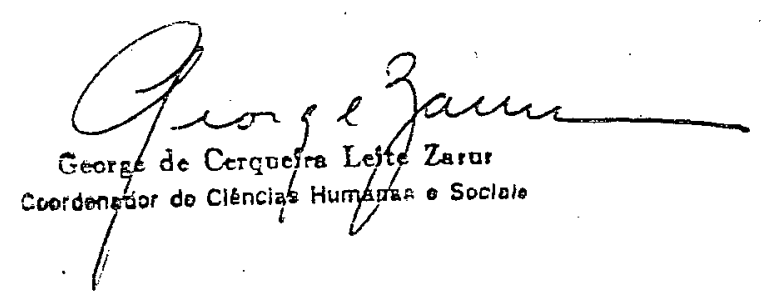


Of.n? 20/82-IGPA.

Do: Instituto Coiano de Pré-histōria e Antropologia

ĀS: Autoridades Federais, Estaduais, Municipais e

Instituições Científicas na Amazônia Brasileira.

AsSUnTC: Apreseñtação

A UNIVERSIDADE CATC̄LICA DE GOIX̄S, através de seu INS TITUTO GOIANO DE PRE-HISTÓRIA E ANTROPOLOGIA (IGPA), apresenta por mieio deste, - ENGENHEIRO WOIF JESCO VON PUTTKAMER FILHO, professor pesquisador em regime es pecial desse Instituto e responsável pelo seu setor de Documentação. Durante o ano de 1.982 deverá, a serviço dessa Universidade, realizar viagens de recorhecimentos e contatos em área da Amazônia, com a finalidade de colher subsỉdios' para un programa de pesquisas sistemáticas.

Considerando a relevância desse trabalho, apoiado pe 1o $\mathrm{CNPq}$ e demais autoridades competentes nacionais e internacionais, e sua im portância para o enriquecimento do acervo científico nacional, vimos solicitar' para o nosso apresentado, todo apoio possivel por parte das Instituições congêneres na Ámazônia Erasileira e por parte das Autoridades Federais, Estaduais Municipais.

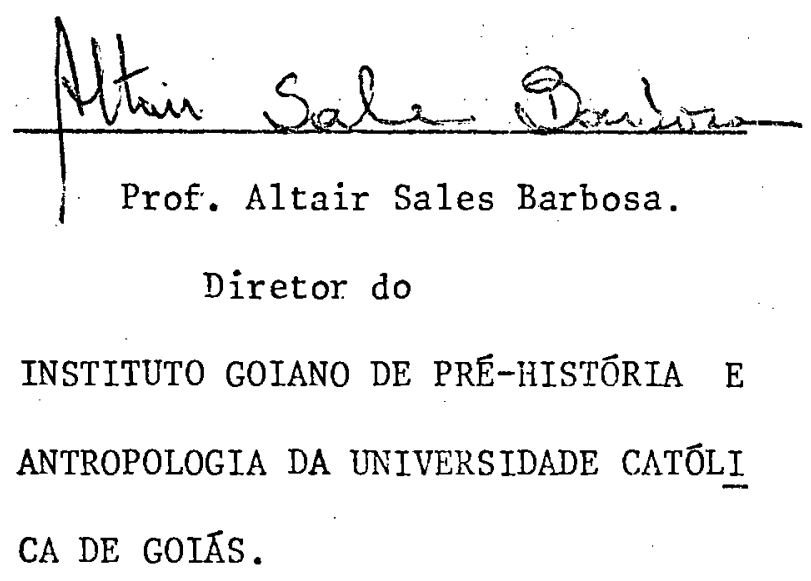




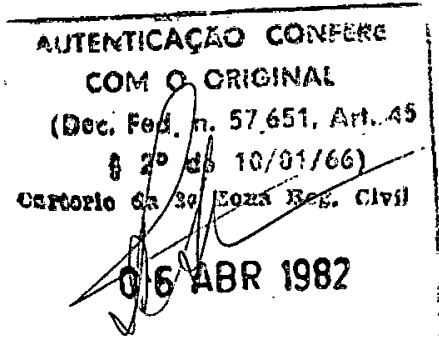

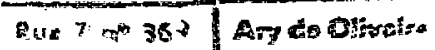

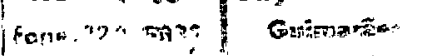
$\therefore \therefore$ 
Desco

$$
\text { C.P. } 310
$$

74.000 GOIANIA-40 
$S / O A B$
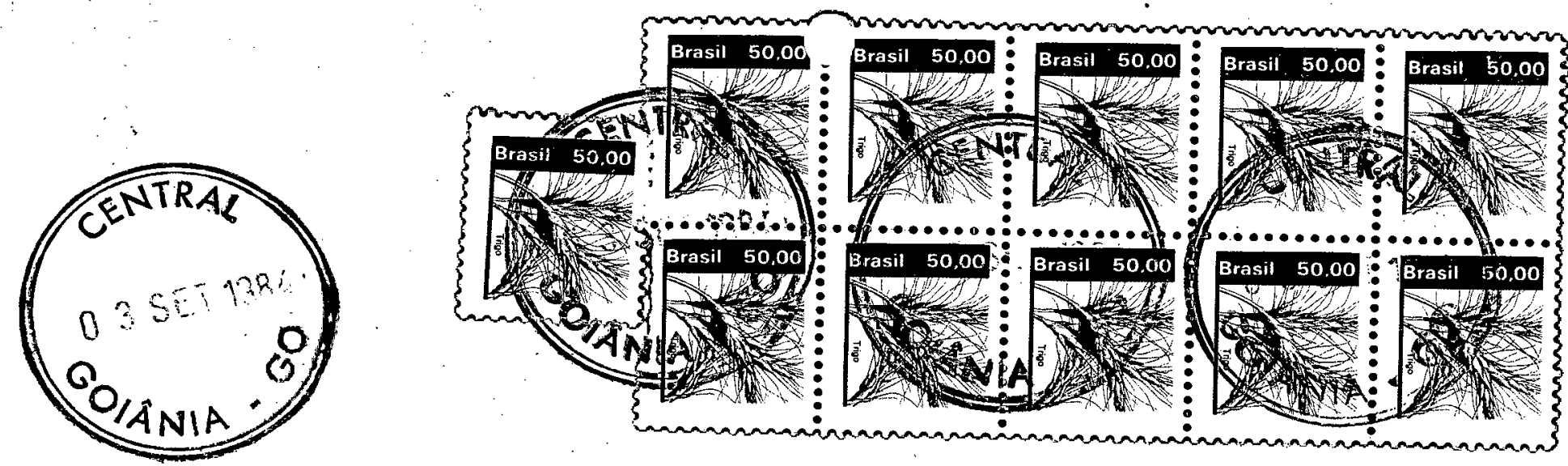

EXMo. sلاz.

DR. JURANDY MARCOS DA FONSECA (PARTICULARMENTE)

FUNAi - EDPFICIO MINTER

BRASILIA -DIF 


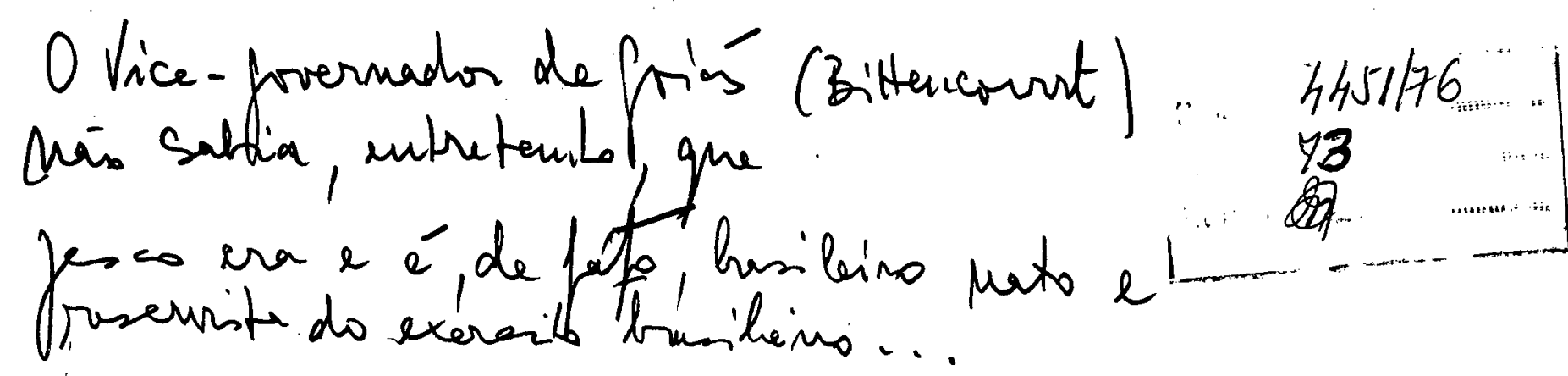

FiG.
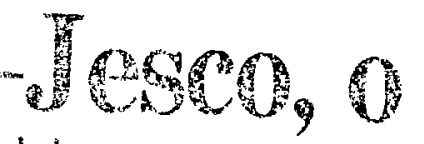

Dngenheirn e naturalista, di. plomado peir Universidade de Breslau, im jovem euorpcu veio para Goís an 1948, demois de haver es. capado da persegnicrão nazista, acompanhondo sich pui, o influente. burso Whif Puttknmer. A familia, de tracicho germanir muito renpeitada no mudo acidental fora vitimn da alucinecáa politica de fitler e, in promida de viver no berco natal teve de emigrar zara a America Lotina. Muis tarde, por csmba unanime, prefariu radicar-se no Irrasil e aqui, no territorto goinno, fez de nosio Pais a sua segunda pátria.

O veho barao, homem de muitas prendas urtisticas, ridadro de cy. trema tidalguia e fira sensibilidade. jä năo mais vive. Cercrdo da estima da simpatin de umo legiao des anigos brasileiros, anigos que aámiravam a sua sensatez e o seu profundo amor pelas coisas de Goias, dorme hoje o sono eterno em campo santo de Coiânia, ngora desfrutario a serena paz dos justos. Seu perfil foi o de um homem que, nasciclo à sombra da nobreza e sem cmbargo decsn postur advincia do sangue. l. a uma convivência rie friante ci. dadania com os que o scolhiam $\mathrm{n}^{\mathrm{a}}$ privan ra do seu relacionamento pes. sual.

-Conheci a engen heiro e naturalis: ta Jesco Puthkaner quando, nos idos ne 1948. servindo no Gabinete Civil do governador Coimiora Bueno, con. cluin o curso de ciéncias jurídicas e sociais na Facaldade de Direito. Merecendo a confiança a amizade do então Chefe do Executivo à época quase sempre me era atribuidio o en. cargo de receber e de ouvir alguns europeus que, impedidos de per.

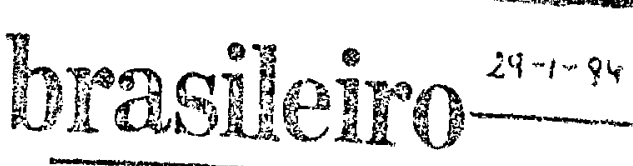




\section{MINISTÉRIO DO INTERIOR \\ FUNDAÇÃO NACIONAL DO ÍNDIO - FUNAI}

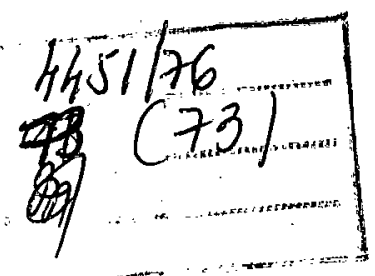

OF.N: $1290 / 83$-PRES/AESP

Em -3นล้ 83

Do: Presidente da FUNAl

Ao: Prof.W.JESCO VON PUTTKAMER

Assunto: Resposta referente ao Cartão datado de 16.10.83

Acusamos o recebimento do cartão enviado por V.Sa,, datado de 16 de outubro último, o qual nos deixou muito satisfeito.

No que diz respeito a oferta de 40 fotolitos prontos para a impressão de cartões postaị, os mesmos serão de grande ut lidade para esta Fundação. Ao mesmo tempo em que agradecemos tão generosa oferta, aguardamos o seu envio para esta Fundação.

Com referência a proposta de Convênio entre a FUNAl e - Instituto Goiano de Prë-Histōria e Arqueología, informamos a V. Sa. que a mesma foi encaminhada aos setores competentes para estudo e anålise. Oportunamente, informaremos a V.Sa, sobre o seu anda mento.

$\mathrm{Na}$ oportunidade, desejamos pronto restabelecimento do acidente de que V.Sa, foi vitima, e reiteramos nossos protestos de elevada estima e distinta consideração.

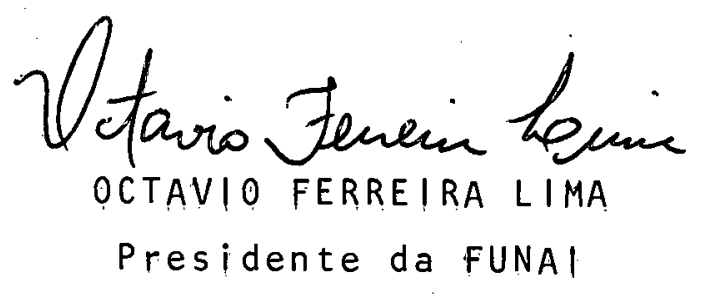

$\mathrm{SR} / \mathrm{mk}$ 

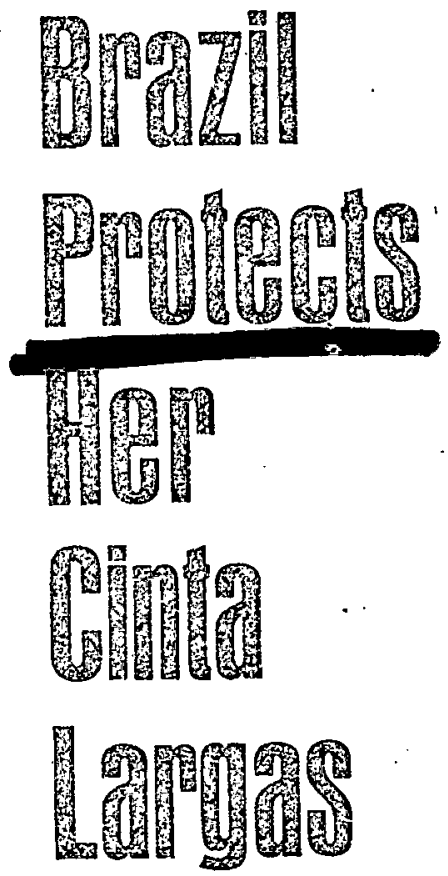

\section{ARTICLE AND \\ PHOTOGRAPHS BY}

W. JESCO

VON PUTTKAMER

In one of civilization's final encounters with the living Stone Age, a group of brave men reach back into time to touch hands with the shadowy "people of the wide belts." The record of that extraordinary meeting reveals proud and still almost unknown Indians-portrayed exactly as they are. -THE EDITOR
M ARILY, wo young men walked toward each other in a 4 clcaring in the green heart of Brazil.

One was a friend of mine. The other, in all likclihood, no civilizado had cver scen except perhaps as a flecting shadow in the great tropical forest of Rondonia Territory. Hc was a Stone Age Indian, a wild warrior whose people for 400 years had escaped the encroachment of civilization.

The two young men came to within arm's reach of each other and stopped. And my friend's heart gave a great bound, for behind the nearly naked Indian, out of the seemingly empty forest, appeared more than fifty warriors, each with a longbow in which a six-foot arrow lay notched.

"Silently the Indians flexed their bows," said my friend. "My hands shook as with the chill of malaria. I shut my eyes.

"Then I heard a new noise, a rustling. I looked in astonishment at the man before me. With hands trembling as much as my own, he was offering me a headdress of palm fronds. -

"In that moment I knew him to be a human being as frightened as myself. I felt also he had love in his heart, as I had in mine.

"I took his gift. I gave him my machete. We turned about and walked each to his own side of the clearing.

"Before my own weeping drowned all other sounds, I heard the clicking of the arrows being withdrawn from the bows."

In this manner one of earth's last Stone Age peoples took their first fearful steps into a bewildering new world of men who know how to fly to the moon. One of the longest, hardest, most dangerous jobs ever undertaken by my native Brazil's National Foundation for the Indian seemed headed f or success.

\section{Few Mysteries Solved in a Year of Contact}

But the task is by no means completed. A year after that first friendly contact, the foundation people working among these tense, wild tribesmen still lived in daily peril of their lives. At any time, a civilizado might inadvertently do some small thing that would be misconstrued by the primitive mind and trigger a massacre. It has happened before.

The Indians have not allowed a foundation worker into any of the 22 villages so far spotted from the air. Of an area population we estimate at between 3,000 and 5,000, only a few women have been seen, and no infants-a bad sign, for it means distrust.

When I temporarily left the pacification team last year after many months as semiofficial photographer and diarist, we had not even learned the name of the Indian group we had met, nor their relationships with the Indians of other villages. Did the people of all the 22 communities belong to the same tribe or, as seems more likely, to sevcral tribes? As yet we do not know. For the time being we are calling all these Indians "Cinta Largas," from the Portuguese words for the broad belts often worn by men and boys of the region.

The language of our new friends was not known to us, nor to the pacified Gaviāo and Arara Indians we had brought along in 
the hope they could interpret for us. I recorded considerable conversation on tape; linguists later identified several words as being of Tupian stock-a language group common to many Brazilian aborigines.

In 1914 Theodore Roosevelt and Col. Cândido Mariano da Silva Rondon, who inspired Brazil to protect her Indians, explored the river now named for the United States President (map, page 426). They saw no Indians. But later, when fortune seekers penetrated Rondonia in quest of wild rubber, jaguar pelts, and diamonds, they were driven back by warriors wearing wide belts.

For years the Cinta Largas were left in peace. Then, in the 1960's, the highway being built from Brasilia to Cruzeiro do Sul came close to their hunting grounds. With the road came more fortune seekers, this time in hundreds. The newcomers were of all kinds, from gunslingers a jump ahead of the police to adventurers of substance seeking tin, rubber, or land for speculation.

\section{FUNAI Must Balance the Interests of Many}

Hostilities with the Indians resumed at once. There were ugly incidents. And though we Brazilians know of no nation that has ever pas'ed through a similar stage of development without committing such sins, my country is ashamed of some of the things then done by its nominally civilized citizens.

Indians were shot on sight. I know several Cinta Lirgas with bullet scars, and one who survived a machete slash that almost split his face. A Cinta Larga village was dynamited from the air. Poisoned foods were left temptingly on trails.

The Indians also did cruel things. They killed the young wife of a settler on the Riozinho River. They murdered a rubber tapper with 13 arrows and gruesomely mutilated the corpse. And once a Cinta Larga proudly showed me his prize trophy, a set of false teeth.

Eventually the government acted. It ordered the National Foundation for the Indian-FUNAI, we call it, from its Portuguese name-into action. FUNAI is the agency with which the government replaced its original Indian Protection Service in 1967; over the years the old service had grown cumbersome and tangled in red tape.

FUNAI's mission is a dual one. First, it pacifies hostile Indians so that Brazil, an underdeveloped nation, may extract the riches of its vast wilderness area as efficiently and painlessly as possible. Second, it protects the Indians it pacifies against the harmful aspects of our civilization with which they cannot cope.

As an example, it prosecutes trespassers on lands set aside for Indian use. It guards its charges against exploitation. It seeks to keep the diseases of civilization

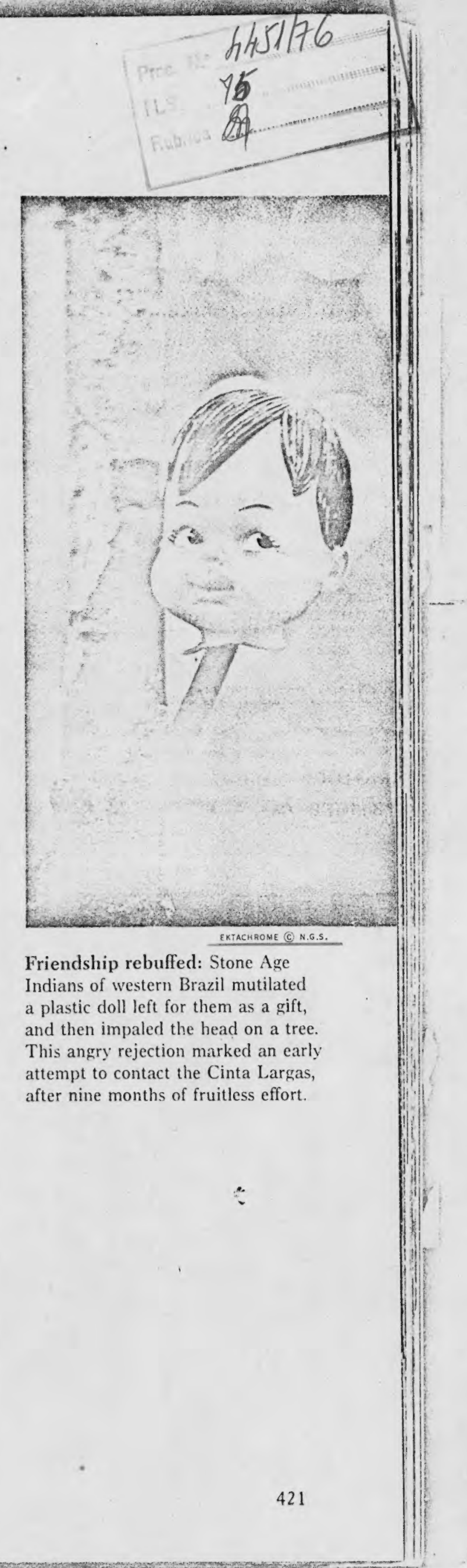


During their months-long "Hirtation," members of a Brazilian Government expedition sought to gain the confidence of the Cinta Largas by leaving gifts of tools and trinkets in the forest. Playing a wordless game of trust, José Moreno (below) ties peace offerings to a hunting shelter frequented by the Indians. Cinta Largas retrieved them unobserved, leaving in exchange their own plumed headdresses, seeds, even arrows. Hinting at preferred presents (bottom), they left a stone ax and clever imitations cors, needle, and knife. After almost a year of such (right). He exchanges, an mow and bamboo-tipped arrows. Armlets carries a six-foot bow and bado hearly nude body.

and a necklace of wild nuts adorial tattoo may signify rank.
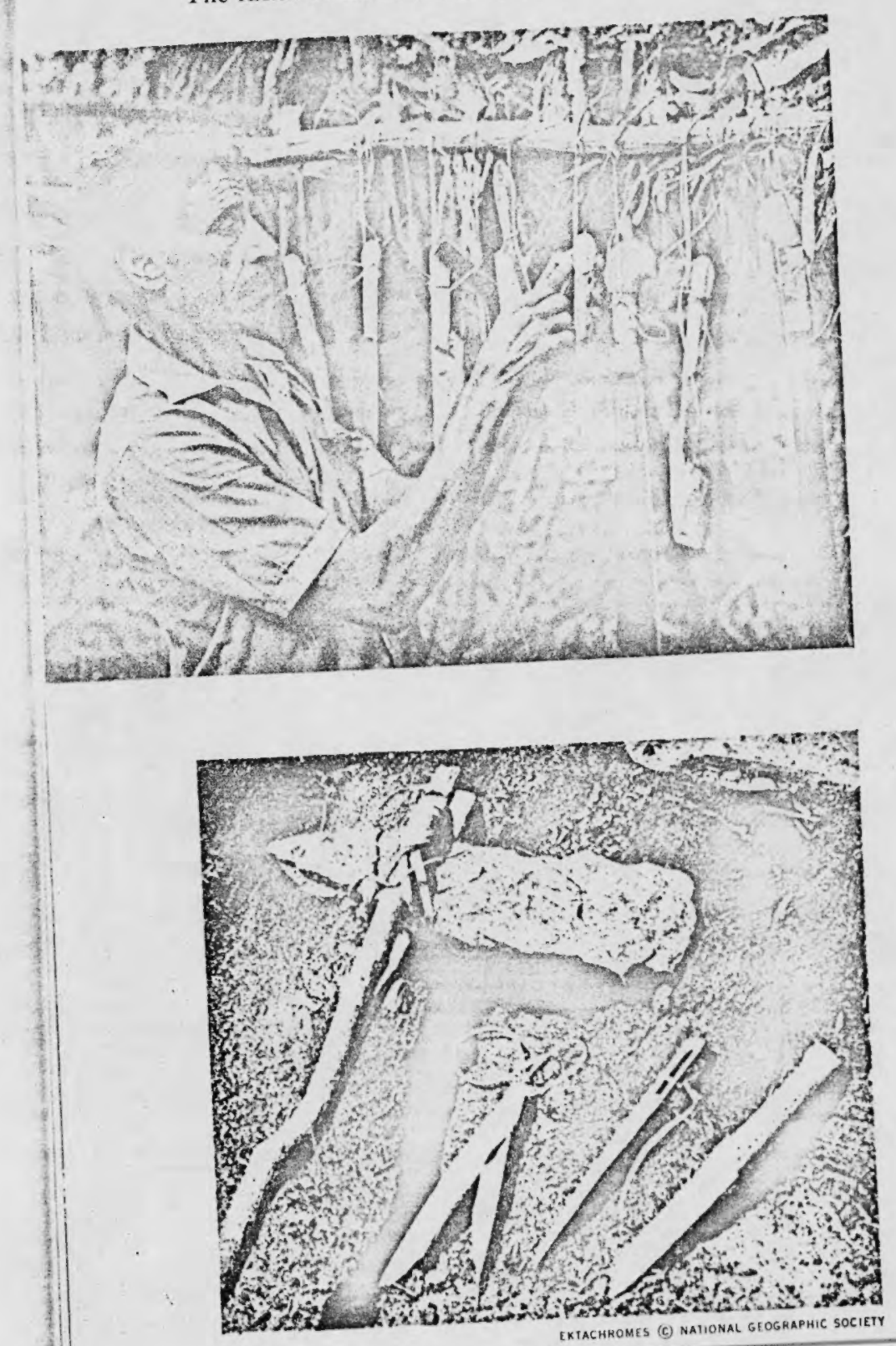
away until the Indians can be immunized; otherwise; measles or smallpox might sweep the region, taking a fearsome toll.

But there is one thing that not even the selfless, dedicated people of FUNAI can prevent. That is the erosion of a simple culture by a strong, complex one.

The process begins the moment a wild man exchanges his stone knife for a steel one, or wears a civilizado's discarded shirt. It ends, at best, in assimilation by civilization, or survival on a reservation that is an island in an alien cultural sea. At worst, it terminates in despair and ultimate extinction.

But in no event can the Stone Age Indian ever be the same again, and that is why each FUNAI sertanista, or Indian expert, carries in his heart saudade, a nostalgic sadness. For he L must live with the knowledge that whether he brings stark tragedy or better lives to the people of the forest, he will unavoidably diminish a simple, fragile beauty the world can never see again.

Still, Funal has a job to do. Francisco Meireles, leader of the Cinta Largas expedition, was earnestly trying to do his when I first met him at the Seventh of September advance pacification camp.

"Chico" Meireles is one of the most famous and experienced sertanistas on the FUNAI roster. Others are the brothers Villas Boas, Orlando and Claudio, with whom I served on the Xingu River during the pacification of the Tchikao tribe a few years ago*

"See the Villas Boas' "Saving Brazil's Stone Age Tribes From Extinction" in the September 1968 GeoGRAPHic. The late Harald Schultz also wrote movingly of Brazil's Indians in the January 1966, May 1964, and January 1962 Geographics.

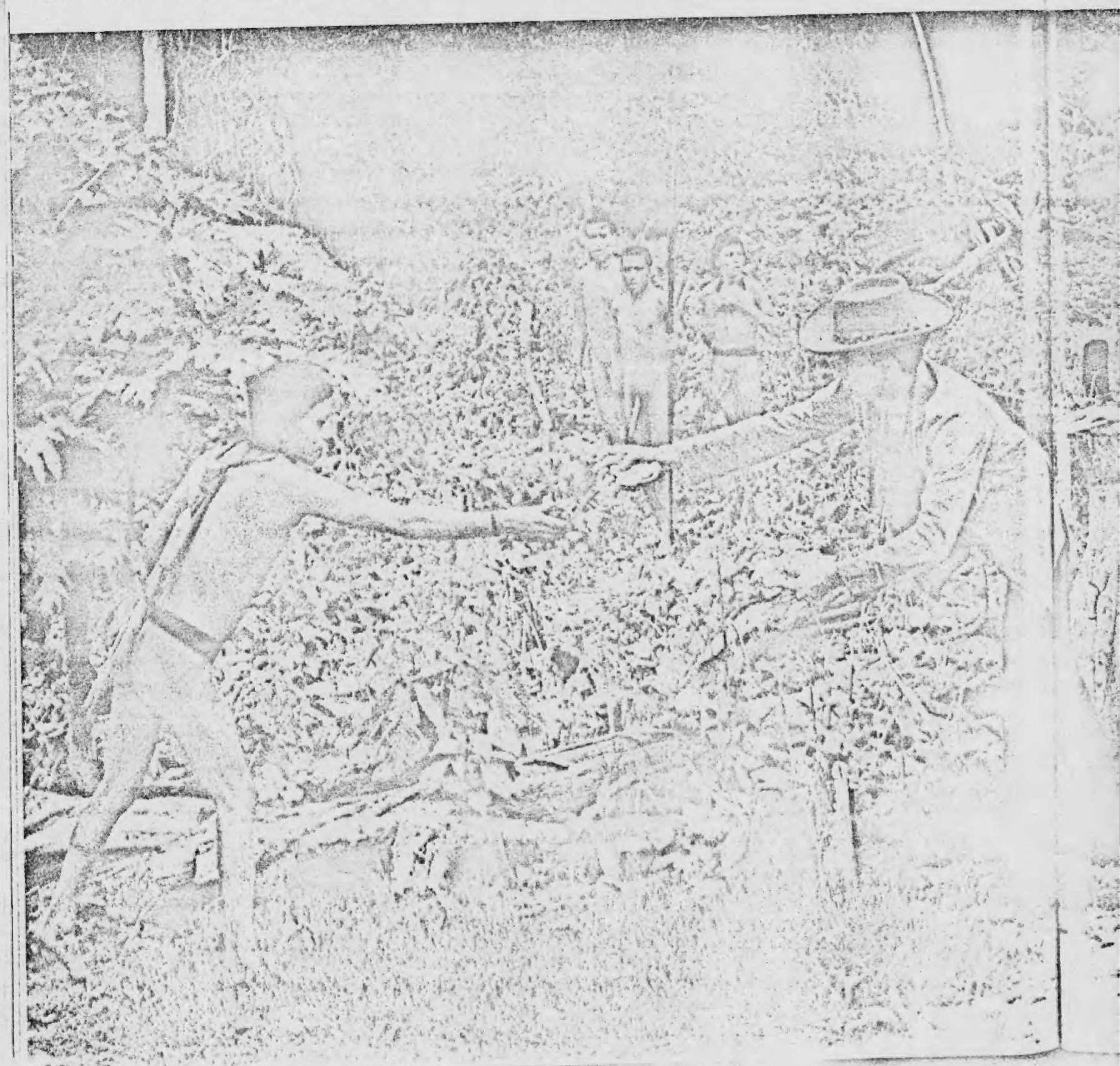




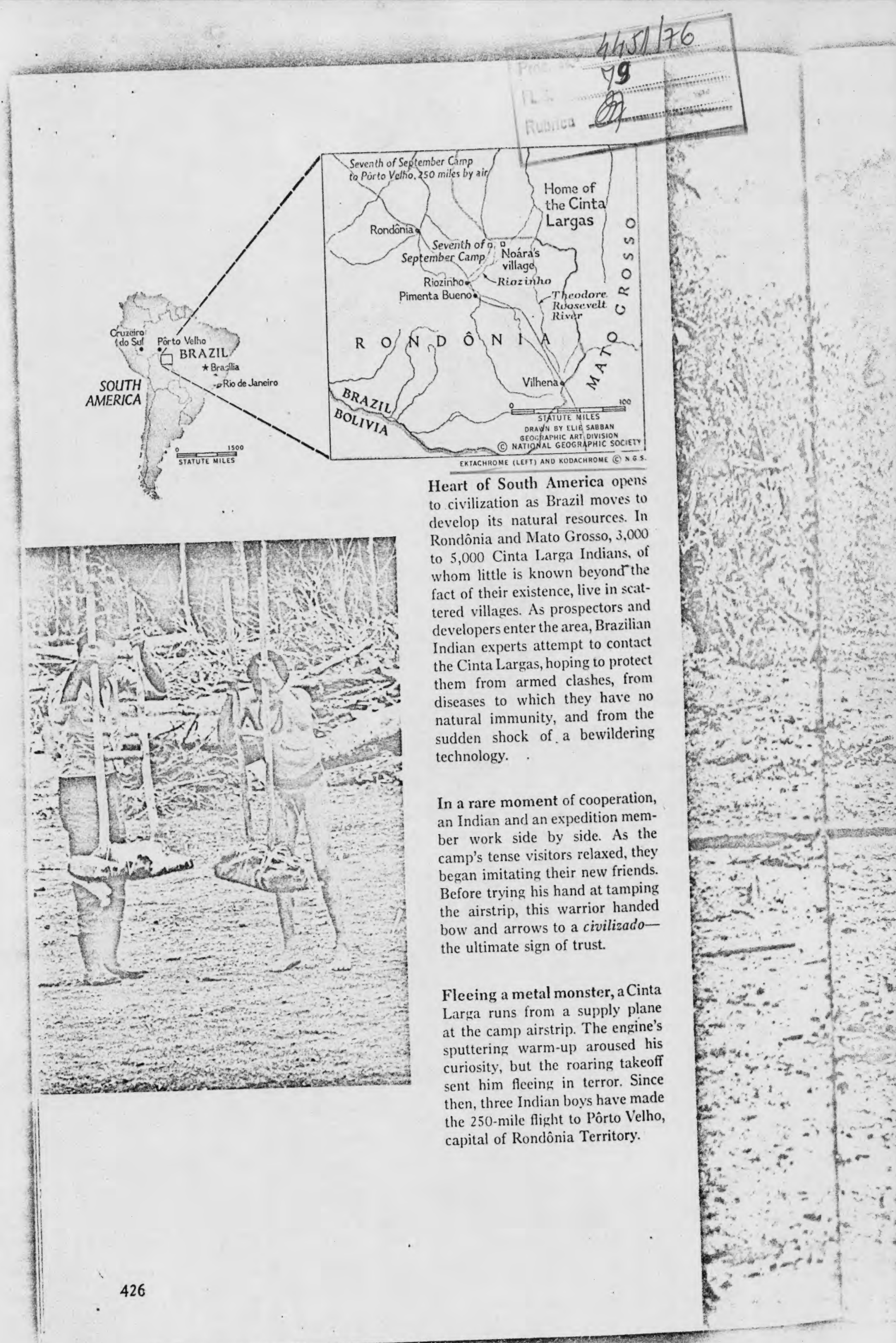


the bush: the cry of a monkey, bird trillsand a very human giggle.

Encouraged, we tried noises of our own Nearing the place of exchange each morning, we sang, we shouted, we banged the boles of the trees with machetes. The best sort of primitive philosophy, this: The man who comes noisily comes in peace.

We turned my tape recorder to full volume, and the forest rang with the singing and flute music of the Indian tribes I had known along the Xingu River. Our interpreters shouted into the forest in several aboriginal languages.

"Do not fear us." "We will not harm you."

"Come to us."

No response. But the exchange of gifts continued, and from it we learned something about the Cinta Largas' tastes. For example, they appeared to have a genuine antipathy toward the lids of aluminum pots: They bent them into uselessness and threw them away.

In the beginning they shattered the mirrors we had left, though eventually they would learn to value them (page 433).

In one of the mule convoys that supplied the camp from the roadside settlement of Riozinho, we found a carton of little plastic dolls. We left them for our friends. Next day we found them ripped apart, the heads stuck on tree limbs (page 421), the bodies, skewered by arrows, lying beside the trail.

\section{Would-be Bathers Must First Oust Fish}

As time passed, the lack of amenities in our daily lives began to get on our nerves. Most sertanistas love the life of the wilderness, but they cannot forget the attractions of a cold beer and a hot bath.

The tub at our camp is a pool in a forest stream. Trusting the water will not be too muddy to wash with, one sets forth for the pool in heavy boots, for many poisonous snakes, including rattlers of respectable size, live near the stream. At poolside one first skims off dead fish, victims of Cinta Larga fish poisoning upstream. Next one throws in a few stones and stirs the bottom with a stick.

This last maneuver is designed to frighten away stingrays and electric eels. The former can inflict severe, even crippling, wounds if stepped or sat upon. The eels, running to six feet in length, can cieliver-a shock sufficient to knock a man unconscious. The ray usually Hees downstream, but the eel, a curious fellow, comes back to see what is going on. When his snakelike head pokes out of the water, it is best to frighten him off with another stone.

There are other forest animals that are not the most congenial of neighbors. Like the Amazon Indians, I consider the big spotted jaguars we frequently hear (but rarely see) a menace, at least to women and children. And there are women and children in our camp. Chico feels that their presence assures the Cinta Largas of our peaceful intentions.

\section{Even Jaguars Yield to Foraging Pigs}

Everyone fears the peccaries, the wild pigs that abound in the forest. The pigs come in two sizes, large and small, and they go about in sizable bands, gnashing their teeth and smelling to high heaven. When we see the larger species-the white-lipped peccaryheaded our way, we look to our guns and our line of retreat; even the jaguars give them the right-of-way.

But most forest creatures are inoffensive: The shy tapir; the capybara, largest of rodents; monkeys of many kinds; deer in assorted sizes; turtles; gaudy birds, such as the brilliant red macaws and the turkey-size mutums, or curassows. Of recessity we hunt and eat them. Otherwise we could not survive here, for our lines of supply from civilization are often disrupted.

In the rainy season, mud, fallen trees, and swollen rivers prevent mule caravans carrying our supplies from making the 56-mile trip from Riozinho to our camp. The trail to camp is an old one cut years ago by rubber tappers, before they were driven out by the Indians.

The mule caravans run another risk: Occasionally the Cinta Largas stampede a packtrain. The mules find their way home, but often without their cargoes.

To keep our minds occupied, we work very hard. We begin to cut an airstrip and a plantation out of the virgin forest, Indian fashion, with machete and fire. We dig a well.

We must frequently take apart and clean our mechanical devices-the little gasolinepowered generator, the radio transmitter, my

Indian clutching camp playful scuerest. Fear mounts booty suddenly yanks an expedition youngster tow the maneuver, the warin the boy's face. "When camp members put a stop to the sure," says the author.

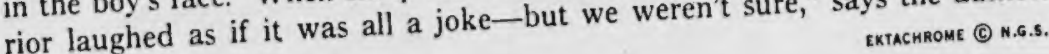


cameras. In this humidity everything quickly turns rusty and moldy.

We shoot at targets. We swat the borrachudos, the biting flies. In the evenings we have tape-recorder concerts, and sometimes I play my accordion.

We have our share of silly quarrels. But also we nurse each other through our attacks of malaria. This illness is a serious thing here, and one of our men has died of it.

\section{Stirring Moment Caps Long Campaign}

One day Chico Meireles was away from camp. His son Apoena-named for a chief of the Chavante tribe, which Chico pacifiedwas in command. Just 20 years old, Apoena was already a fine sertanista, lacking only the experience of his father to make him his equal in the forest.

Big stars mark the day in my diary:

"At last the Cinta Largas have made overtures! Returning to camp from the place of exchange, our people heard shouting behind them. They looked back.

"There in the clearing four warriors stood in plain view, waving and calling in a language no one understood.

"Apoena was summoned. By the time he arrived, only one Indian remained in sight. When Apoena tried to approach, he too ran into the forest. The jungle fell silent."

Five days later the Cinta Largas called again from the forest. It was then that Apoena and the magnificent young warrior leader we now know as Noára (opposite) reached trembling hands to each other across the millenniums of history.

Faithful to the policy of leaving the initiative to the Indians, Apoena returned to camp to await the Cinta Largas' next move. It came the following morning. While two score armed warriors watched from the far side of the stream, four boys about 15 years old crossed our log bridge and trotted into camp.

Wondering why the Indians sent boys instead of adults, we nevertheless met them with smiles, holding out new axès and machetes.
These the youngstere snatched avidly and took across the stream, after which they returned and held their hands out for more.

For an hour we gave out presents and were given things in return-ornaments and arrows. As our supplies dwindled, we tried to break off the trading by ignoring the outstretched hands. At this the four boys simply ran through camp and picked up whatever took their fancy.

One entered the cookshack, took every pot and skillet he could carry, and set off for the forest at a run, pursued by the enraged cook.

"Let him have them!" shouted Apoena. "Do you want us all massacred?"

Indeed, on the other side of the stream, the watching warriors were fitting arrows to their bows. Had our cook laid a hand on that boy, I am sure we would have paid for it with our lives. For though we carry arms, we will never violate the commandment handed down by FUNAI's spiritual founder, Colonel Rondon: "Die if necessary, but never kill."

\section{Machete Opens a Puzzling Container}

Encouraged by the success of the kitchen raid, the four boys now all but took the camp to pieces in their search for treasure. They dug in what th y thought likely hiding places, they searched the sleeping huts, poked into every drawer and cupboard.

One lad was puzzled about how to open a suitcase, but not for long: He slashed into it with a machete. He fingered the clothes, money, and papers within in wonder, but took only a knife, after first discarding its sheath.

Among the camp dogs was a silly, friendly one. The boys carried it away. It escaped and came home that night, but was taken again next day. This went on for two weeks, until the dog tired of the game and stayed with the Indians of its own accord. Another, an old mongrel, bit the lads, and they left it alone.

At first our visitors were extremely tense and nervous. Any sudden moves on our part, any attempts to get close to them, put them to flight. But as the days passed and we let

With a king's composure, proud Chief Noára pays a call at the expedition's camp. Bark belts, one slung over his shoulder, may serve as armor; warring Cinta Largas use arrows tipped with fire-hardened bamboo. But disease, not war, could spell the Indians' doom. The expedition hopes to immunize them soon against such illnesses as measles and smallpox, to which these forest dwellers have no resistance. 


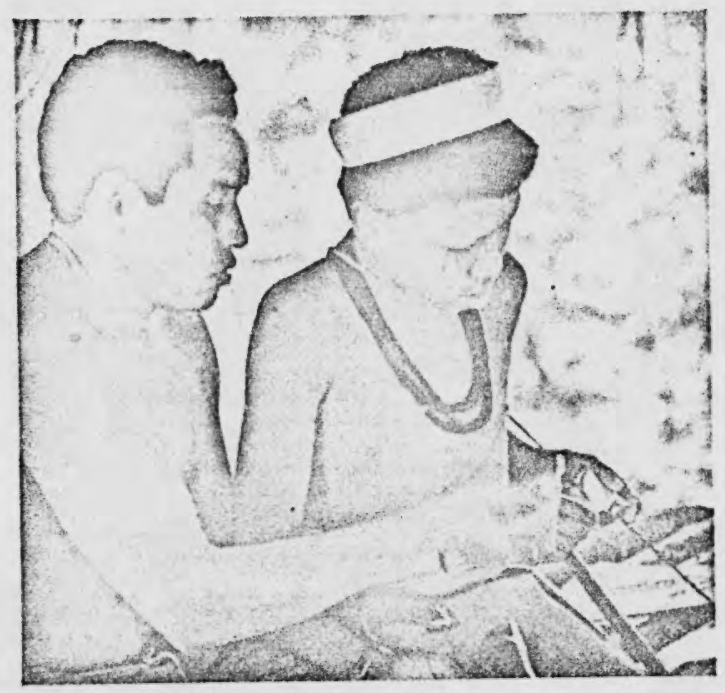

"Magic" from another world draws Indians to the camp. The author's writing worried them: When he jotted down their words and repeated them, the Indians ripped his notes in alarm. Lured to a ball-point pen, one drew lines, a circle, and a squiggly pattern (far left). An ink marker makes an instant success with a youngster, who decorates his body while clutching a plastic bottle (middle, left).

Matches, first regarded as sorcery, intrigue Takanine, here lighting dozens at a time (left).
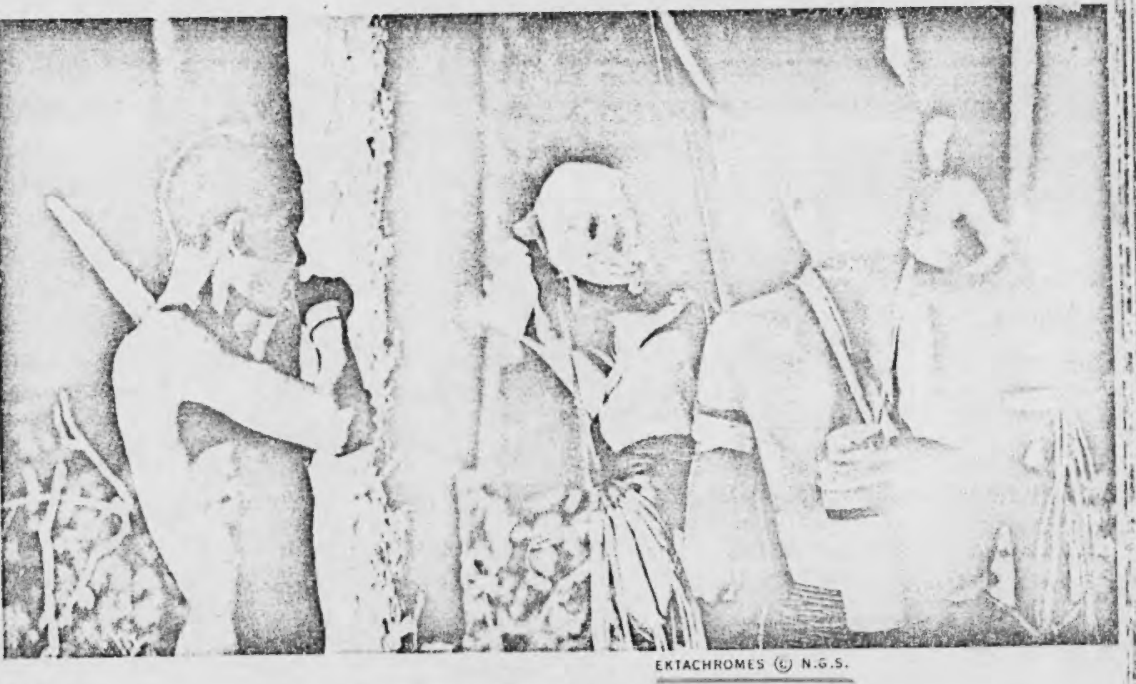

A mirror frightens, then fascinates Cinta Largas (above), who have also appropriated a cap and a vacuum bottle.

Struggling with a wheelbarrow (left), an Indian fails to realize the purpose of the wheel as he pushes the legs into the ground. The Indians often took things whose use they did not understand, but they usually discarded them later in the vicinity of the camp. 


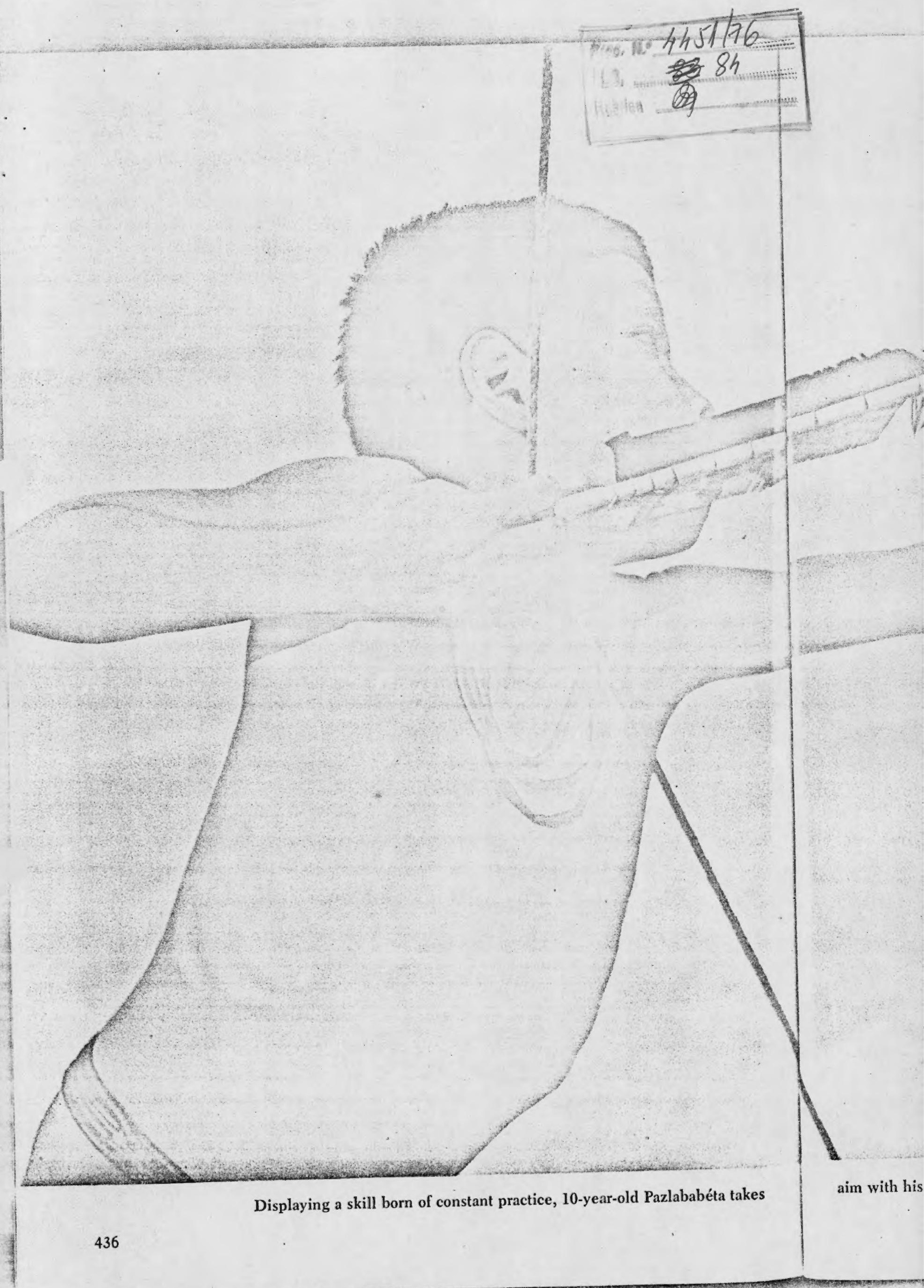




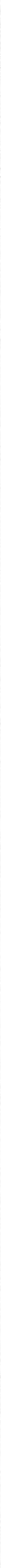




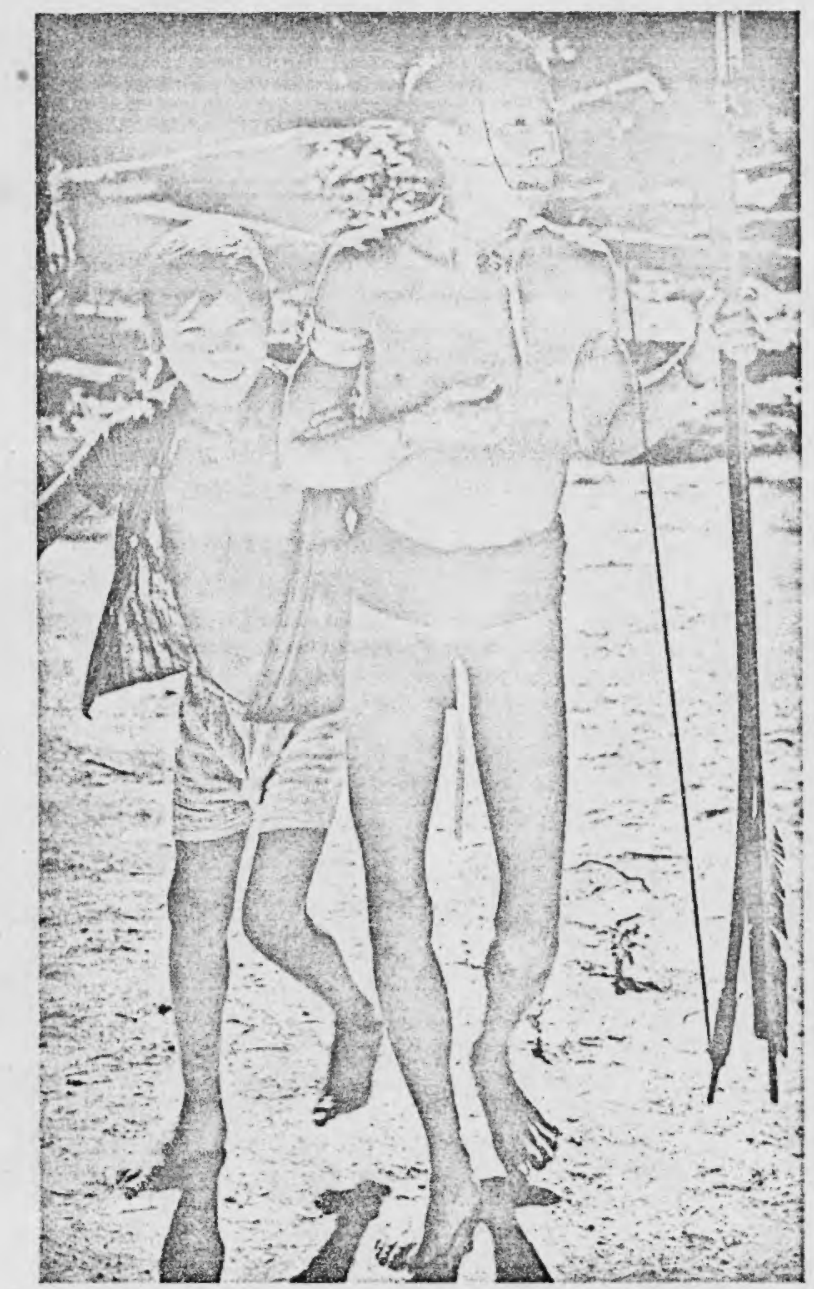

Wilderness waltz: A singing, prancing Cinta Larga, wearing an ornamental nose plug (above), joins 12year-old Raimundo Fortunato in an impromptu dance. Children of expedition caboclos-people of mixed European and Indian blood-helped break the ice in early contacts with the Cinta Largas. Families of expedition members move into camps in Indian territory to avoid the appearance of hostility.
Armadillo for dinner: Indian row the armored beast on a grill of stub at the camp's edge (opposite) 0 . young tribesman greets an expet tion member with the open affertion that marked the Cinta Largas' final acceptance of their new friend.

Warrior and baby-sitter (below) young Takanine fashions a head band for a little civilizado, the brother of Raimundo. By age 1 , Cinta Larga boys take on the role of adults - hunting and helping to pro tect villages. Shifting for themselve groups of two or three wander for days through the vast forest, where jaguars and wild pigs are an ever present danger.

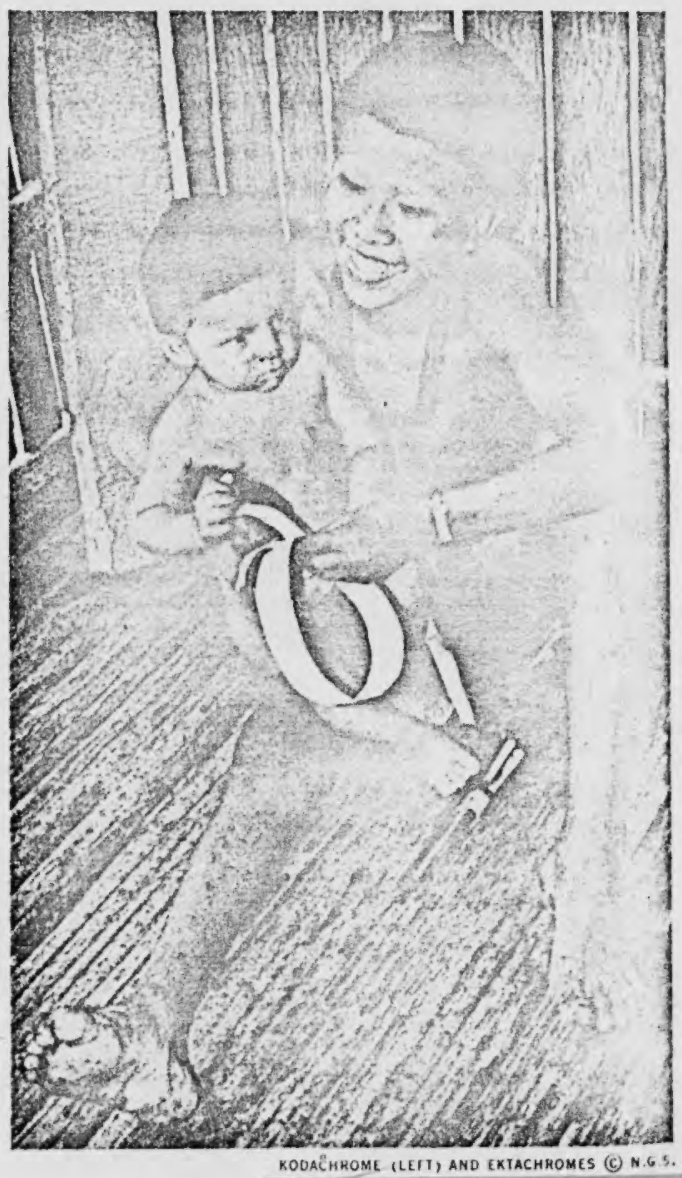

s

.

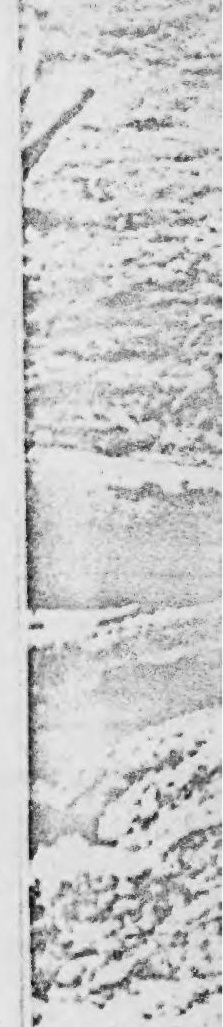

ingeringers? 


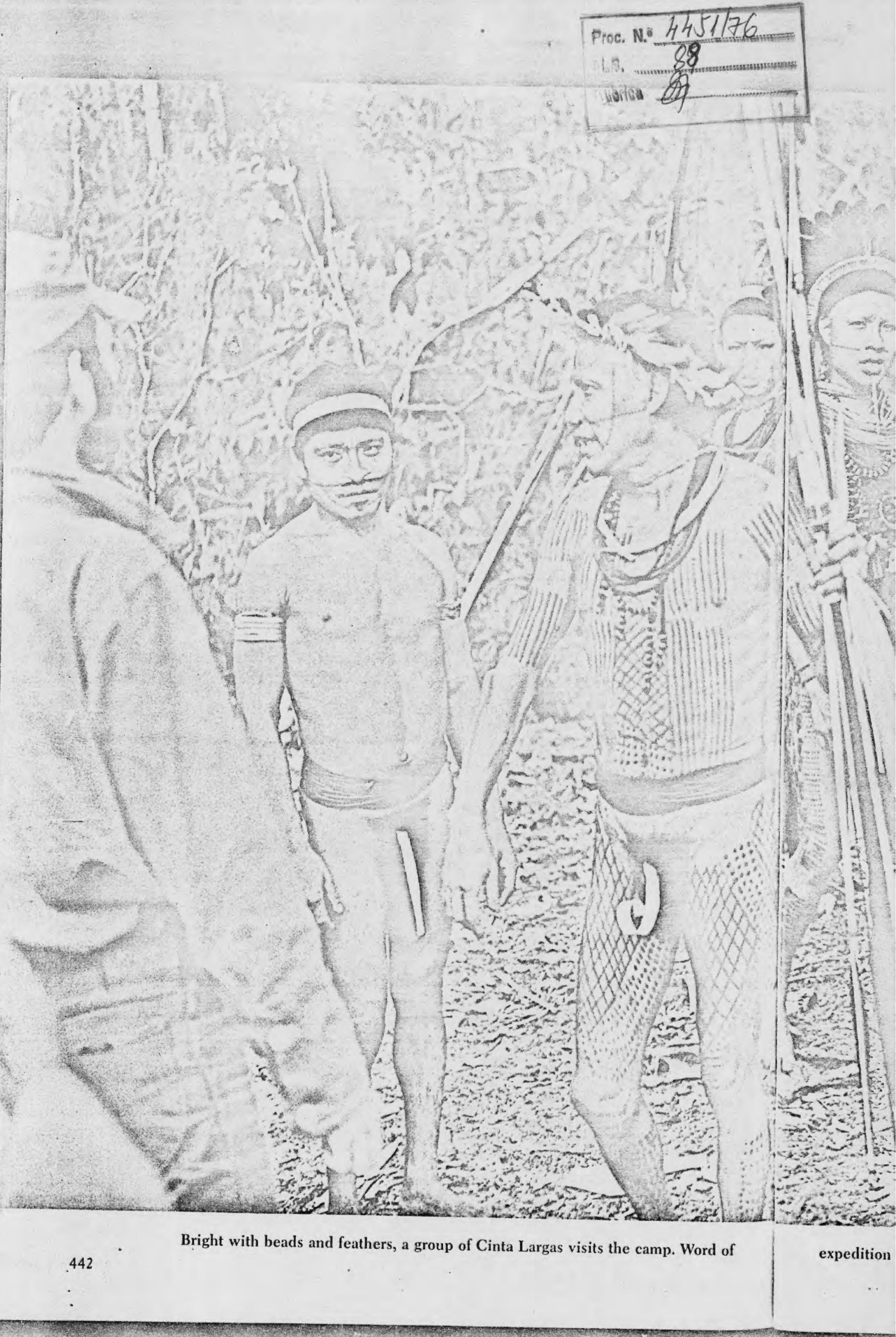





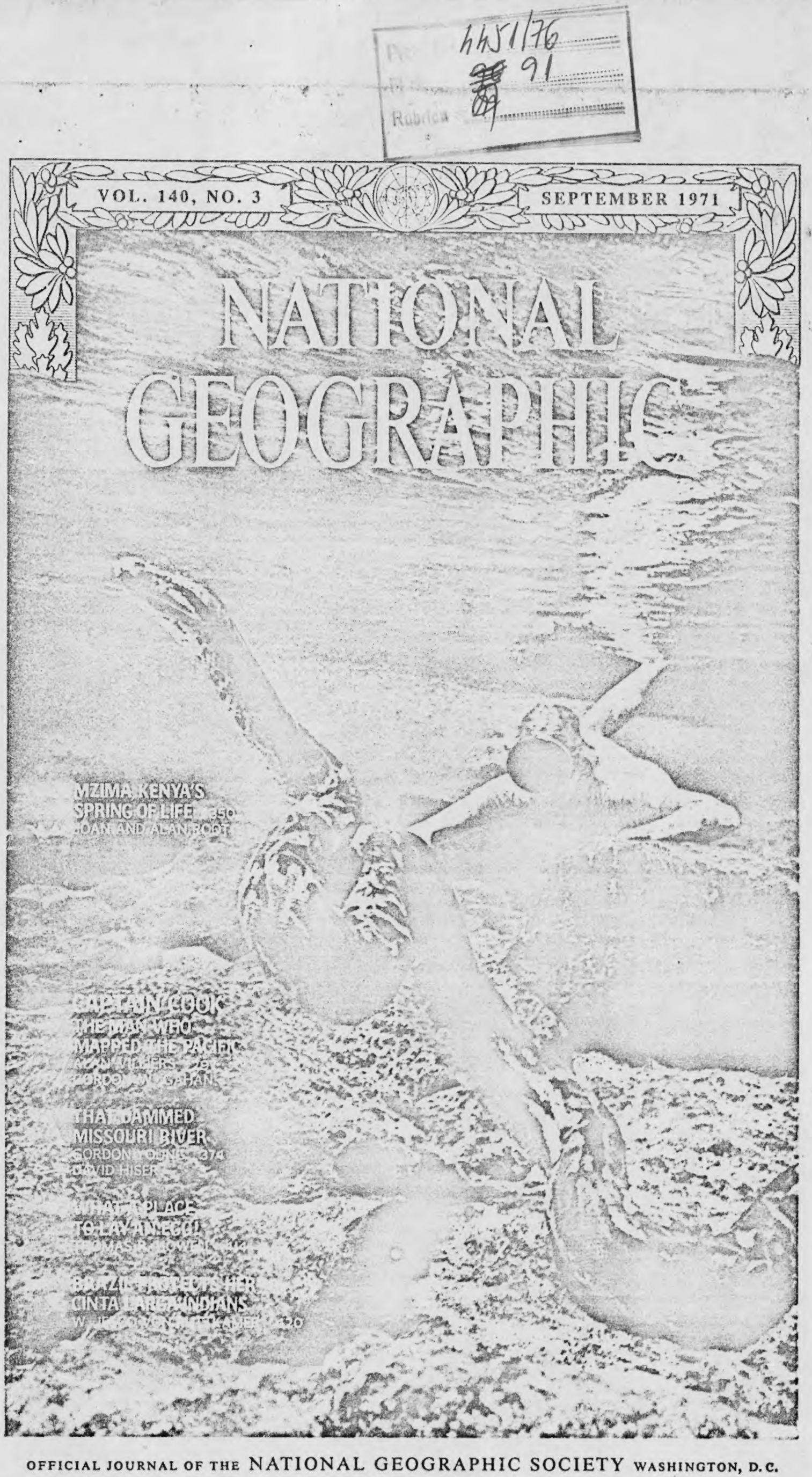




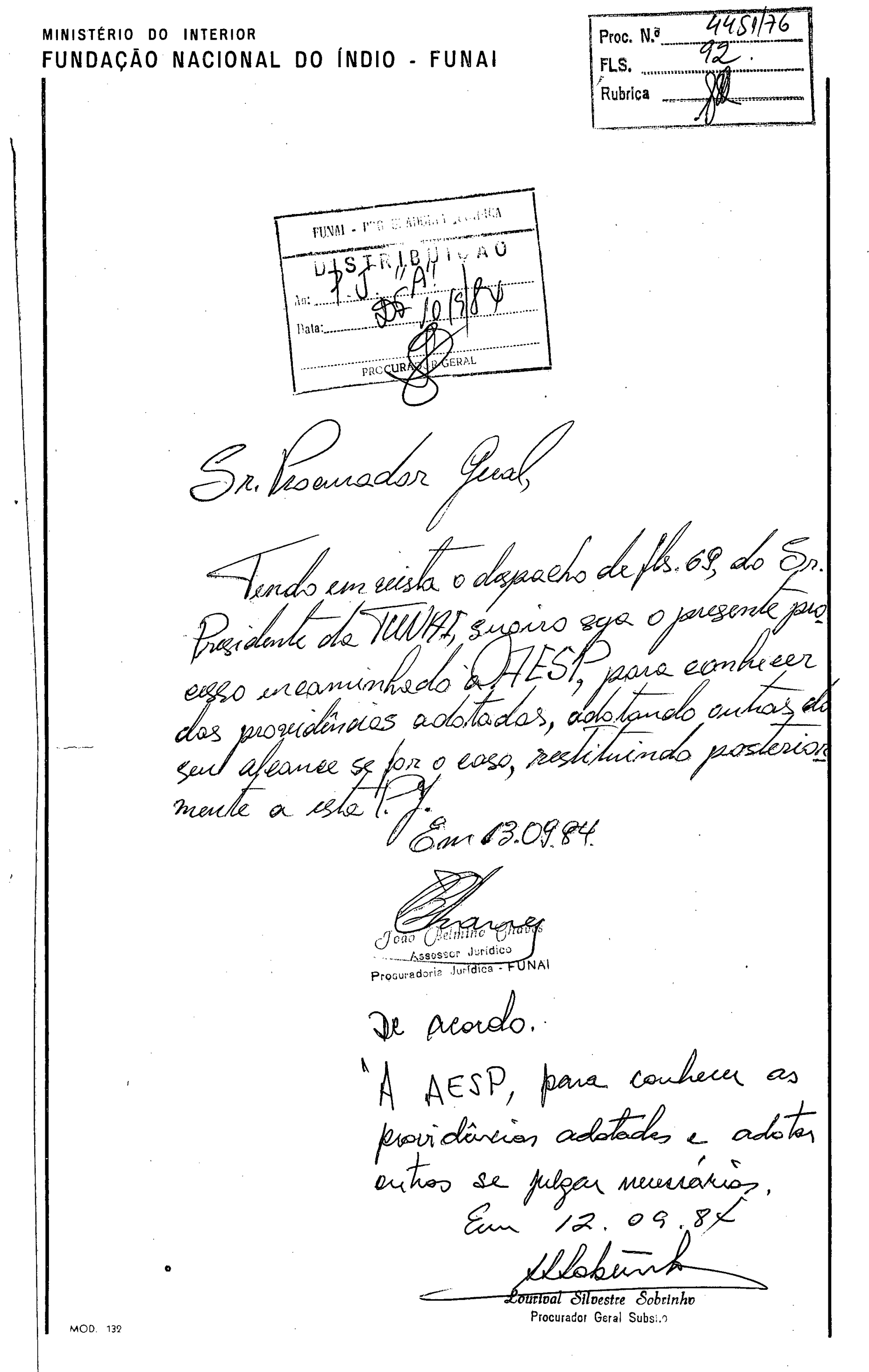


Qo Redato Sylvio Reiver, proce coukerer e providncian o que cadber.

AESP, $17 / 09184$

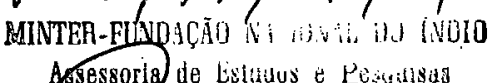

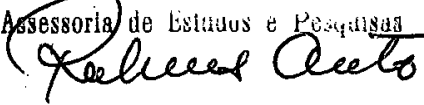

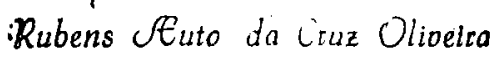
Chofo 


\title{
MINISTERIO DO INTERIOR
}

\section{FUNDACAO NACIONAL DO INDIO - FUNAI}

\author{
INFORVAÇAO NO Hl//84-AESP \\ Ref:. Processo FUNAI/BSB/04451/76
}

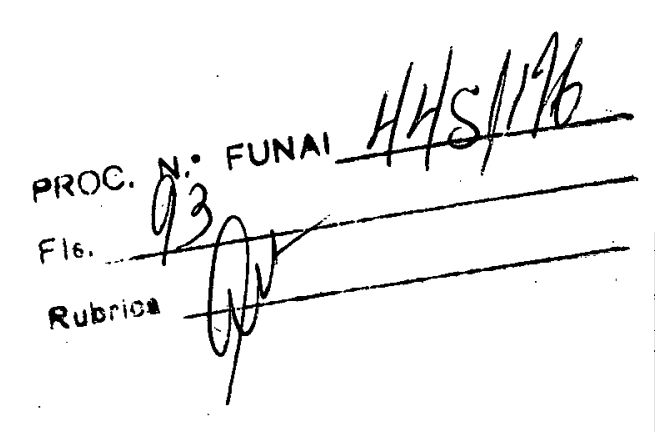

Senhor Assessor-Chefe da AESP:

Em despacho exarado à fls. 69 do presente proces so, o Sr. Presidente desta Fundação solicita à Douta Procura doria Jurídica "conhecer, reexaminar o assunto e, após encaminhar à AESP", tendo em vista correspondência que the foi encaminhada pelo Sr. WOLF JESCO VON PUTTKAMER (IFITHO):

Já à fls. 92, a Douta Procuradoria Jurídica enca minha o presente processo para esta Assessoria "para Eonhecer providências e adotar outras que julgar necessárias". Estranhamente, não houve o reexame solicitado pelo Sr. Fresidente da FUNAI.

Por se tratar de determinação da autoridade maior desta Fundação, não podemos nos furtar em reexaminar o assunto em tela, visando acima de tudo, a defesa dos interesses da comunidade indígena.

No presente processo, não se encontra em julgamen to a pessoa do Sr. WOLF JESCO VON PUTTKANER (FILHO), nem tão pouco a qualidade do trabalho realizado pelo mesmo, o qual consicieramos excelente. O que está em julgamento é o fato de que o referido profissional tem violado uma série de regras emanadas por esta Fundação quanto ao ingresso em áreasiindígenas, bem como o não pagamento de direitos autoràis e de ima gem dos índios por ele focalizados em filmes, fotografias e slides, direitos estes regidos pela Lei no 5.988 de 14.12 .83 e pela Portaria no 907/N-FUNAI de 18.05 .84 . 
MINISTÉRIO DO INTERIOR

FUNDAÇĀO NACIONAL DO ÍNDIO - FUNAW

\section{A "correspondência" do Sr. WOLF JESCO VON}

PUTTKAIIER (FILHO) se resume em um "patrótico" quadro verde e amarelo colocado em xerox do ofício no 802/PRES/PJ/84 de 27 de agosto de 1984, à ele encaminhado pelo Sr. Presidente da FUNAI, onde o fotógrafo diz:

$$
\begin{aligned}
& \text { "Jurandy - Recebi essa carta hoje. } \\
& \text { Voltei de Rondônia me sentindo bas } \\
& \text { tante doente (pressão alta, e per- } \\
& \text { nas inchadas e com uma irregulari- } \\
& \text { dade no coração, pois sou diabético. } \\
& \text { lias tão logo esteja melhor vou até } \\
& \text { ấ. Pedi a Universidade résponder } \\
& \text { a carta e dar os informes desejados. } \\
& \text { Estamos trabalhando num convênio } \\
& \text { com a FUNAI" }
\end{aligned}
$$

\section{Diz o Sr. WOLF JESCO VON PUTTKAMER (FILHO) que} "pedi a Universidade de responder a earta e dar os informes desejados". Acontece que a Universidade Católica de Goiás na da tem a sver com a cobrança que está sendo feita ao fotógrafo. Afinal quem comercializou as fotografias e filmes foi o profis sional WOLF JESCO VON PUTTKANER (FILHO) e não a Universidáde Católica de Goiás.

Por outro lado, não há, a té o momento, nenhum con vênio firmado entre a FUINAI e a Universidade Católica de Goiás, como o Sr. JESCO dá à entender.

\section{Anexou o Sr. WOLF J:SCO VON PUTTKAMER (FILHO) à} sua "Correspondência" uma delcaração do Coordenador de Ciências Humanas e Sociais do CNPq, Sr. GEORGE DE CERQUEIRA LEITE ZARUR, datada de 14 de agosto de 1984, na qualestesafirma o interesse do CNPq" no trabalho de pesquisa fotográfica desenvolvido no território federal de Rondônia (?) pelo Sr. JESCO VON PUTTKAMIER" ( o grifo é nosso). 
Como se pode observar, o Sr. Qpordenador de Ciên cias Humanas e Sociais do CNPq declara ser do interesse daquela entidade o trabalho de pesquisa fotográfica desenvolvido pelo Sr. JESCU VON PUTTKANER em Rôndônia, sem referir-se diretamente ao trabalho fotográfico em áreas indígenas. Além do mais, nunca se colocou em dúvida a importância ou qualidade do trabalho executado pelo fotógrafo e sim, o fato do mesmo ingressar em áreas indígenas sem autorização expressa da FUNAI e a questão do pagamento de direitos autorais e de imagem aos indígenas.

O Sr. WOLF JESCO VON PUTTKANER (FILHO) anexou ain da à sua "correspondência" cópia xerox de uma apresentação datada de 6 de abril de 1982 assinada pelo Diretor do Instituto Goiano de Pre-História e Antropologia da Universidade Católica de Goiás; xerox de um artigo de autoria do Sr. José Luiz Bittencourt publicado no jomal "Folha de Goiás" de 29 de janeiro de 1984 sob o título mijesce, o brasileiro"; original do ofício no 1290/83-PRES/AESP de 3 de novembro de 1983 enviado pelo Sr. Presidente da FUNAI; e xerox de artigo e fotos de sua autoria publicado no National Geographic Nagazine sob o título "BRAZIL protects her Cinta Largas".

No que se refere a carta de apresentação do $\mathrm{Sr}$. Di retor do Instituto Goiano de Pré-história e Antropologia da Universidade Católica de Goiás, a mesma nada tem a vêr com a causa em questão.

Já na xerocópia do artigo publicado pelo jornal "Folha de Goiás de 29 de janeiro de 1984 sob o título "JESCO, - BBRASIEIRO", de autoria do Sr. José Iriz Bittencourt, fica mais uma vez comprovado que, há anos, o fatógrafo WOLF JESCO VON PUTTKAVER (FILHOO) vem vïolando o direito de imagem do sil vícola brasileiro. 
Diz o Sr. José Iuiz Bittencourt em seu artigo que desde 1948 "o jovem JESCO PUTTKAMER, que a todos impressiona pela invulgar estatura física, logo se interessou por estudos etnográficos e, partindo para contatos permanentes com os nossos silvícolas, logrou obter valioso acervo relativo aos Cara jás, Cintas Largas e grupos arredios das margens do rio Aripua 侸. Sete filmes científicos foram editados pela BBC de Iondres e algumas de suas histórias sobre índios do Brasil mereceram ser publicadas na Revista "National Geographic Society". Tem ainda 18 livros escritos a respeito de suas incursões no campo da etnografia e um deles está sendo agora impresso pela Universidade Católica de Goiás, para lancamento em janeiro próximo, sob o título de "Curumim" (o grifo é nosso).

0 ofício no 1290/83-PRES/AESP do.Sr. Fresidente da FUNAI, datado de 3 de Novembro de 1983, também anexado pelo Sr. WOLF JESCO VON PUTTKAIVER (FILHO) diz respeito a uma oferta do fo tógrafo em fornecer 40 fotolitos prontos para a impressão de car tões postais à esta Fundação, oferta esta aceita através do referido ofício.

Entretanto, até a presente data o Sr. WOLF JESCO

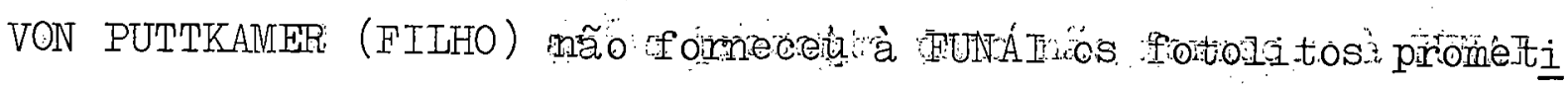
as..:

Finalmente, no que diz respeito ao artigo "BRAZIL EROTECTS HER CINTA IARGAS", publicado na Revista "National Geographia Nazine" com o texto e fotos de W. JESCO VON PUTTKAMER, fica claro que o referido profissional comercializou suas fotos com a NATIONAI GOOGAPHIC SOCIETY, uma vez que abaixo das mesmas encontra-se o crédito C)NG: (Copyright- National Geographic Society), o que comprova que o direito de autor foi repassado para a NGS. É lógico que o fotógrafo, para assim proceder, recebeu re muneração da National Geographic Society. 
MINISTERIO DO INTERIOR

FUNDAÇÃO NACIONAL DO ÍNDIO - FUNAI.

Em vista de tudo quanto foi exposto, somos de opi nião, salvo melhor juizo, que as providências sugeridas às fls. 62 e 63 do presente processo, são as únicas capazes de ressarcis dos índios sobre os direitos de imagem à que fazem jus mo tivo pelo qual sugerimos seja o assunto encaminhado, mais uma vez, à Bouta: Procuradoria Jurídica, para a adoção dàs medidas que se fizerem necessárias.

É: o que temos à informar, submetendo a presente à superior consideração de V.Sa.

Brasília, 26 de setembro de 1984

- INTER - FULCLGLO MACIONAL CO WNDO

Assessertia do ef studos \&f Pesquisas

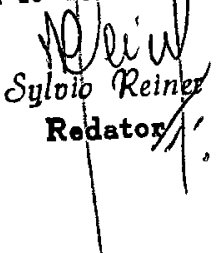

$\mathrm{AESP} / \mathrm{SR} / \mathrm{ICl}$ 
Ofício no $139 / 84-\mathrm{GR}$

Goiânia, 17 de setembro de 1984 .

Exmo. Sr.

JURANDY MARCOS DA FONSECA

DD. Presidente da FUNAI

BRASILIA - DF
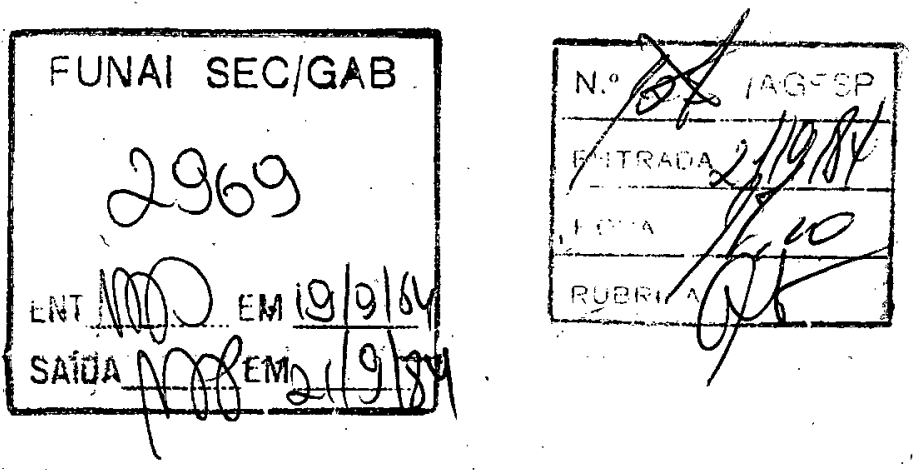

Senhor Presidente,

Com respeito ao Ofício no $802 / \mathrm{PRES} / \mathrm{PJ} / 84$, da FUNAI, dirigido ao nosso pesquisador, Sr. Wolf Jesco von Put tkamer Filho, desejamos fazer. alguns esclarecimentos.

o Sr. Jesco encontrava-se no Plänalto da Alta Lídia, desde o dia 20 de agosto, a serviço da Universidade Católica de Goiás, para concluir os trabalhos de documentação fotográfica iniciados há cinco anos atrás, junto às Frentes de Atração da FUNAI. Porém, tão logo tomou conhecimento da proibi ção de sua entrada naquela área indigena, retirou-se imediata mente deixando no Posto da FUNAI os filmes que havia batido e grande quantidade de alimentos e ferramentas.

o mesmo não se preocupou em efetuar pagamen to de direitos autorais porque antes da Portaria $907 / \mathrm{N}$, que re gulamenta o assunto, já havia obtido a autorização do Delegado da 8 a DR da FUNAI e a permissão (verbal) do antigo Presidente, Dr. Otằio.

Esclarecemos ainda que esta pesquisa foto gräfica é de interesse do CNPq e da UCG, não tendo nenhum fim comercial. Visa apenas contribuir para o acervo nacional sobre o indio brasileiro, sendo todo o material doado ao Instituto Goiano de Pré-História e Antropologia e colocado à disposição para as pesquisas cientificas. A própria FUNAI muito tem se va lido do material fotográfico obtido pelo nosso pesquisador, bem como dos vôos por ele fretado quando se dirige às áreas indige nas. 
UTILIDADE PUBLICA DECRETO N 73729 DE 04/03/1974 CGCIMFIN N 01587609/0001-71

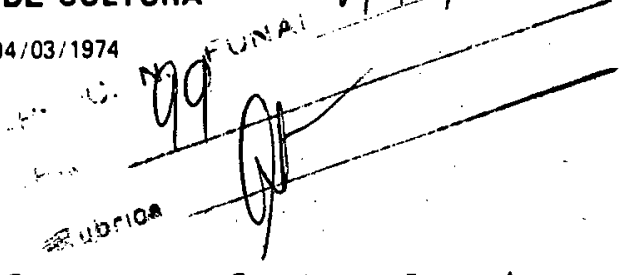

À oportunidade, manifestamos forte desejo de que a presente situação seja equacionada, .. adequadamente; de acordo com o realismo que salvaguarde as atuais preocupações da FUNAI, no tocante aos direitos e bem estar das nossas comu nidades indigenas, assim como as necessidades da pesquisa na área em foco. O Sr. Jesco deverá ir brevemente à FUNAI, com es ta finalidade. No momento, ele está impossibilitado, por motivo de saúde.

Apresentamos, na oportunidade, nossos pró testos de elevada estima e consideração.

A AESP

solícitando conlecer. an 190984

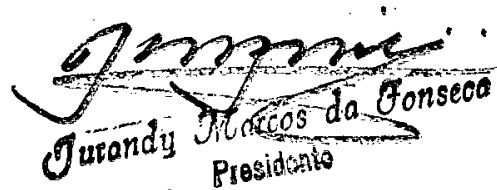

Atenciosamente,

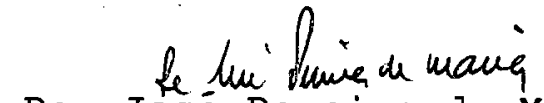

Pe. José Pereira de Maria

- REITOR - 


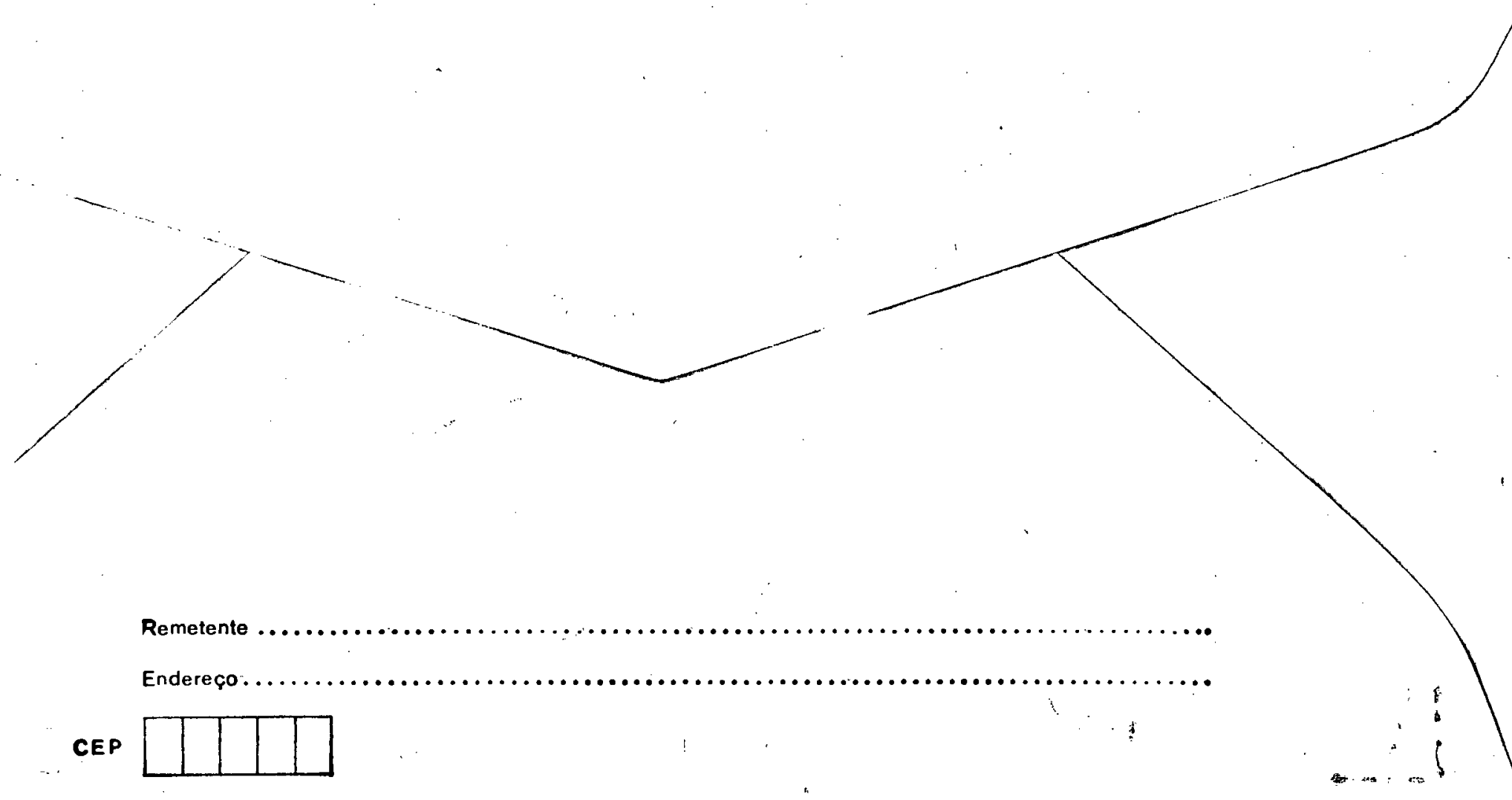


UNIVERSIDADE CATÓlica DE GOIÁS MANTIDA PELA SOCIEDADE GOIANA DE CULTURA

UTILIDADE PÚBLICA DECRETO N.० 73729 DE 04/03/1974

I $1 \mathrm{mo}$. Sr.

JURANDY MARCOS DA FONSECA

DD. Presidente da FUNAI

3 BRASILIA - DF RPC 


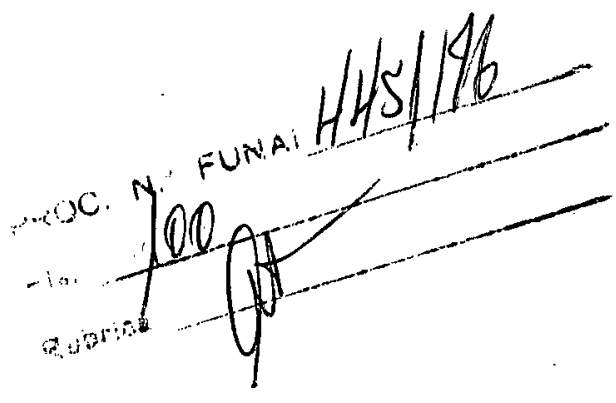

Senhor Assessor-Chefe da AESP:

Trata-se o presente de ofício encaminha do ao Senhor Presidente da FUNAI pelo Magnífico Reitor da Uni versidade Católica de Goiás, Pe. José Pereira de Maria, nơ: qual presta esclarecimentos sobre a atuação do fotógrafo WOLF JESCO VON PUTTKAMER (Filho), tendo em vista correspon dência enviada àquele profissional pelo Sr. Presidente da FUNAI, visando a solucionar problemas referentes ao não paga mento de direitos autorais e de imagem à indios por ele foca lizados em filmes, fotografias, cartões postais, gravações, etc...

Afirma o Reitor da UCG em seu ofício que desde o dia 20 agosto $\circ \mathrm{Sr}$. Jesco se encontrava no Planal to da Alta Lídia a serviço da Universidade Católica de Goiás, "para concluir os trabalhos de Documentação fotográfica iniciados há cinco anos atrās, junto às Frentes de Atração da FUNAI Diz ainda que tão logo tomou conhecimento da proibição de sua entrada naquela área indígena, o fotógrafo retirou-se imediatamente, "deixando no Posto da FUNAI os filmes que havia batido e grande quantidade de alimentos e ferramentas". Esclarece ainda o Magnifico Reitor que "o mesmo não se preocupou em efetuar pagamento de direitos autorais porque antes da Portaria $907 / \mathrm{N}$, que regulamenta o assunto, já havia obtido autorização do Delegado da 8a.DR da FUNAI e a permissão (verbal) do antigo Presidente, Dr.otávio". (O grifo é nosso).

\section{Finalmente o Reitor da UCG esclarece} que "esta pesquisa fotográfica é de interesse do CNPq e da UCG, não tendo nenhumircomercial. Visa apenas contribuir para o acervo nacional sobre o Indio brasileiro, sendo todo material doado ao Instituto Goiano de Pré-História e Antropologia e colocado à disposição para as pesquisas científicas". 


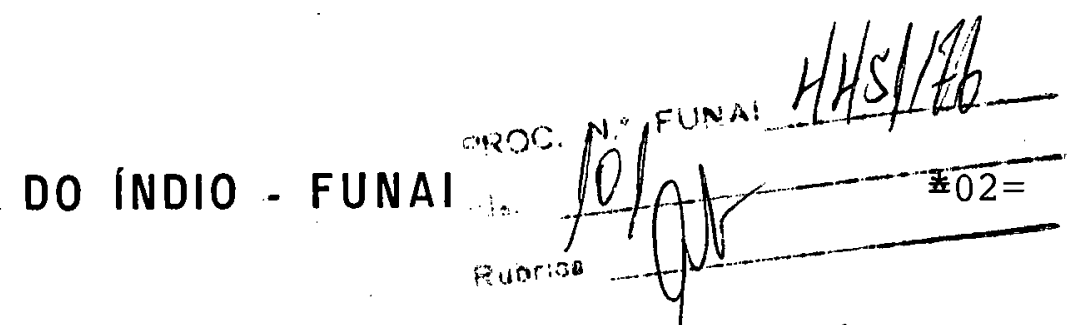

Analisando o ofício db Magnifico Reitor, Pe. Jošé Pereira de Maria, da Universidade Católica de Goiás, observamos que desde o dia 20 de agosto o Sr. WOLF JESCO VON PUTTKAMER (Filho) se encontrava no Planalto da Alta Lídia, a serviço da Universidade Católica de Goiás, onde a FUNAI desenvolve os trabalhos de atração dos indios URU-EU-WAU-WAU, sem autorização expressa do órgão tutelar para concluir os trabalhos de documentação fotográfica iniciados há cinco anos atrás, junto às Frentes de Atração da FUNAI.

Quanto à a奥egação do Reitor da UCG de que o Sr. WOLF JESCO VON PUTTKAMER (Filho) "não se preocupou em efetuar pagamento de direitos autorais porque antes da Portaria 907/N, que regulamenta o assunto, já havia obtido a autorização do Delegado da 8a.DR da FUNAI e a permissão, (verbal) do antigo Presidente, Dr. Otávio, a mesma em nada justi fica a atuação do fotógrafo em área indígena. Inicialmente, a ninguém é facultado ignorar a legislação em vigor, uma vez que, mesmo que a Portaria 907/N tenha sido baixada em 18.05. 84, desde 14.12.73, portanto quando o Sr. WOLF JESCO VON PUTTKAMER (Filho) iniciou os trabalhos de documentação fotográfica da atração dos indios URU-EU-WAU-WAU, encontra-se em vigor a Lei 5.988 que regula os direitos autorais e dá outras providências.

No que se refere ao fotógrafo possuir autorização do Sr. Delegado da 8a.DR da FUNAI, cabe lembrar que o Regimento Interno da FUNAI, aprovado pela Portaria Mi nisterial no 091 de 29.6 .83 em seu Capitulo. IV, artigo 45 re za o seguinte:

"Art. 45- Ao Presidente, a lém das atribuições previś tas no artigo 8\% e itens do Estatuto, incumbe:

IX- Conceder autorização pa ra pesquisas, estudos e o exercício das atividades em terras indigenas, por outras entidades ou pessoas estranhas ao quadro da FUNAI". 


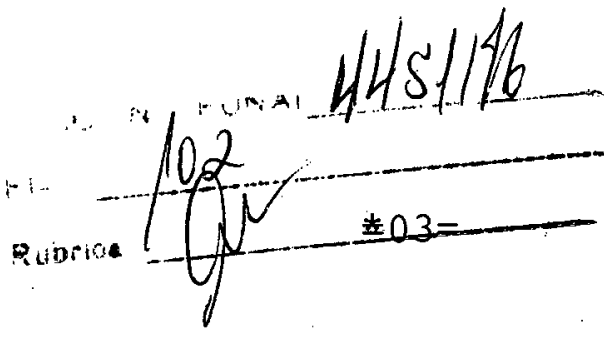

Claro ficafque o $\mathrm{Sr}$. Delegäo da 8a.DR não possui competência para autorizar o ingresso do Sr. WOLF JESCO VON PUTTKAMER (Filho) em área indígena.

Quanto ao fotógrafo possuir "permissão (verbal) do antigo Presidente, Dr. Otávio" desconhecemos existid esta modalidade de procedimento para ingresso. em área indigena, uma vez que a Autørização para Ingresso em Årea Indígena é fornecida, em formulário próprio, assinado pelo presidente da FUNAI, ao autorizado. Tal procedimento já era regulado através da portaria no $448 / \mathrm{N}$ de $1977 \%$ que foi revogada quando da assinatura da Portaria no 907/N de 18.05. 84.

Estranhamos também a afirmação do Magní fico Reitor da UCG de que a pesquisa fotográfica do Sr. WOLF JESCO VON PUTTKAMER (Filho) "não tem nenhum fim comercial". Acreditamos que o Sr. Reitor não tenha tido oportunida de de ler o relatório que o Sr. WOLF JESCO VON PUTTKAMER (Filho) the encaminhou relatando as atividades e contatos por ele mantidos nos Estadosie Alemanha, numa viagem de seis (06) semanas nos meses de maio e junho de 1984, cuja xerocópia: se encontra às fls.35 a 44 do presente processo. Fazemos esta afirmação tendo em vista que no referido relatório, O Sr. WOLF JESCO VON PUTTKAMER (Filho) afirma textualmente à fl. 37 do presente processo:

"A convite do Diretor do Museu de Berlim, Prof. Dr. G. Hartmann, hospedei em sua casa. Ali ele se inte. ressou em adquirir duas mil (2.000) fotografias de valor etnológico incalculável, mas como eu queria doar estas fotografias à Universidade Católica de Goiás, apenas permiti que tirasse cópias (duplicatas) e depois devolvesse os ori ginais. o Prof. Hartmann, 


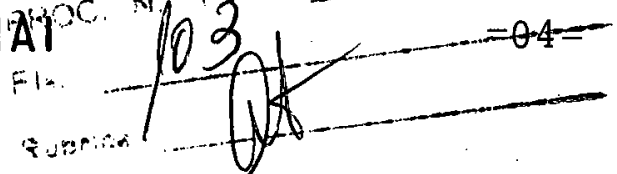

ainda trai adquirir mais ou menos mil (1.000) duplicatas dos slides de Londres, cujos originais voltarão e oportunamente serão doados à UCG" (OOgrifo é nosso)

Mais adiante, à fls. no 40 , O Sr. WOLF JESCO VON PUTTKAMER (Filho) informa:

"Outro contato não mencionado, realizado na Alemanha foi com a Revista GEO, tipo National Geographic Society dos E.U.A, muito grande e rica. Mas, infelismente, competidoras. Queriam que agosto próximo eu fosse fazer a reportagem sobre os Uru Eu Wau Wau, para eles. Mas, como não quero este atrito com a National Geographic, disse para o pessoal da GEO que trabal ho para eles a partir do ano que vem". (o grifo é nosso)

Como se pode observar claramente, O Sr. WOLF JESCO VON PUTTKAMER (Filho), ao contrário do que afirma em seu ofício o Magnífico Reitor da Universidade Católica de Goiās, utiliza seu material fotográfico, cinematográfico, fonográfico, etc..., para fins comerciais.

Em vista do exposto somos, salvo melhor juízo, da seguinte opinião:

1. Que o presente processo seja encaminhado ao Sr. Presidente desta Fundação para que o mesmo tome conhecimen to das atividades envolvendo o fotó grafo WOLF JESCO VON PUTTKAMER (Fi1ho), visando a que o mesmo não seja 
s.

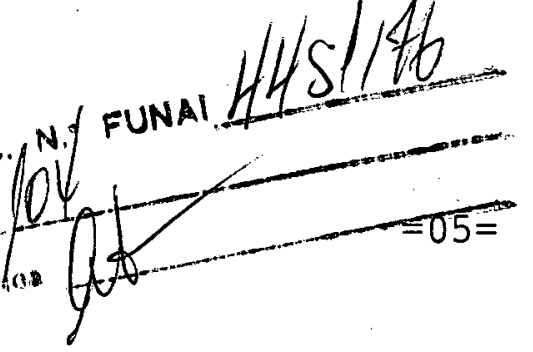

envolvido pelo respectivo profissio nal, possoa por demais simpática e persuasiva, como aconteceu com todos os Presidentes, desde a criação da FUNAI;

2. Seja enviado ao Magnífico Reitor da Universidade Católica de Goiās o ofício em anexo, acusando o recebimen to do oficio no 139/84-GR de 17 de setembro de 1984;

3. Que o presente processo, após aprecia ção por parte do Sr. Presidente da FUNAI, retorne à Douta Procuradoria Jurídica, para aguardar a vinda do Sr. WOLF JESCO VON PUTTKAMER. (Filho) visando a obtenção de um acôrdo amigável e, caso isto não seja possível, acionar judicialmente o referido fotó grafo.

E o que temos à informar, submetendo a presente à Superior consideração de V.Sa.

Brasilia, 04 de outubro de 1984 .

$\mathrm{AESP} / \mathrm{SR} / \mathrm{sb}$

MINTER - FLINDACÁD NHCOONL DO INCIOO

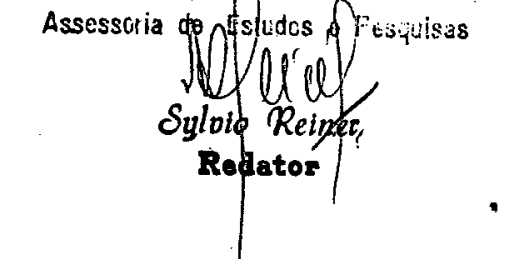

De acoibro cour o parecer.

Senbuetencos nimatra di oficio a courideraces do Suntor Presidecte, abieitiendo posterior encancier Ranear to a. PJ para as medidos que 
MINISTERIO DO INTERIOR

FUNDAÇÃO NACIONAL DO INDDIO - FUNAI

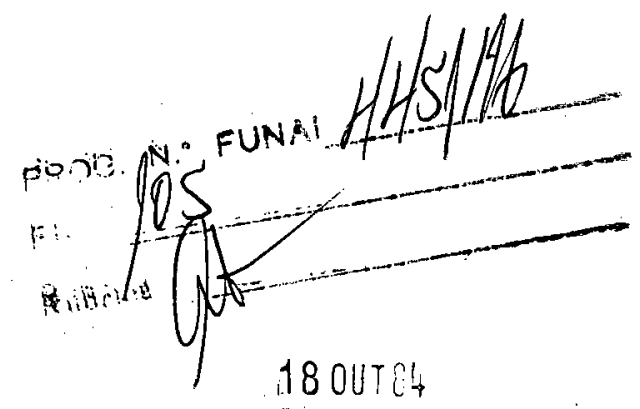

OF. NP 923 /84-PRES/AESP.

Presidente da FUNAI :

Magnifico Reitor da Univergldade Catölica de Golấs

Acusa recebimento "do officto no 139/84-GR.

Magnifico Reitor,

Acusamos o recebimento do Ofíc1o nP 139/84-

GR, de 17 de setembro de 1984 , onde Vossa Magnificencia esclarece sobre a atuação do $\mathrm{Sr}$. Wolf Jesoo von Puttkamer F1lho, em-äreas indigenas.

Não podemos delxar de reconhecer a importâncla do trabalho desenvolvido pelo referido pesquisador mas, ao mes mo tempo, nẽo podemos de1xar de defender as comunldades 1ndígenas no que diz respeito aos seus direitos autorais e de 1magen, regulados pela Le1 no 5.988 de 14.12 .1973 e pela Poxtaria n8 907/A, de 18.05 .1984 .

E degejo, tambēm, desta Fundação, de soluc1onax a situação do Sr. Wolf Jesco von Puttkamer Filho, e para tantoaguarảmos sua presença em Brastl1a, tão logo o mesmo esteja recuperado do seu estado de saúde.

Cabe esclarecer, ainda, que as autorizaçöes para ingresso em ärea indígena, são de acordo com o Regimento Interno da Fundação Nacional do Indio, de competêncta exclusiva des ta presidência, através de documento prpprio, fornecido ao autor 1 zado.

de elevada estima e distinta consfideração.

Na oportuniáde, reiteramos nossos protestos 
FUNDAÇÃO NACIONAL DO ÍNDIO - FUNAI

INFORMAÇÃO NO OO2/85 - AESP

Ref: Proc.FUNAI/BSB/4451/76

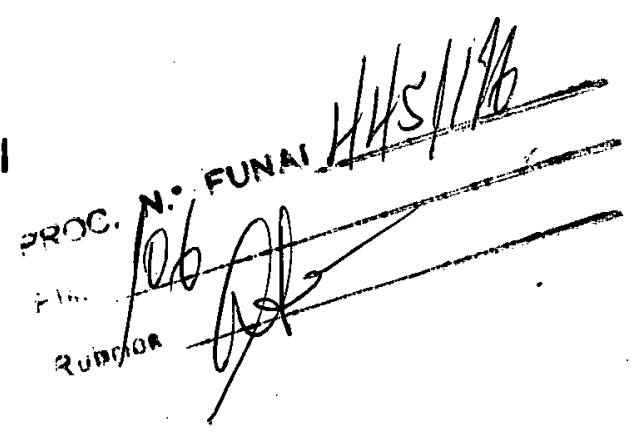

Senhor Chefe da AESP:

Em 18 de outubro de 1984, através do ofício no 923/84-PRES/AESP, encaminhado ao Magnífico Reitor da Univer sidade Católica' de Goỉás, esta Fundação acusou o recebimento do Ofício no 139/84-GR, esclarecendo a atuação do fotógrafo WOLF JESCO VON PUTTKAMER FILHO em áreas indígenas.

Na ocasião, o Senhor Presidente da FUNAI infor mou que "E desejo, também, desta Fundação, de solucionar a situação do Sr. Wolf Jesco Von Puttkamer Filho, e para tanto aguardamos sua presença em Brasília, tão logo o mesmo esteja recuperado dó seu estado de saúde".

Decorridos mais de dois meses do envio do ofí cio do Senhor Presidente da FUNAI, o fotógrafo WOLF JESCO VON PUTTKAMER FILHO ainda não compareceu à sede desta Fundação para legalizar sua situação.

Cremos, salvo melhor juízo, já haver decorrido um prazo bastante razoável para que o mesmo se restabelecesse do seu estado de saúde.

Em vista do exposto, somos da opinião que o presente processo retorne à Douta Procuradoria Geral, para que a mesma adote as medidas legais cabiveis, visando a garantir o pagamento de direitos autorais e de imagens dos ín dios focalizados pelo $\mathrm{Sr}$. fotógrafo WOLF JESCO VON PUTTKAMER FILHO.

E o que temos a informar, submetendo a presen te à superior consideração de V.Sa.

BSB, 手 de janeiro de 1985 .

$\mathrm{SR} / \mathrm{sb}$

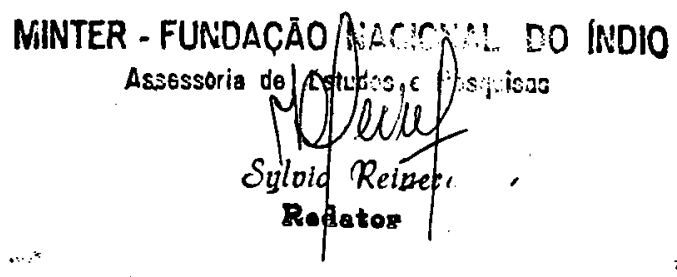


MINISTÉRIO DO INTERIOR

FUNDACÃO NACIONAL DO INDIO - FUNAI pROO.

DESPACHO NQ $0 / 0 / 85$ - AESP

REF。: Processo FUNAI/BSB/4451/76

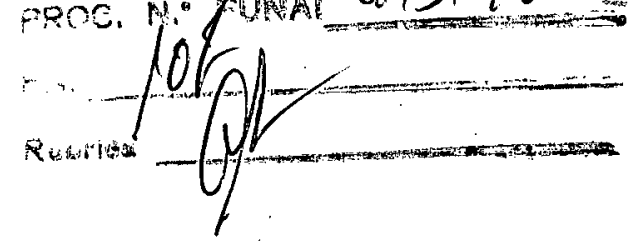

Encaminhemse à Procuradoria Juridica, para as providências julgadas necessárias.

Em, 14/janeiro/1985

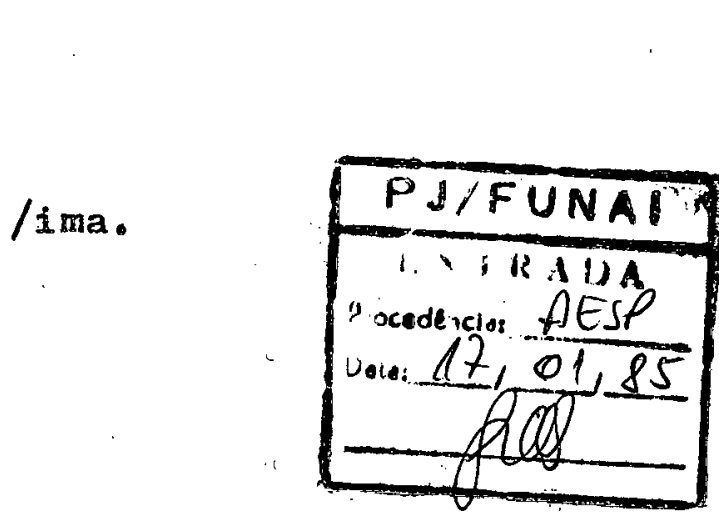

a' Dra. Neura $8 m \quad 16.01 .85$

Harvalow

Matia Mexiliadora C. Caroalho

Qugrande. ve, de oudeu, retorno da tora verea, de qenias, en: 04/02/85.

quacheino Sed RJ.

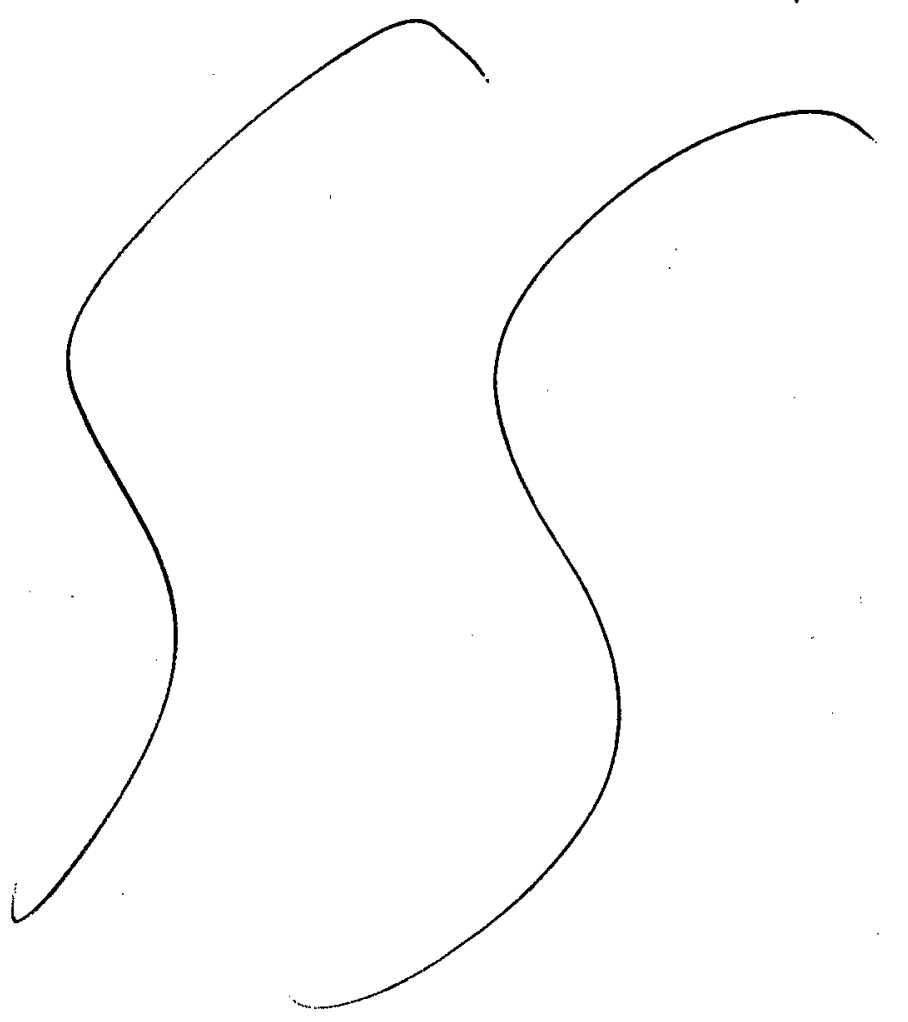


A conaideracáo da Sra Prounadora firal com mimuta de ificio e pareer

Ein, 06.02 .85

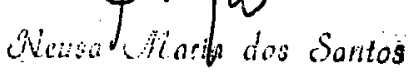

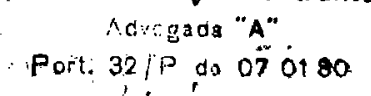


EMENTA - solicitação para ingres sar em áreas indígenas para fins de estudo e documentação, pela NÄTIONAL GEOGRAPHI SOCIETY.

Trata o presente processo sobre autorização pa ra ingresso em área indígena com o objetivo de elaborar documentá rios fotográficos e filmagens, sobre o processo de interiorização do Brasil, que na sua maioria, foram realizados pelo Sr. WOLF JES CO VON PUTTKAMER, conforme consta de seu relatório de fls. 35/44. Para nossa surpresa, vimos constatar, que o $\mathrm{Sr}$. JESCo vem utilizando seu material fotográfico, cinematográfico, fonográfico indígenas, para fins comerciais, como se pode verifi car no seu relatório, às fls. 35, quando ele diz que o Diretor do Museu de Berlin se interessou em adquirir duas mil (2.000) fotogra fias, "de um valor etnográfico incalculável."

o que mais admiramos, è que em plena vigência da Lei no 5.988/73, que regulamenta o direito autoral no Brasil, é que o próprio órgão tutelar concedeu autorização à fotógrafos, ceneastas, escritores, como se o indio fosse em objeto em exposi ção, não respeitando a sua individualidade, e desrespeitando o próprio Estatuto do Indio-Lei no 6.001/73 - Capítulo II - Dos crị mes contra os Indios- que, no seu artigo 58, İtem II, dispõe:

\section{IN VERBIS.}

Art. 58 - "Constituem crimes contra os indios e a cultura indigena."
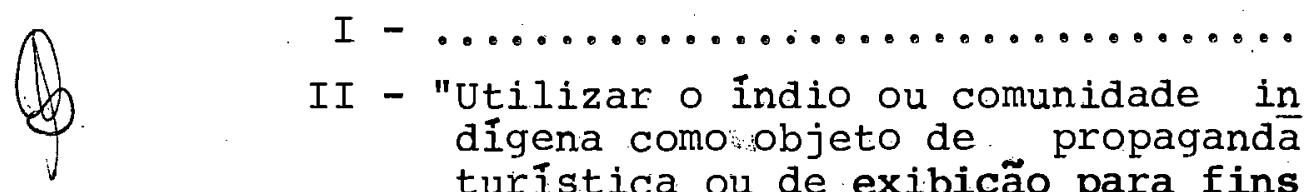

II - "Utilizar o índio ou comunidade in dígena como objeto de propagandā turistica ou de exibição para fins lucrativos. Pena-detenção de dois a seis meses." 


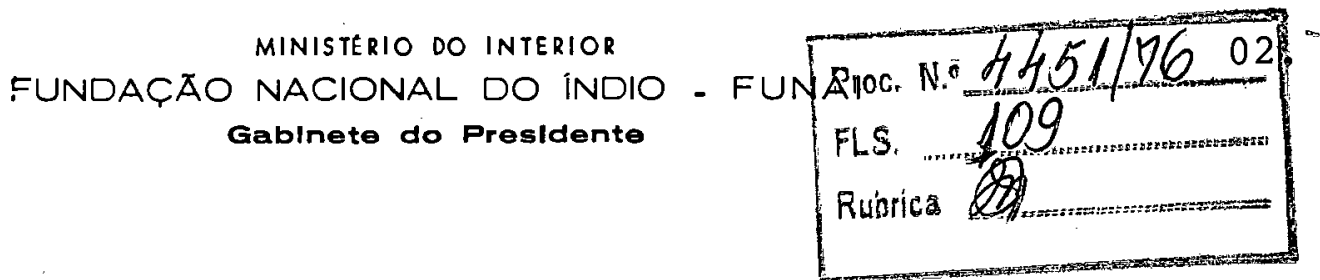

Como se vê, a própria FUNAI tem agido sem obser vância de lei, no que, nos deixa constrangidos para agir judicial mente contra os usurpadores dos direitos autorais indigenas.

Por outro lado, temos de reconhecer que o traba lho do Sr. Wolf Jesco Von Puttkamer é de excelente qualidade, nes te ponto não existe a menor dúvida, mas o que está em discussão é a violação de uma série de regras emanadas por esta FundAção, no que se refere ao ingresso do referido Senhor em áreas indígenas, bem como o pagamento de direitos autorais e de imagem dos indios por ele focalizado em filmes, fotografias e. slides, direitos es tes regidos pelas Leis supramencionadas e regulamentados pela Por taria no 907/N-FUNAI, de 18.05.84.

Assim, tendo em vista o órgão tutor ter autori zado o ingresso do Sr. Wolf Jesco Von Puttkamer; por diversas ve zes em áreas indígenas, julgamos que seja mais prudente convidálo mais uma vez a comparecer nesta Procuradoria Jurídica, a fim de um acordo amigável, com o objetivo de indenizar às comunidades indígenas utilizadas no seu trabalho fotográfico, razão pela qual, juntamos minuta de oficio dirigido ao referido senhor, para a as sinatura do Sr.Presidente.

E o nosso entendimento.

"sub censura".

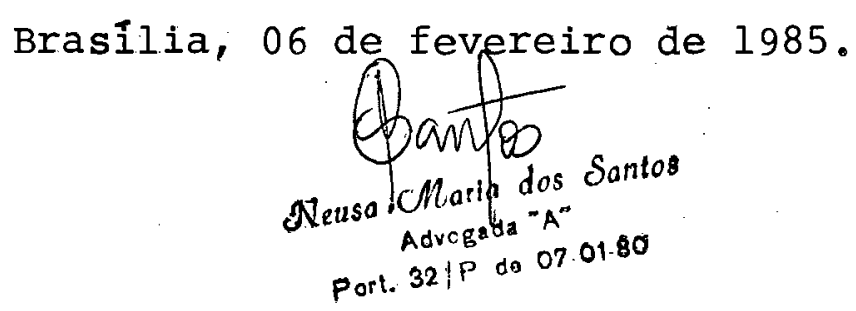

Mod. ${ }_{116}$ NMS/ Ird.PJ 
Fls.

Ref : PROC/FUNAI/BSB/04451/76

\section{Aprovo o Parecer no 007/PJ/85.}

Submeta-se à assinatura do sr. Presiden te o anexo projeto de ofício, cuja cópia, após a expedição do mesmo, deverá ser anexada a este ex pediente.

A seguir, tendo em vista que $\circ$ assunto já foi detidamente examinado pela AESP, encaminhe se àquela Assessoria solicitando pronunciamento quanto as bases para cálculo do acordo a ser pro movido, objetivando indenizar os indios pela comercialização de trabalhos de documentação audio visual em áreas indígenas.

Brasília, 06 de fevereixo de 1985.

\section{Harvallo}

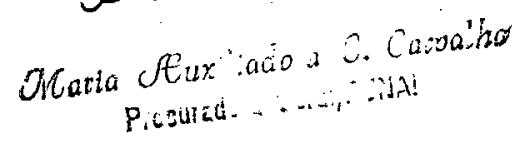

ia AESP, de ordene.
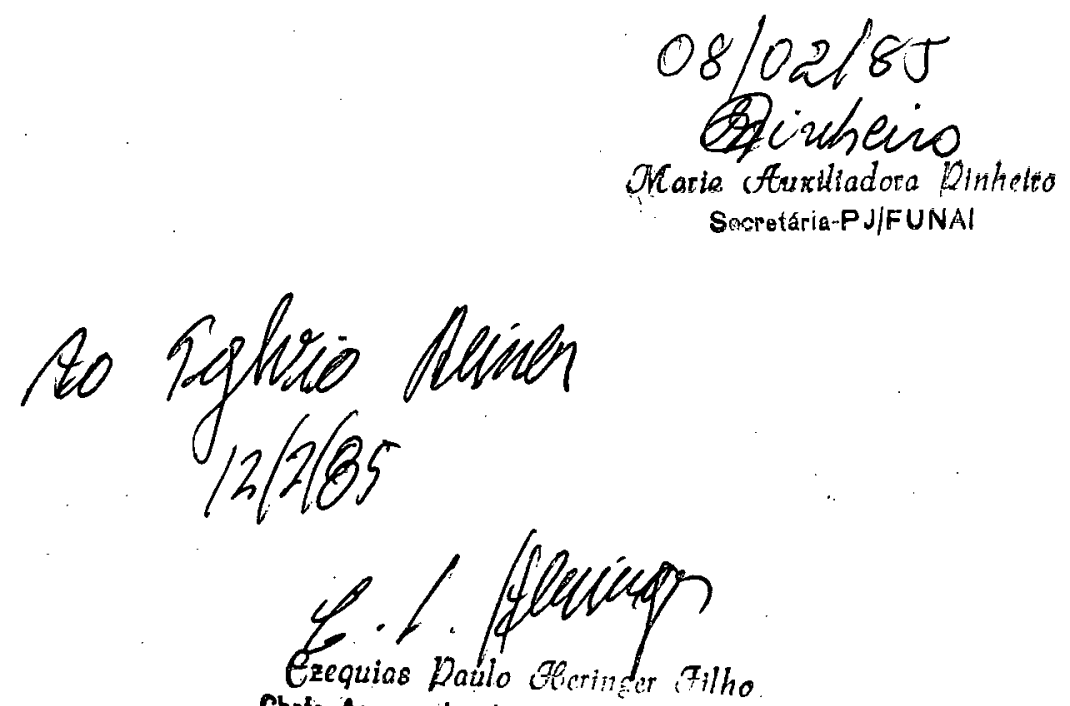

Chofe Assessoria de Estudos \& Pesquisas AESP-FUiVAI 
Fls.

Ruteried

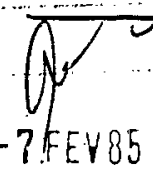

DO

: Presidente da Fundação Nactonal do Ind1o - FUNAI

AO

- Sr. Wolf Jesco Von Puttkamer (Filho)

ASSUNTO : Solicitação (FAZ)

A Fundação Nacional do Indto na preocịpação de preservar o direito dos indIgenas brasllelro, vem mais uma vez solicigar o seu comparecimento junto à Procuradoria Jur $\underline{I}$ dica, desta Instituição, a fim de tratar de assunto de seu in teresse e dos Indios, na forma constante dos termos do oflcio no 802/PRES/PJ/84, datado de 27.08.84, dirigido a V.Sa.

Outrosstm, Informa que o não atendimento por parte de V.Sa., a FUNAI tomará as medidas judictals que o ca so requer.

Na certeza de poder contar com a sua compreen §ão, no sent1do de se chegar a uma solução amtgável, aprove1 ta a oportusindade para apresentar-lhe protestos de considera ção e apreço.

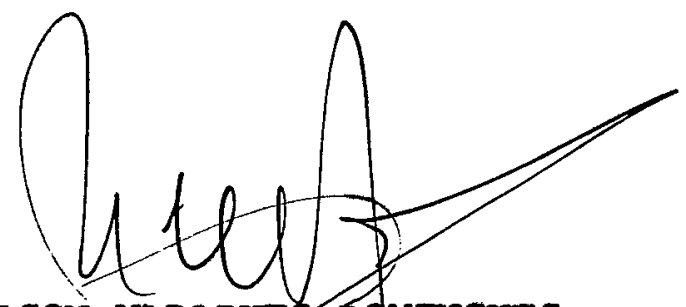

NELSON MARABUIPO DQMTNGUES

Presilente/FulNAI

IIme Senhor

WOLF GESCO VON PUTTRAMER FILHO

$74.000-$ GOIANIA - GO. 


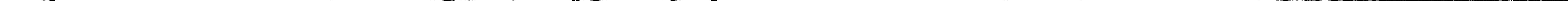




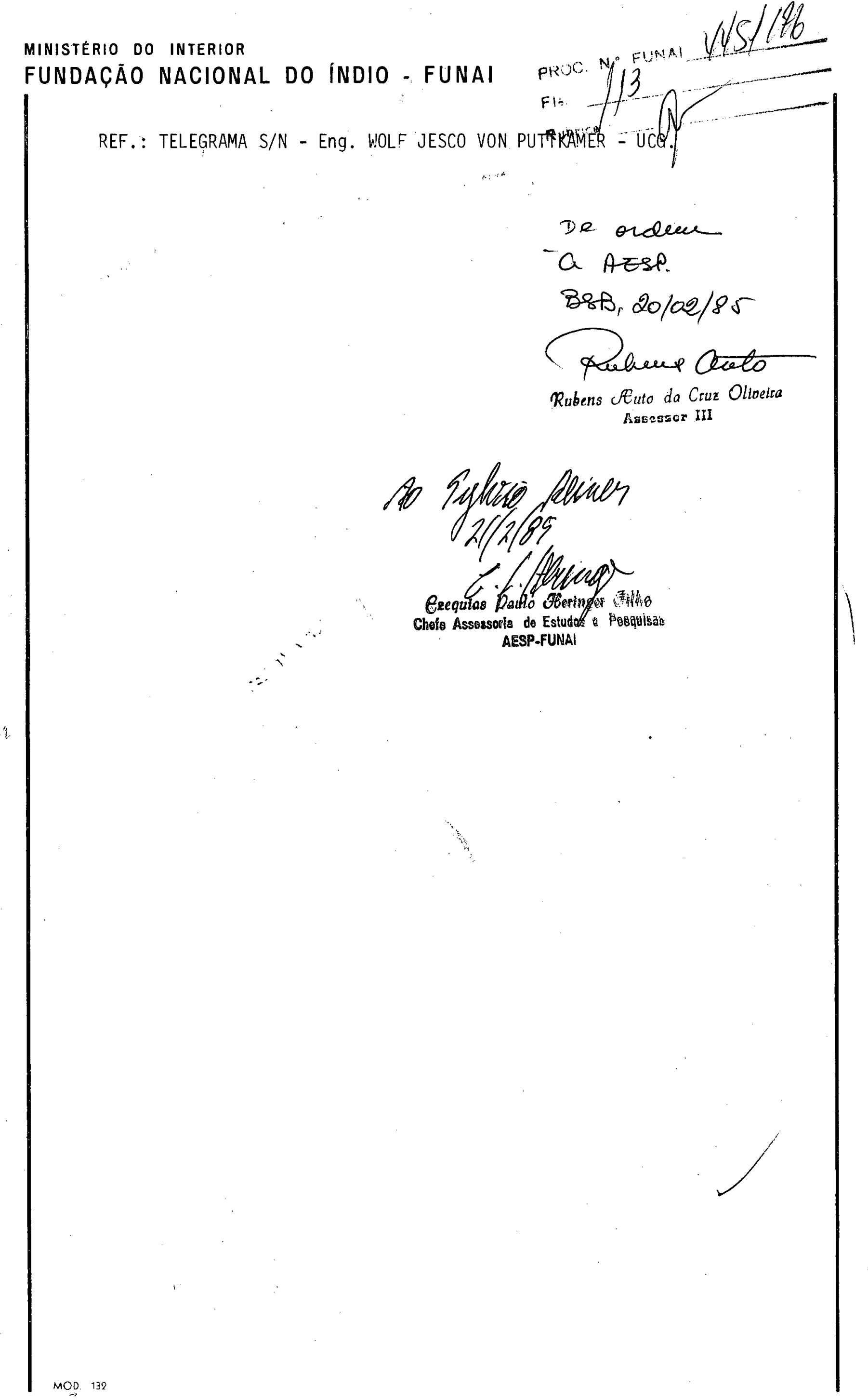


DO

: Fresidente da Fundação Nacional do Indio - FunaI

AO

: Sr. Wolf Jesco Von Puttkamer (Filho)

ASSUINTO : Solicitação (FAZ)

A. Fundação Nacional do Indio na preocịpação de preservar o direito dos indigenas brasileiro, vem mais uma vez solicigar o seu comparecimento junto à procurajoria Jurí dica, ciesta Instituição, a fim de tratar de assunto de seu in teresse e dos indios, na forma constante dos termos do oficio no 802/PRES/PJ/84, datado de 27.03.84, dirigiào a V.Sa.

Outrossim, informa que o não atendimento por parte de V.Sä., a FUNAI tomará as medidas judiciais que o ca so requer.

Na certeza de poder conter com a sua compreen ção, ro sentido de se chegar a uma solugão migável, aprovéta a oportufadade para apresentar-lhe protestos de considera ção e apreçc.

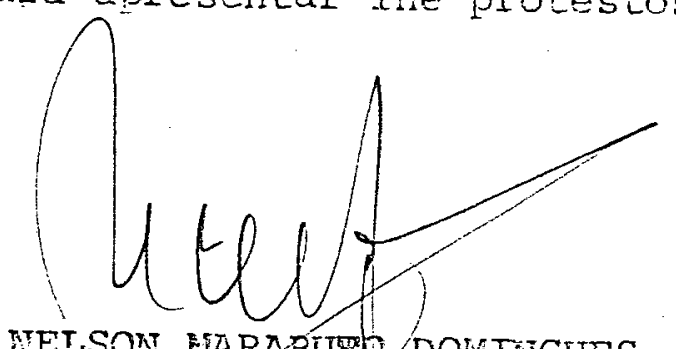

NELSON MAPABUED DOMTIGUES

présidente/FInIAI

IImo Serihor

WOLF GESCO VON PUTTEFIER FILHO

$74.000-$ GOIENIA - GO.

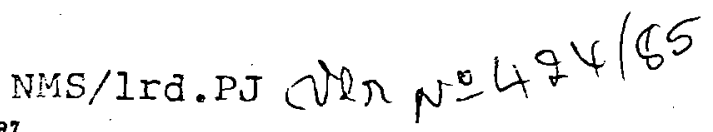

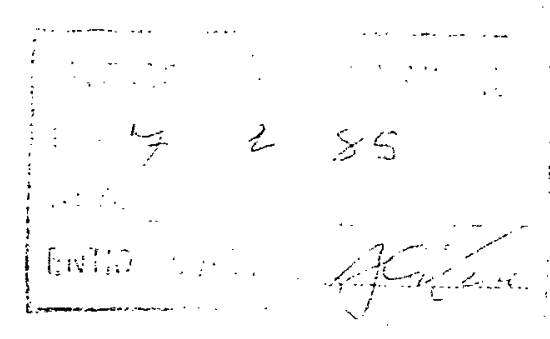


UTILIDADE PUBLICA DECRETO N ${ }^{\circ} 73729$ DE 04/03/197/ CGCIMF) N॰ 01587609/0001-71

Instituto Goiano de Pré-História e Antrópologial

Of: n? $023 / 85-$ IGPA

$\mathrm{AO}$

Presidente da FUNAI

Dr. Nelson Marabuto. Domingues

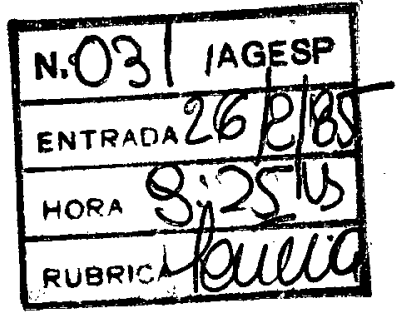

SIA TRECHO 04 , Lote 750

Brasilia-DF.

Senhor Presidente,

Ao tomarmos conhecimento do oficiono 103/PRES/PJ/85, desejamos esclarecer a V.Sa. que o pesquisador e documentarista Prof. Wolf Jesco von Puttkamer Filho faz parte do quadro do Instituto Goia no de Pré-História e Antropologia, tendo doado ao mesmo o acervocons tituido de fotografias, slides e filmes de populações indígenas.

Torna-se importante salientar que o material citado está servindo de fonte de pesquisa aos alunos e professores da Univer sidade Católica de Goiás, com fins exclusivamente culturais e cientí ficos.

Acreditamos que o referído professor ainda não aten deu à solicitação de seu comparecimento a Brasília por motivos de saūde, uma vez que, em virtude de prescrição médica, encontra-se im possibilitado de viajar. Tão logo seu estado de saúde o permita, com parecerá a esta instituição, atendendo assim à solicitação de Vossa' Senhoria.

Aproveitamos o ensejo para apresentar a V.Sa. os nossos protestos de estima e consideração.

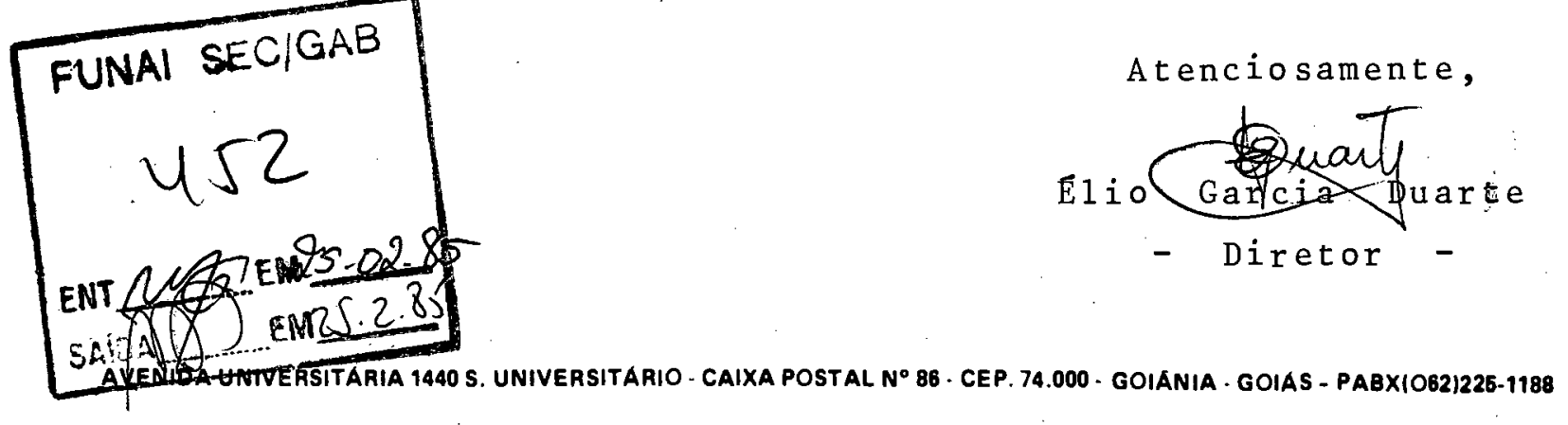




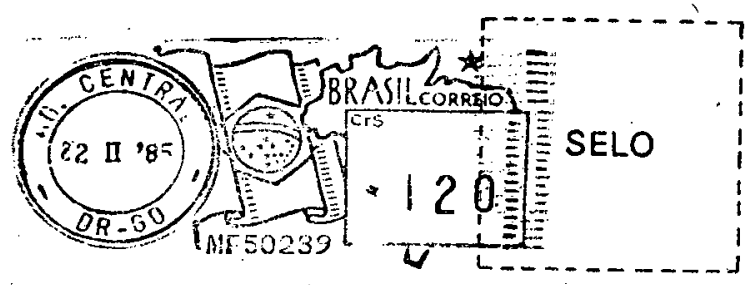

A0

Dr. Nel son Marabuto Domingues

Presidente da FUNAI

Fundação Nacional do Indio - FUNAI

SIA - Trecho 04, Lote 750

Brasilia-DF.

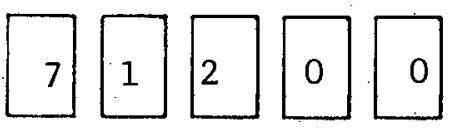




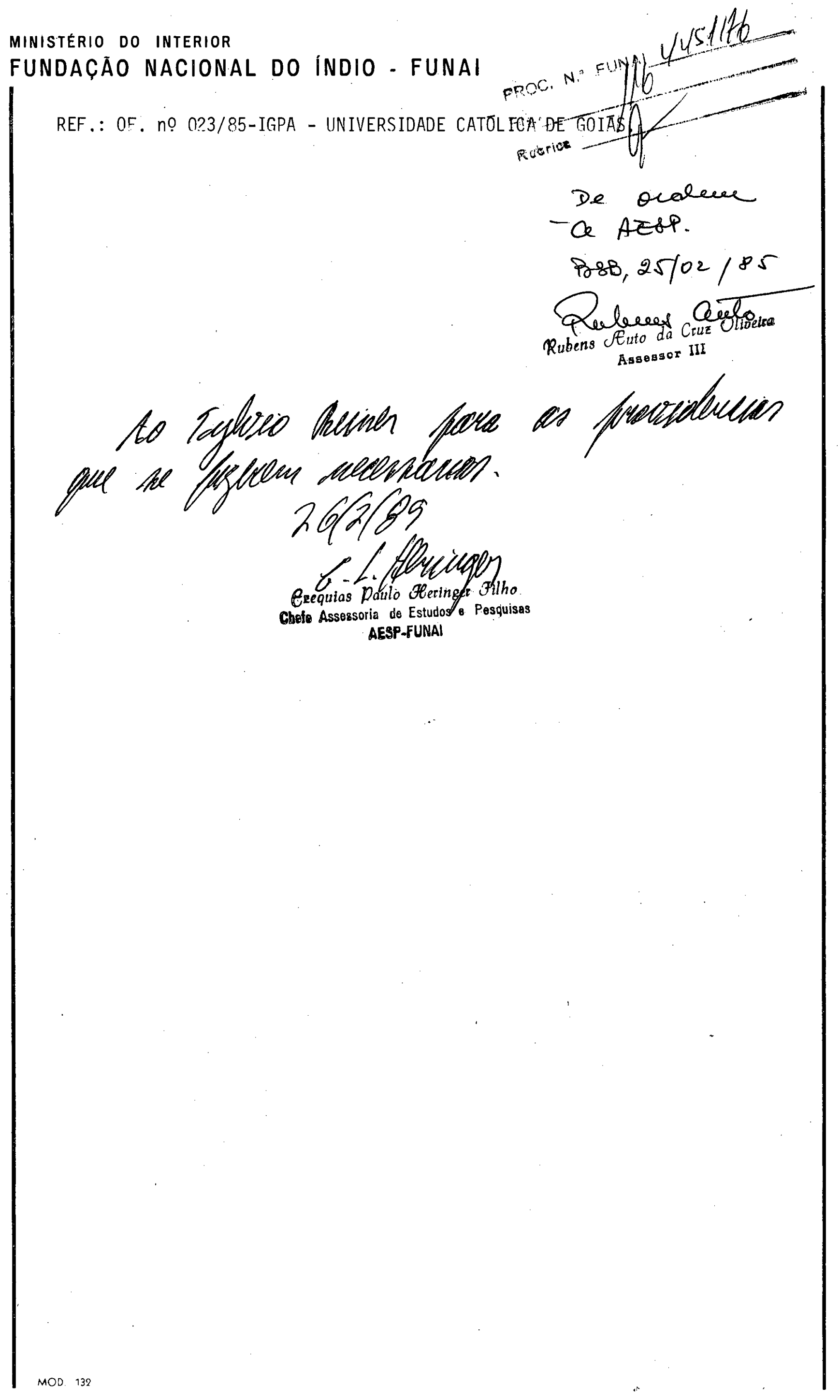


PARECER NO 035 185-AESP

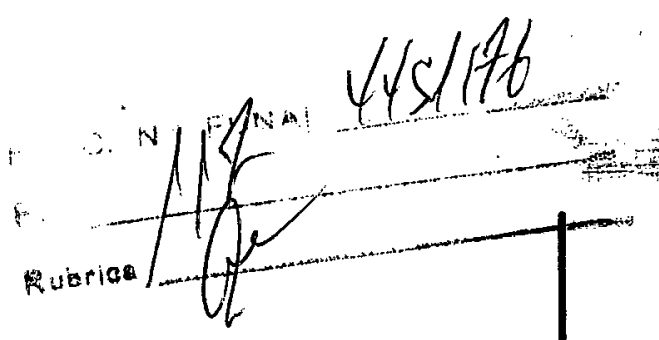

Ref.: Proc.FUNAI/BSB/04451/76

Sr. Chefe da AESP:

O Jornal "JORNAL DE BRASILIA" em sua edição de 24 de março do corrente ano, publicou com "chamada" na la. pági na, no seu suplemento "JORNAL DE DOMINGO", matéria de página interna sobre o fotógrafo WOLF JESCO VON PUTTKAMER (filho) sob o título "EU FOTOGRAFEI A ALMA DO INDIO BRASILEIRO" na qual o profissional afirma, entre outras coisas, que:

a) Nesses 35 anos de trabalho" produzi 200 a $300 \mathrm{mil}$ fotos de indios e milhares de metros de filme em $16 \mathrm{~mm}$ ".

b) "A Universidade me convidou para ser coordenador de uma expedição à Rondonia, na frente de atração URUEU-WAU-WAU.... Ela quer pesquisar e documentar essa cultura ainda intocada: o trabalho heróico da FUNAI na reserva; as cavernas no planalto de Ataliba; o Apadi, que eles usam em suas flechas.

Devemos ir com a antropóloga Bete Minalin. Mas é ne cessārio autorização da FUNAI e espero conseguir a licença".

c) A "chamada" da la. página diz que "doente, sujeito a um infarto a qualquer momento, mesmo assim, Jesco Puttkamer, um brasileiro que passou mais de dois anos nos campos de concentração alemães, planeja. mais uma viagem de estudos ao território dos UruêWau-Wau, em Rondônia. (o gripo é nosso)

d) Respondendo a uma indagação do repórter sobre " Fâ zer esse tipo de coisa hoje em dia está mais difí cil com a FUNAI cobrando para entrar nas Reservas" Jesco afirma: "Acho justo que se cobre dessa gente que usa a imagem do índio para fins comerciais. Mas não deveria impor dificuldades a quem, já com sá crifícios, procura documentar a vida e a belezadeles. 


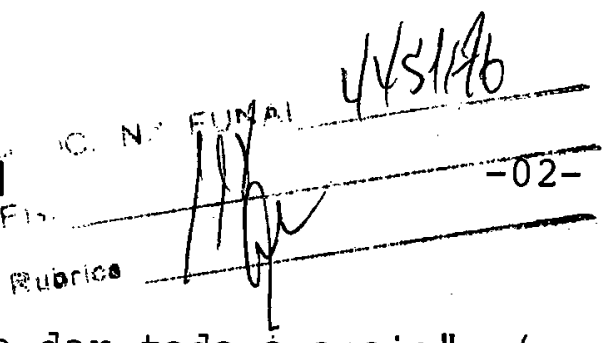

Aos pesquisadores, deveria se dar todo ó apoio". (o grifo é nosso).

e) Ao responder a uma indagação do Jornalista sobre: "O se nhor chegou a procurar o CNPq (Conselho Nacional de Pes quisas), por exemplo ?" o fotógrafo Jesco Von Puttkamer declarou: "Eu não tinha contato com essa gente. E não sou homem de procurar gabinete. Eu procurava os sertanistas la na frente". (o grifo é nosso).

f) O fotógrafo Jesco Von Puttkamer afirma, ainda, em sua entrevista que o material que doou há 5 anos à Universi dade Católica de Goiás" è considerado o maior acervo do mundo sobre o índio do Brasil". (o gripo é nosso).

Analisando detidamente a Reportagem publicada pelo "JORNAL DE BRASILIA", observa-se o seguinte:

1. Das 200 a $300 \mathrm{mil}$ fotos produzidas pelo Sr. Jesco Von Puttkamer Filho, em āreas indígenas, a FUNAI recebeu ape nas uma ínfima parte delas (não chegam a mil fotografias e slides) e quanto aos milhares de metros de filme em $16 \mathrm{~mm}$ esta Fundação não recebeu do referido profissional um centímetro sequer;

2. Na sua entrevista o fotógrafo JESCO PUTTKAMER afirma que pretende ir com a antropóloga Bete Mindlin à frente de atração Uru-Eu-Wau-Wau pesquisar e documentar aquele grupo tribal. Mas na: "chamada" de la. pāgina que o Jor nal publicou sobre a entrevista do Sr. Jesco Puttkamer, consta que o mesmo se encontra "doente, sujeito a um in farto a qualquer momento".

Diz ainda o fotógrafo na sua entrevista, no ponto que aborda os Uru-Eu-Wau-Wau que "é necessārio autorização da FUNAI e espero conseguir a licença".

Ora. O Sr. Jesco Von Puttkamer (filho) é fotógrafo, não possuindo formação antropológica. Não cabe portanto, ao mesmo pesquisar e documentar os Uru-Eu-Wau-Wau, mas, no máximo, documentā-los, desde que autorizado pela FUNAI. De fato o fotógrafo afirma que pretende solicitar auto rização à FUNAI, mas, no nosso entender, seria arriscado concedê-la, tendo em vista sua idade avançada (65 anos) 
nuoracin

e seu precário estado de saúde pois o prōprio jornal afirma que o mesmo se encontra "doente, sujeito a um infarto a qualquer momento", e não é desejo desta în dação que o fotōgrafo sofra esse enfarto em área indígena.

3. O fotógrafo Jesco Puttkamer acha justo cobrar direitos autorais "dessa gente que usa a imagem do indio para fins comerciais" mas que a FUNAI "não deveria impôr di ficuldades a quem, já com sacrifícios, procura documen tar a vida e a beleza" dos indios.

Não é fácil aceitar que o Sr. Jesco Puttkamer não te nha ganho nenhum centavo pelos filmes que produziu pa ra a BBC de Londres; pelos cartões postais produzidos pela firma MERCATOR, de São Paulo; pelas reportagens publicadas pelo NATIONAL GEOGRAPHIC MAGAZINE; etc... o próprio Sr. Jesco Puttkamer afirma em relatório ane xado ao presente processo (fls.37) haver vendido $2 \mathrm{mil}$ fotografias e mil slides ao Museu Etnológico de Berlim. Para se ter idéia sobre o preço cobrado, no Brasil, pa ra a comercialização de fotos e slides, anexamos ao presente parecer a tabela de preços cobrado pela AGIL Fotojornalismo, empresa sediada nesta capital.

claro fica, portanto, que o fotógrafo Jesco Puttkamer também "usa a imagem do índio para fins comerciais", devendo pagar, como qualquer outro, os direitos auto rais a que os indios fazem jus de acordo com a legisla ção vigente no País.

4. o próprio fotógrafo, em certo trecho de sua entrevista afirma não ser homem de procurar gabinete".

Eu procurava os sertanistas, lá na frente". No nosso entender, as leis e portarias foram elaboradas para serem cumpridas por todos. Cabe, somente ao Sr. Presidente da FUNAI, ouvida a Assessoria de Estú dos e Pesquisas, conceder autorização para ingresso em āreas indígenas, e o Sr. Jesco Puttkamer não deve se constituir uma excessão, obtendo a autorização dos ser tanistas na frente de atração. 
5. Diz também o fotógrafo Jeşo putkamer haver doado todo o material que possuia à Universidade Federal de Goiás e que este material documental "é considerado o maior acervo do mundo sobre o indio brasileiro". No nosso entender o acervo documental recolhido pelo $\mathrm{Sr}$. Jesco Puttkamer durante mais de 30 anos em áreas indigenas brasileiras deveria ter sido doado à FUNAI, que, agindo corretamente ou não (não nos cabe aqui jul gar este fato) permitiu que o fotógrafo realizasse seu trabalho junto aos seus tutelados, e não à Universida de Católica de Goiás.

Por uma questão de Justiça, entretanto, cabe aqui uma indagação:

Teria a FUNAI recursos financeiros, técnicos e humano para preservar tão importante acervo? Cremos que no mo mento, lamentavelmente a resposta seria NÃO haja visto - material atualmente existente na Assessoria de Comu nicação Social, arquivado em dependências sem condi ções adequadas de refrigeração; sem que sejam feitas reproduções periodicas do acervo existente, visando sua conservação, etc...

Cremos haver chegado a hora de estudar-se uma fórmula visando a conservação do material documental audioví sual jā existente nesta Fundação, bem como, a amplia ção gradativa desse acervo, que nada mais é do que a memória do indigenismo brasileiro; que deve ser conser vado e ampliado, visando as futuras gerações.

Em vista do exposto, somos salvo melhor juizo, do seguinte parecer:

a. Tendo em vista o precário estado de saúde em que se encontra o Sr. Wolf Jesco Von Puttkamer (filho), aguar dar por um razoável espaço de tempo, sua completa recu peração, a fim de que o mesmo, compareça a sede desta Fundação, atendendo convocação, que the foi feita atra vés do ofício no 103/PRES/PJ/85; 
FUNDAÇÃO NACIONAL DO INDIO - FUNAI

Rubic:

b. Obter do $\mathrm{Sr}$. Wolf Jesco. Von Puttkamer Filho o pagamen to, mesmo que simbólico - isto é não se cobrando rigo rosamente de acordo com as tabelas de preços atualmen te vigentes - dos direitos autorais devidos às diver sas nações indígenas por ele retratadas;

c. Encontrar uma fórmula visando a que o Sr. Jesco Puttkamer forneça à esta Fundação cópia do acervo docu mental que doou à Universidade Católica de Goiás.

d. Comunicar à 8a.DR que o sr.Jesco Von Puttkamer (Filho) continua proibido de ingressar em áreas indígenas, até a solução das pendências existentes para com a FUNAI;

e. Somente conceder nova autorização para ingresso em área indígena ao Sr..Wolf Jesco Von Puttkamer (Filho) quando o mesmo resolver suas pendências para com a FUNAI e as comunidades indígenas, bem como comprovar que se encontra completamente recuperado em seu esta do de saúde.

$E$ nosso parecer, o qual submetemos à superior con sideração de V.Sa.

Brasilia, 29 de março de 1985

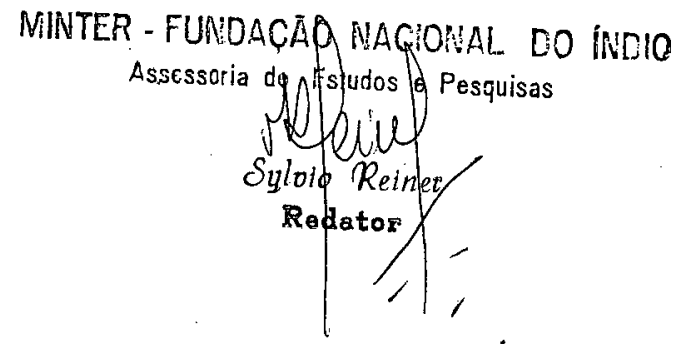

$\mathrm{SR} / \mathrm{mik}$ 


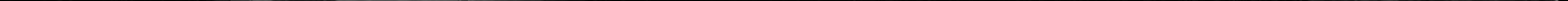


jeseo

Con a Cúpula da National fogapplic cricicty en Wabling tou (Mais 84). 


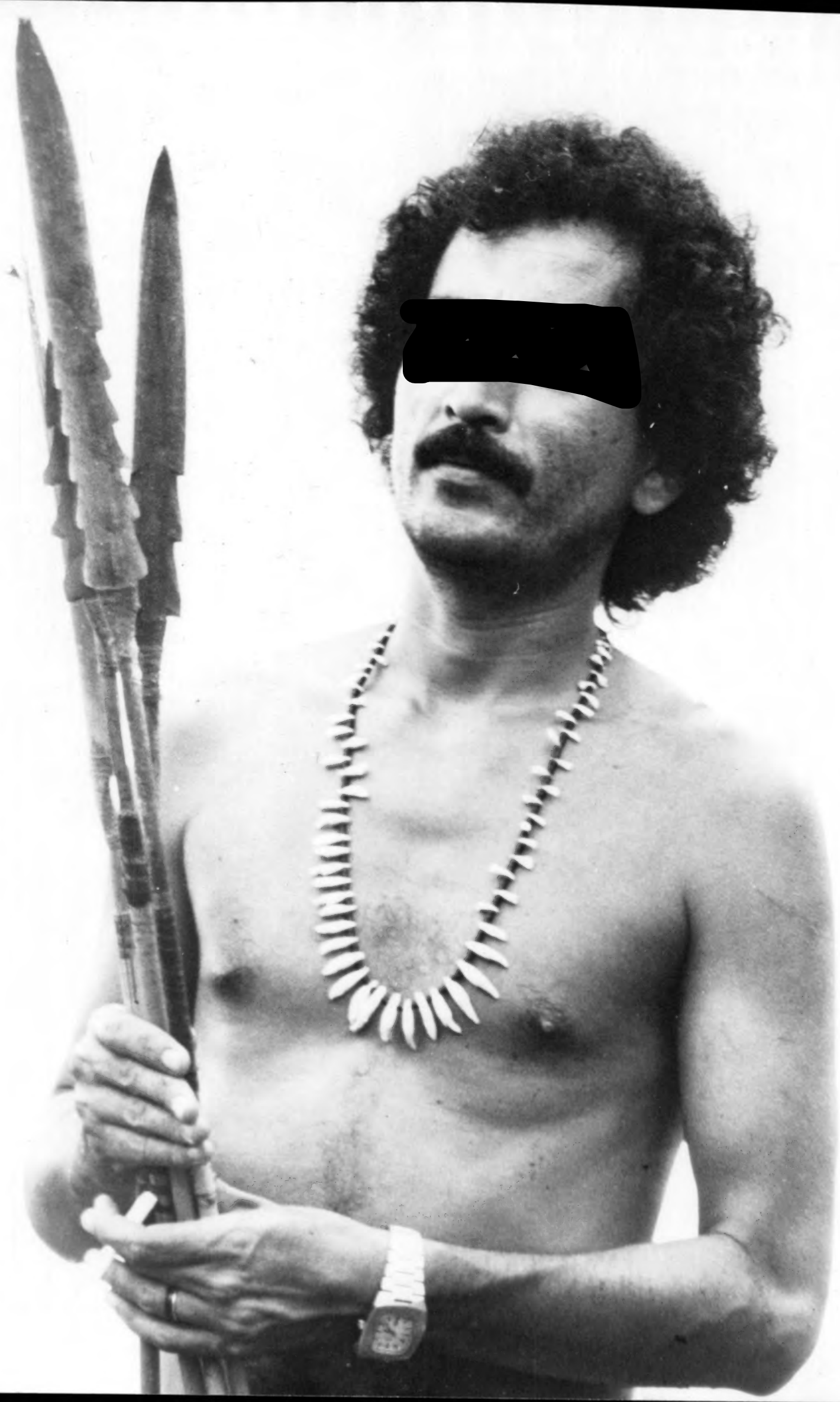


Osertamista da Funai

Com feedres dos indios URVEU-WHU-WHO.

Foto: Jesco 


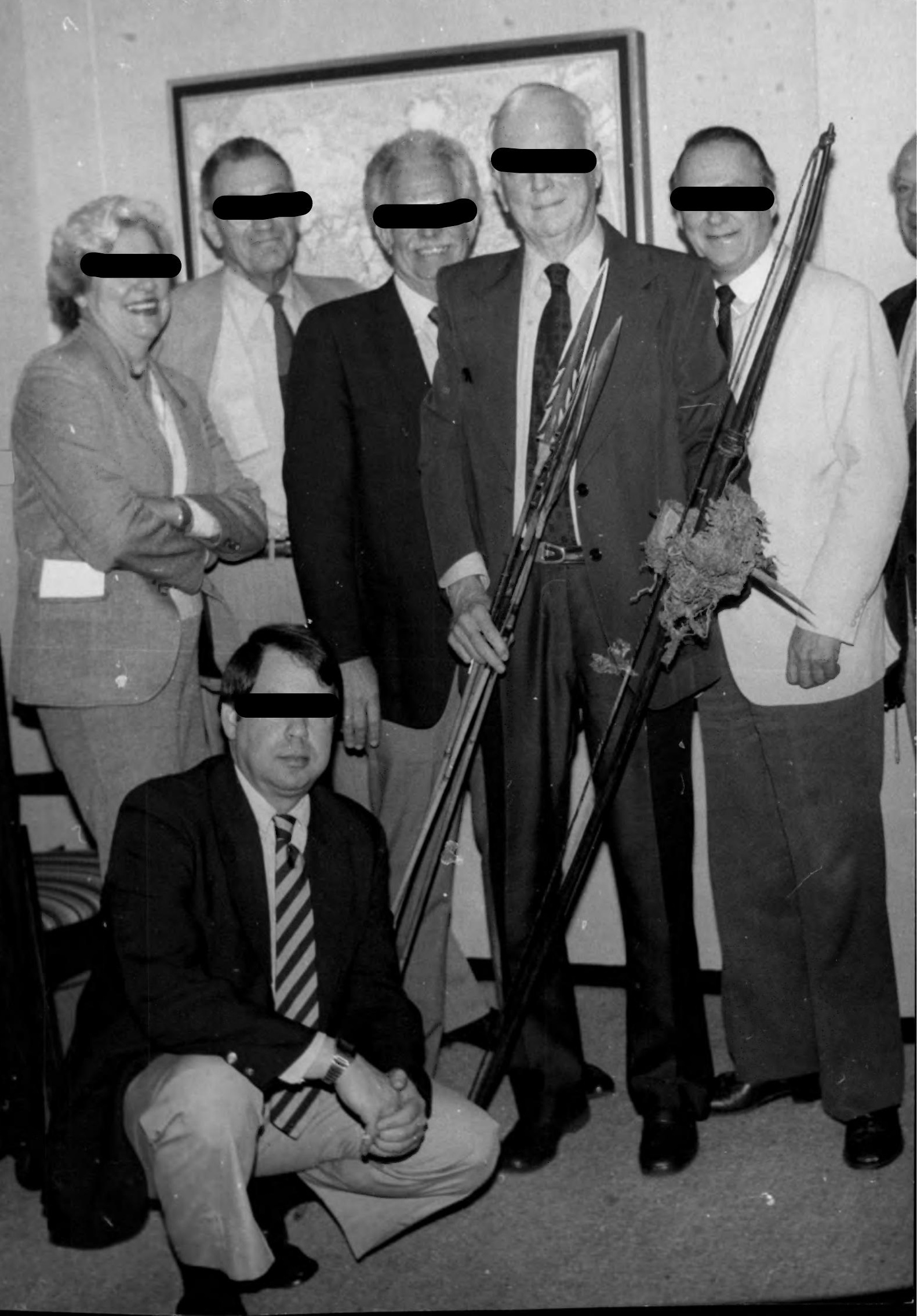


jesco

Com a Cúpular de National forpaphic Srciety

en Washingtore, en Mvio ey 


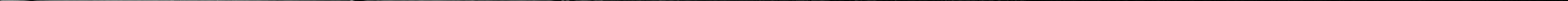


Jes co

Gim a cúpula

da Maktional feopaphic cue.

en Wasteingtom (Maio 1984) 
EXMOSNR.

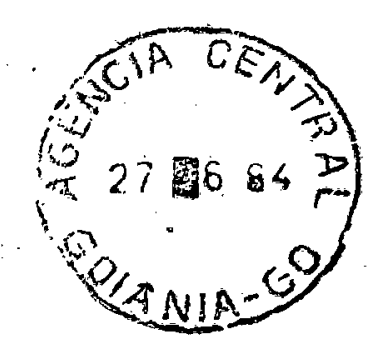

PRESIDENTE DA FUNAP DR. IURAND Y MARCOS DA FOUSECA

$$
\text { BRASILIA-D.T. }
$$

ED'Ficio "MinteR" 
Jesco

74.000 GOIANIA-COO

TE. 251.01 .03

(062) 
tist

SRTN - Ed. Brasilia Radio Center Salas 3029/31 - Tol. 225-2925 Tolét (00.1) 2257 - Caixa Postal 04-0177 4
AGll Fotojornalismo

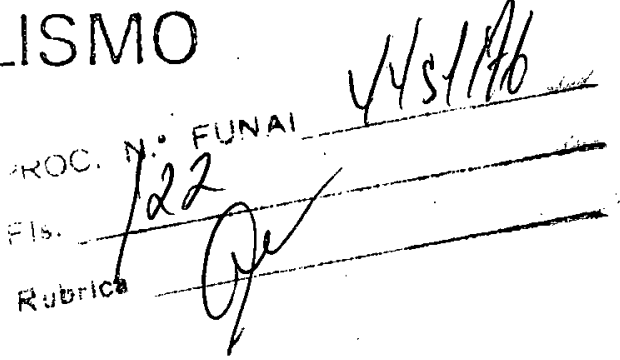

\section{LABORATÓRIO P/B:}

REVELAÇÃO DE NEGATIVOS:

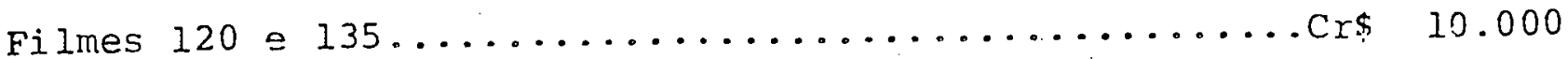

Contato (cada folha $18 \times 24$ ).................... 12.000

OBS.: Filmes puxados sofrem acréscimo de $50 \%$.

AMPLIAÇÕES :

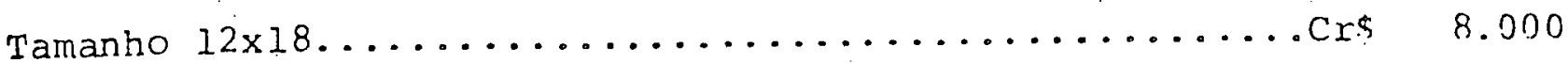

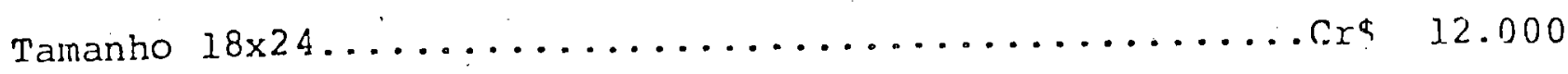

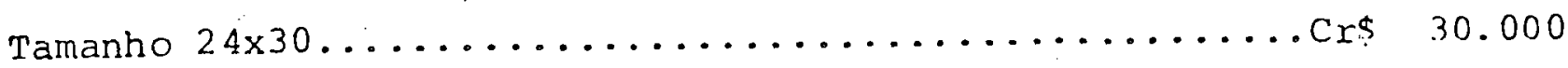

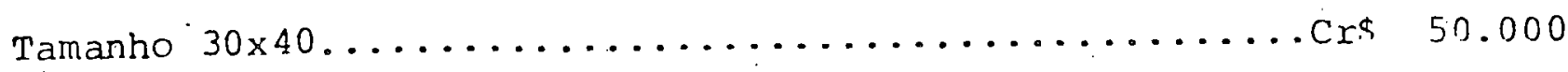

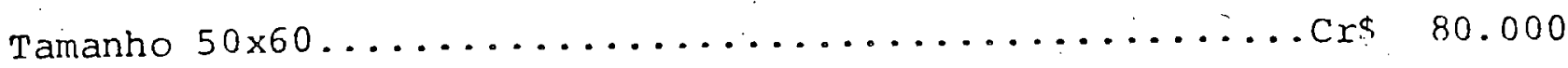

Metro quadrado.......................... combinar

REPRODUÇÕES P/B E REVERSÃO DE CROMO:

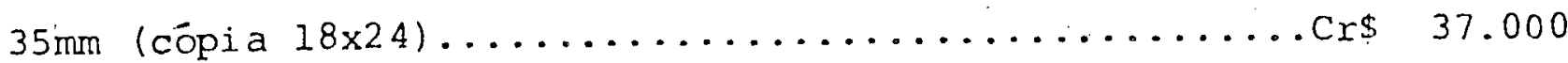

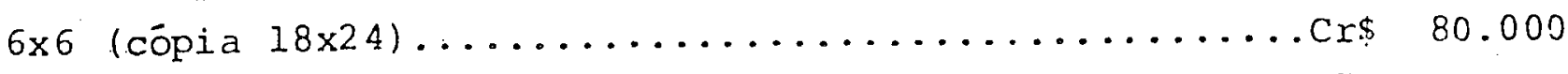

cópias subsequentes............. (vide tabela de ampliações acima)

REPRODUÇÕES COR:

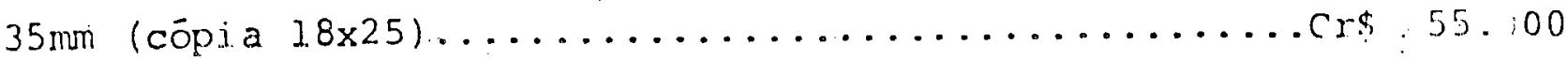

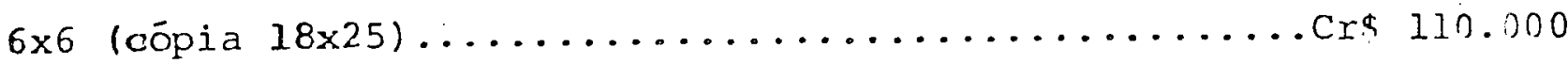

cópias subsequentes...................... combinar

Duplicação de slides (mínimo de 10) .............. 7.500 cadà

OBS.: Originais maiores que $30 \times 40 \mathrm{~cm}$, retoque a combinar. 
SRTN - Ed. Erasina Radio Comior

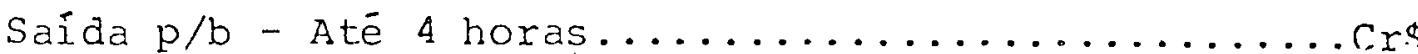

Saída $\mathrm{p} / \mathrm{b}$ - Dia inteiro...................... 160.0no

Adicional por foto utilizada:

- Jornais................................. $\$$

22.000

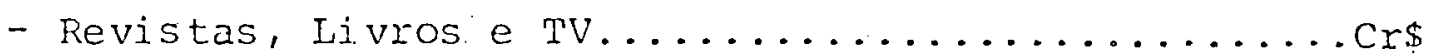

25.000

- Fascículos e Periódicos específicos................ $\$$

48.000

Saída cor - Até 4 horas....................... $\$ 140.000$

Saída cor - Dia inteiro........................ $\$ 220.000$

Adicional por foto utilizada:

- Jornais................................. $\$ 30.000$

- Revistas, Livros e IV...................... $\$ 44.000$

- Fascículos e periódicos específicos................ 65.000

Saida mista (cor e D/b) - Até 4 horas................. 190.000

Saida mista (cor e D/b) - Dia inteiro................ 260.000

OBS.: 1- A Capa será cobrada ao preco de arquivo.

2- Reportagem Comercial 35m, acréscimo de $50 \%$.

3- Reportagem comercial 6×6: acréscimo de $100 \%$.

\section{AROUIVO/USO COMERCIAL}

COR $\quad P / B$

Publicidade/Posters/Te levisão......Cr\$ $430.000 \ldots$ Cr\$ 290.000

Capa de disco/Embalagens............ $\$ 430.000 \ldots$ Cr $\$ 290.000$

Folhetos/Relatórios/catálogos .....cr\$ $290.000 \ldots . C r \$ 185.000$

Calenaários/Cartazes/Displays......Cr $\$ 290.000 \ldots$ Cr $\$ 185.000$

out-doors ......................... $\$$. 1.000 .0000 .000

Audiovisual........................ $\$$ Cr $\$ \quad 60.000 \ldots 00$

Referència/Lay-out............... $\$ 110.000 \ldots \ldots$ cr $\$ \quad 74.000$

OBS.: 1- Formato $6 \times 6$, acréscimo de $50 \%$.

2- Foto vinculada à reportagem desconto de $30 \%$. 
SRIN - Ed. Brasii: Rádio Center

Salas 3029/31 - Tel. 225-2925 Tolox (061) 2257 - Caixa Postal 04-0177 70.710 - Brasilla - DF

\section{AGIL FotOJORNALSMO}

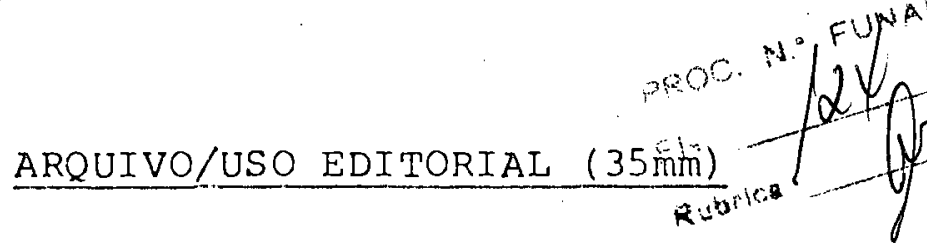
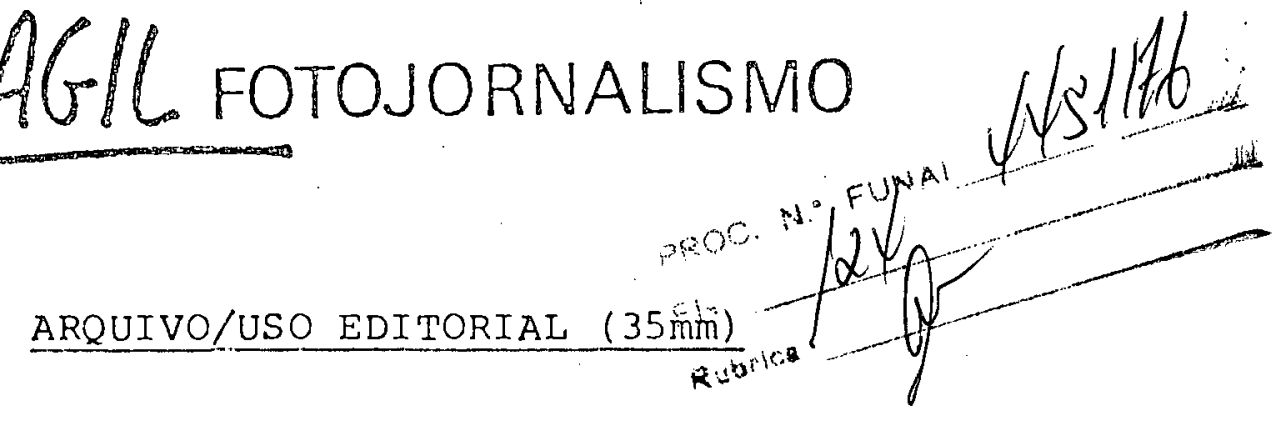

JORNAIS - DIŔRIOS E SEMANAIS:

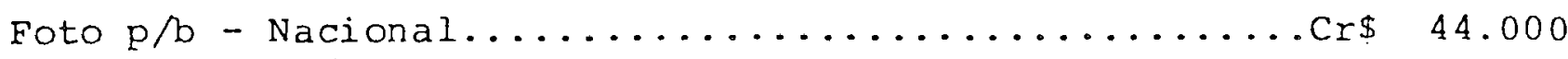

Foto $\mathrm{p} / \mathrm{b}$ - Internacional........................ $\$ 60.000$

Foto cor - Nacional......................... $\$ 60.000$

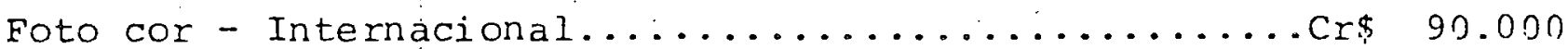

Capa - Acréscimo de $100 \%$.

REVISTAS SEMANAIS:

Foto $\mathrm{p} / \mathrm{b}$ - Nacional......................... 50.000

Foto $\mathrm{p} / \mathrm{b}$ - Internacional...................... 80.000

Foto cor - Nacional............................. $90.00 n$

Foto cor - Internacional........................ $\$ 140.000$

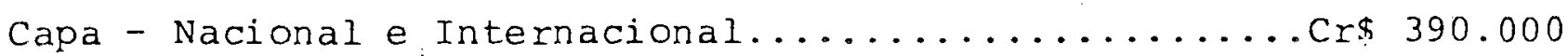

REVISTAS QUINZENAIS A TRIMESTRAIS, LIVROS E TV:

Foto $\mathrm{p} / \mathrm{b}-$ Nacional............................ $\$ 60.000$

Foto $\mathrm{p} / \mathrm{b}$ - Internacional........................ $\$ 90.000$

Foto cor - Nacional............................ 100.000

Foto cor - Internacional........................ $\$ 160.000$

Capa - Nacional e Internacional.................... $\$ 390.000$

FASCICULOS E PERIÓDICOS ESPECIFICOS:

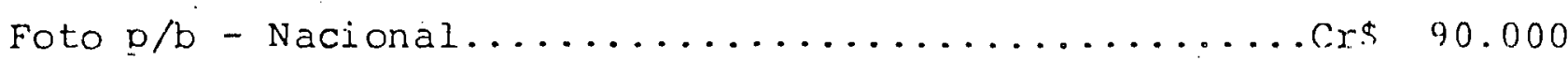

Foto $\mathrm{p} / \mathrm{b}$ - Internacional....................... 130.000

Foto cor - Nacional........................ $\$$ 120.000

Foto cor - Internacional......................... 180.000

Capa - Nacional e Internacional...................... 450.000

OBS.: Formato $6 \times 6$ : acréscimo de $50 \%$. 


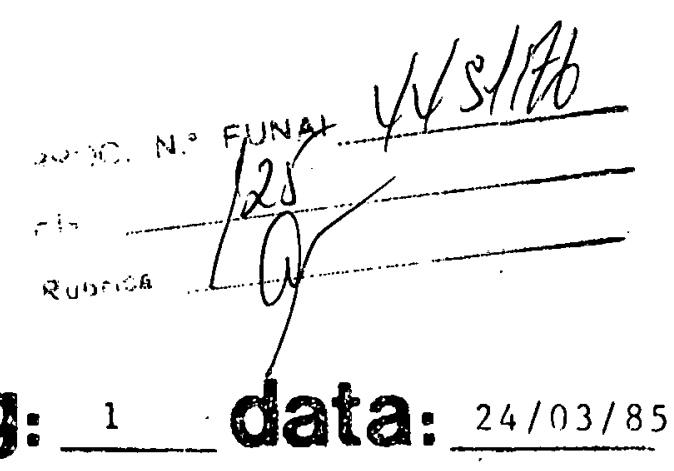

Boente, sujeitó a um infarto quálquế momento mesmo assimi Jesco Puttkamer úm brasileiro quê passou thais de dós anos nos campos: de Ĺconcentracáo alemáes: planeja: Imais uma viagem de estudos ao territorio dos Uruê.Wau.Wau, ém Rondónia. Aós 65 anos de idade, sua mágoa é a de na to ter recursos para editar 18 volumes de um dírio do 20 thil páginás, reforcado por maís de 200 mil fotografias iselecionadas. Tudo is so, $a^{\prime}$ respeito dos indios brasileiros : " paixâo que diz ter her-" dado de seus pais.:Proféssor do Ins: tituto Góbiano:de Pre. Ilistória e An. tropologia: Jesco tem esperança de que alguma entidade se interesse por: sua obra $e$ venha' a editar os seus? livios ( (Jornal de Domingo) 
Um admirador dos povas indigenas, Jesco Puttkamer há mais de trinta anos pesquisa seus costimes e os fotografa com uma câmara transparente de sensibilidade como demonstram estas suas fotos abaixo. Nesta entrevista ao Jornal de Brasilia, Jesco relembra sua vida com as úndios e sótem um lamento: não ver sua obra publicada

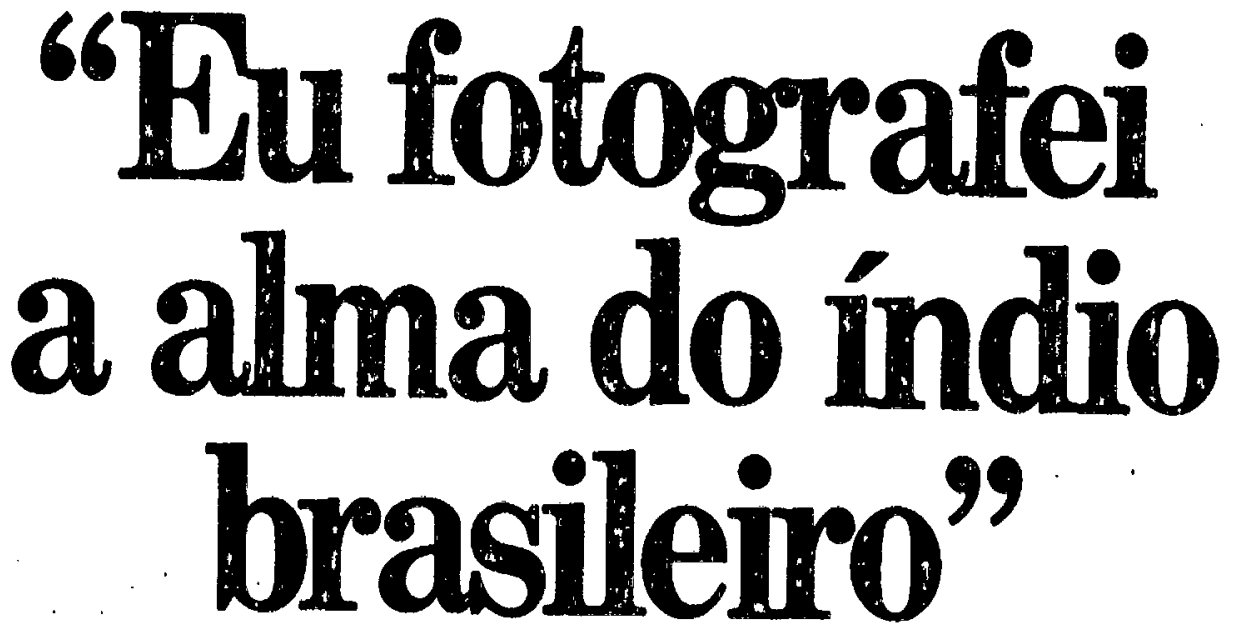

No bairro onde mora, em Goiania. ele conhecido como "um doutor alemaio, esquisito, pesquisador de ervas medicinais" A reclusão em que vive, depois de passar mais da metade de sua vida nas seluas brasileiras, criou essa lenda que, como qualquer outra, so tangencia a verdade. Jesco Put. thamer Filho não é doutor e sim professor lcomo alids sempre preferiu ser chamailo), não tem nada de esquisito, a questão das er. vas medicinais é quase um acaso em seu imenso trabalho e tampouco es alemão. Embora seja filho de alemães e tenha estudado nas melhores uniuersidades germa. nicus, o brasiloiro nascido hd 65 anos em Niterdi, Riu de Janeiro.

Nesta entrevista, realizado Rraças ao apoio da Assessora do Museu de Arte de Goiania, Vera Gomes, o professor Jesco nào ronde sua mogoalpor ter devotado tanto tempo a filmar e fotografaros indios, com seus proprios recursos enquanto, verifica i hoje que a Universidade Catolica de Goiánia não tem recursos para editar seus 18 volumes. Essá obra equivale ds 20 mil paginas de didrio que es. creveu, acrescidos de fotografias selecionadas de um total superior a 200 mil.

Seriamente doente lele tem uma obstruçào no coraçào e um dos ven. triculos bate mais rapido do que o outro). sujeito a um infarto a qual. quer momento, o professor tem a recomendacajo expressa dos médicos para náo receber visifas. os lucros no meu ideal os indios. A convite de Villas Boas fui para $X i n g u$. Depois, a pedido do extinto Conselho Nacional de Protecão ao Indio. fui viajando pelo Amazonas. Cheguei aos lugares mais remotos. Por exemplo, subindo o rio Juruá de canoa. peguei um afluente, o rio $\mathrm{Im}$. breu, e fui até a divisa com o Peru. onde havia indios semi-arredios.

JBr - Qual era o seu trabalho?

Jesco - Fazer investigacöes sobre eles.

$\mathrm{JBr}$ - Que tipo de investiga. ç̄es?

Jesco - Sảo coisas incriveis que deixei anotadas nos diários que se acham na Universidade Católica de Goiánia. Doei todo esse acervo Só tem uin defeito: escrevi.os todos inglês, pensando que era mais fácil achar uma editora: Mas agora Universidade nāo tem dinheiro para traduzir as $20 \mathrm{mil}$ páginas crevi. Datilografadas. elas formam 18 grandes volumes. Há dois anos gue tento publicar e falta dinhe. o primeiro está pronto, cliama.se Curumim. São observaçòes e fotos sobre as criancas indigenas.

JBr - Professor, por ter pas. sado tanto tempo com as frentes atraçāo, o senhor nảo se considera um sertanista?

Jesco - Eu não fui um sertanista. Era só um companheiro. Pri. meiro dos Villas Boas e depois dos Meirelles. O A pocna, inclusive, meu afilhado. Tenho estado com nos últimos 15 anos, uma parte fascinante do Brasil ، ain. Aa ram indinca rantatar relatar como aconteceu um desses contatos? Um mais interessante. onde tenham acontecido surpresas.

Jesco - Eles foram muitos. cada um diferente do outro e com surpresas muitas. Está tudo des. crito nos meus diários. Um desses foi com os indios Txikāo, no rio Jatobá. Nos descemos com os dois aviōes, dois "teco-tecos.", numa clareira a mais ou menos sete quilómetros da aldeia, pensando que os indios não chegariam lá Mas, assim que aterrissamos, eles já haviam nos cercado. Nāo se podia decolar, nem nada. Eles estavam nervosos, batendo com as flechas nos arcos... E nós nem queriamos um contato tảo depressa. Iamös so dejxar presentes, preparar um "tapiri" de trocas como sempre faziamos.

JBr - Que aconteceu?

Jesco - Orlando e Cláudio des. ceram. Mandaram o resto ficar no

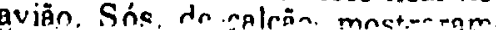
yue estavim uesurmuans: guravain os facoes, abanando e un. dando na direcào deles. Entāo os in. dios gritaram horrivelmente, to maram os facòes dos dois e pediram mais. Desceu Piuim, um Kayabj auxiliar de Orlando, que levou mais facōes. Dentro de meia hora nós descemos e tudo se transformou numa festa.

$\mathrm{JBr}$ - Mas nem sempre é fúcil assim.

Jesco - Com os Urue-Wau. Wau, mais recentemente, foi preciso dols anos e mejo de preparo. 
Um brasileiro que passou mais cracto alemas concenrração alemảes, solteiro, trabalhan. do atualmente como professor do Instituto Goiano de Pré.História e Antropologia, Jesco ainda sonha e faz projetos. Ele acredita que al. guma entidade, talvez governa. mental, assuma o trabalho de editar seus liuros (sem comparação na his. tória do Brasill e jd está planejando mais uma viagem de estudos ao território semi-explorado dos Urue. Wau-Wau, em Rondonia. Se a saude permitir.

JBr - Desde 1950, o senhor documenta o Indio brasileiro. De onde veio esse interesse?

Jesco - Porque sou filho de alemão, e alemảo tem uma grande veneração pelos indios. Meus pais eram fazendeiros pobres no Brasil mas meus tios eram barôes ricos na Alemanha e estudei lá, por conta deles. Lembro que naquele tempo (década de 1940) os meninos não brincavam de futebol, preferiam brincar de indio nas ruas. $O$ alemảo já tem essa doença, esse fascinio pelo índio. Ele só vê virtudes. E esse fascínio pegou em mim.

$\mathrm{JBr}$ - Durante a Segunda Guerra o senhor estava lá?

Jesco - Como era brasileiro, fui preso pelos alemâes. Sofri dois anos e meio num campo de concentraçảo. Fuzilaram meu irmảo, Olavo. Cheguei a entrar na lista de fuzi. lamento, mas escapei. Foi uma cicatriz muito grande na minha alma. E, por esse motivo, talvez, veio essa vontade de procurar essa gente que ainda vive livre - os indios. Por outro lado, sempre fui um gran. de fä de Rondon, a quem considero 0 maior de todos os brasileiros.

$\mathrm{JBr}$ - E o retorno ao Brasil?

Jesco - Quando voltei, em 1949, já era químico formado (pela Universidade de Brestlav, Erlander e Munique), especializado em Ciên. cias Naturais. Arranjei emprego na Praia Vermelha, Rio de Janeiro, como assistente de um professor alemão. Até que conheci o gover. nador de Goiás. Jerônimo Coìmbra Bueno, que me convidou para trabalhar como seu secretário particular, atendendo as diversas correntes migratórias.

$\mathrm{JBr}$ - Como foi feito o contato com os indios?

Jesco - O governador tinha o ostume de levar diplomatas es. crangeiros e a imprensa até Xavan. tina e, mais tarde, $\mathrm{S}$ ingu, onde es. tavam os irmãos Villas Boas.

$\mathrm{JBr}$ - Qual foi sua reaçảo ao se encontrar com eles pela primeira vez? ?

Jesco - Levei um choque. Mas veio depois uma admiracảo for midável. Saber que ainda existe uma gente tảo pura em seus pen samentos, E uma coisa indescritivel.

$\mathrm{JBr}$ - Como foi o começo do seu trabalho com eles?

Jesco - Comprei uma chácara em Goiânia, onde produzia mudas, ovos, manteiga, hortaliças. Quando o negócio começou a render investi
$\mathrm{JBr}-$ Essa questáo do contato mplica um sério conflito de ordem cultural. Uma forte corrente antropológica considera o fato uma Invasāo. $\mathrm{O}$ que o sen hor acha disso?

Jesco - O melhor seria deix́. los em paz, Mas como a nossa ci. vilizaçāo nả̉o pensa em parar, é um dever nosso ir na trente e tentar preveni-los contra o que vem por ai.

$\mathrm{JBr}$ - Como eram feitos os contatos?

Jesco - Eles eram preparados com muito cuidado senảo se trans formavam em desastres. Na hora mesmo, não se sabe se quem tem mais medo sâo os índios ou somos nós. E como dizia um ás da aviação alemâ, que depois se tornou meu amigo: "Coragem é a forca com que se domina o medo". Medo todo mundo sente. A noite, quando se escuta um passarinho e você sabe que ele nảo é da noite ou mesmo do lugar... Ouvir pés descalços em vol. ta do barracâo... Vem o medo. F você sabe que não pode dar tiro em indio. Pode, no máximo, atirar para assustar.

$\mathrm{JBr}$ - $\mathrm{O}$ senhor poderia me presentes gritavam da mata rmos embora. Atacaram o posto diversas vezes, flechavam as redes.

$\mathrm{JBr}$ - Eles usavam o curare?

Jesco - Não. Só mais tarde descobrimos que usam veneno nas flechas. Mas isso foi uma surpresa porque achávamos que ao sul do Amazonas os indios nao usavam is. so. Essa tribo revelou que extraem esse veneno da entrecasca de uma árvore, a Padia. Ele não é como a curare, que paralisa os nervos; o Padia tem um anticoagulante. faz correr muito sangue. Por issespode se tornar um remédio muito po deroso em casos de derrame $/ \mathrm{e}$ ataques cardiacos.

$\mathrm{JBr}-\mathrm{Nessas}$ andancastodas o senhor aprendeu algum dialeto?

Jesco - Logo depois do contato. uma das coisas mais agradáveis interessantes forer pesquisa lin. guistica e procurar falar o idioma deles. Fato que eles consideram uma prova de amizade. Mas eu não desenvolvia porque os indios que já conhecia deixavam para trás. Eu gostava mesmo era de estar nas frentes de atraçâo.
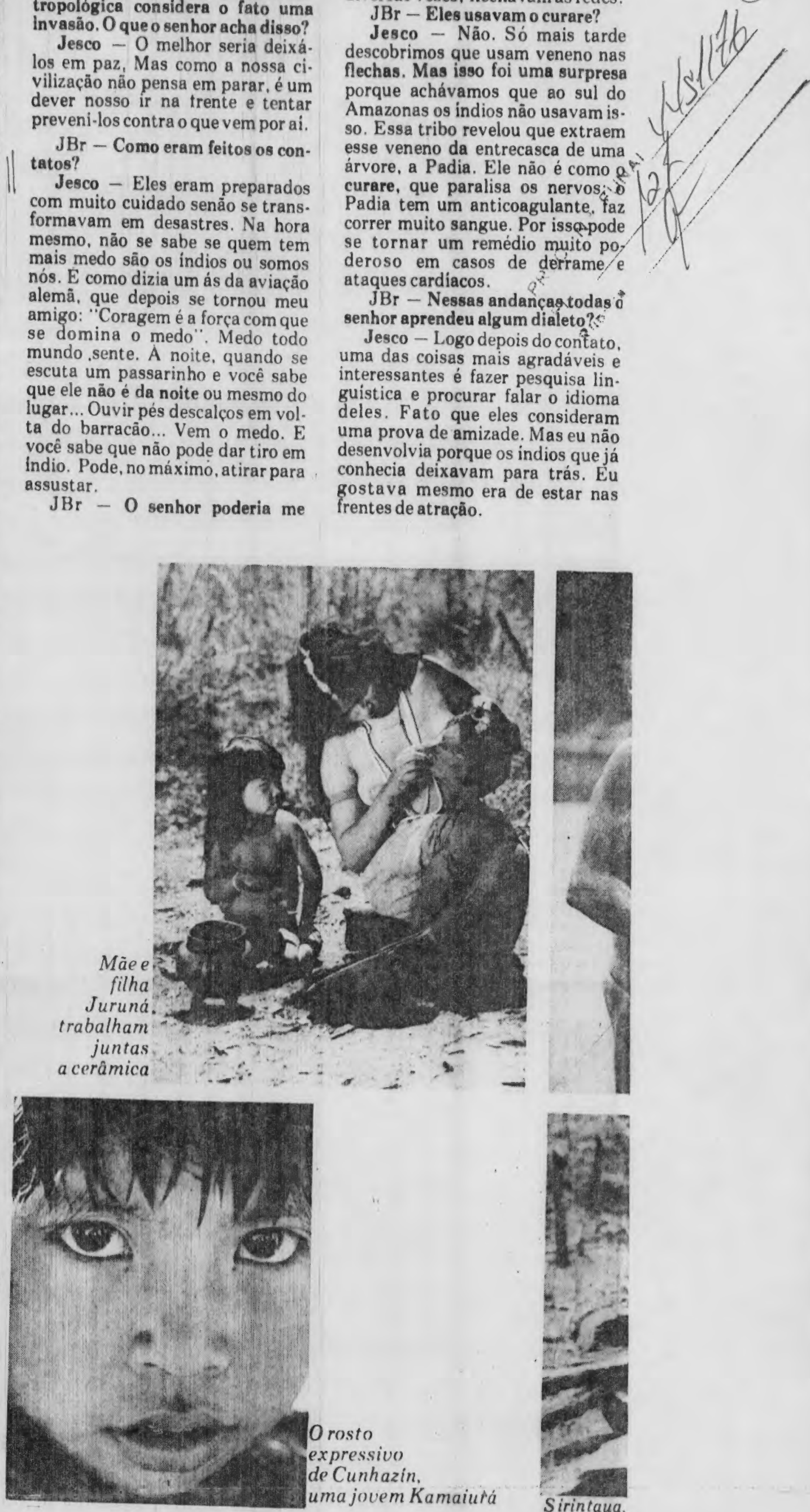

, 

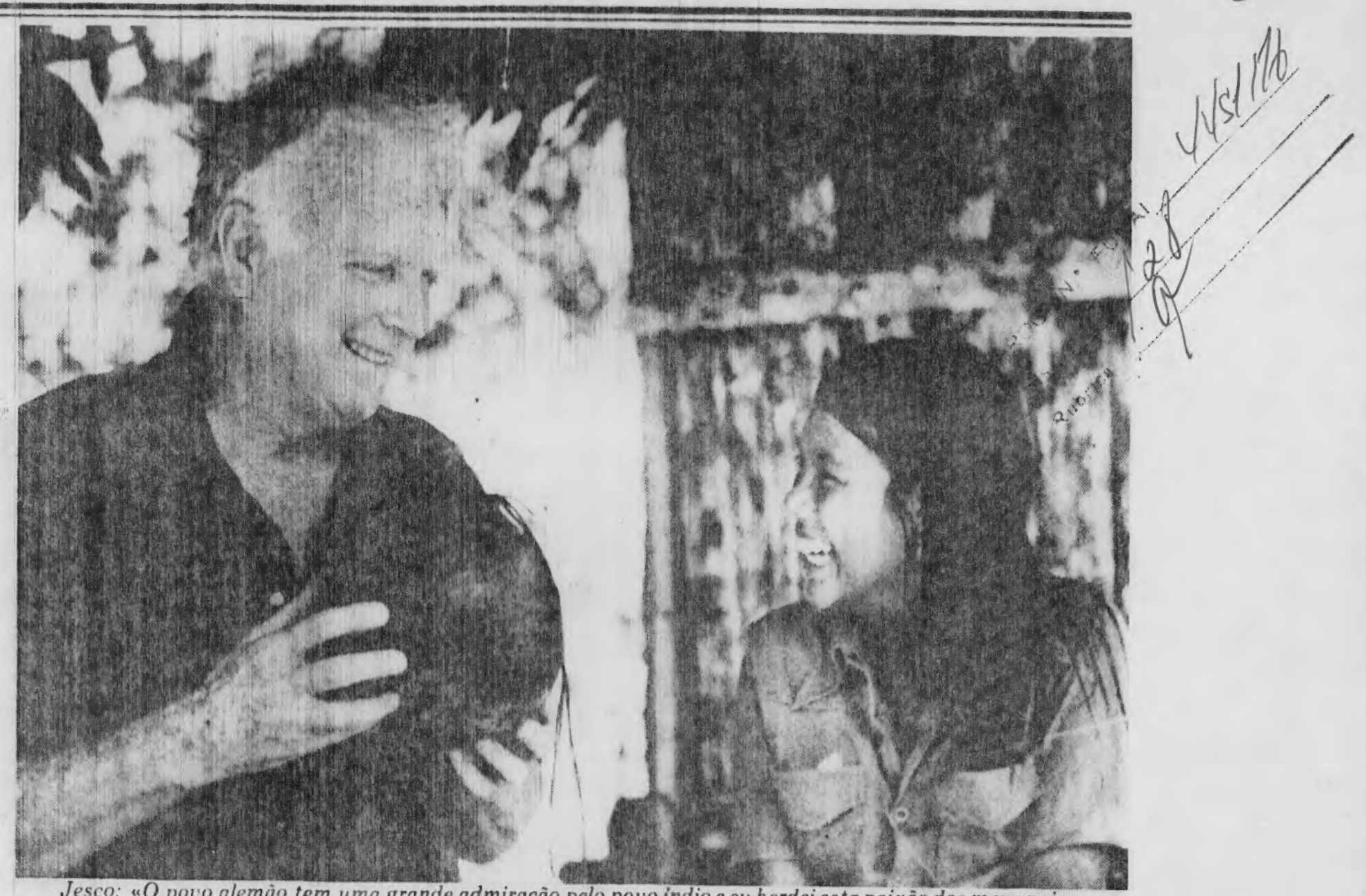

Jesco: "O povo alemáo tem uma grande admiraçào pelo povo indio e eu herdei esta paixầ dos meus pais

$\mathrm{JBr}$ - $\mathrm{E}$ como eram essas viagens na mata?

Jesco - No periodo da seca, por exemplo, as cabeceiras dos rios secam de tal maneira que temos que "vazar" as canoas por cima das àrvores caidas, usando a casca da Im baúba. No fim fica tåo dificil que larga-se as canoas e vai-se com a bagagem nas costas.

$\mathrm{JBr}-\mathrm{O}$ fato do senhor ter a pele tảo clara e os cabelos louros chamava a atençåo deles?

Jesco Eles puxavam meus cabelos. Queriam levar um pedaço Acham curioso, estranho, mas sim pático.

JBr - Qual a sua opiniảo sobre o trabalho do sertanista?

Jenco Admirável Euma clas. se de pessoas que so tem aqui no Brasil. O primeiro foi Rondon e seus oficiais, que viram a necessidade de proteger esses índios do exterminio - ele foi o maior de todos. Outros grandes são os irmãos Villas Boas, Orlando, Cláudio e Alvaro. Depois. Chico Meireles e seus auxiliares. Agora seu filho. Apoena. Eles näo gostam de publicidade, mas tudo que pudermos fazer para documen tar seus feitos heróicos ainda é - vuco. Atualmente, há gente da 1. unai que trabalha nas frentes e tem pouco apoio. Geralmente esse pessoal de Brasilia näo tem com preensảo do que é necessário.

$\mathrm{JBr}-\mathrm{O}$ que o senhor acha da Funai atual, com indios em postos chaves e Marabuto como o sexto neosidnenten H.w bravion?
Jesco Acho que sim. Tan credo, inclusive, estudou no mesmo colégio que eu, o Ginásio $\mathrm{S}$ anto Antonio, em $\mathrm{S}$ ảo João Del Rey. Tenho uma veneraç̃o muito grande por ele. E um homem sério, sincero, honesto.

$\mathrm{JBr}-\mathrm{O}$ senhor estaria de acordo com as lideranças indigenas, que pedem o encaixe da Funai numa nova estrutura polit ica?

Jesco - Sem dúvida, a Funai deve ser desligada do Ministério do Interior.

$\mathrm{JBr}$ - Megaron falou-me que, apesar do avanço politico do Indio, ainda nåo é tempo dele assumir a presidéncia da Funai.

Jesco Sim. Nho acho que um indio vá conseguir verbas melhor que outras pessoas. Năo é preciso nem ser tão indigenista. Basta uma pessoa que tenha força de expressảo política. Neste País é necessario.

JBr - Nesses 35 anos de tra. balho, o que foi documentado?

Jesco - Modéstia a parte, sou considerado um dos melhores fotógrafos do mundo. Sou cola borador da National Geographic que já publicou cinco trabalhos meus. Produzi 200 ou 300 mil fotos de indios e milhares de metros de filme em $16 \mathrm{~mm}$, tudo com o dinheiro ganho em minhas atividades agricolas. Meus diários foram feitos de madrugada (das 4:00 às 6:00 horas), à luz de velas, nas frentes de atracäo. Muitas vezes, em noites perigosas, a caneta tremia, recean. curava fotografar a alma dele. E consegui, como consegui me fazer amigo deles. Porque fotografar é uma coisa muito antipática e eles terminavam colaborando comigo.

$\mathrm{JBr}$ - Fazer esse tipo de coisa hoje em dia está mais difficil com a Funai cobrando para entrar nas reservas?

Jesco - Acho justo que se cobre dessa gente que usa a imagem do indio para fins comerciais. Mas nảo deveria impor dificuldades a quem. já com sacrifícios, procura mentar a vida e a beleza deles. Aos pesquisadores, deveria se dar todo apoio.

$\mathrm{JBr}$ - $\mathrm{O}$ senhor já mostrou seus filmes em Londres?

Jesco - Sim. Levei-os uma vez. Recebi uma pequena gratificação. Ela mal deu para pagar a passagem de ida e volta e a estada.

$\mathrm{JBr}$ - Fol esse o único apoio que recebeu até hoje?

Jesco - Me deram mais um pouco de filmes para continuar trabalho.

$\mathrm{JBr}$ - E o governo brasileiro?

Jesco - Nada. Ninguém. Para essas coisas nảo têm dinheiro.

$\mathrm{JBr}$ - 0 senhor chegou a procurar o CNPq (Conselho Na. cional de Pesquisas), por exemplo?

Jesco - Eu nào tinha contato com essa gente. E não sou homem de procurar gabinete. Eu procurava $\rightarrow \longrightarrow$ os sertanistas, lá na frente.

$\mathrm{JBr}$ - Tanto trabalho. Qual o 
Jesco - Ninguém está gostan. 10. Mas acho que Marabụto nảo merece nenhuma 'critica porque. ambora nảo o conheça pessoalmen te, tenho observado o esforco que stá fazendo. Ele é um homem nuito bom. Se é que está cometen. to erros, é por estar defendendo o ndio. Então, nỗo é a Funai que deve ver tachada de culpada, mas essa in. elicidade que é a falta de recursos. leveriam, talvez, aplicar menos em 3rasilia, nesse aparato burocrático.

$\mathrm{JBr}$ - Mas comparando a atual unai com os tempos do CNPI, aelhorou alguma coisa?

Jesco - O serviço deles tem ielhorado. Além do mais, todas es. as criticas têm dado resultado. Se åo fossem elas, talvez se aco. rodassem. Não melhorou mais orque não tem dinheiro. Visitei. no no passado, uma frente de atracão ue nem tinha muniçâo para caçar. ité a Petrobrás cortou a gasolina orque deviam demais.

$\mathrm{JBr}-\mathrm{O}$ senhor acredita que om a Nova República de Tancredo situação do indio brasileiro deve selhorar? do 0 ataque dos indios. Há cinco anos doei à Universidade Católica. mas como ela nẫo tem dinheiro para publicar isso me dá um certo des gosto. Porque antes de morrer gos. taria de ver minhas coisas publi cadas, daria uma última auto. satisfação.

$\mathrm{JBr}$ - De quando sầo as pri meiras filmagens?

Jesco De 1960, com a má. quina de Orlando. Há milhares de filmes que nunca foram editados.

$\mathrm{JPr}$ - Por que os doou?

Jesco _. Lá eles conservam com controle de umidade. Aqui em casa cheguei a perder alguns filmes.

JBr: Não pensou em vender?

Jesco - Nunca ofereci a ninguém porque minha intençāo nåo era comercial. Era somente vontade de fixar essa coisa linda que via desaparecendo debaixo dos meus dedos. $O$ indio comecava a se vestir. a andar com roupa suja (porque não tinha sabão), ficar doente, perder os dentes. Esse nảo era o indio que eu admirava. Aquele com arco eflexa, que nảo tinha soberano, nem com. plexo de inferioridade. Eu pro. teira dedicada a historiar o indi brasileiro?

Jesco - A satísfação de ter feito esse material que está na Univer. sidade. E considerado o maior acer. vo do mundo sobre o indio do Brasil. Mas ainda é pequeno porque nilo pude estar em todos os lugares.

$\mathrm{JBr}$ - Qual fol a sua cobertura? Jesco - Todo trabalho dos måos Villas Boas, em oito anos mais 10 anos com Chico Meirelles um tempo com o CNPI: mais re! centemente, com Apoena

$\mathrm{JBr}$ - Mas o senhor não parou. Jesco - A Universidade me convidou para ser coordenador de uma expedição à Rondônia, na fren. te de atração dos Urue-Wau.Wau, qu

quer pesquisar e documentar essa cultura ainda intocada: o trabalho heroico da Funai na reserva; as cavernas do planalto de Ataliba: Apadi, que eles usam em suas flechas. Devemos ir com a antro. póloga Bete Mindlin. Mas é neces sário autorização da Funai e espero conseguir a licença.
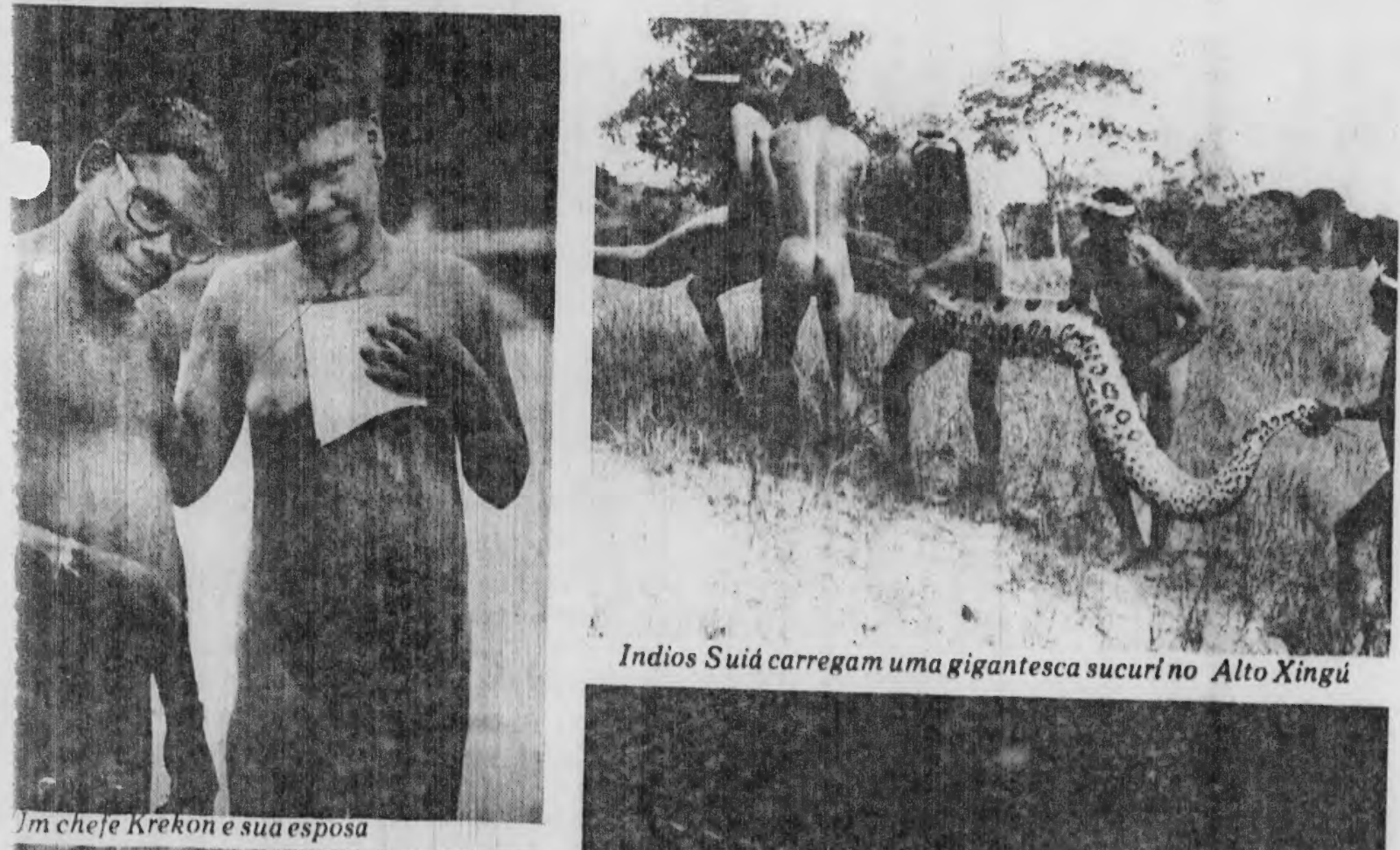

Indios Suid carregam uma gigantesca sucurino Alto Xingú

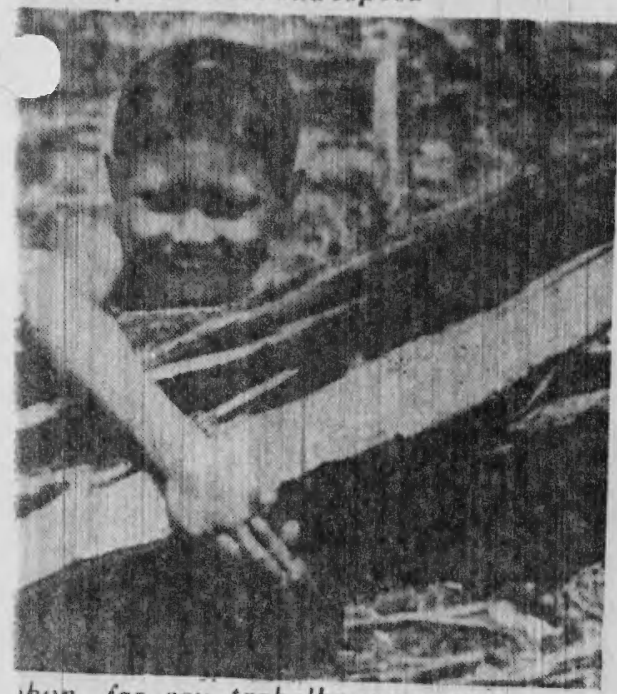

kon. faz seu trabalho rom prazer

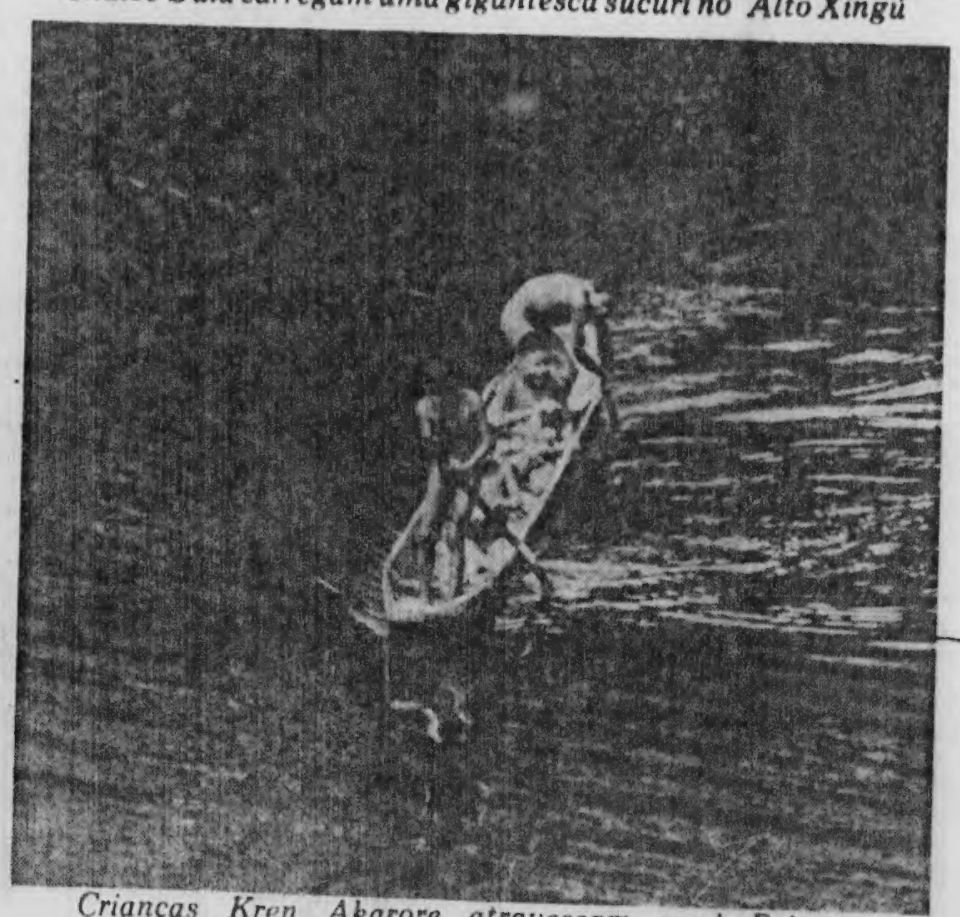

Crianças Kren Akarore atravessam o rio Peixoto 




